

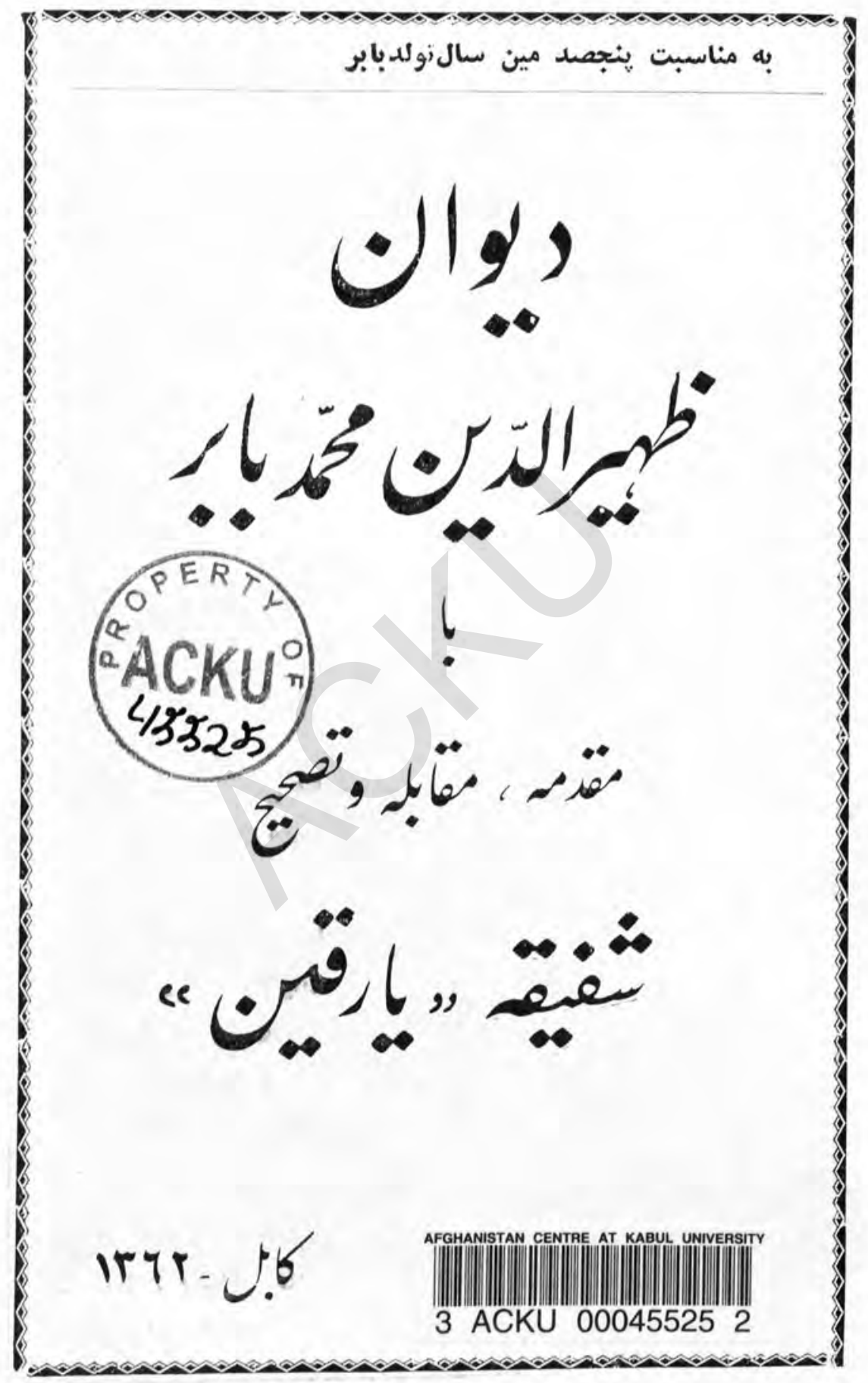


- ديوان ظهيير الدين محمد بابر - با مقلمه، مقابله وتصحيح : شفيقه يار قين

ـ نشركردة: اكايمى علومج.د.1. - مركز زبانها وادبيات علمركيات - دييارتمنت مليتهاى برادر - طرح هشتى از : محمد شفيع (رغظيمى" _خطاط :استاد عزيزالدين و'يلى ديلى

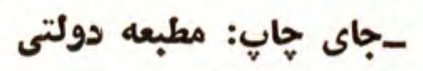
ـ تيراث : يكهزاد جلد

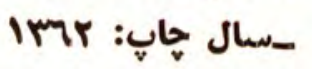




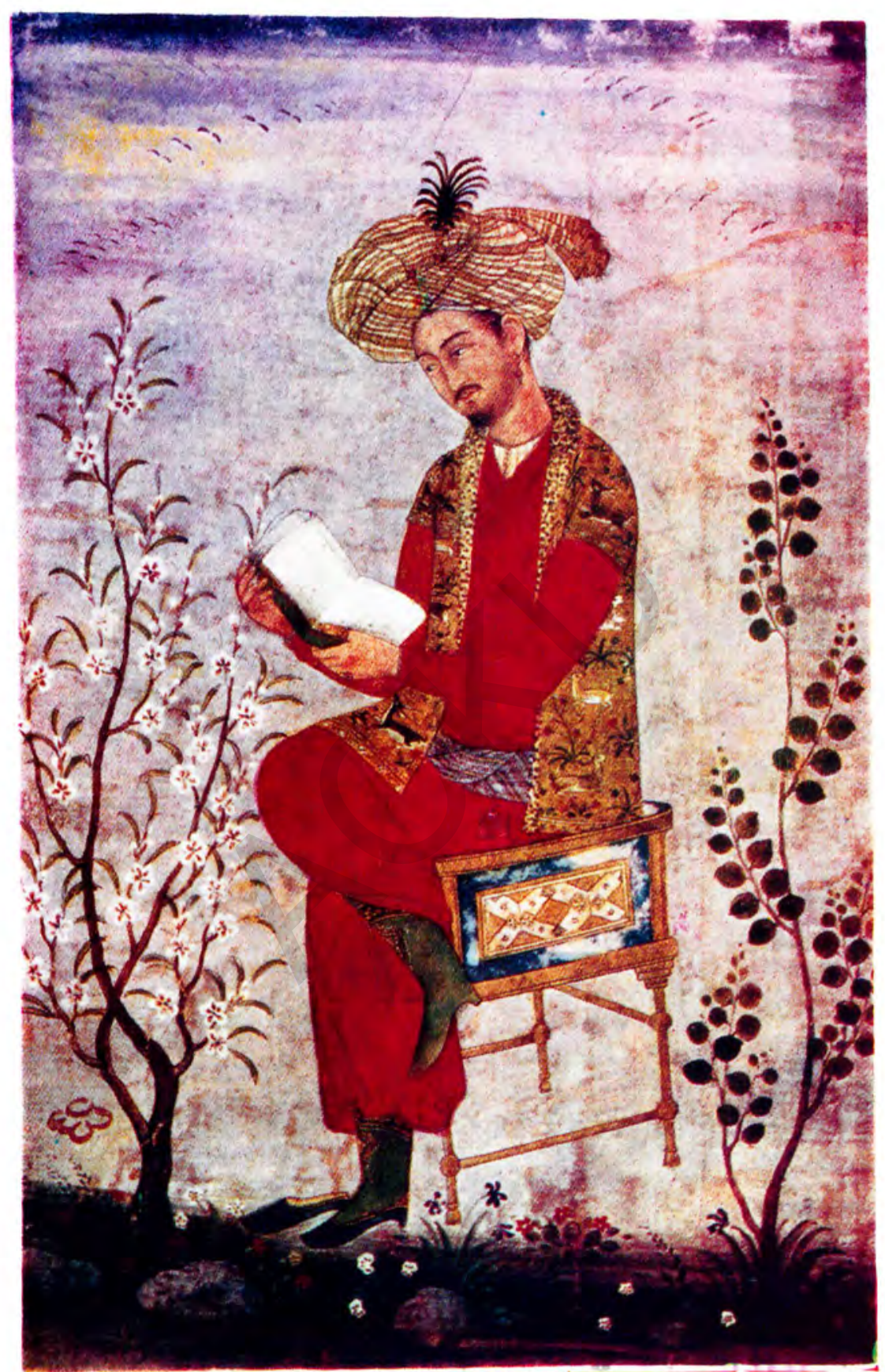

ظهيمرالدين محمد بإبر 


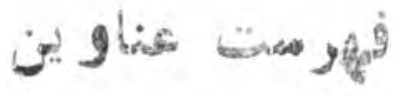

الـــ

سر آغاز

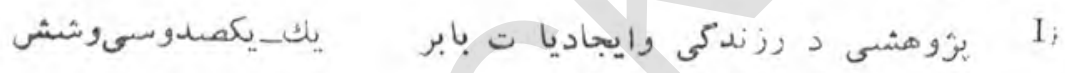

\section{بخش نخست}

سيماى جند بعدى بابر

الف ـفشردهبتارى برزيستناهة بابر

نينج

ب-بابر فرمانروا

يانزد.

ج-بابر مؤرخ

بيستويك

دـبابر سرايشكر اديبودوستدار هنر

بيستوشش

$$
\text { هـ - مبابر منتقد دقيق وزرف نكر سكر }
$$

$$
\text { آثار وايجاديات دوبم بابر }
$$

سيوجهار

الف- بابر نامه 
سنىو هشت

$929+7=$

جهل

:

Sis

بنجاهو هنت

هفتسادو دو

هفتادوبـهـ

هفتادو نـ

همتادوبهيها

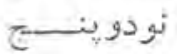

ب-رساله عروض ج-رسالك مبين د-ترجمأ منظوم رسنالة والديه هـيديوان اشيعار ورخط با.برى

\section{بخش سوم: \\ شناخت شعر بابر}

الف- شعر بابراز نظر شكل ب - درونمايهي ومحتواىشعربا! ا-ماشعار تاريخى

r r الشعار وصف الحال rاشمار عشقىى ئاشعار اجتماعى وراخلا قي بنش

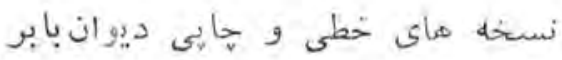

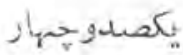
الفـ- نسخهل هاي خطبي ديوانبابر

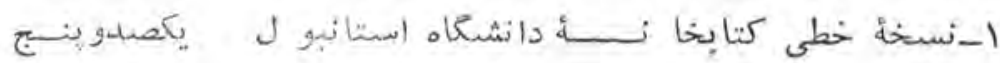
بكصدوشش

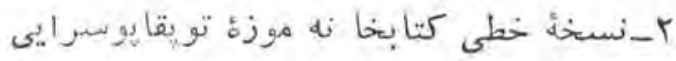
يكعدو r- نسخة خطئ كثابخانه يكمساو هفت

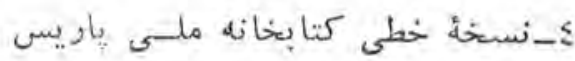
يكمبرو

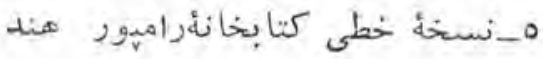


بِ-نسخهُ ماي هابي ديوان بابر

ن.

Lifligh.

نوistí.

o.

ه د.

يكصوريازده

يكسدويازده

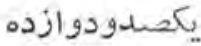

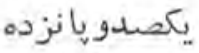

يكمدوسى

rAYーI

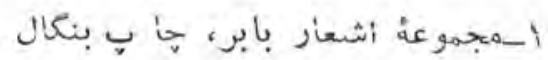

$$
\text { r-اشعار بإبر شاه ؛ منتشرة: استانبول }
$$

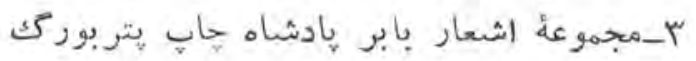

ع_منتخب آثار بابر

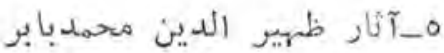

$$
\text { 7-7يو ان هندبابو }
$$

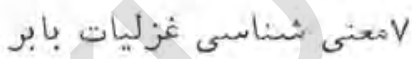

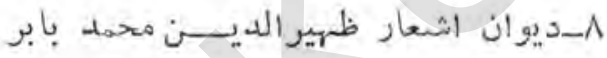

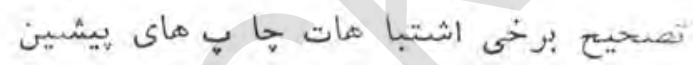

II 


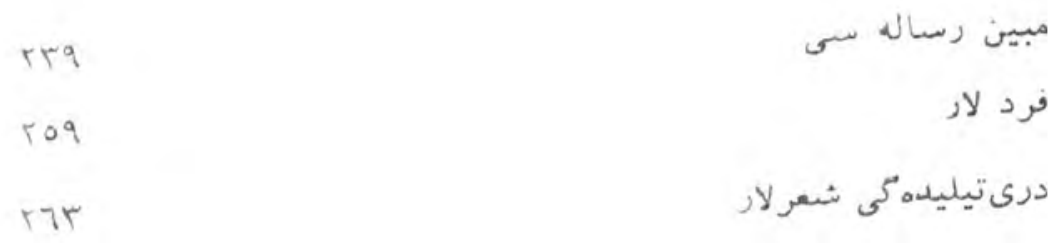

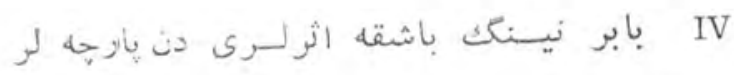

177

r.A

rAK

$r \cdot \Lambda$

rio
عروض رسالك سيى دن

بابر نامه دن يارجه لر

لغتنامه ديوان بابر ل V V

فهرست اسماى خاص لون

كتابشناسى ديوان بابر VII 


\section{س س آناز}

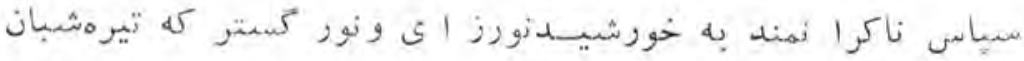

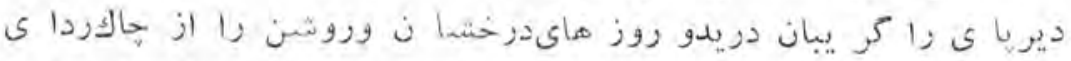

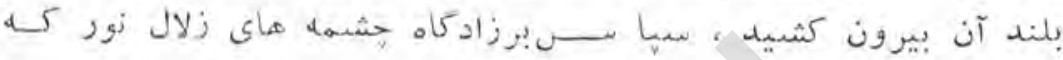

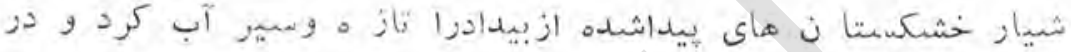

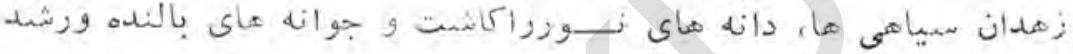
يابندة روشنى رابه رويش وبايشىآورد، تا شبسمتان خاموش و خواب

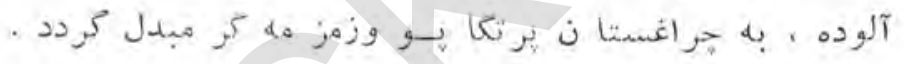

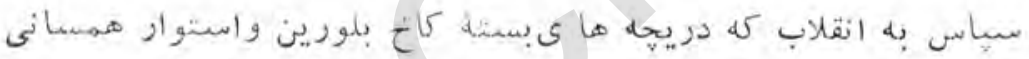

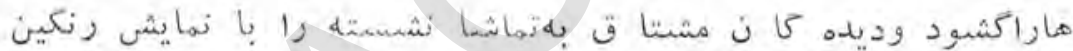

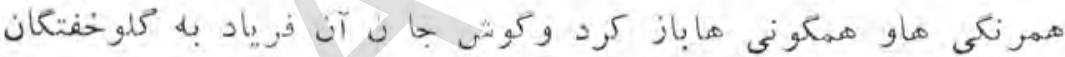

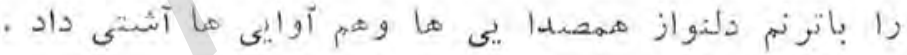

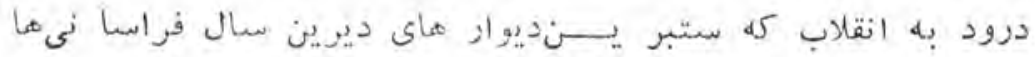

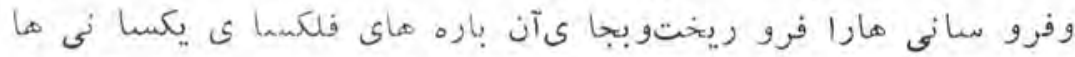

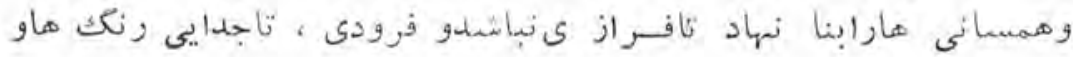

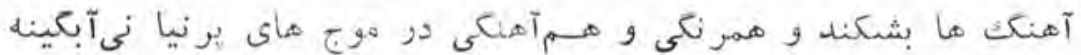

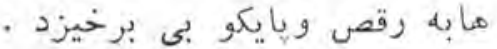

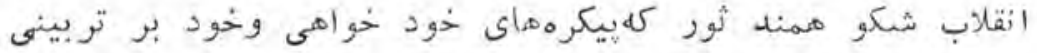

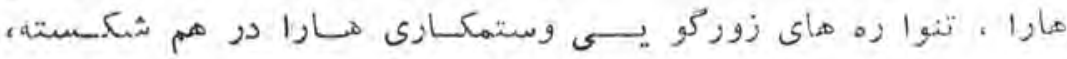




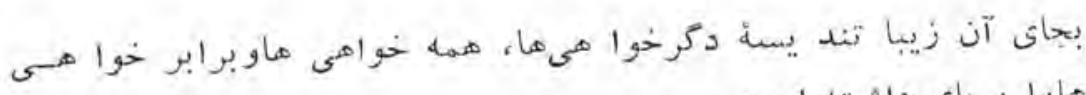
هارا بر ياى داشته است .

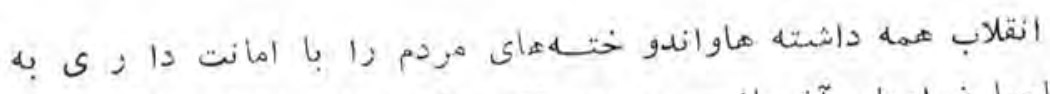

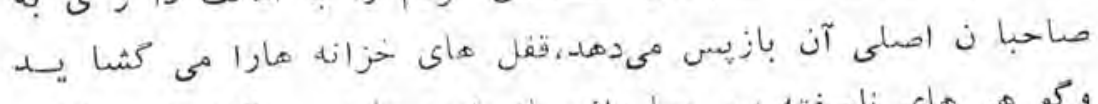

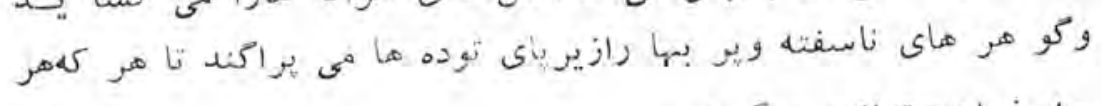

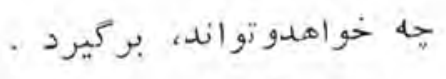

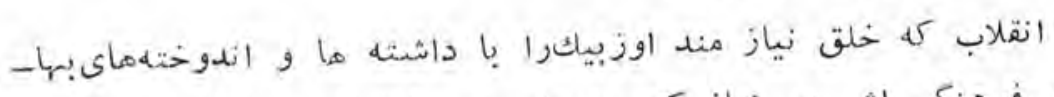

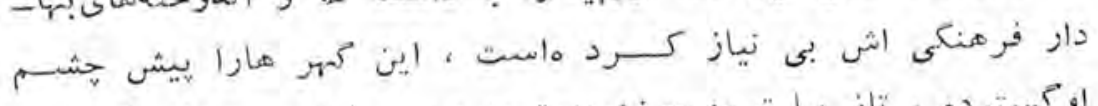

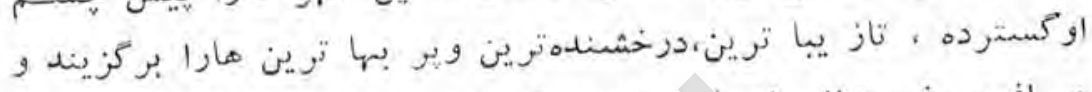

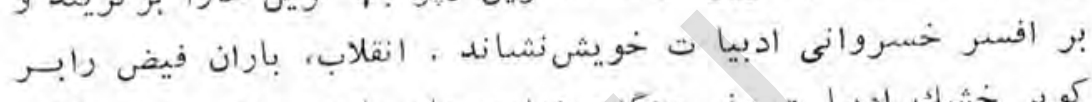

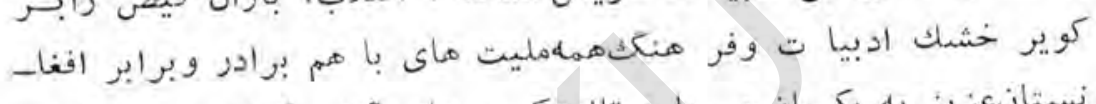

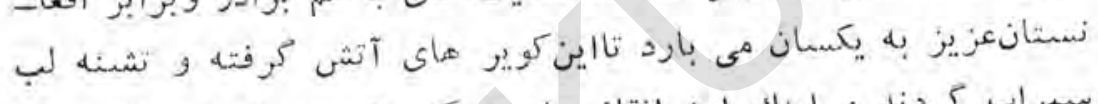

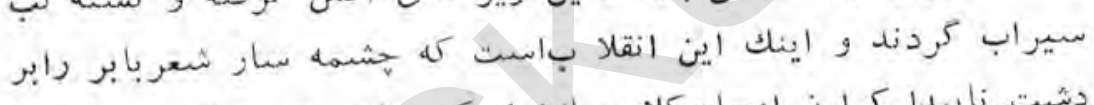

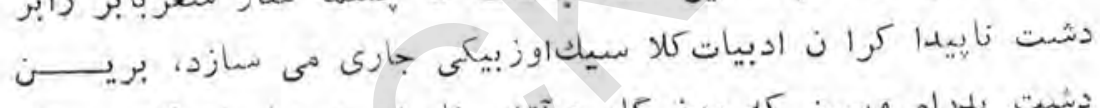

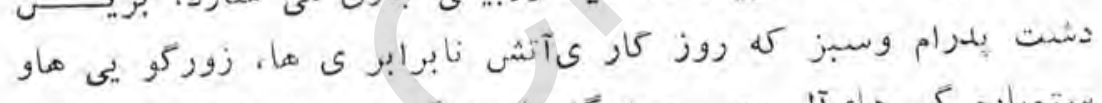

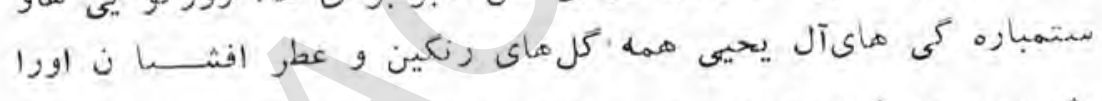

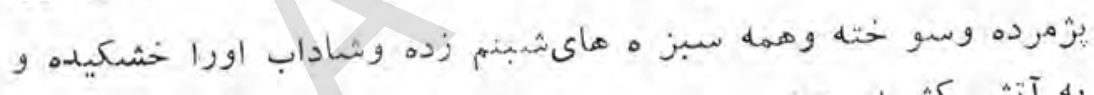

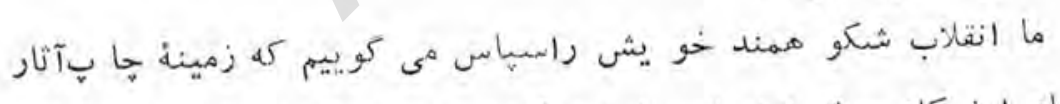

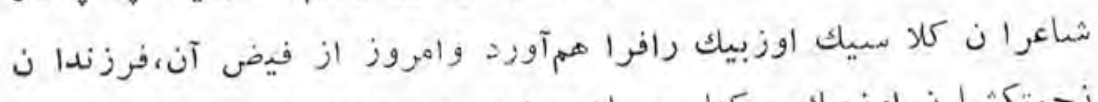

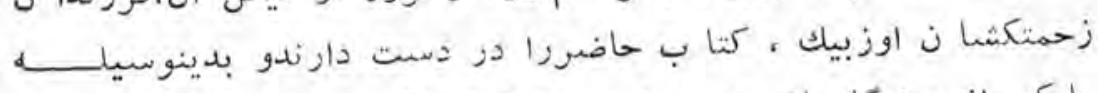

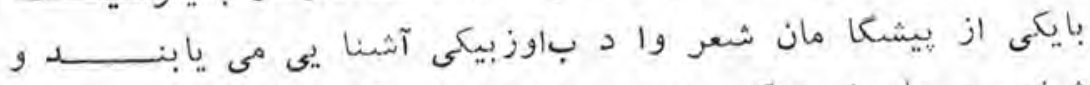

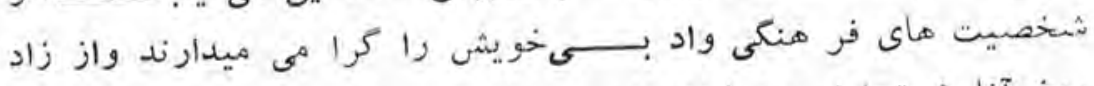

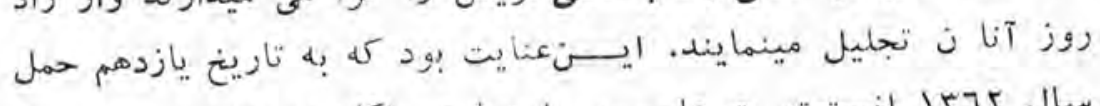

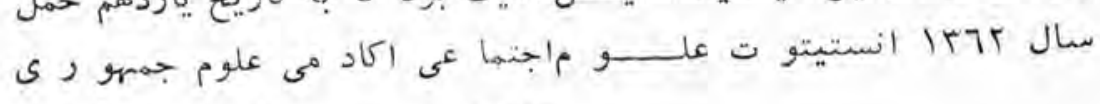


دموكر ا تيك افغا نستا نبنجصفمينسال تولد ظهير الدين محمد بابررا

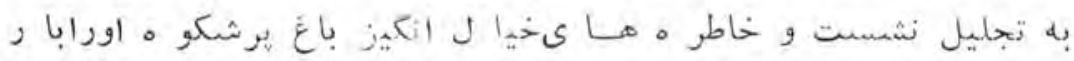

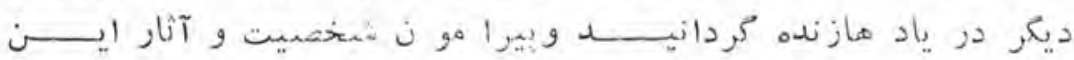

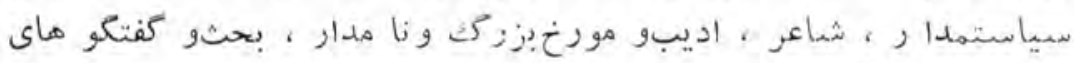

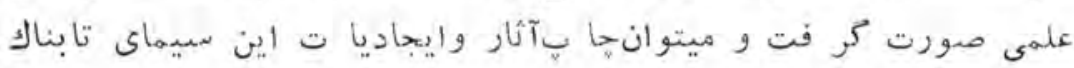

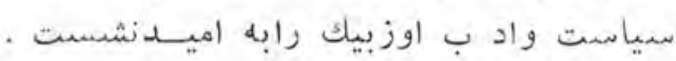

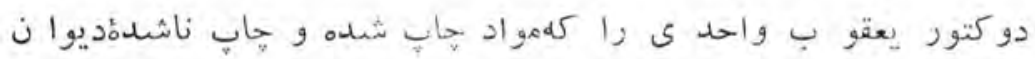

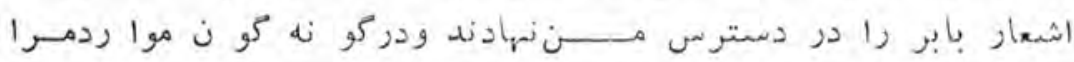

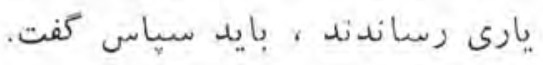
بكذار خورشيد انقلاب يور شكو مثور بر زندكى همه مردم زحمتكش

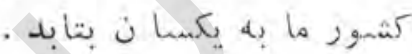

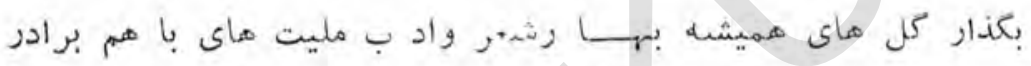

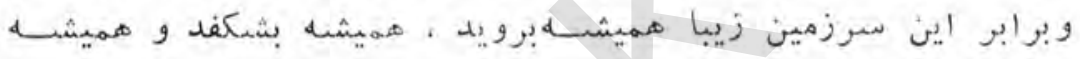

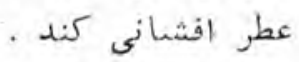
شفيقه يارقين

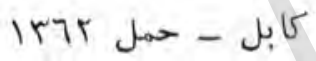




$$
\text { "زو هشیى }
$$




\section{بخش زخست}

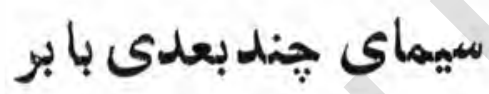

\section{الف - فشرده جستارىبرزيستناهة بابر:}

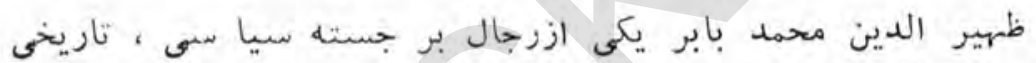

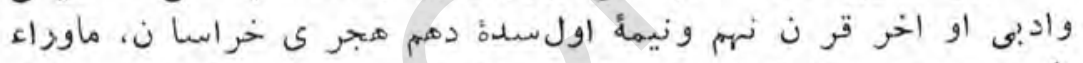

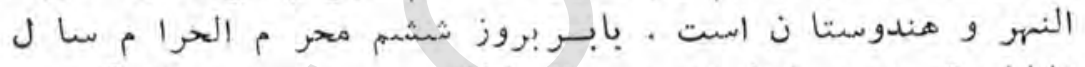

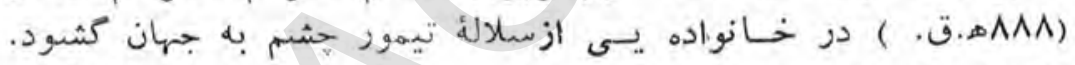

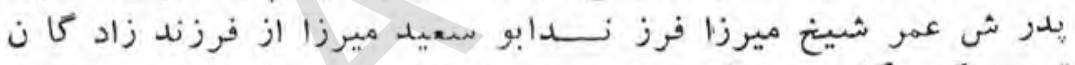

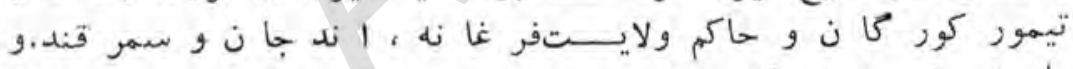

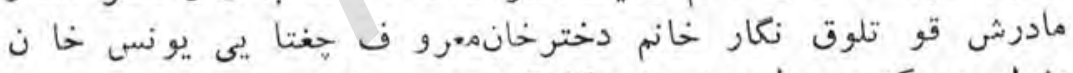

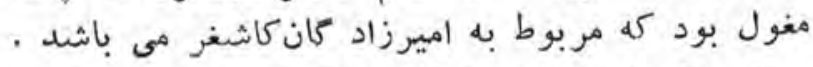

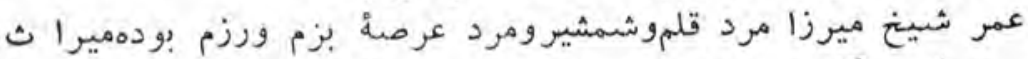

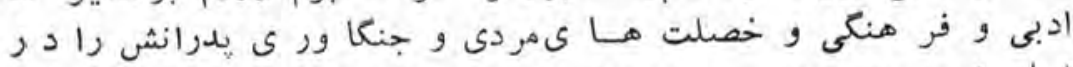

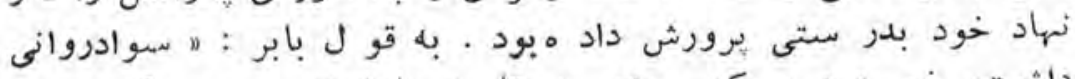

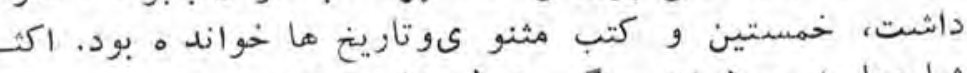

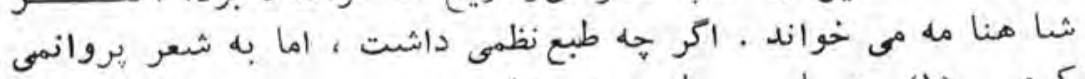

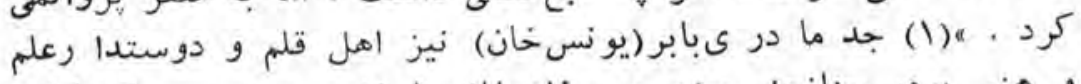

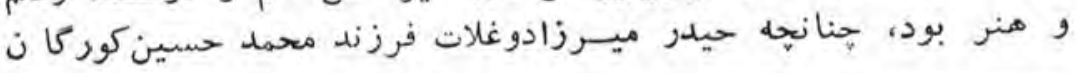

1- توزوك بابرى، تـرجمةعبدالرحيي خان خانان، طبع بمبئى، 


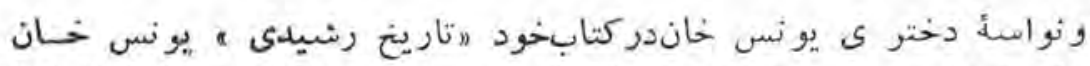

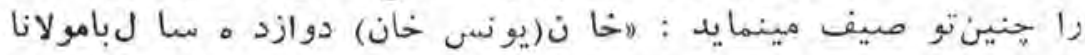

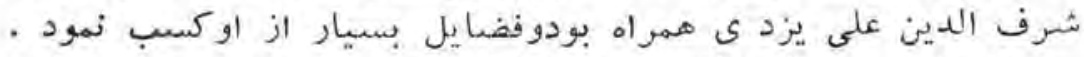

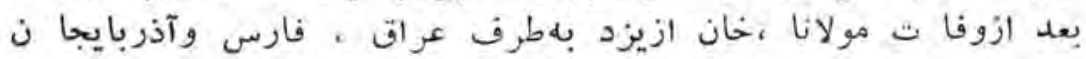

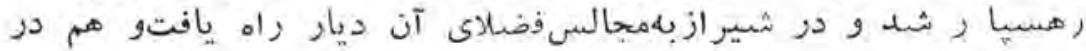

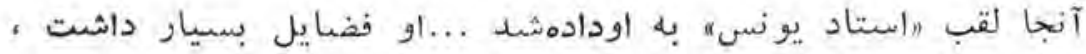

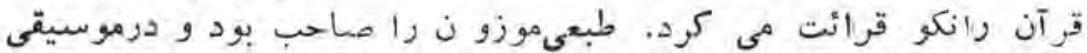

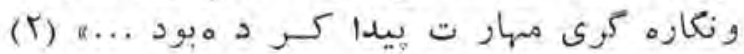

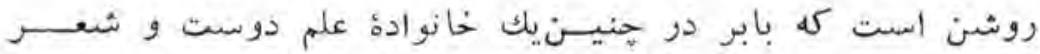

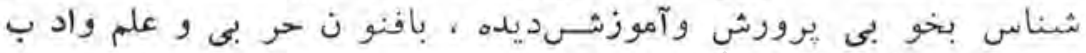

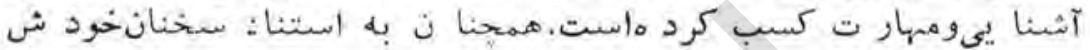

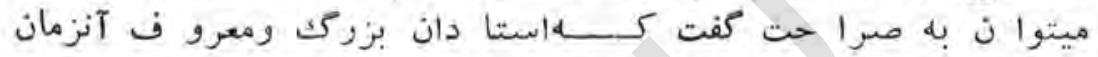

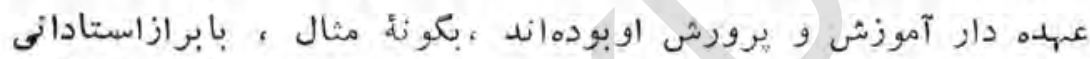

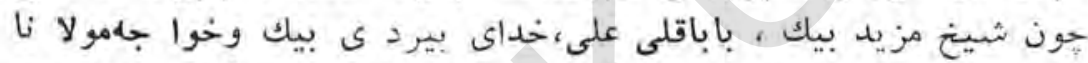

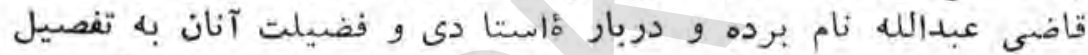

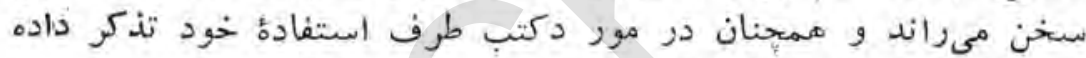

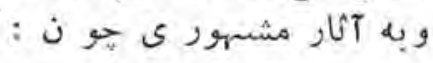

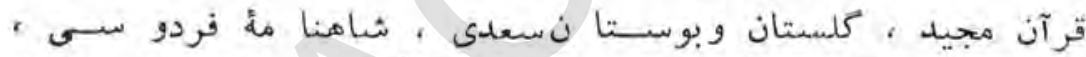

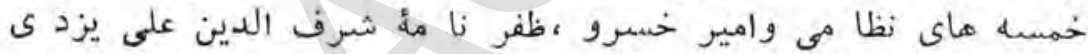

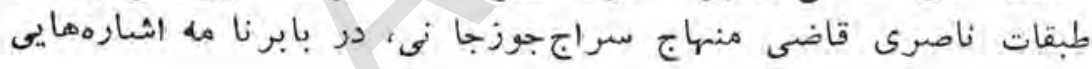
.

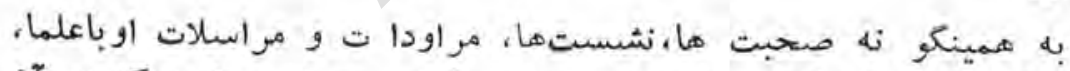

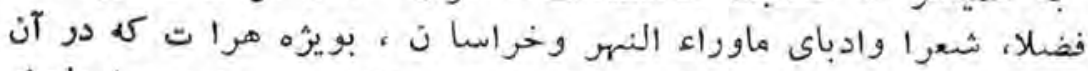

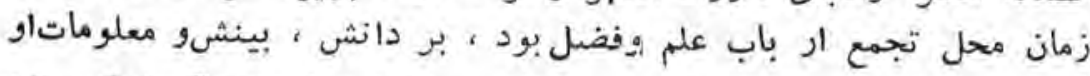

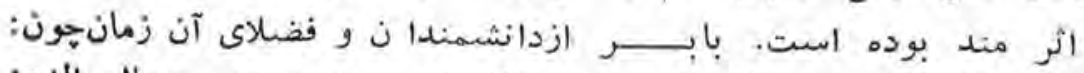

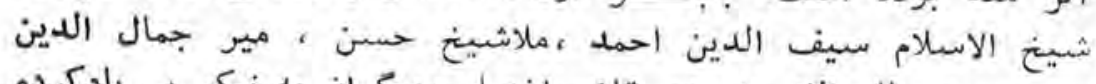

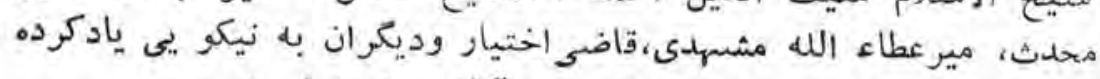

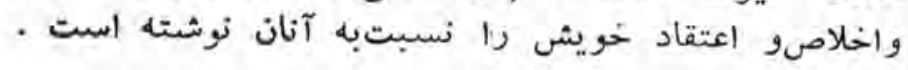

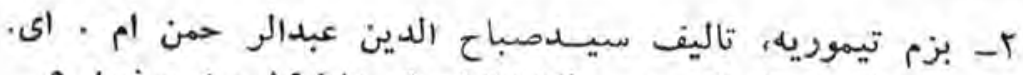

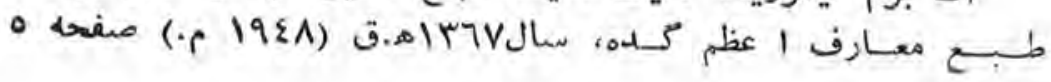




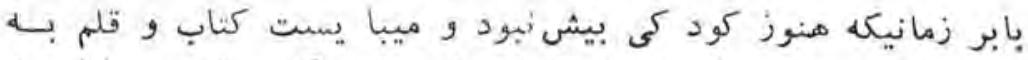

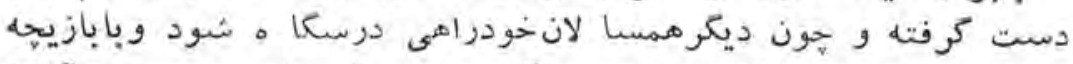

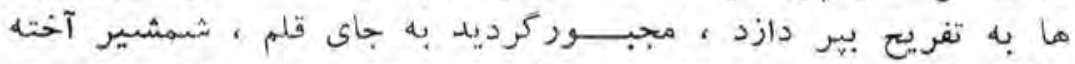

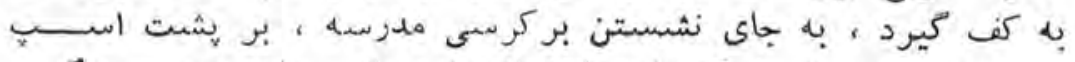

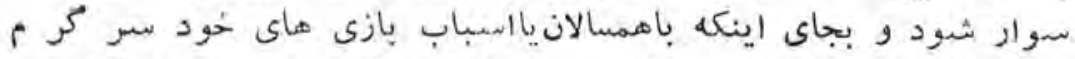

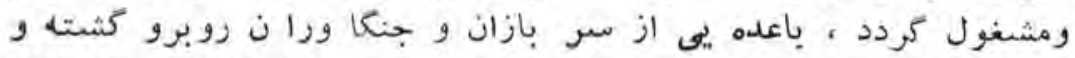

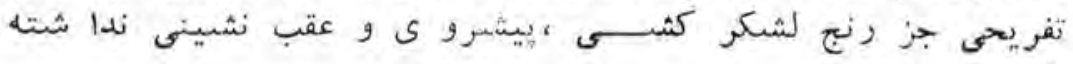
- باثلد

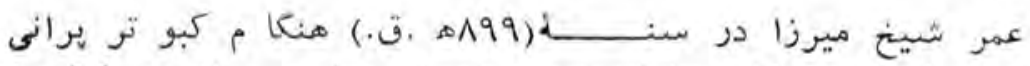

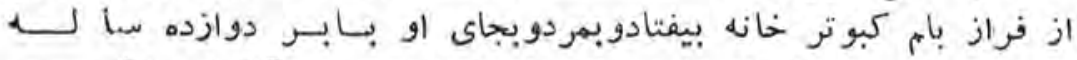

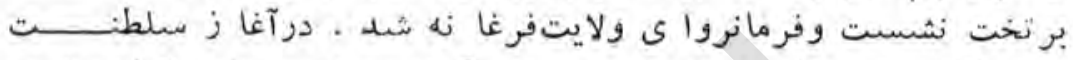

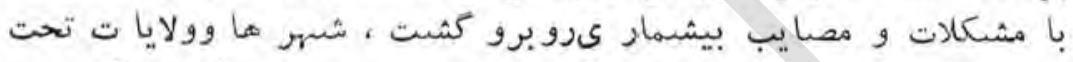

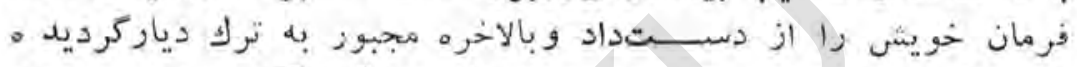

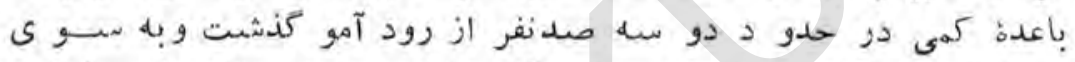

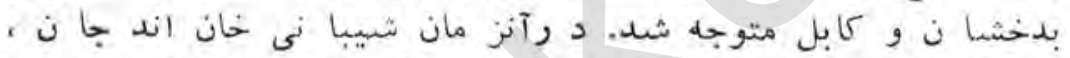

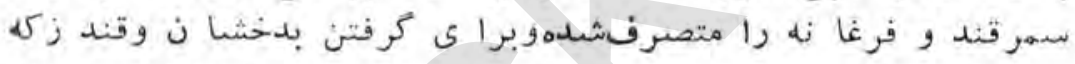

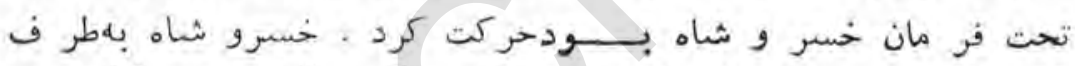

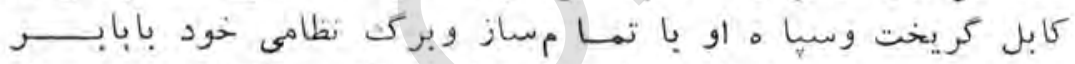

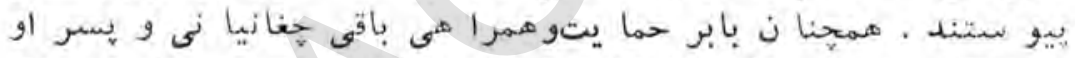

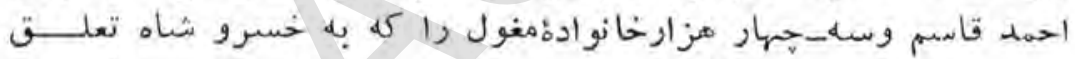

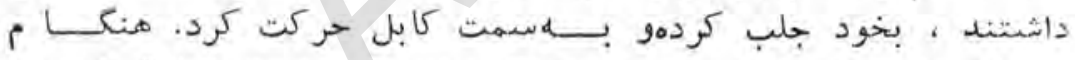

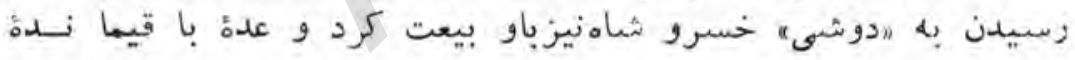

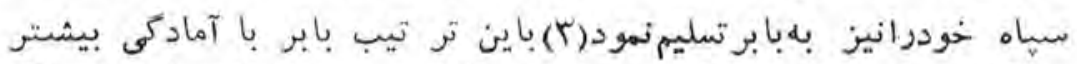

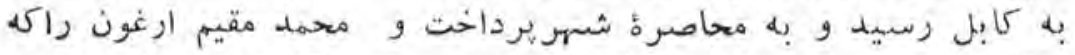
درآنوقت عهله دار حكو مت كابـل بود ، محبور كرد كل تبسيم شود.

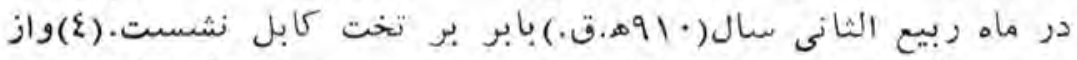
همين سال به بعل بخت واقبا ل بهاو روآورد و شيهر ها وولايا ت

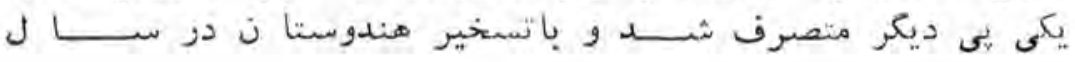

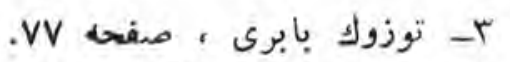

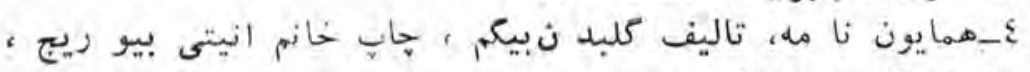

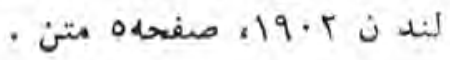




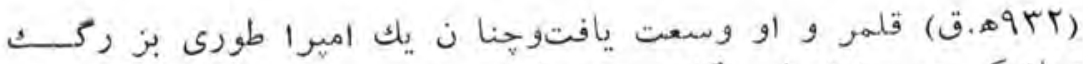

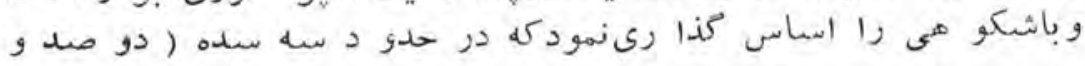

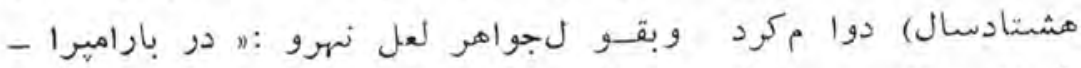

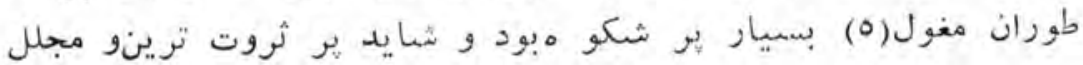

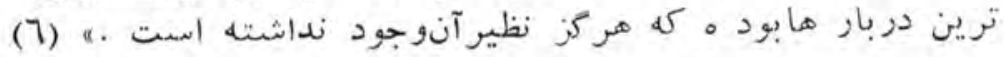

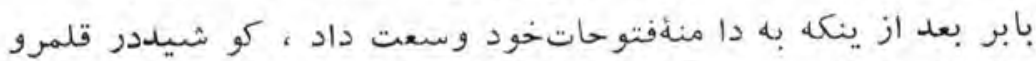

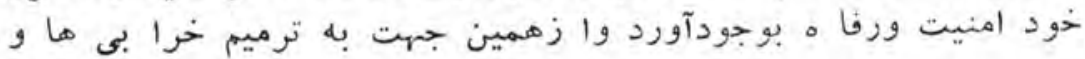

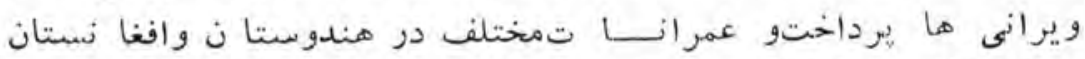

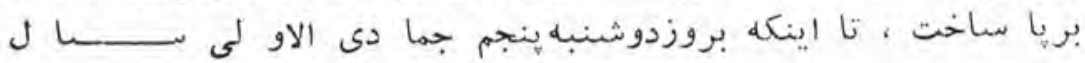

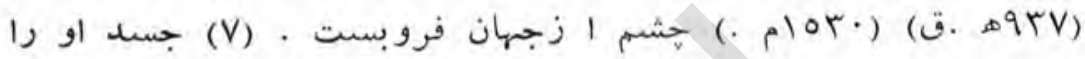

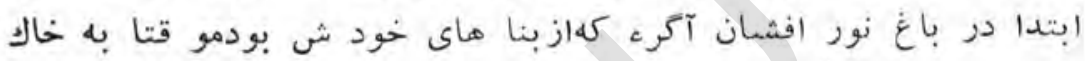

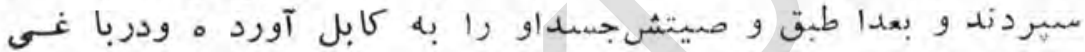

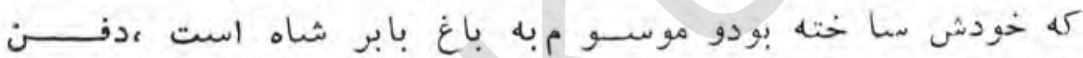

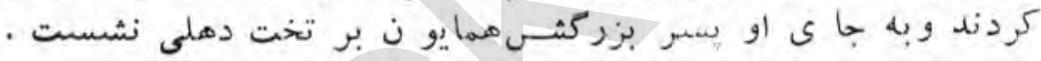

0-اين اصطلاح از طرف ارو هاييان به غلط استعمال شده، بهتبر

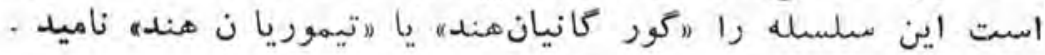

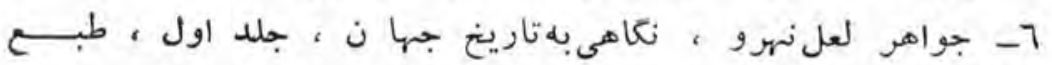
تهرا ن : تصفحه

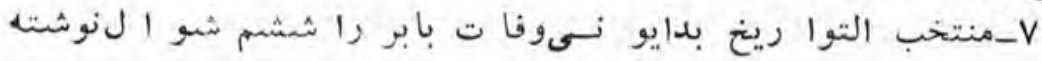




\section{ب-بابر فر مائروا :}

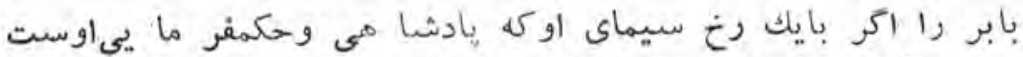

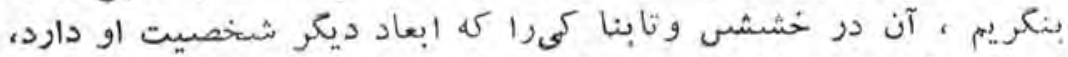

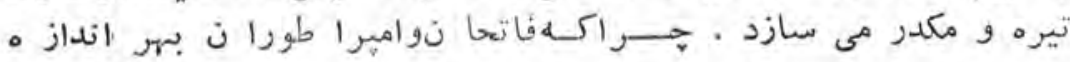

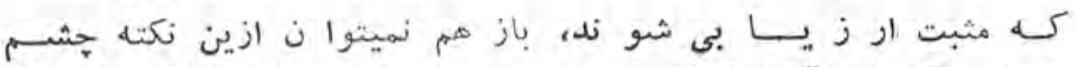

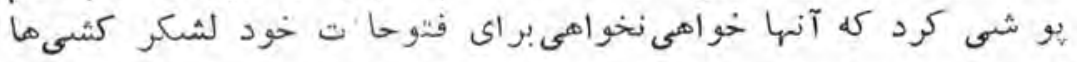

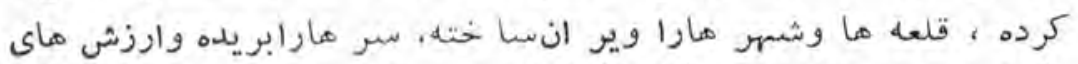

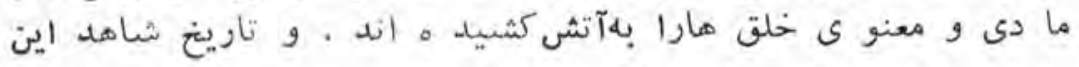

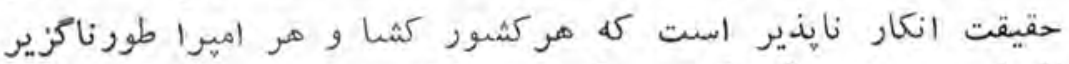

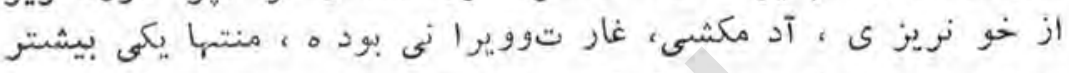

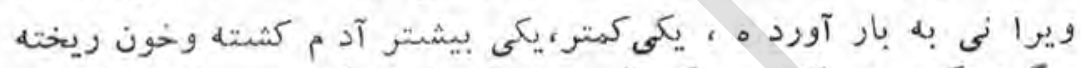

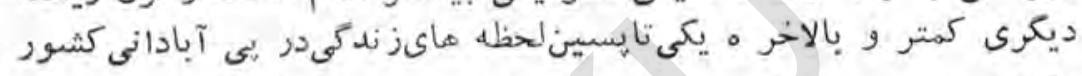

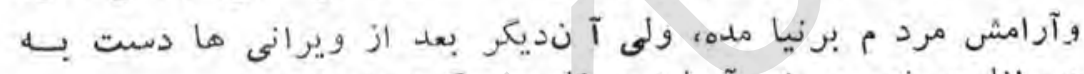

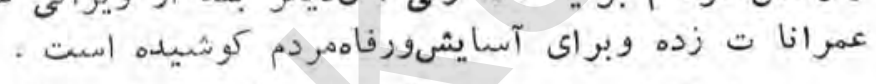

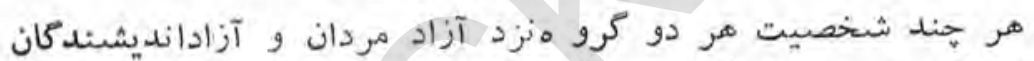

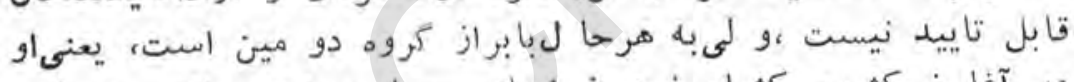

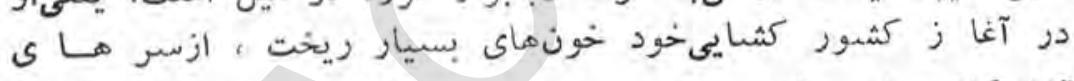

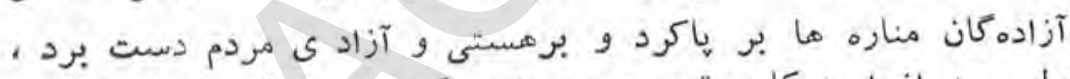

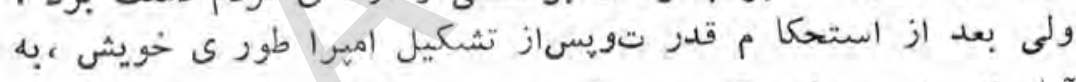

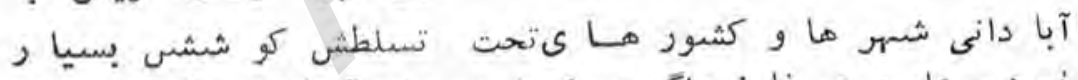

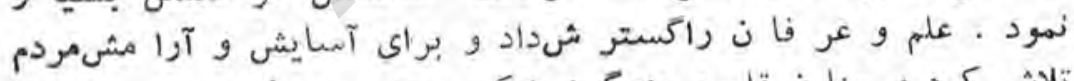

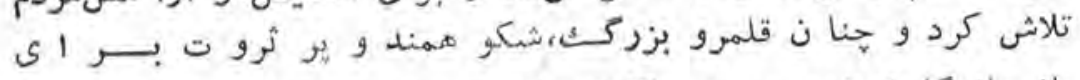

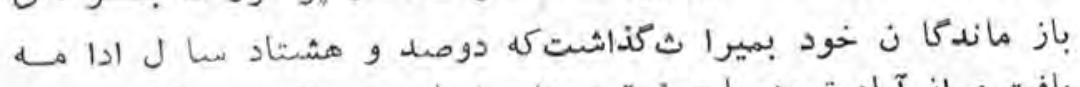

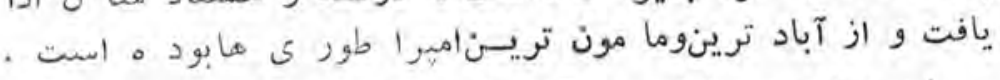

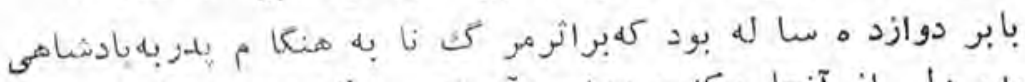

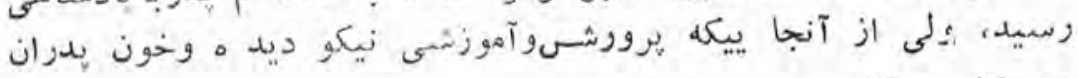

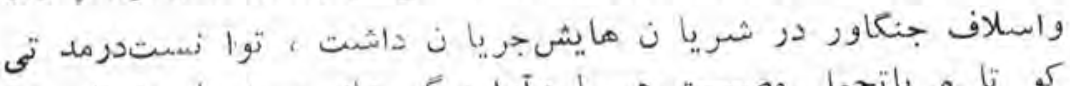

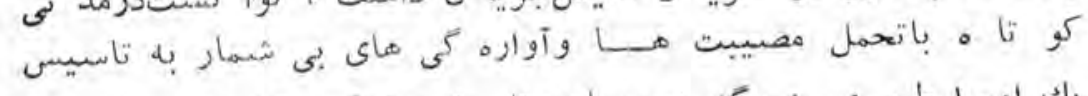

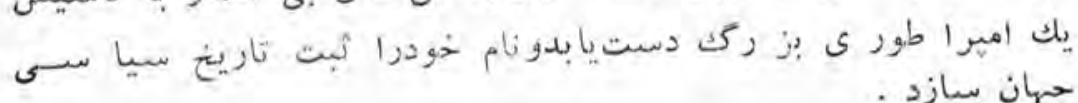

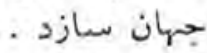




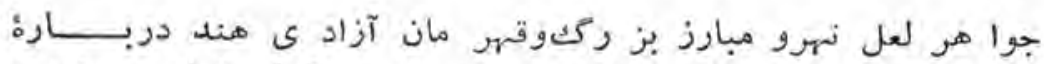

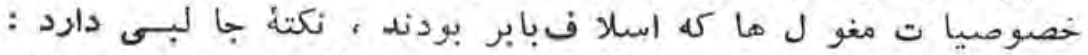

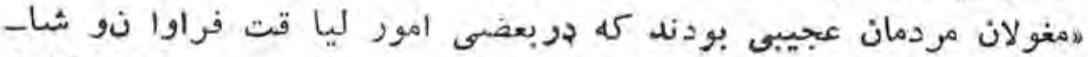

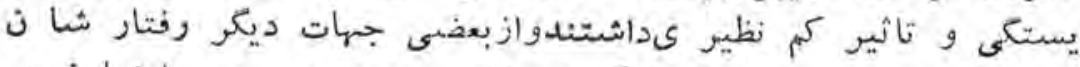

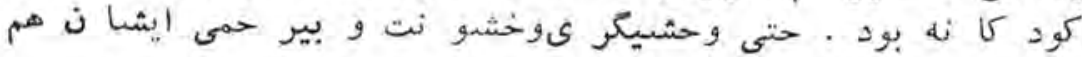

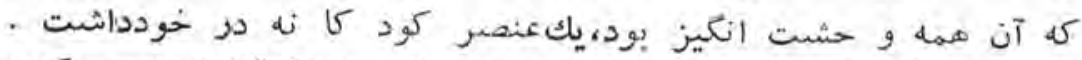

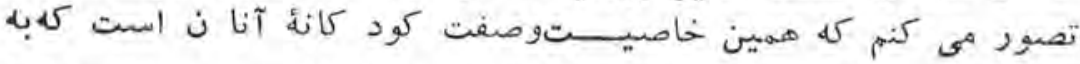

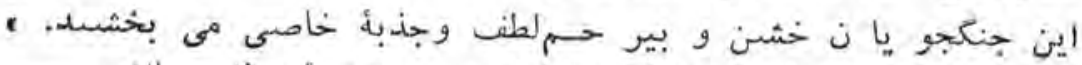

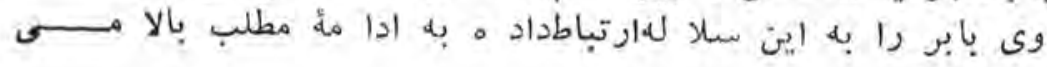

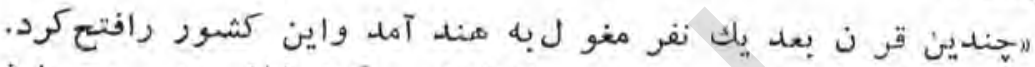

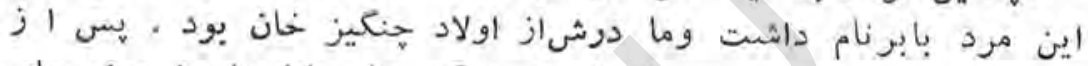

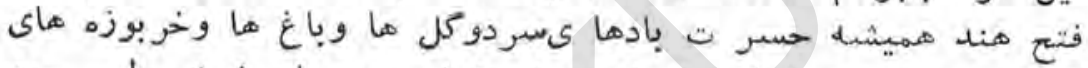

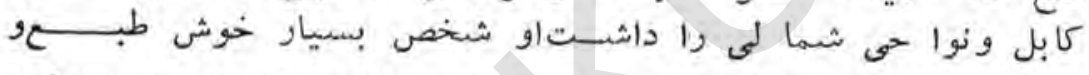

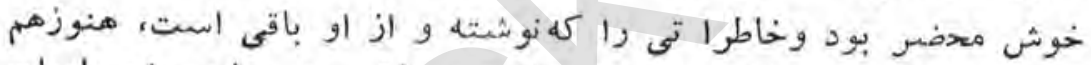

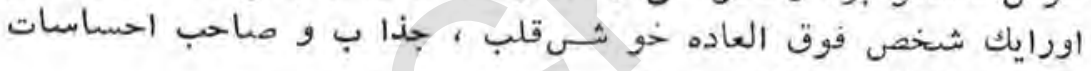

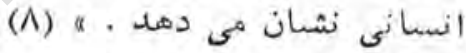

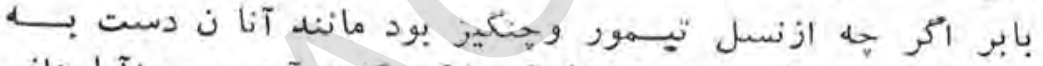

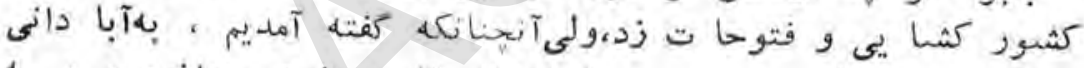

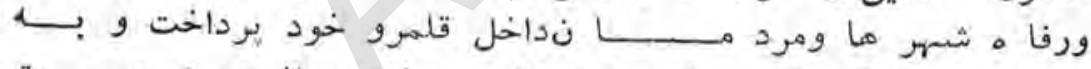

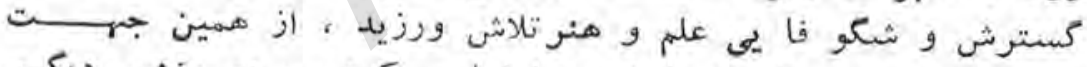

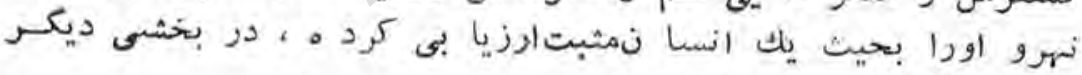

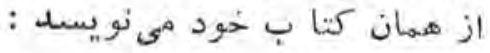

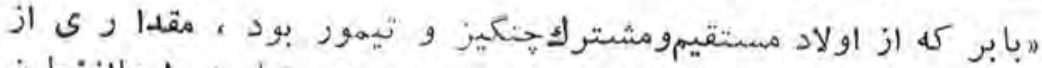

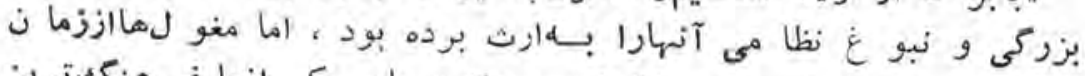

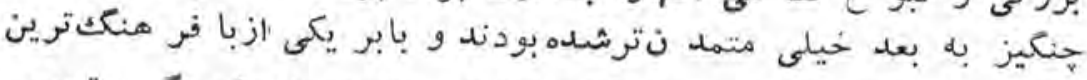

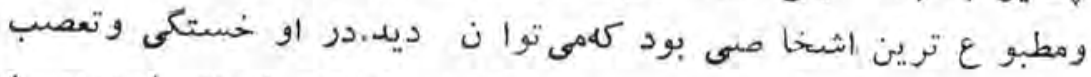

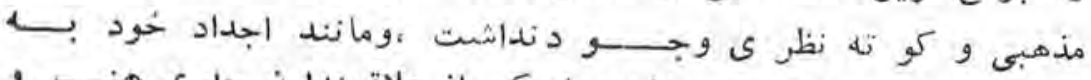

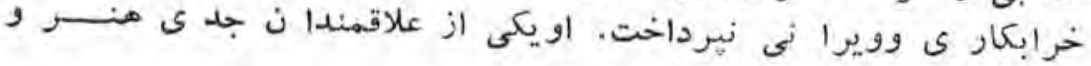

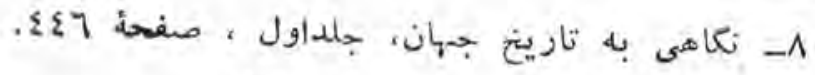




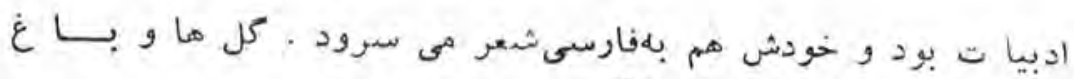

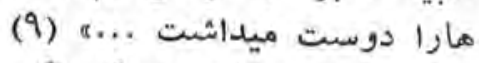

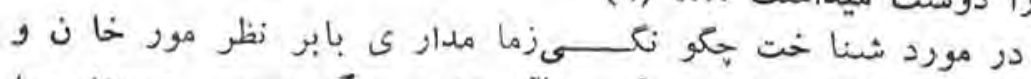

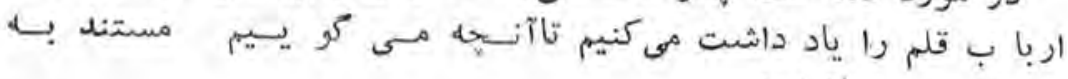

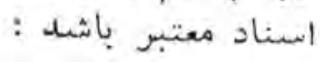

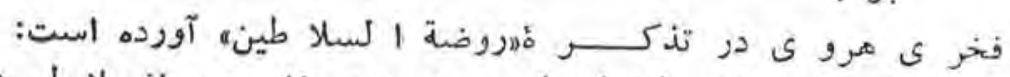

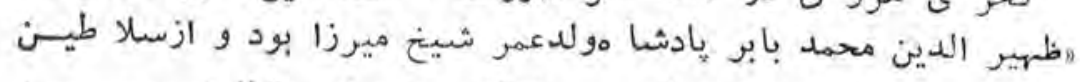

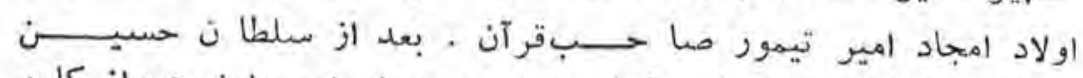

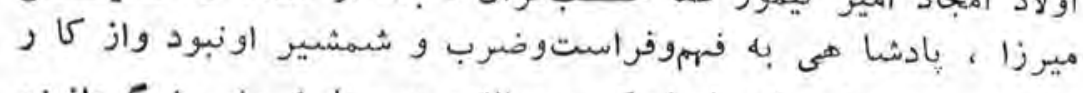

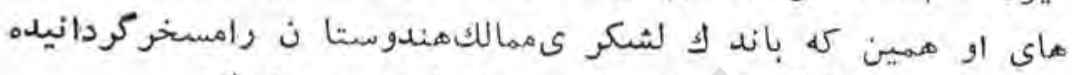

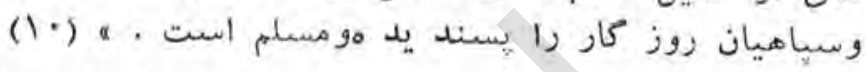

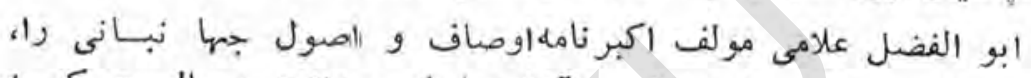

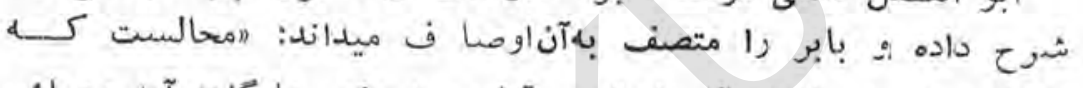

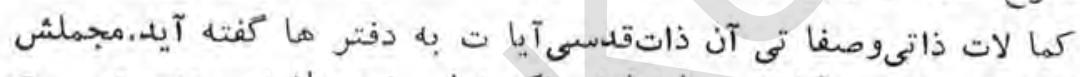

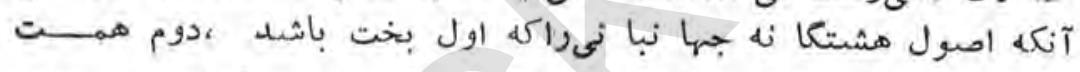

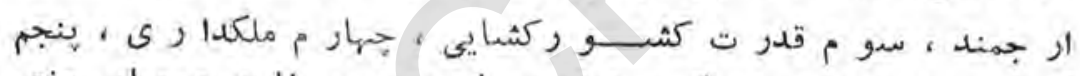

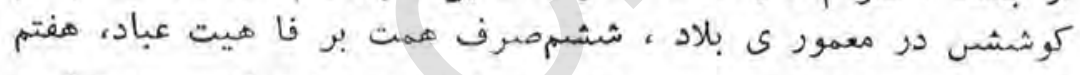

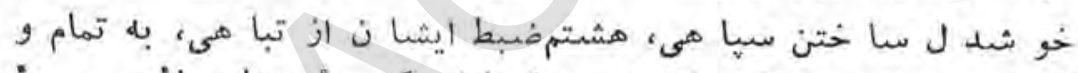

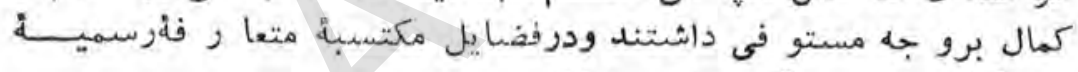

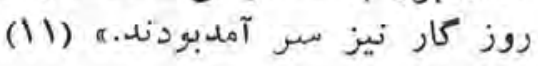

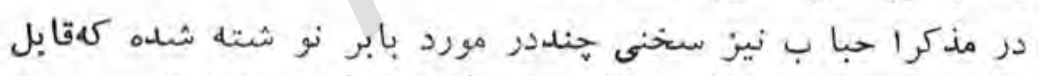

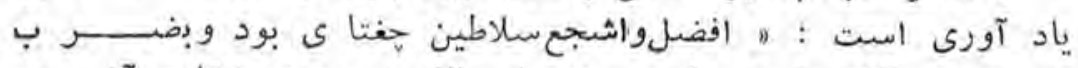

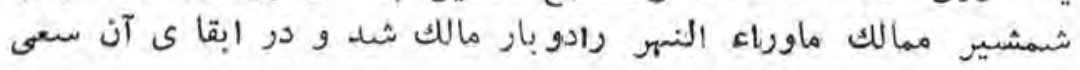

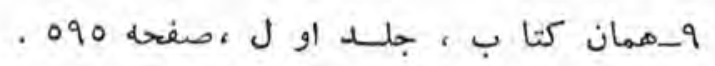

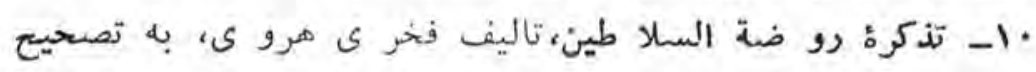

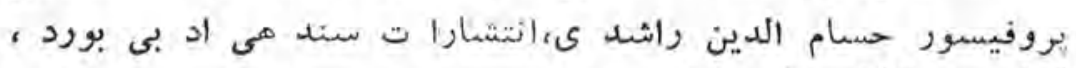

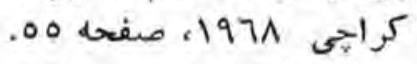

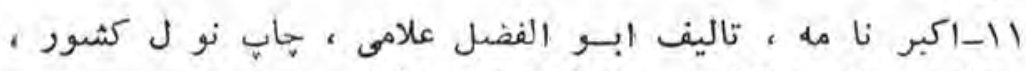

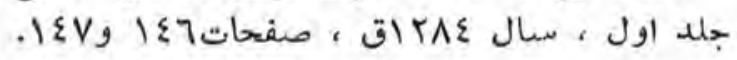
- مفتث 


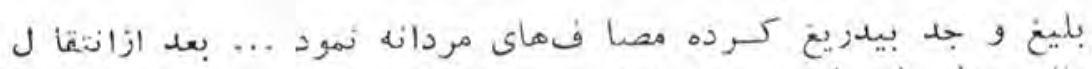

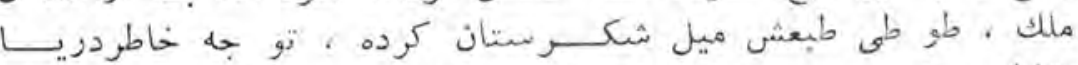

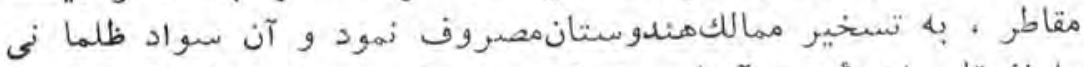

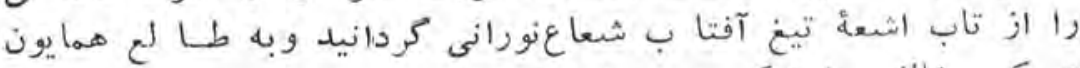

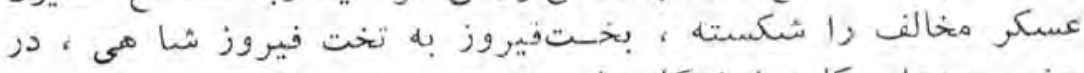

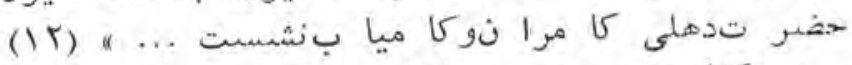

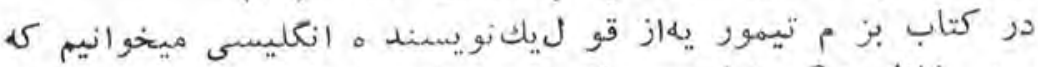

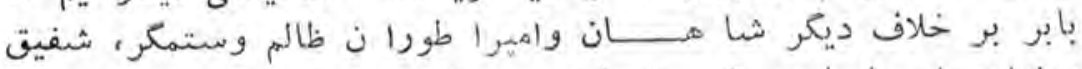

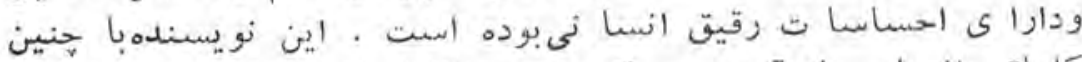

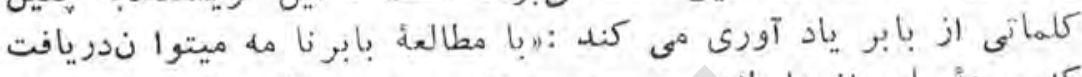

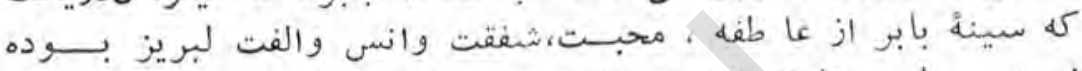

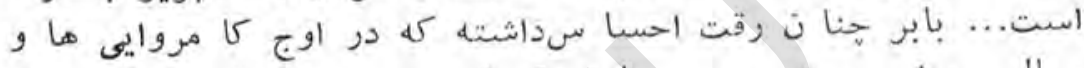

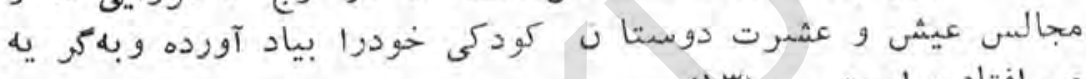

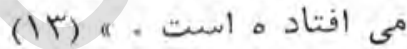

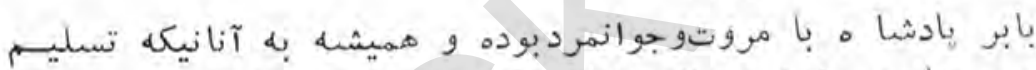

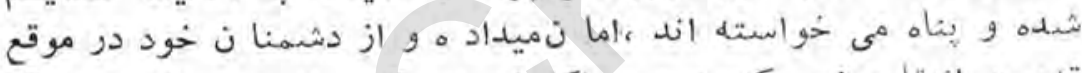

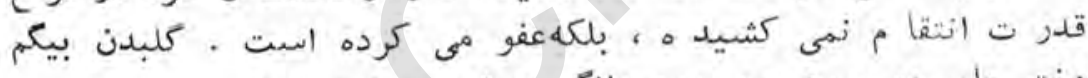

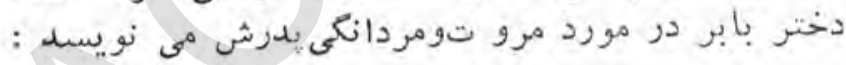

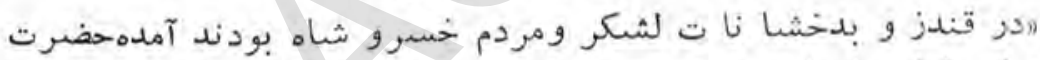

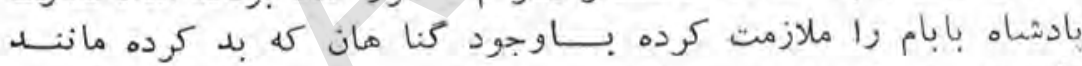

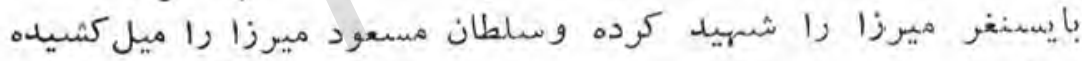

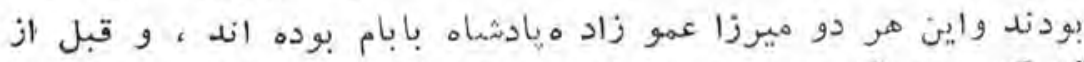

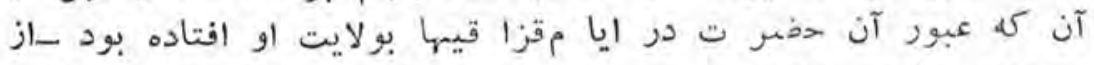

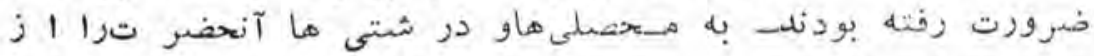

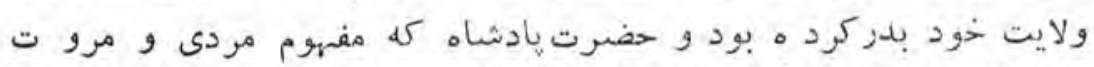

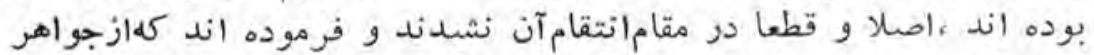

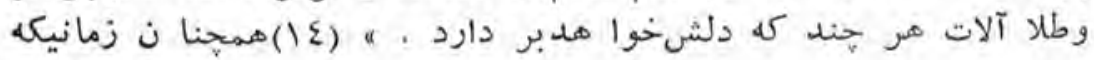

كاب- مذكر احباب، نسخة خطى.

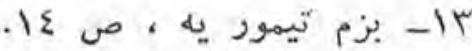

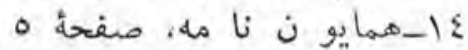




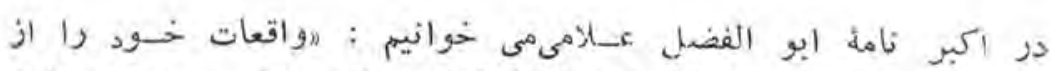

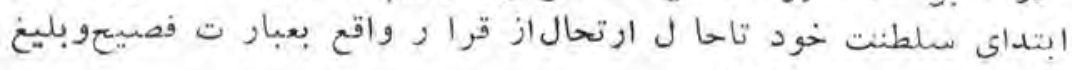

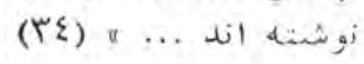

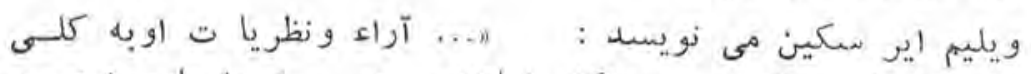

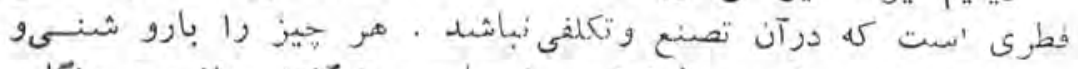

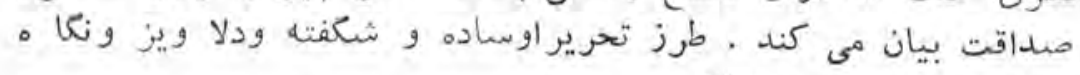

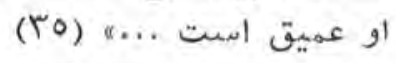

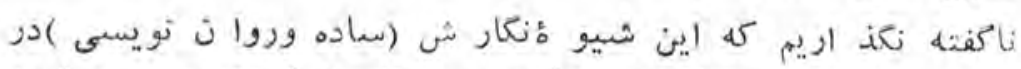

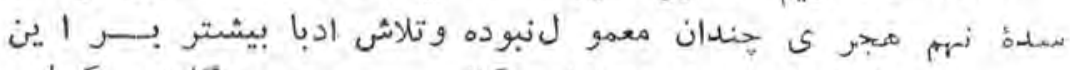

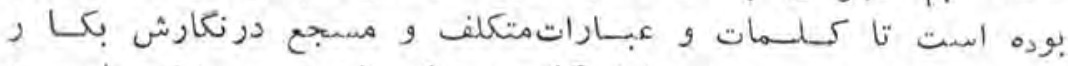

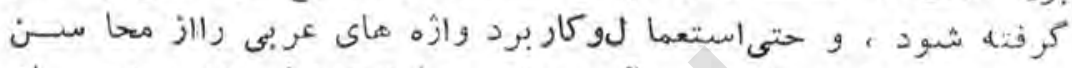

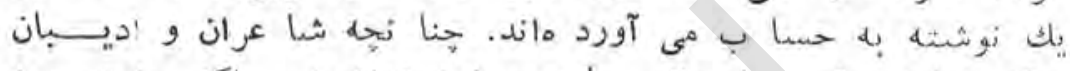

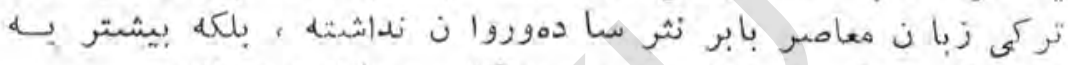

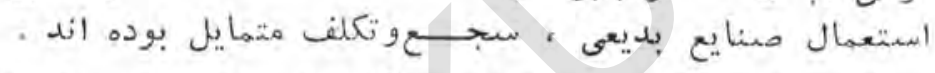

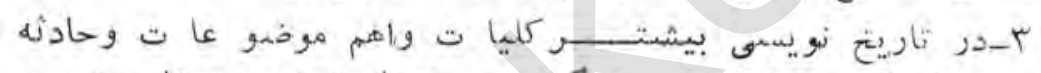

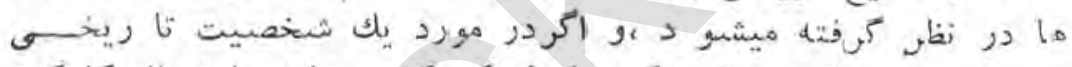

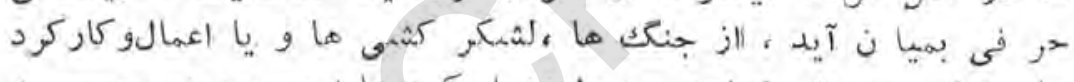

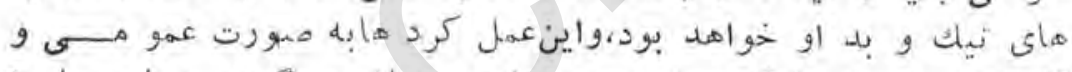

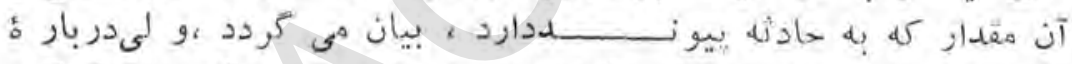

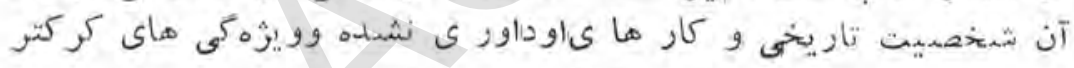

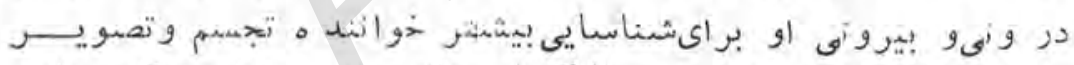

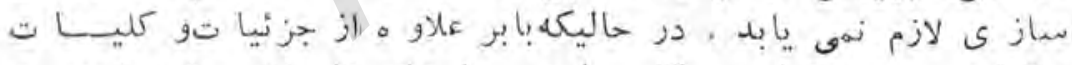

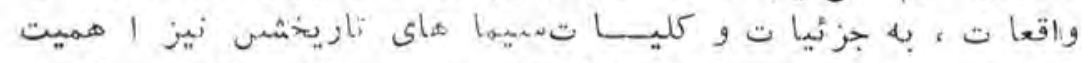

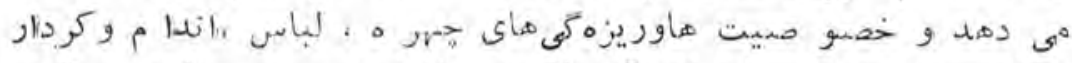

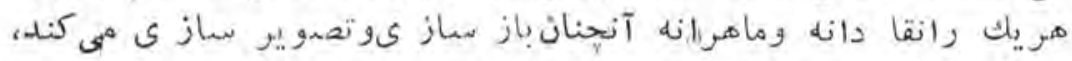

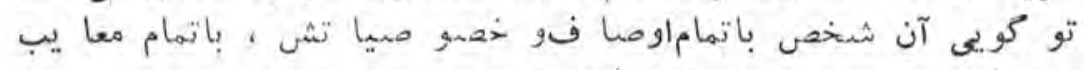

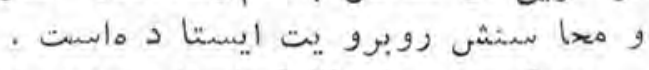

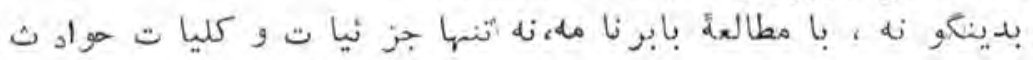

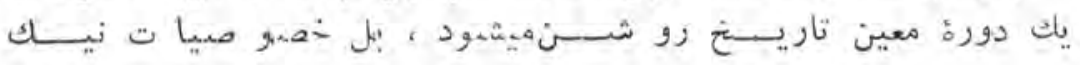

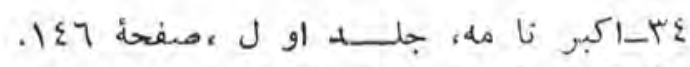

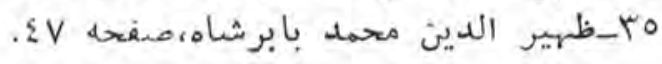




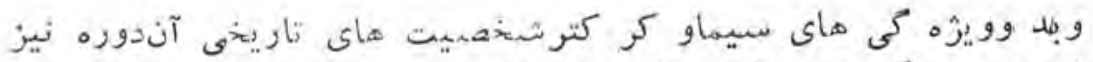

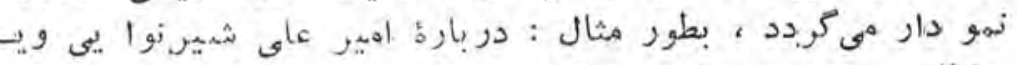

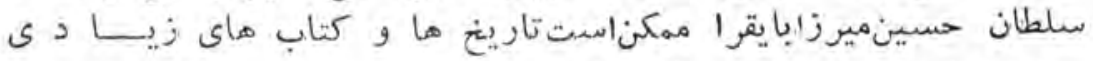

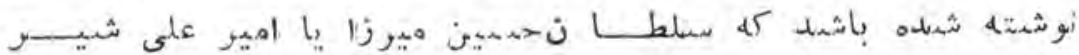

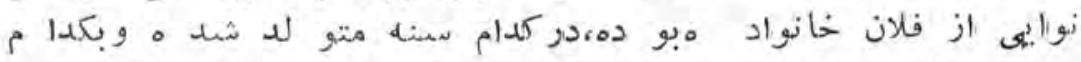

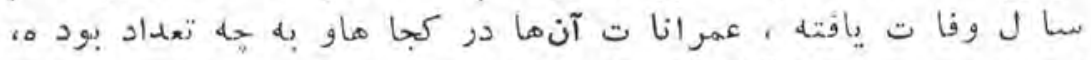

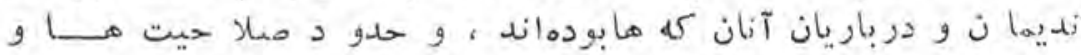

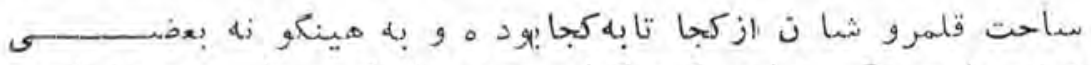

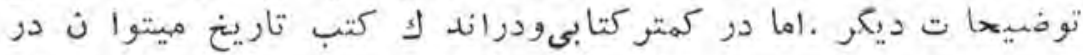

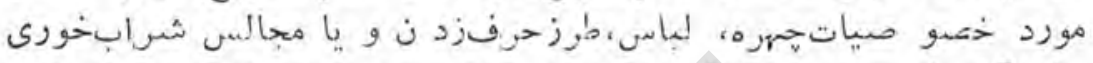

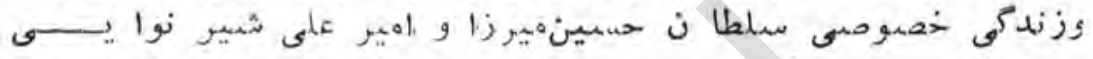

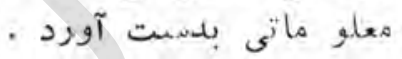

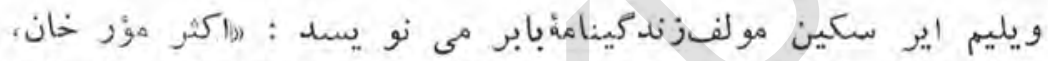

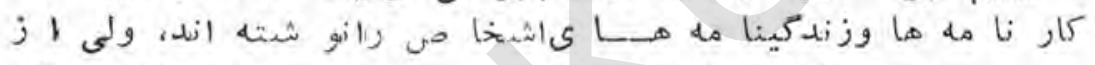

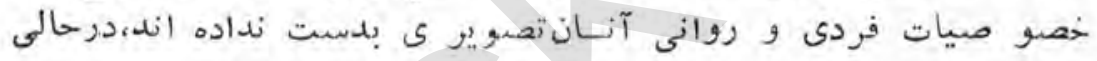

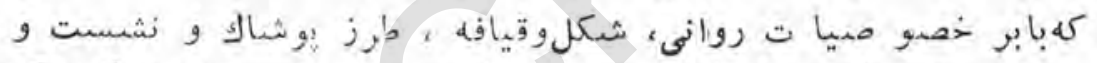

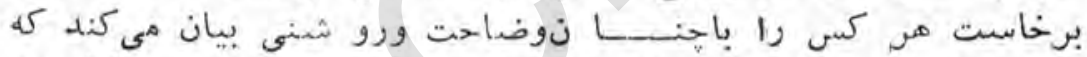

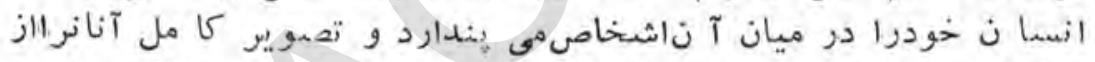

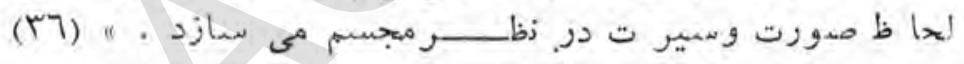

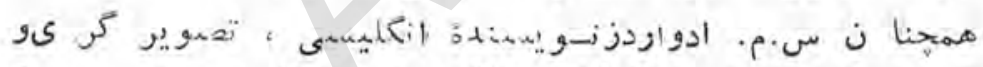

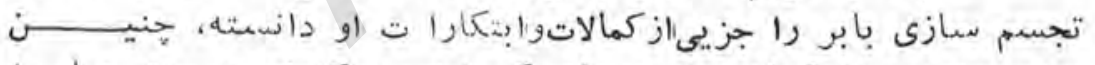

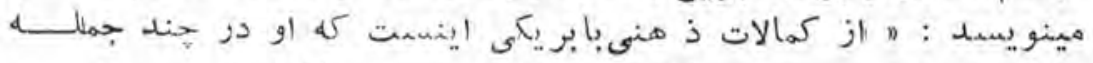

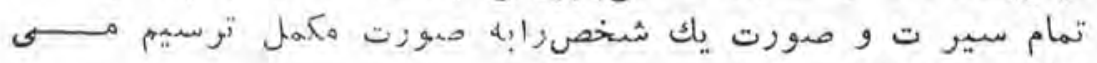

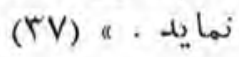

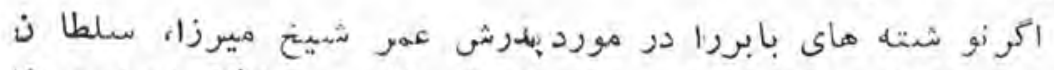

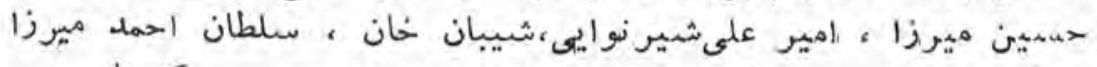

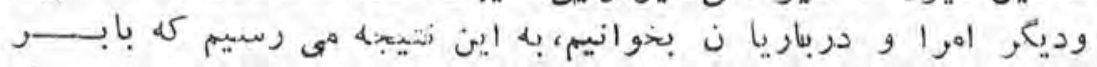

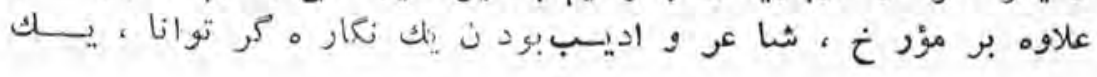

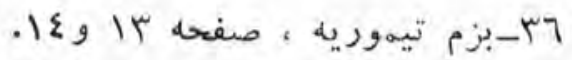

IV 


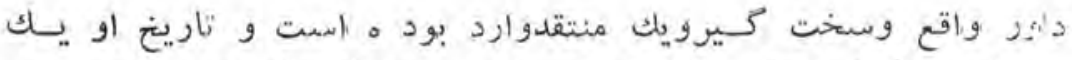

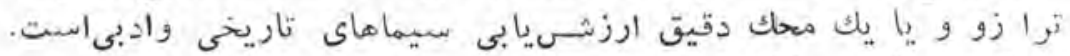

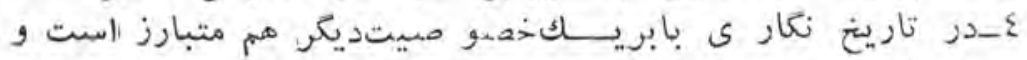

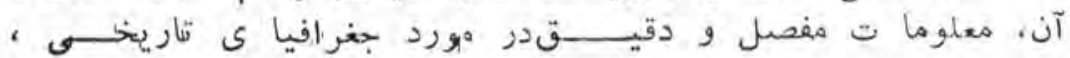

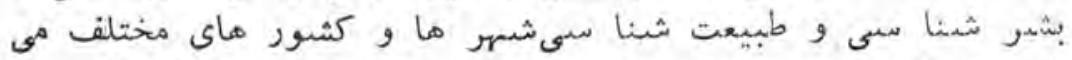

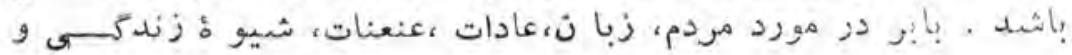

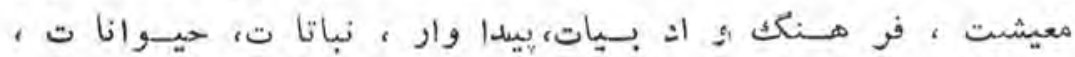

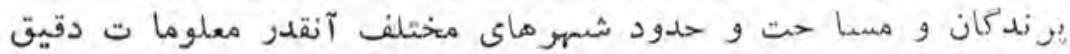

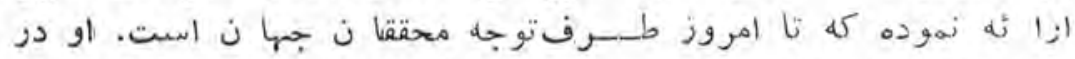

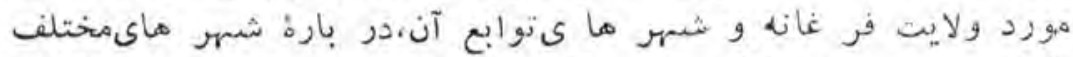

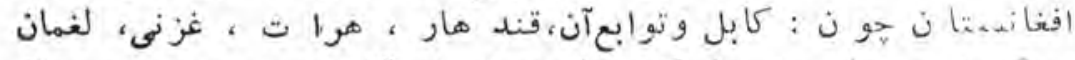

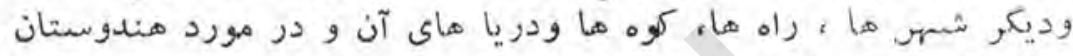

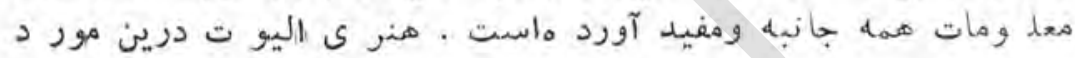

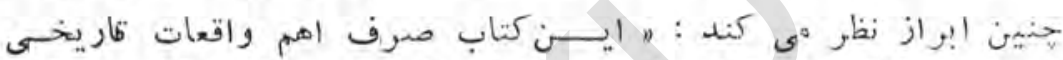

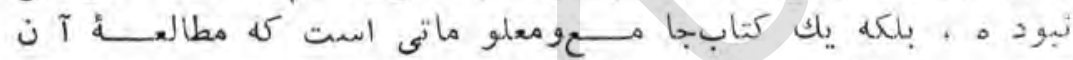

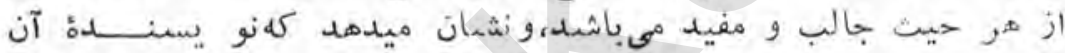

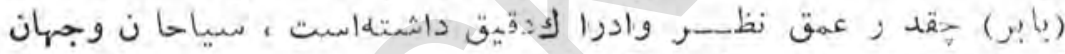

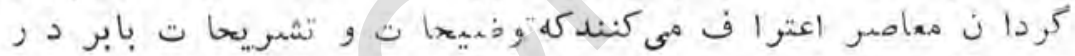

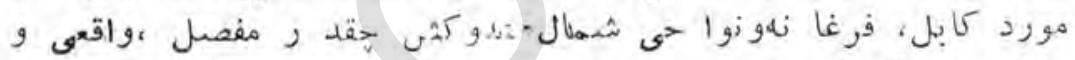

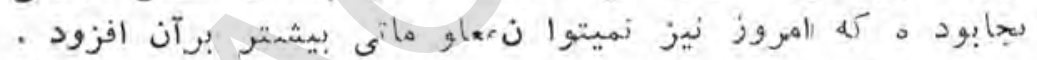

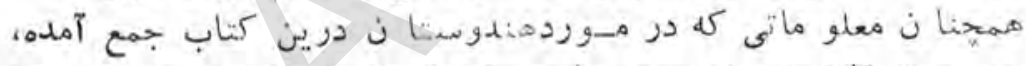

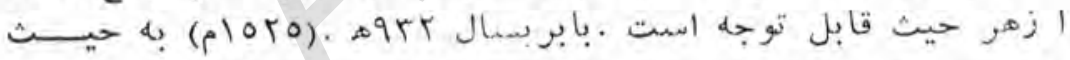

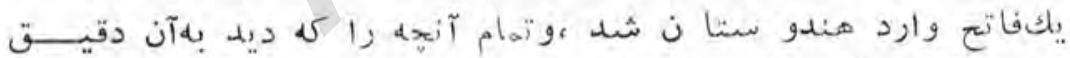

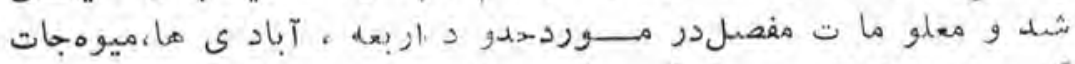

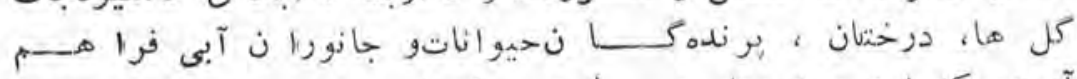

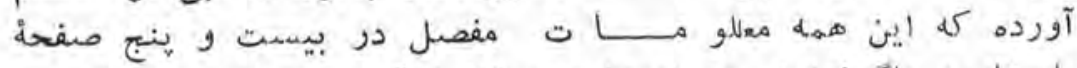

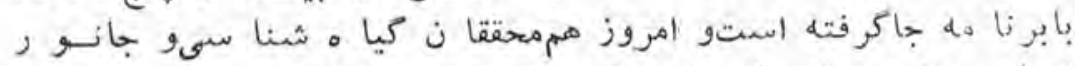

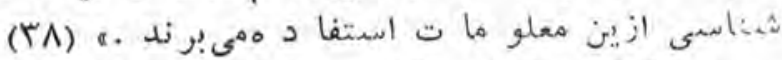

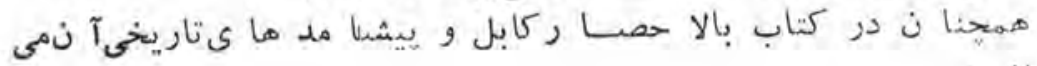
i >

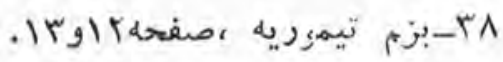




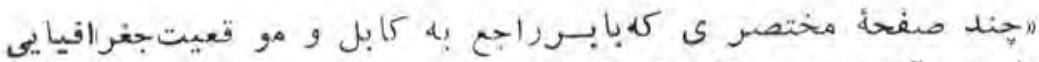

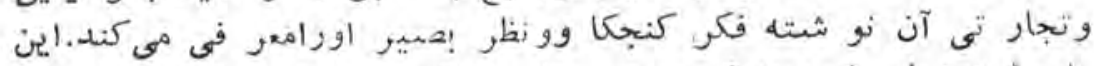

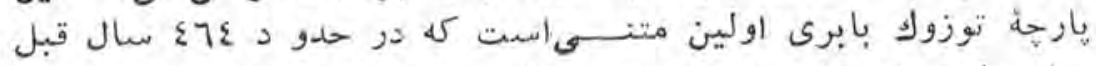

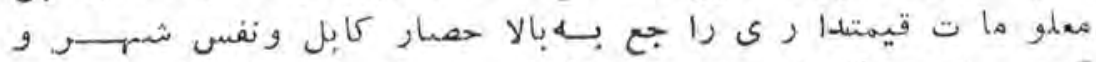

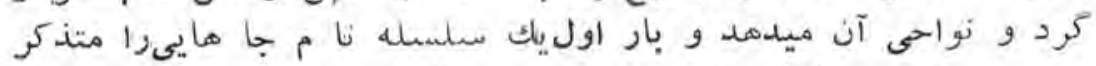

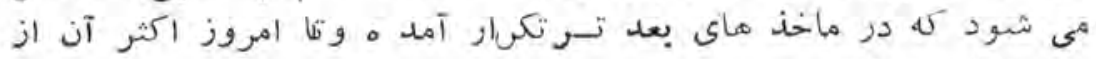

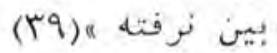

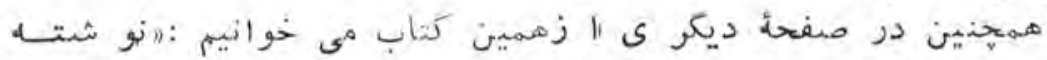

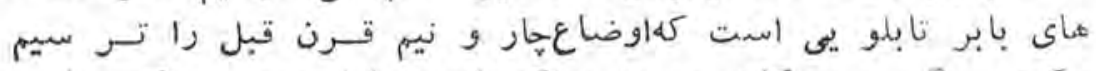

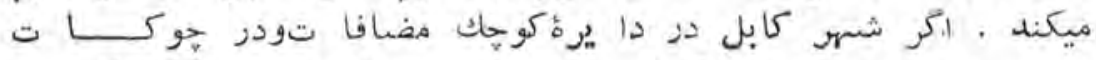

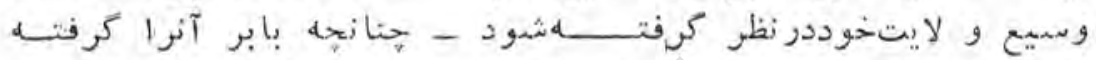

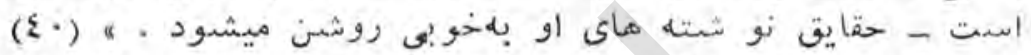

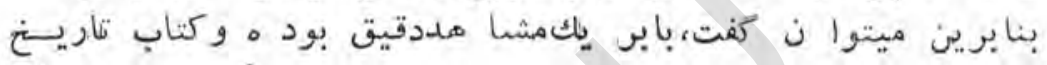

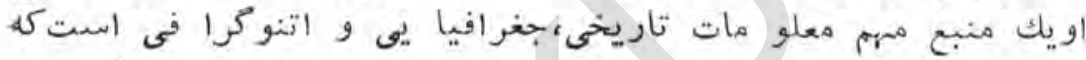

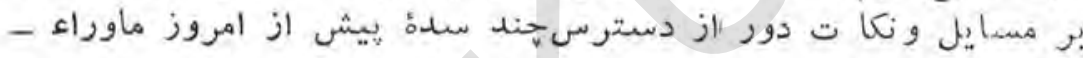

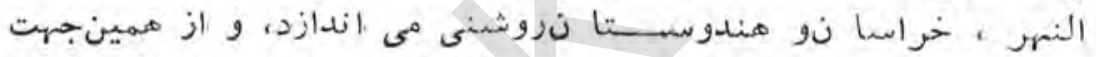

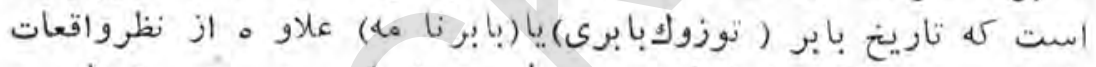

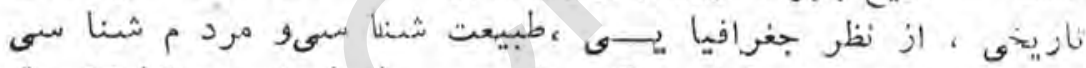

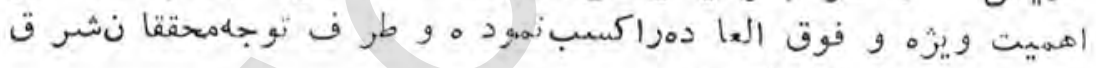

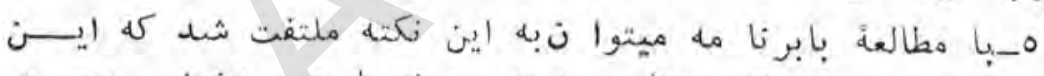

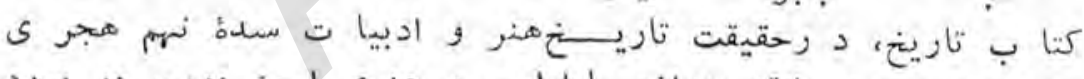

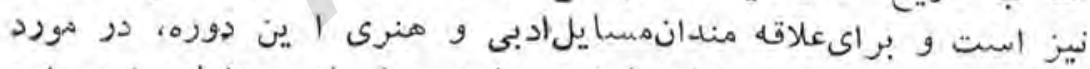

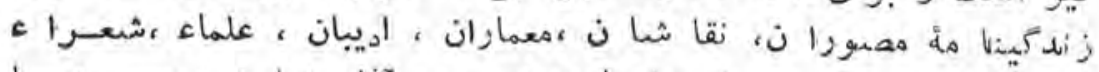

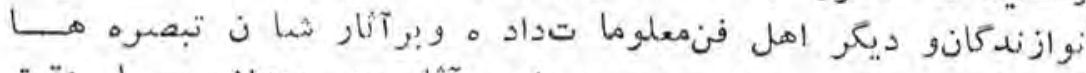

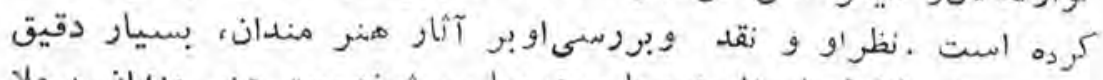

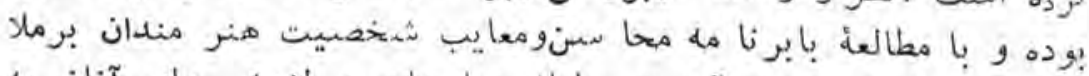

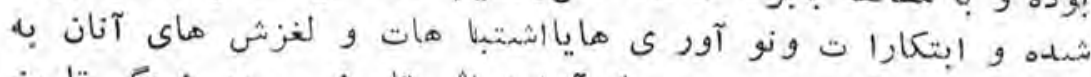

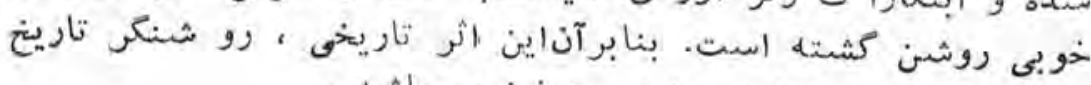

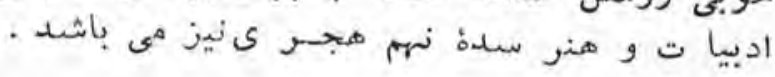

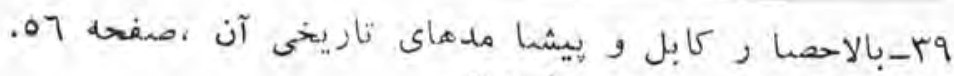
. 


\section{د - بابر سرايشكسر اذيب ودو ستدار هنر :}

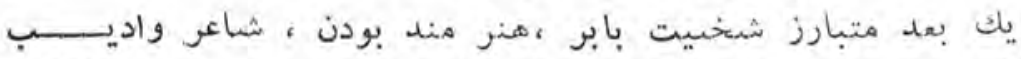

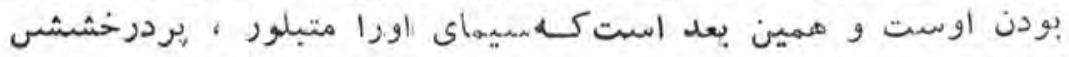

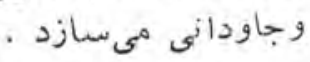

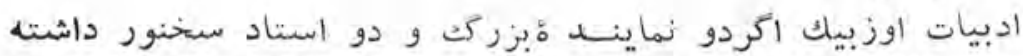

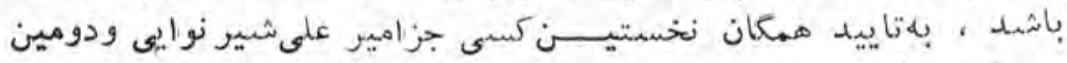

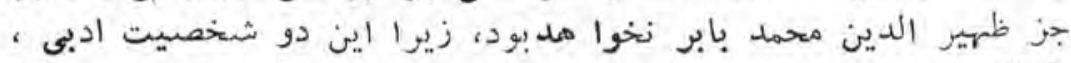

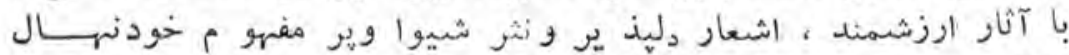

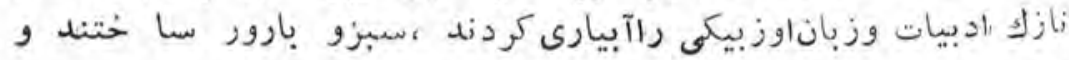

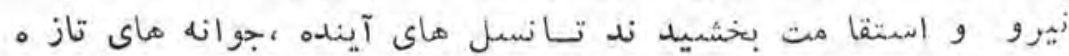

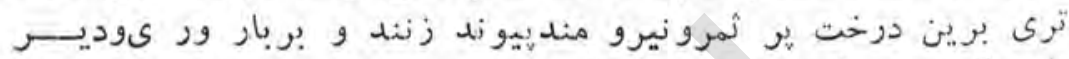

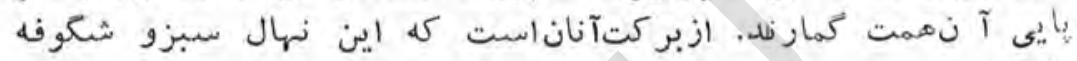

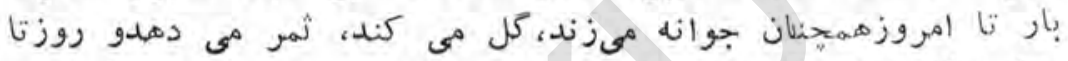

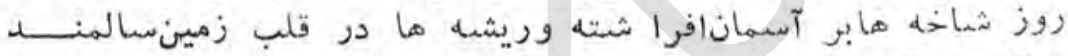

$$
\text { - كن }
$$

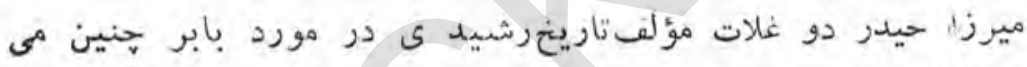

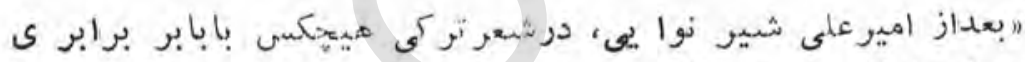

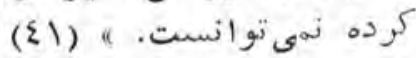

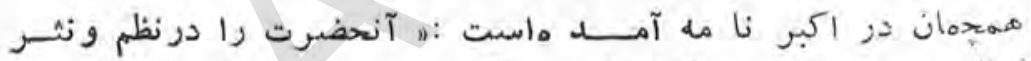

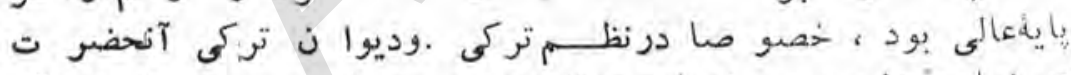

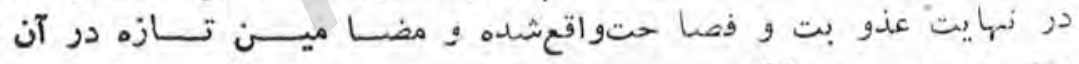

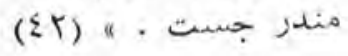

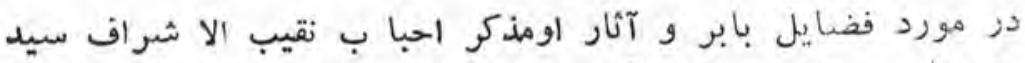

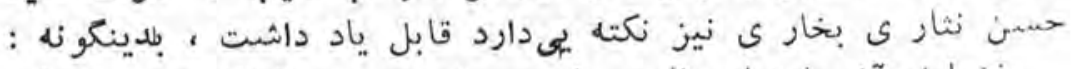

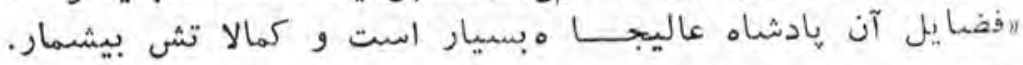

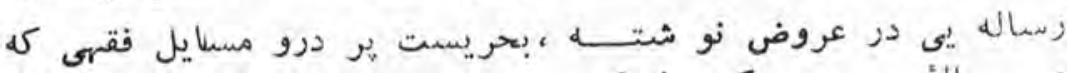

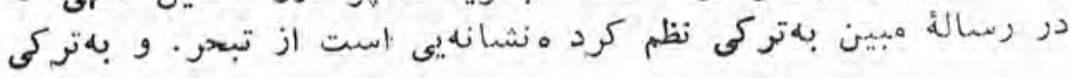




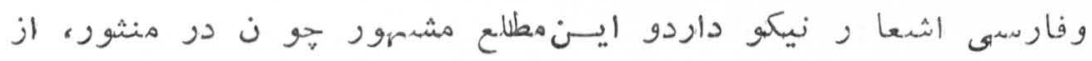

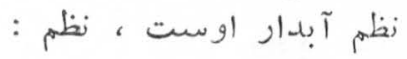

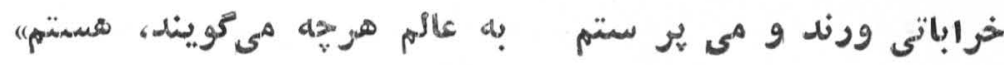

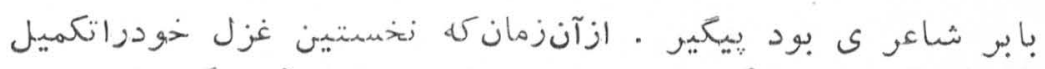

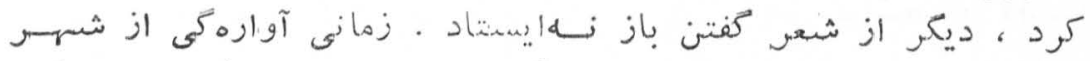

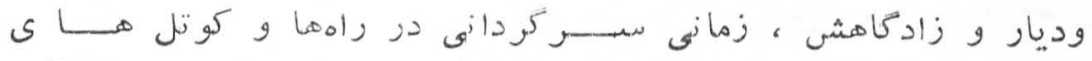

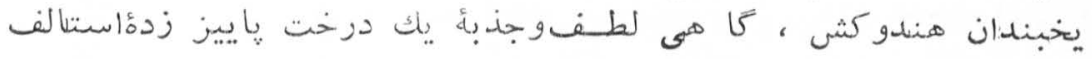

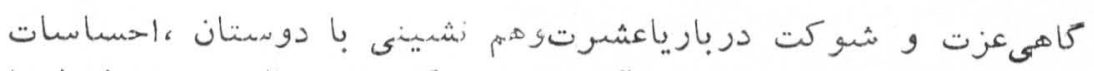

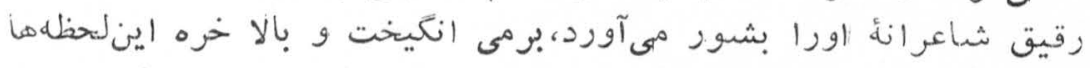

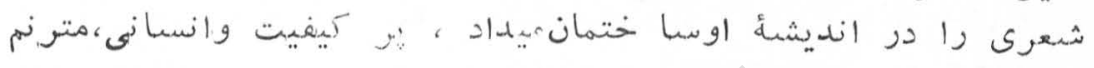

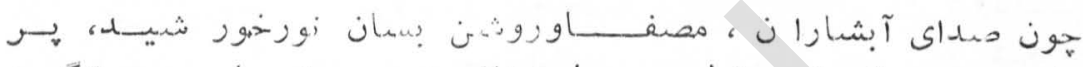

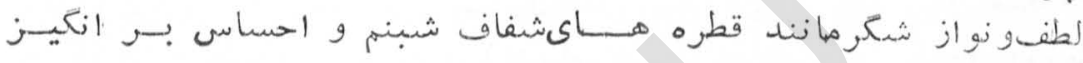

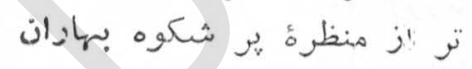

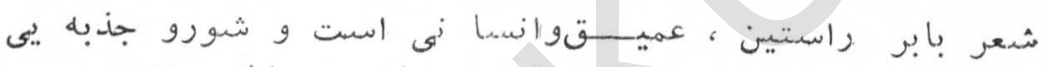

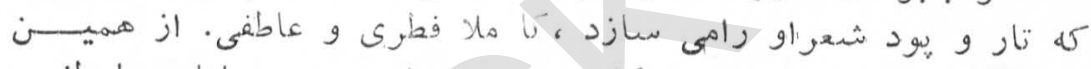

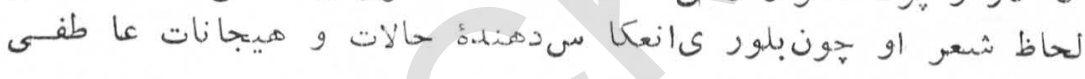

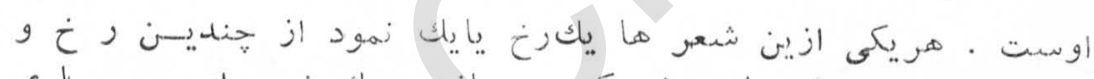

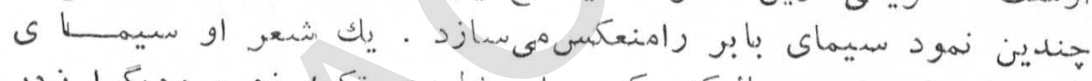

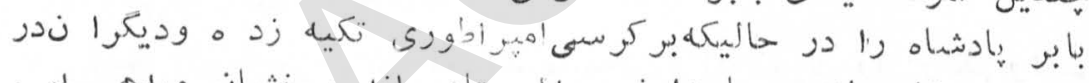

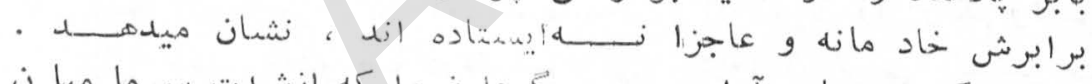

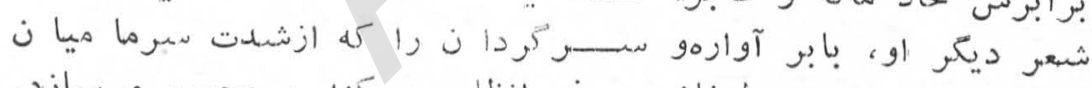

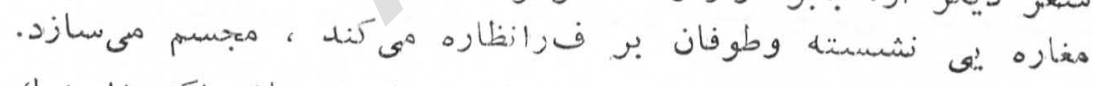

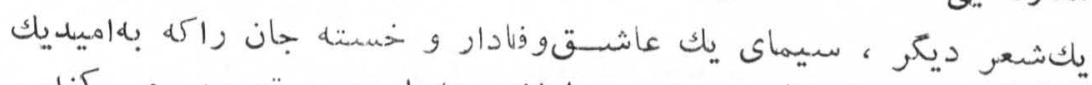

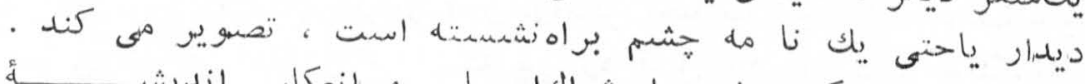

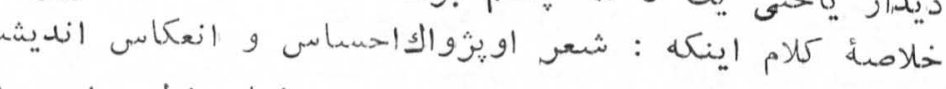

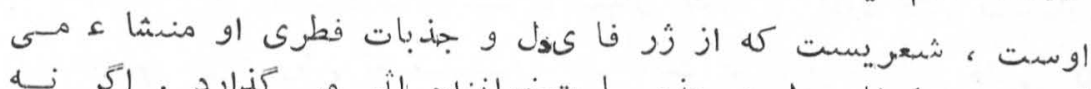

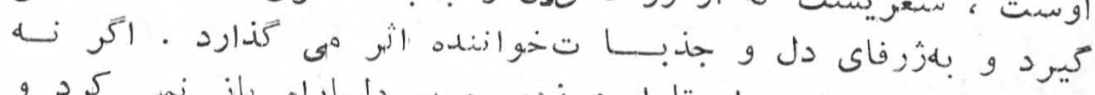

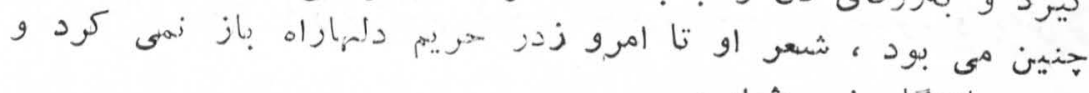

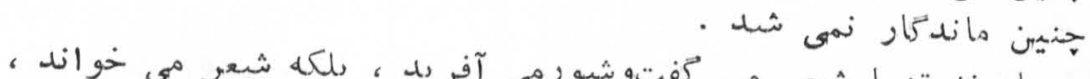

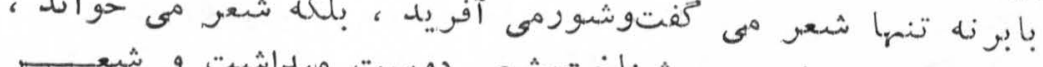

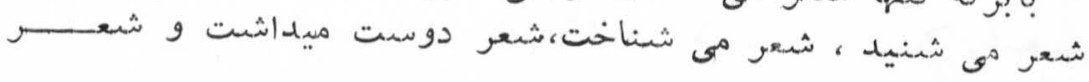




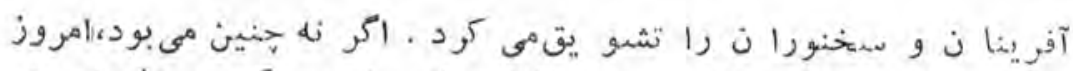

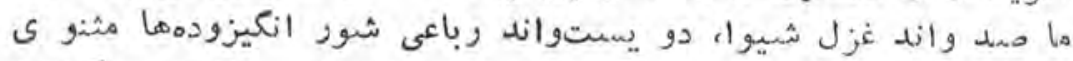

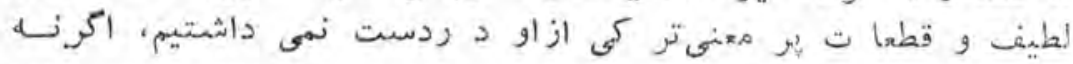

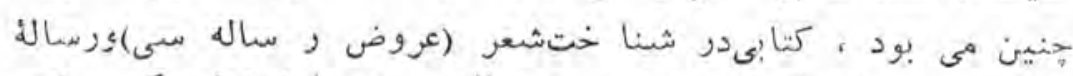

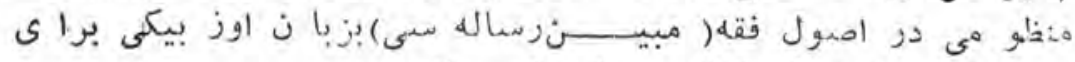

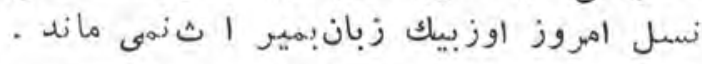

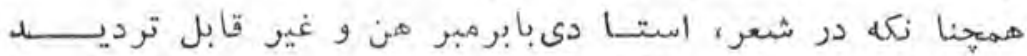

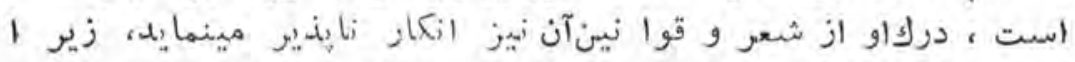

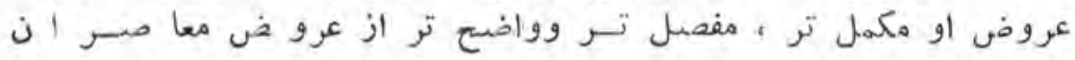

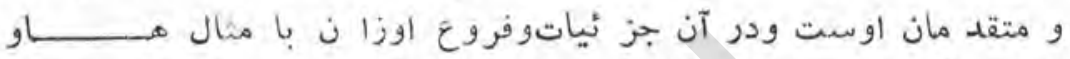

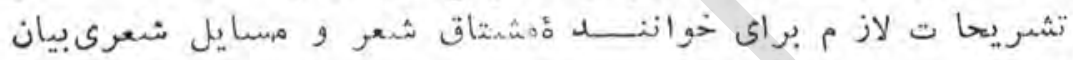

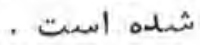

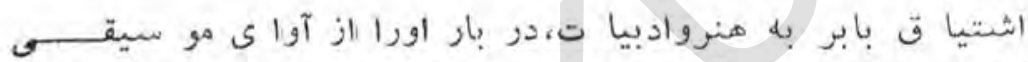

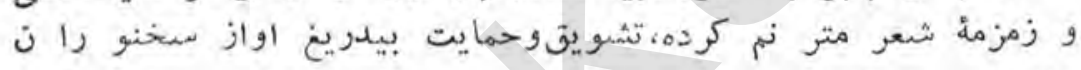

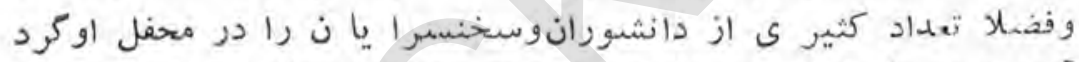

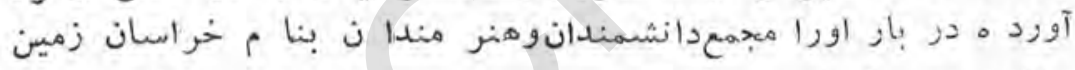

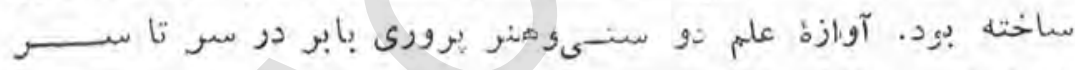

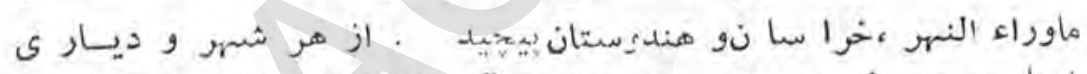

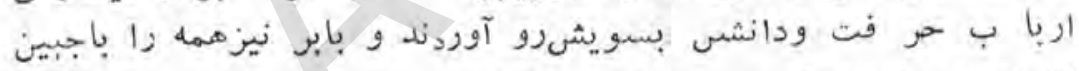

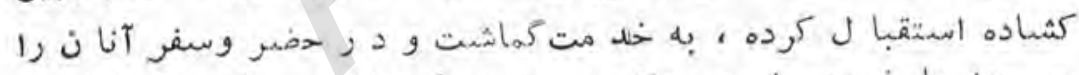

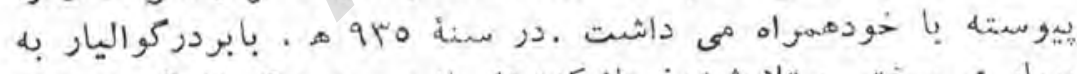

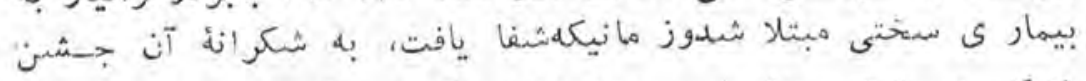

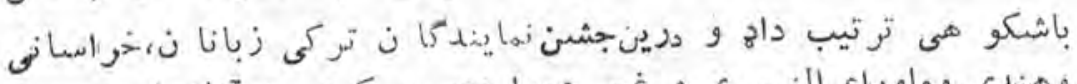

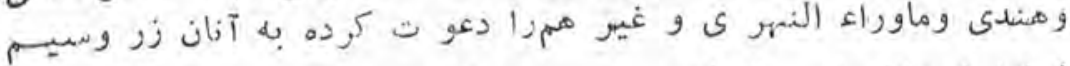

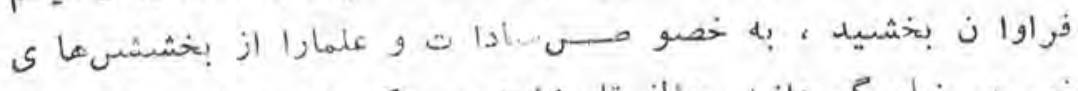

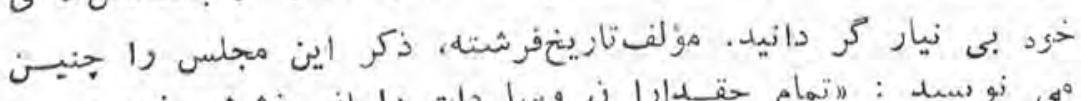

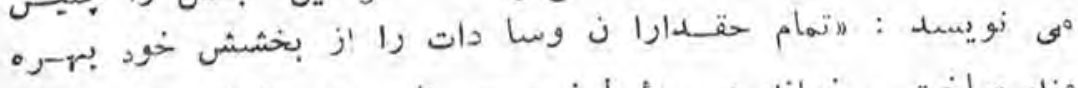

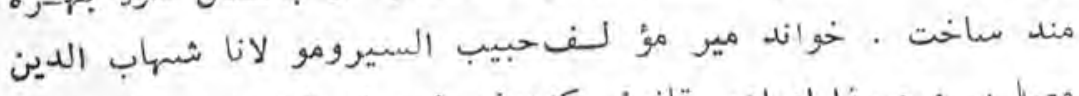

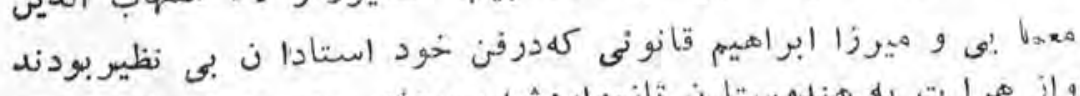

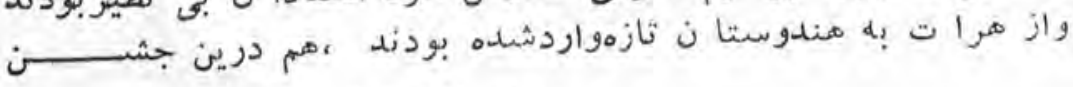




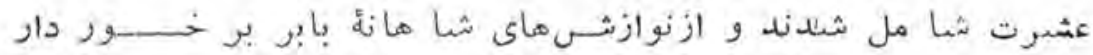

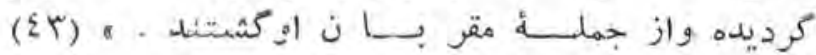

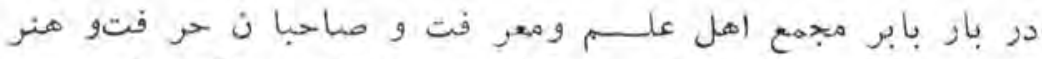

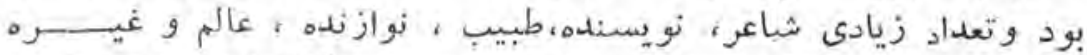

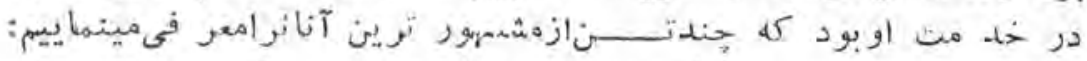

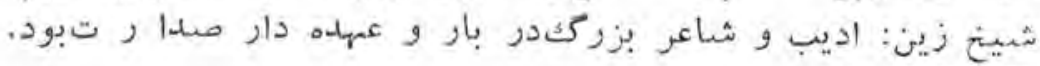

به علو م زمان خويش و قوف كاملدداشت . در بإنشاء بيش از هركس

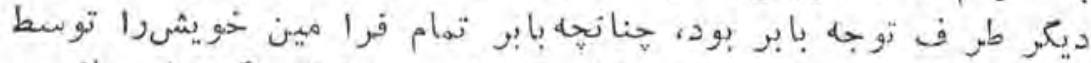

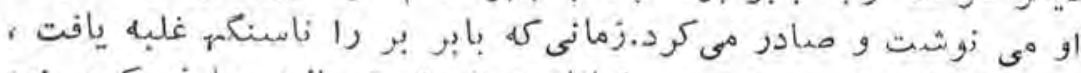

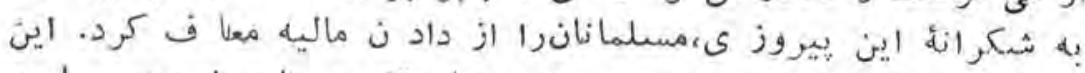

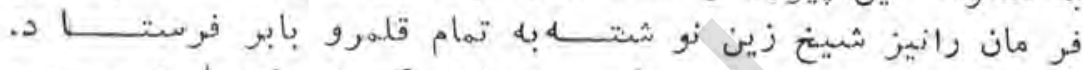

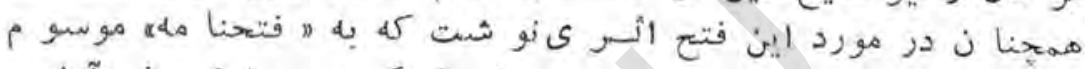

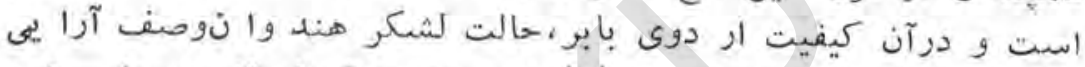

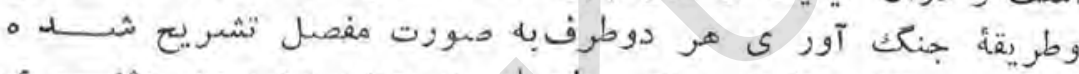

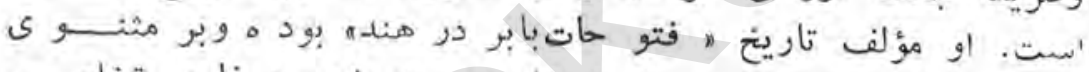

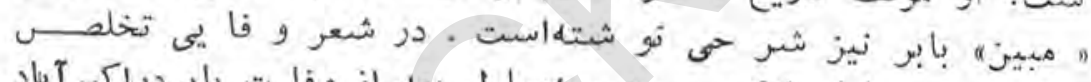

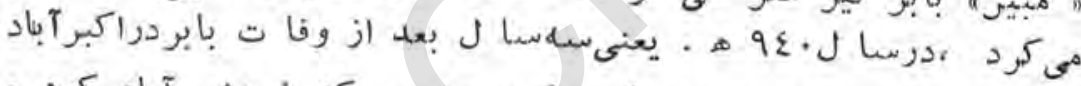

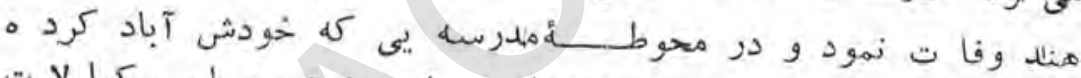

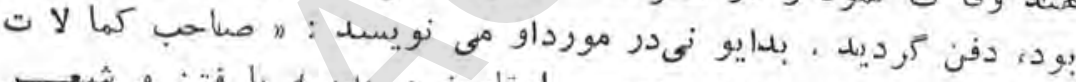

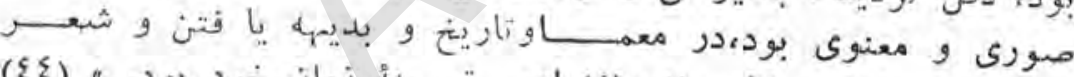

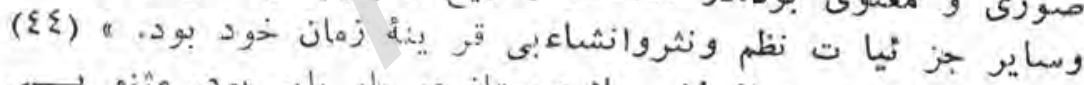

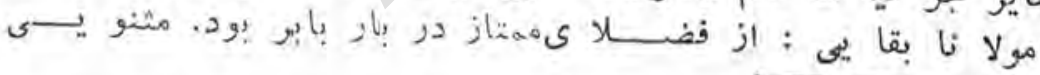
نوشته به بابر الهداء كرد

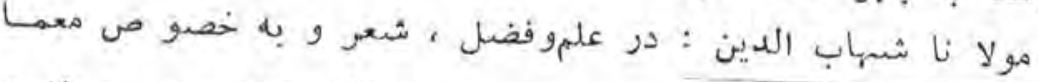

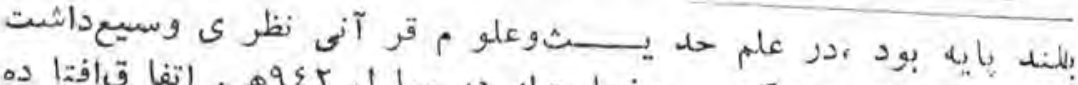

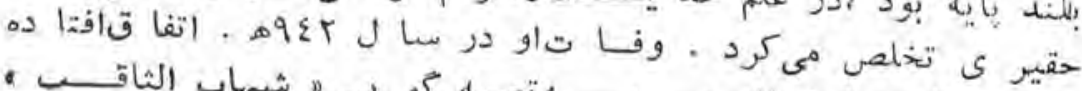

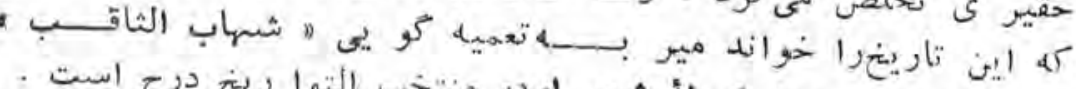

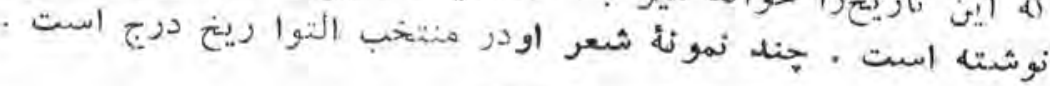

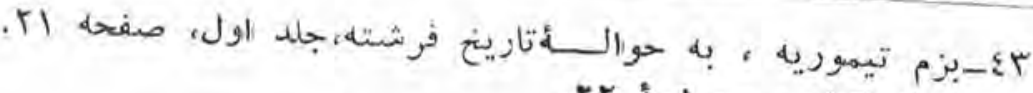

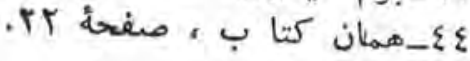




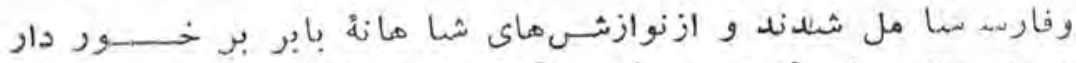

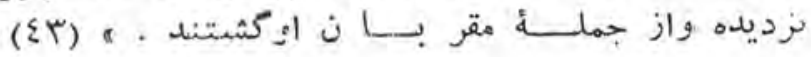

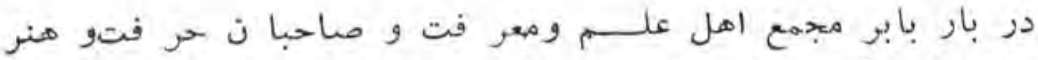

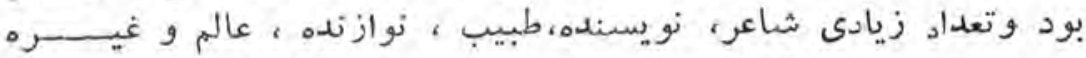

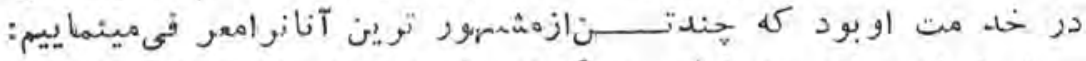

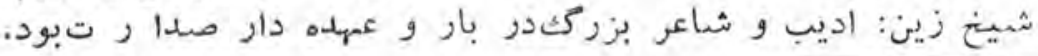

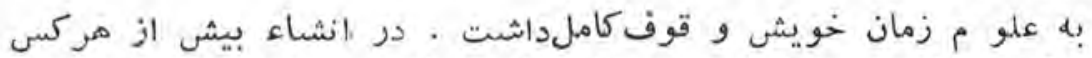

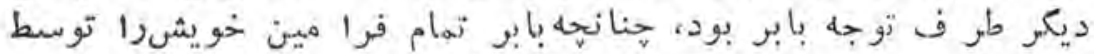

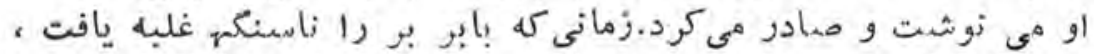

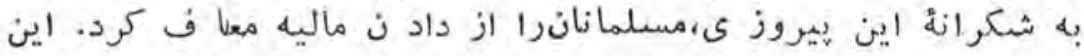

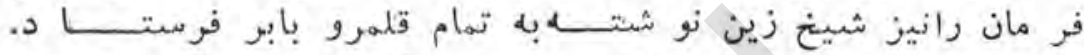

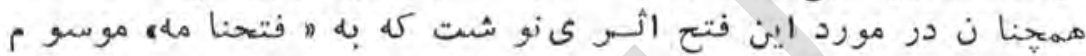

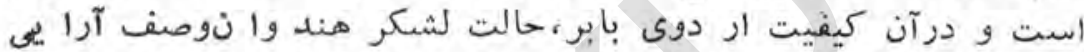

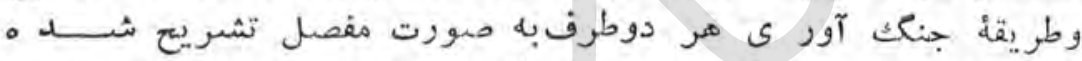

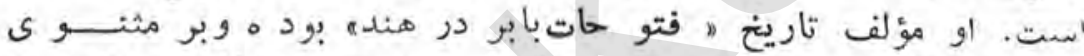

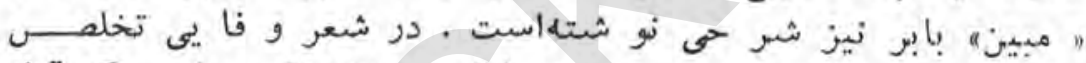

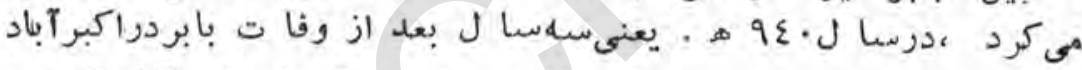

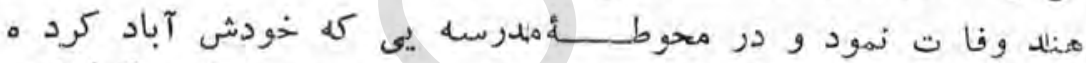

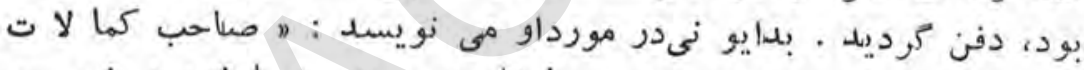

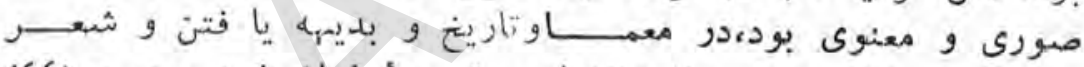

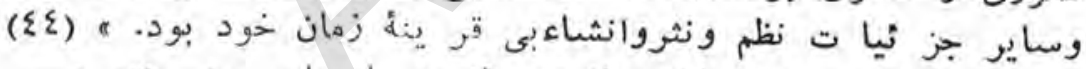

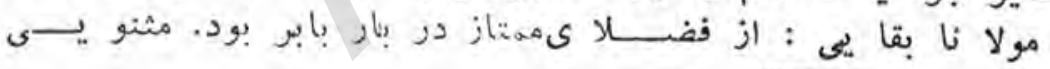

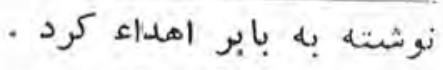

مولا نا شهباب الدين : در علموفضل ، شعبر و به خصو ص معمد

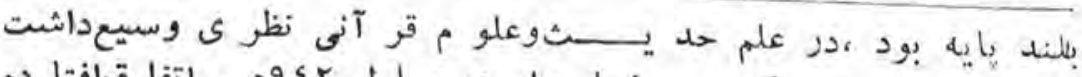

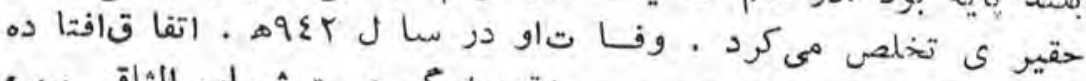

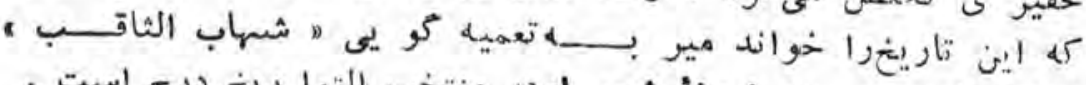

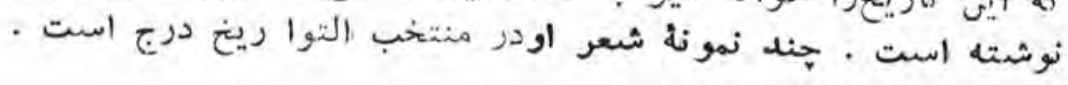

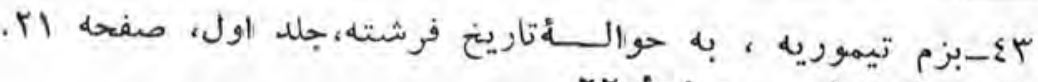

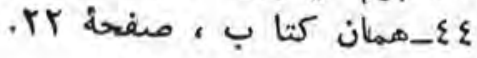




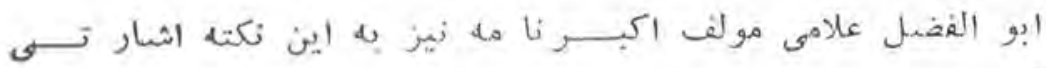
:

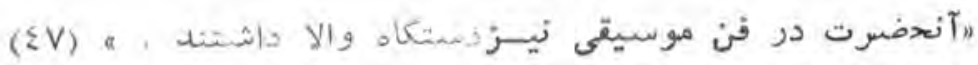

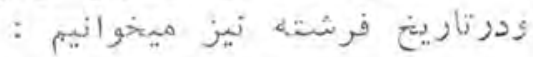

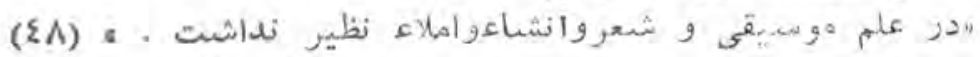

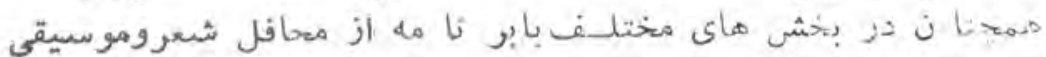

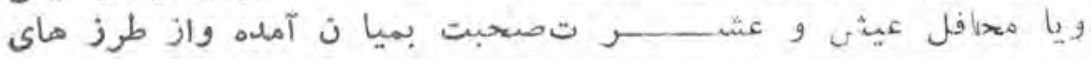

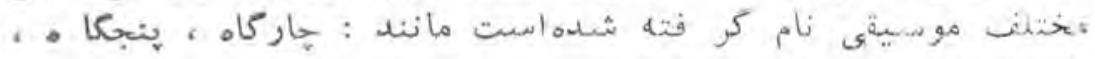

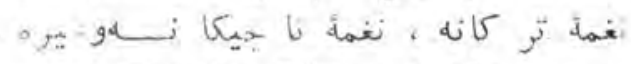

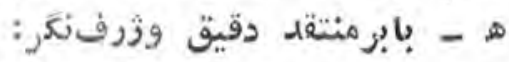

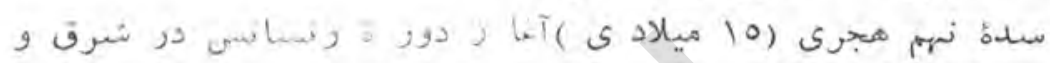

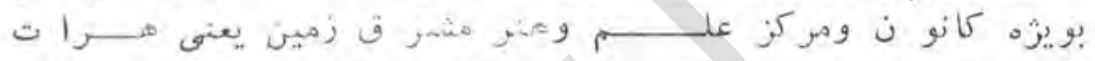

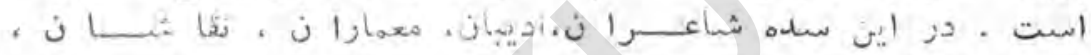

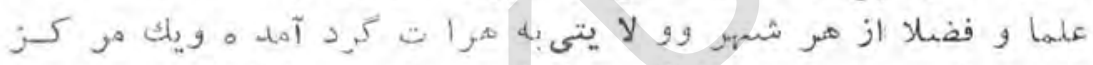

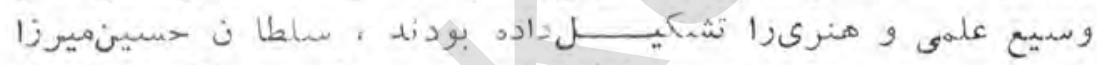

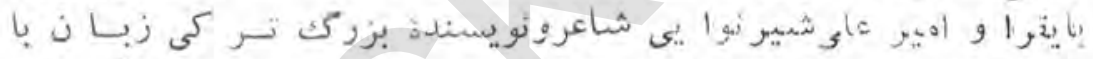

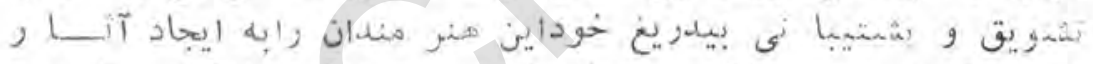

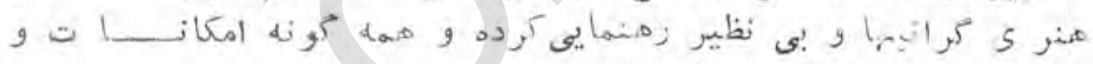

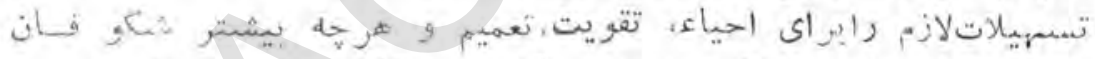

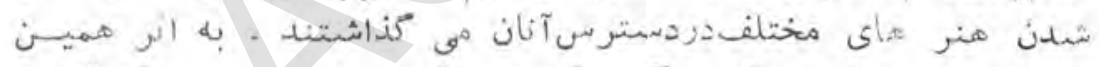

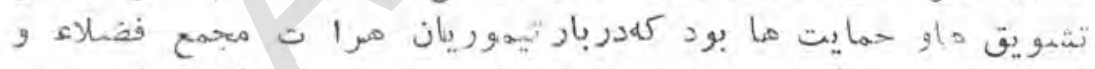

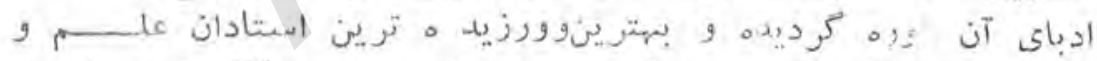

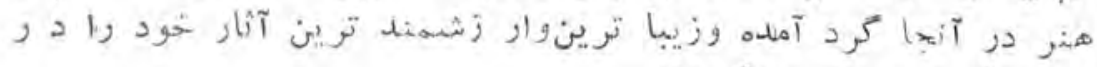
آنجا وآنز

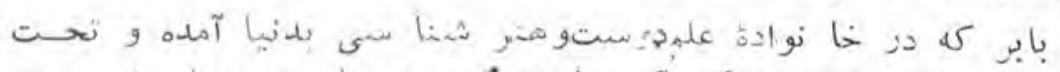

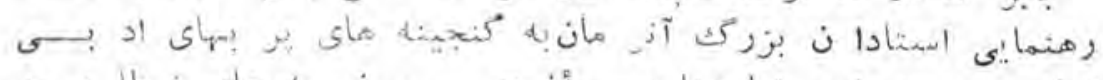

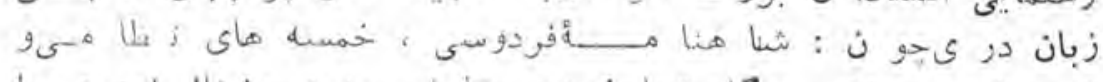

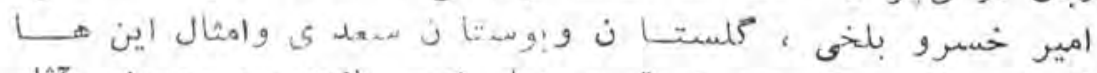

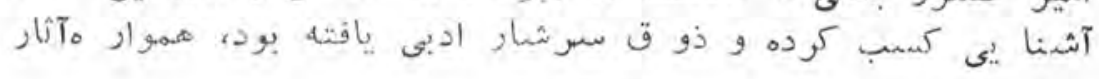

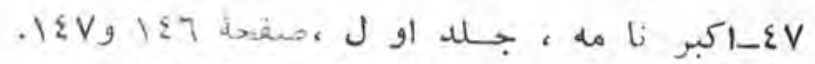

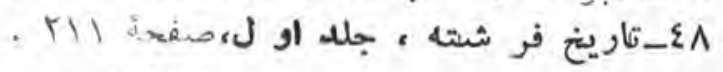




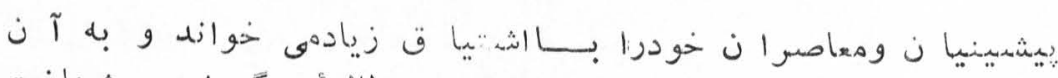

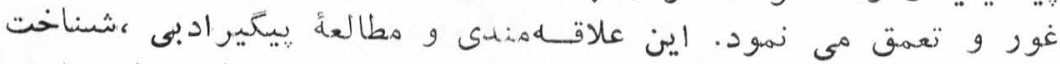

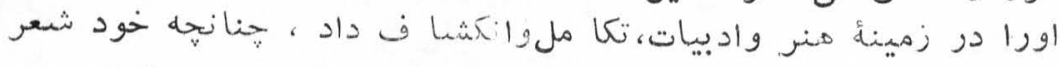

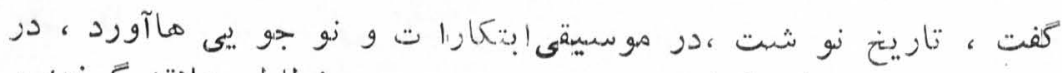

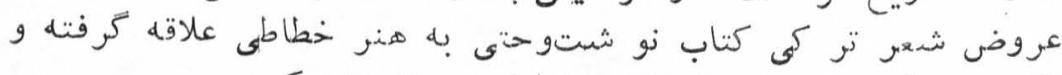

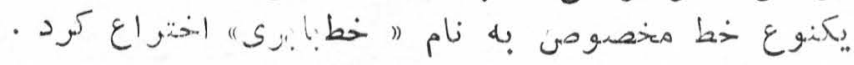

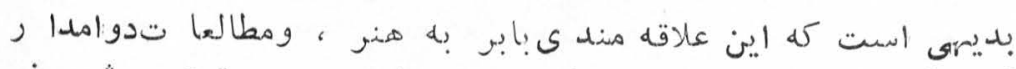

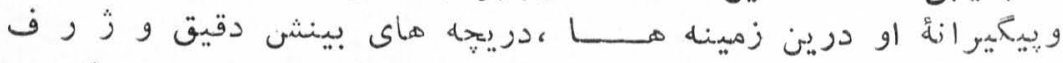

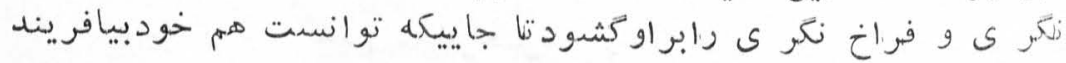

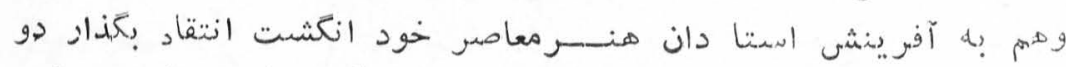

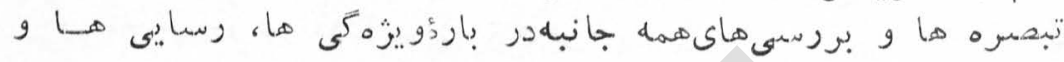

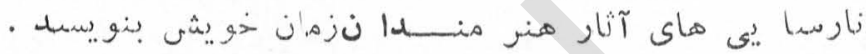

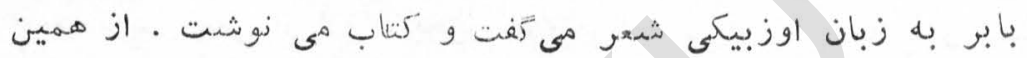

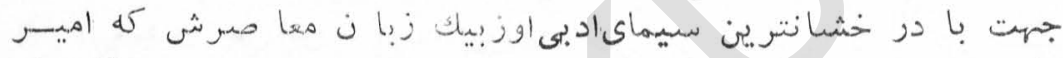

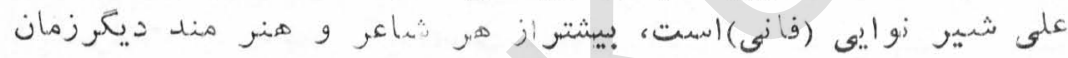

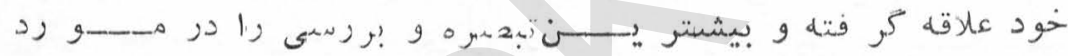

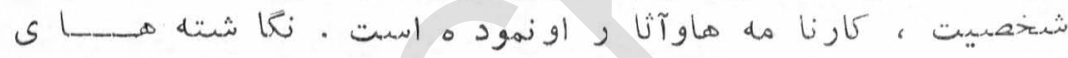

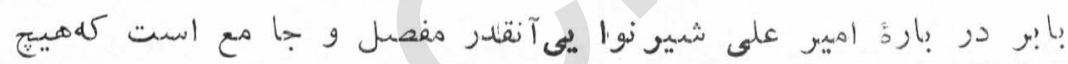

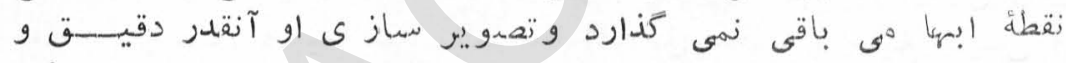

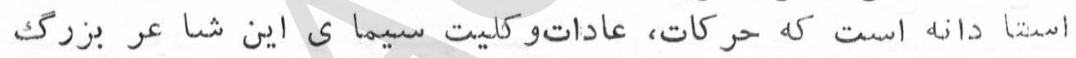

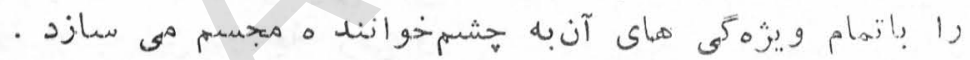

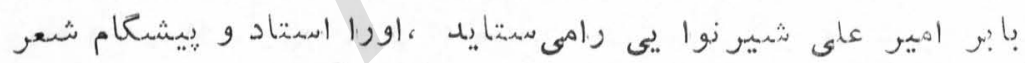

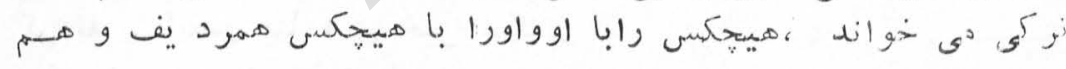

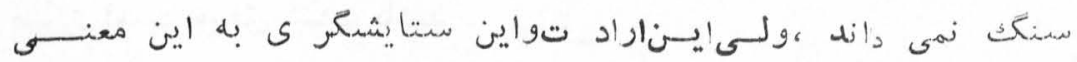

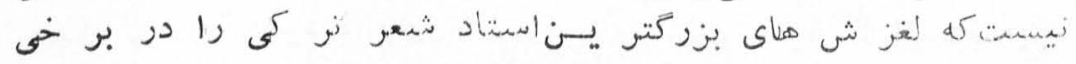

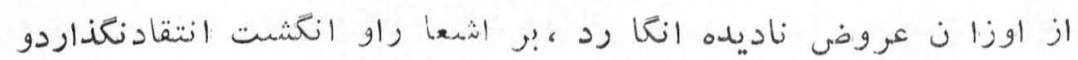

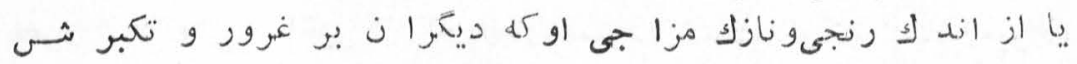

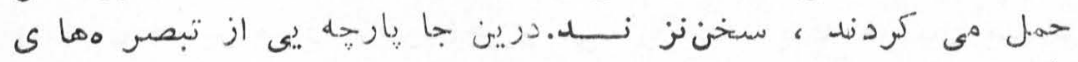

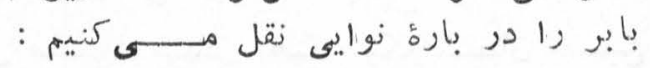

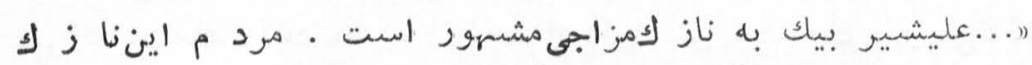

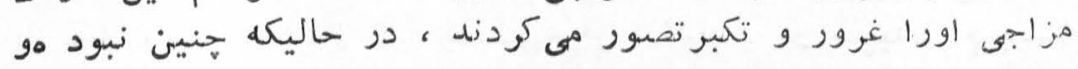




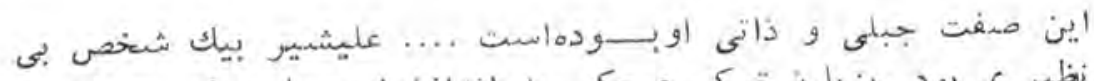

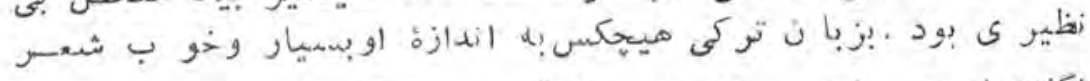

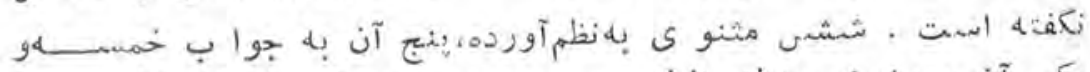

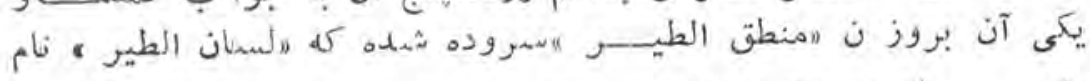

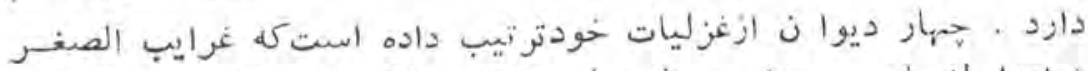

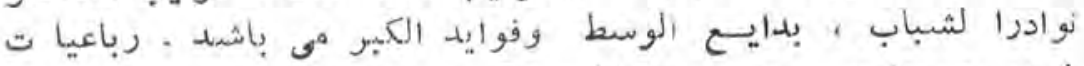

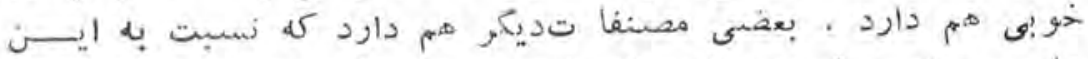

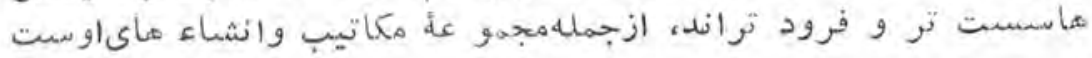

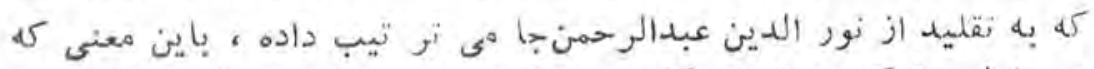

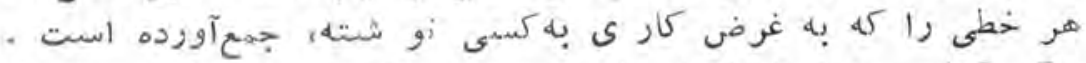

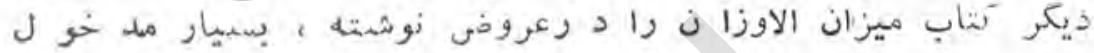

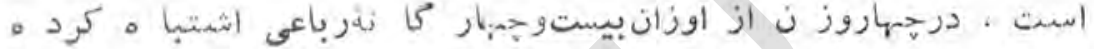

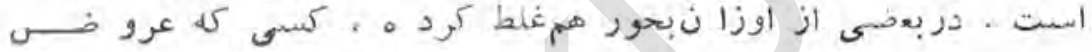

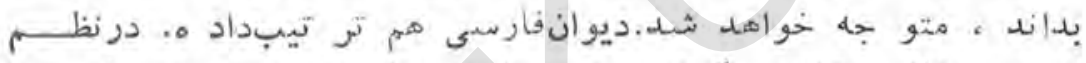

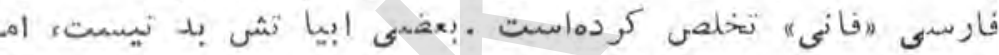

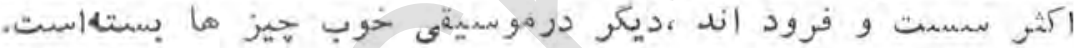

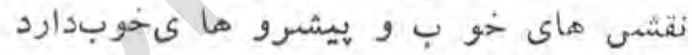

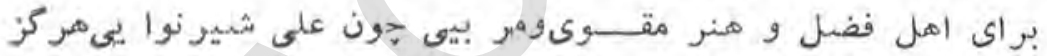

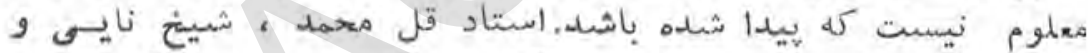

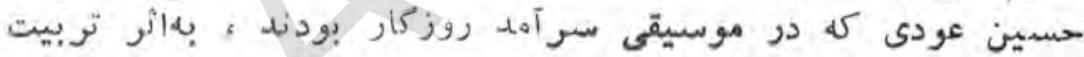

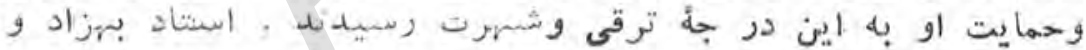

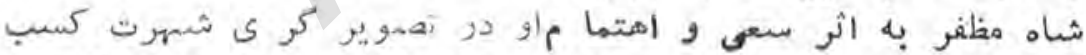

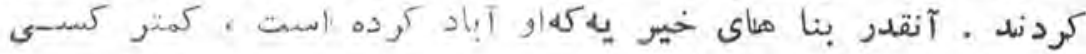

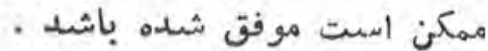

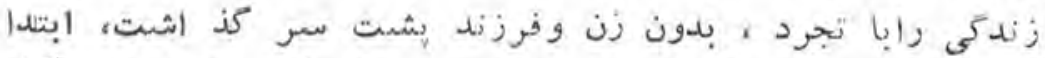

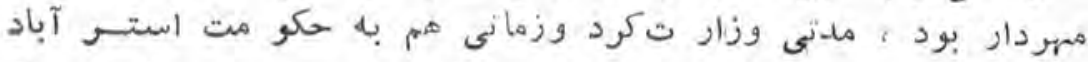

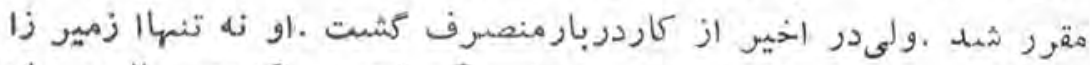

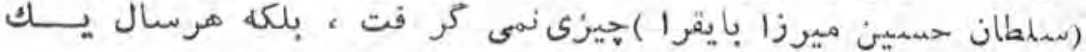

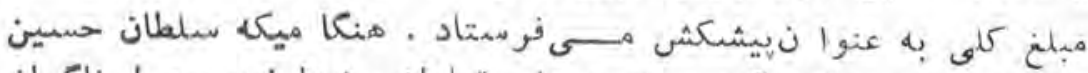

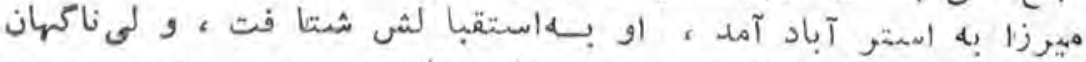

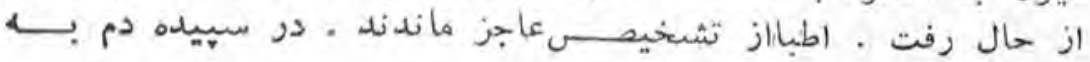




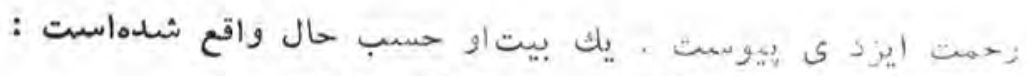

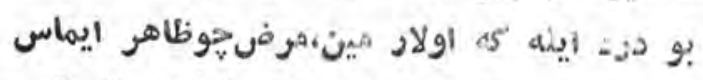

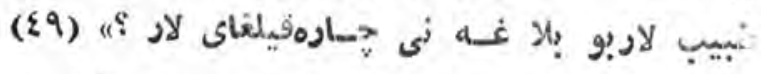

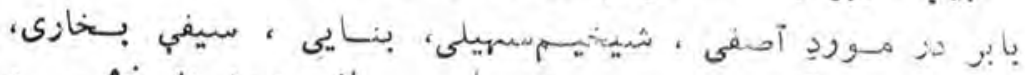

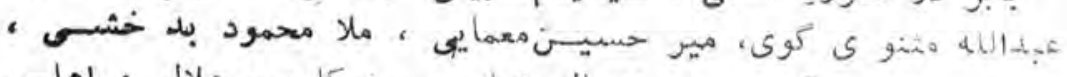

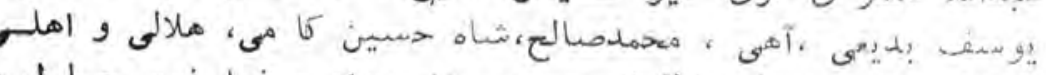

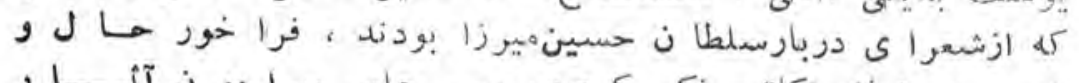

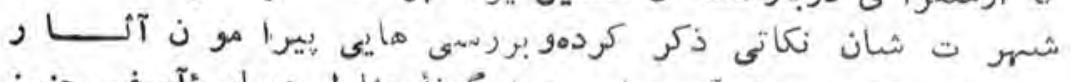

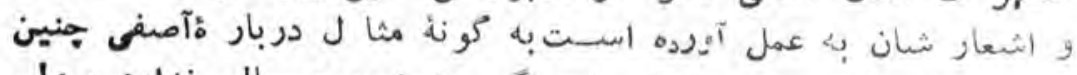

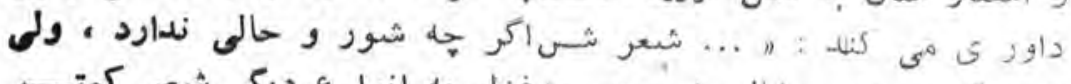

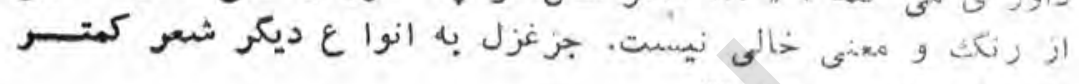

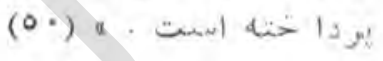

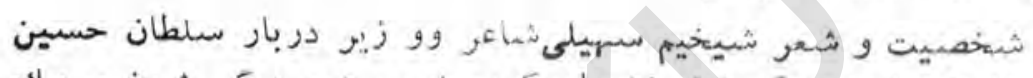

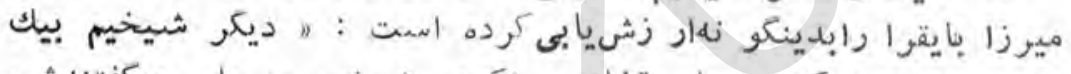

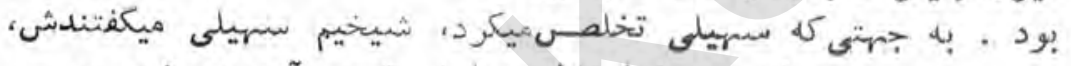

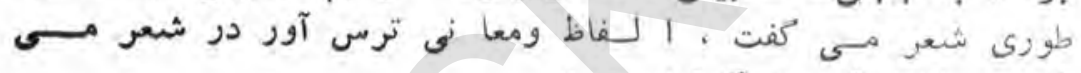

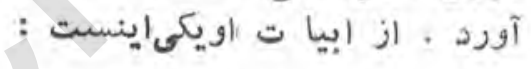

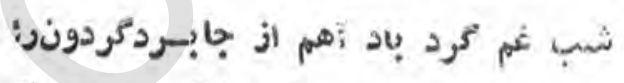

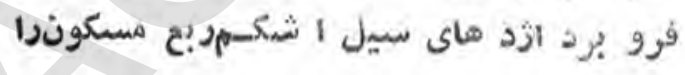

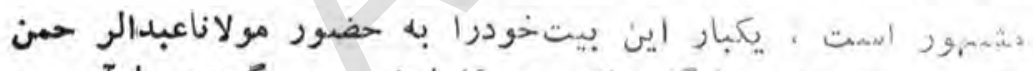

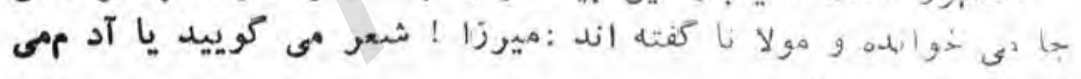
(01)

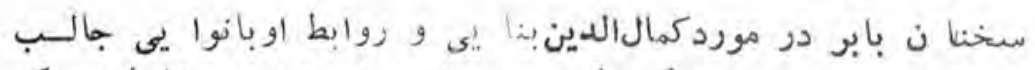

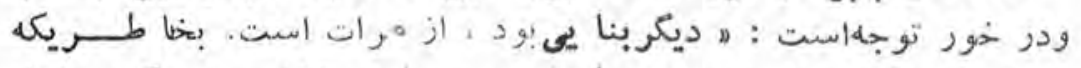

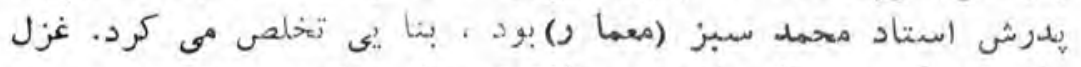

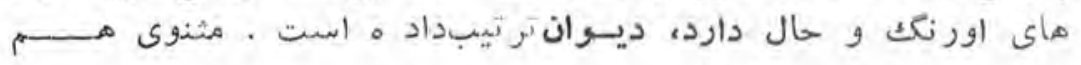

q q 9

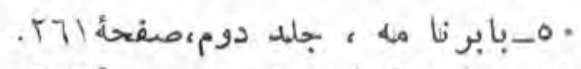

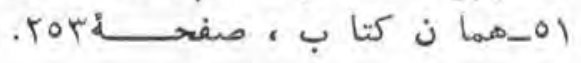
- 


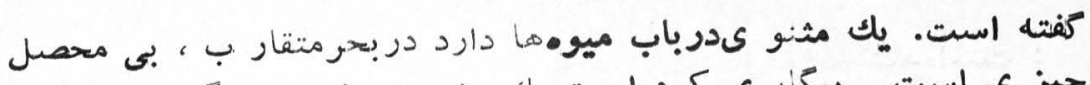

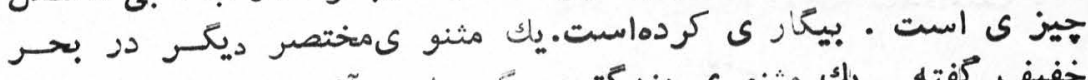

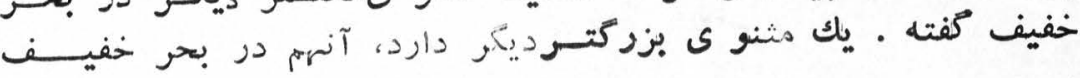

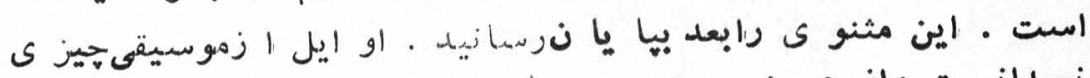

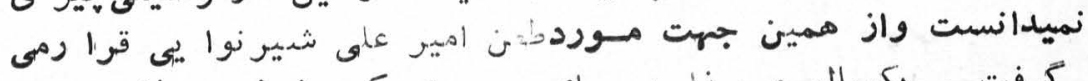

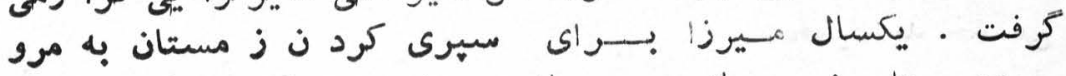

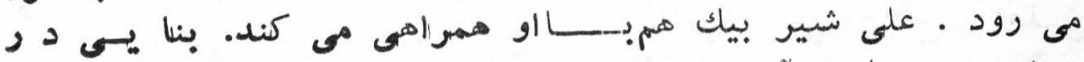

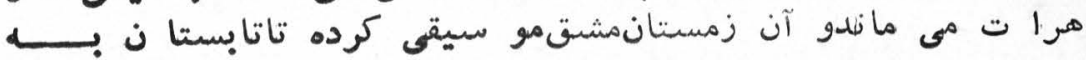

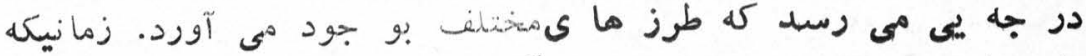

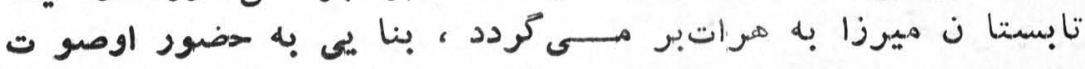

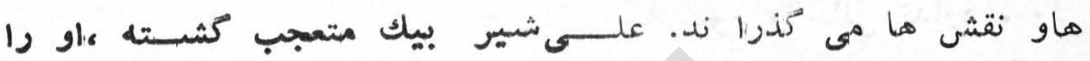

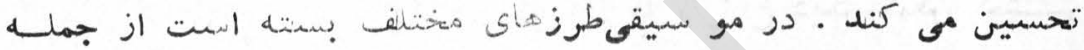

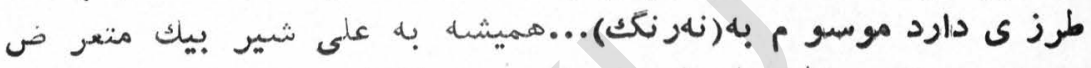

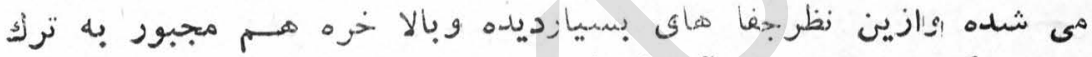

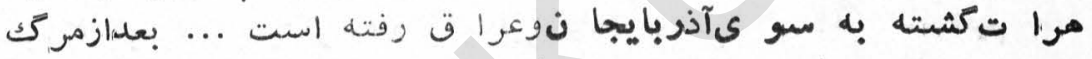

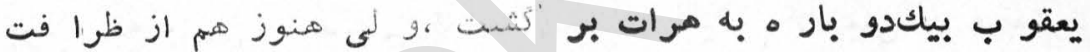

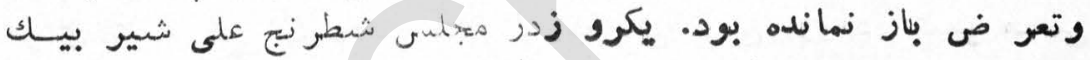

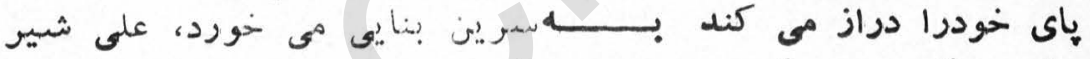

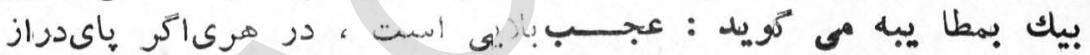

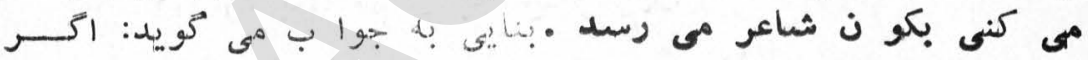

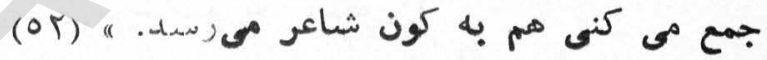

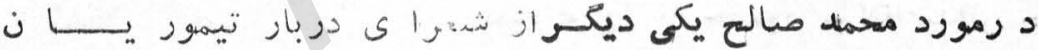

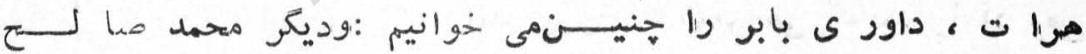

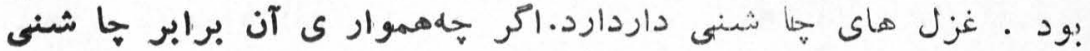

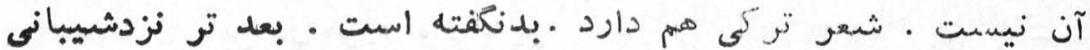

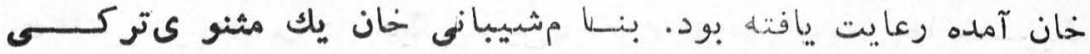

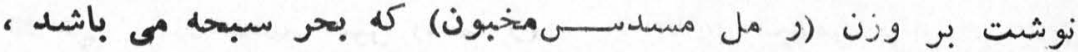

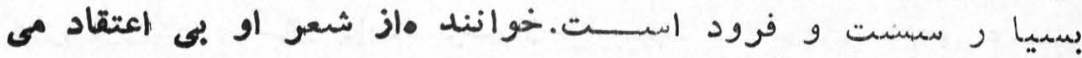

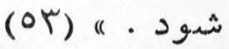

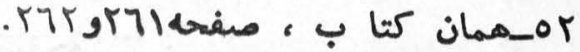
ror or 


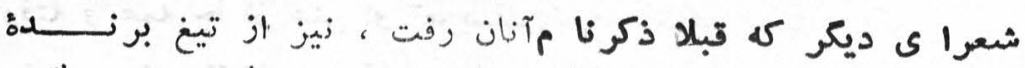

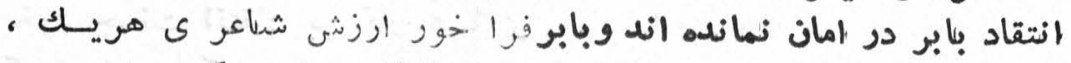

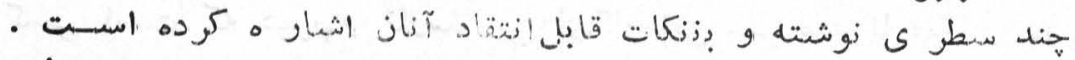

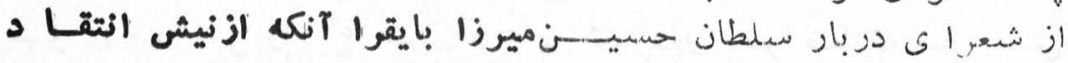

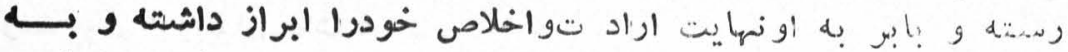

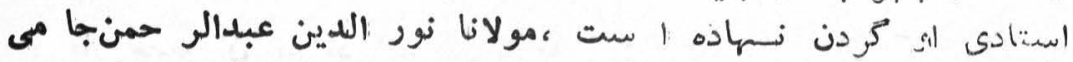

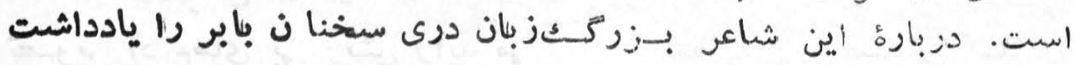

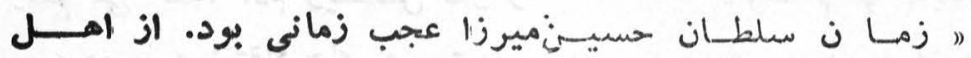

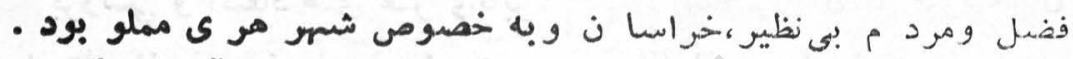

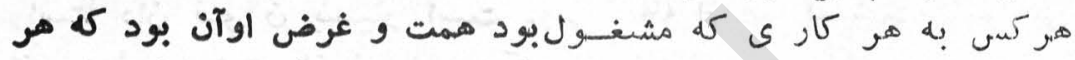

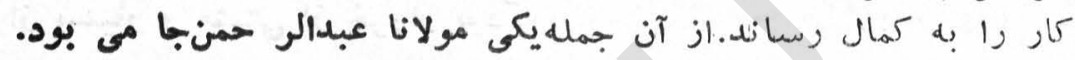

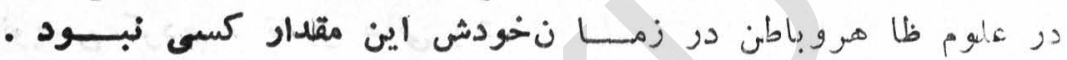

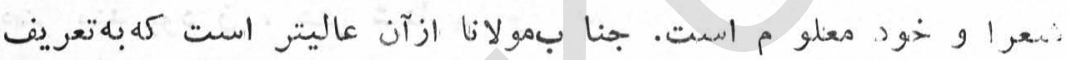

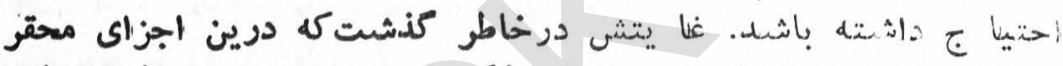

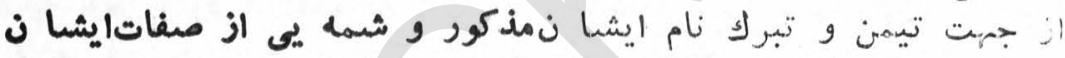

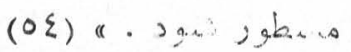

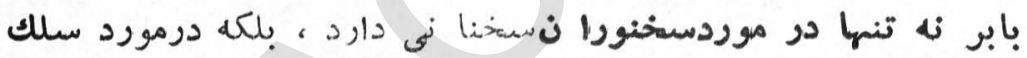

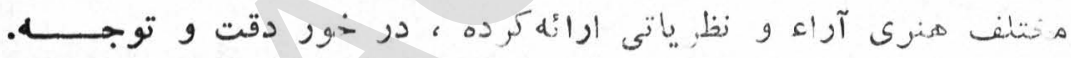

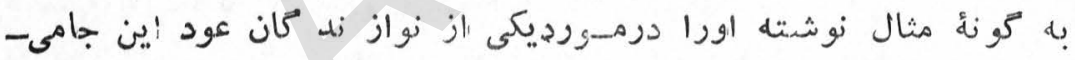
آوريم:

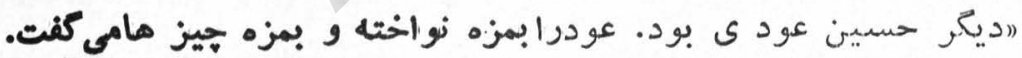

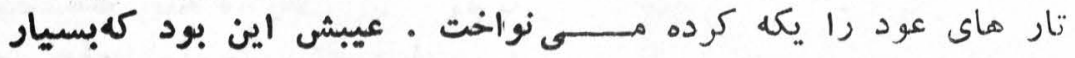

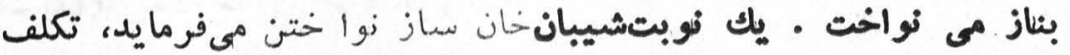

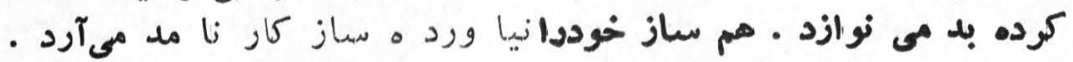

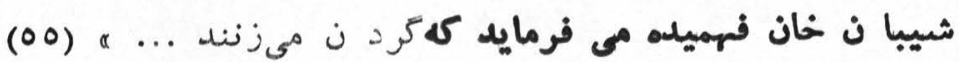

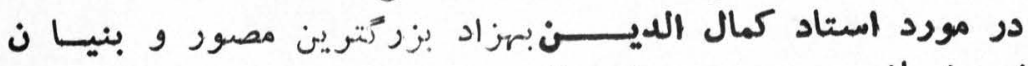

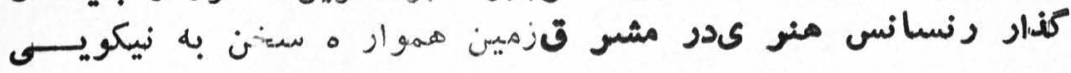

\&

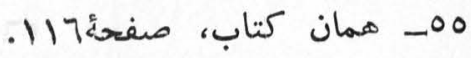




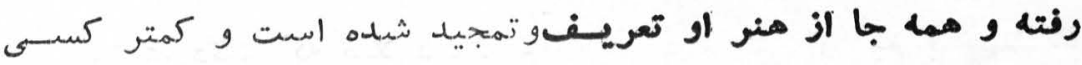

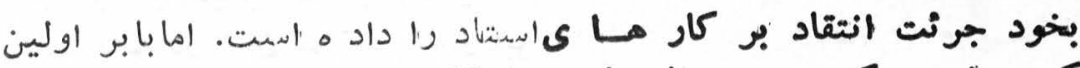

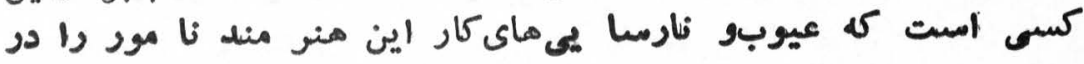

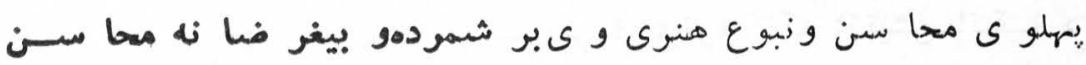
ومعا يب اورابيان داشتهاست ونست : منرى :

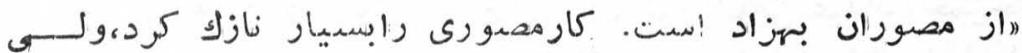

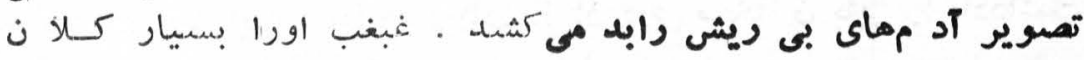

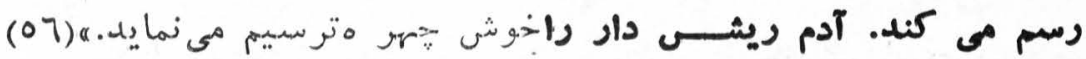

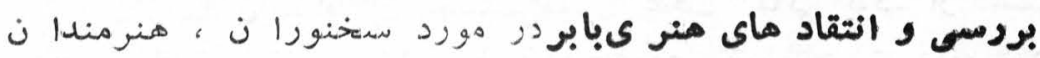

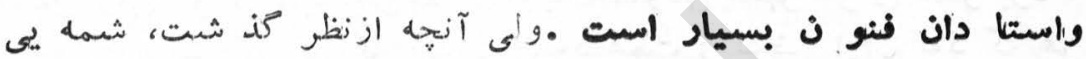

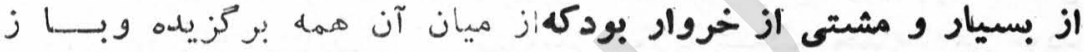

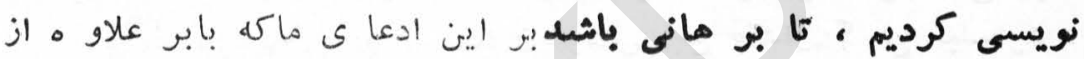

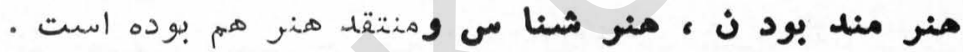




\section{مبخ موم}

\section{آثار و ا يجاد د يات با بر}

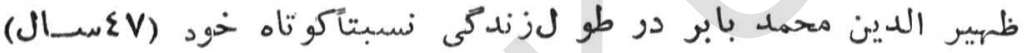

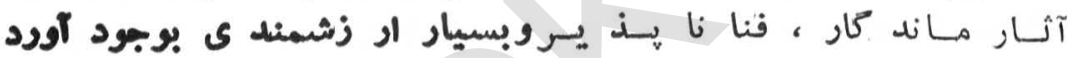

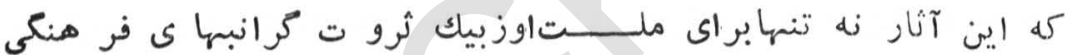

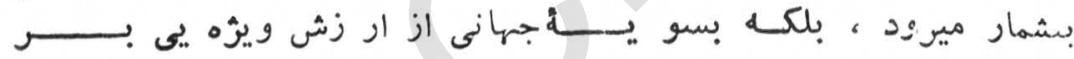
خور دا راست.

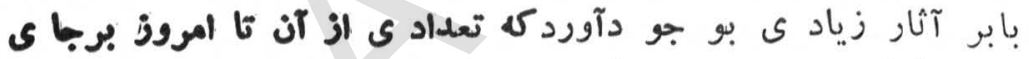

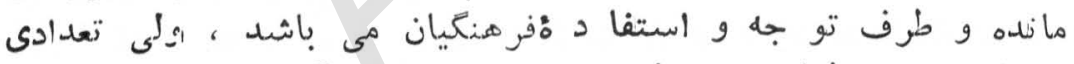

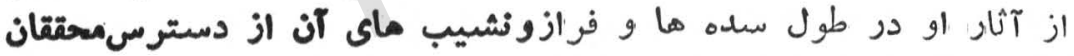

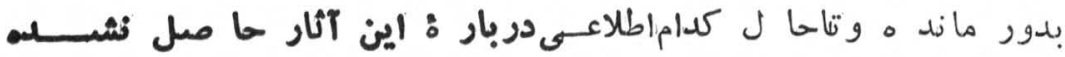

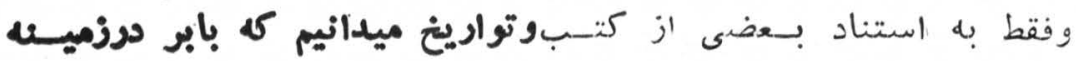

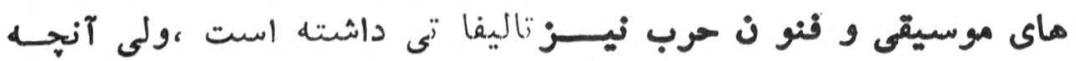

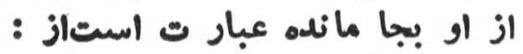

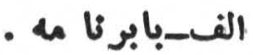

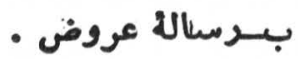

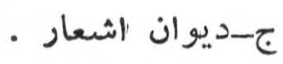

د-ترجما منظوم رسا للووالديه . 
هـ -مثنوى مبين در فقله حنفـى كه هريك رابصورت فشرد همعرفى :

الف - الف - بابر نامه :

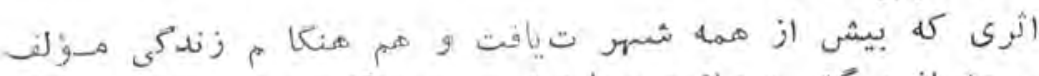

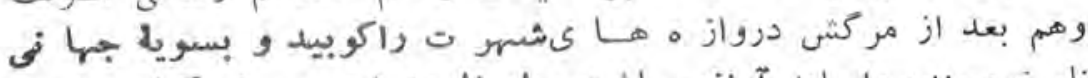

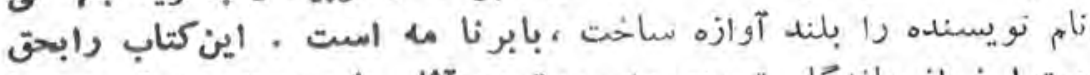

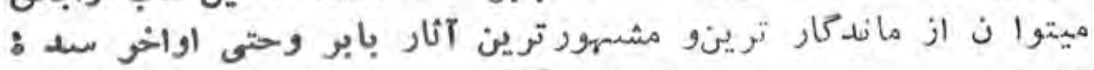

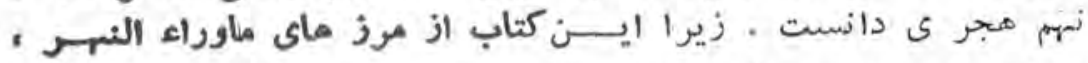

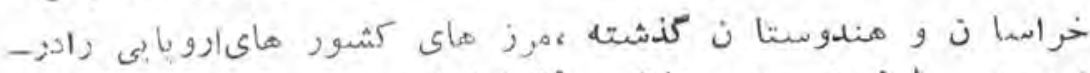

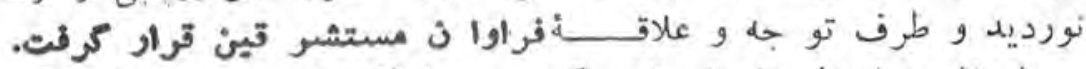

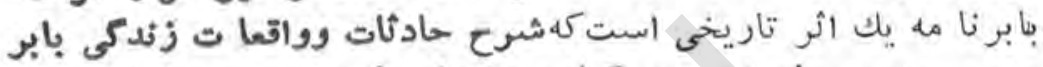

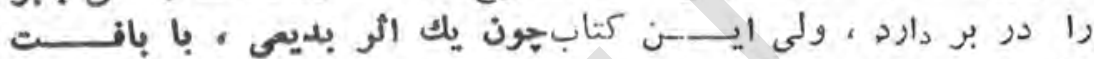

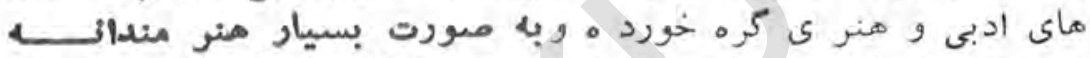

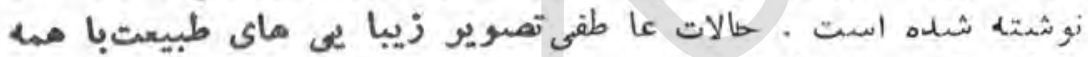

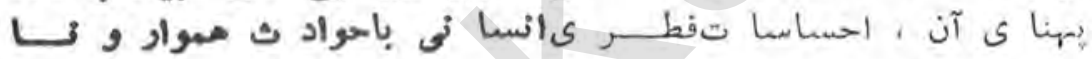

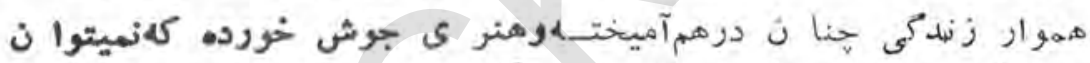

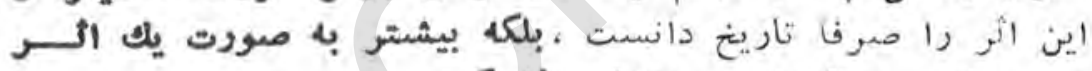

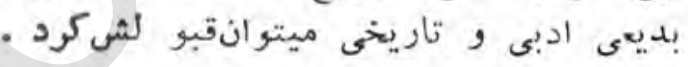

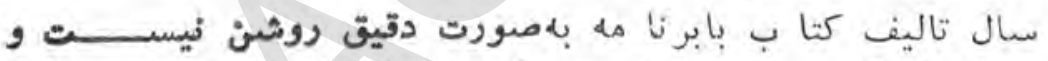

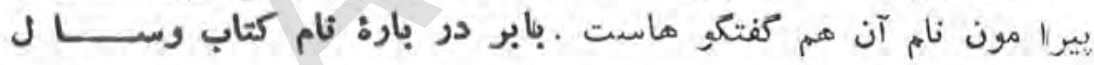

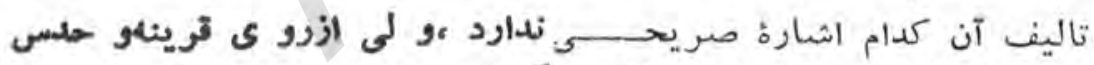

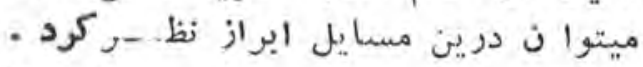

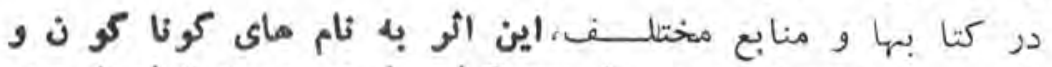

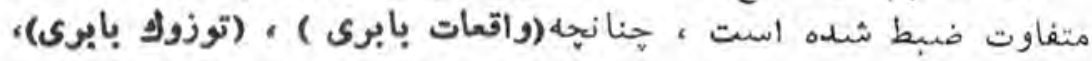

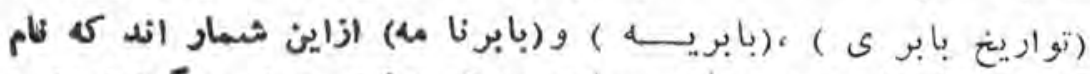

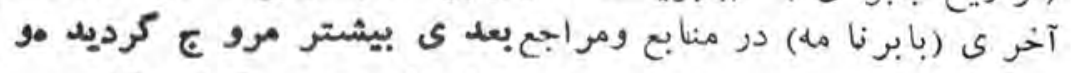

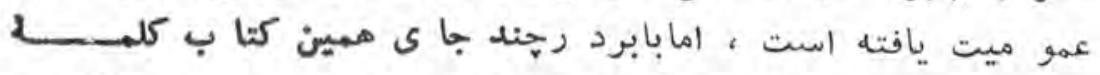

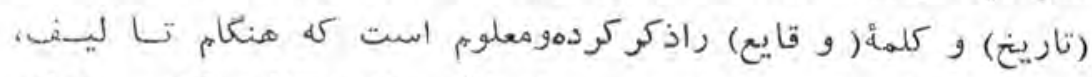

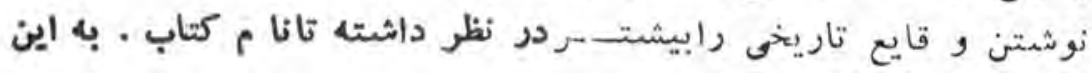
شعر توجه كنيد : 
بوعالم ارا عجب الم لار كوردوم

عالم ايليدين طو فه ستم لار كوردوم

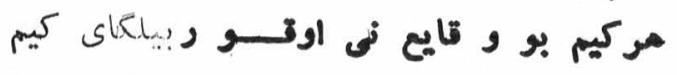
نىدنج و نى محنت ونى غم لاركوردوم

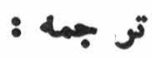

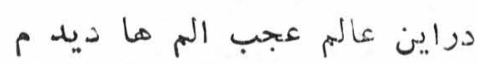

از دست بشع طر فه ستم مـاديدم

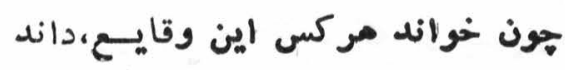

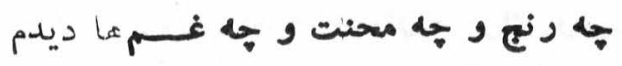

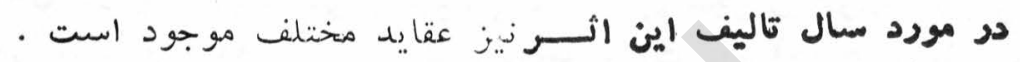

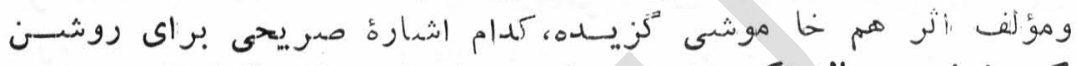

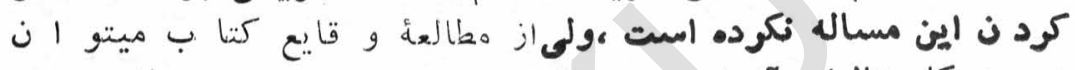

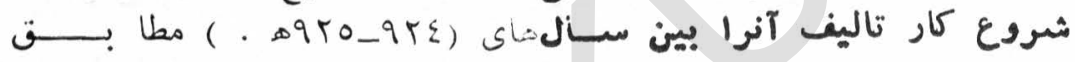

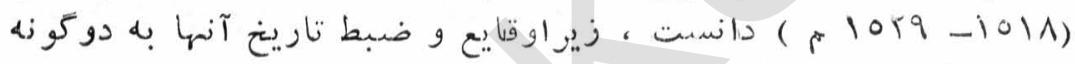

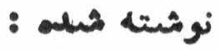

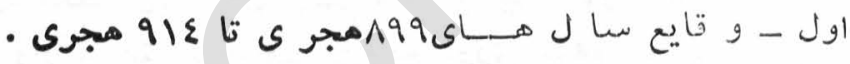

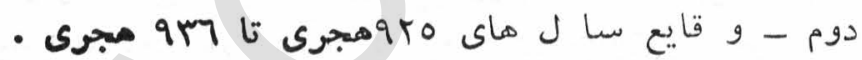

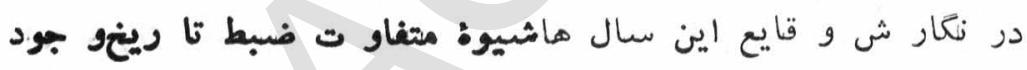

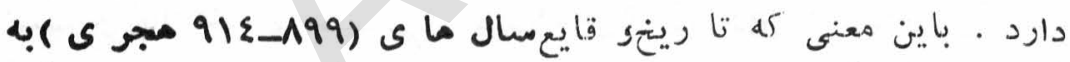

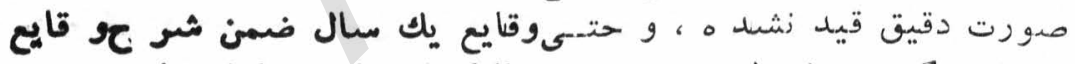

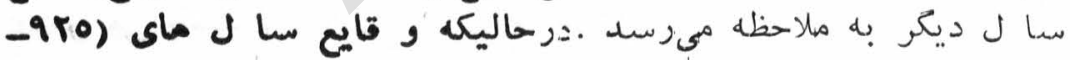

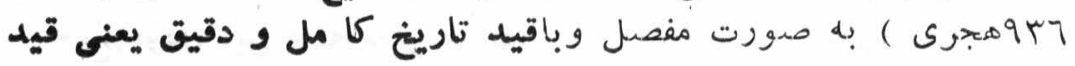
ساعت ، روز،هفته،هاه و سالشنوحكرديده وازين تفاو ت تاريخ نويسى

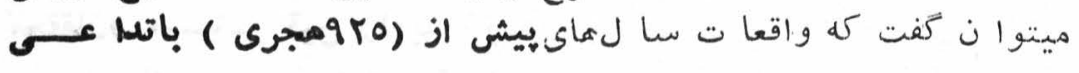

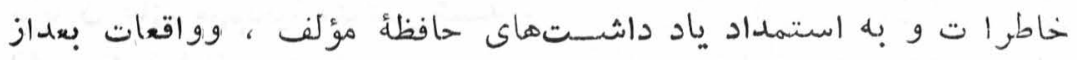

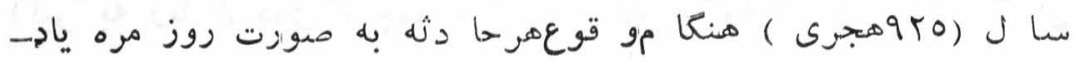

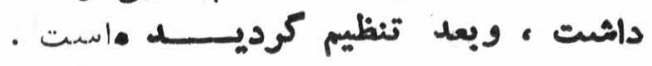

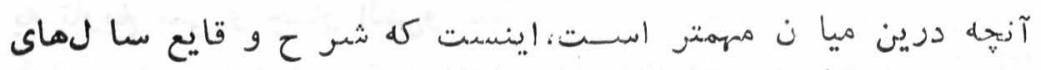

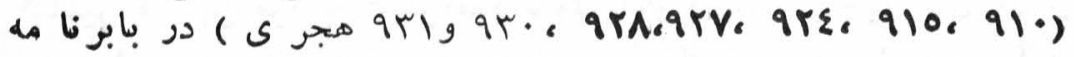




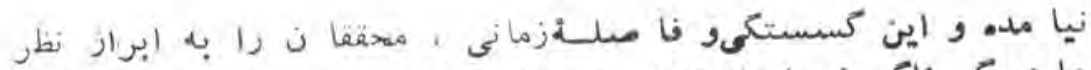

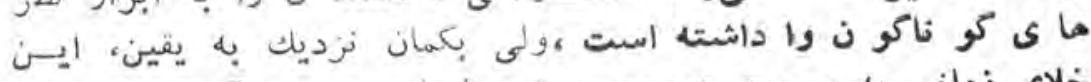

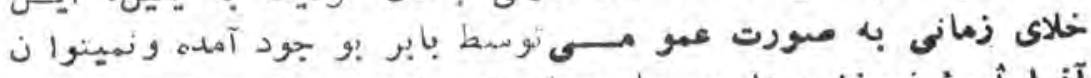

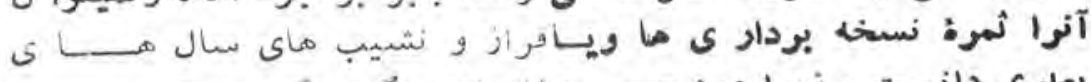

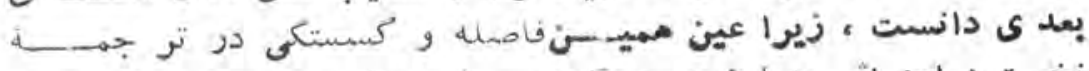

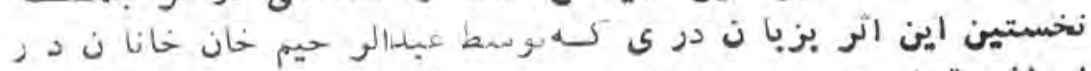

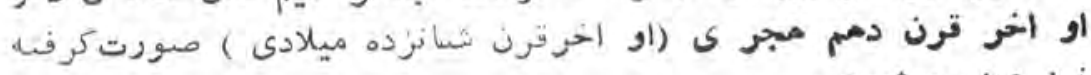

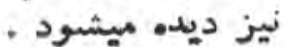

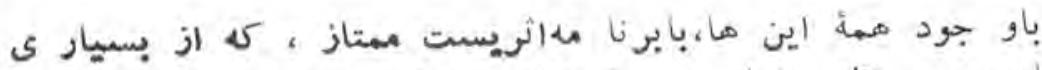

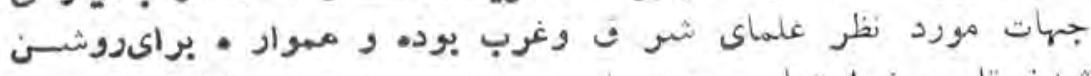

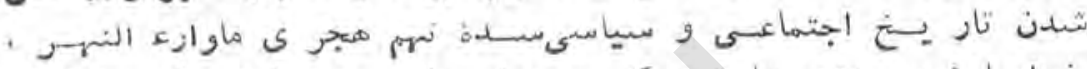

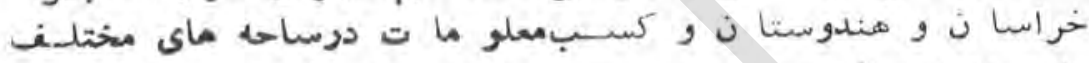

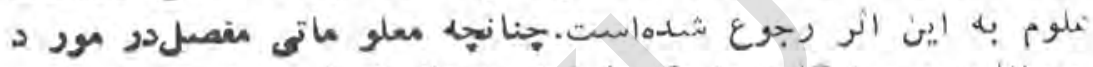

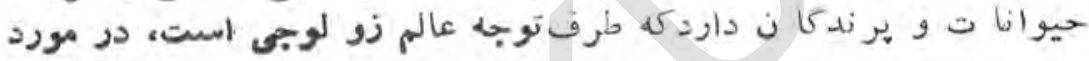

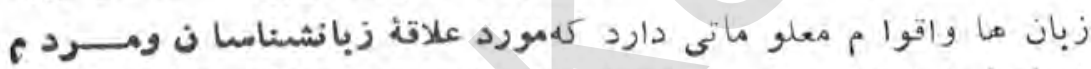

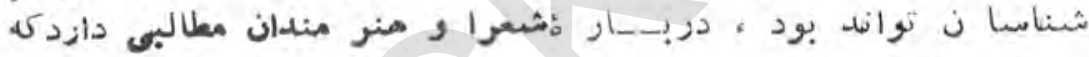

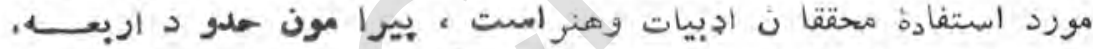

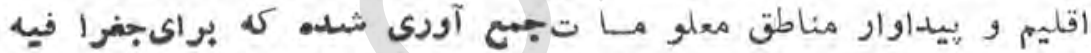

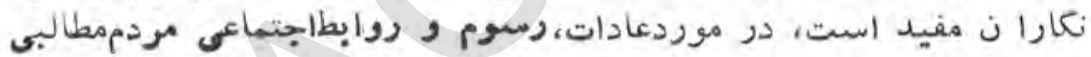

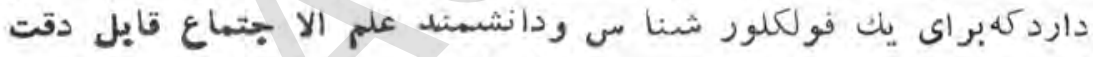

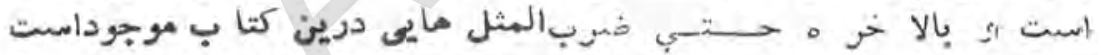

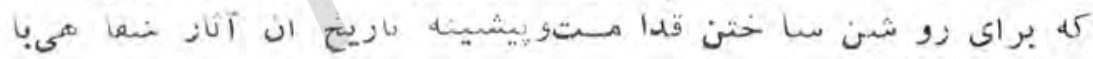

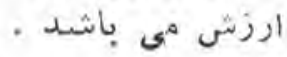

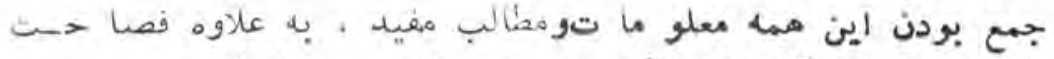

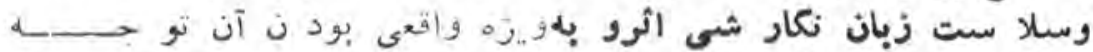

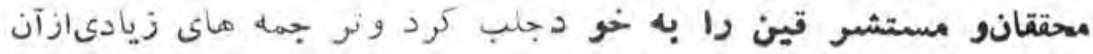

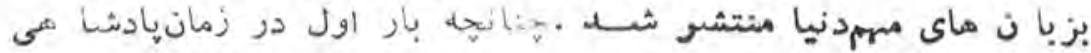

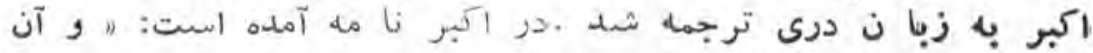

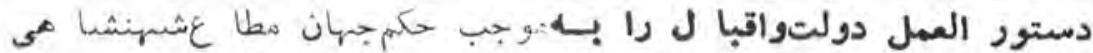

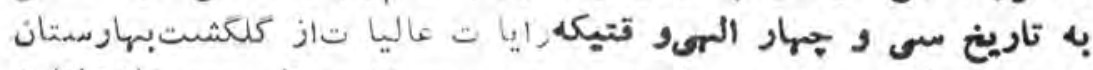

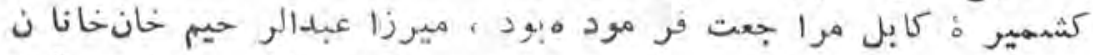

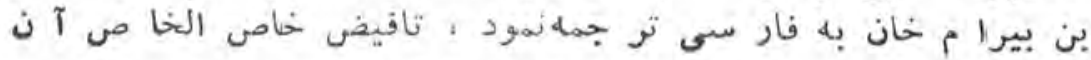




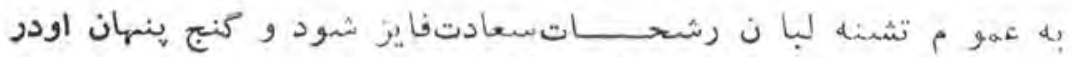

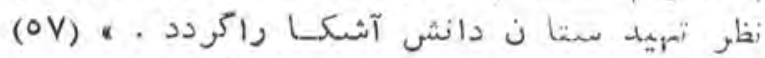

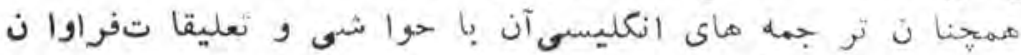

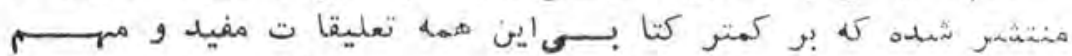

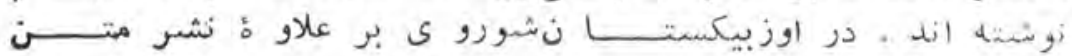

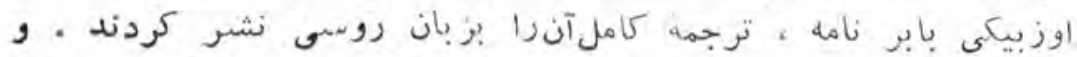

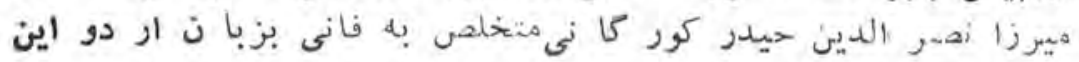

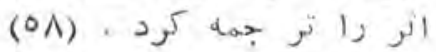

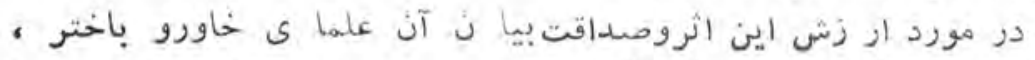

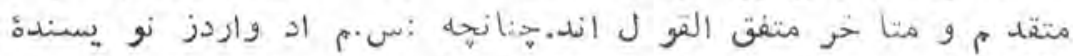

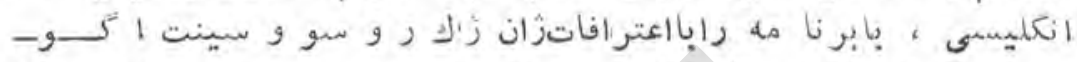

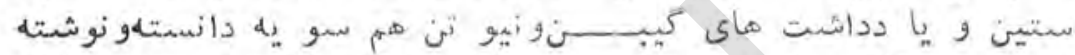

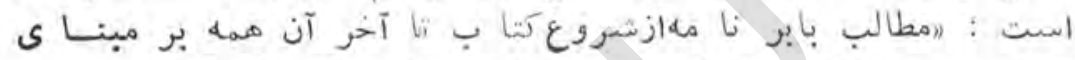

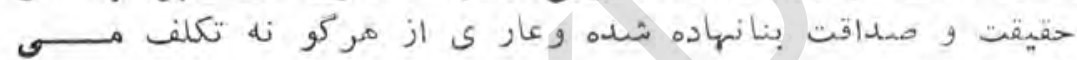
(09) «.

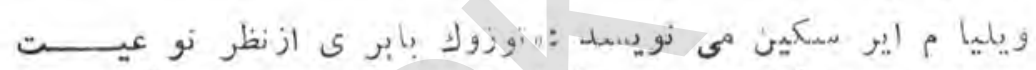

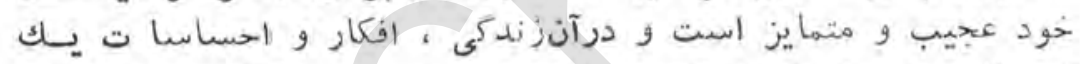

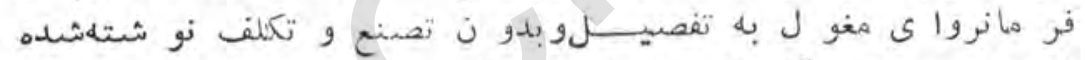

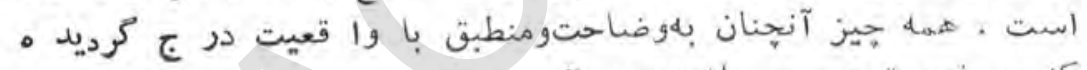

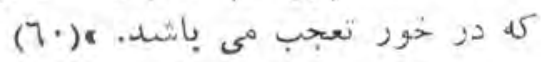

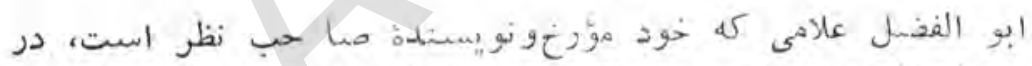

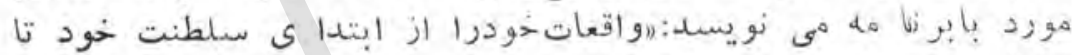

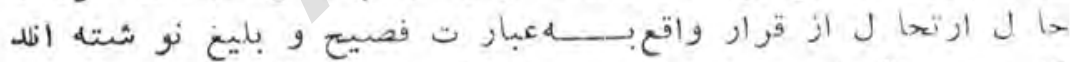

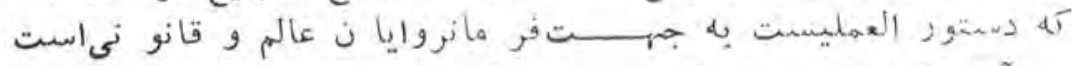

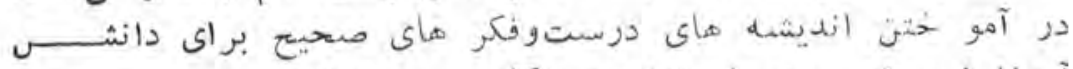

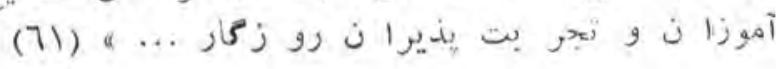

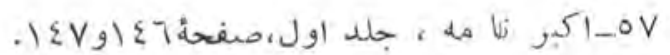
人

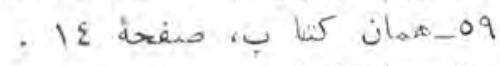

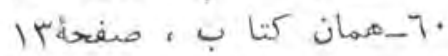

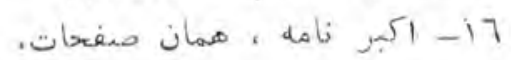




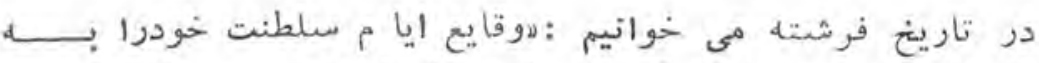

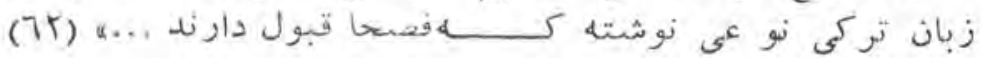

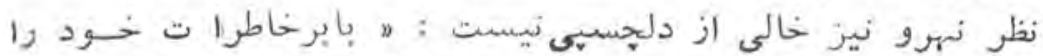

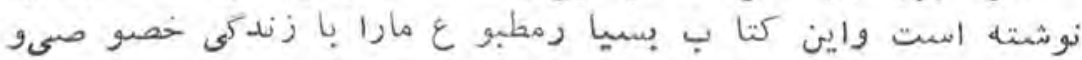

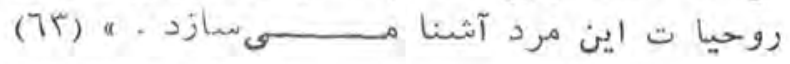

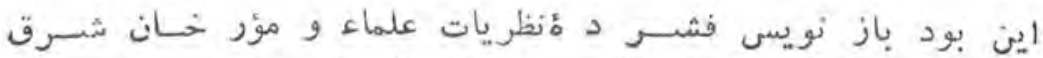

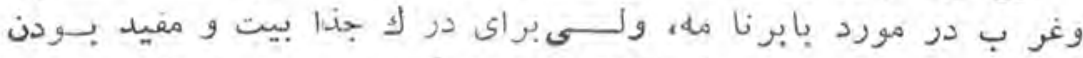

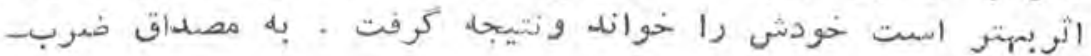

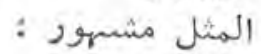

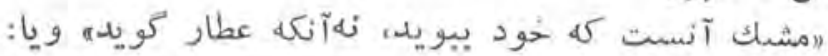

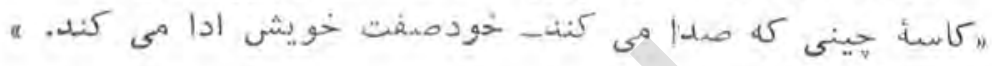
: بـ- رسالة عروض

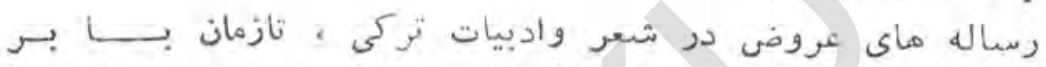

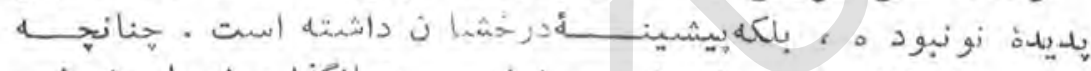

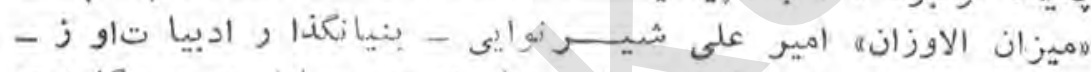

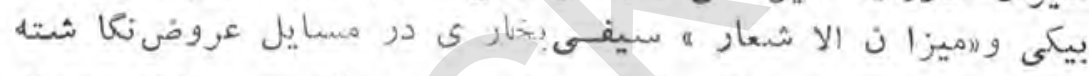

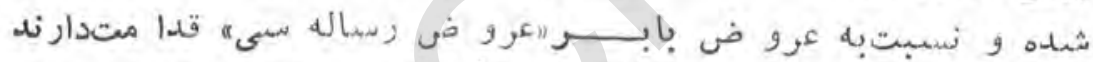

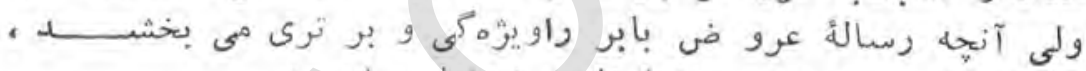

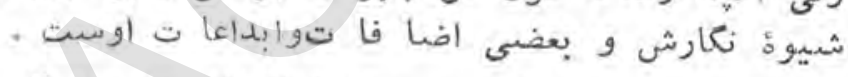

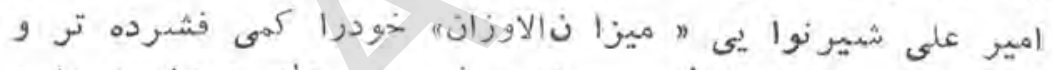

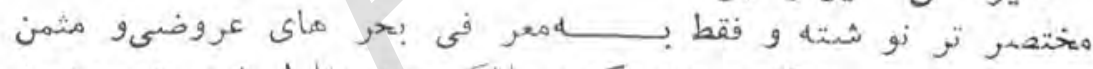

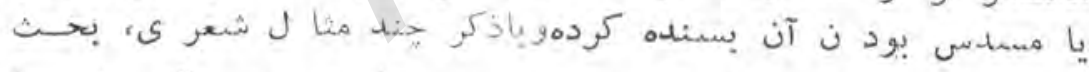

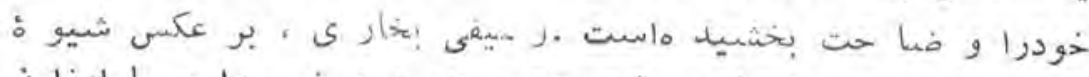

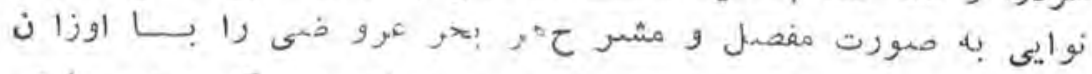

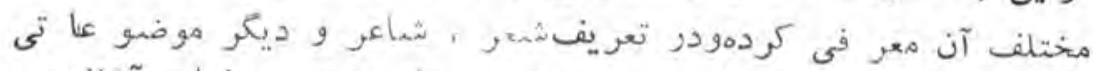

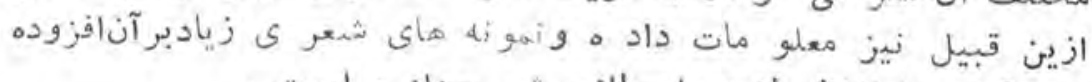

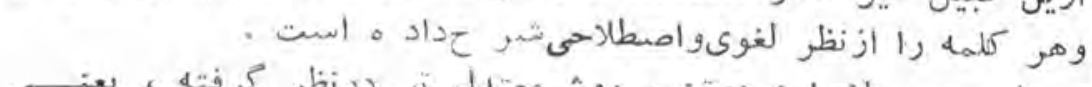

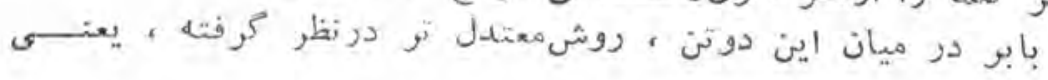

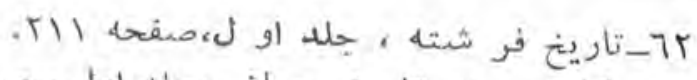

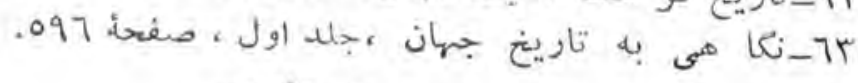




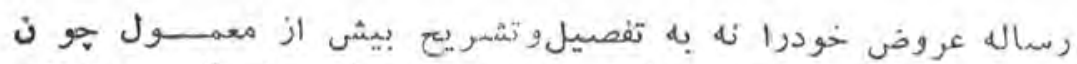

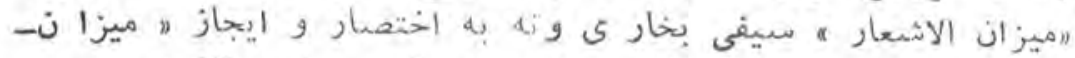

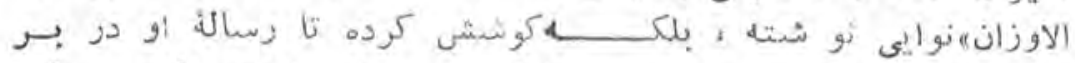

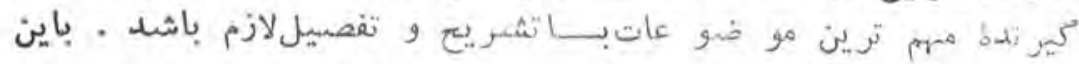

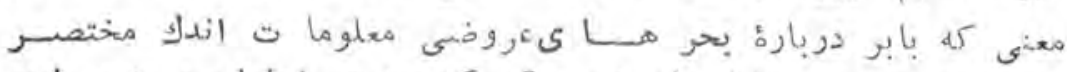

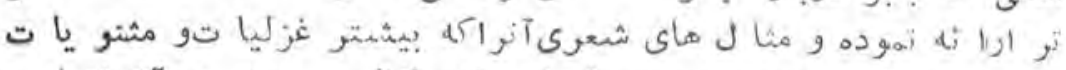

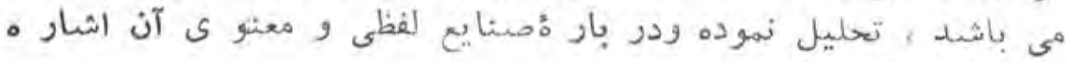

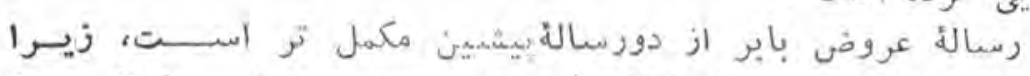

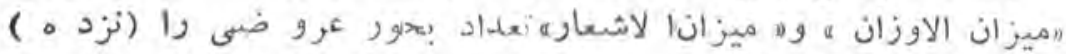

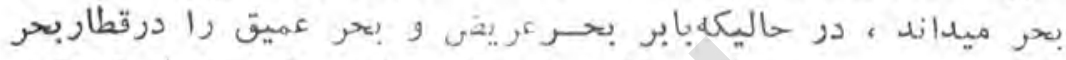

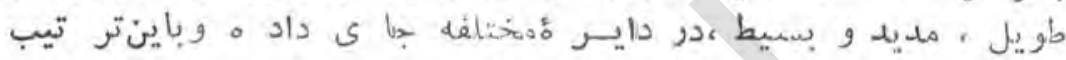

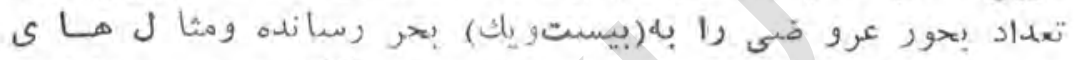

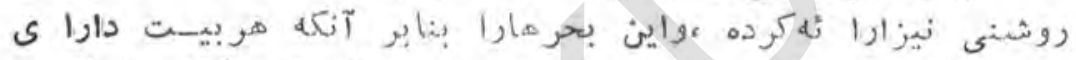

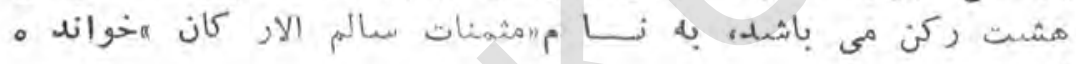

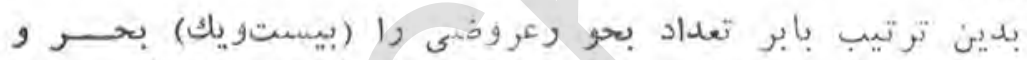

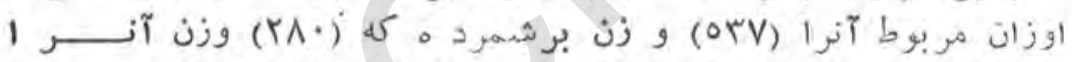

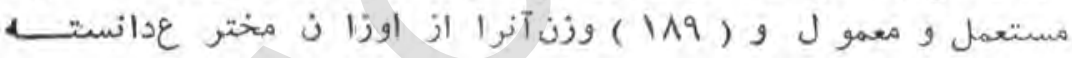

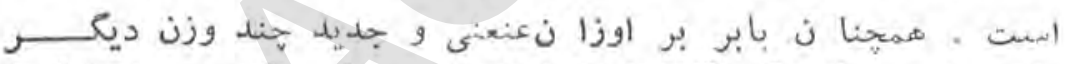

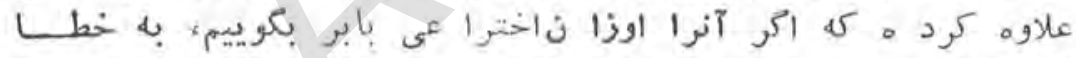
نر فته إيسم

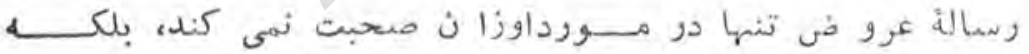

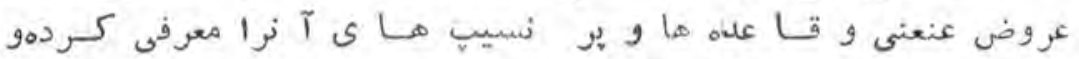

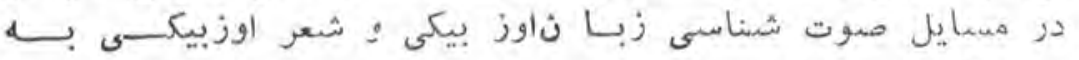

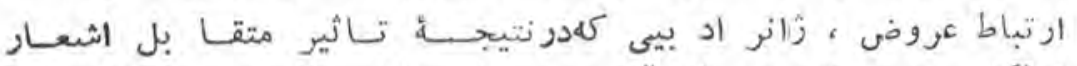

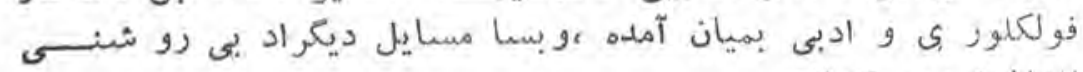

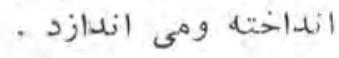

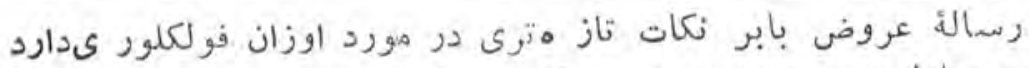

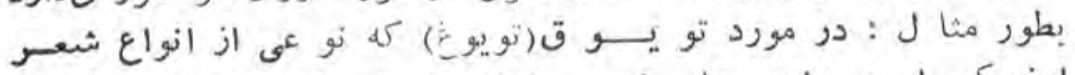

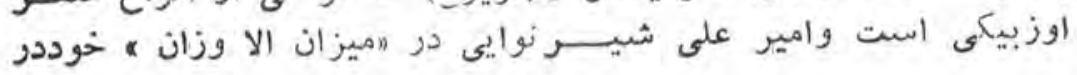




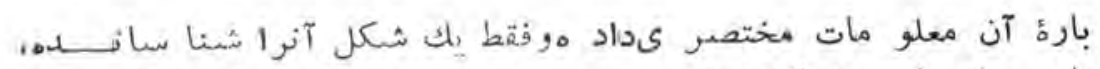

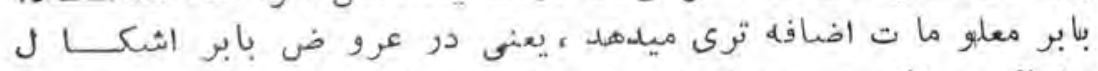

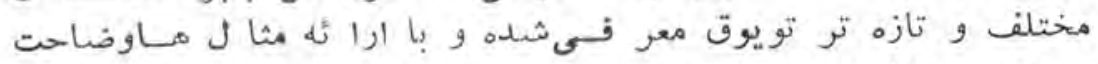

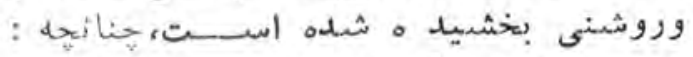

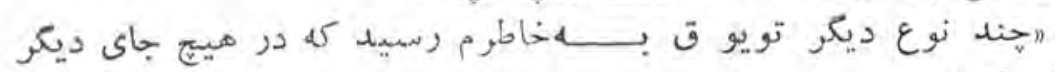

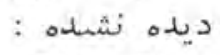
يكى اينكه در هر بههار قافيه ، تجنيسي مر اعا تميشود،بدينكونه:

$$
\begin{aligned}
& \text { وصلدين سوز دير كا يو ت ياراهنا }
\end{aligned}
$$

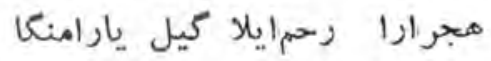

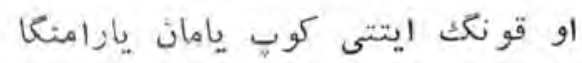

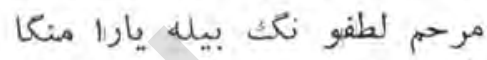

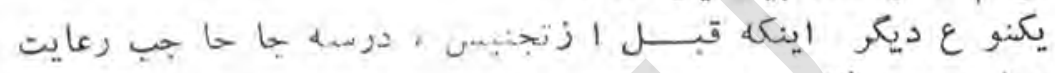
شده است عملو دملا:

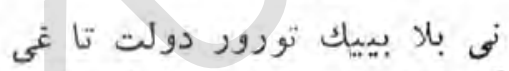

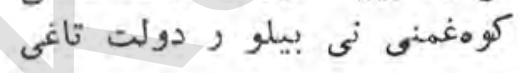
همتى تو ت داغى دولت ايستاكيل

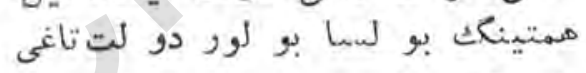

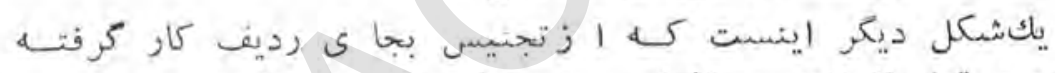

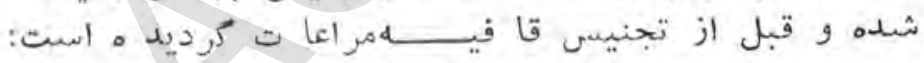

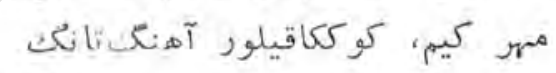

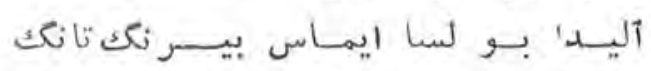

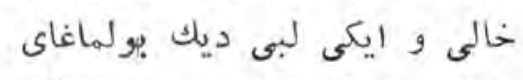

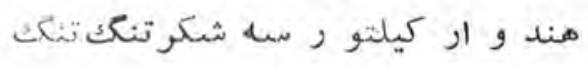

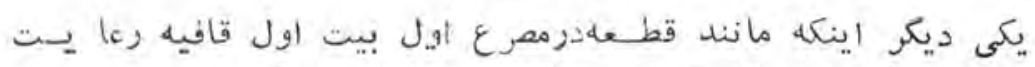

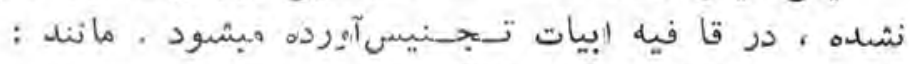

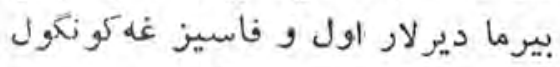

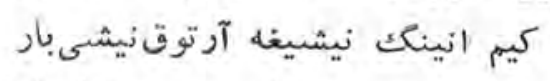

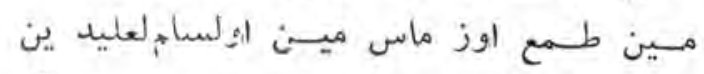

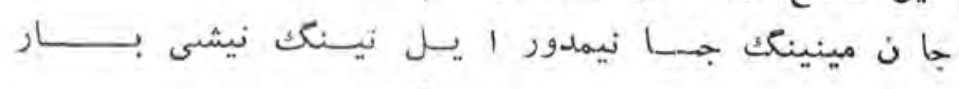
$-$ 
يك نو ع ديكر اينكة تجنيسنرعايتششده، قا فيه درسه مصنرع مراعات ميشموة مثلا: مثلا:

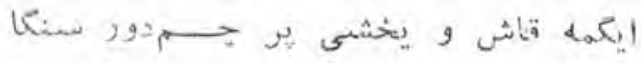

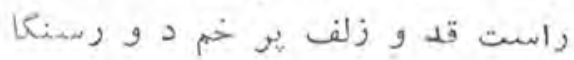

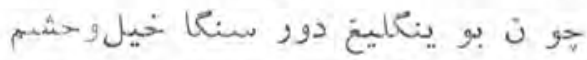

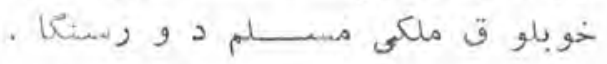

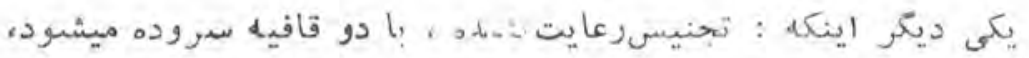

مثال :

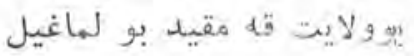

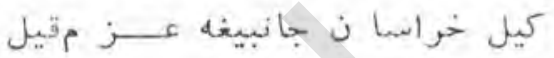

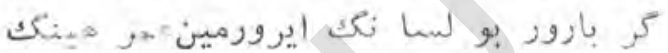

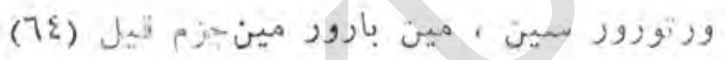

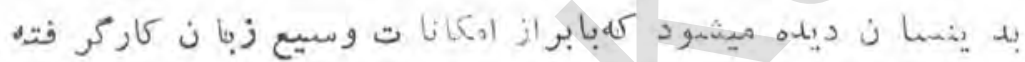

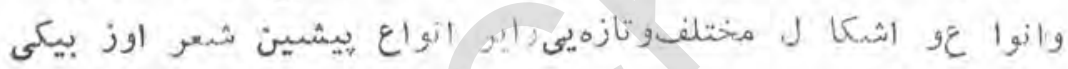

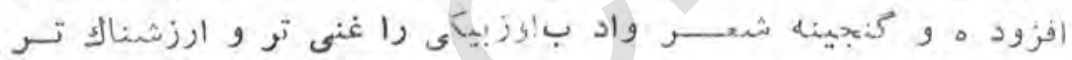

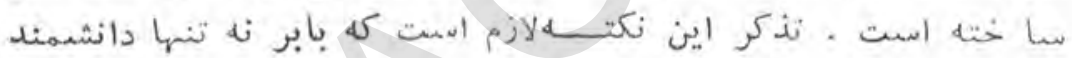

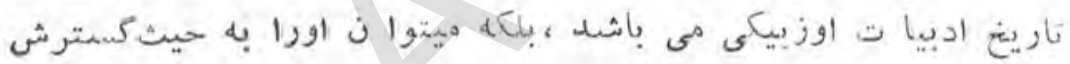

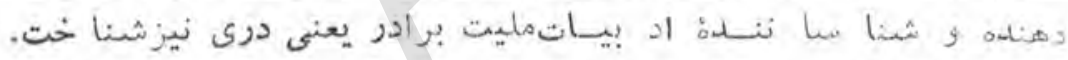

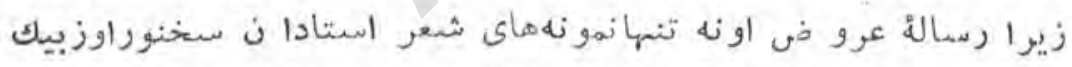

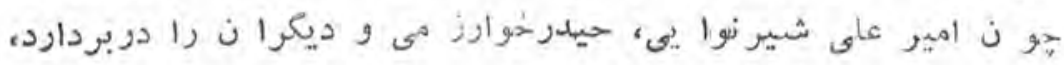

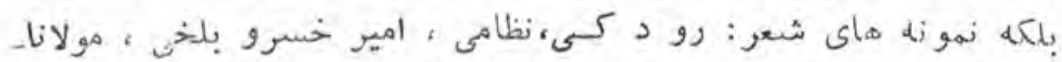

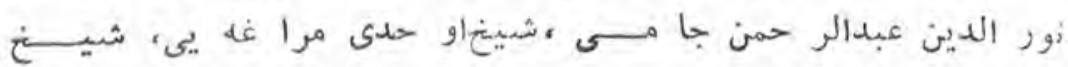

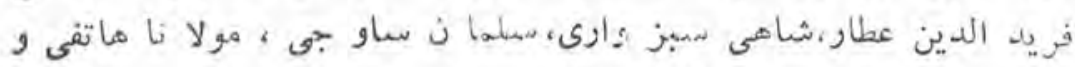

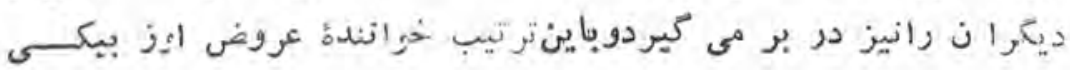

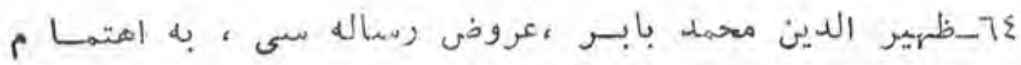

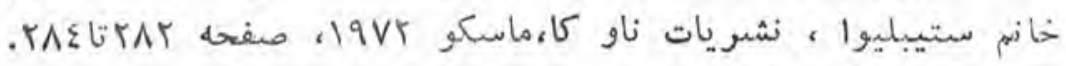

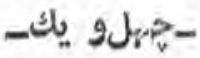




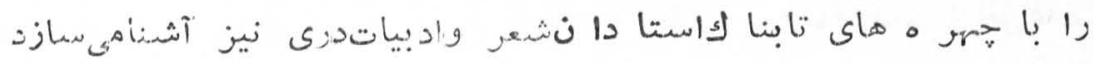

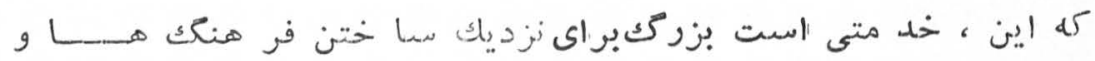

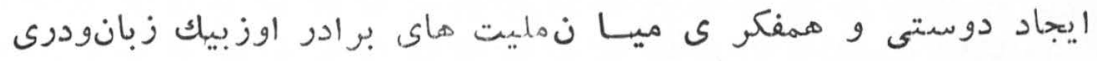
زبان .

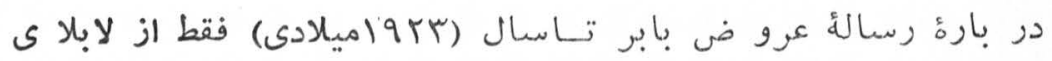

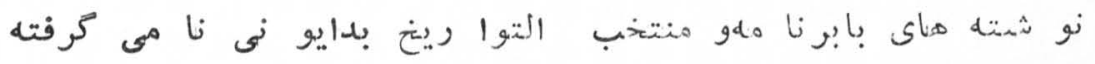

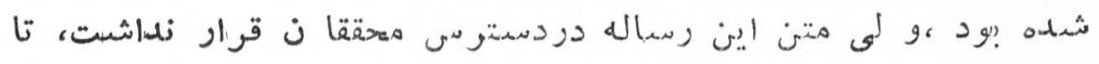

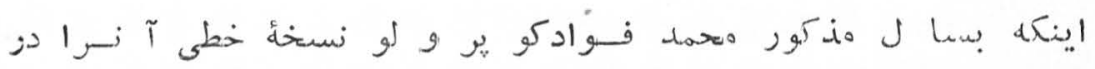

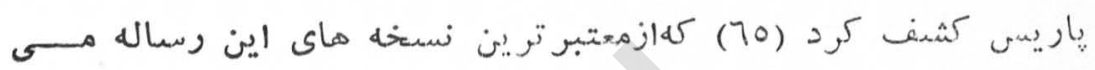

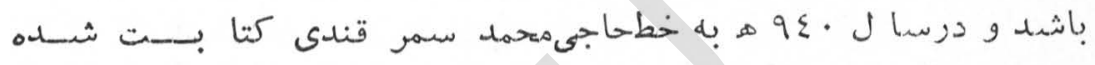
اسمت. (77)

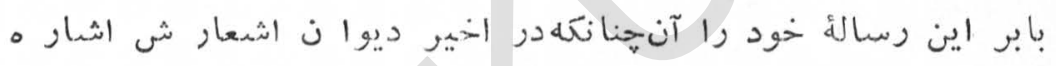

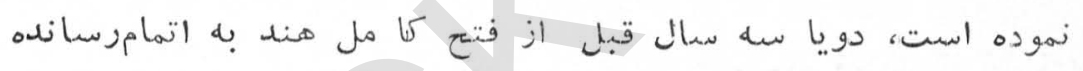

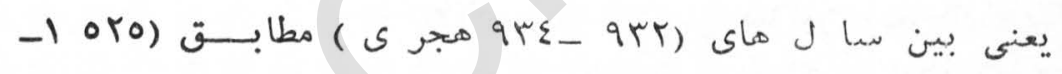
مود.

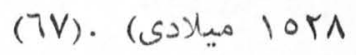

:

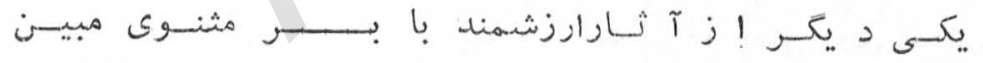

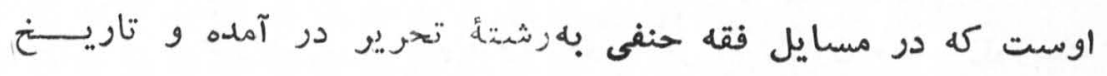

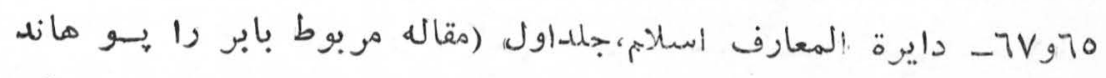

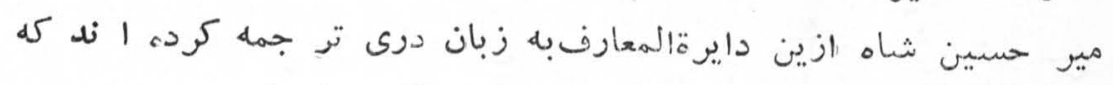

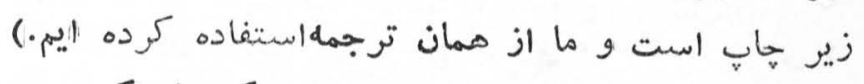

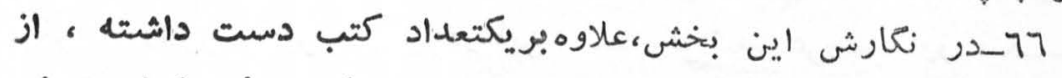

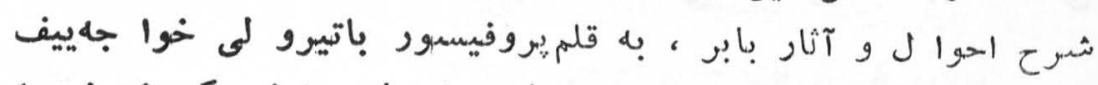

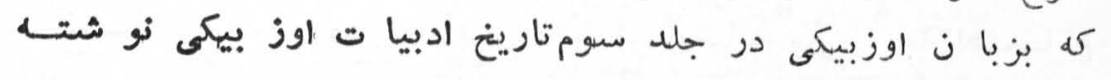

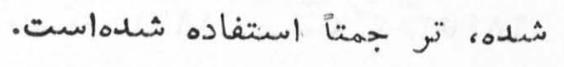


نكارشن آن به استناد ستئخود ش

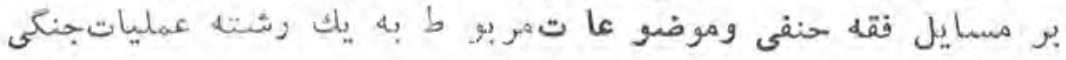

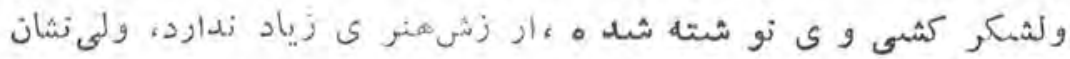

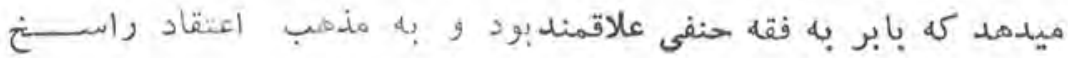

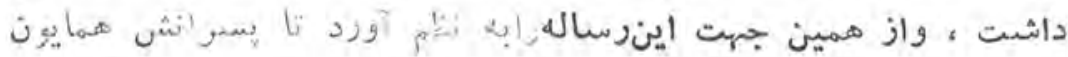

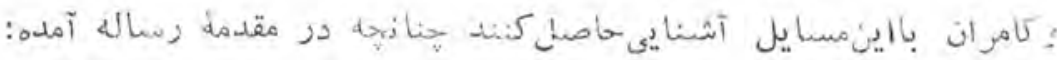

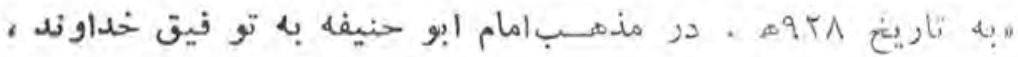

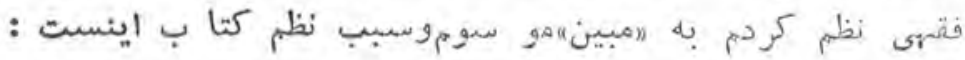

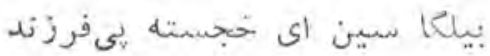
جكريم بير لله جانيمه بيوند

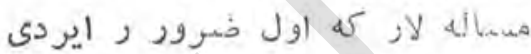

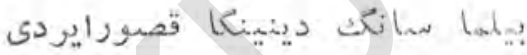

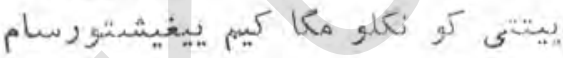

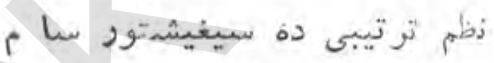
تا آنى ضبط قيلغا سين آسان

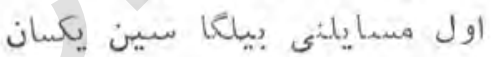
تانعلا ليق كونده كيم حسبـابـاولغا ى منكا اجرو سنكا ثواباولغا ى لعه

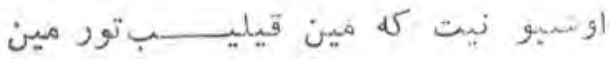
اول هميايل كه مين بيليب تورمين جمعيد م سعى واهتمام قيلاى سينينك آ تينكغه مين تمســامقيلاى بى بقا دنيا ايشى سهل دورور دين ايشينين قيلغا ى اول كهاهل دورورو د.ين ودانشى ده هم كو نافزو نبول

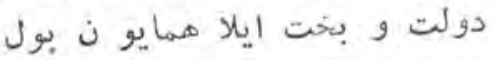

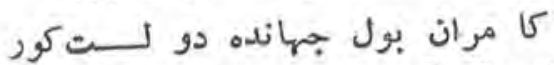
يوز تو مان آب روى ون عـز توله دور. 


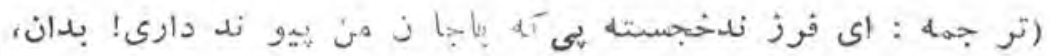

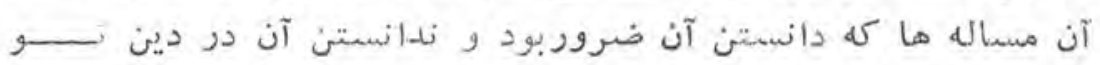

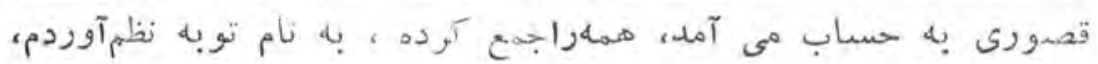

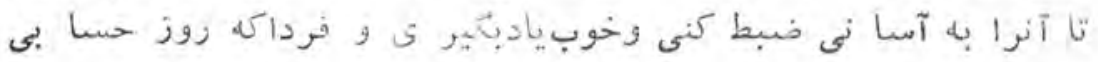

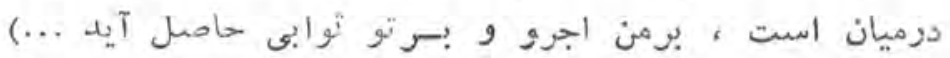

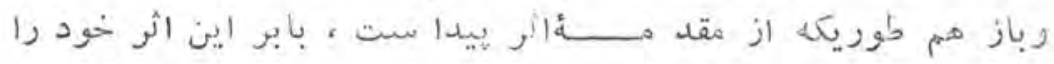

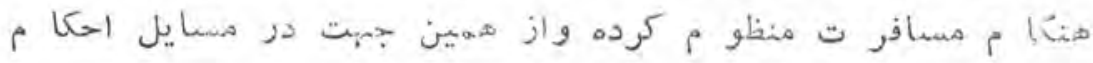

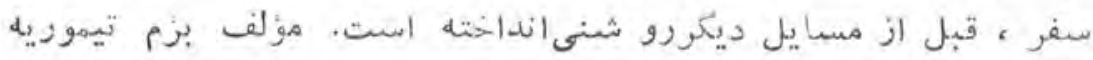
در بحث مربوط به بابر مئى نويسد:

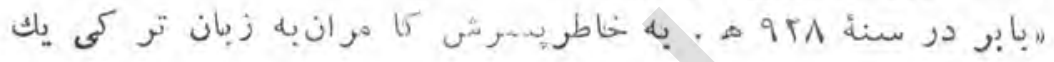

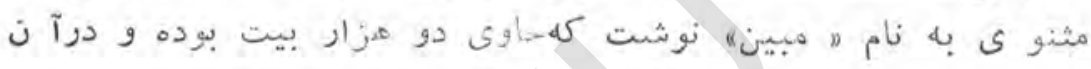

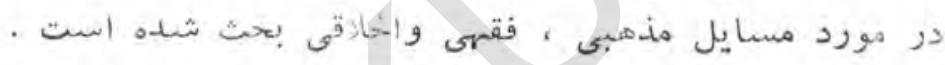

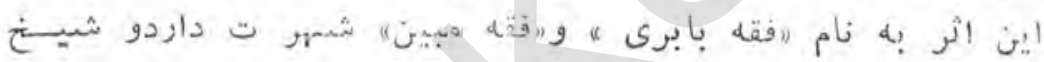

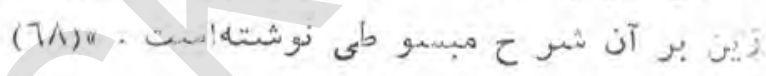

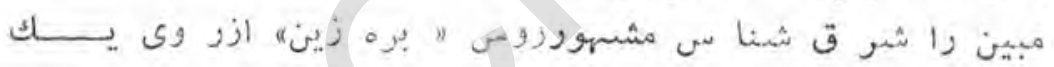

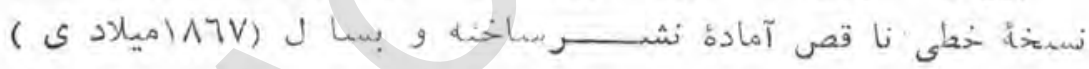

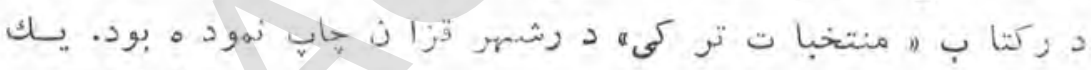

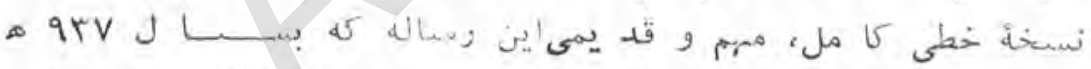

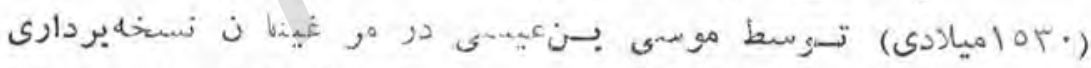

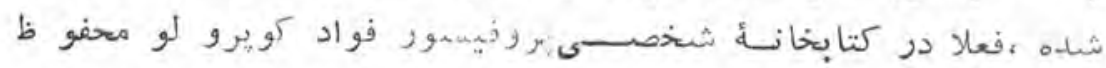

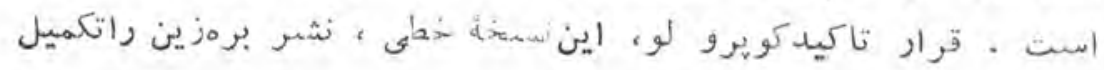
$\cdot(79) \cdot 250$

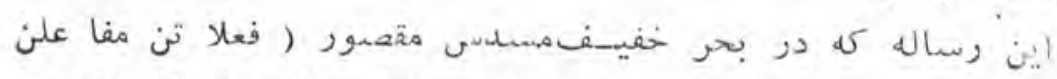

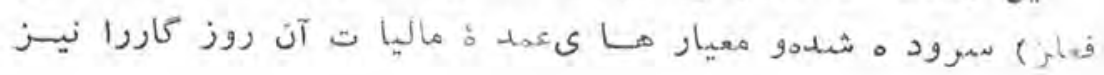

117

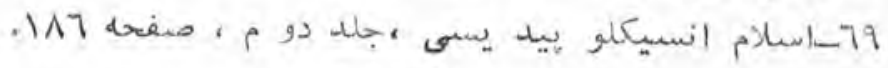

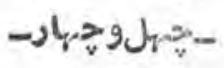




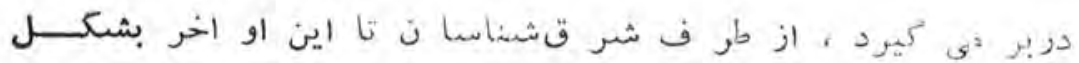
(Mobin)

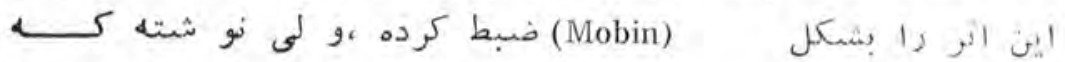

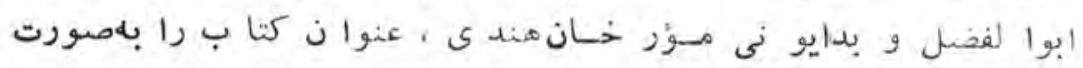

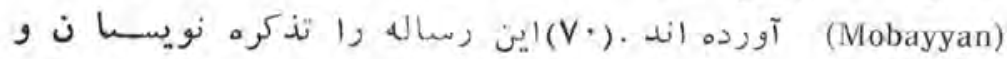

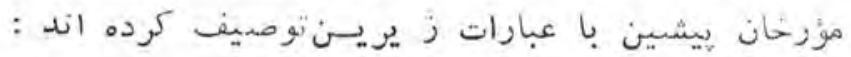

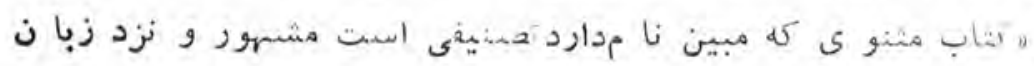

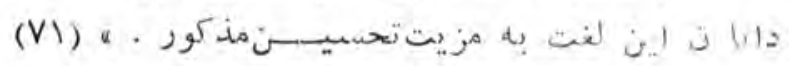

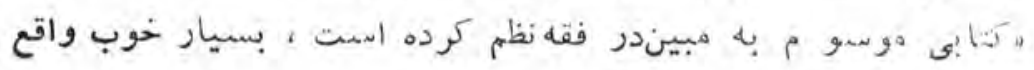
(VT) a. . מ

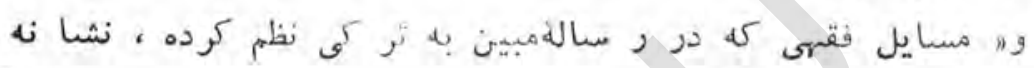
1

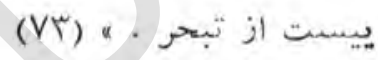

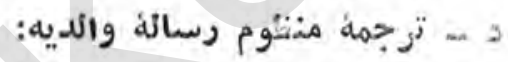

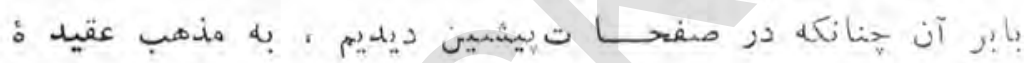

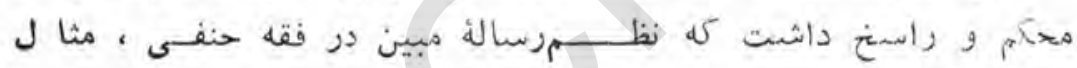

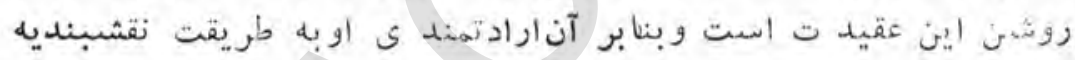

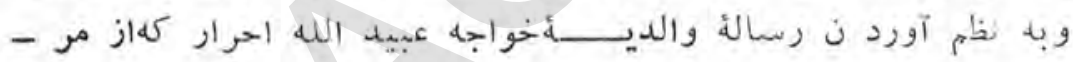

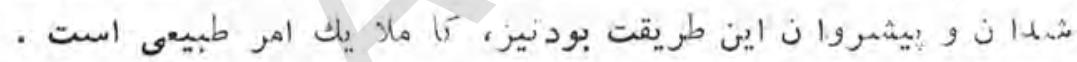

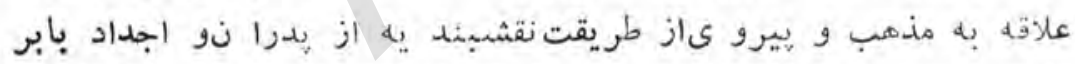

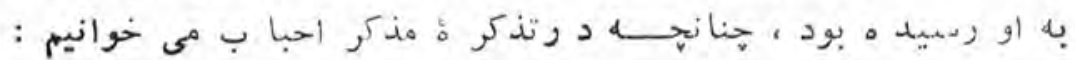

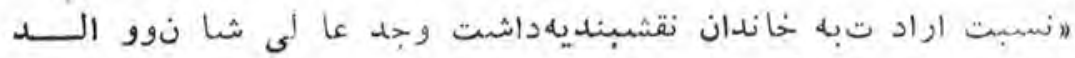

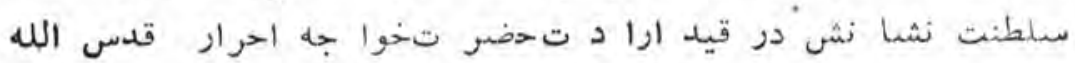

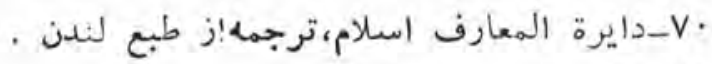

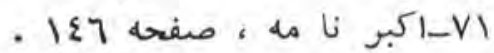

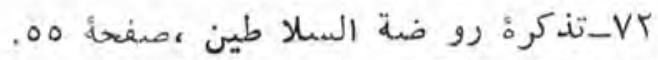
• 


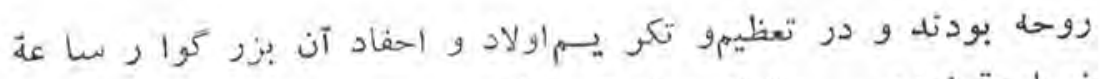

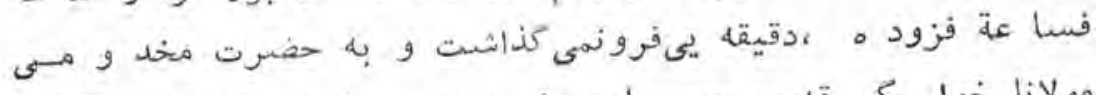

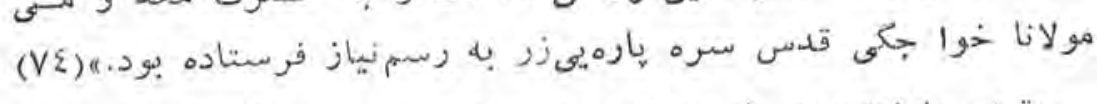

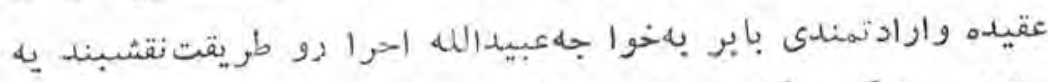

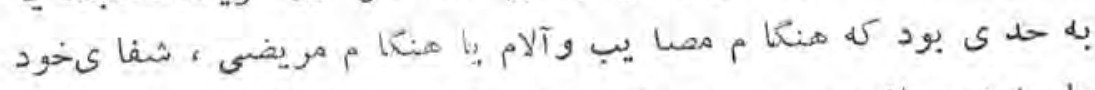

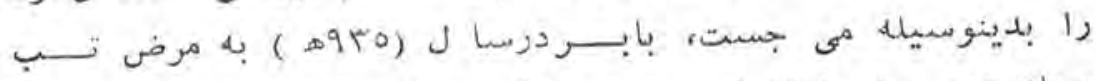

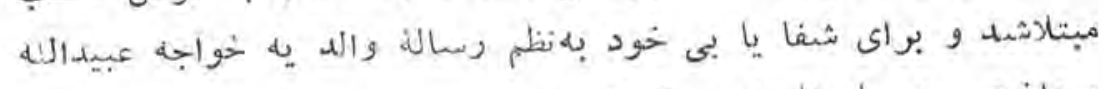

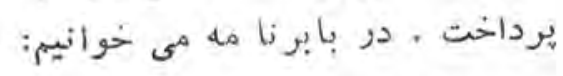

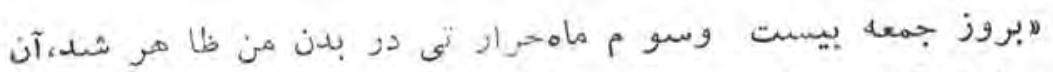

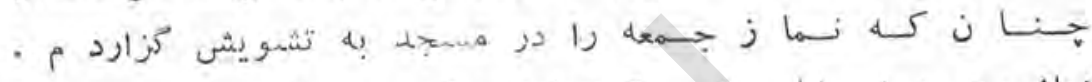

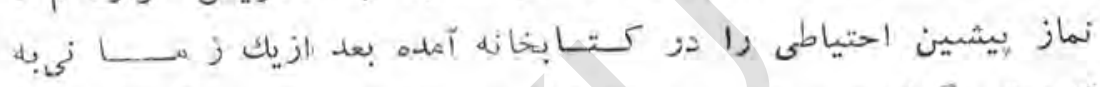

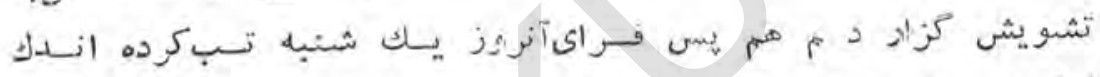

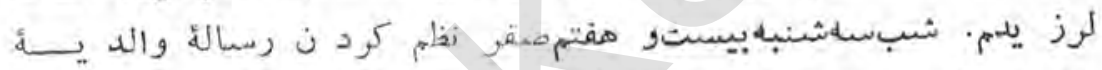

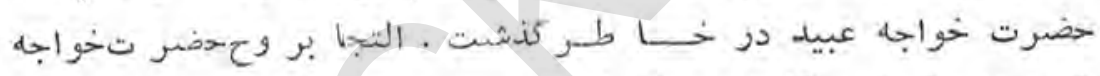

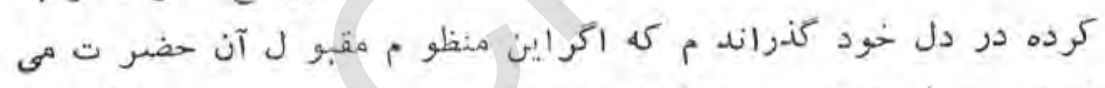

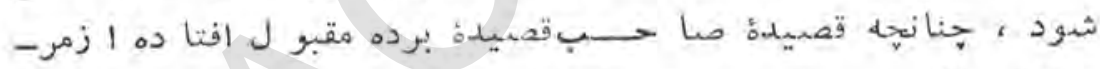

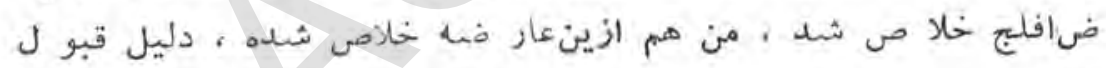

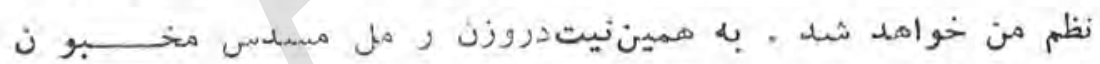

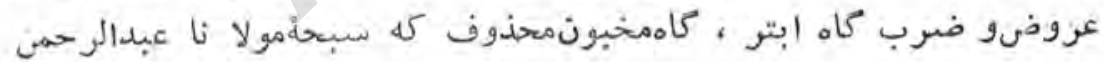

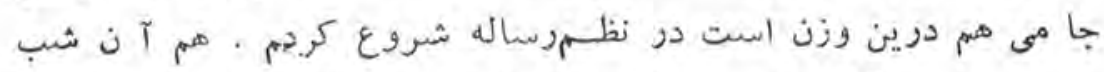

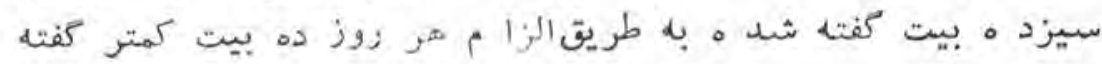

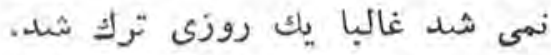

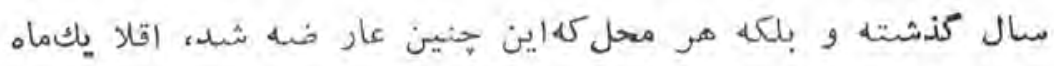

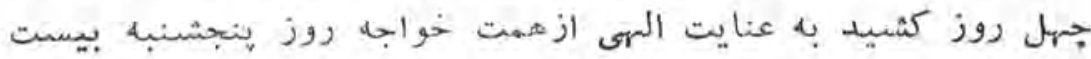

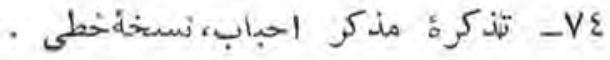
- 


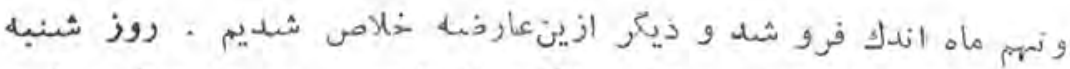

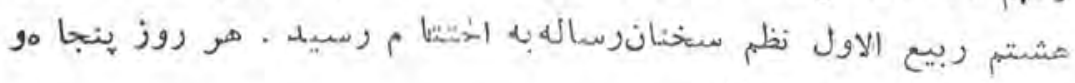

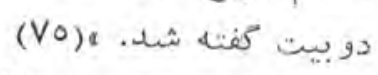

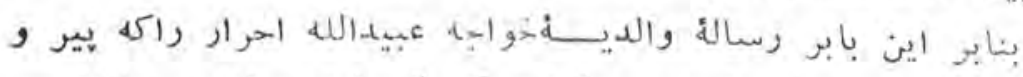

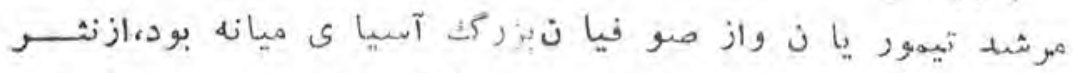

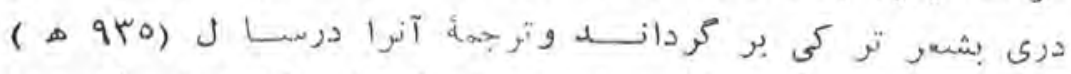

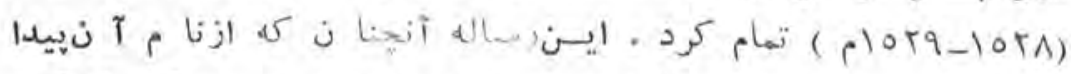

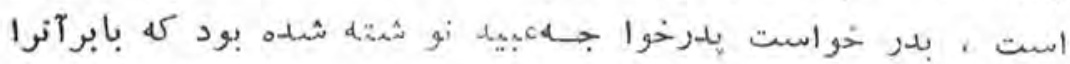

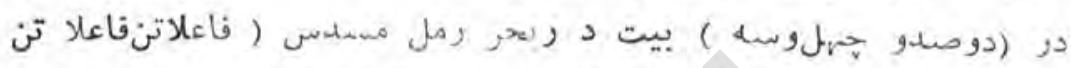

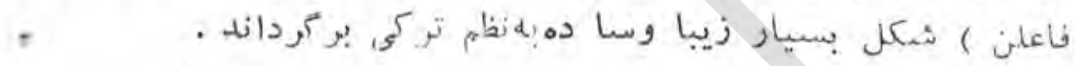

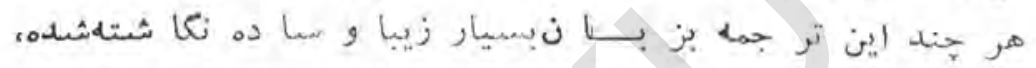

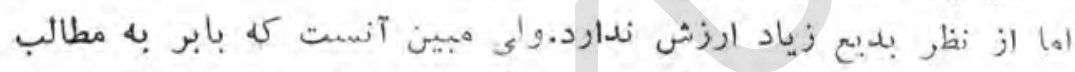

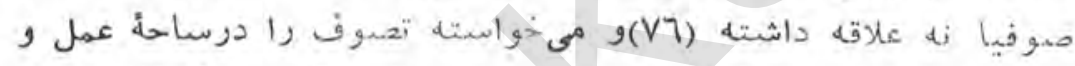

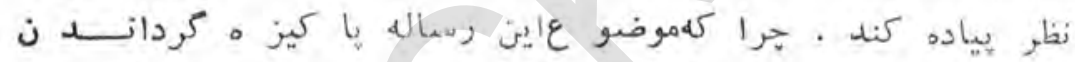

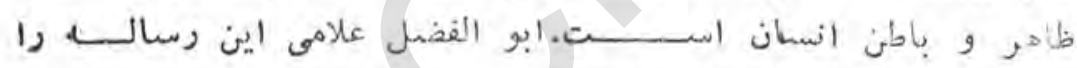

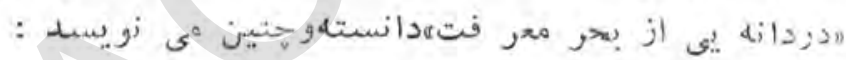

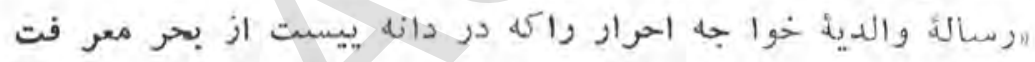

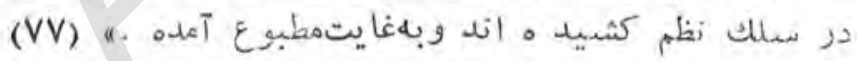

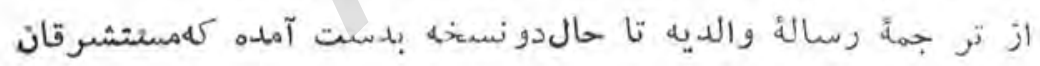

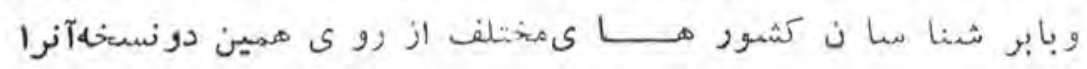

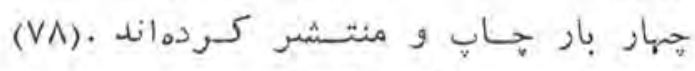

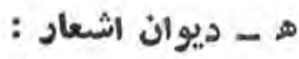

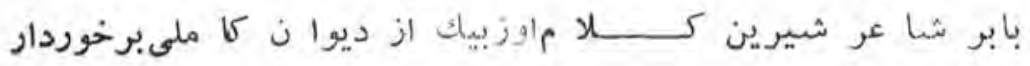

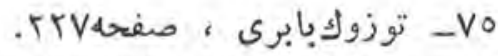

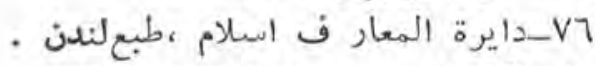

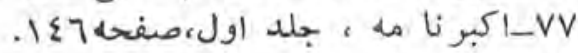

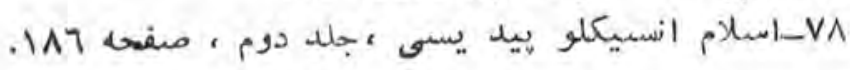




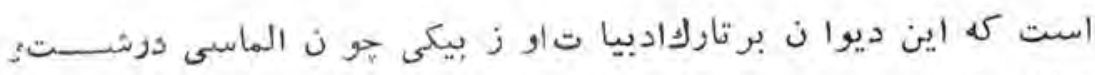

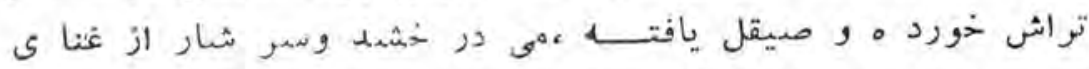

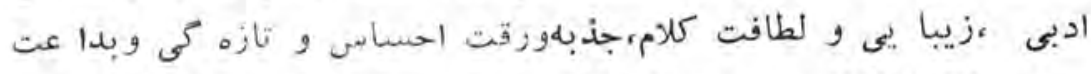

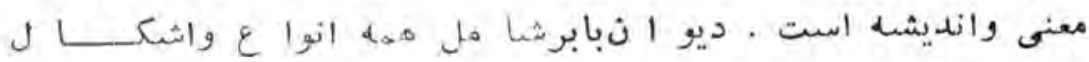

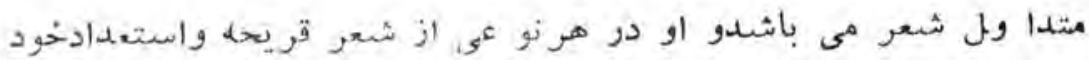

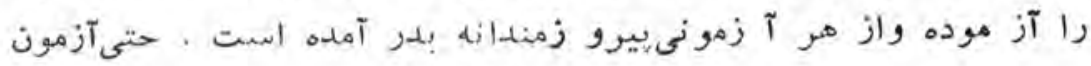

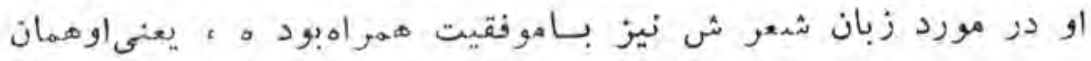

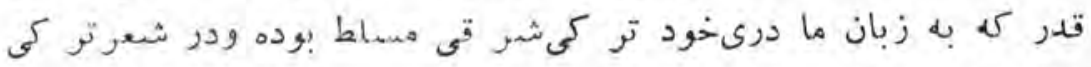

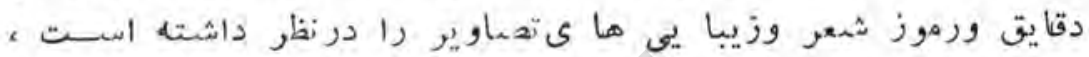

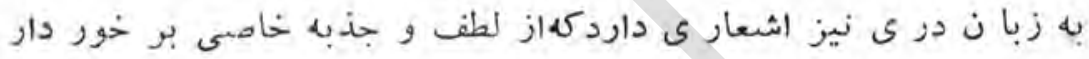

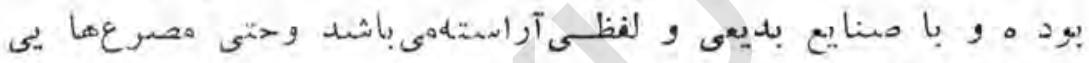

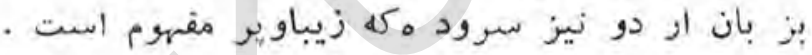

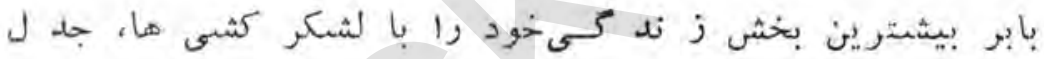

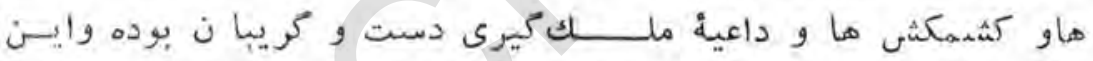

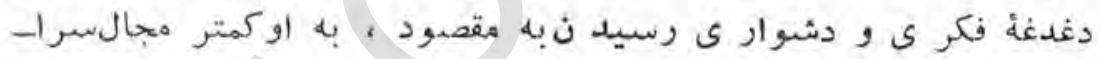

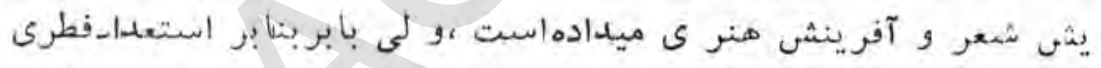

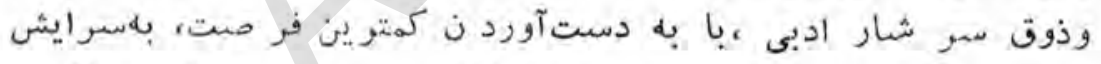

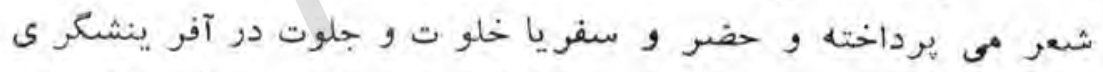

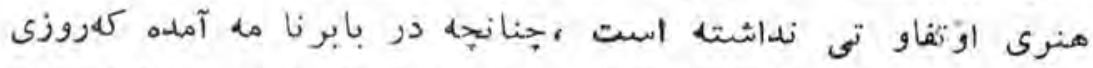

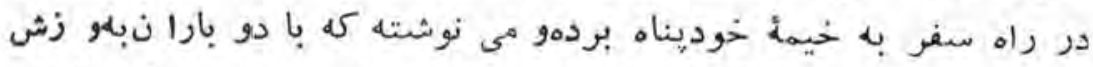

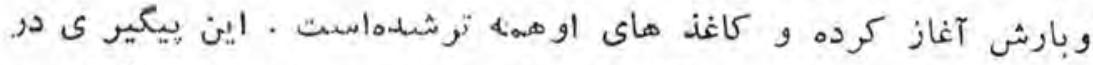

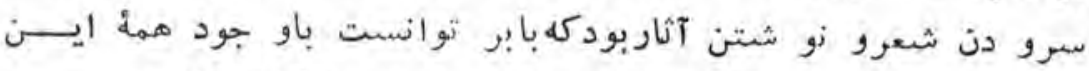

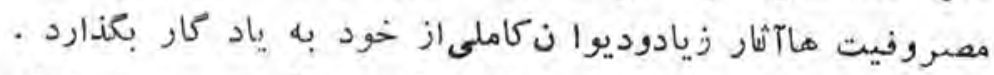

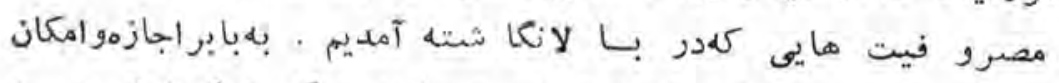

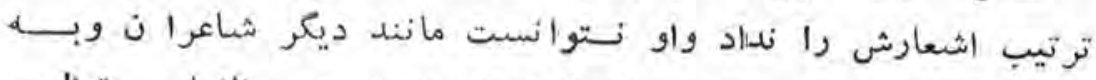

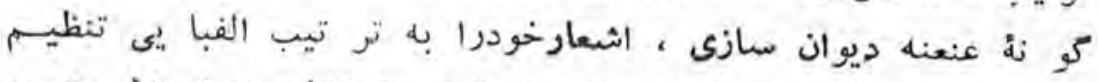

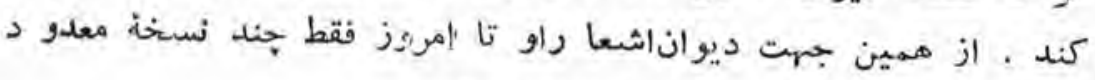




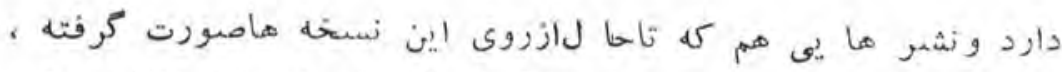

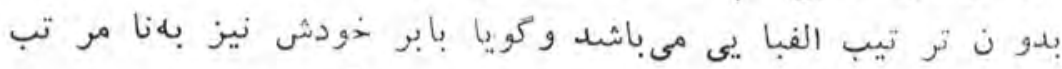

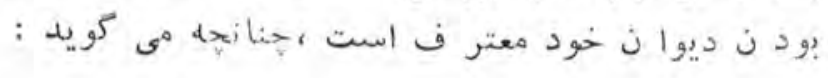

ديوانيهه نى ربط ونى تر تيـبدورورر

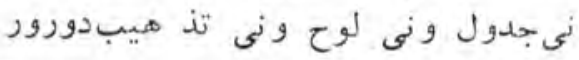

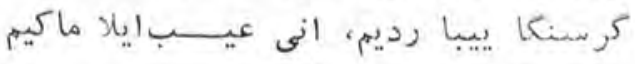

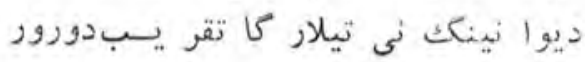
:

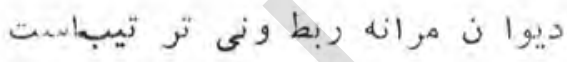

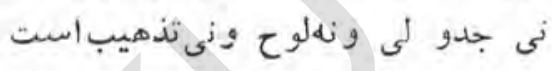

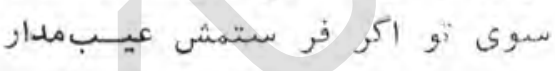

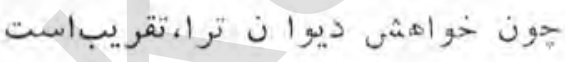

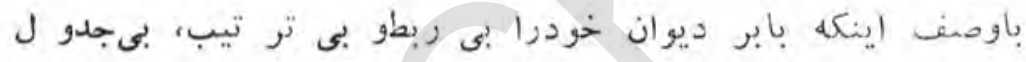

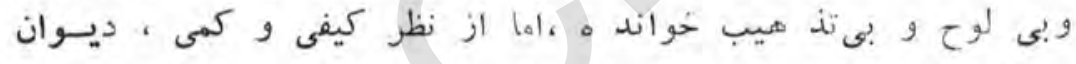

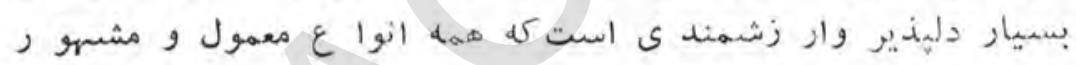

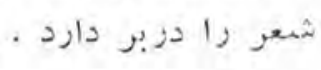
:

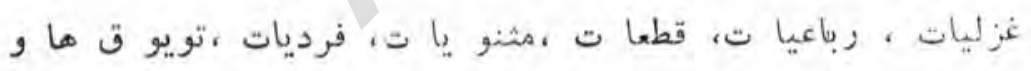

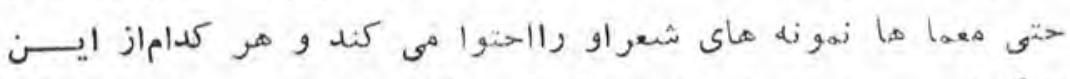

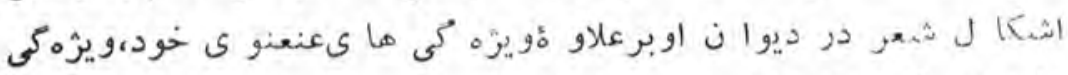

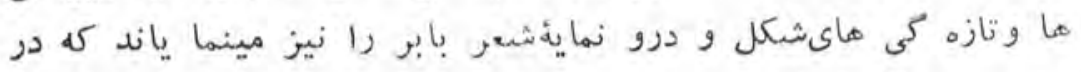

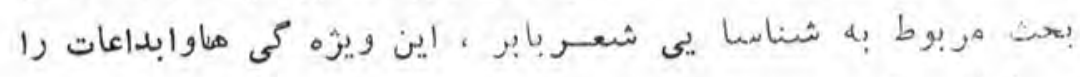

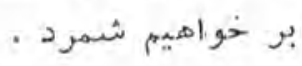

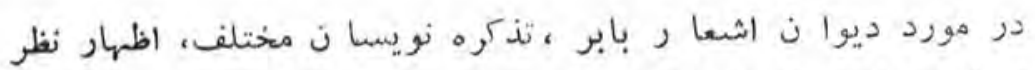

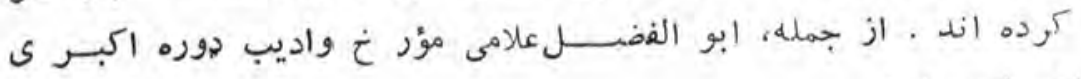
مى نويسد : 


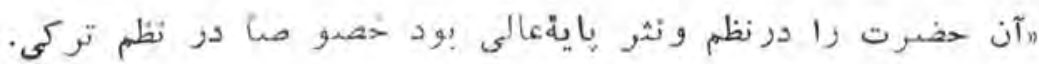

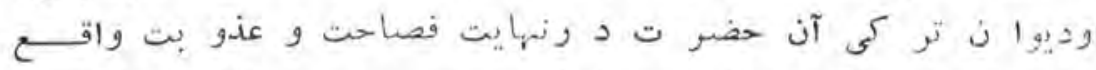

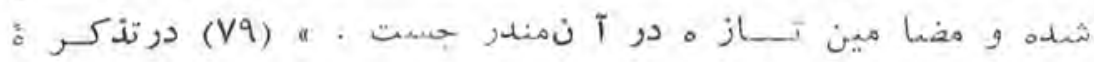

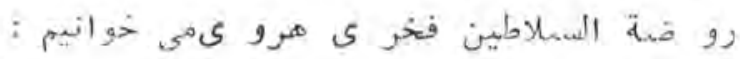

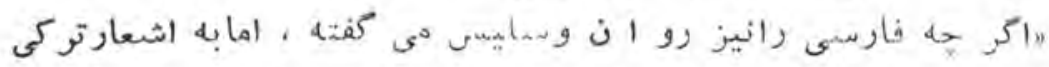

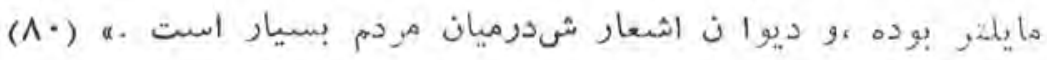

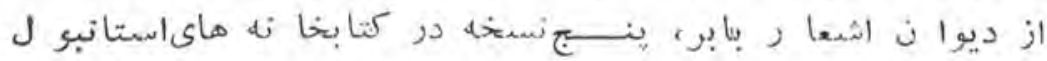

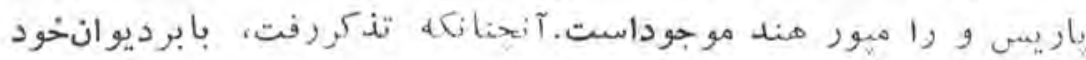

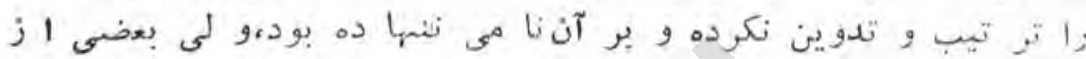

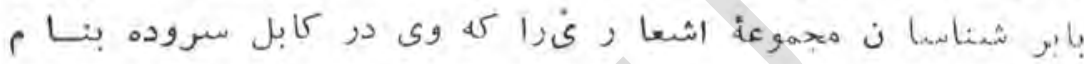

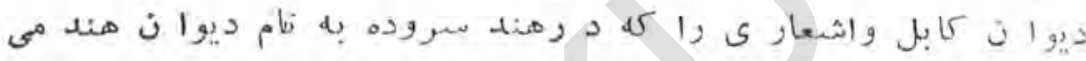

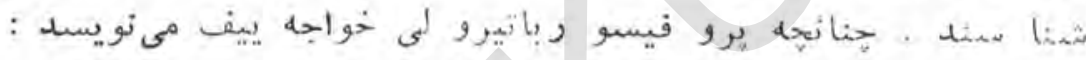

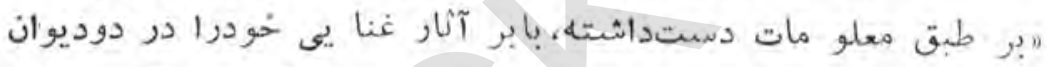

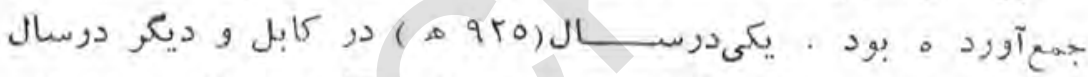

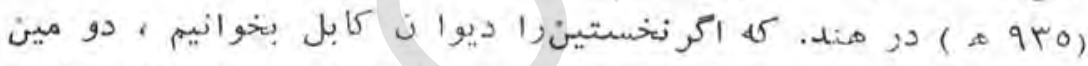

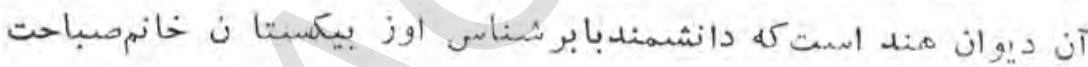

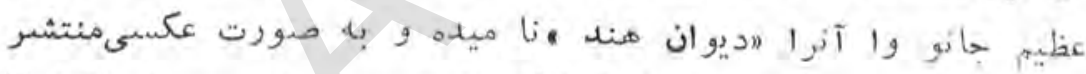

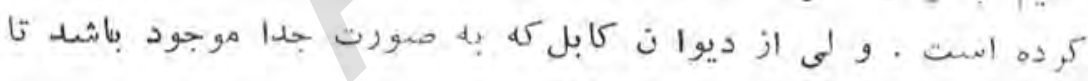
(A)

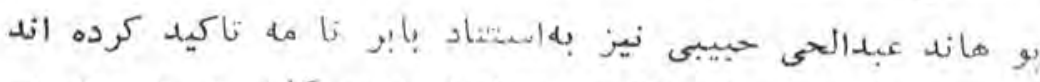

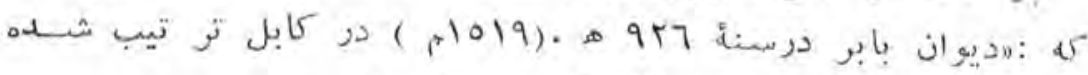

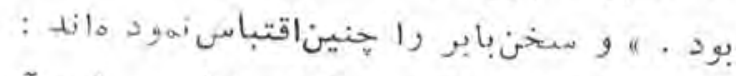

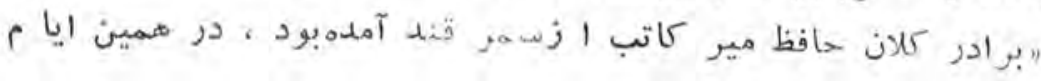

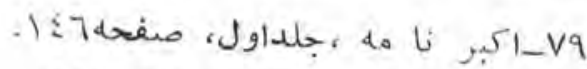

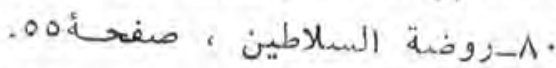

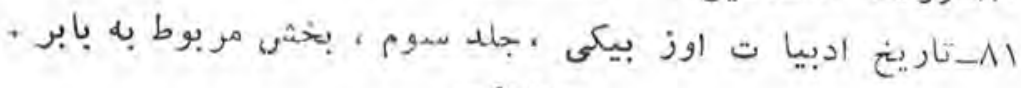

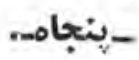




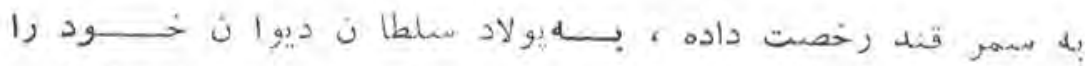

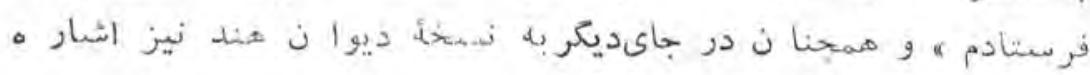

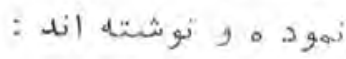

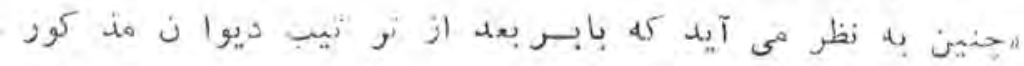
م 240 o

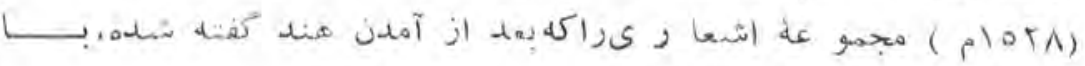
(AT) a " آ

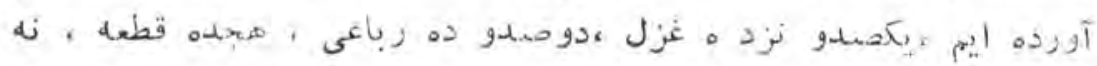

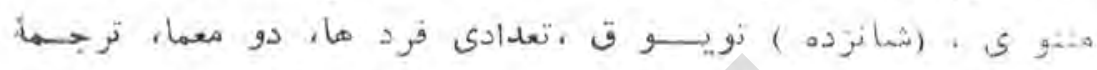

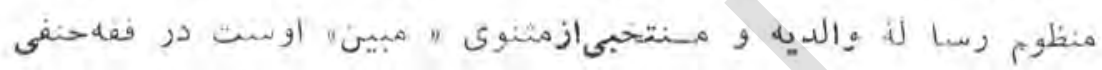

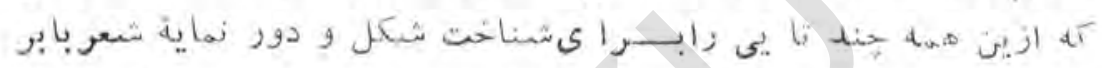

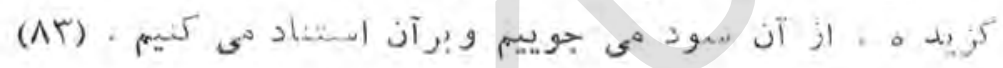

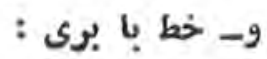

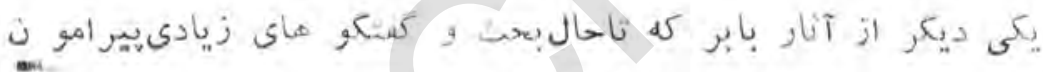

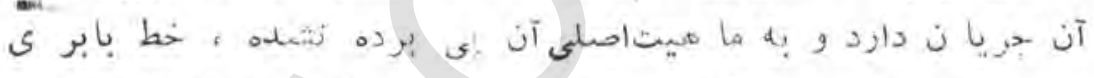

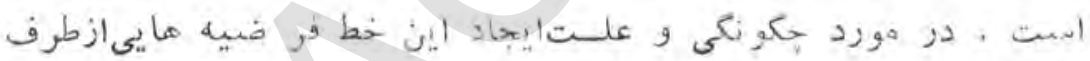

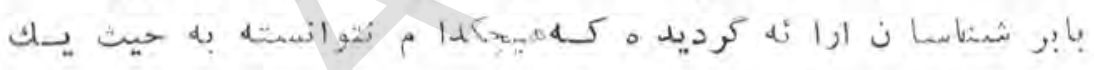

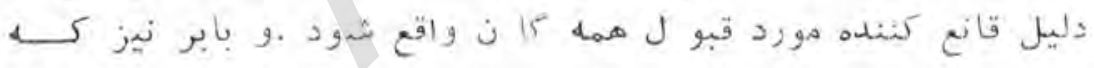

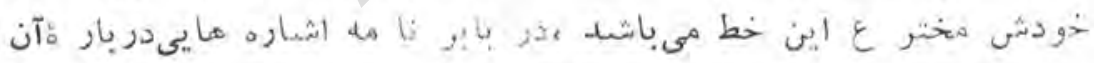

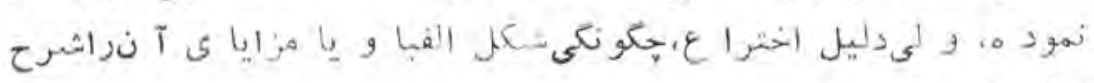
ن

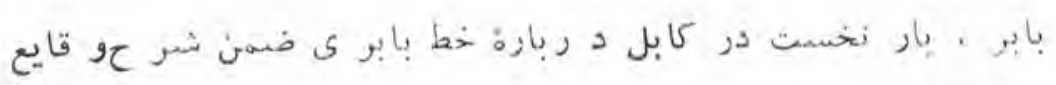

V. V79 79 .

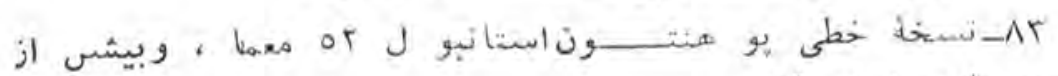

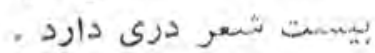




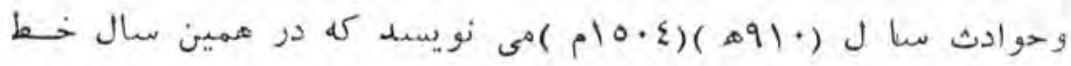

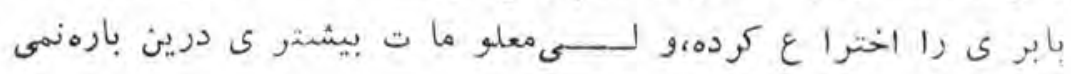

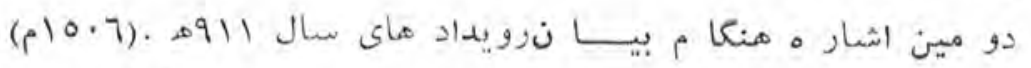

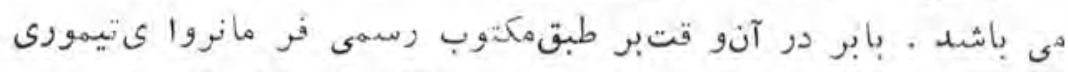

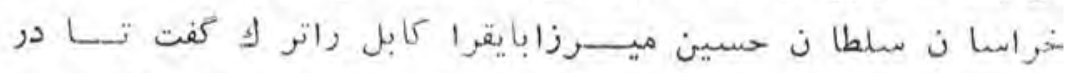

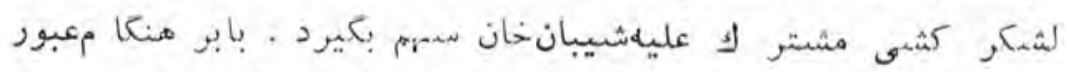

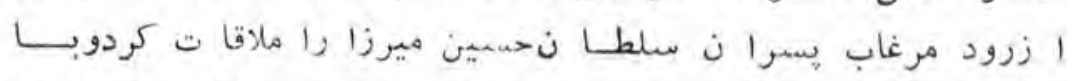

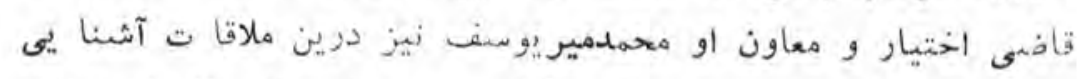

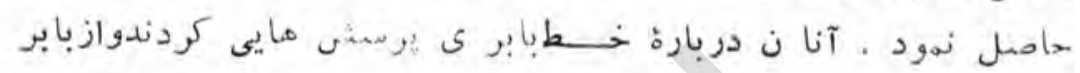

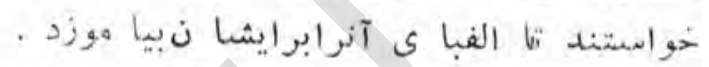

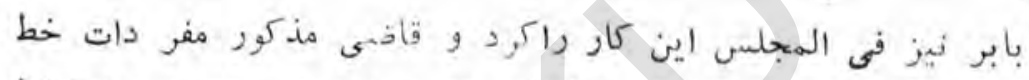

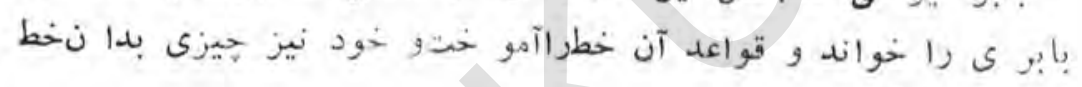

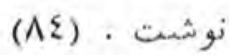

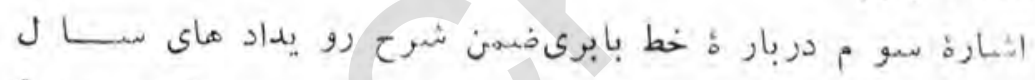

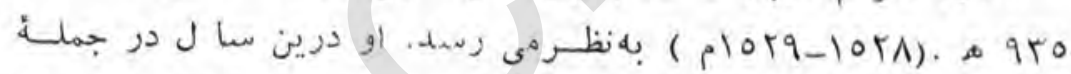

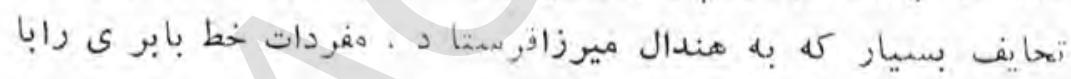

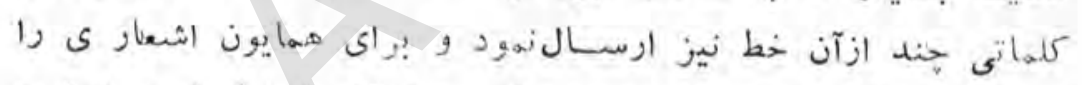

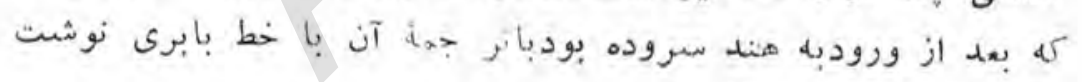

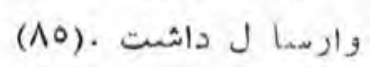

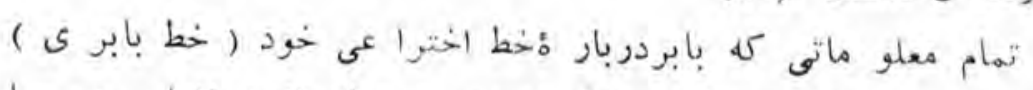

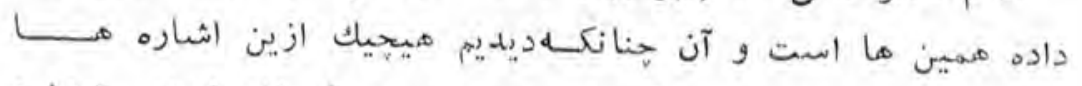

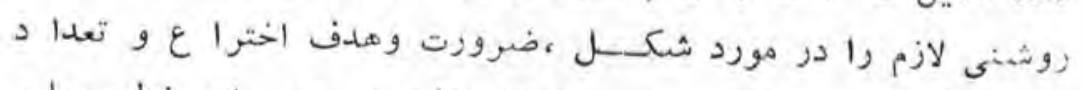

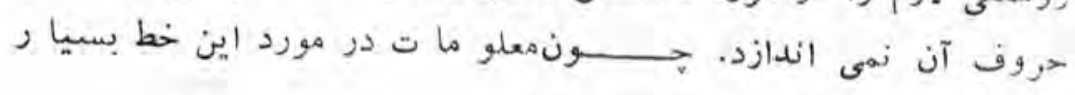

ع

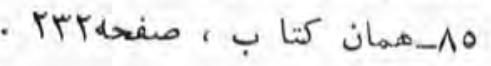




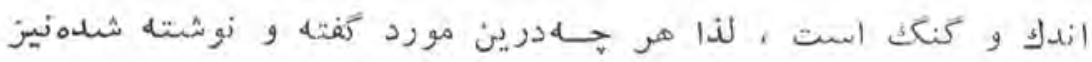

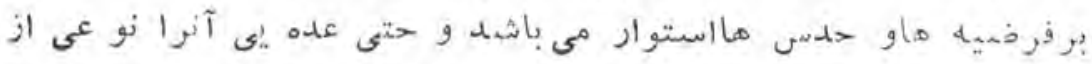

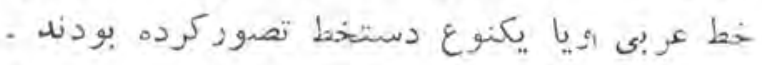

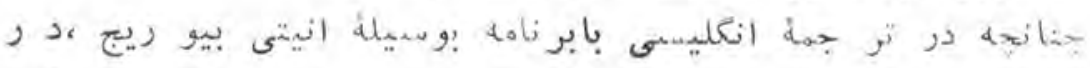

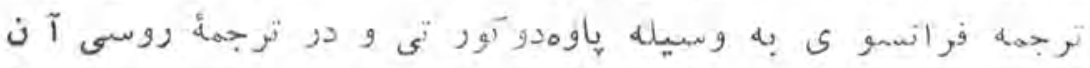

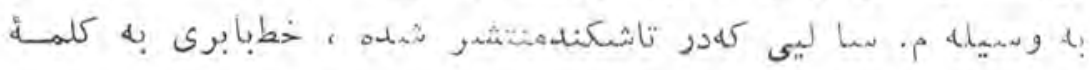

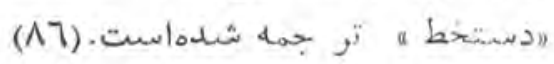

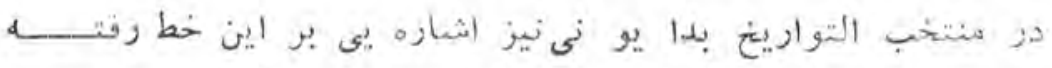

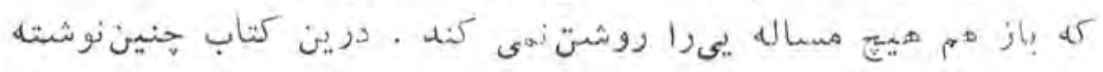
$\therefore$ :

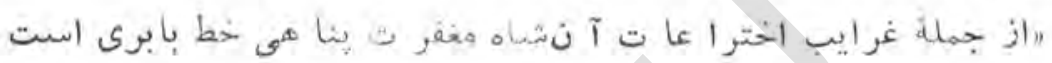

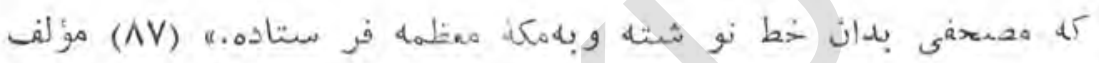

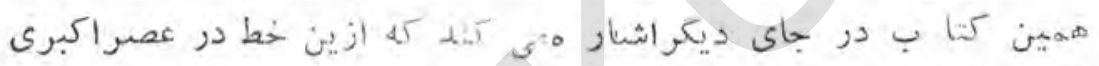

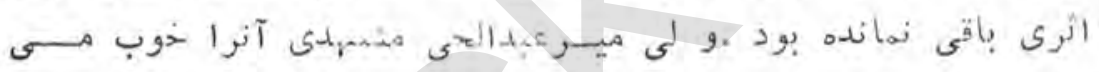
$\cdot(\Lambda \Lambda) \cdot \operatorname{com}$

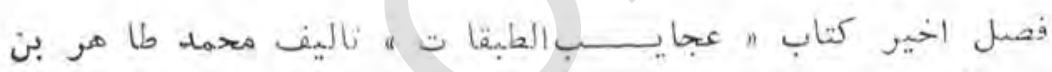

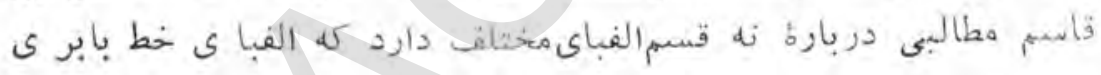

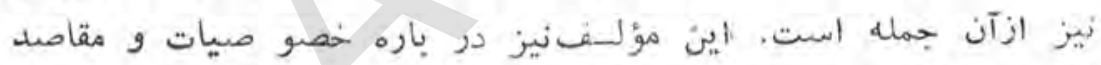

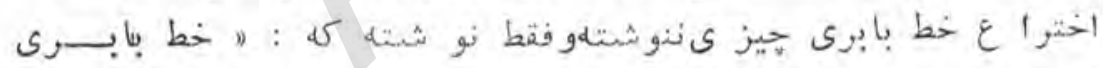

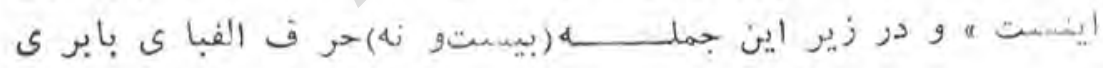

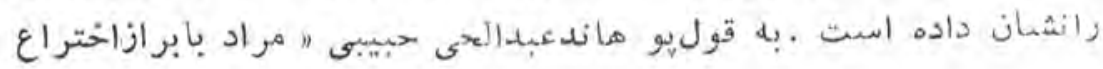

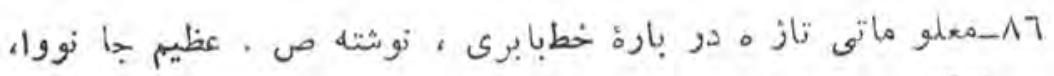

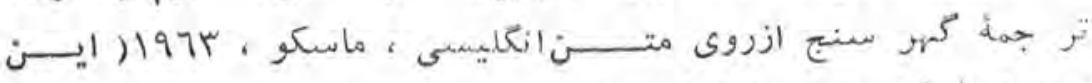

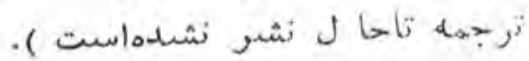

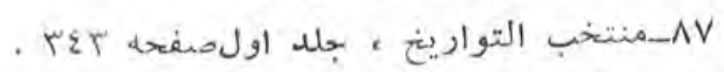

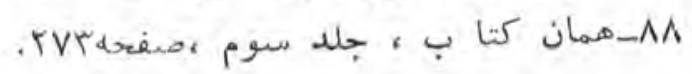


اين خط تنهانو شتن هتون زبـا نعر بى و قرآن بوده ، زيرادر جملك

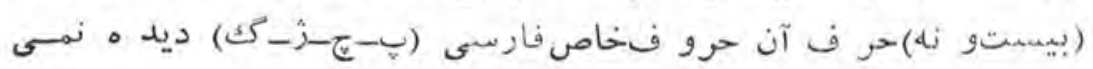

$$
\text { (19) ش ش ش }
$$

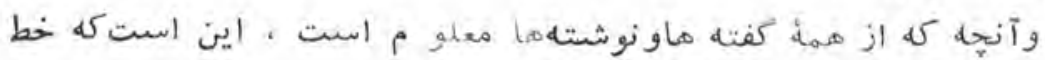

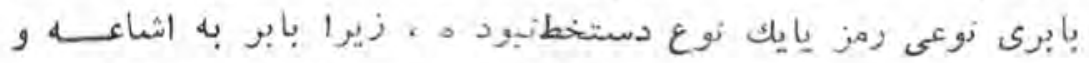

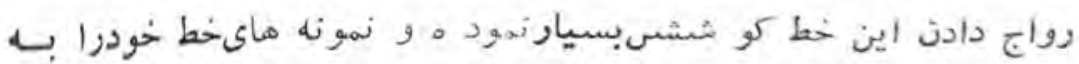

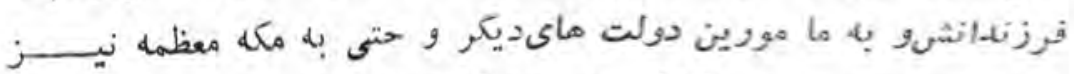

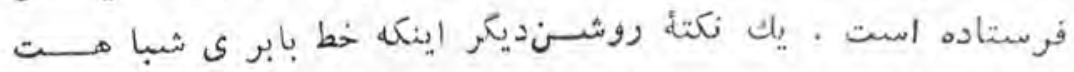

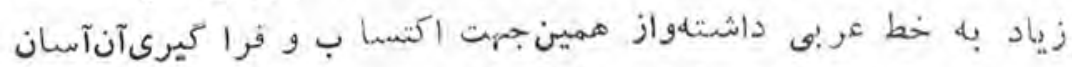

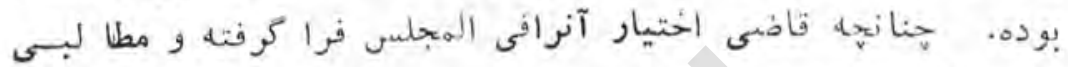

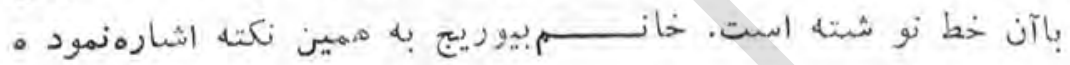

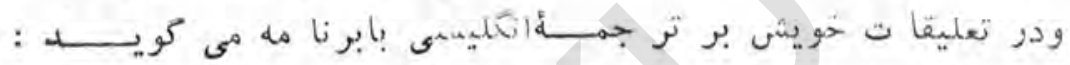

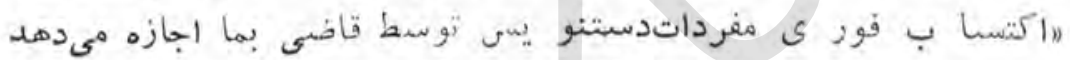

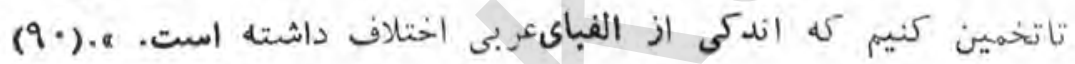

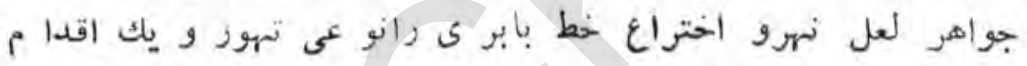

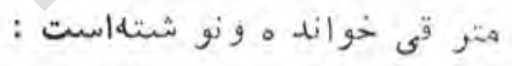

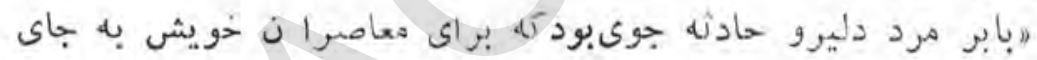

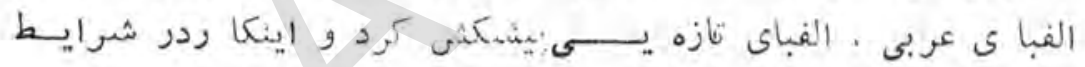

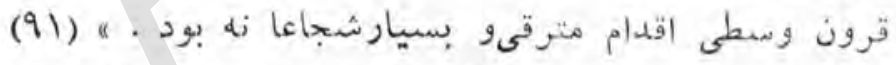

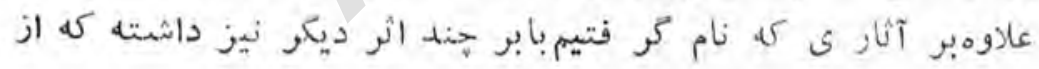

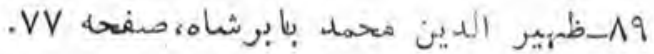

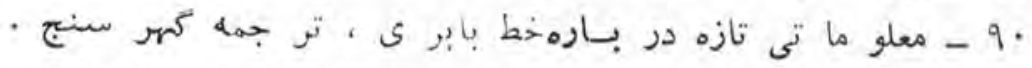

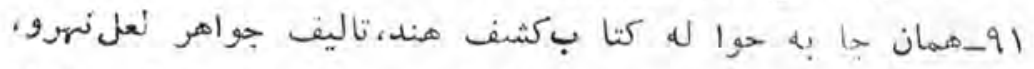

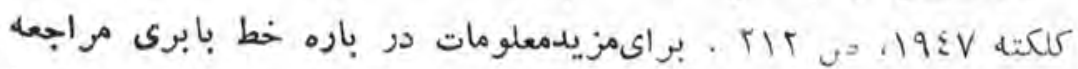

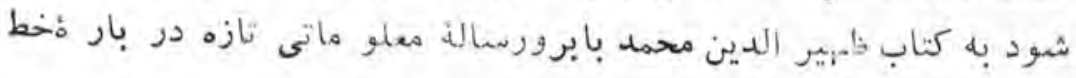




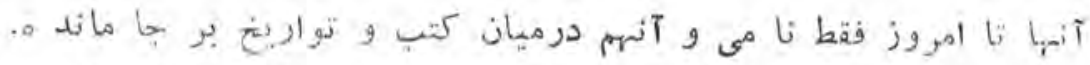

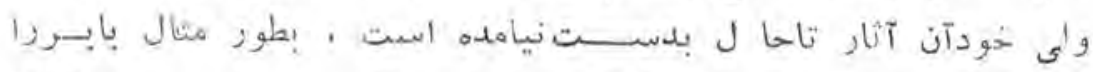

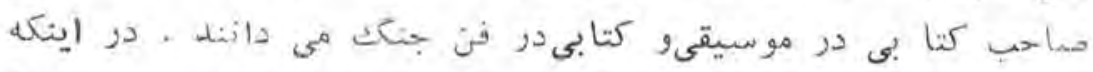

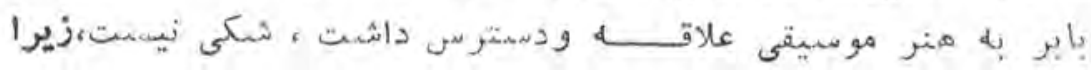

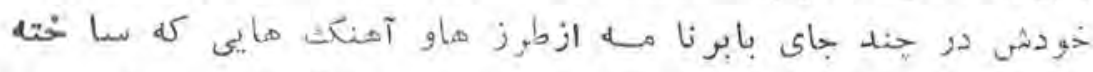

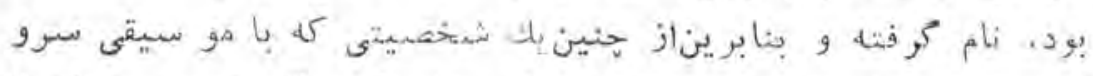

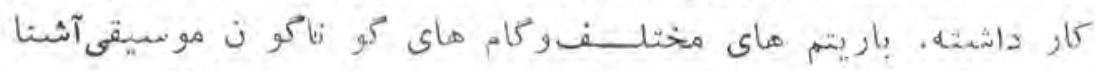

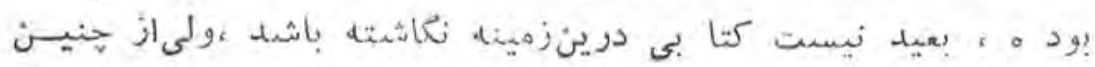

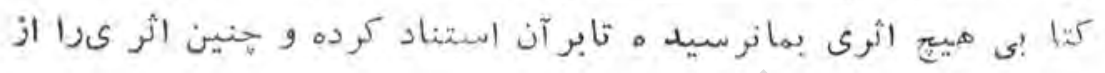

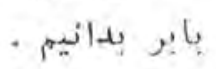

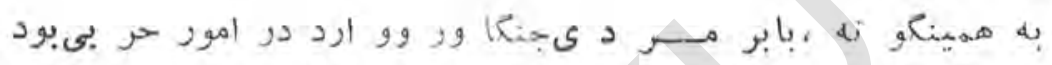

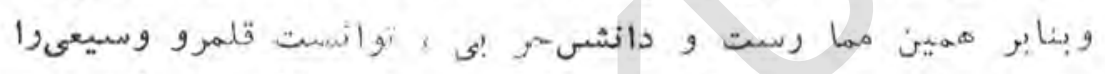

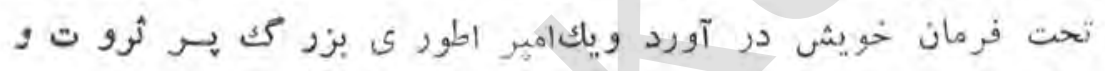

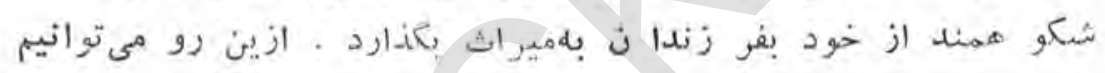

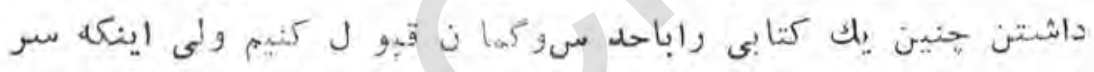

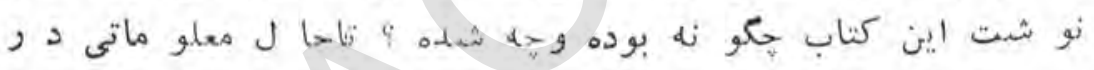

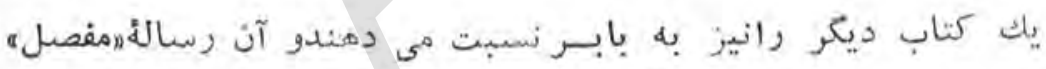

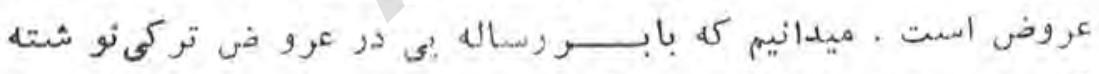

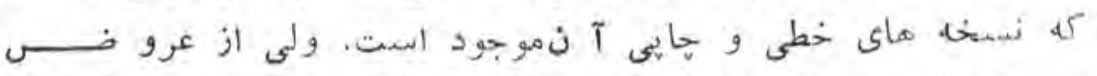

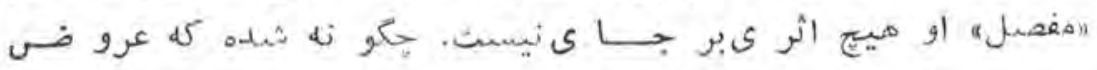

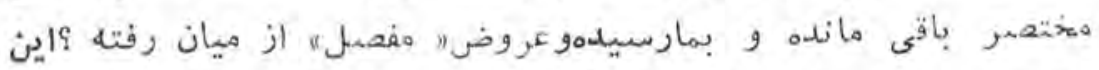

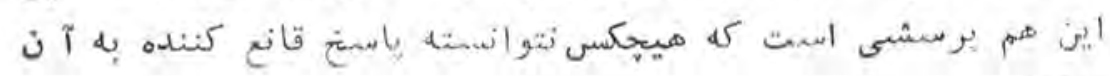
- tols

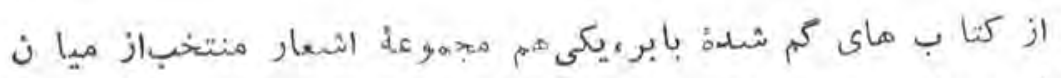

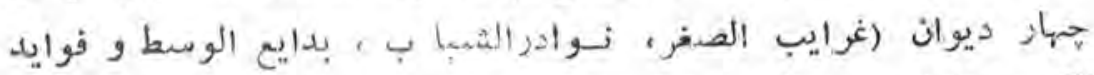

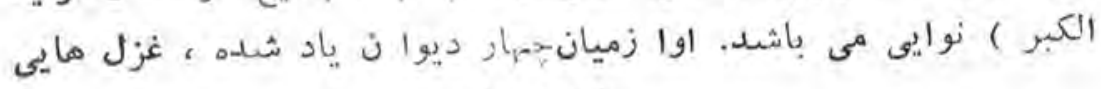




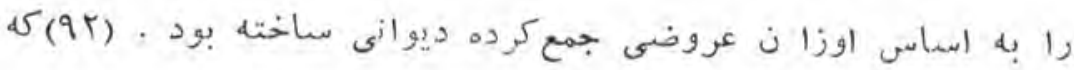

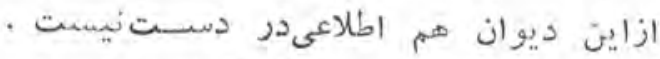

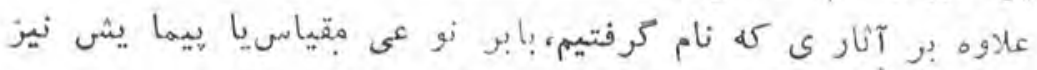

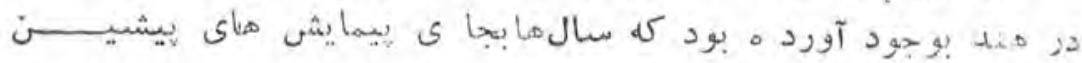

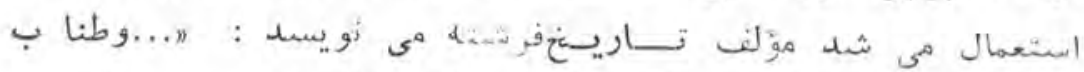

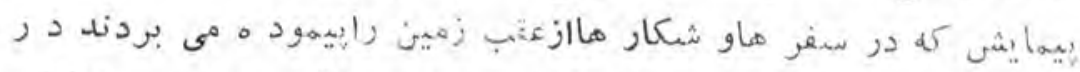

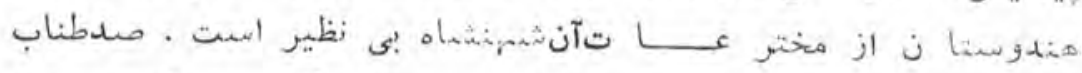

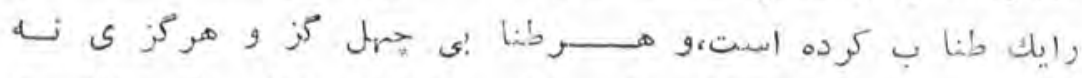

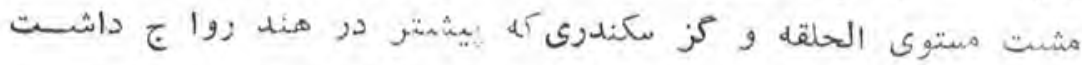

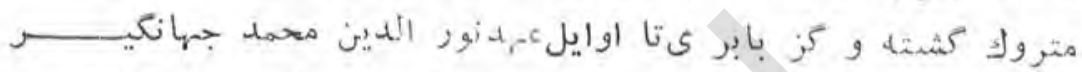

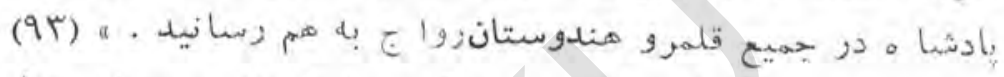

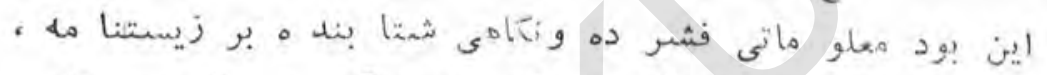

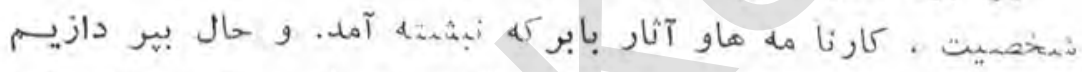

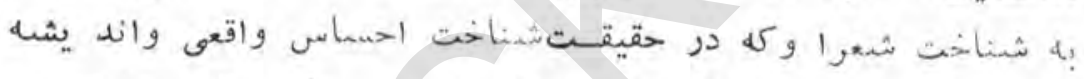

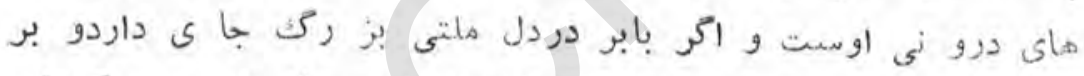

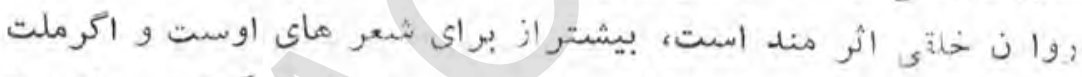

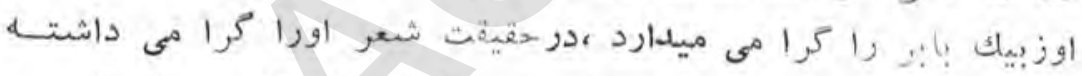

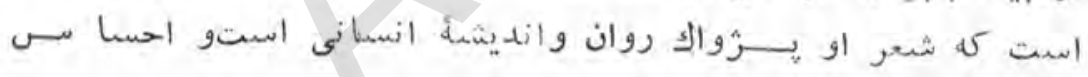

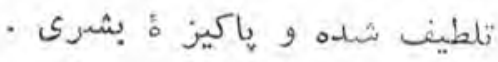
بياييد شعر اورانيزبنا سيه

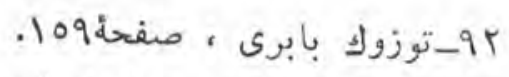

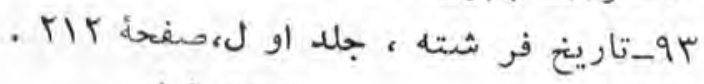

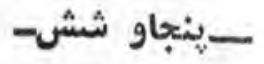




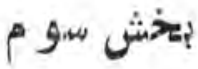

\section{شنا ختص شتعر با بر}

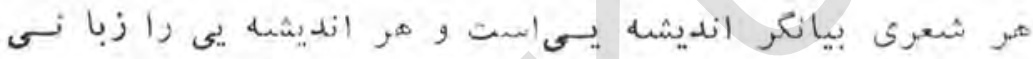

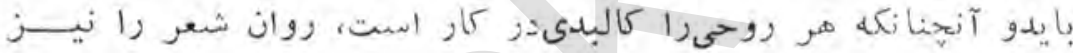

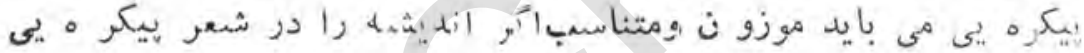

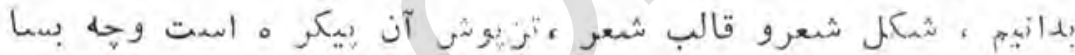

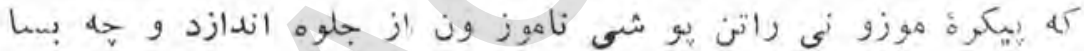

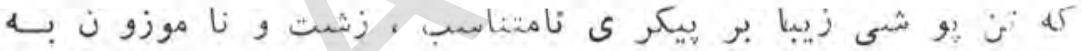

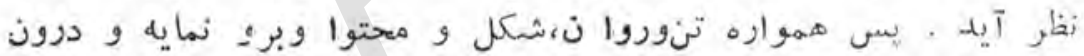

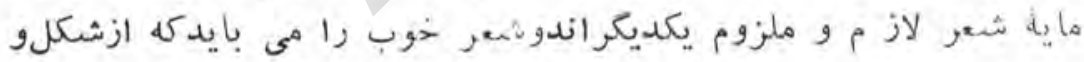

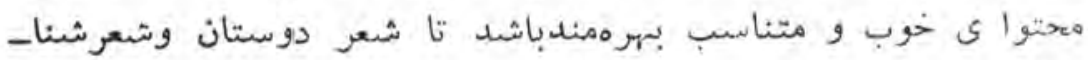

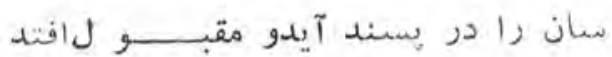

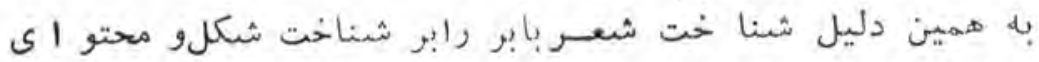
-

\section{الف - شعر بابر از زظر شعل:}

بابر زمانيكه به شعر سرود نآغاز كرد و نخستين كام هارا بو

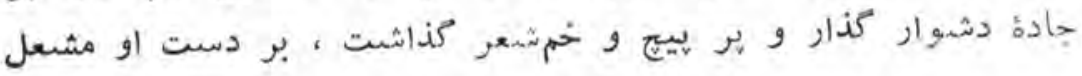




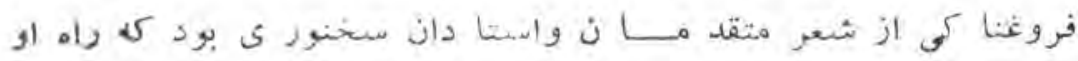

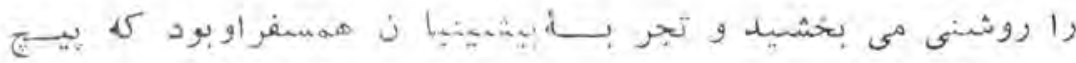

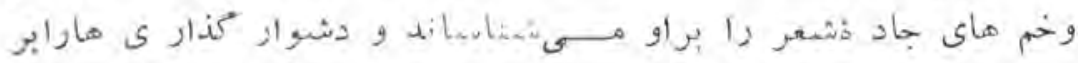

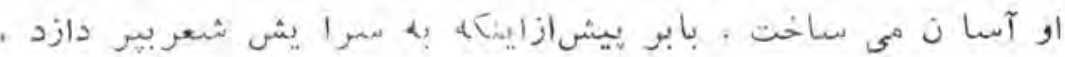

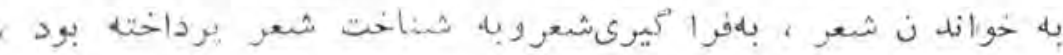

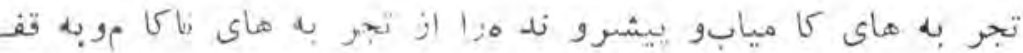

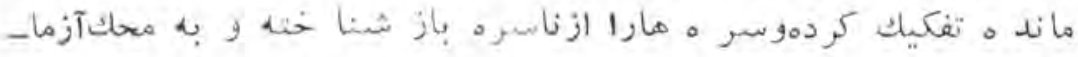

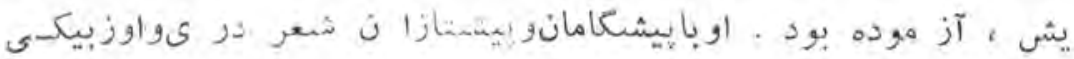

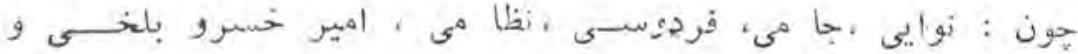

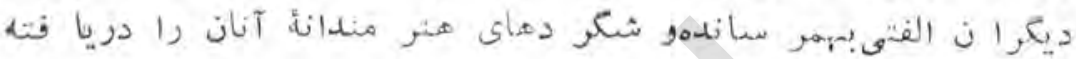

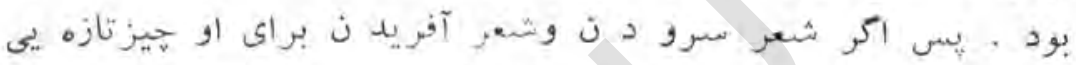

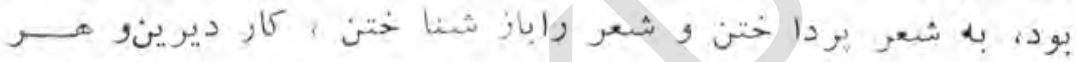

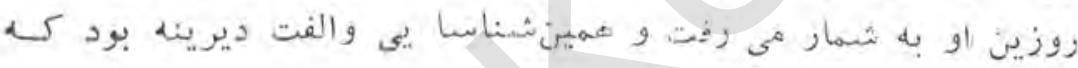

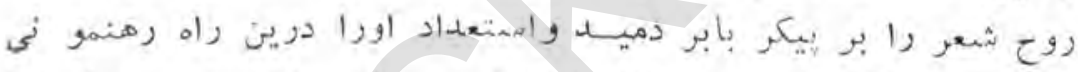

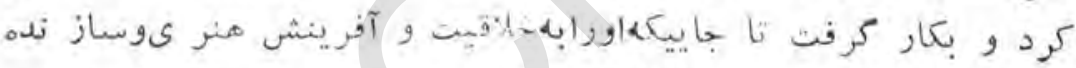

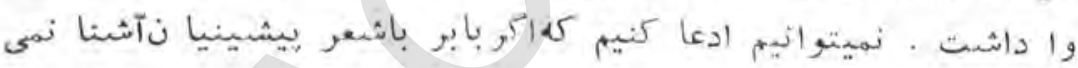

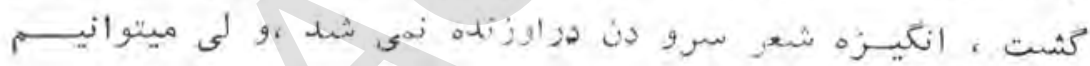

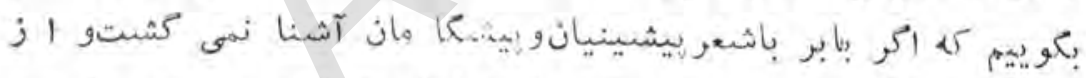

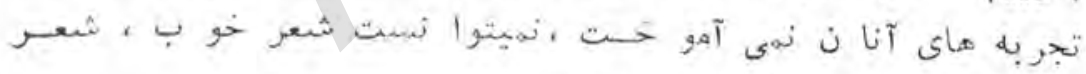

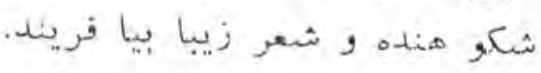

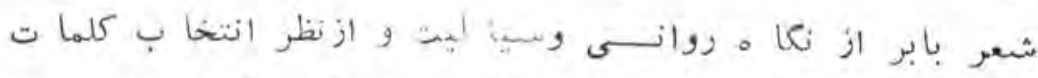

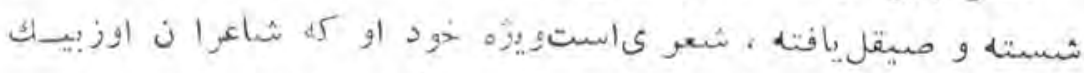

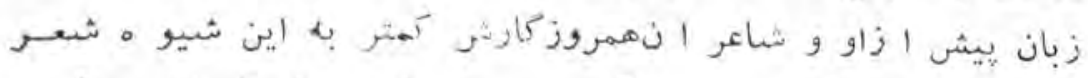

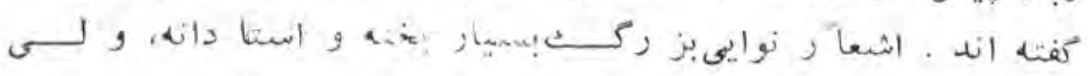

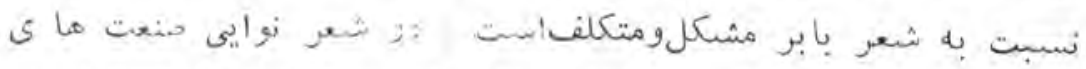

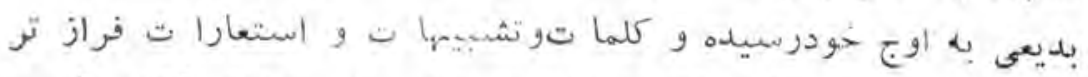

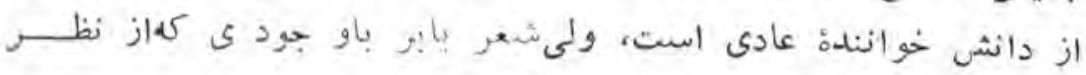




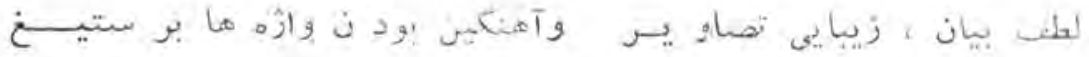

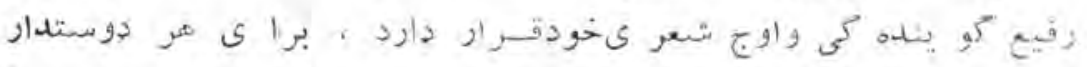

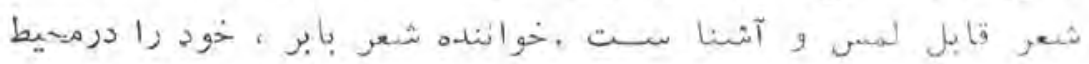

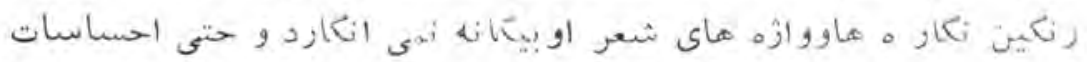

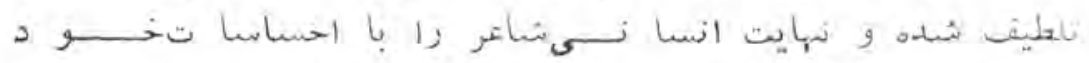

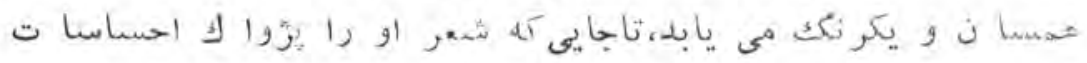

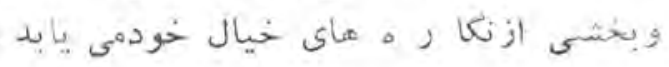

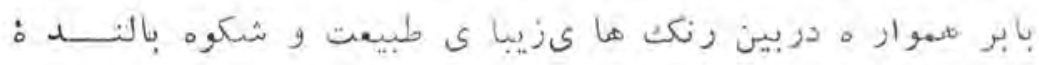

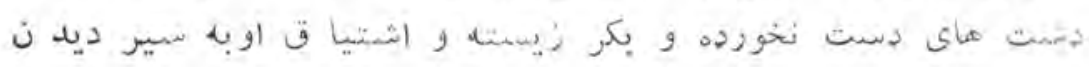

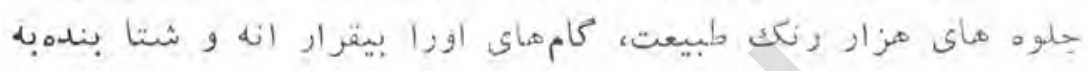

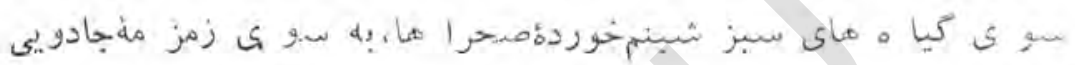

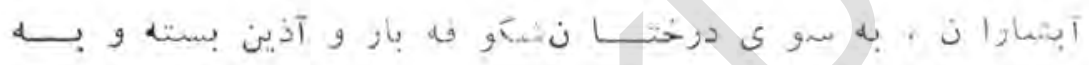

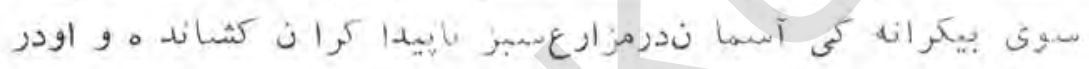

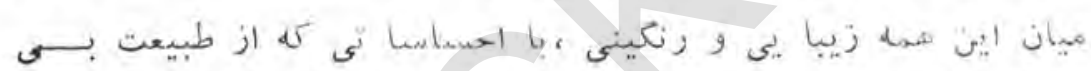

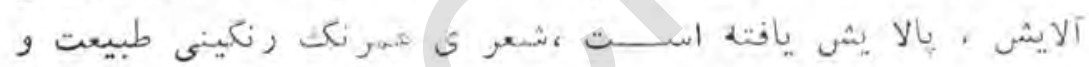

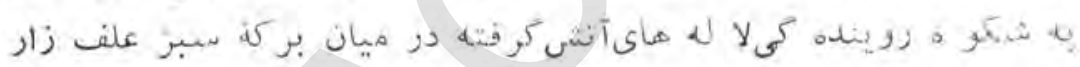

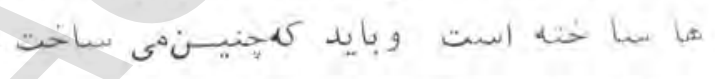

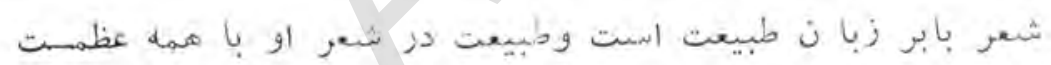

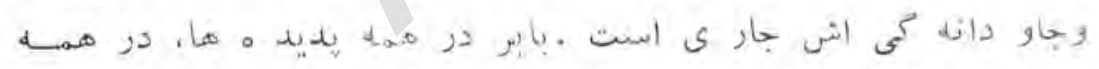

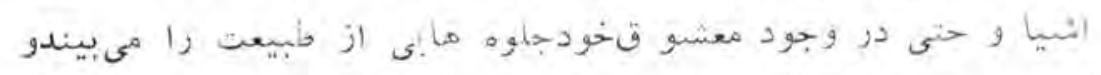

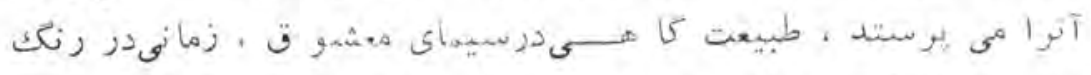

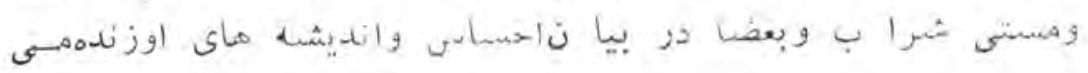

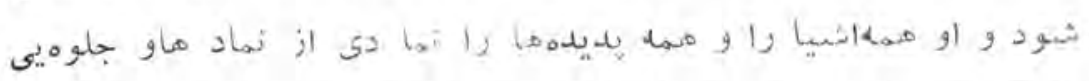

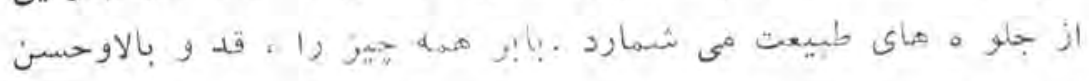

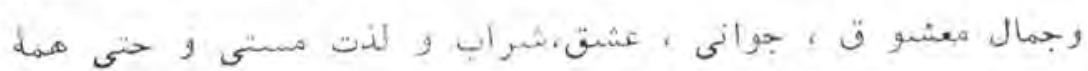

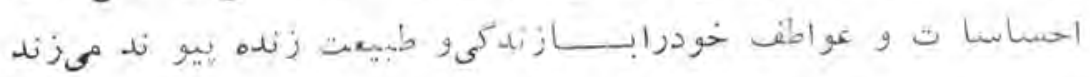

$$
\text { - }
$$




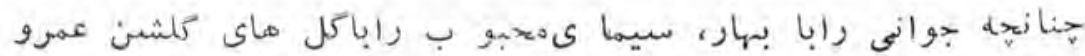

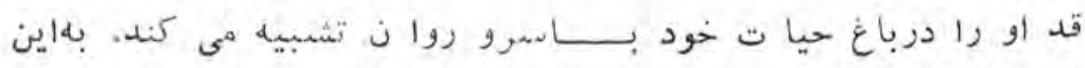
شعر او توجه كنيد : ثران

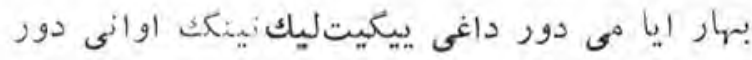

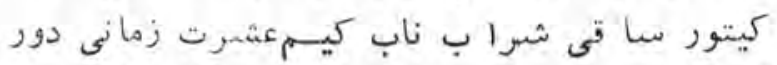

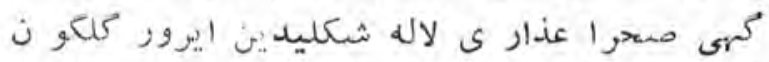

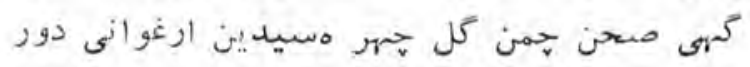

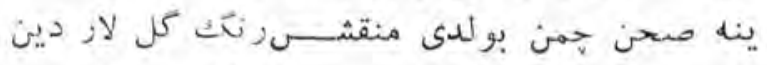

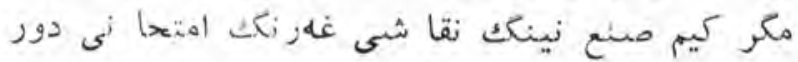

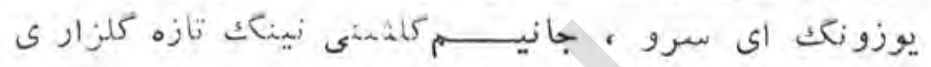

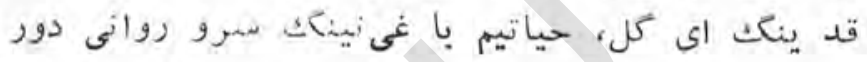

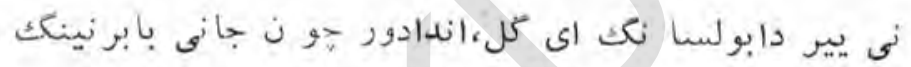

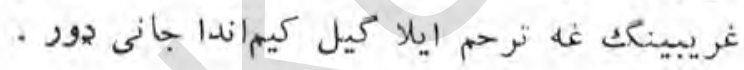
تر جمه : ايا م بهار است و و زمانجوانى

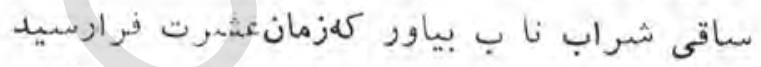

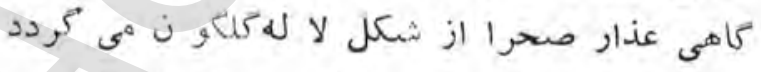

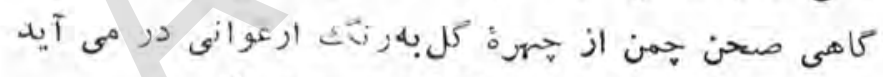

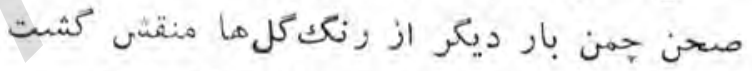

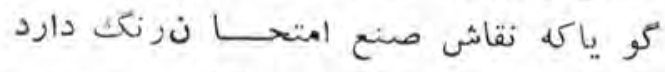

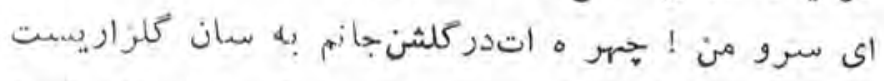

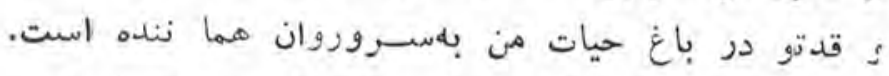

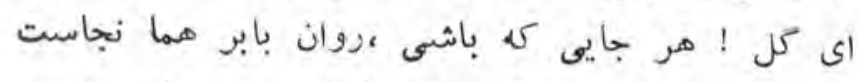

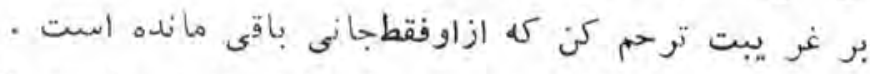

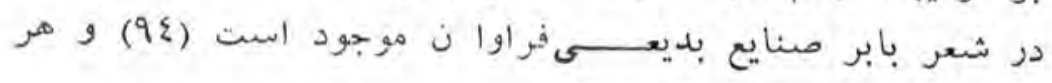
؟9-نسخخه خطى ديوا ن بابـــرموجود در كتا بخها نأ بو هنتون

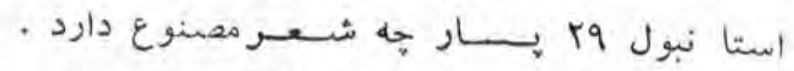




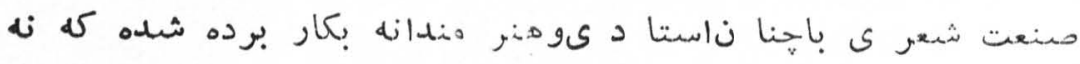

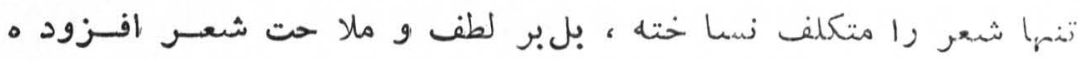

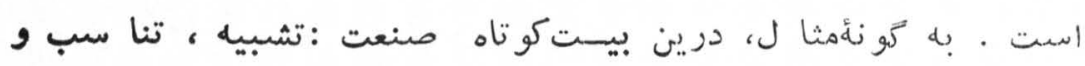

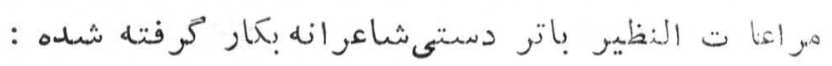
خطى بنفشهله ، نحدى لاله، زلفـى ريحان دور

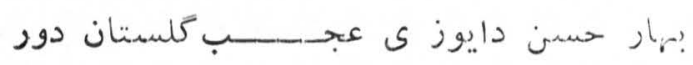

$$
: \operatorname{dox}
$$

خطش بنفششه ، خدش لاله ،زلفزيحان است

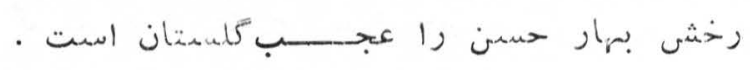

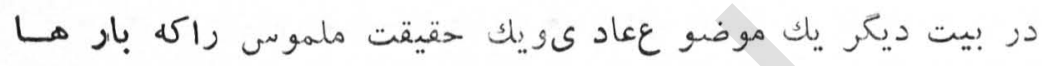

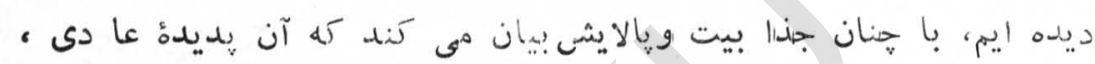

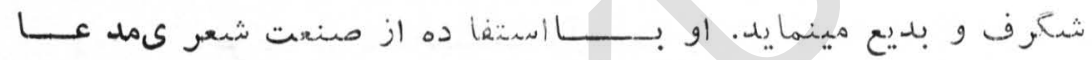

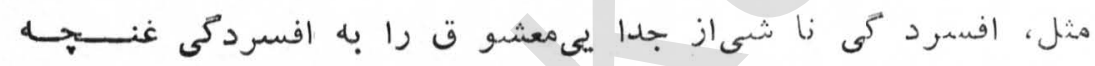

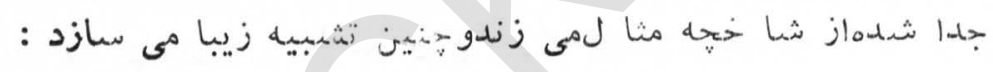

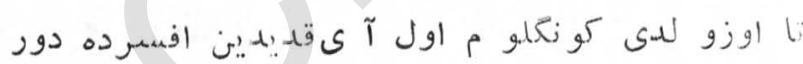

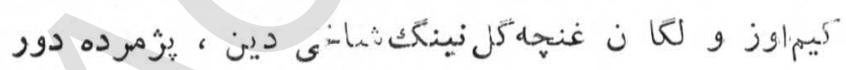

:

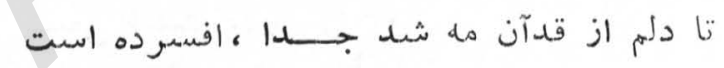

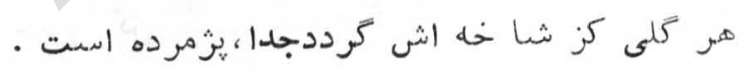

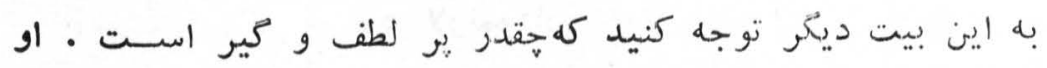

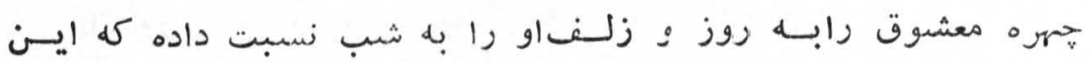

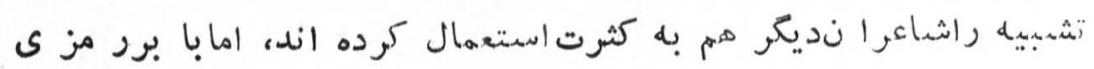

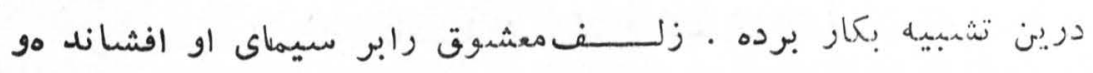
زوز رازير هادر سياه شب ينهان سا خته و باز نكته ظريفتر اينكهبا

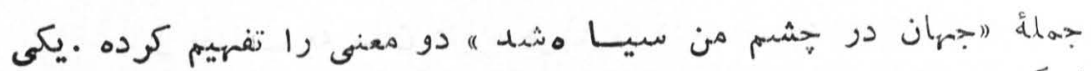

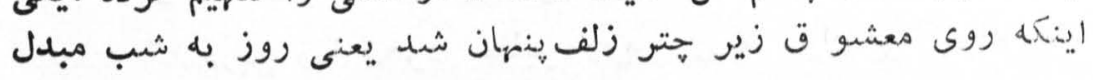

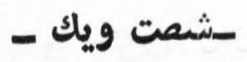




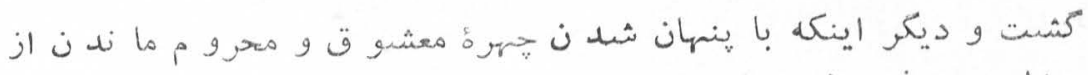

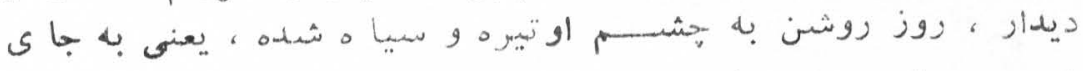

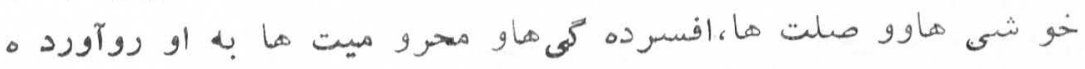

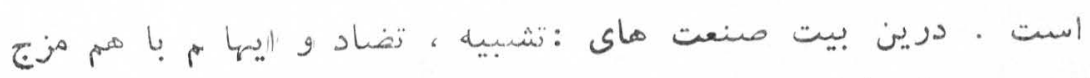

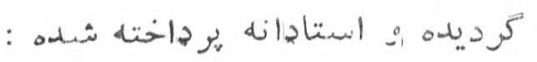

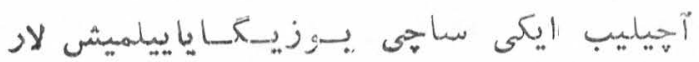

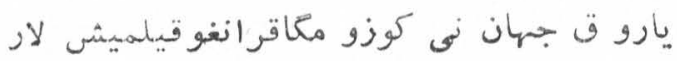

تر جمه

دوز لفش باز كشته صور تش يجو ن باز مى يوشلد

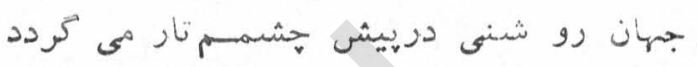

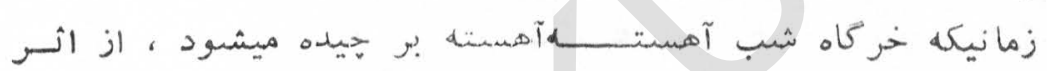

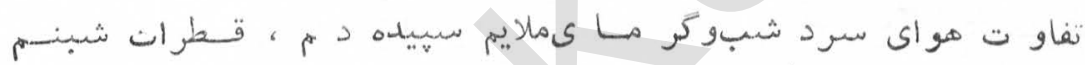

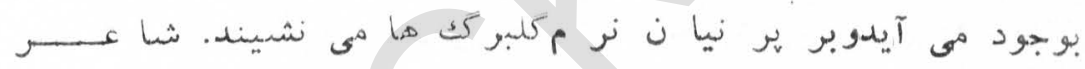

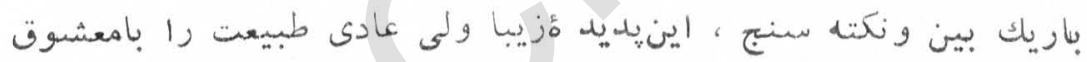

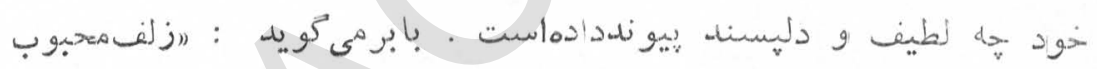

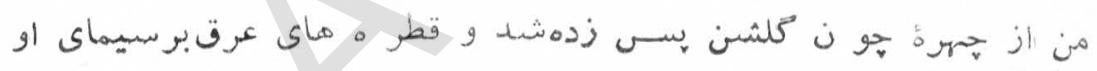

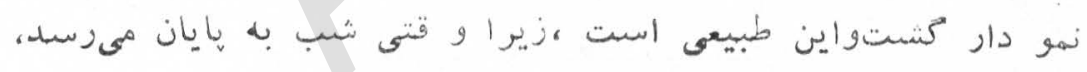

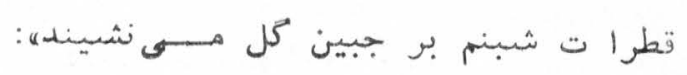

$$
\begin{aligned}
& \text { آحيلد ى زلفى و خوى لارنهودار اولدى يوزيدا }
\end{aligned}
$$

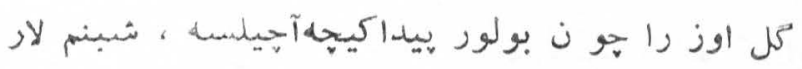

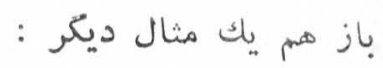

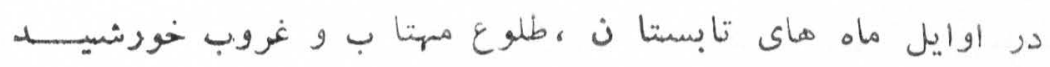

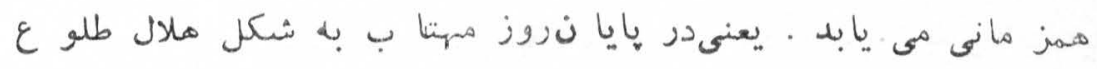

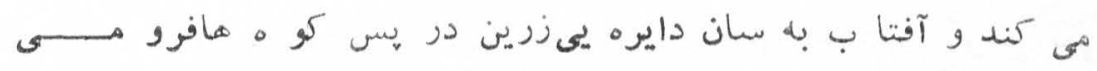

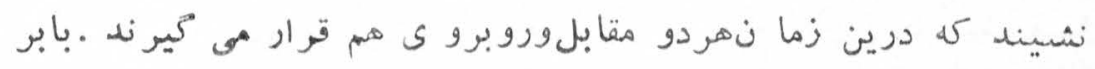




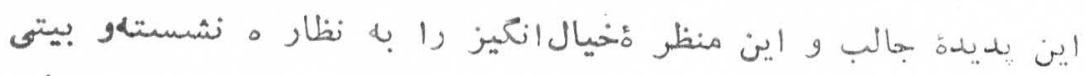

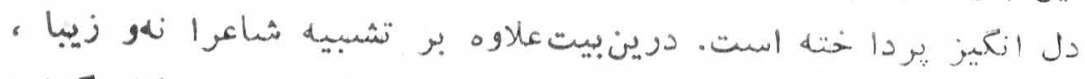

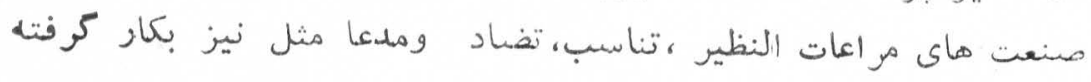

$$
\begin{aligned}
& \text { اول آى نينككيوز ى بير لهتوش بولوب دعوى حسن ايتتينك }
\end{aligned}
$$

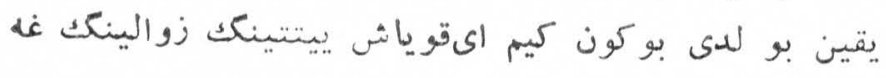

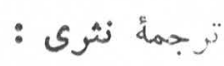

$$
\begin{aligned}
& \text { باصورت آن ماه روبرو شدى ودعوى حسن كردى }
\end{aligned}
$$

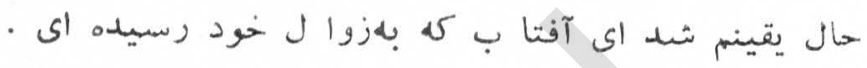

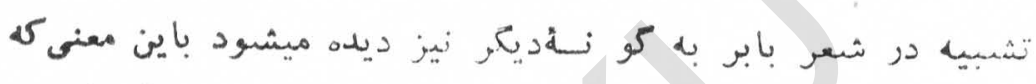

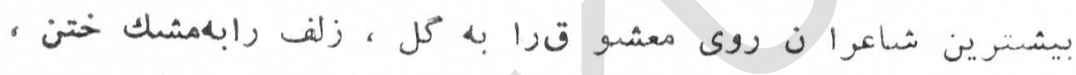

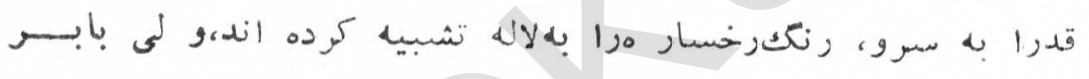

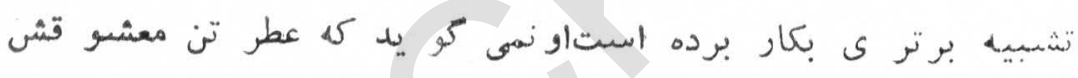

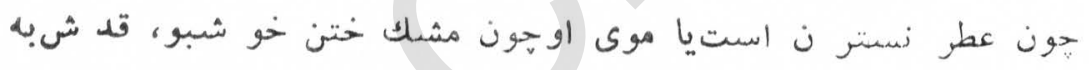

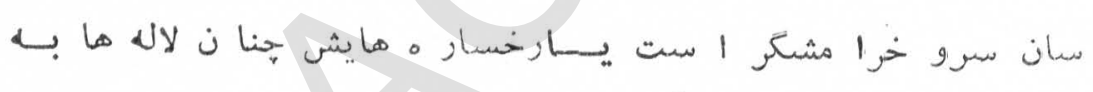

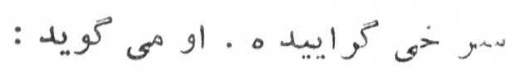

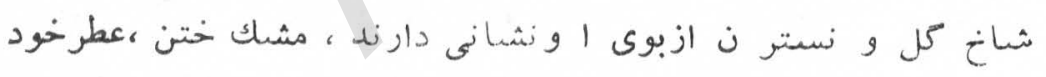

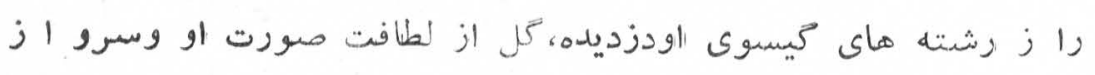

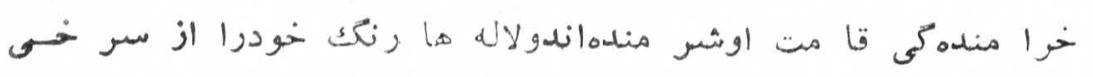

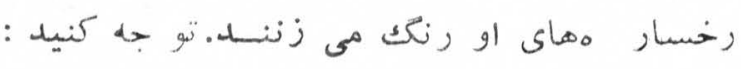
شاخ كل ونستر ن، ياد بيرور ،بويى دين

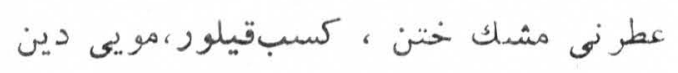

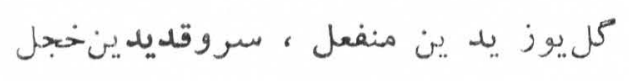

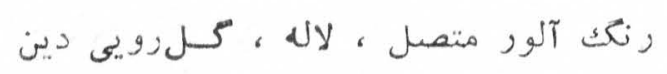

\section{شصت وسه -}




$$
\text { : تو }
$$

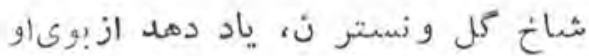

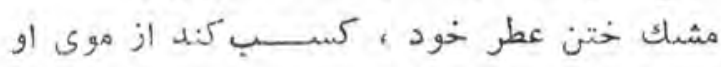
كل زرخشس منفعل ، سروز قدش خحل

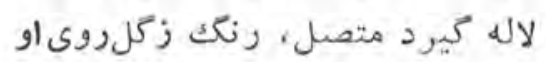

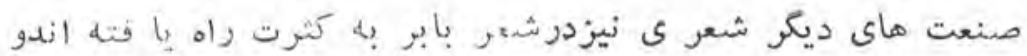

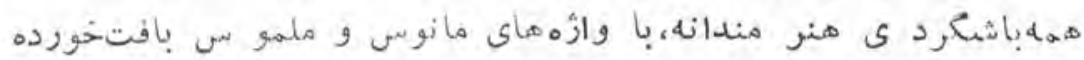

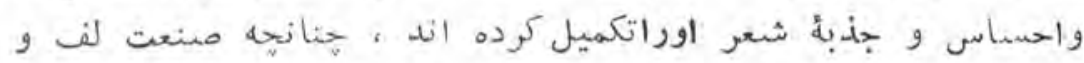

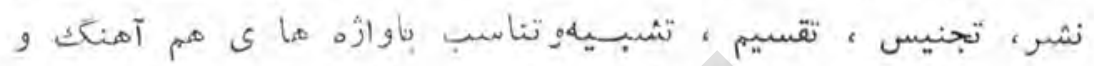

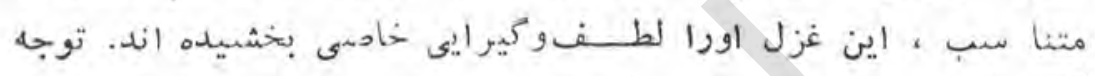
:

خطينكك بيله يوزو نككو كا كسو أكث سنينكك اي جا ن

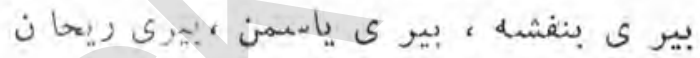

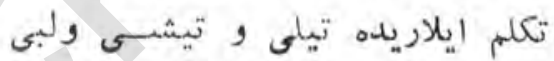

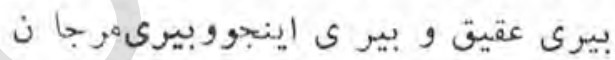

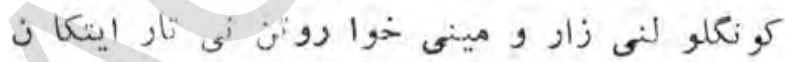

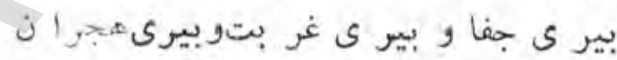

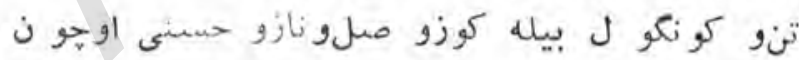

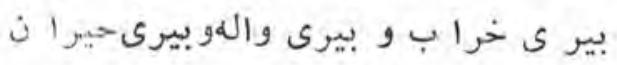

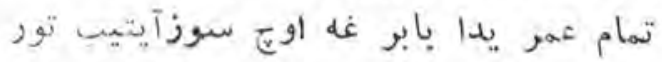

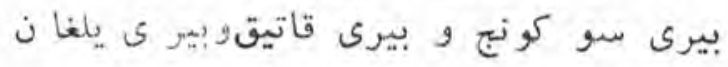
: خط تو ، صورت تو ، كاكلتواى جانا ن

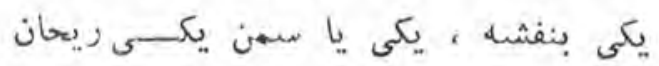
به كاه حرف زبان تو با لـب ودندان

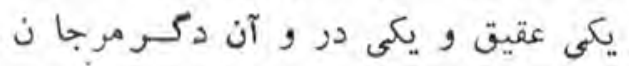




$$
\begin{aligned}
& \text { نهو ده خو ار ، دلم زار و جسم من جيون تار }
\end{aligned}
$$

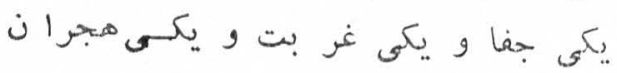

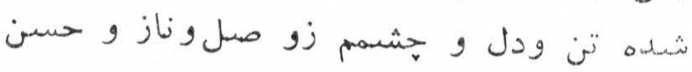

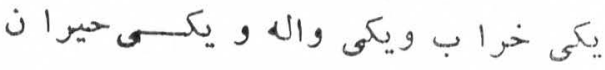

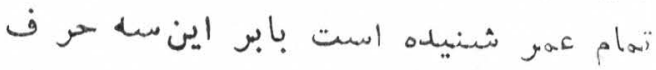

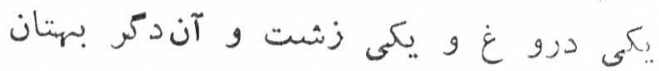

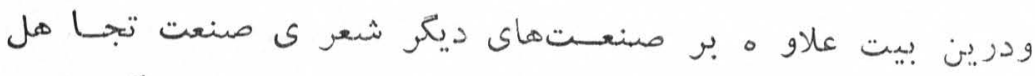

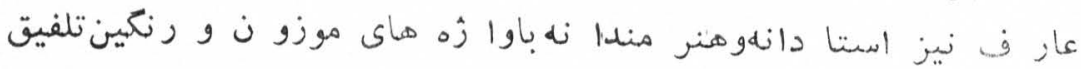

$$
\text { وآهيز ش يافتله اسبت : }
$$

كولك وسمه دا اول آى قاشى كويانيال، دور

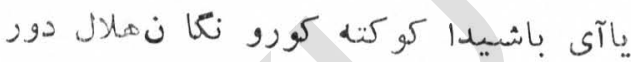

$$
\text { : ترجمأ نشرى }
$$

باودمهأ سياه ابروى آن ما مجنسان خيا لى به نظر مسى ر سـد

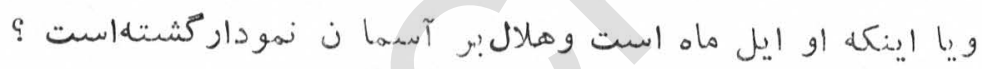

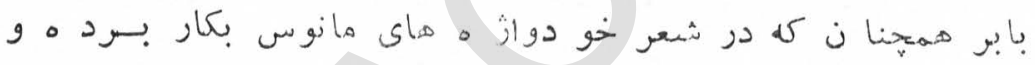

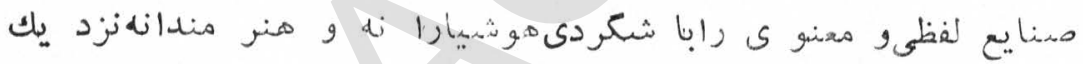

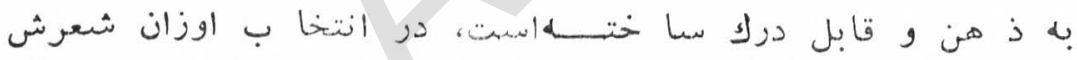

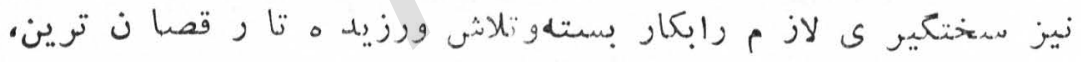

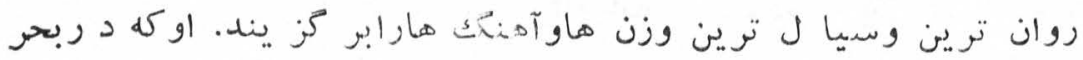

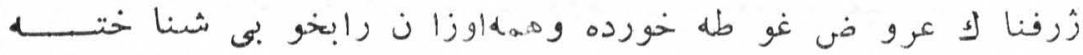
الست ، تشتخيصشدر كز ينشريتمها ىمنا سب با ايلده هاو كفتنى هاى

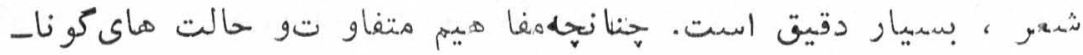

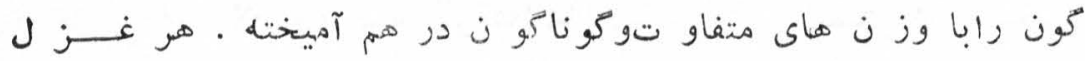
او هـ هنا نكله يك موضو ع تازه وريك حالت عا طفى دكر كونه رابيان

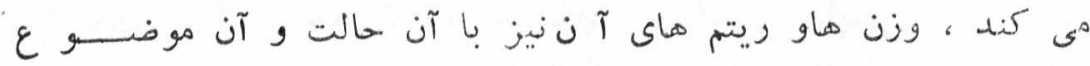

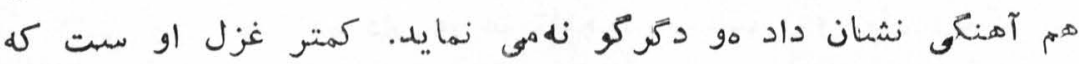


موضوع يكسان وائزن يكسان داشتهباشل ، از همين جهت سيرباغتشان

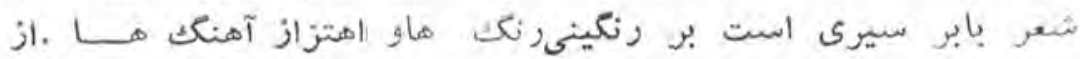

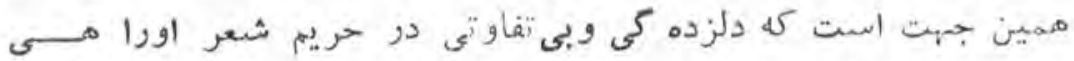

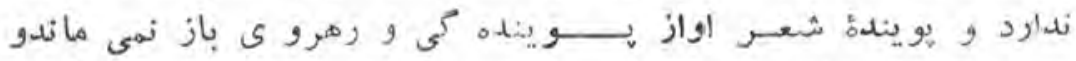

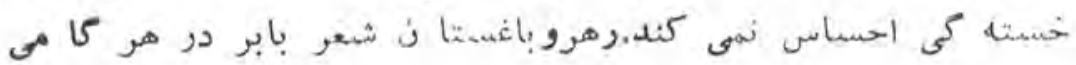

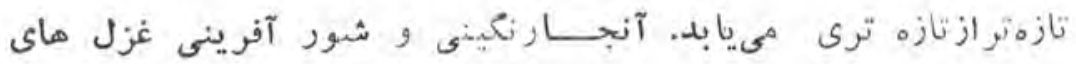

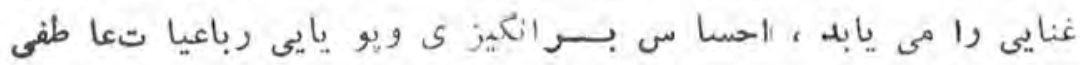

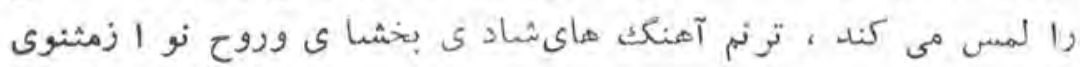

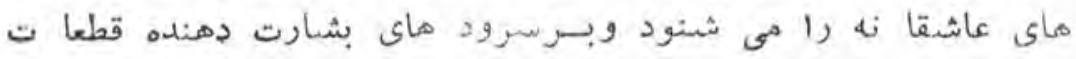

$$
\text { اوكو ثن فرا ميدارد ماثل }
$$

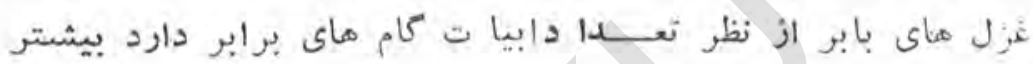

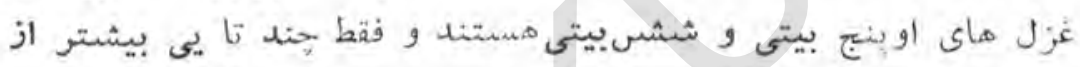

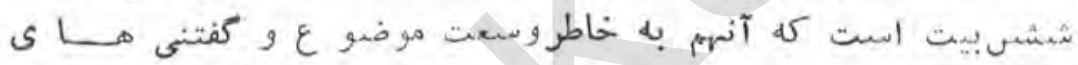

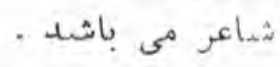

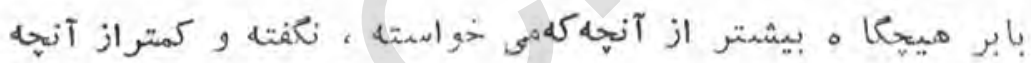

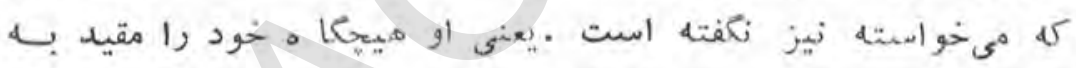

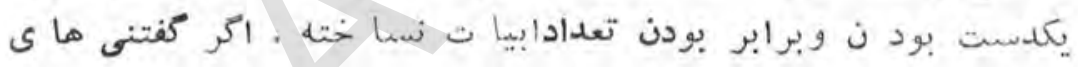

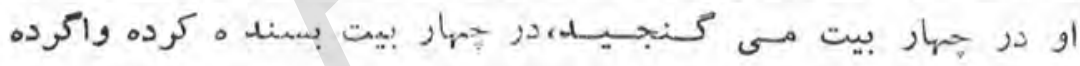

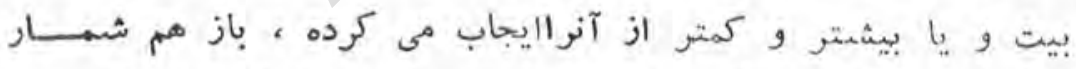

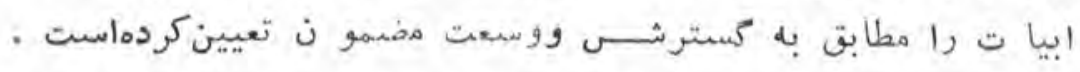

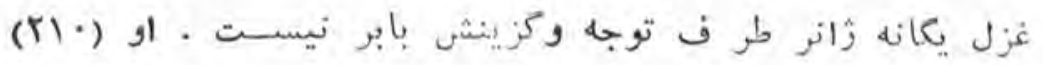

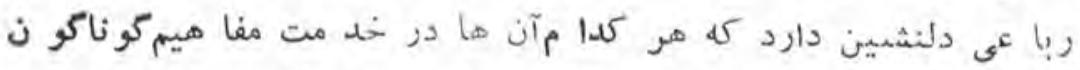

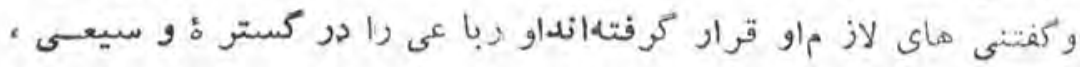

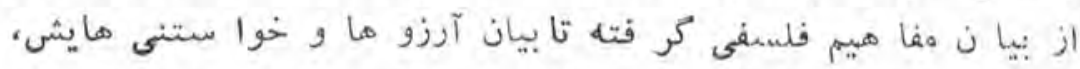

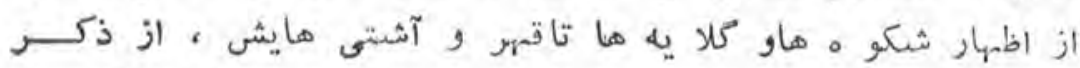

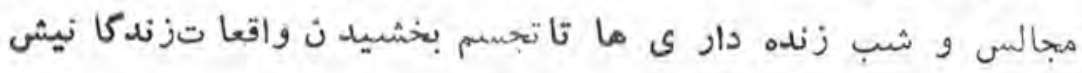




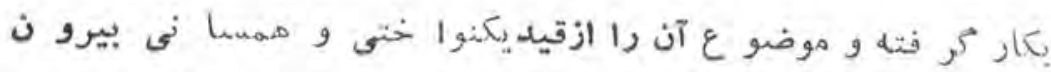

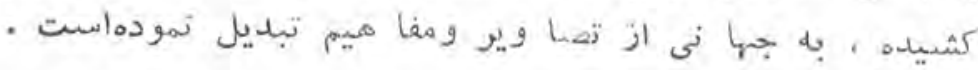

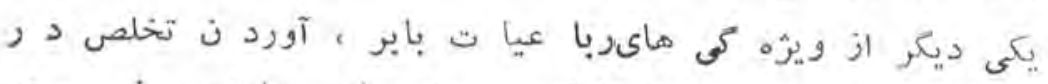

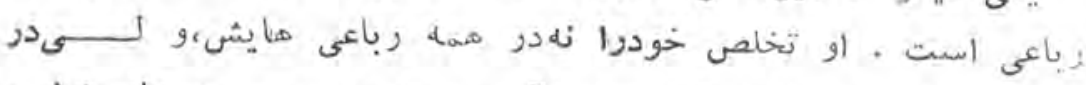

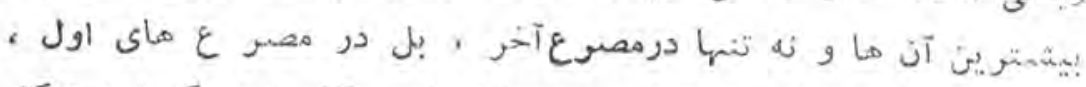

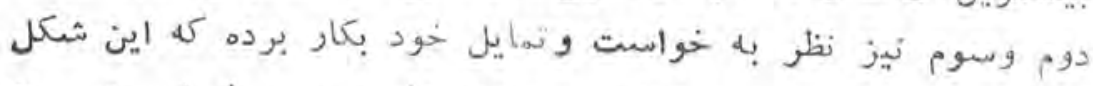

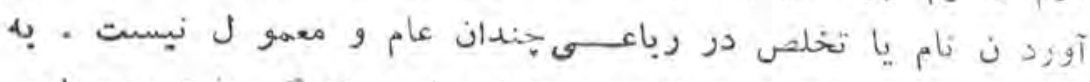

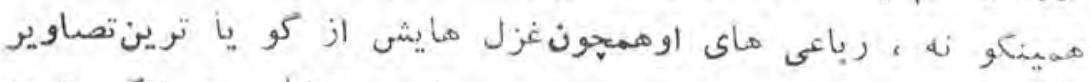

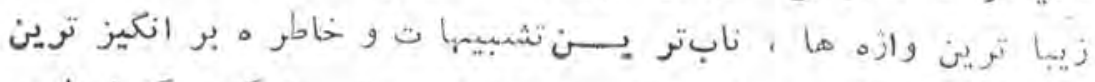

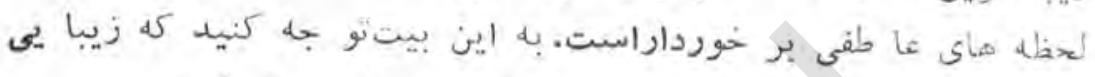

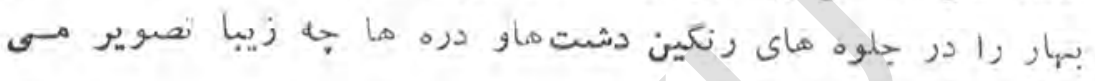

خاطر نى بهار فصلى دا كمبت آلادور كوز نو ريثى رنك لاله و دشت بشآلادور خوش اول كم تلالار نإيو روبسيس ايتسا.

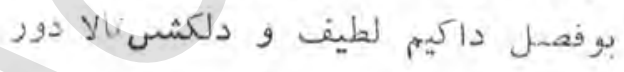
:

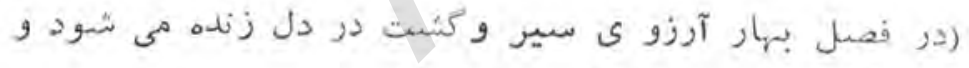

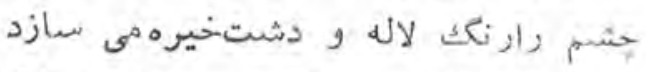

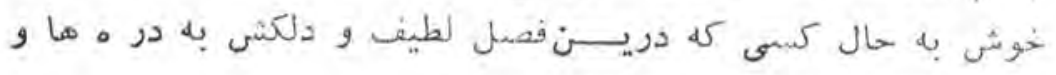

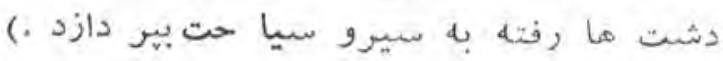

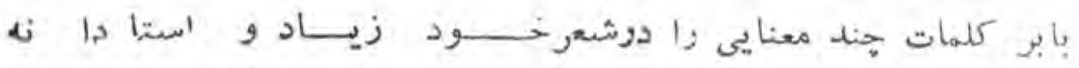

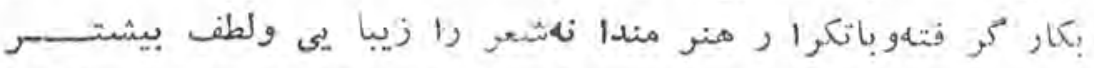

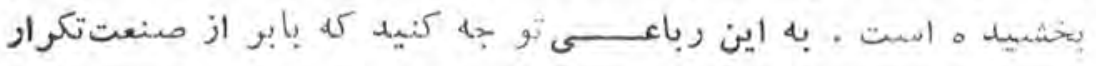

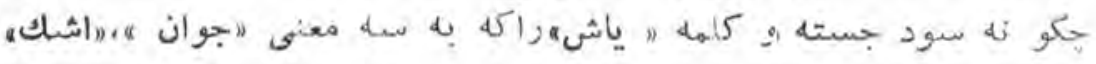

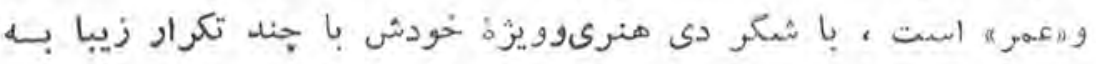


هر سه معنى بكار بر ده و زباعسى إطيفى از آن آفريده :

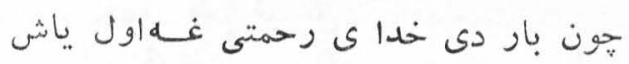

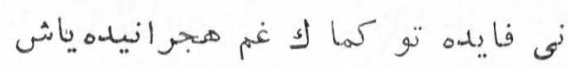

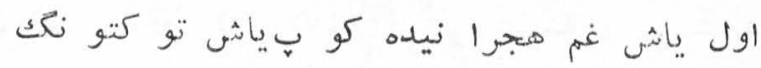

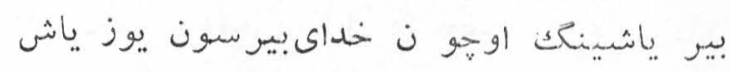

تر جمه :

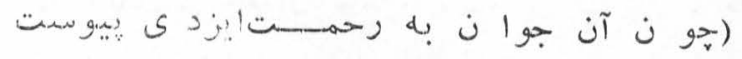

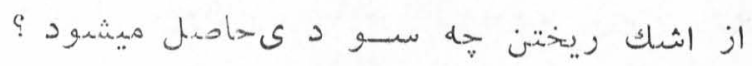

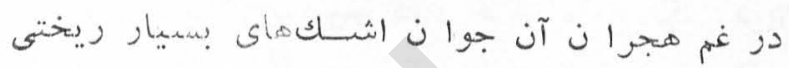

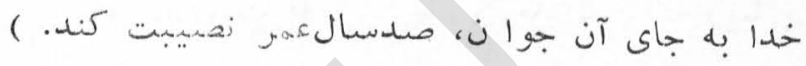

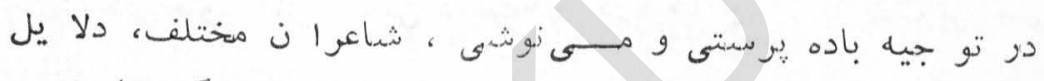

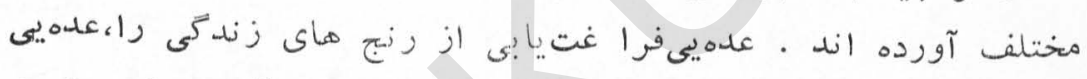

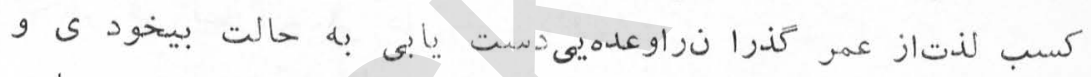

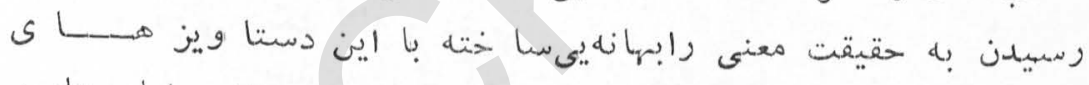

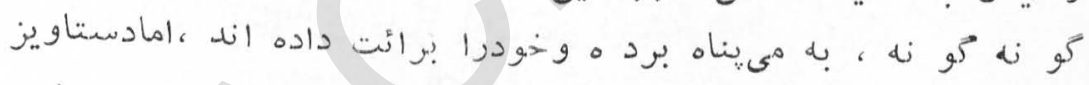

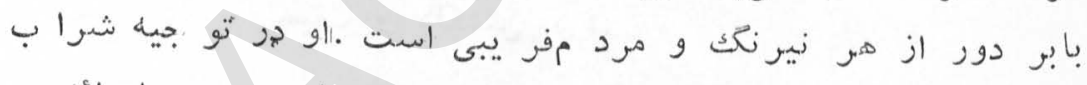

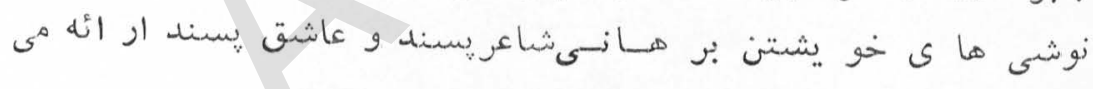

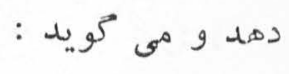

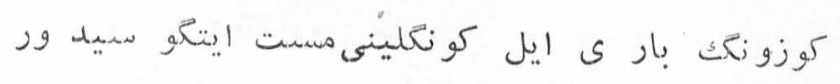

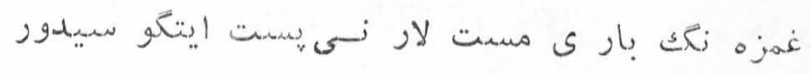

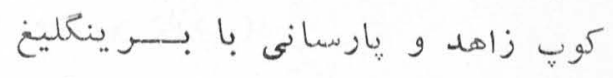

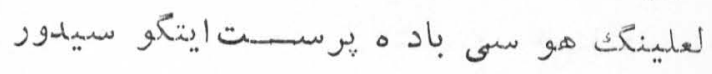
:

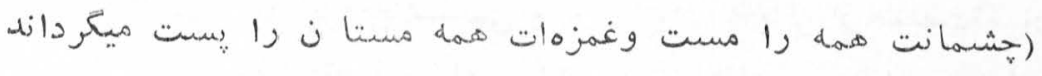

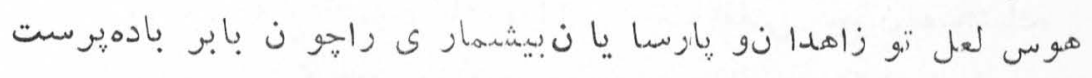
مى سازد ( 


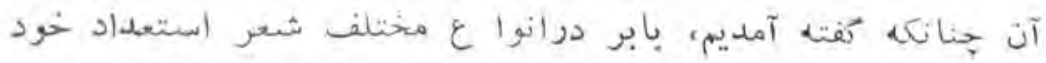

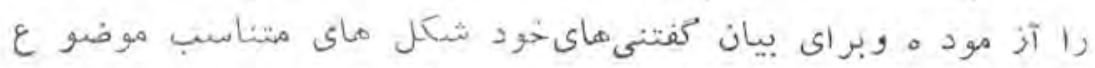

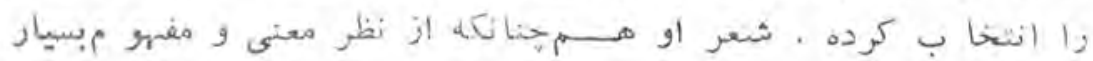

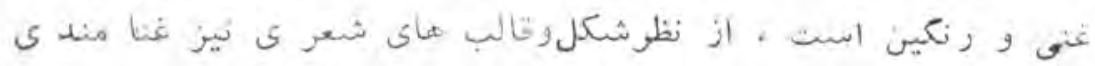

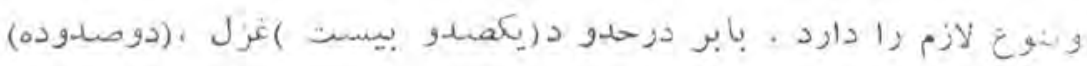

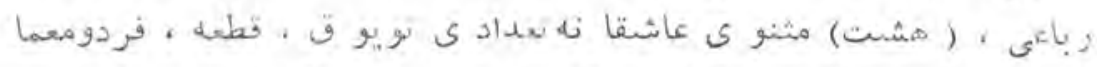

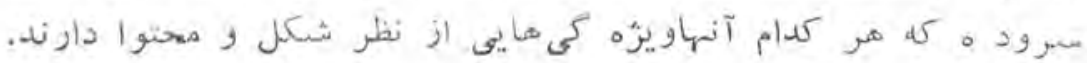

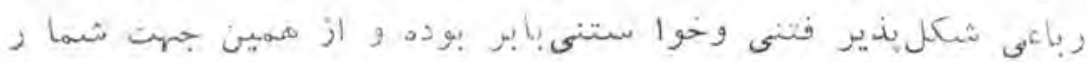

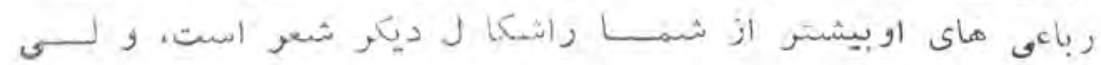

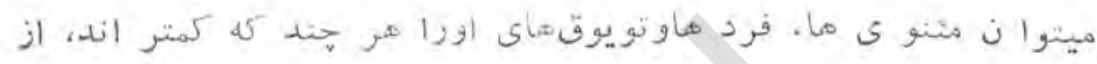

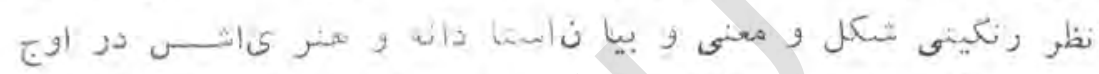

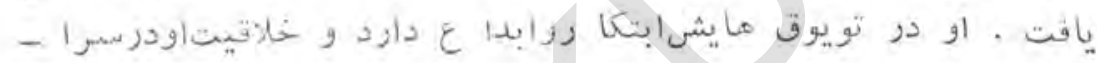

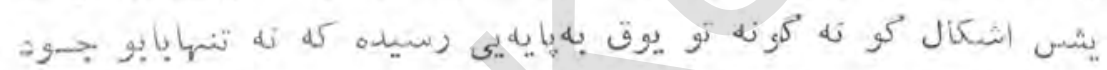

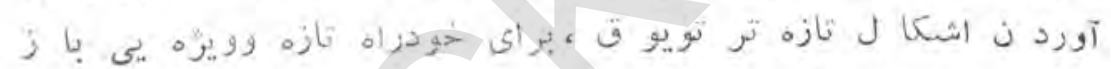

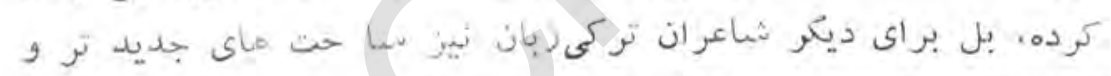

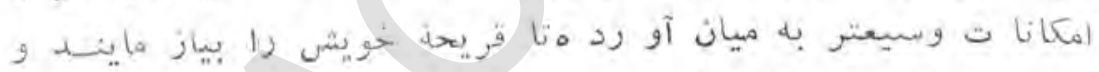

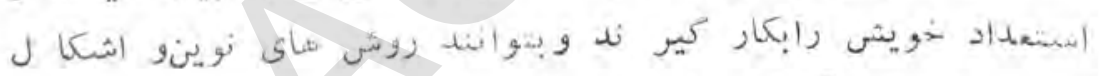

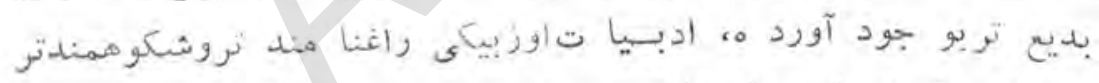

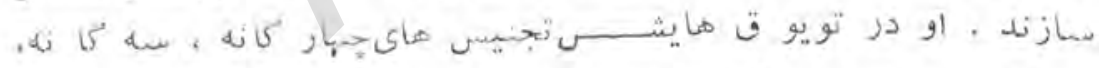

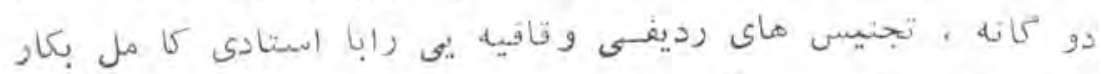

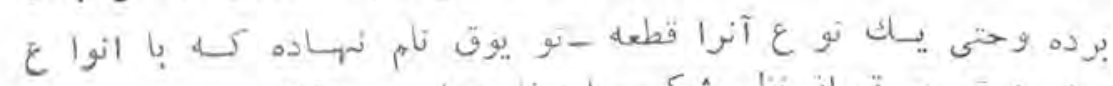

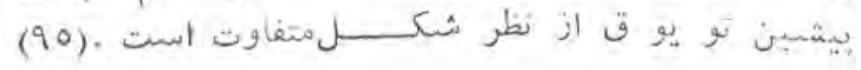

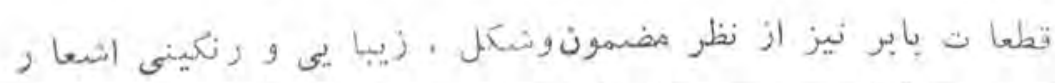

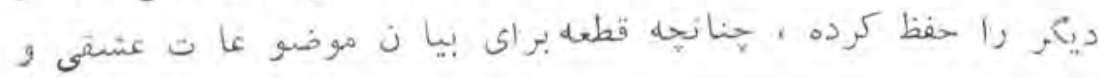

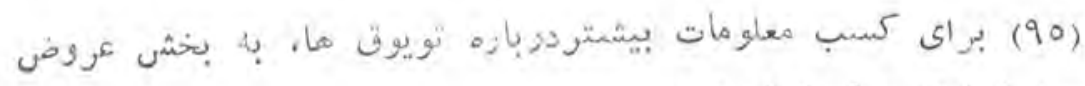
. 
عاطفى ، رزمىو حماسى و يند واندرز بكار كرفته شده استومطابق

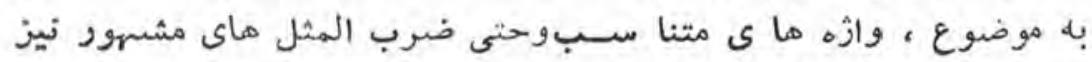

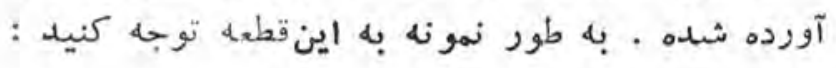

$$
\begin{aligned}
& \text { باتر ك ستيز ه مكن اى ميســر بيانه } \\
& \text { جالا كى و مردانكى تركعيانست }
\end{aligned}
$$

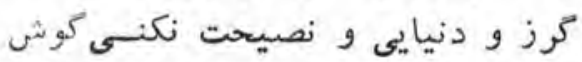

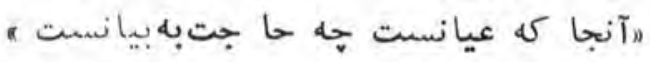

قطعه ديكر بيان احسا ساوستدر تلاش رسيد ن به بيروز ى ماو

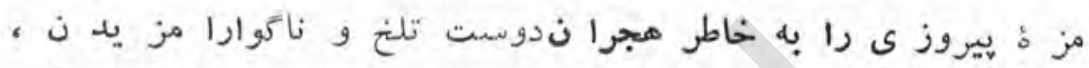

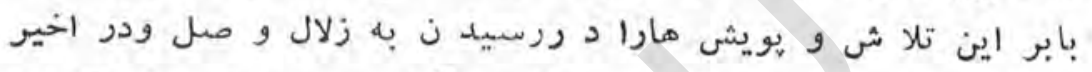

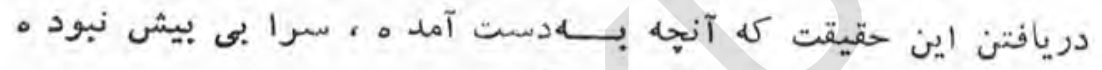

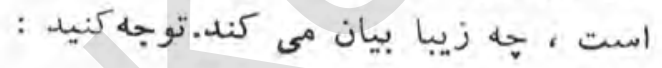

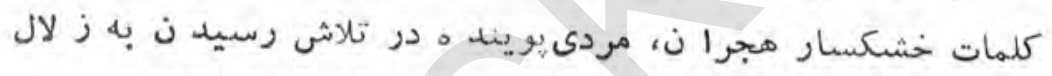

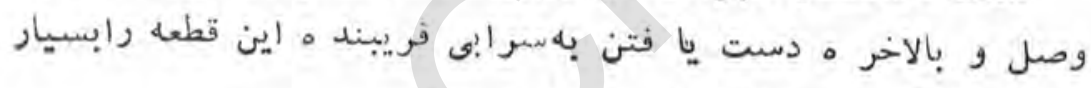
دلنشين و كويا مى سازد :

هجران جو ليدا جهد بيله بويهلازاوروب

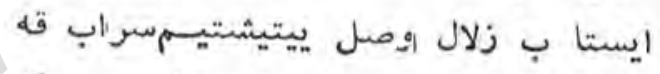

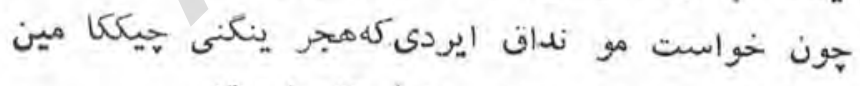

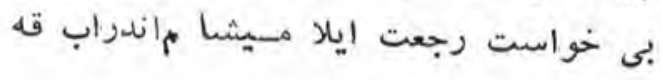

ترجمه :

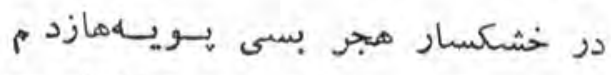

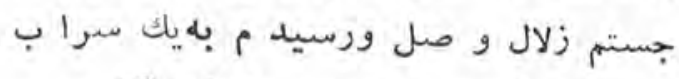

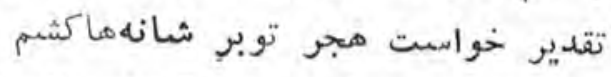

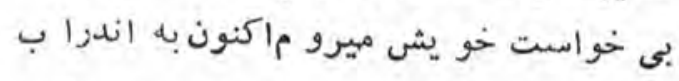

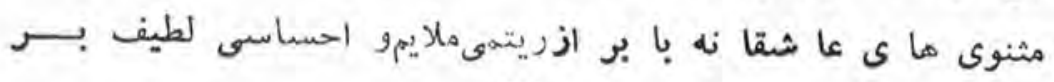




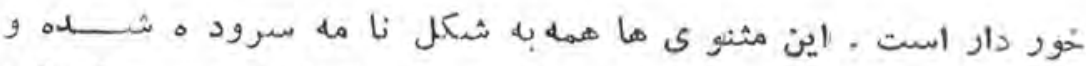

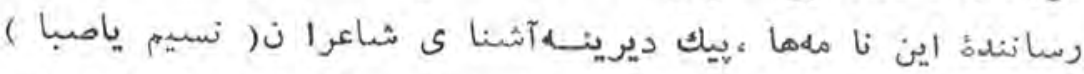

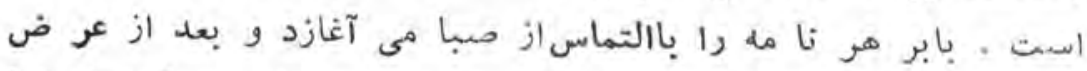
سلام ، نياز و آرمان هاىخو يشتن را به دوست ابراز مينمايدونا مهرا

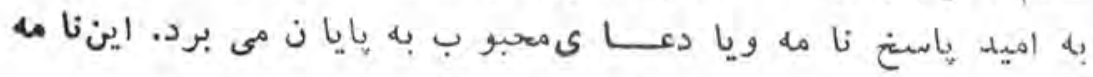

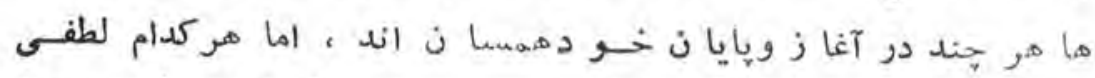

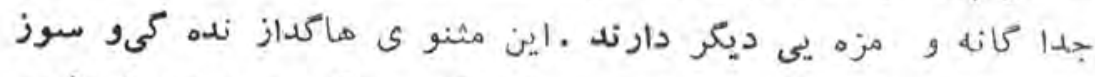

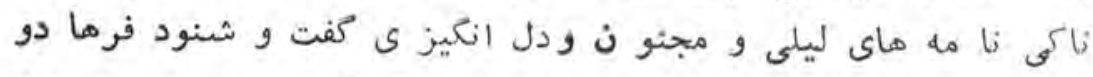

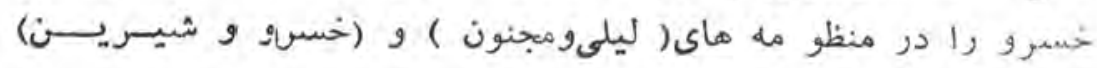

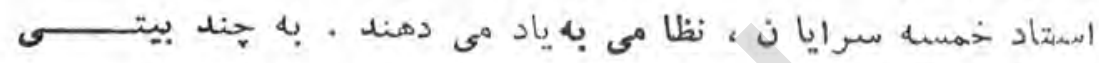
از مشنوى اوتو جه كنيد :

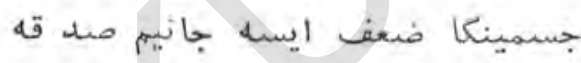

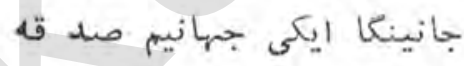

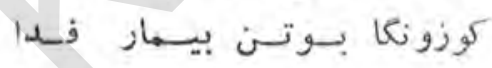

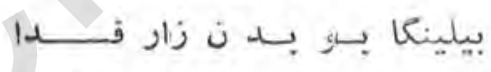
سين سيز ين جسمر بيلاجا ننى نيتاى ؟

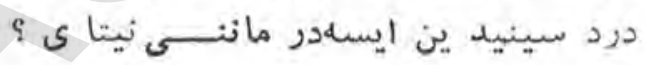

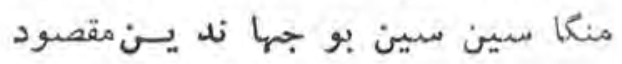
نى جها ن جسبم ايلا جا نديســن مقصود قا متينك ينكليغ اوز ون يا ش تايقيل عمر حسنو نكث كيبى دلكش تايقيل قاصد ينكث كيلد ى صفا كيلتو ردى نيل

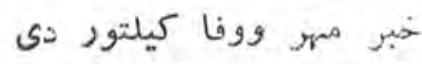

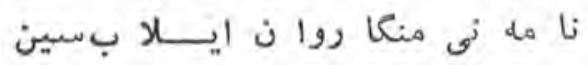
جانى يو ق جسميمه جا ن ايلاب سين

$$
\text { كورو با ن نا ملهن اوزدين بارديم }
$$




$$
\begin{aligned}
& \text { او قوبا ن سوز ينى سوز دين بارديم }
\end{aligned}
$$

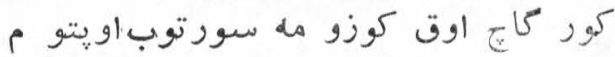

$$
\begin{aligned}
& \text { اوريكا ج او ق باشيمه قو يو بوقو يتوم } \\
& \text { بار پإه مضهمو نى آنينكك خو ب ايردى } \\
& \text { بارى لفظى داغى مو غو بايردى إنى }
\end{aligned}
$$

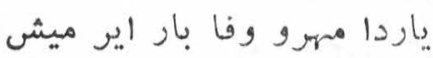

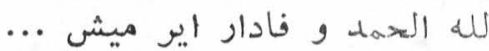

$$
\begin{aligned}
& \text { : }
\end{aligned}
$$

اكر بله تن تو ضعفى برسلد، جانم صد قه اشى باد . بله جانتو هر دو جمهانم صدل قله باد ، بل جشمانت ، تن بيمار م فلدا و بله كموت اينبلدن

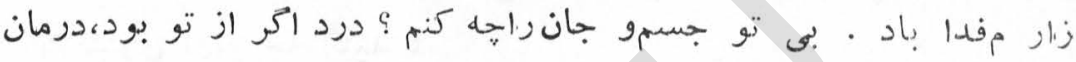

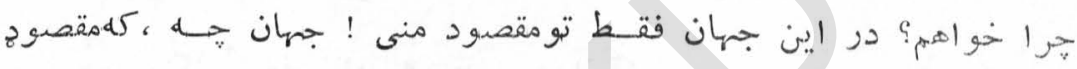

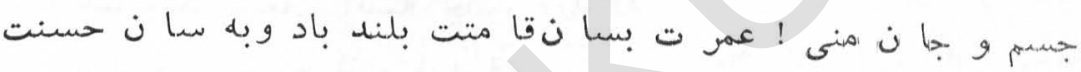

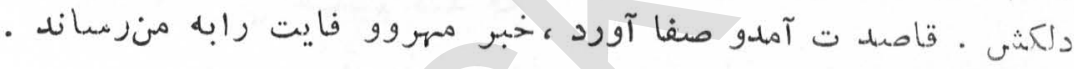

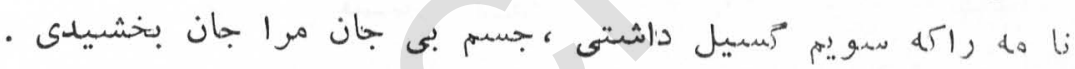

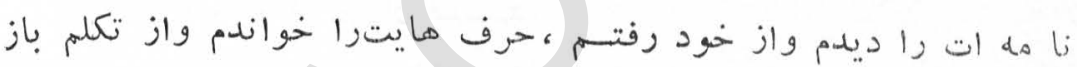

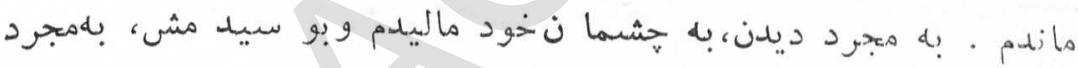

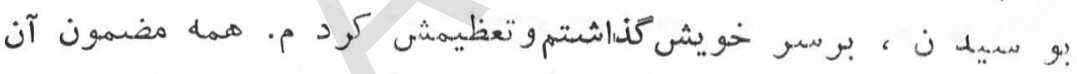
خوبا و هر لفظش مر غو ب بود .دانسمته كله در يار من مهروو فا ينى

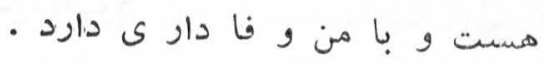

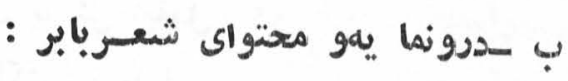

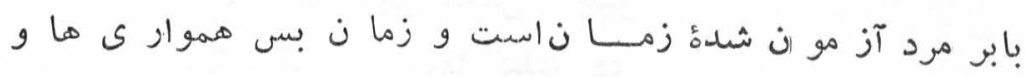

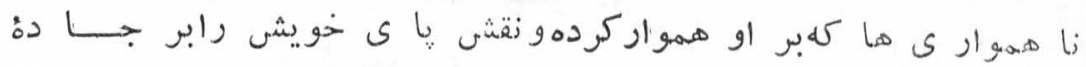

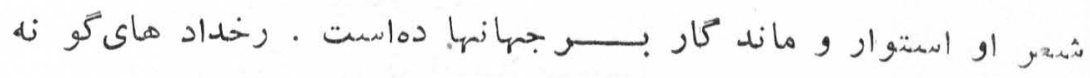

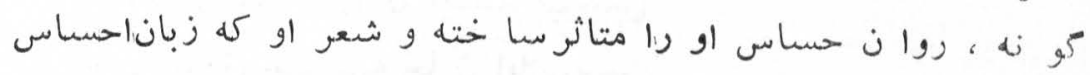

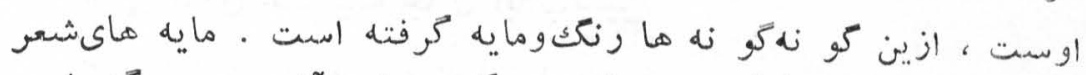

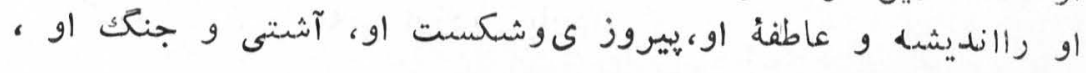




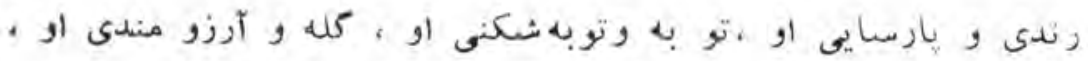

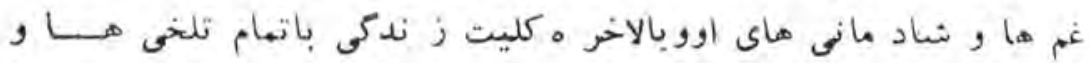

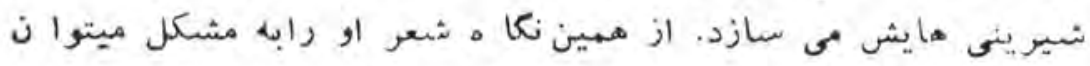

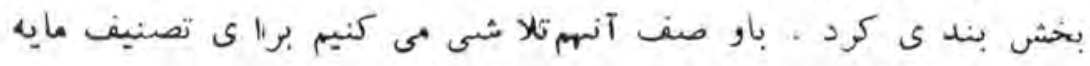

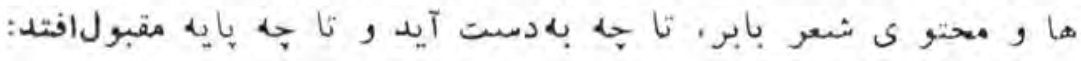

$$
\text { : أشعار تاريخهى - }
$$

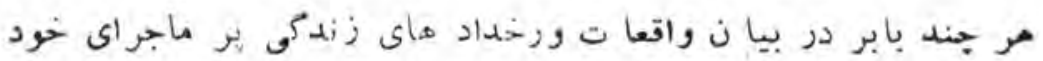

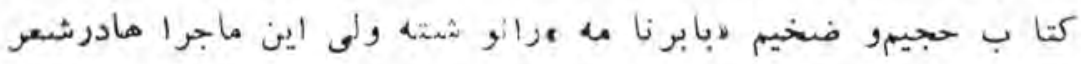

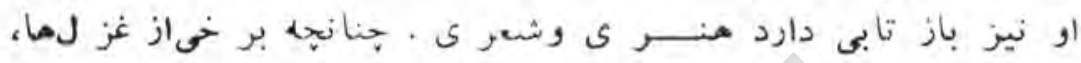

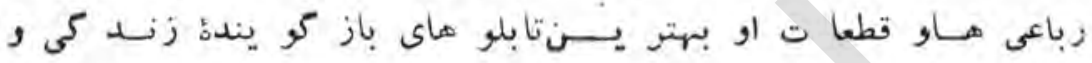

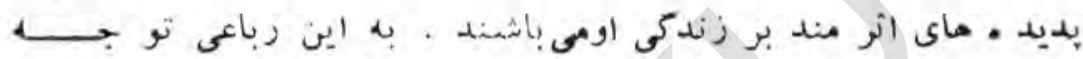

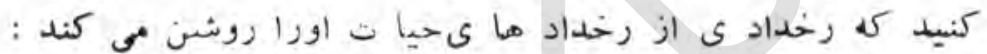

بابر هتر جه اولسله لنكر (97) سلماريغه

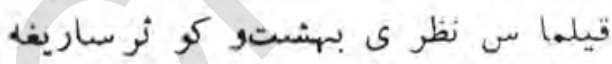

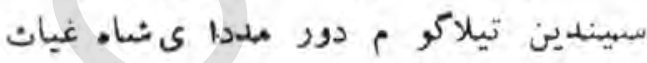

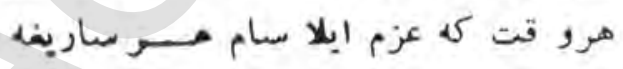
:

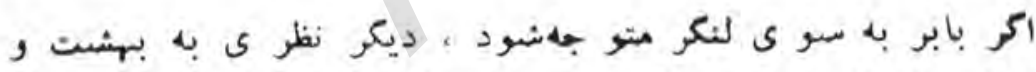

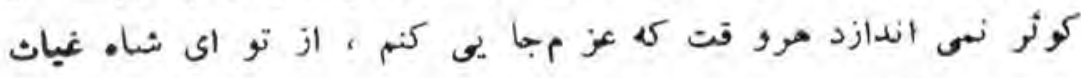

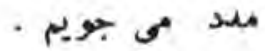
ويا اين رباعى كع باز كو يندة:لشكر كشى و در كير ى اوبامردم

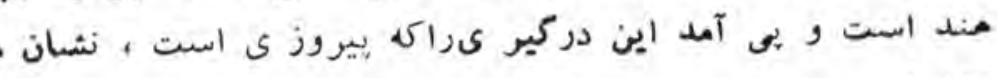

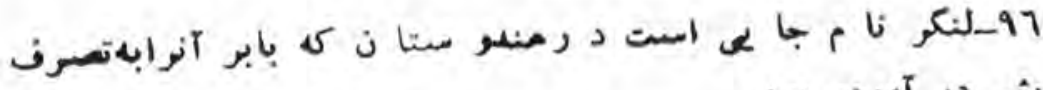
خوِيش در آوردث. بود . 


$$
\begin{aligned}
& \text { اسلام اوهو ن آوارذ ياز عبـولدوم } \\
& \text { كفار و, هئود حرب ساز ى بولدوم } \\
& \text { جزم ايلاب ايديم اوزنى شهيدبو لماققه } \\
& \text { المثة للها كله غاز ى بو لدوم } \\
& \text { : }
\end{aligned}
$$

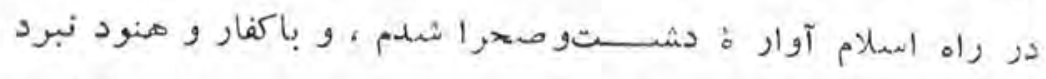
آزما بي كردد م عزمخودرا براىشهيدثشند جزم كرده بود م،منت خداىرا

رباعى زير از تب نوبتى اوحكايتهى كثيد كه ذكر هفصل ائن بيمار ى

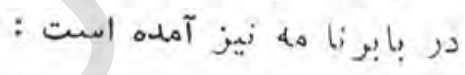

دا ايسيتمه كو ندا محكمي بولادورن

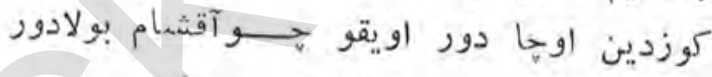

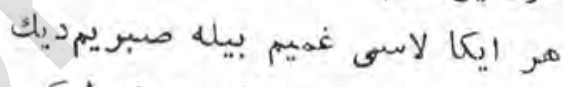

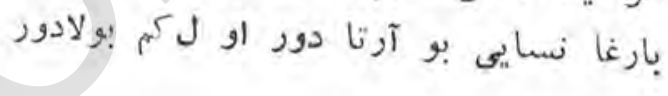
:

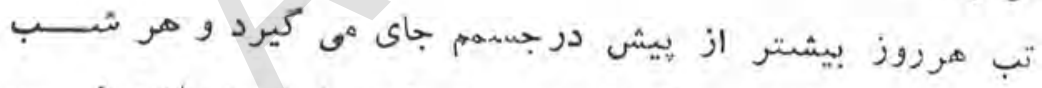

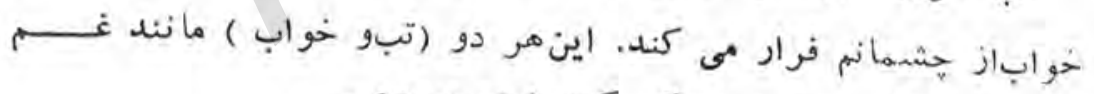
وهسبر م ، يكى بيشتر و يكى كمتر شيده ميرود . باز هم يك رباعى ديكر در بيا نآواره كى هاى اودر كوتل هاو راه

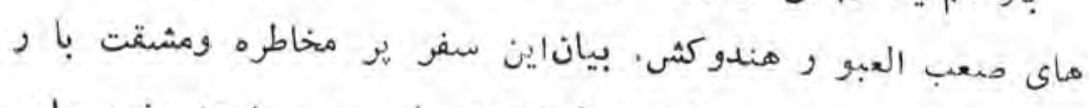

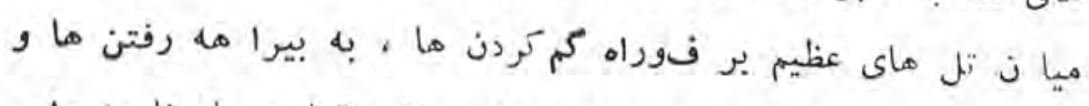

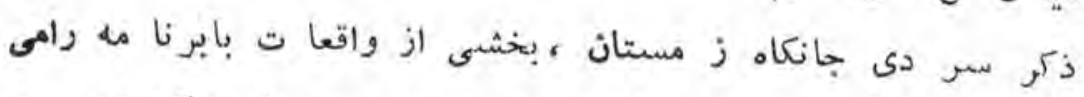
سازد ، و لى اين حادثهدر قالـــب يك رباعى ؛ بسيار نيكو تصو ير 
قيشن بو لدى و بولدى بار جهتاموتاشى قار

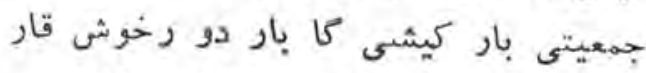
بو قيش دايمان يو ل ويريشا نيشي نحاليم

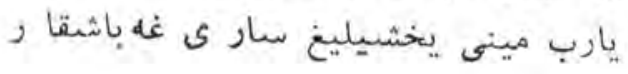

$$
\text { : }
$$

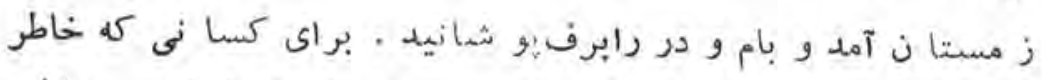

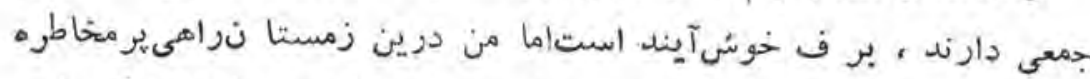

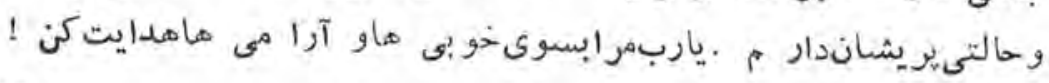

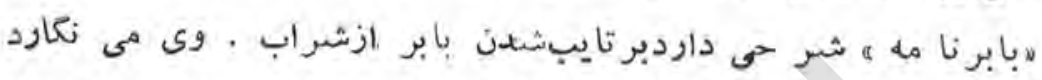

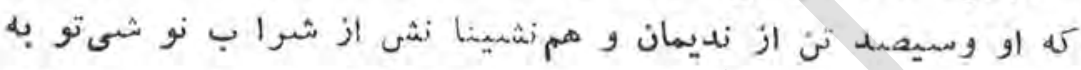

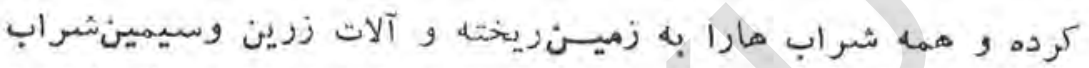

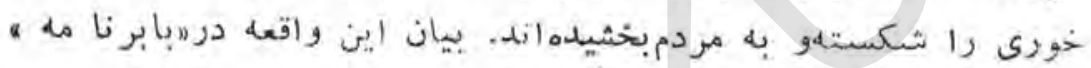

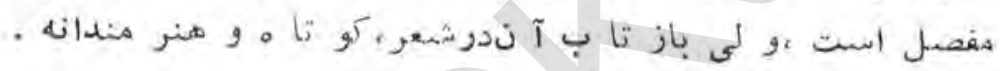

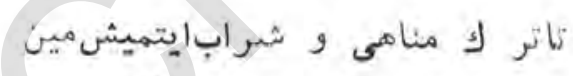

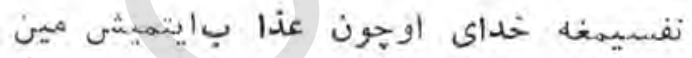

$$
\begin{aligned}
& \text { تو به ايشيكى هنوز آ خو قايردى }
\end{aligned}
$$

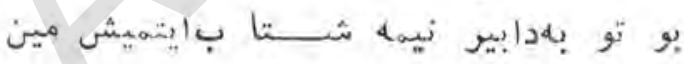

$$
\begin{aligned}
& \text { تر جمه : }
\end{aligned}
$$

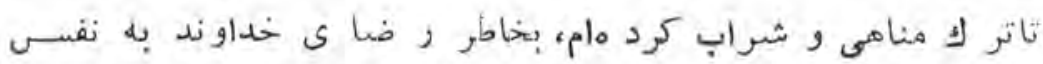

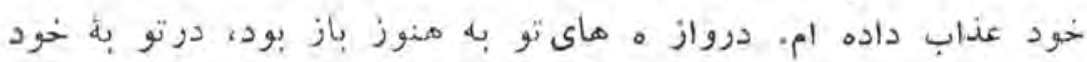

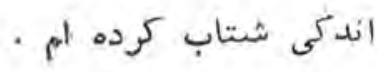

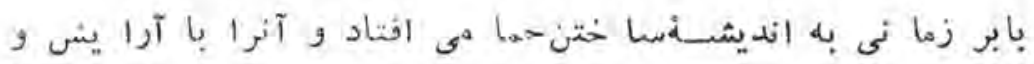

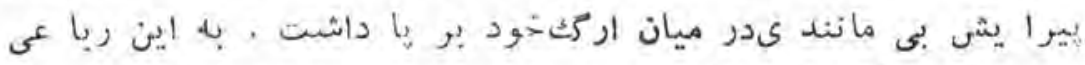

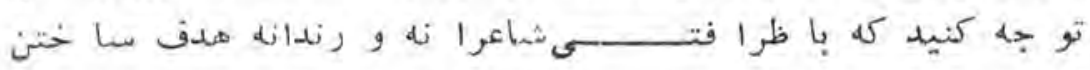

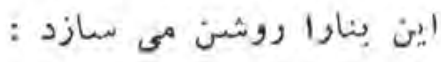




$$
\begin{aligned}
& \text { حمام كه اركك ايحينده بـيـيد اتيلديم }
\end{aligned}
$$

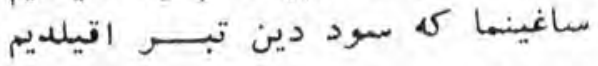

$$
\begin{aligned}
& \text { سود أو شبو ايما سبو كيم بـوتدبير بيله }
\end{aligned}
$$

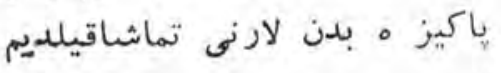

$$
\begin{aligned}
& \text { تر جمه : }
\end{aligned}
$$

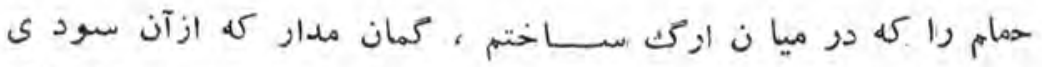

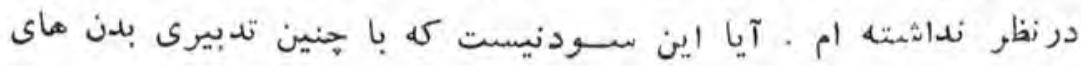

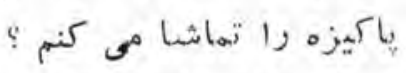

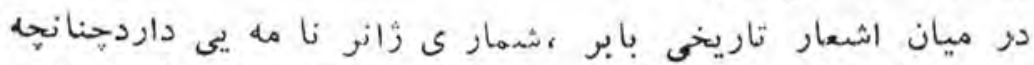

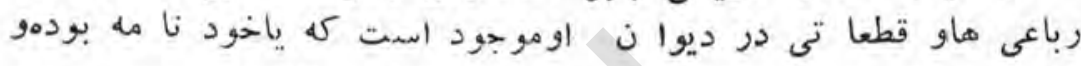

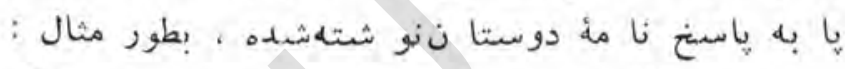

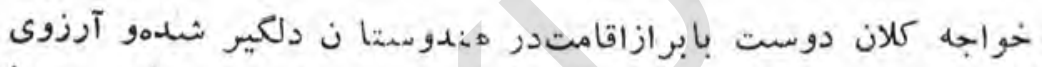

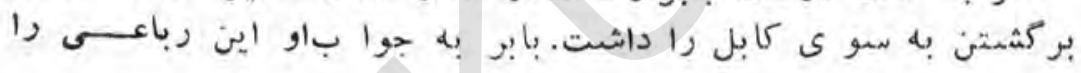

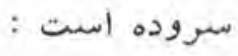

اظهار لطافت و ظرا فت قيلاسيز هر نكته دايوز تو مان كتا بستقونيلا سبيز كرهندايشى تيسكار ىاير ماسنى اوجيو ن ؟ ايسيغ بير دين ساووغ ظرا فتقيلاسيز :

$$
\begin{aligned}
& \text { اظهار لطافت اء ظر افت كرد ى }
\end{aligned}
$$

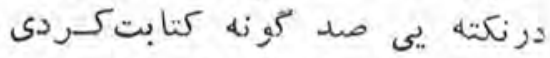

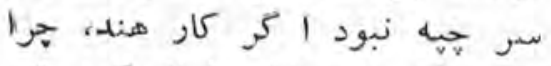

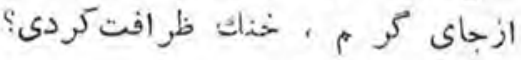

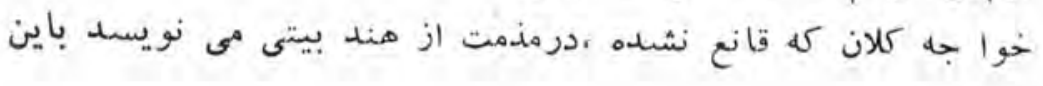

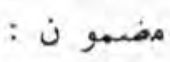

$$
\text { اكر به خيرو سلامت كذر زسندكنم }
$$

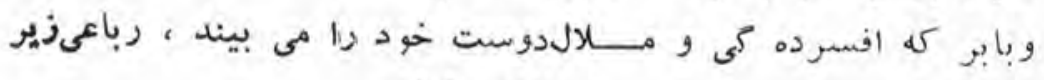




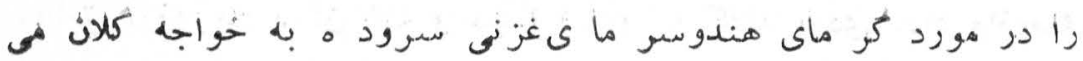

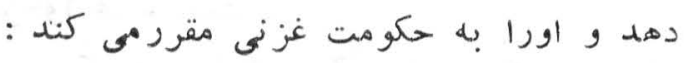

$$
\begin{aligned}
& \text { يوزشكر دى بابر كه كريمغفار }
\end{aligned}
$$

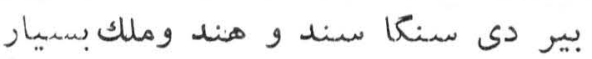

$$
\begin{aligned}
& \text { ايسيق ليغى غه كر سنعايوقتور طاقت }
\end{aligned}
$$

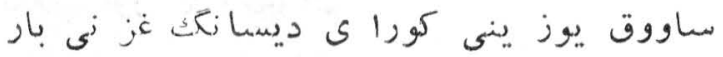

$$
\begin{aligned}
& \text { تر جمه : }
\end{aligned}
$$

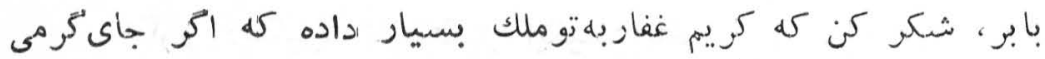

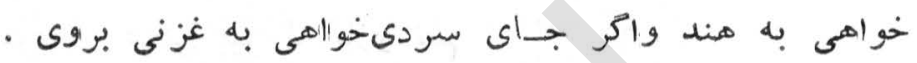

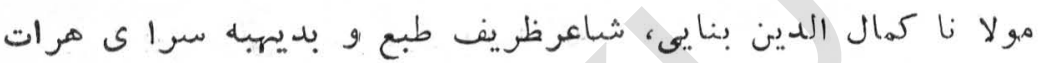

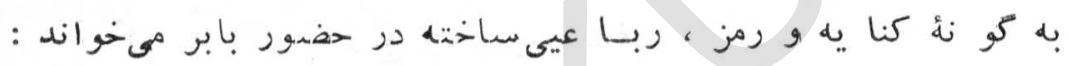

$$
\begin{aligned}
& \text { نى غله هرا كز و تو انم نوشيد }
\end{aligned}
$$

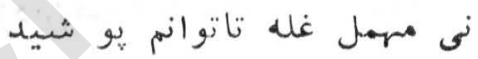

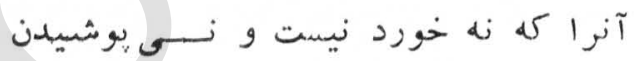

$$
\begin{aligned}
& \text { در علم و هنر كجا تواندكو شيد }
\end{aligned}
$$

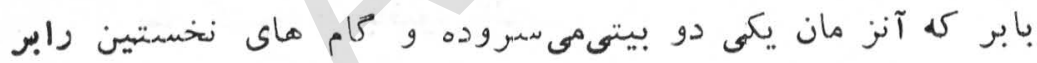

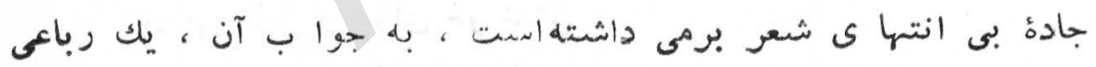

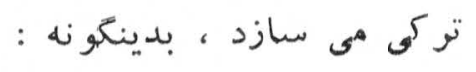

ايش لار بار ى كو نكلو نكما كى ديك بو لغو سيدور

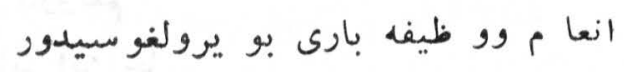

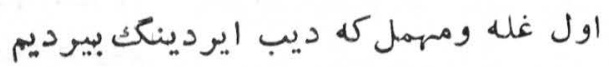

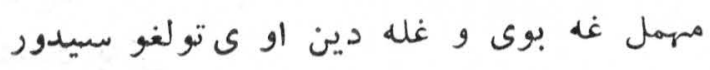

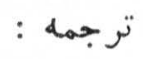

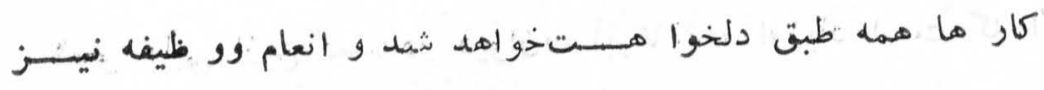

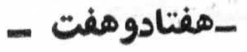


مطابق آرزو يت . آن غله و مهـل(مله) كه كفته بودى ،داد مازهمله.

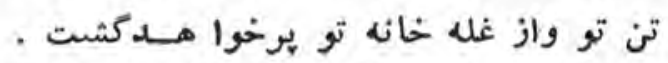

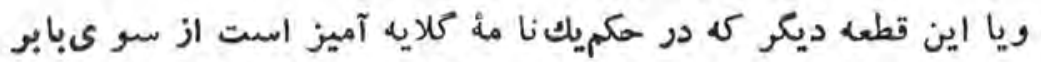

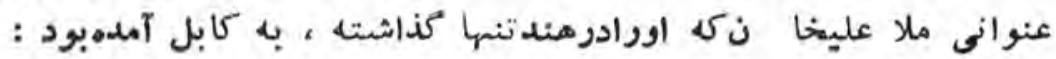

$$
\begin{aligned}
& \text { اي آلاركيم بو هند كثور يدين }
\end{aligned}
$$

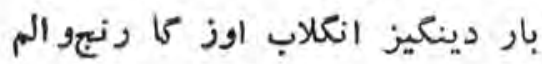

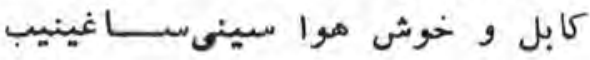

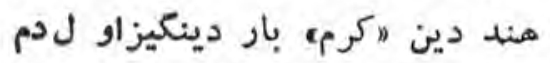

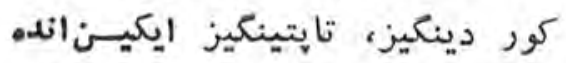

$$
\begin{aligned}
& \text { عشرت و عيش بير له نازو نعم } \\
& \text { بيز داغی اولما دوك بحمدالله } \\
& \text { كر خه كو بي دنج ايدىوبيحــنم } \\
& \text { حظ نفس و مشقت بد ند نى } \\
& \text { سيز دين اوتتى واو تتى بيزدينهم } \\
& \text { تو جمه : } \\
& \text { اي كسا نى كن باز كشور مثند }
\end{aligned}
$$

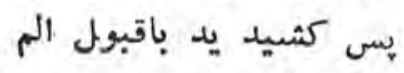

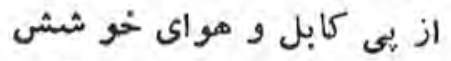

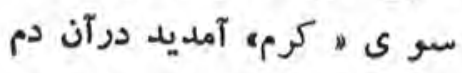

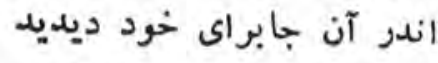

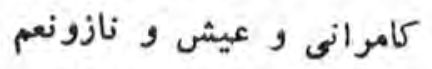

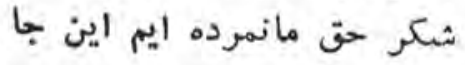

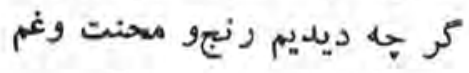

$$
\begin{aligned}
& \text { حظ نفس و مشقت بدنى } \\
& \text { بكذ شت از شمها واز ما مهم بمان }
\end{aligned}
$$

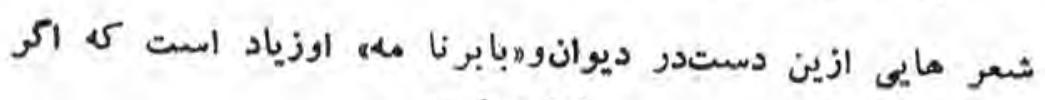




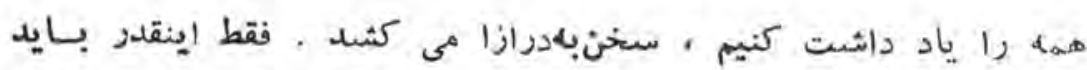

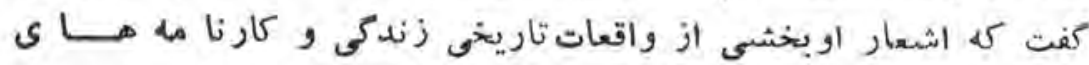

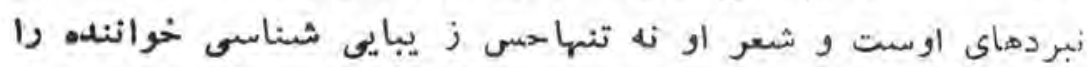

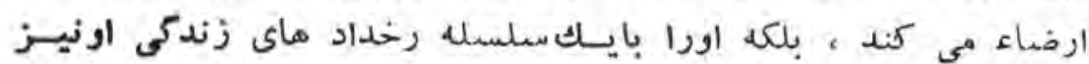

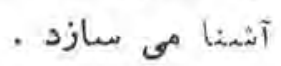

r- اشعلار وصف الحال:

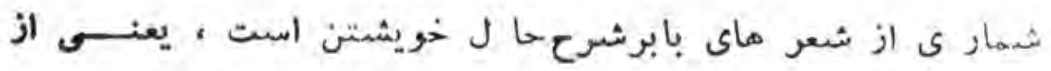

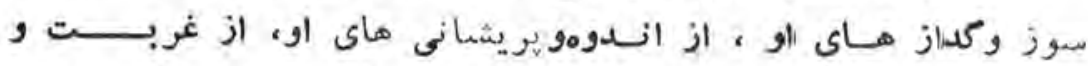

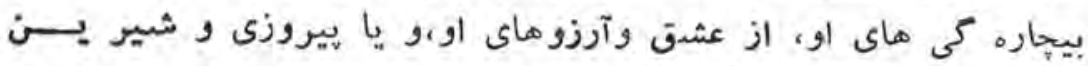

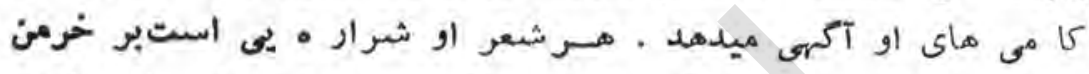

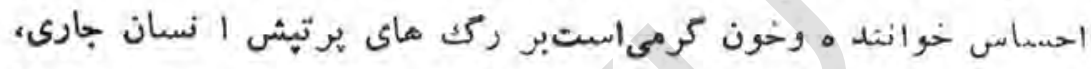

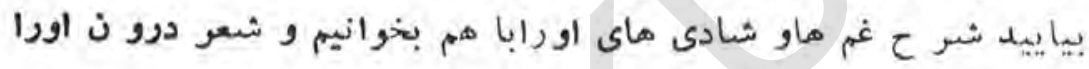

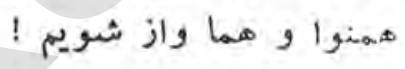

$$
\begin{aligned}
& \text { ياد ايتماس ايميش كيشى نسىغربت نه كيشه }
\end{aligned}
$$

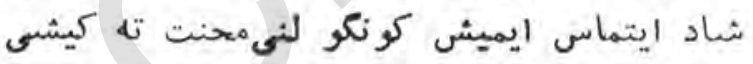

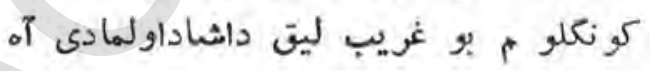

$$
\begin{aligned}
& \text { غربت ته سيوو نماس اير ميشىالبته كيشى لمرئ } \\
& \text { تر } \\
& \text { 1) } \\
& \text { شادان نكند بهوقتمحنت كسرا } \\
& \text { هن شاد نكشتم اندرين غربت، بآه }
\end{aligned}
$$

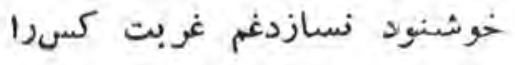

$$
\begin{aligned}
& \text { ويا اين بيت : }
\end{aligned}
$$

آه وو اويلا سرو دو مب درد و غمهم مشبتيم

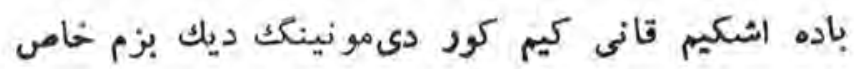




$$
\text { آه و واويلاسر ود م ، درد وغم هم صسحبتم }
$$

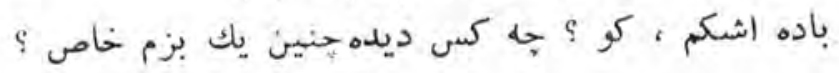
بابرسا ل ها ازديار آبايسـى ودوسمتا ن و يارا ن بدور مانده واين غربت و تنهايى خاطر اورا بسـى افسرد كه اين افسردهـى درشيعر او

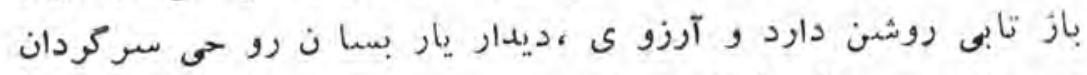

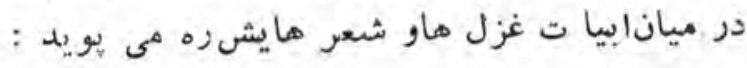

غربت تا اول آى هجرى مينهىير قيليبتور

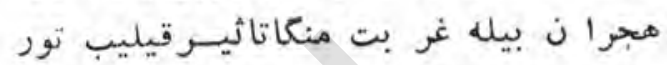

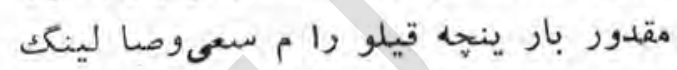

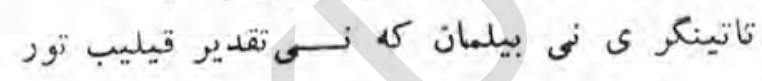
تر جمان :

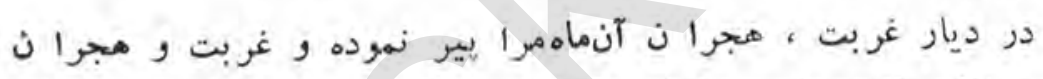
برمن ثاثير كزده است تاجايى كـهمقدور است در وصا ل

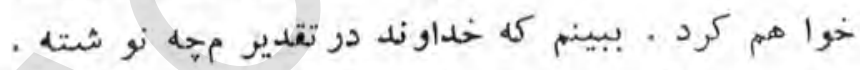

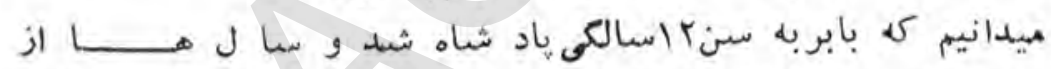

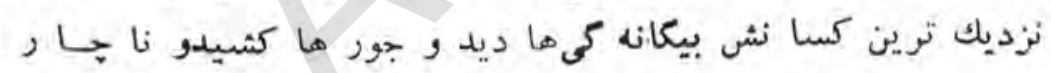

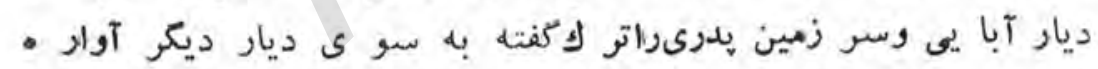
شد ، اين بيو فا يق يارو ديارو ايندشمنى دوستا ن ويارا ن، مضمون

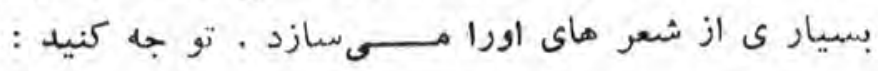

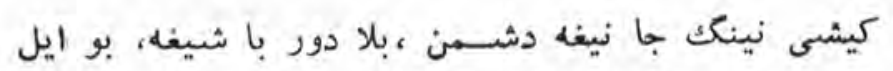
اكر با شين طفيل اليلاب وكرجانين نثار ايتسه لينه ديار و يار دين بابر جفا و جوريل

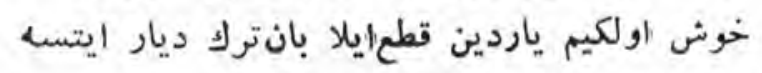
تر جمها : اينِ قوم برسر و جا ن انسا نبلاو دشمن است ، هر جند كه سر 


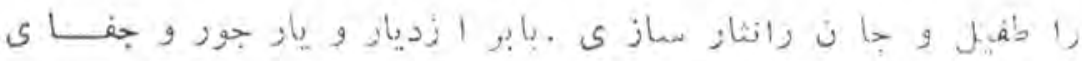

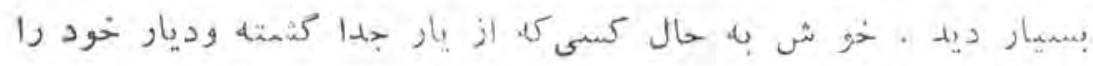

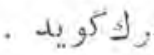

ودرين بيت بيرار كي وبىاعتمادىاو نسمبت به الهل جمبان انعكا بي

:

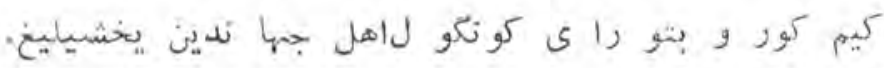

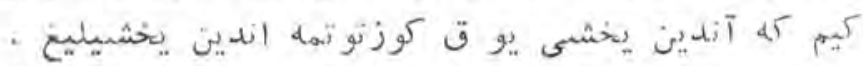

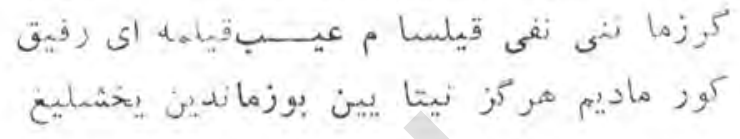
:

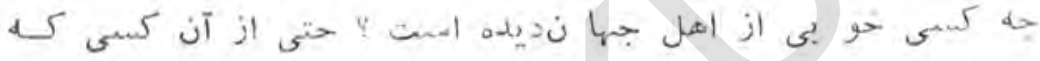

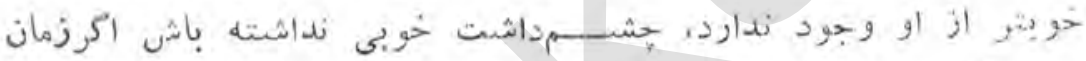

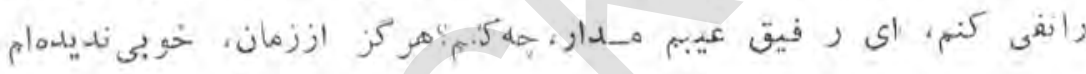

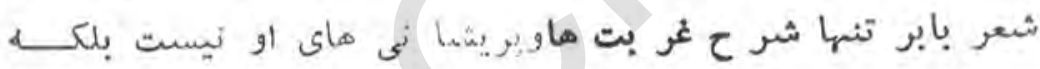

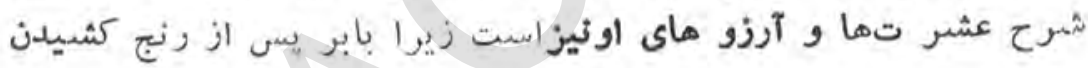

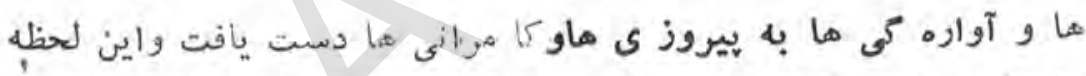

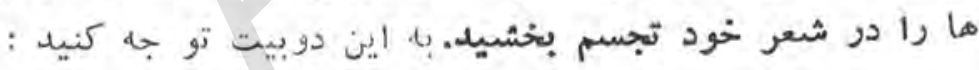

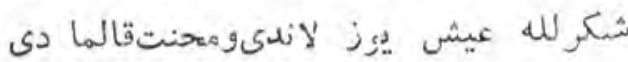

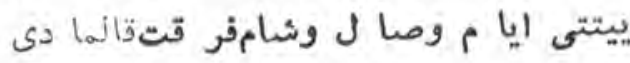

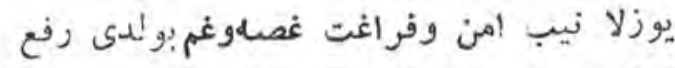

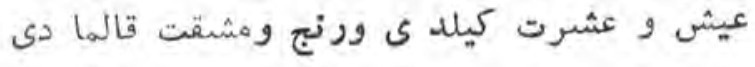
تر جمه : شكر لله عيش رو آوردو محنتمانماند در رسيد ايا موصلوشا مق فرقت.مانماند _هشتادويك- 
رو نمود امن وفر اغت ، غصله وغم گُشت رفع

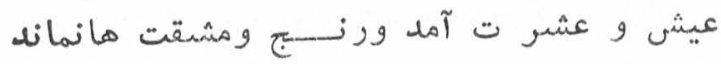

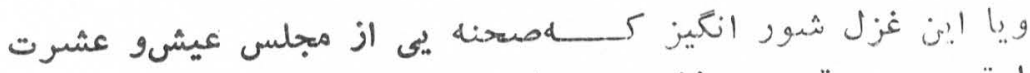

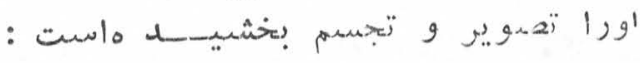

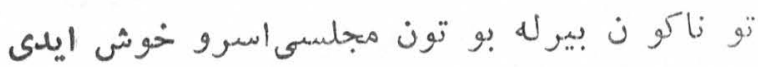

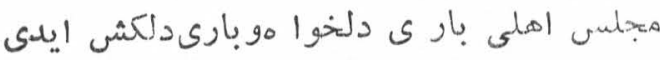

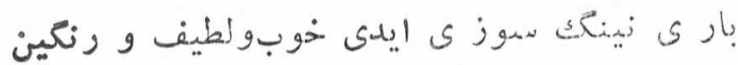

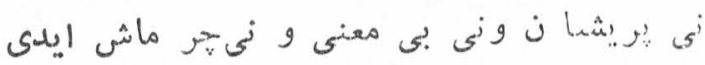

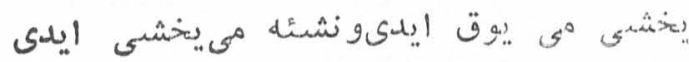

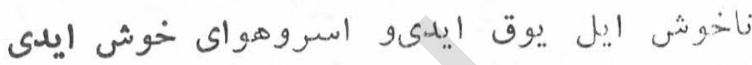

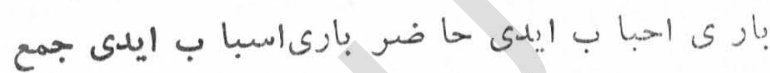

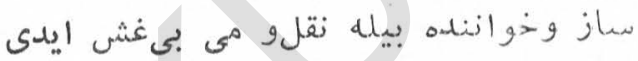

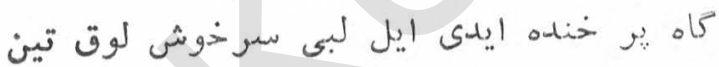

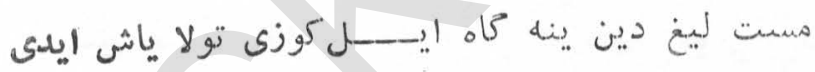

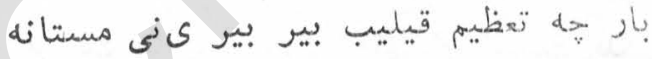

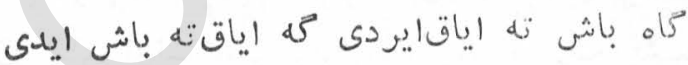
تون ياز يميغه هاه بو زوع ايسلدوواندين سونك

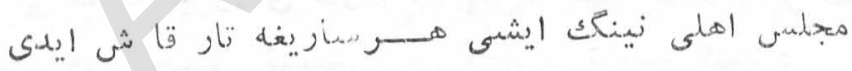

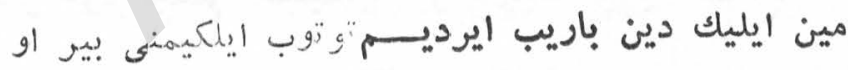

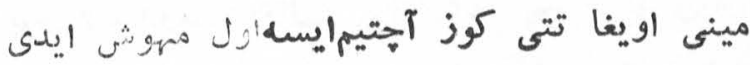

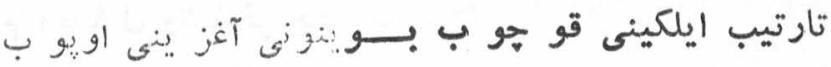

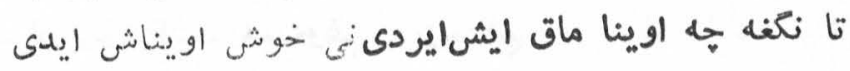

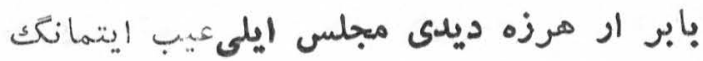

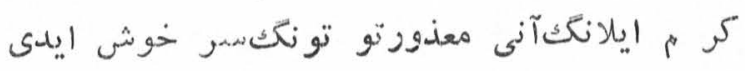

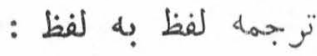
د.يروز مجنس خدو شبى بود اهل مجلس همل دلخوراهو دلكش بودند 
صحبت ماي شا ن خوب ، لطيف ورنأين بود

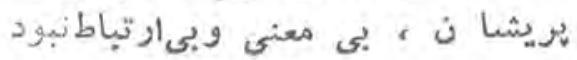

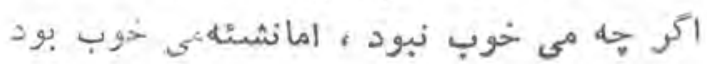

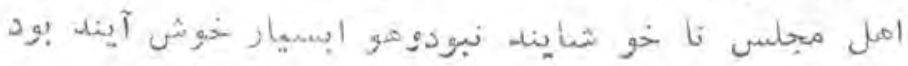

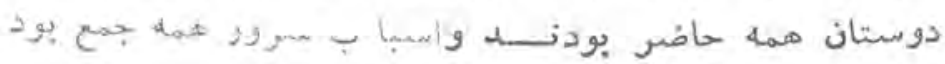

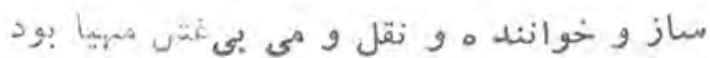

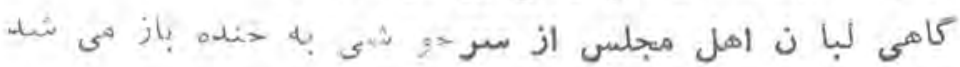

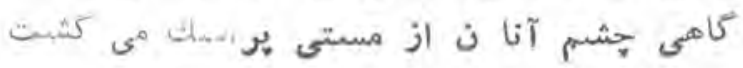

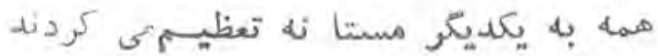

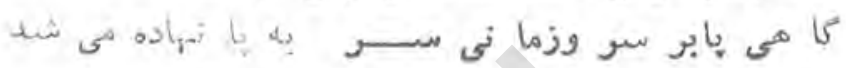

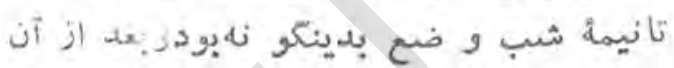

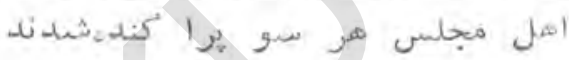

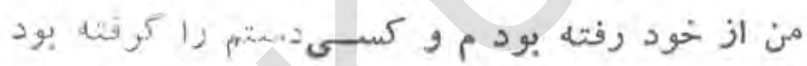

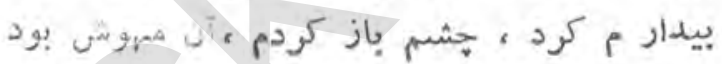

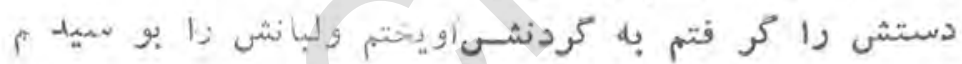

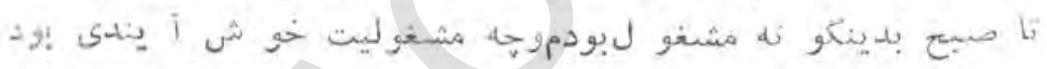

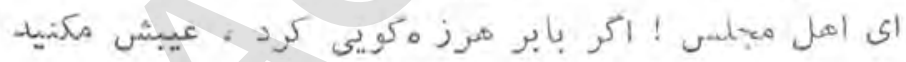

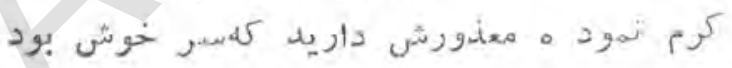

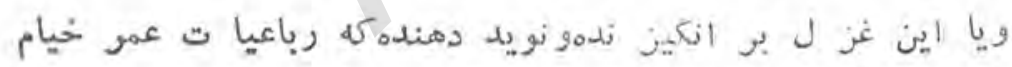

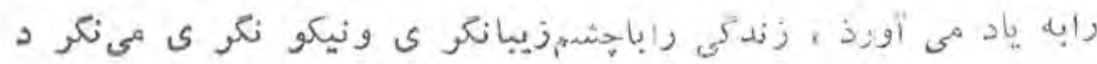

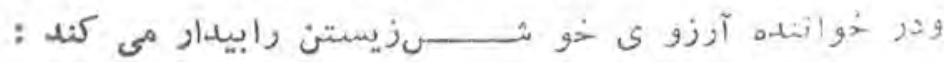

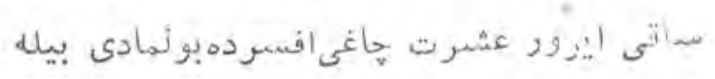

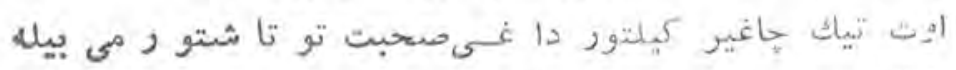

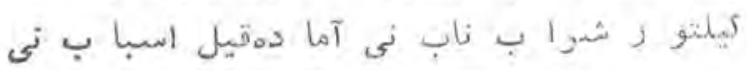

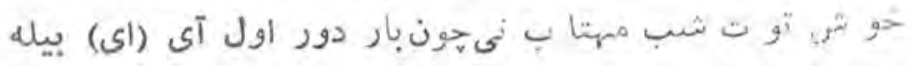

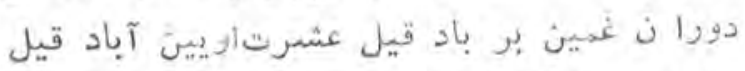

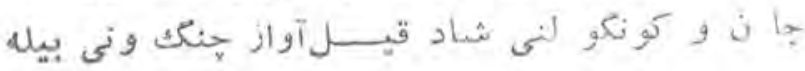




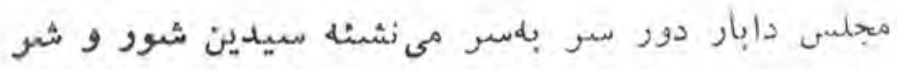

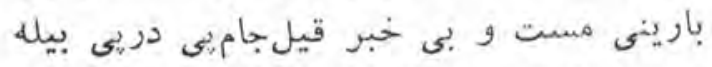

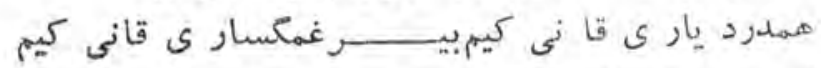
ابر بهار ى قانى كيم بأبر كيبى يبيغلاى بيله ترجمه لفظ به لفظ:

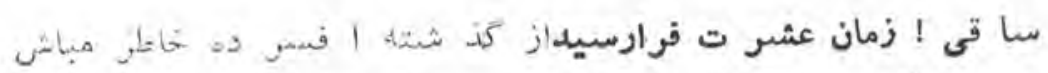

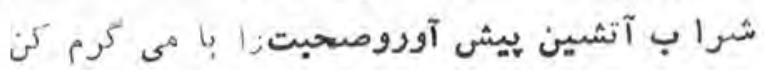
شرابنا ب بيا ور و اسبا ب راآهاده سناز

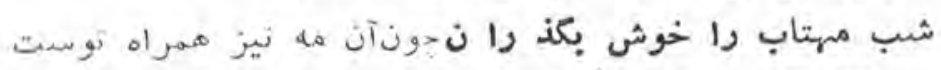

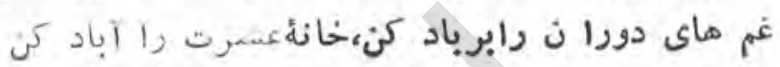

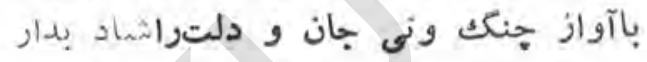

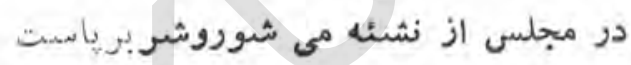

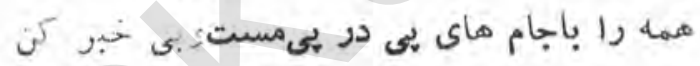

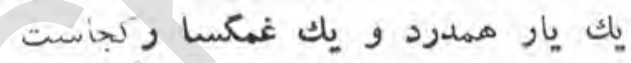

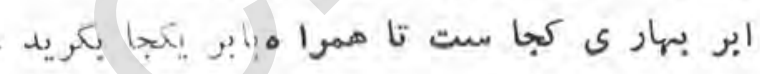

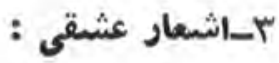

عشق د رادبيا ت مشرق زميـئمضمون مهه واساسنى براى كفتن

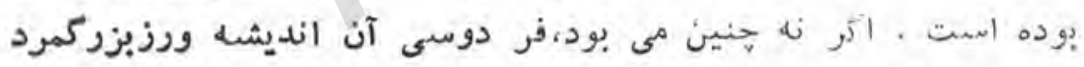

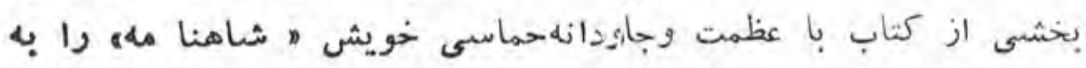

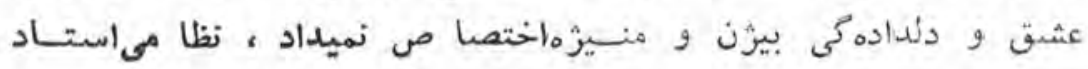

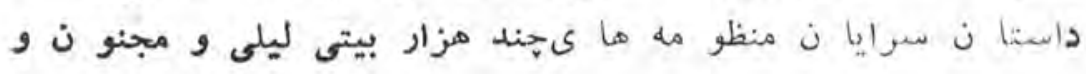

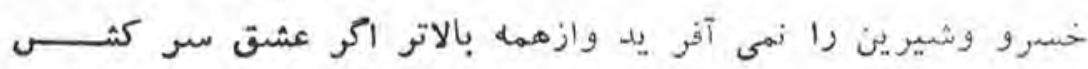

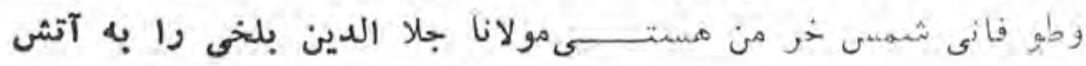

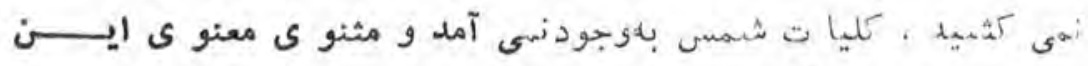

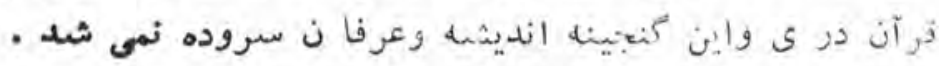

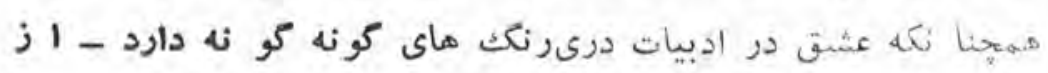
- 


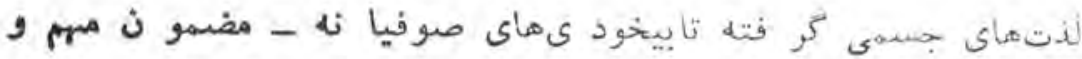

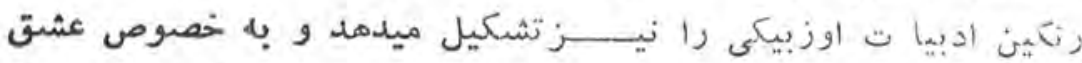

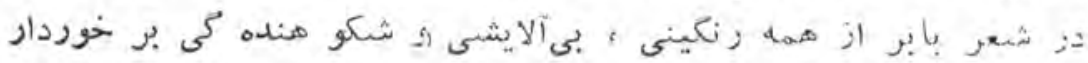

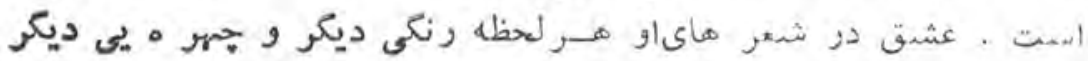

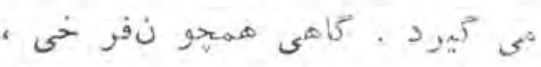
از

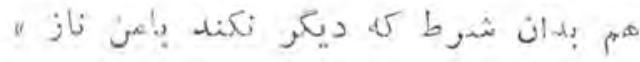

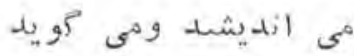

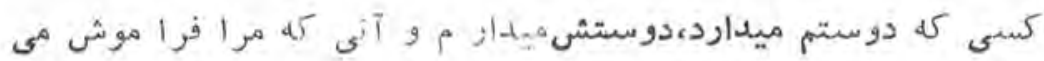

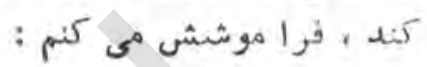

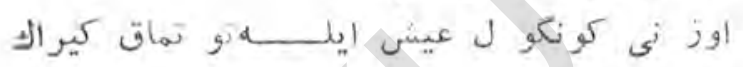

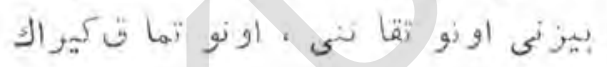

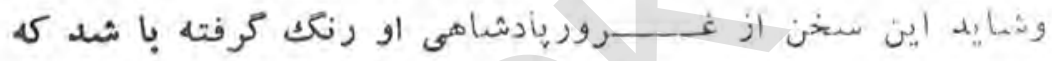

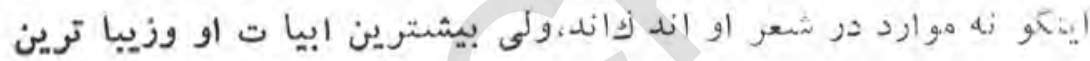

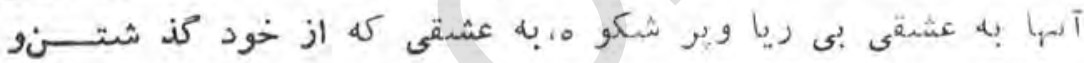

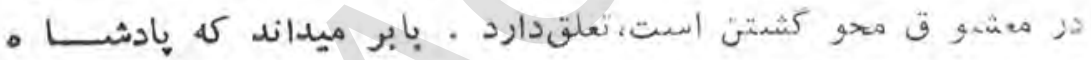

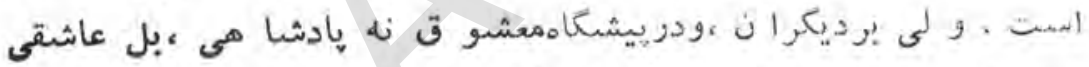

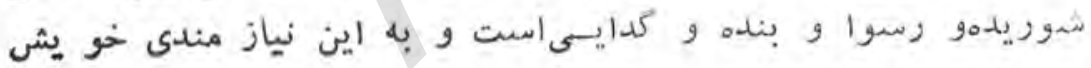

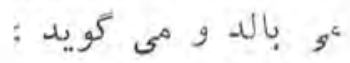

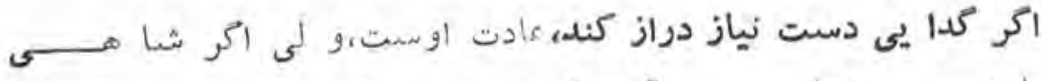

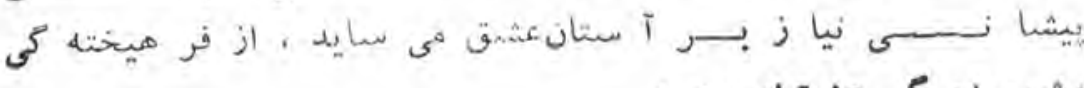
وشوريلده كى عشتاوست :

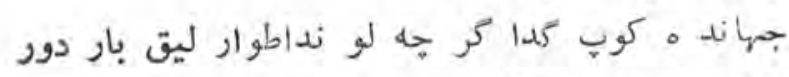

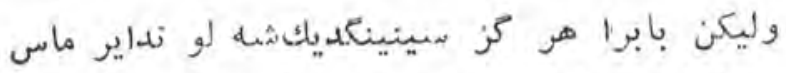

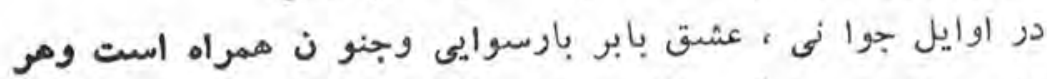

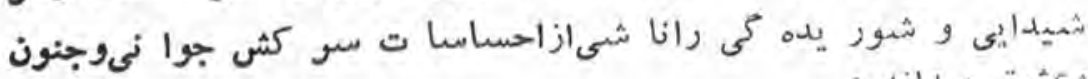
وعشق ميداند : 


\section{نىقيلسا م ايلامه اى يار عيـب كيم. ميندا}

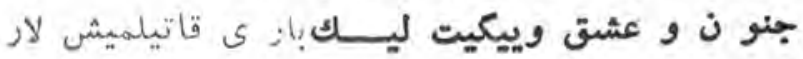
تر جمه :

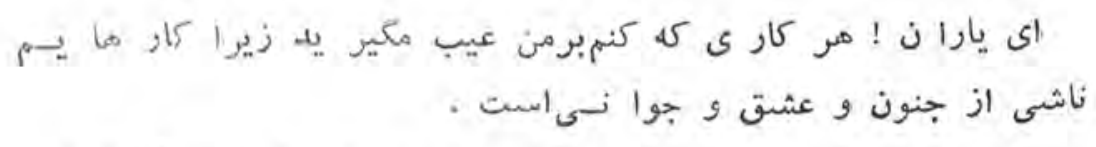

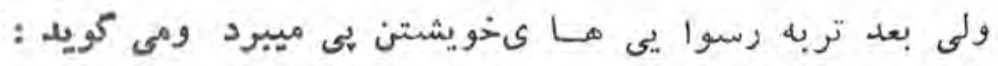

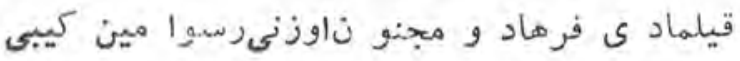
كيم بو نوع ايش ايش ايماستورميج عاقل قيلغ فيلغو ديك تر جم:

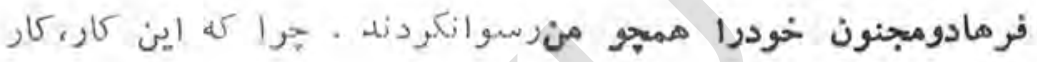
• ميتج آدم عاقلى نيست

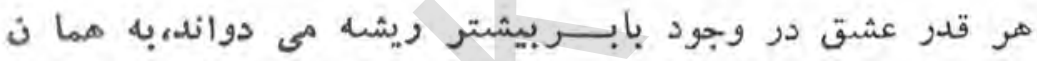

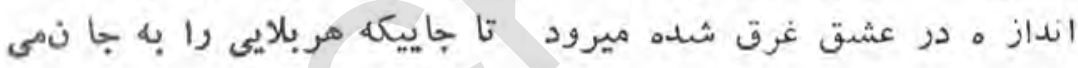

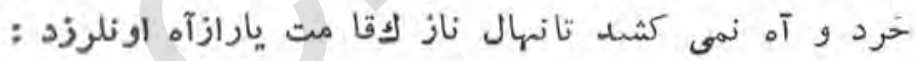

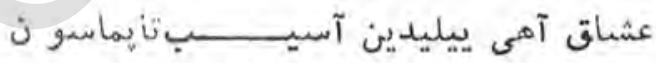
قد ينك كه حسن باغيدا، ناز كُنهال دور

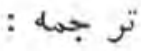

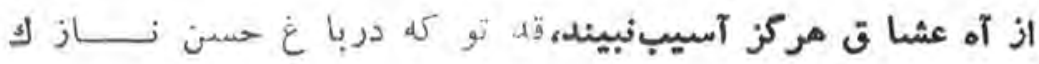

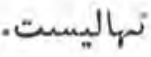

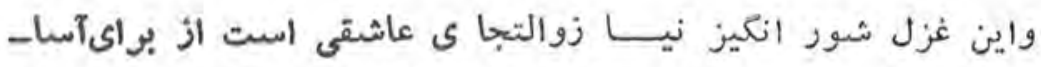

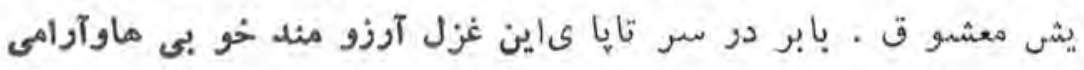

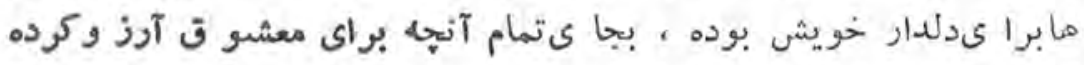

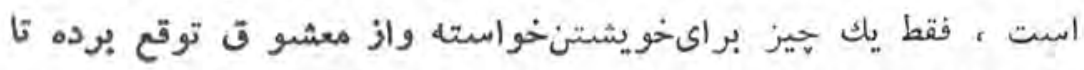

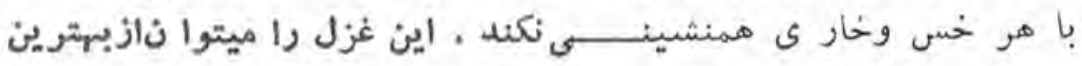
نياز مائعاشقا نه خواند : 


$$
\begin{aligned}
& \text { عشتق ايلى نينك آهى دين او ل لمرو قد خم بو لـماسمو ن }
\end{aligned}
$$

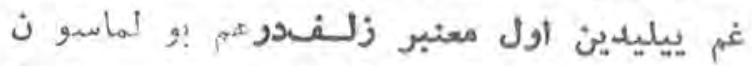
: آه عاشق ، تقا مت آن سروء هر مز خهم مباد

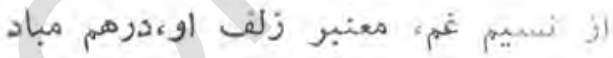

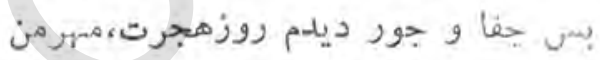
از سبر هن ، سائه سرو قد تو، كم مباد

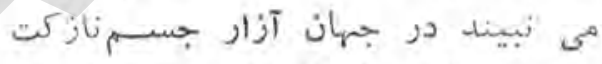

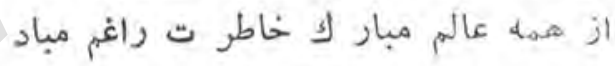

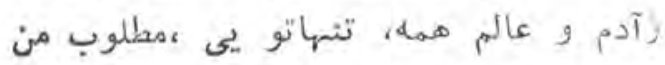

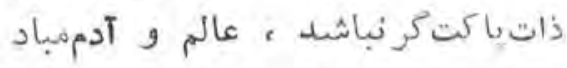

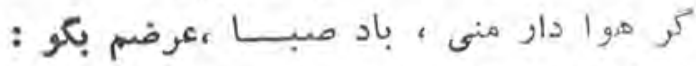

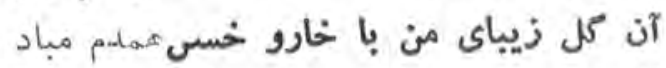

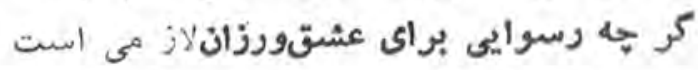
اوجو بابر هيجيا ه رسواى اينغالم مباد بخشايش و فدا كار ىاز مفاتهمه عششا ق واقعى است و بإبربيش

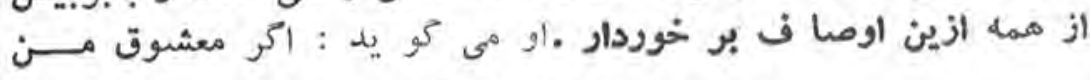


هزار كو نه بلا بوسرم بياورد ازاوروبر نمى كردانم واكر جنين كنم ،

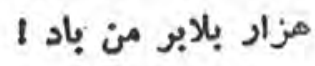

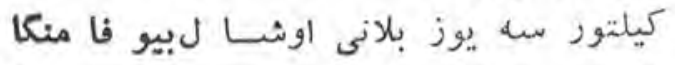

كيلسو ن اكر يوزون بوز منى ايوورسام بلا منكا

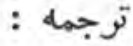

كرصد بلا بياورد آن بيوفا بهمن

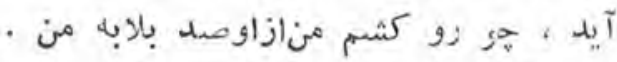

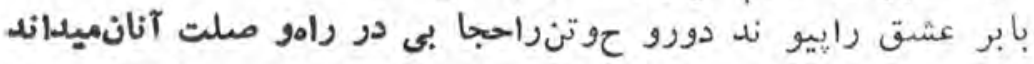

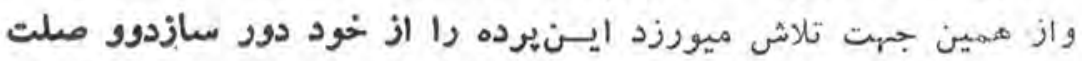

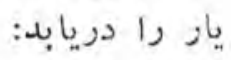

تن حجا بين رفع قيل كر يـاروصلين إيستا مشانك

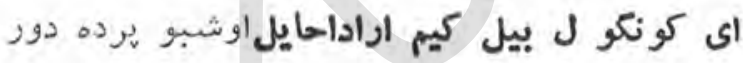
ترجمه :

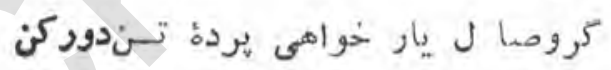

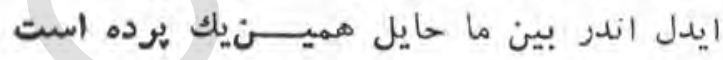

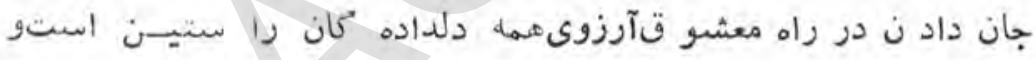

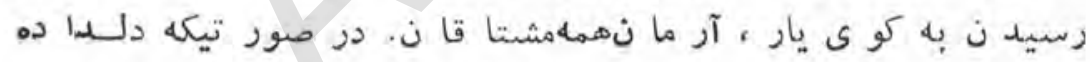

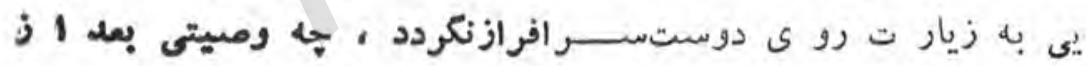

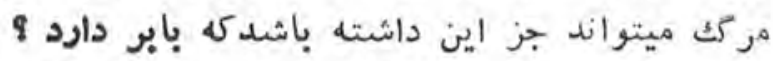

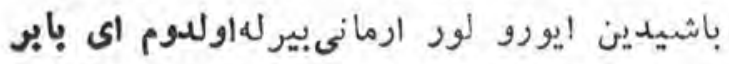

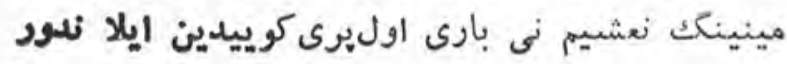

$$
\text { : }
$$

شابم خاك از براى اينكله بركردسرش كردم كريم

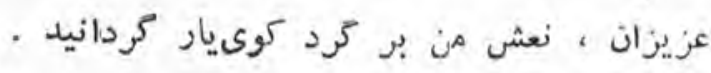

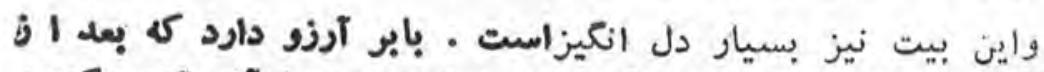

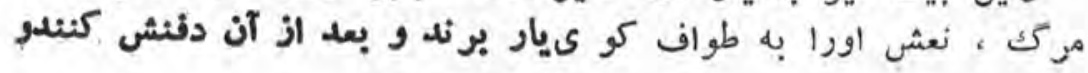

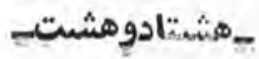


برسنك مزار ش آرزو هاى قلـباورا بثو يسند ثآنجه در درو ذقبب

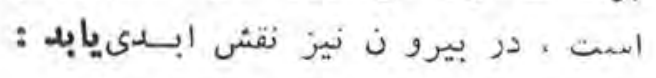

دوستلار كو نعلو مداكين قبر يمتاشى غه ئه ياز غاسيز

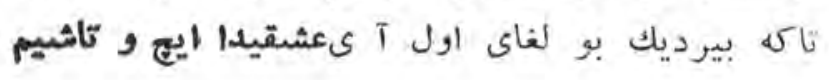

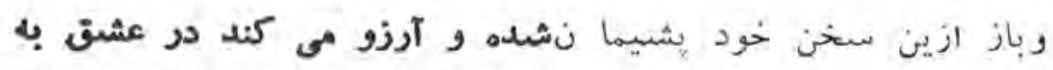

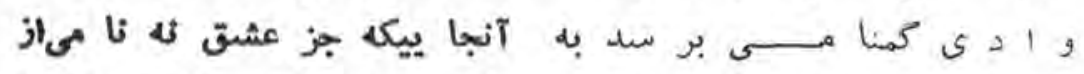

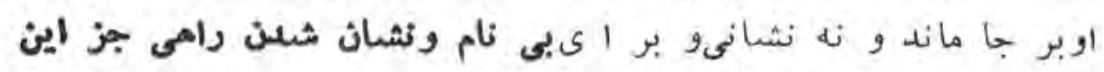

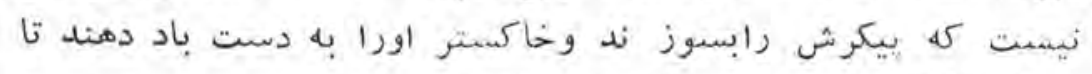

$$
\text { مر ذرة آنرابه دور دست ها ما ببردوبياشد : }
$$

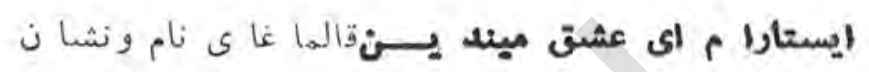

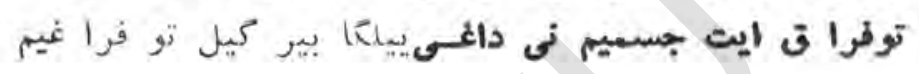

$$
\text { : ترجمها : }
$$

$$
\begin{aligned}
& \text { درره عثق آرزو هوارم نشان من مباد } \\
& \text { خاك كنجسمينو خاكمبدهبردستياد }
\end{aligned}
$$

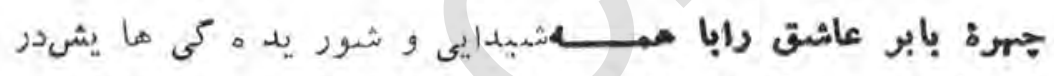

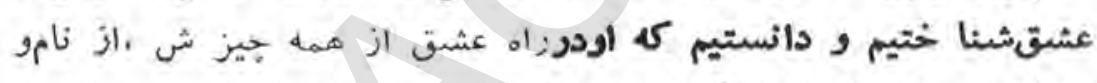

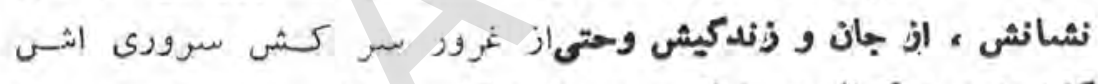

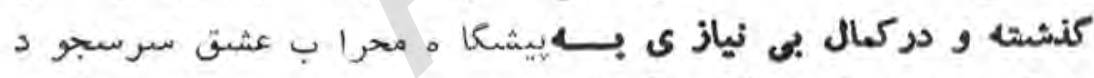

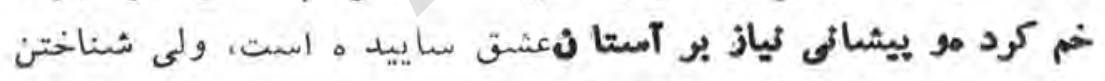

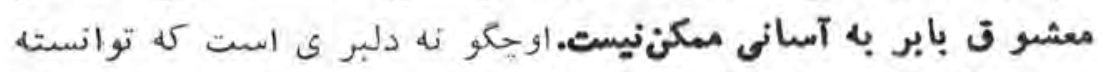

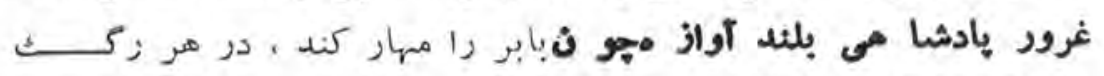

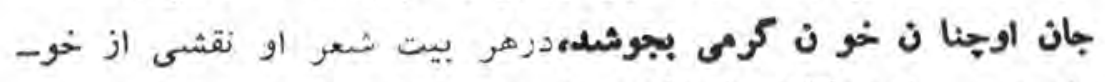

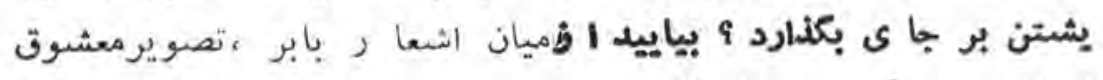

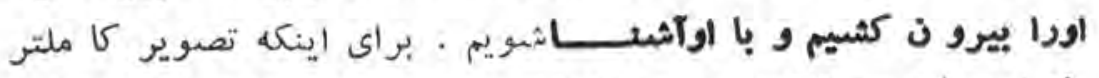

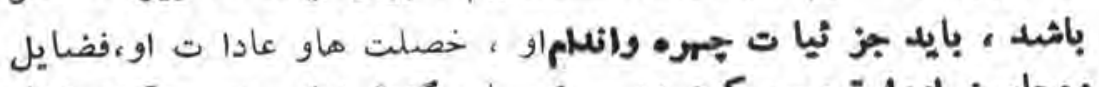

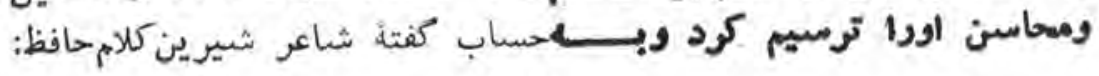

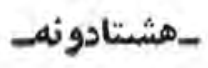




$$
\begin{aligned}
& \text { "شاهلهدآن زيسيت كله مو ينىو ميانىدارد } \\
& \text { بندة طلعت آن باش "نه آنىدارده" }
\end{aligned}
$$

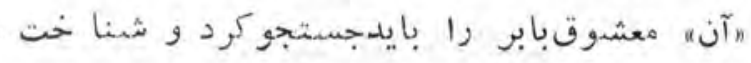

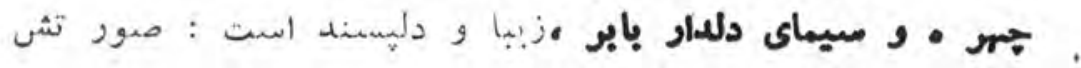

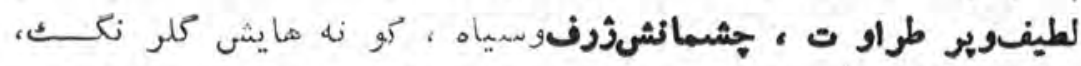

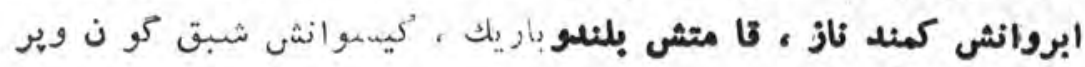

شكن است .

به اين تصاوير شعر امى تو جهنيد : كو نكو لما بو لدى عجايب بــلاقراسا جينكث

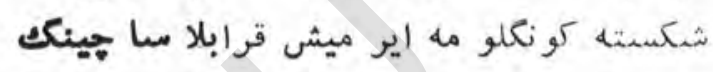

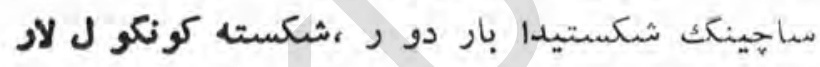

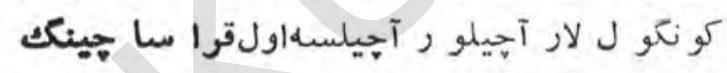
:

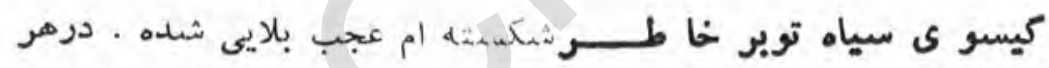

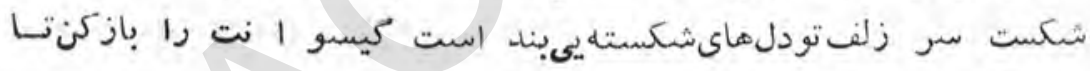

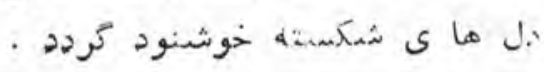

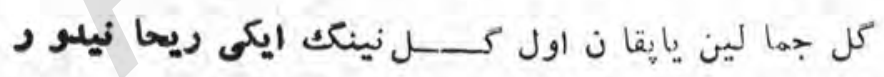
غنحه سرين آحقا ن اول ايكىلب إخندانى دول دور

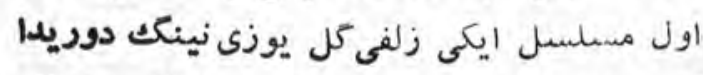

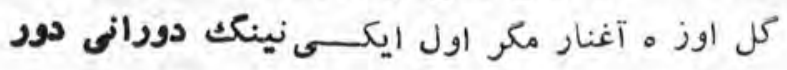
ترجمه :

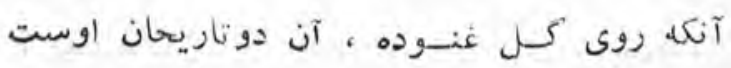

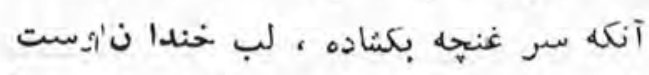

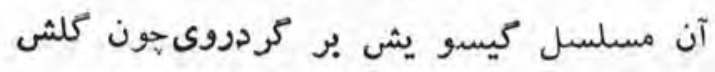
روي كل خفته، تو كويى نوبـت بتودوران اوست بردون - نود- 


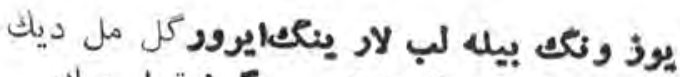

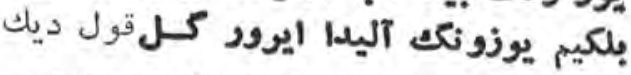

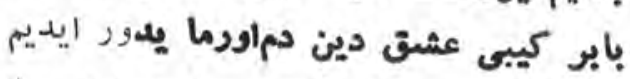

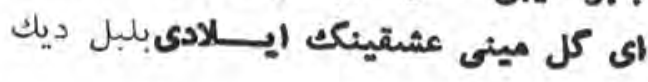

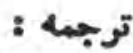

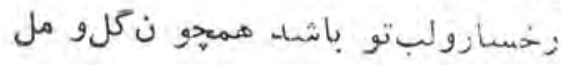

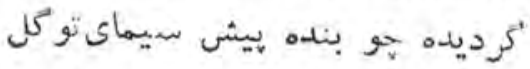

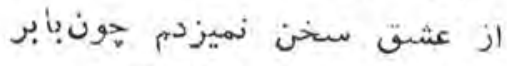

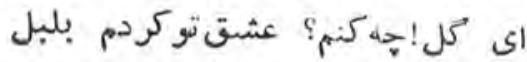

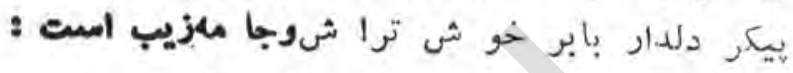

كرسيمبرك كل نى قيلسهلباساوزيكا

بولغاى مو اي كلندا مكو نكلا كبيله تنينك ديك

: ترجمه :

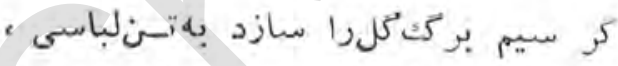

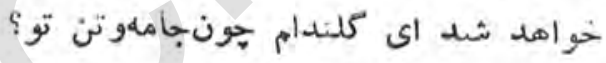

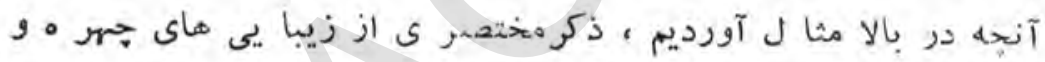

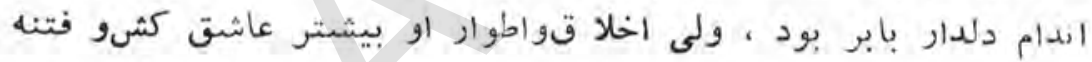

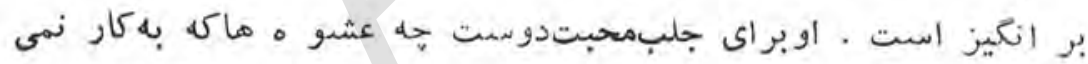

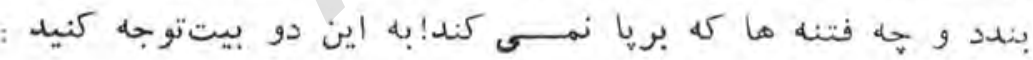

سوزلاب اول لعل شكر خا نسىشكر ريز ايتا سين

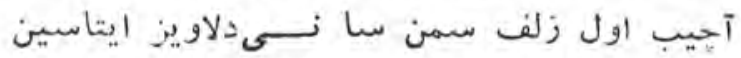

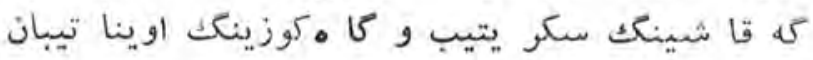
نى بلا فتنه مينينك جانيمه انكيز ايتا سين : سخن آرى به لب و، لعل هشكر ريز كنى،

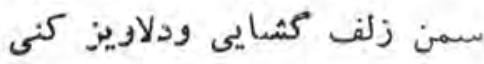

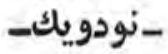




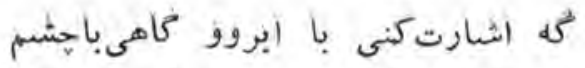

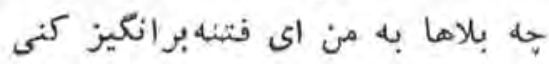

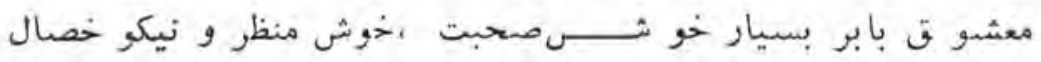

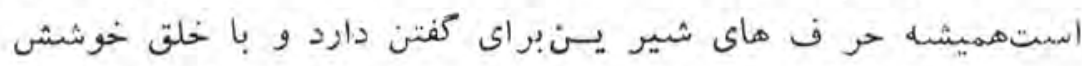

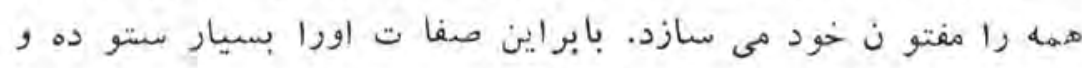

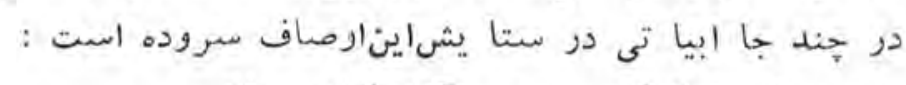

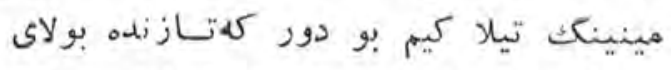

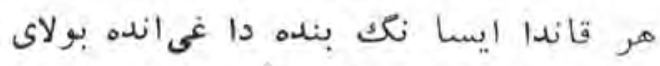

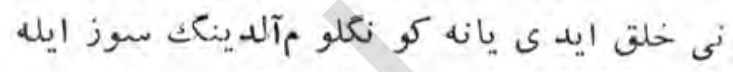

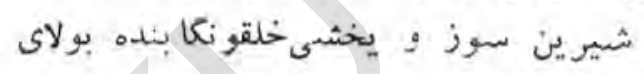

ترجمل :

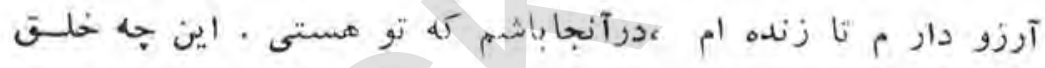

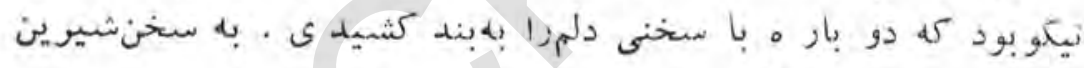

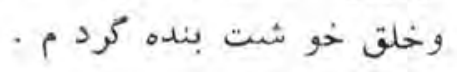

اين رباعى ديكر نيز درستا يشخوش طبن طبعى و سخن دانى اوست :

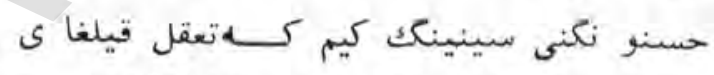

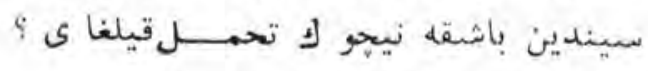

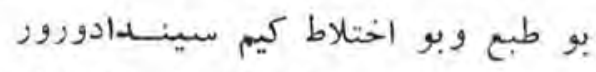

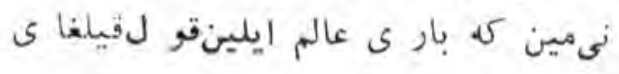
ترجمه :

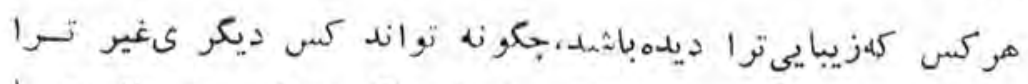

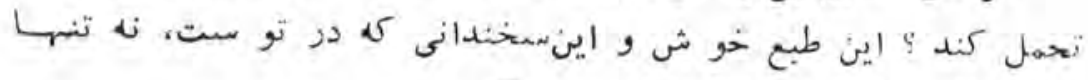

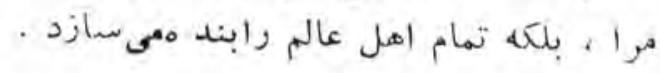

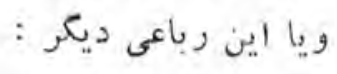

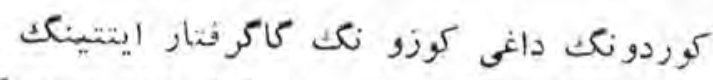

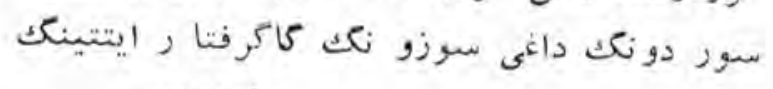




$$
\begin{aligned}
& \text { بو طلبع و كلا مينكك بيله اوز بـاندينك اوجو ن }
\end{aligned}
$$

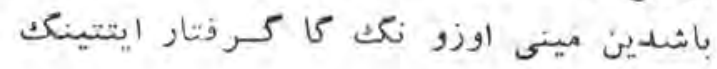

$$
\begin{aligned}
& \text { : }
\end{aligned}
$$

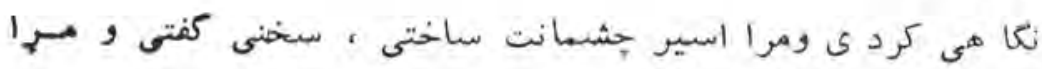

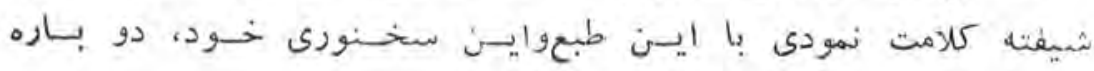

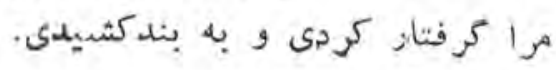

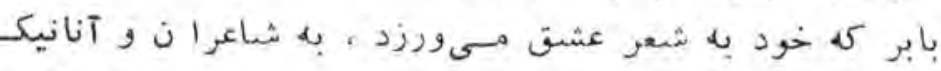

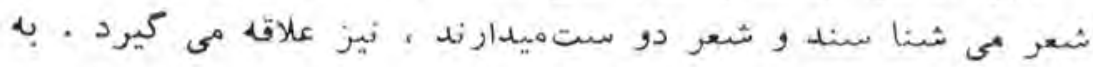

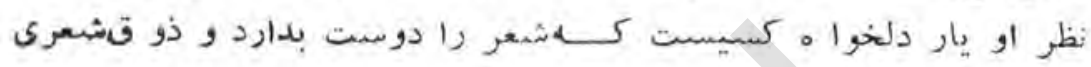

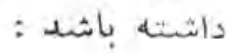

$$
\begin{aligned}
& \text { يأر اول دور كيم شعر غله ميلـى بولسه } \\
& \text { نيشكاى كيشىشعر غير خيلى بولسه }
\end{aligned}
$$

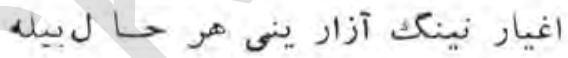

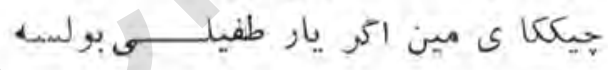

$$
\begin{aligned}
& \text { ترجها : }
\end{aligned}
$$

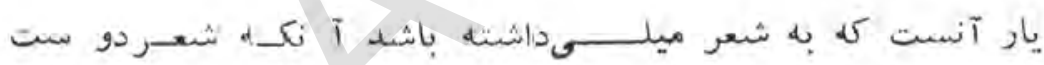

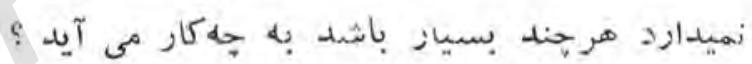

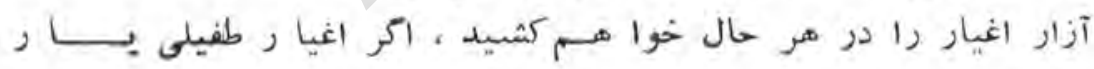
. $\sin$

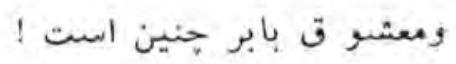

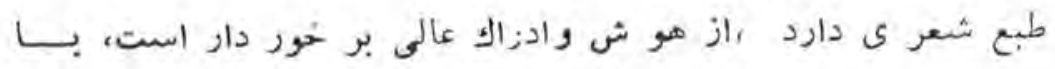

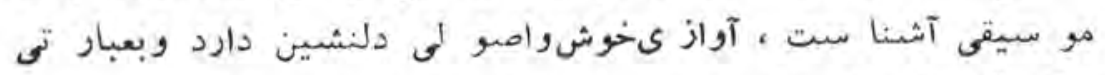

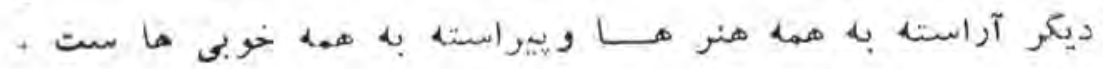
بابر جنين نصوير ى از اوبد بستهيدهد :

$$
\begin{aligned}
& \text { ادراكينكك و طبع و, هوشو نكسابنده بولاي } \\
& \text { آواز و امو ل و جو ثيو نكابندهبولاي }
\end{aligned}
$$




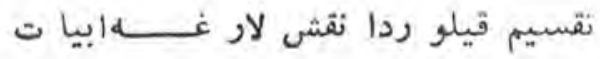

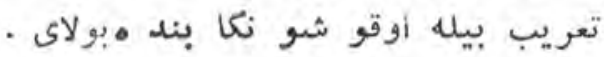

$$
\begin{aligned}
& \text { : }
\end{aligned}
$$

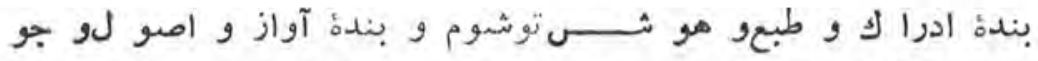

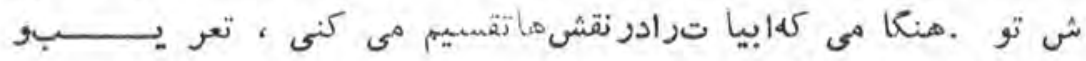

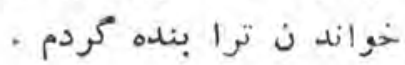

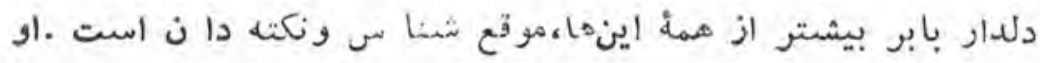

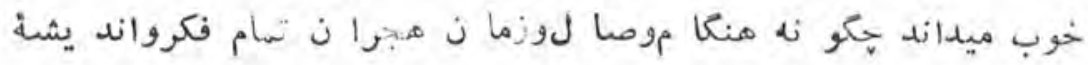

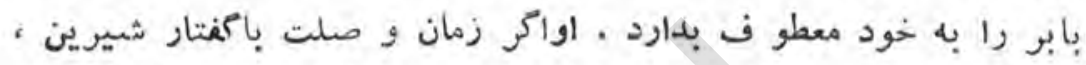

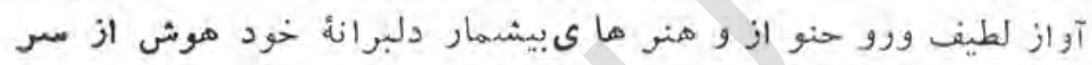

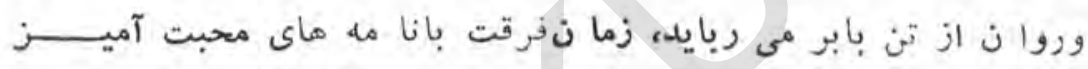

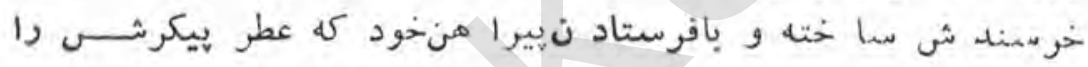

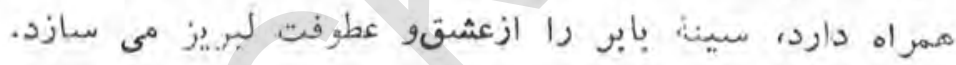

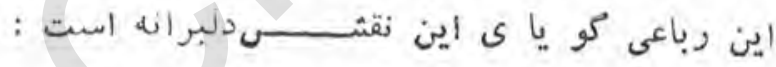
خطينك بيله كو نكلا كينك كهارسا ل التيتينك

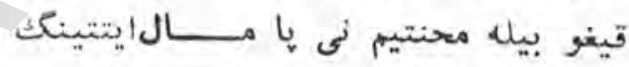

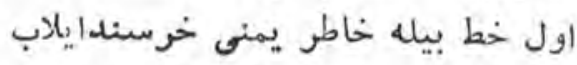

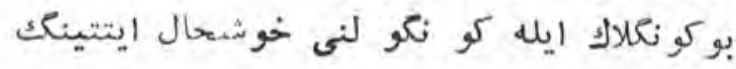
ترجمه :

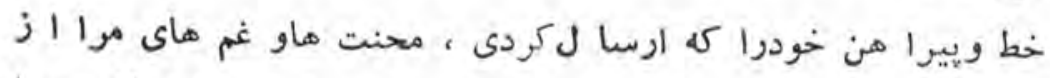

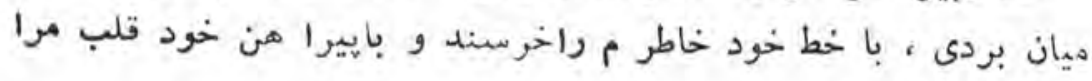

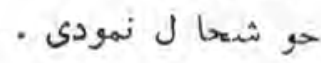

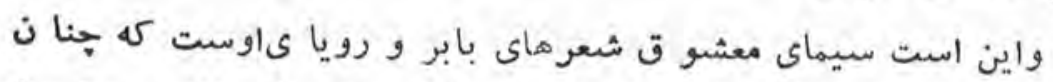

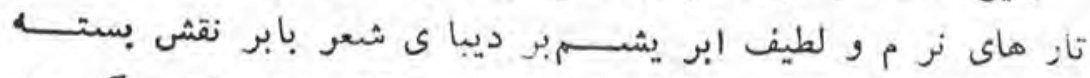

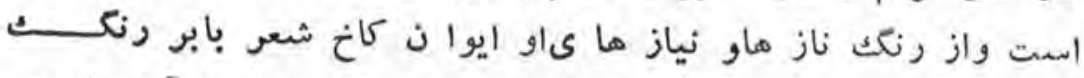

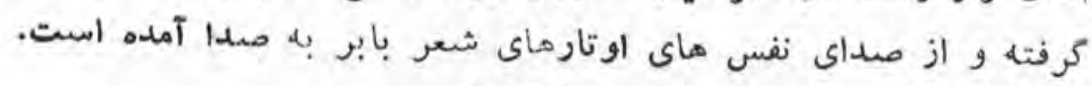
-نودوحار- 


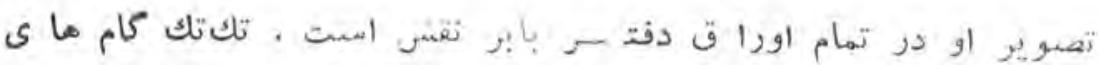

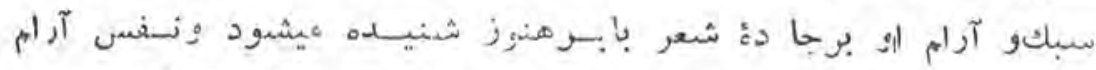

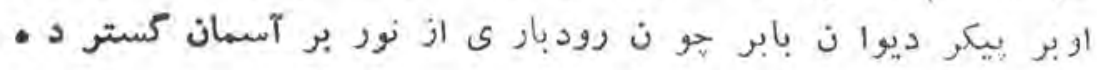

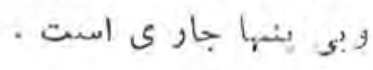

\section{:}

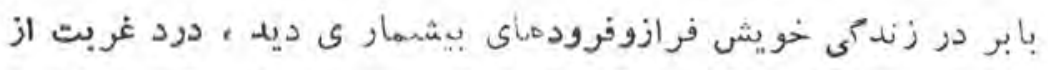

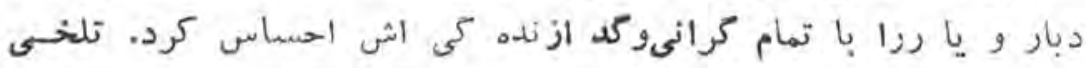

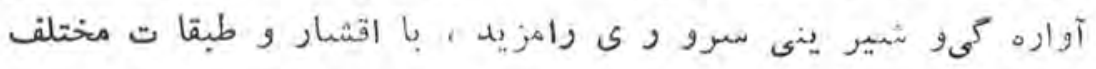

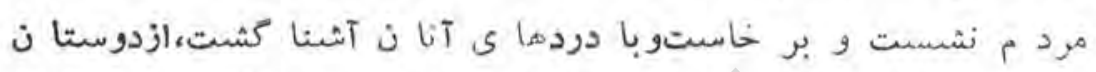

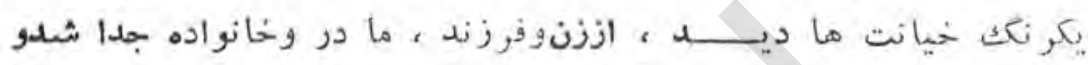

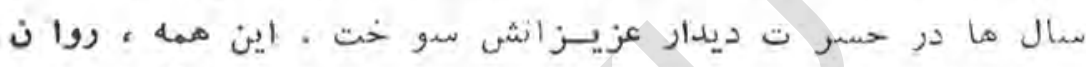

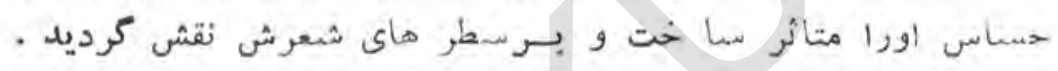

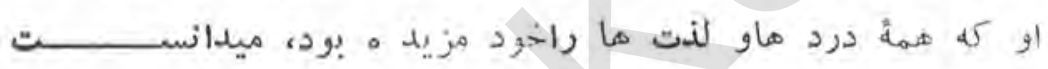

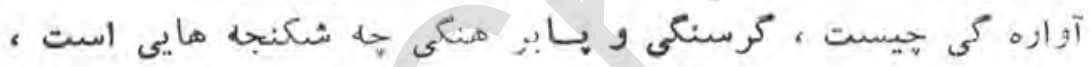

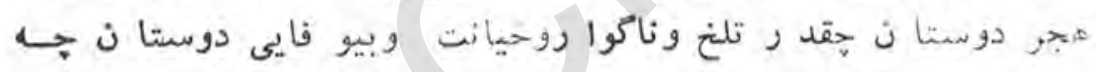

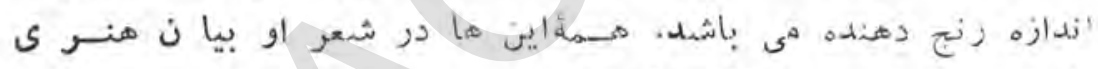

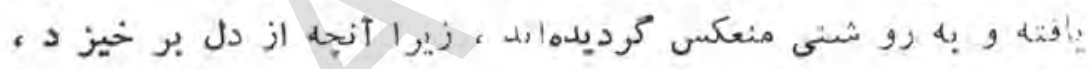

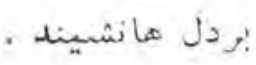

بابر كله عمر ى را در الشكر كشى هاو مسافر تها سير ى كرده واز دوستا ن خود جدا ماند ه است ،صحبت هو ستان و جهع آمدنآنانرا

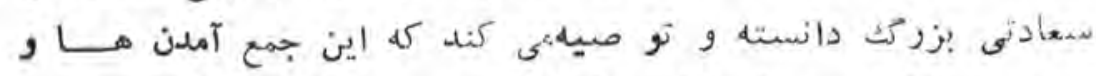

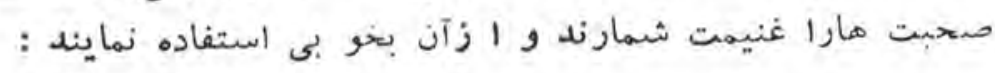

$$
\begin{aligned}
& \text { احبا ب ييغيلما ق نى فرا غستست توتو نكيز }
\end{aligned}
$$

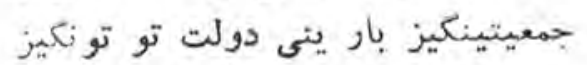

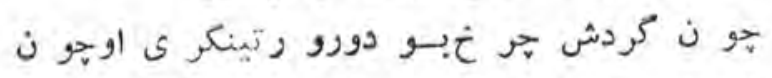
بير بير نى نيجه كو نى غنيهت تونو نورونيز 
يارا ن ، جمع خويش رافرا غتدانيد جمعيت خو يش وا سماجتهانيد

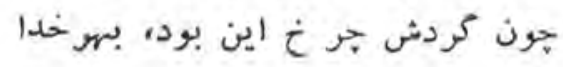
يكديكر خويش را غنيست دانيد

واين دبا عى ديكر مكمل ربا عى بالا است . او از دوستا ن يكر نكك

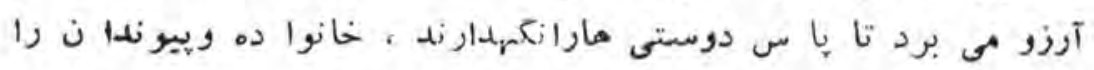

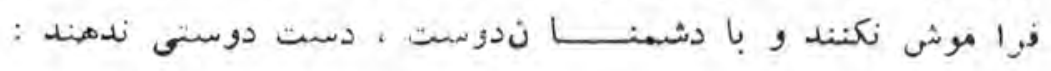

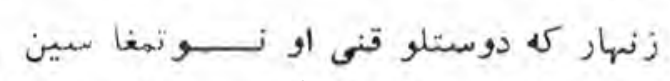

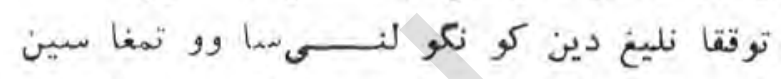

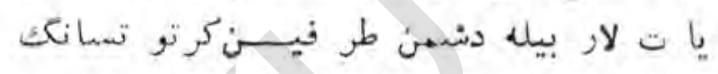

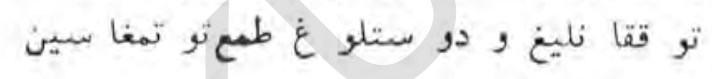

:

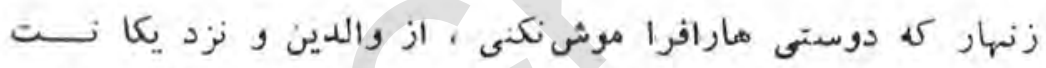

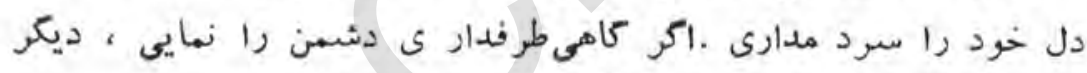

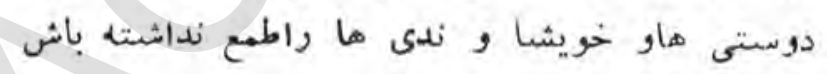

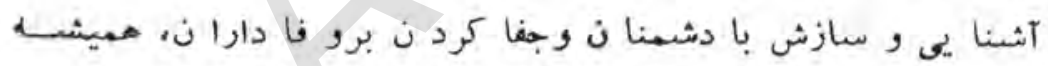

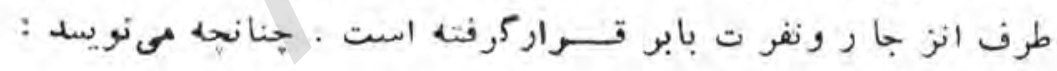

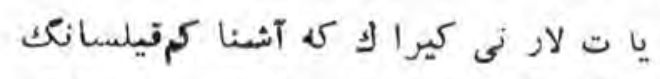

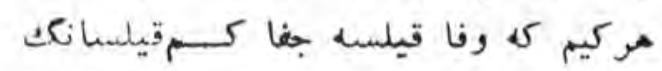

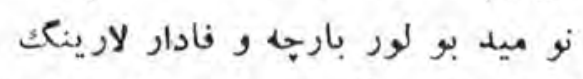

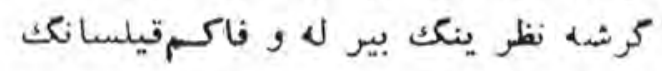

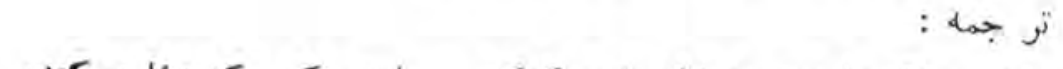

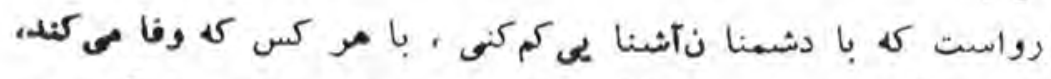

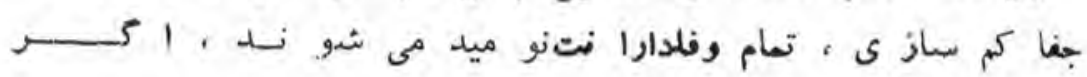
بانظر شا هانهات،وفاكم كنى. 


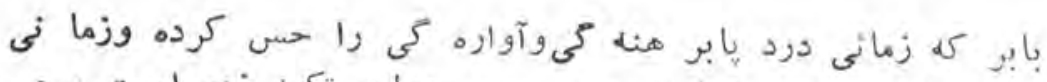

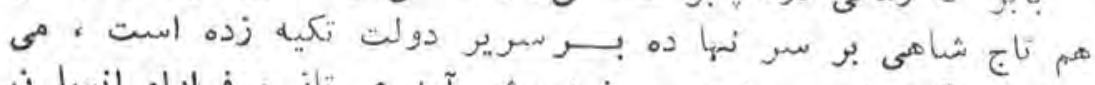

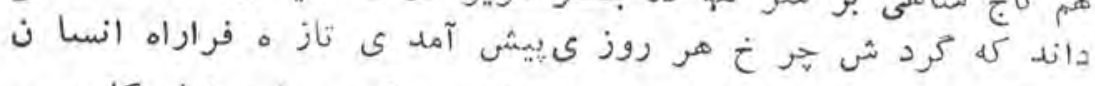

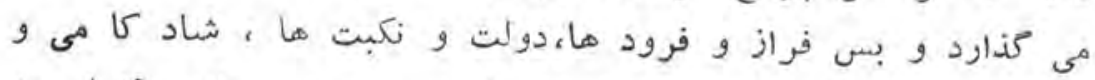

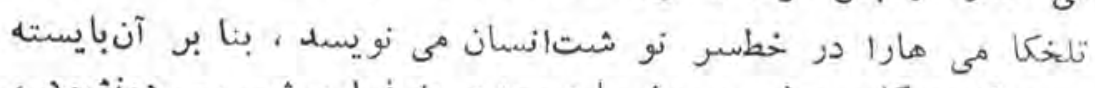

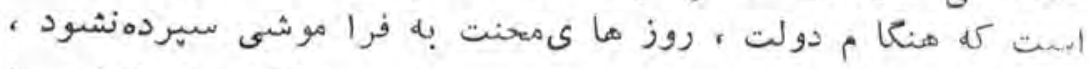

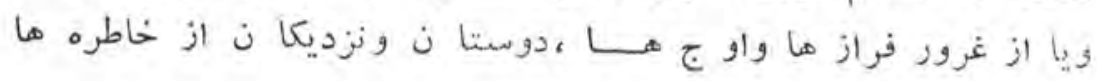
:5ز نكردد :

$$
\begin{aligned}
& \text { دولت قه ييتيب محنت ايليـــــن اونو تهل }
\end{aligned}
$$

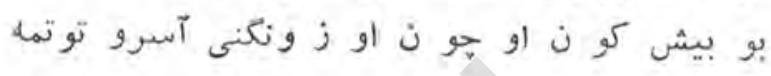

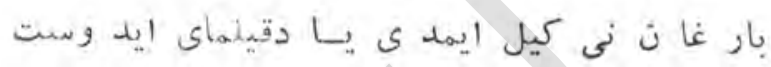

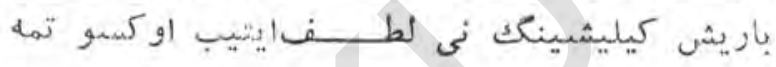

$$
\begin{aligned}
& \text { ترجمه : - 20 }
\end{aligned}
$$

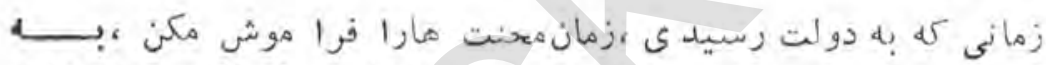

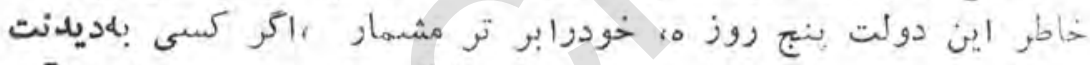

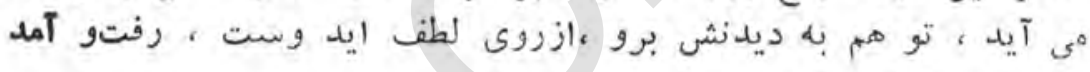

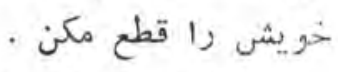

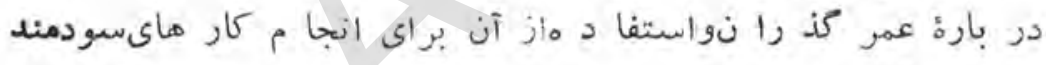
رباعي یند آميزى دارد :

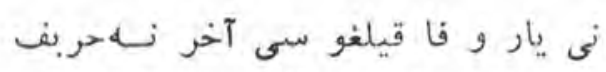

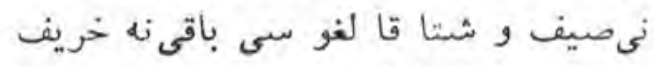

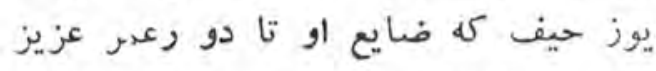

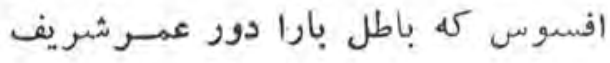
تر جما :

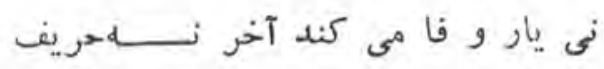
نى صيف و شتا باقى است آخر نهار آنريف نيف 
صد حيف كه ضايع شود اينغمرعزيز

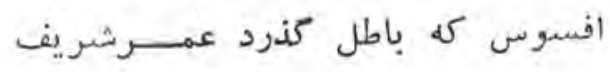

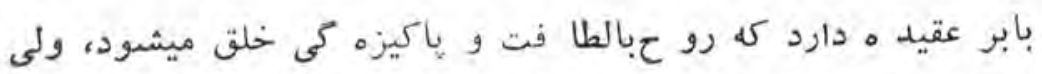

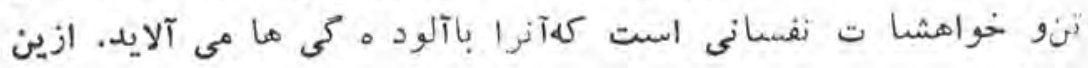

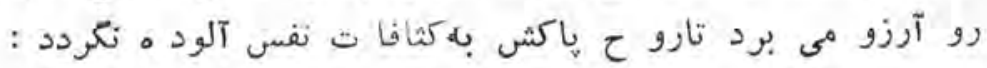

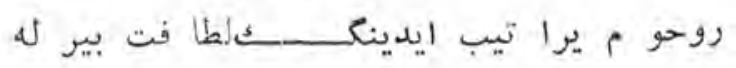

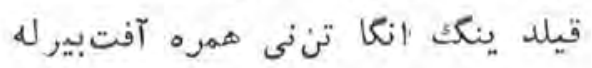

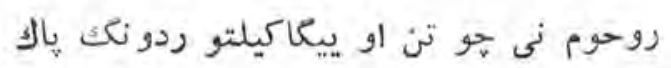

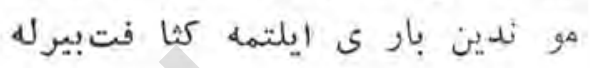

$$
\text { : }
$$

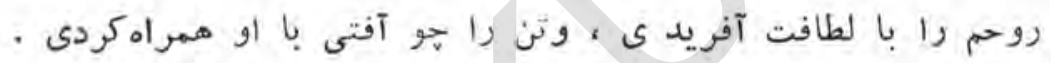

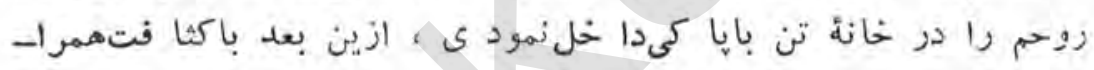

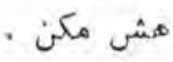

راضى نكهدا شتن و خو شنو دسا ختن مردم وداشتن حسن سلوك نداك

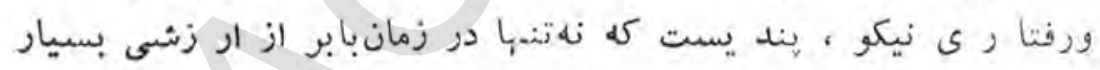

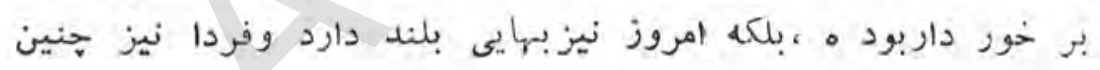

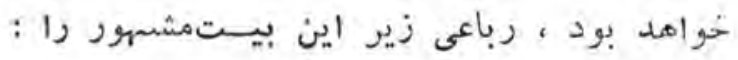

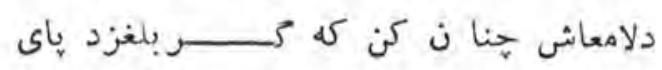

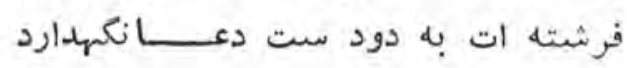
صراحت بيشتر داد ه است :

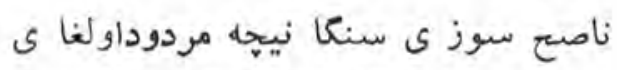

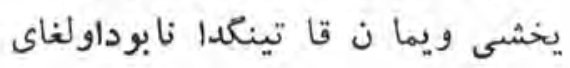

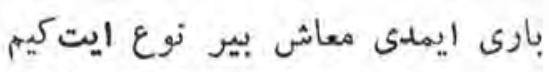

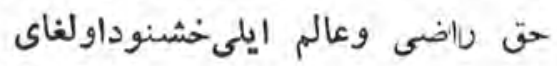




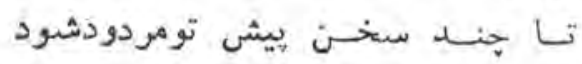
فيكى وبد ىنزد تو نابود شود

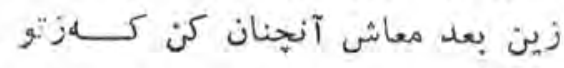

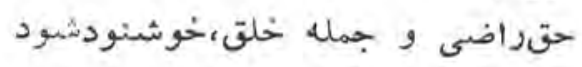

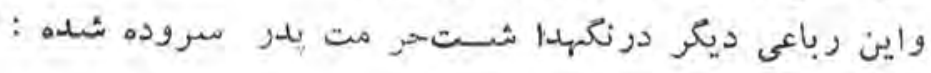

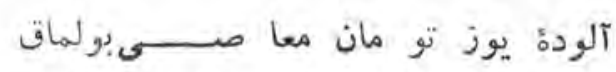
يوز رنجو توما ن عذا ب خأ صى بوز لماق

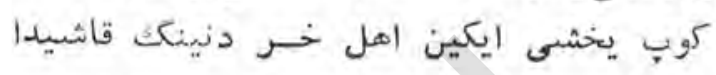

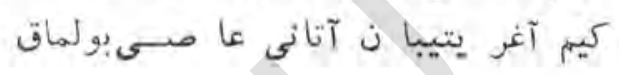
:

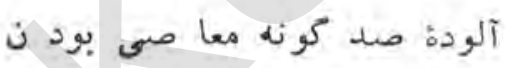

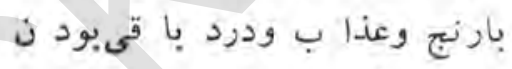

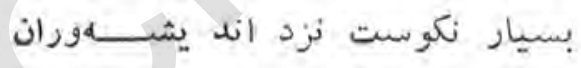
زآزار بدر كمتن و عا صبى بودن

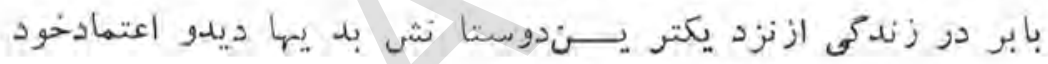

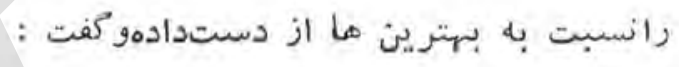
كيم كورو بتور اي كو نكو لأهل جهاندين يخشيليغ كيم كع آندين يخشى يو ق كو زتو تمه آندين يخشيلين :ترجهـ :

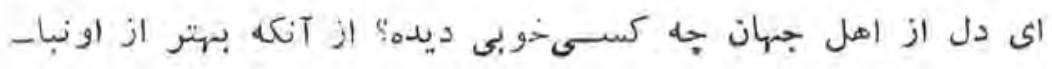

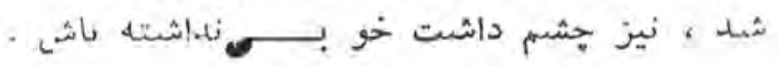

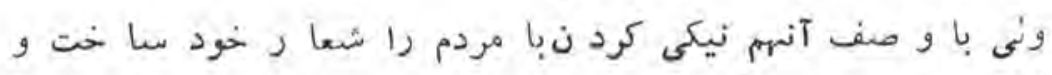

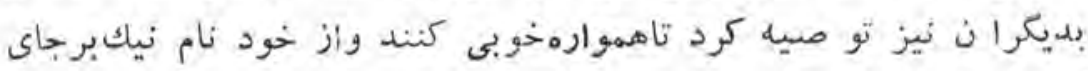
: ندارند 


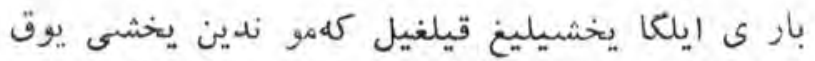

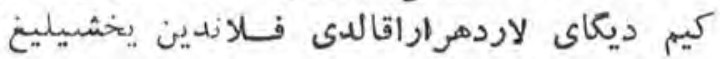

ترجمه :

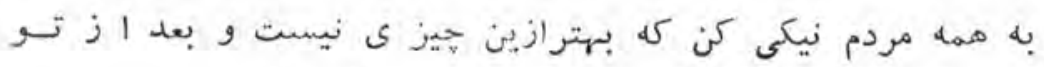

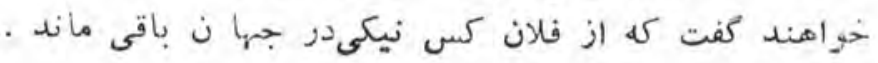

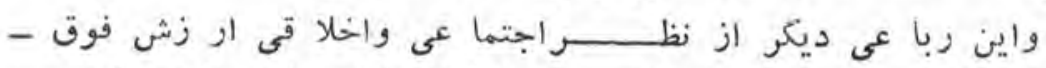

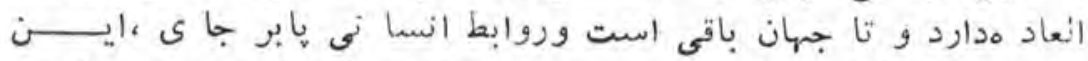

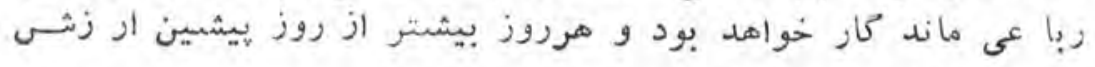

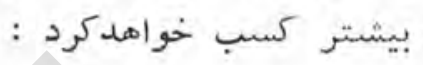

هر كيم كه و فا قيلسه وفاتابقوسيدور

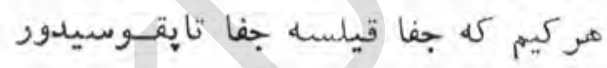
يخشى كيشى كور ماكاى يمانليقهر كز

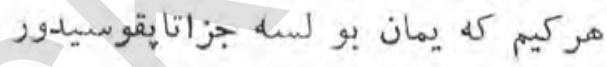
ترجمه :

هر كس كه وفا كند ، وفا مس كسى بيند

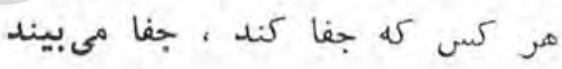

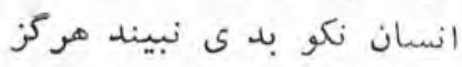

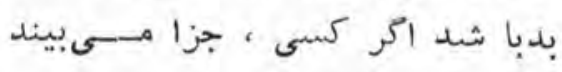

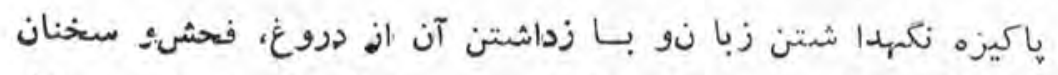

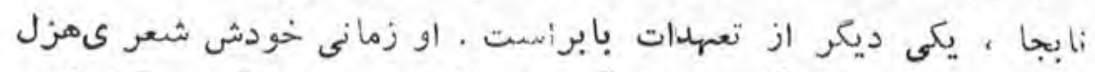

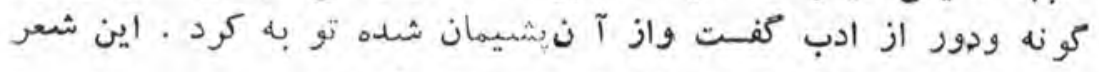

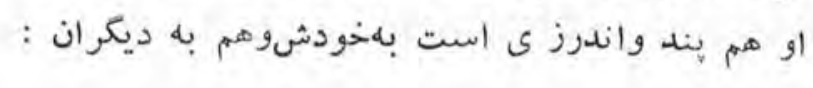

نى قيلا يين سينينك بيله إىتيل

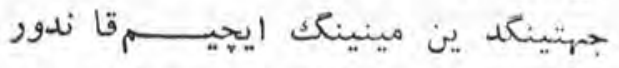

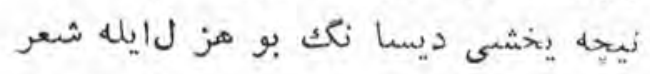

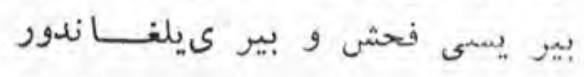


كرد يسا نكف قو يمايين بو جرمبيله

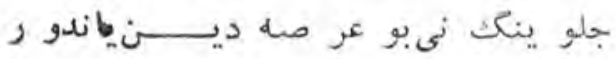

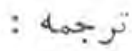

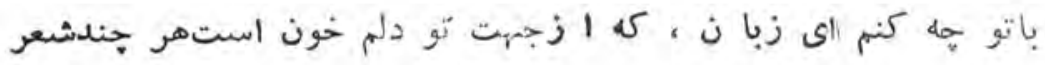

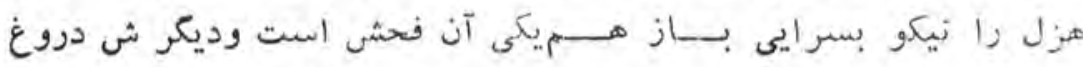

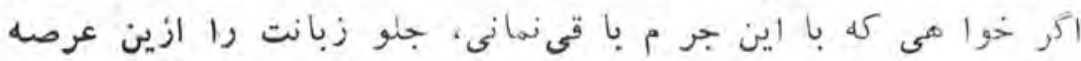

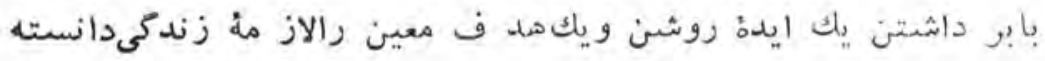

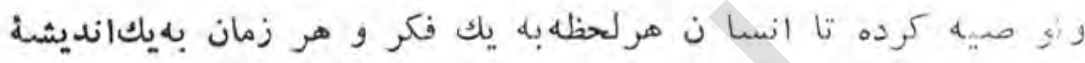

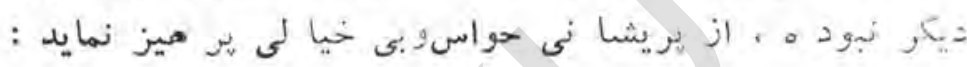
اعضا و جوار حينك نى حا ضرقيلغيل

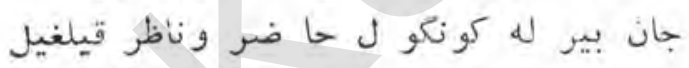

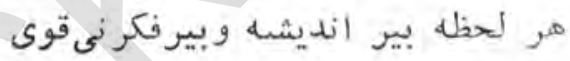

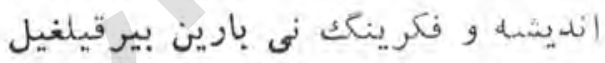

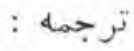

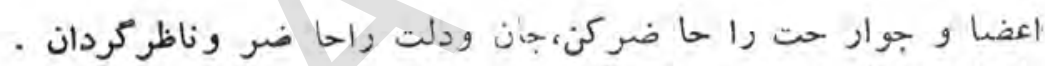

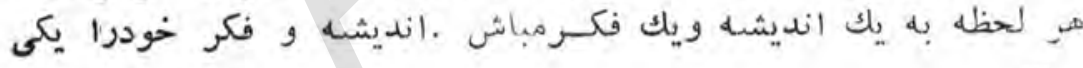
ساز .

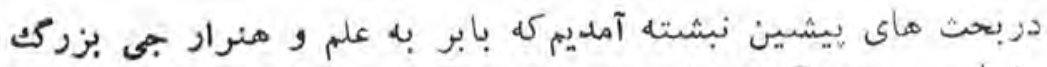

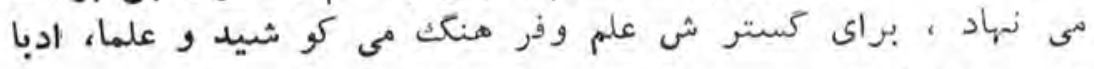

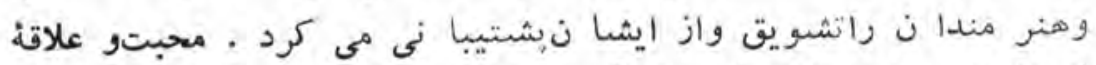

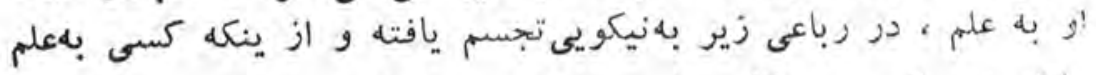

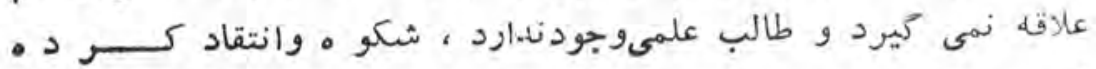
استت :

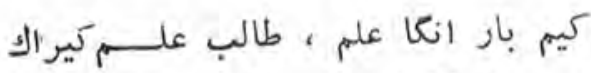

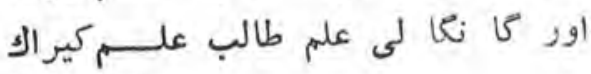




\section{مين طالب علم و, طالب علمـــــــيوق

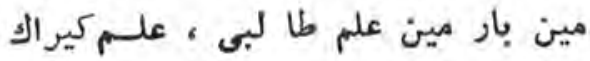

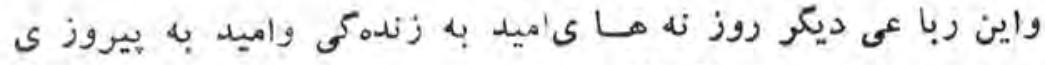

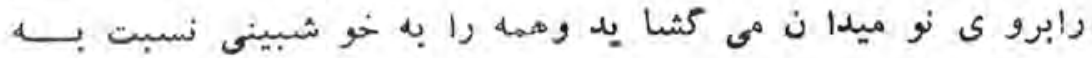

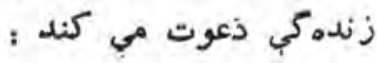

دشمن نى كه بو دهر زبر دستـقيلو رئر

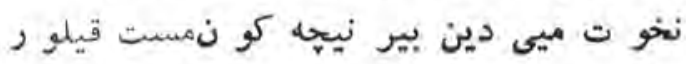

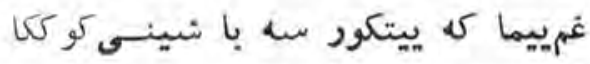

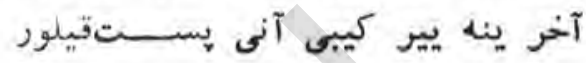

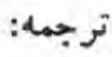

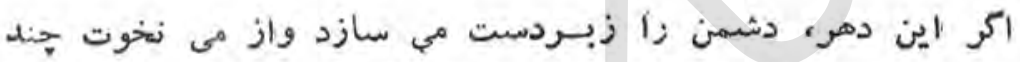

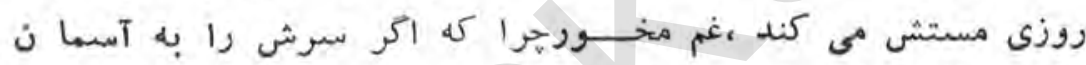

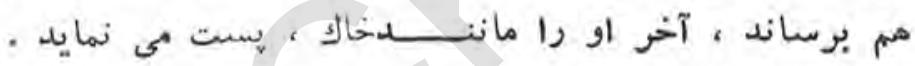

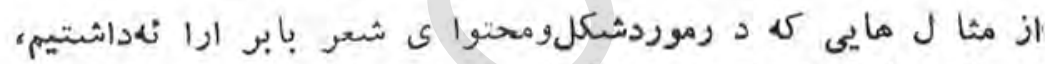

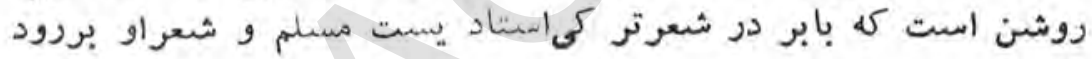

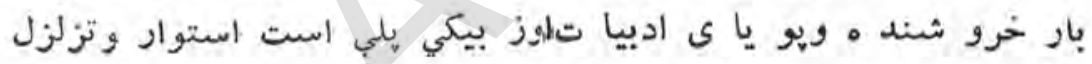

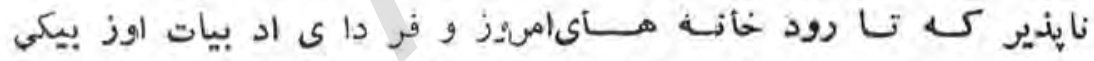

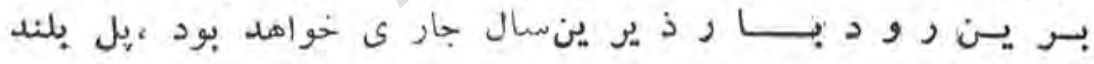

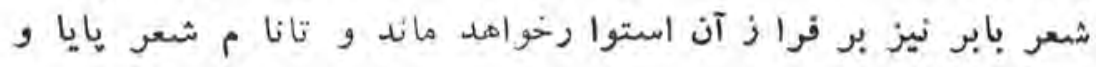

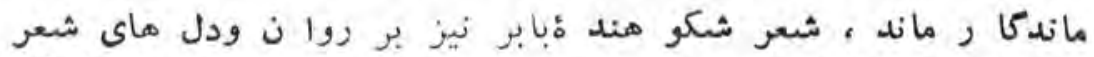

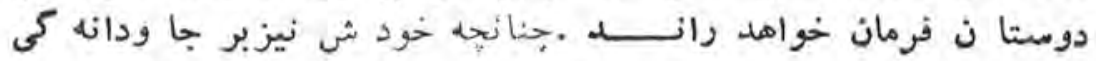

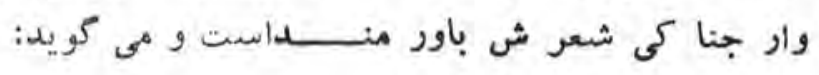

الشعار ينكث كيم شعر آ تىتابولغاى

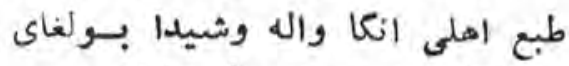
هر لفظى در وبحر معانى اندا

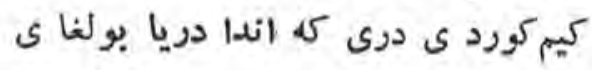




\section{اشعا ر توتا كه شعر هايا باشثد}

هر اهمل دلي واله اوشيدا باشد

هو لفظ درو بحهـ معـ نسى مر اوست

$$
\text { كة ديده درى كه بحر و دريــاباشد؟ }
$$

ويا دراين بيت كه به بيرو ى1 زشسر حافظ :

"عر اقو فارس كر فتى به شعرخوش حافظ

$$
\text { بياكه نوبت تبريز وو قت بغدا داست " }
$$

بر محبو بيت اشعار خوداشار هكرده مى نويسد :

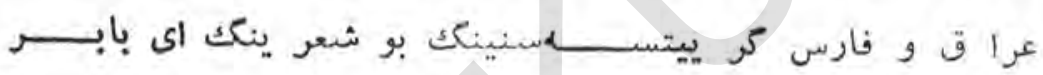

آنى حفظ ايتكو سى حا فظ ،مسلم ورتقو سى سلما ن

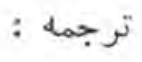

رسد سو ى عرا ق و فارس اينشعرت اكر بابر كند حفظش ز دل حافظ ، مسلمداندش سلمان 


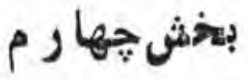

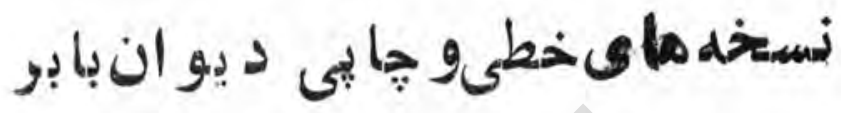

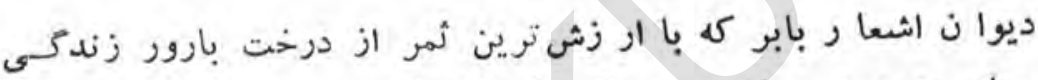

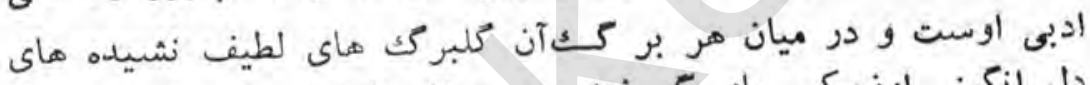

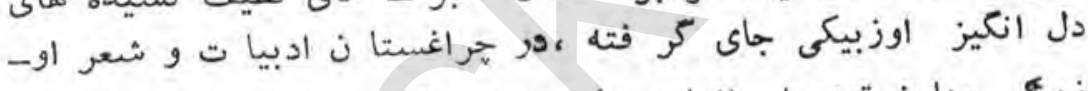

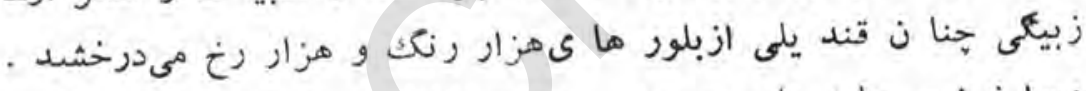

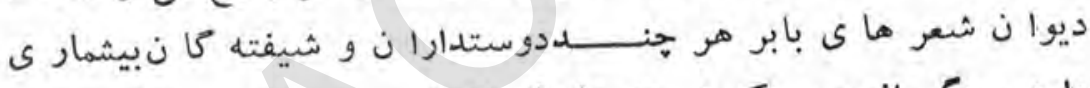

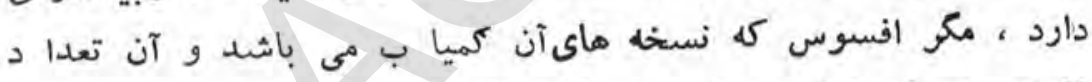

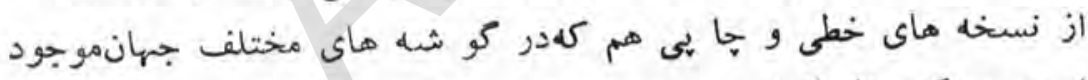

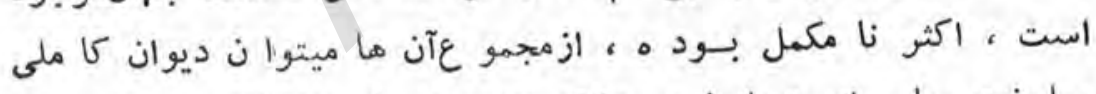

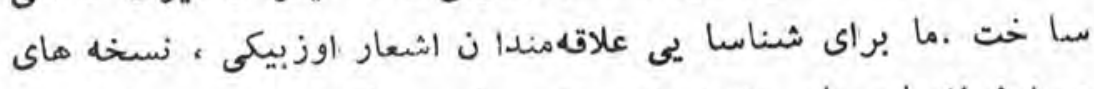

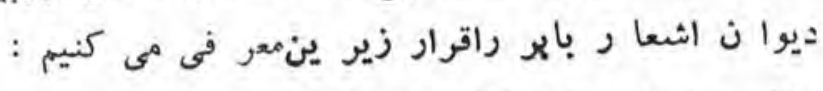

\section{الفـ نسخه هاى خطي ذيوانبابو:}

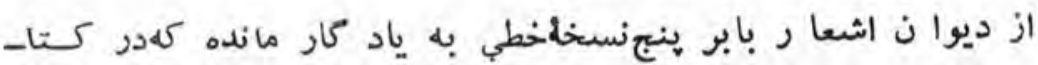

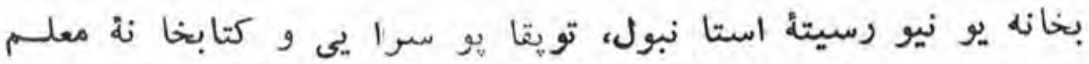

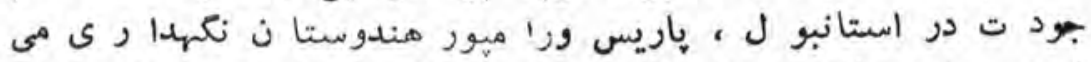

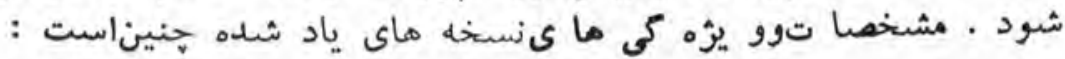
- يكمدو جيهاد ماي 


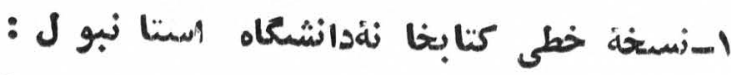

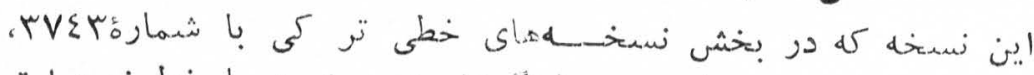

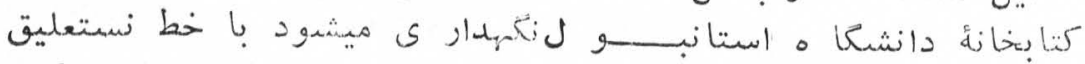

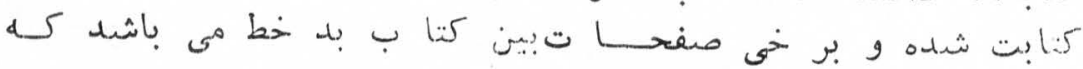

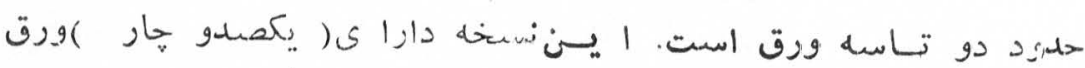

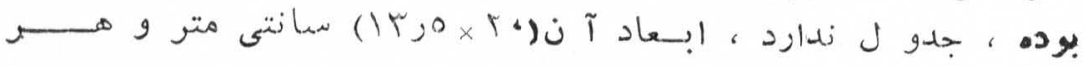

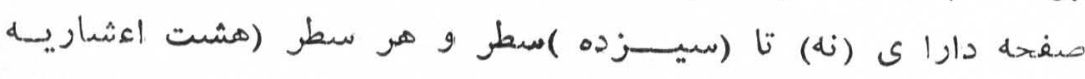

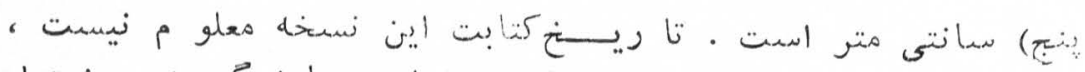

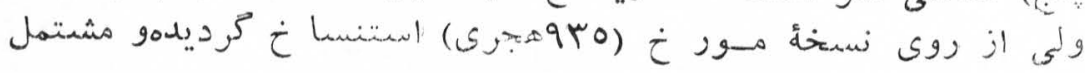

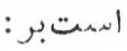

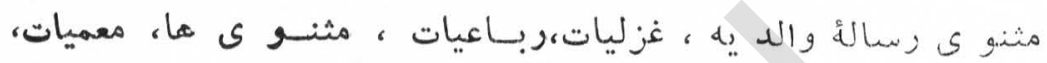

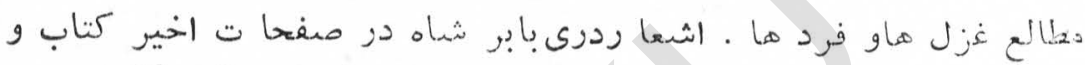

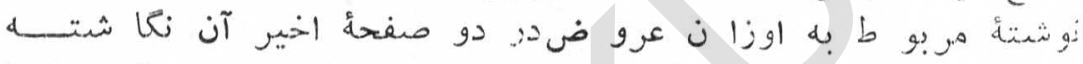

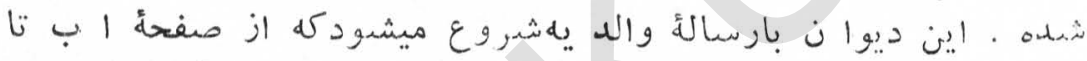
:

$$
\begin{aligned}
& \text { ورق سيزده ب تا هبل هدوبغزئليات }
\end{aligned}
$$

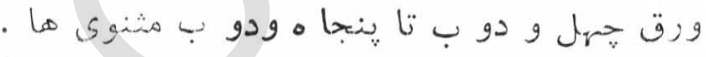

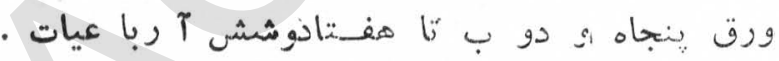

$$
\begin{aligned}
& \text { ورق هفتاده شش آ تا هشتاذب معهميا ت }
\end{aligned}
$$

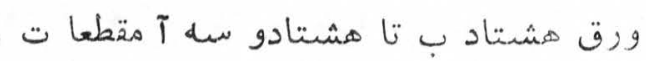

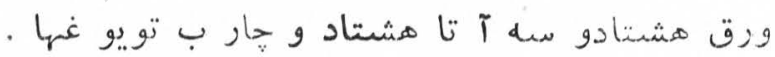

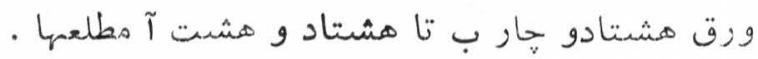

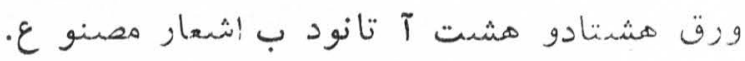

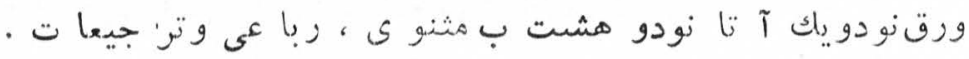

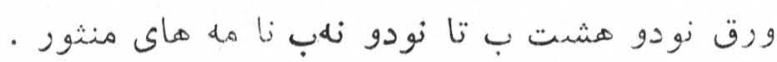

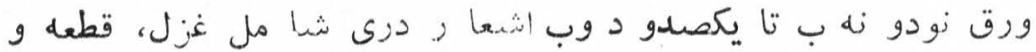




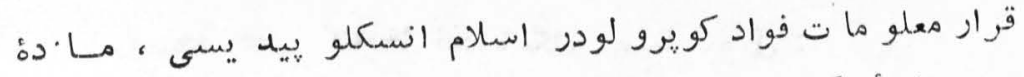

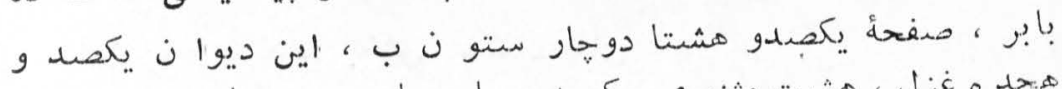

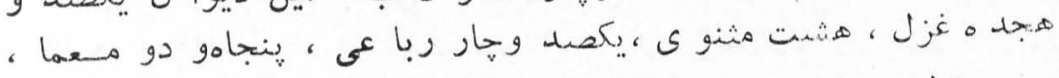

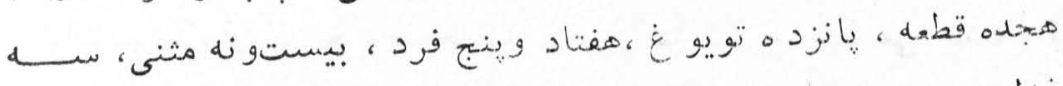

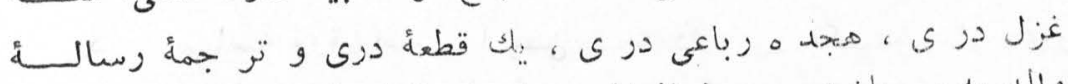

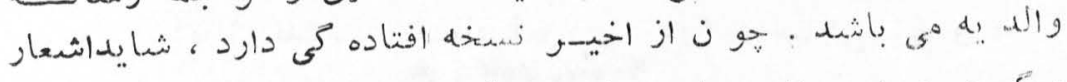

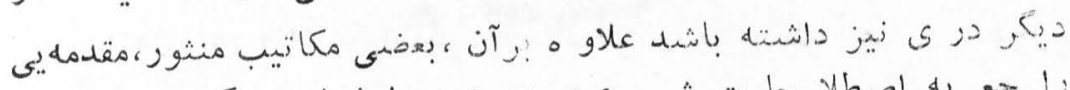

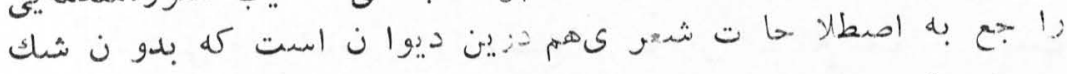

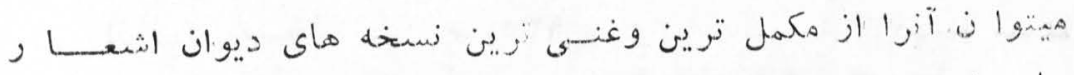

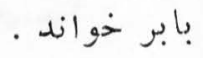

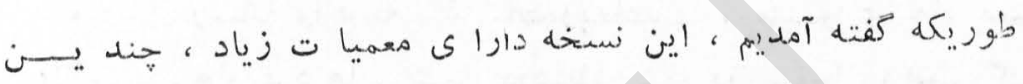

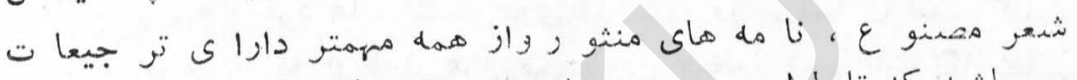

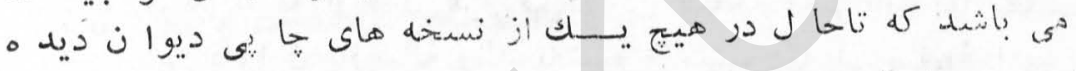

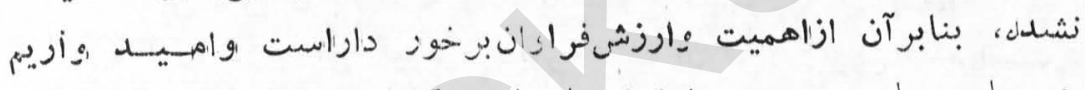

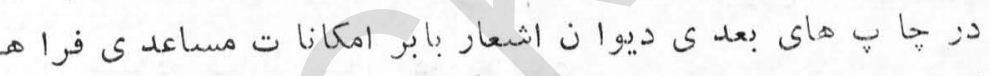

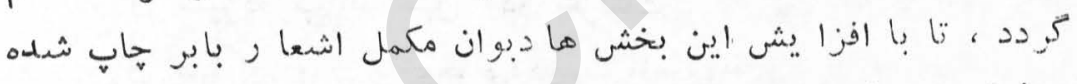

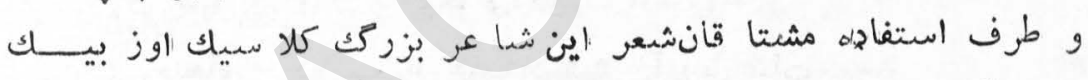

$$
\text { قر ار كيرد }
$$

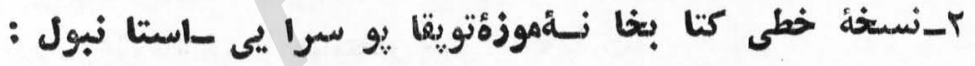

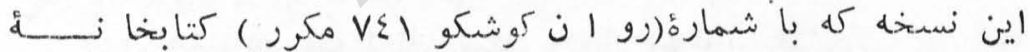

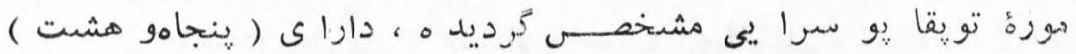

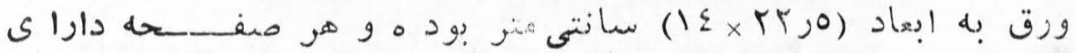

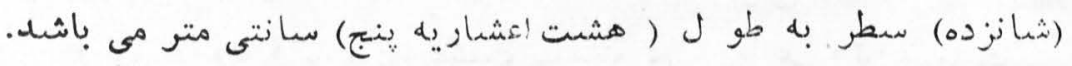

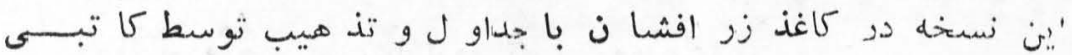

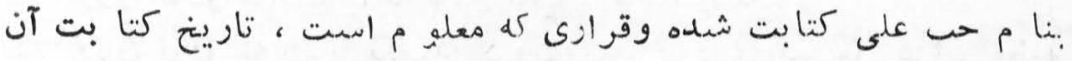

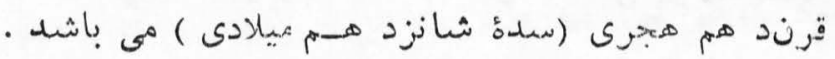
ا.ين ديوا ن مشتمل بر غزليا ت، مشنو يا ت ، رباعيا ت ، مفر دات ،

$$
\text { --.يكمدو شش - }
$$




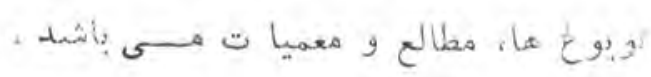

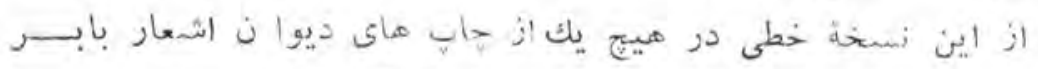

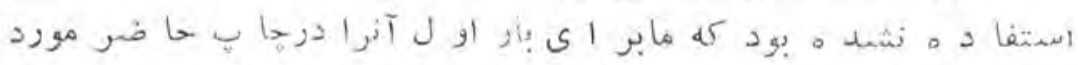

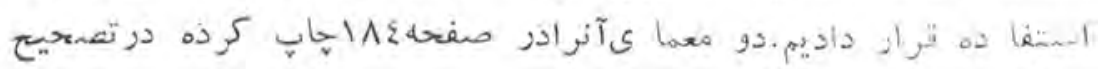

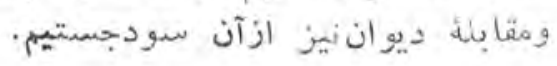

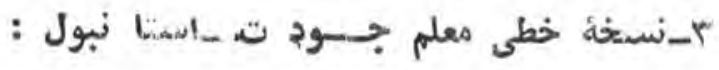

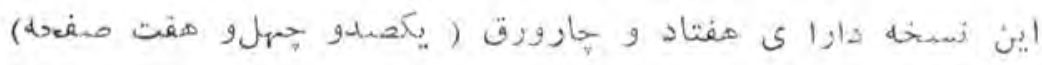

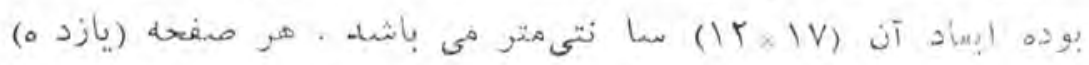

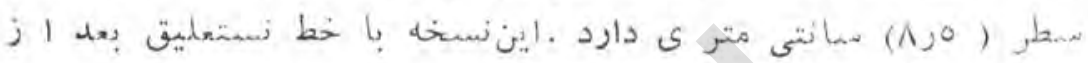

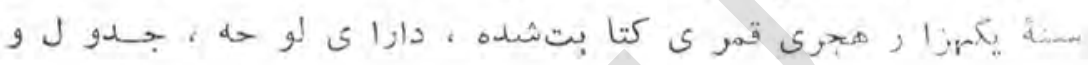

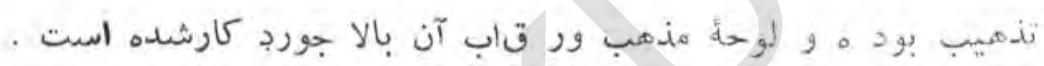

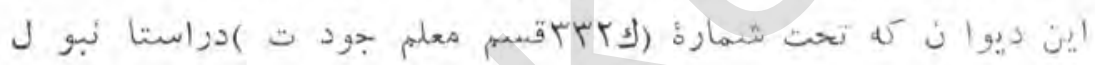

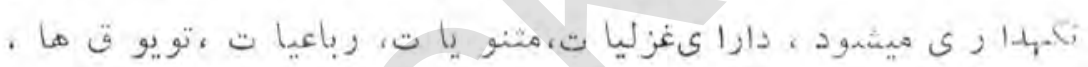

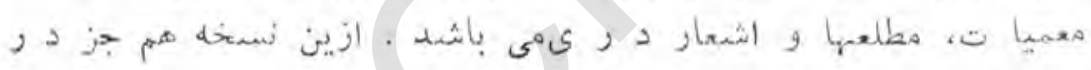

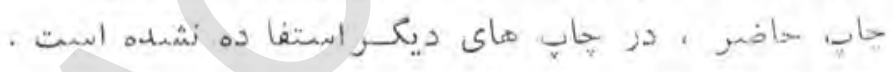

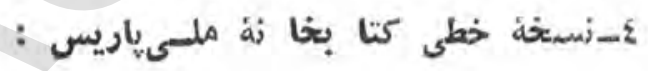

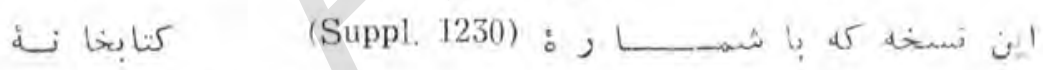

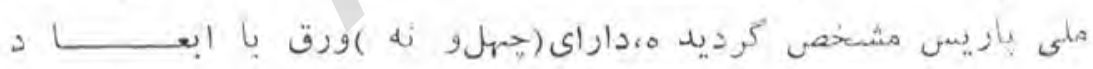
(1) TI)

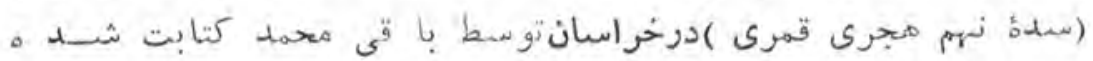

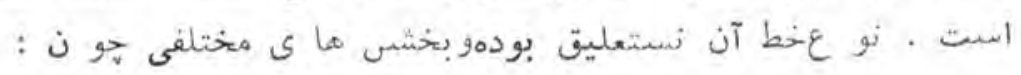

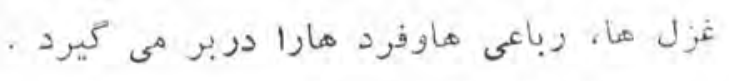

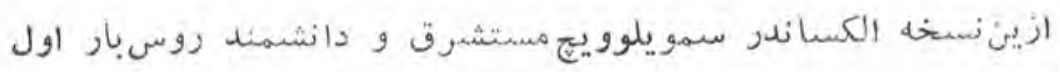

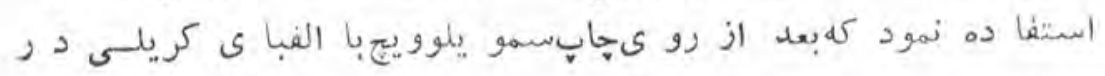

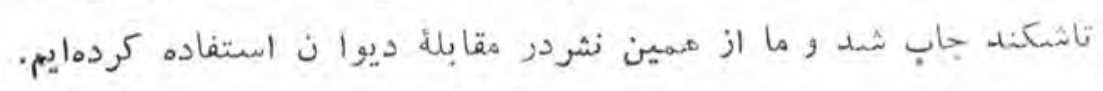




\section{: -}

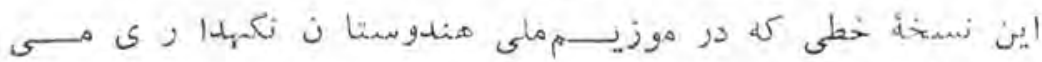
i

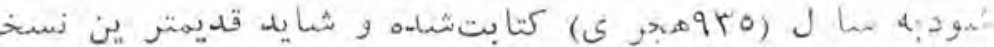

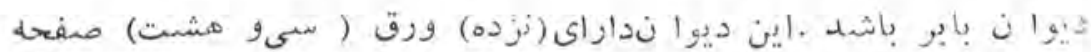

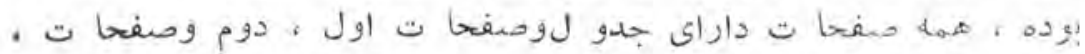

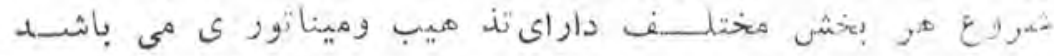

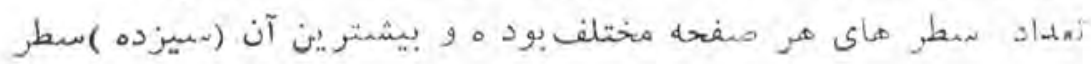

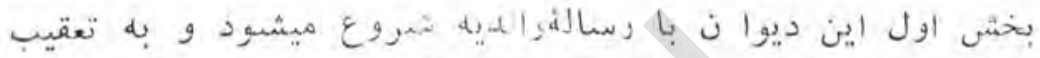

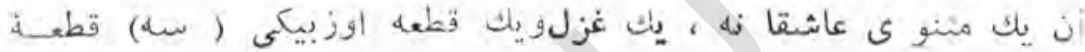

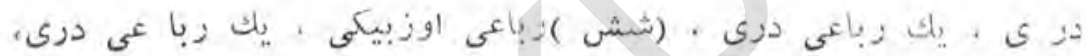

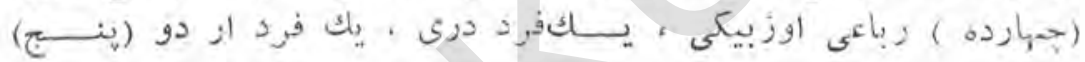

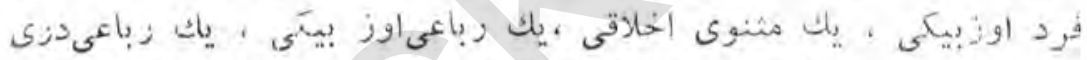

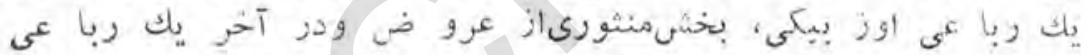

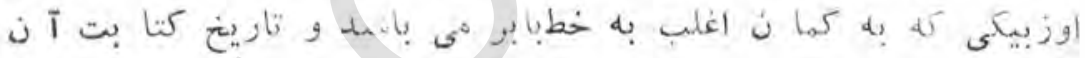

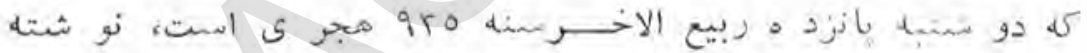

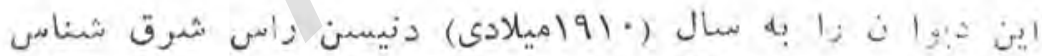

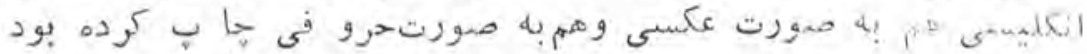

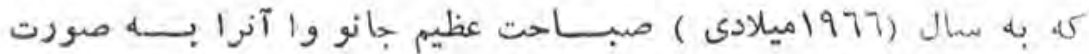

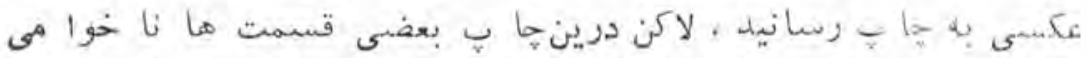

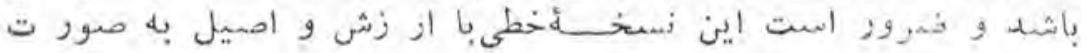

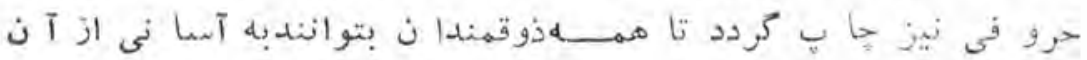

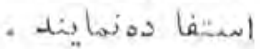

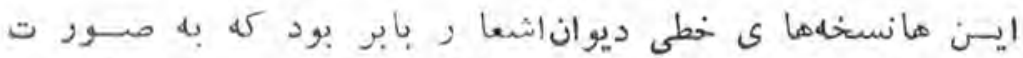

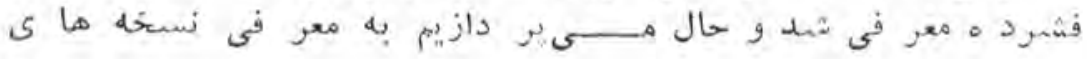

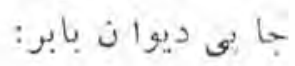




\section{1- مجمو عهُ اشعار بابر، هِابِئكال :}

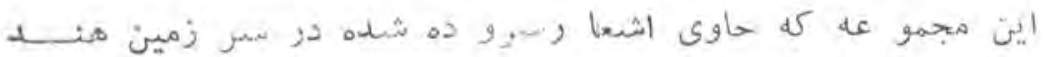

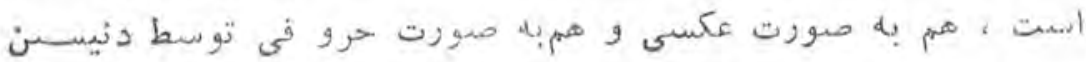

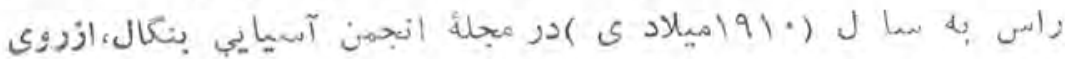

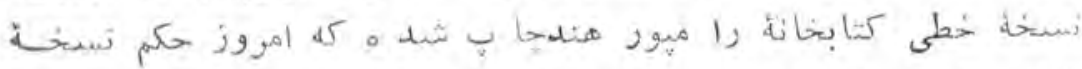

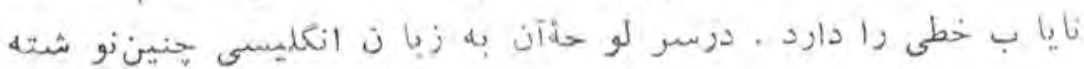
ثده اسمت :

A collection of poems ty the Emperor Babur (Jornal and procee dings of the Asiatic socieiy of Bengal, Vol, VI, Extra Number. Calcutta, 1910), Editedby: Denison Ross.

\section{:}

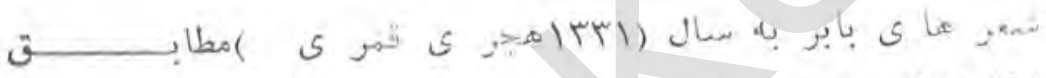

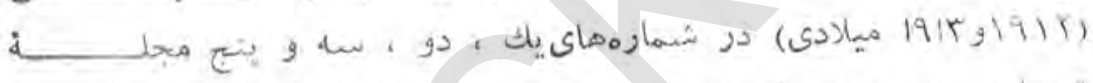

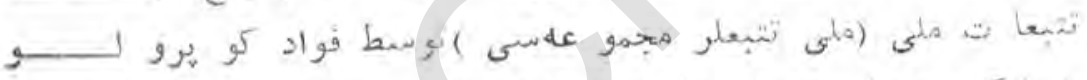

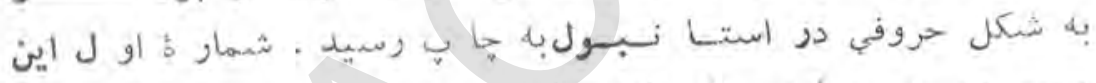

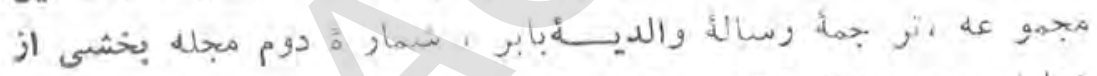

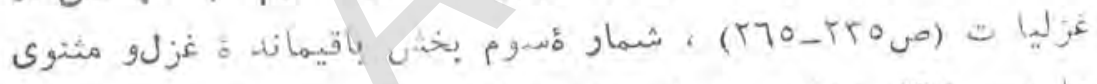

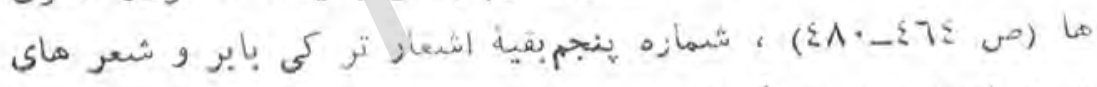
. 20

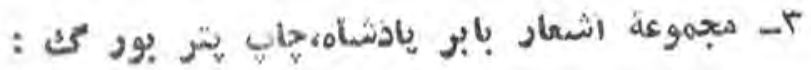

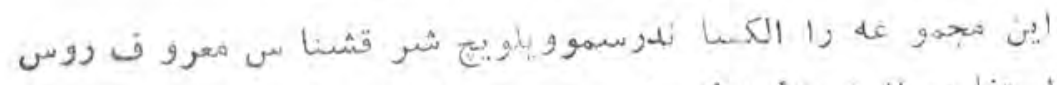

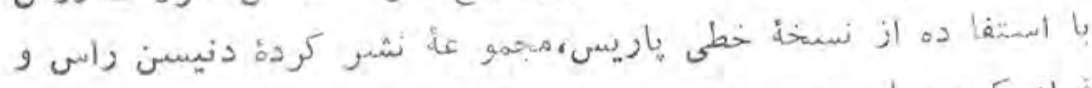

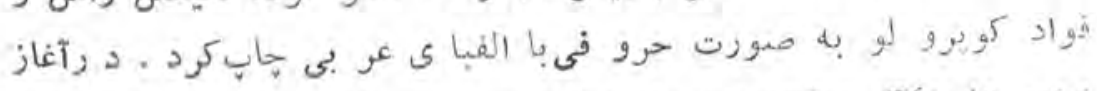

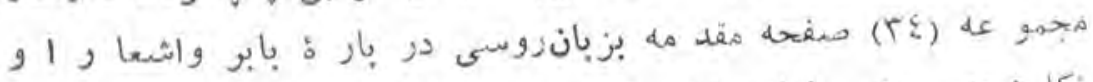

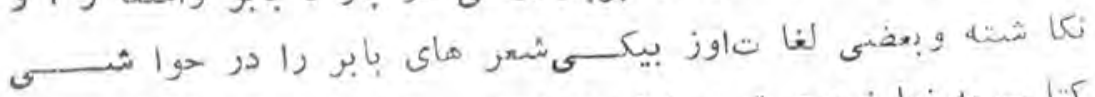

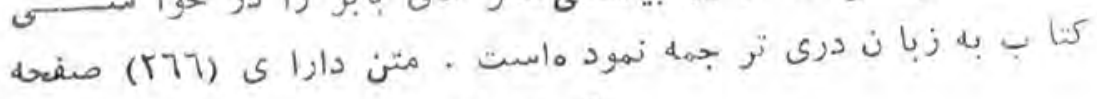




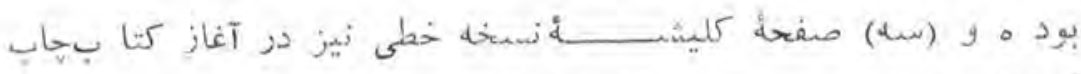

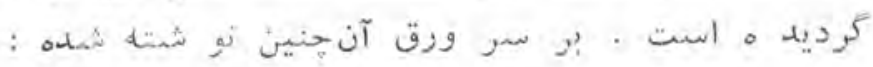

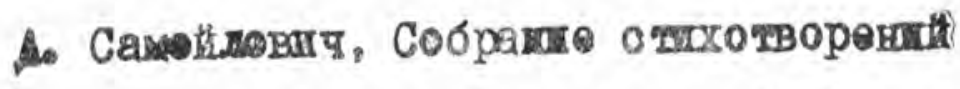 ватарагора Бабуре, II атрбург, I9I7.}

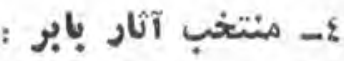

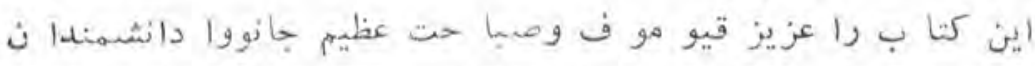

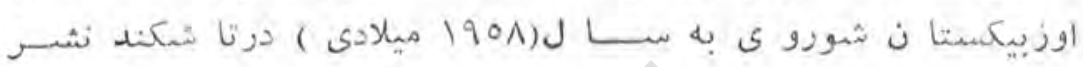

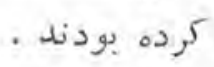

:

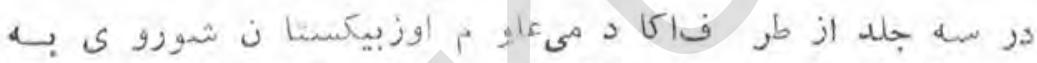

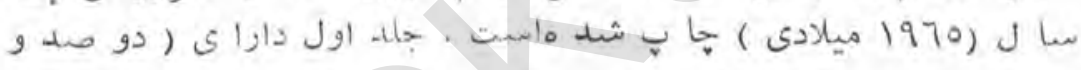

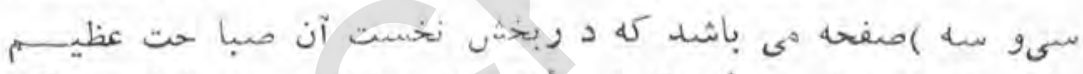

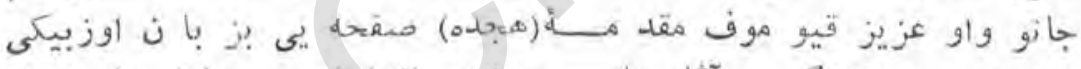

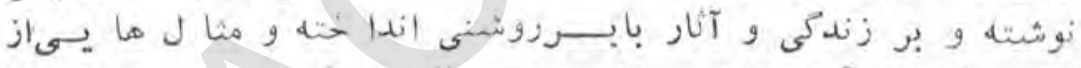

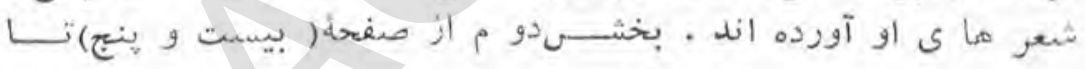

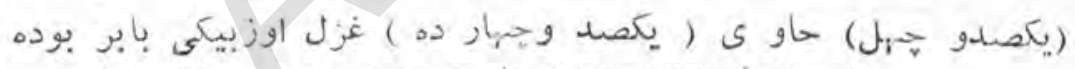

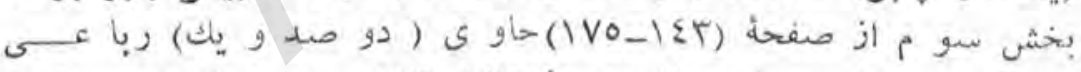

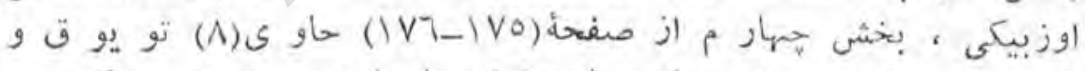

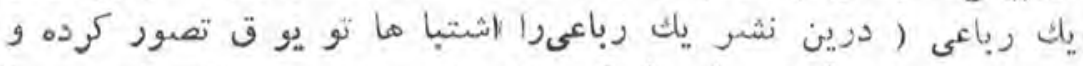

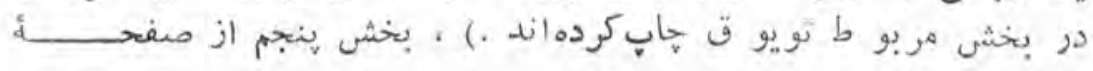
حاوى(يازده ) (IAT_ IV9)

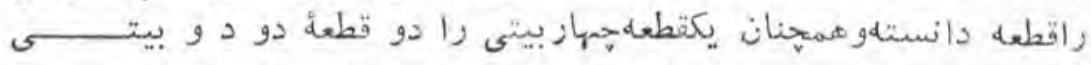

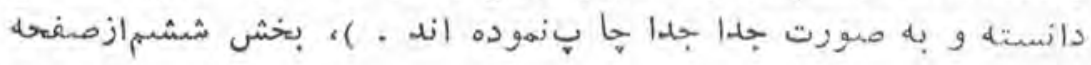

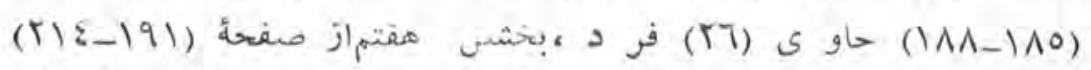

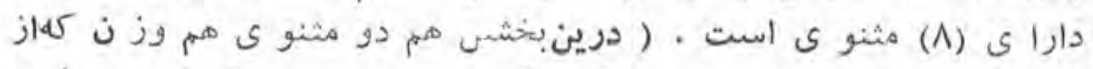

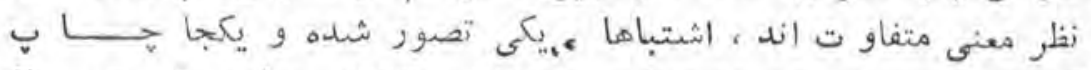

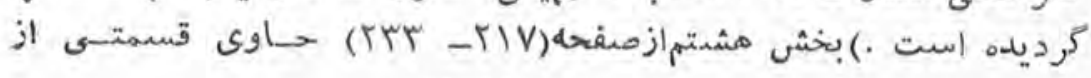




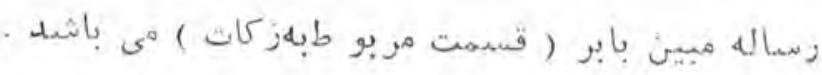

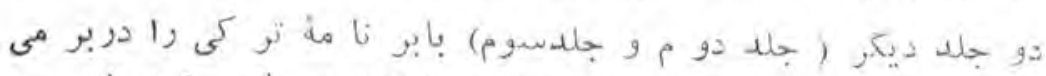

.

هن خان

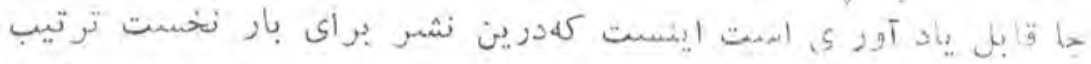

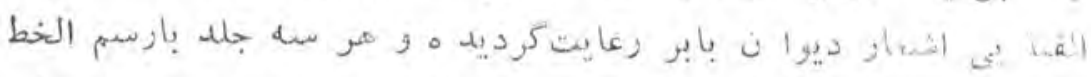

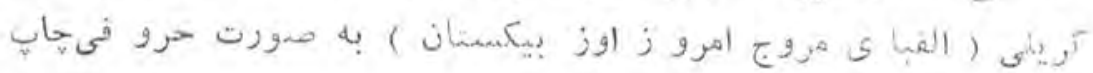

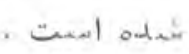

\section{ج- ديوان هند بانبر}

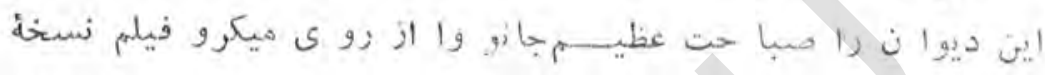

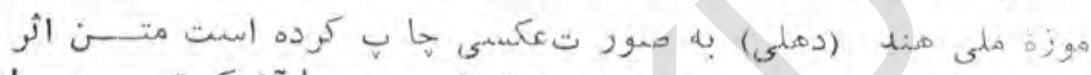

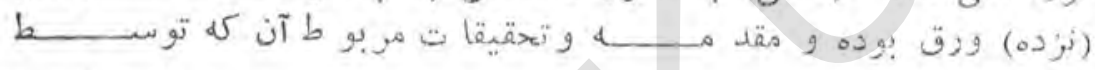

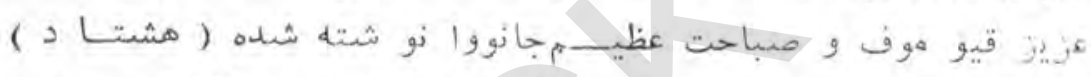

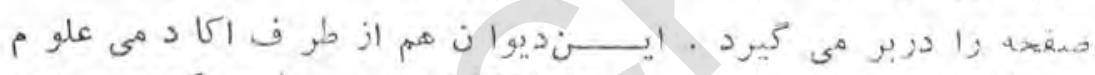

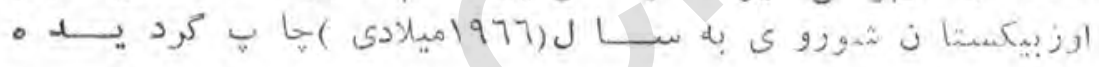

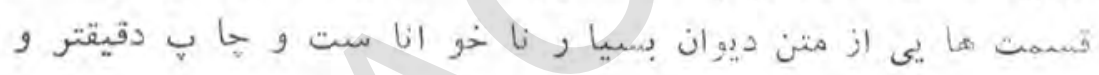

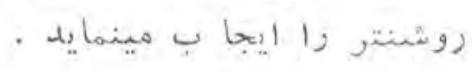

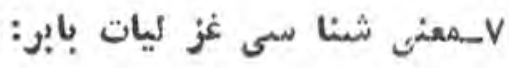

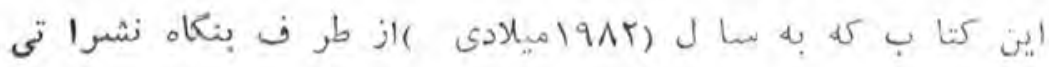

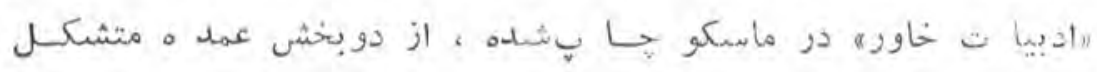
: اسmت

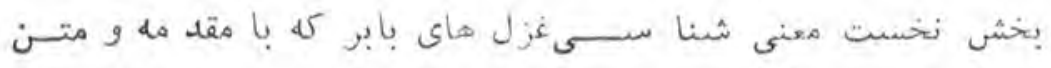

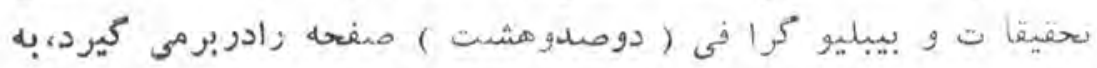

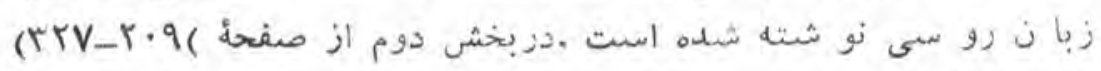

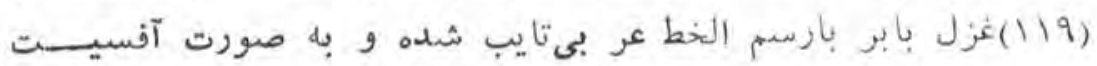

\section{- يكمسرو يازدمه}




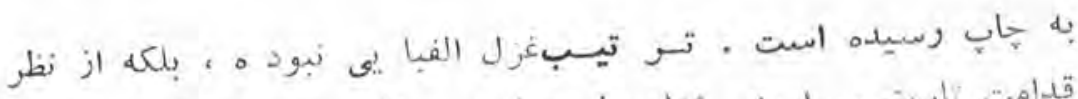

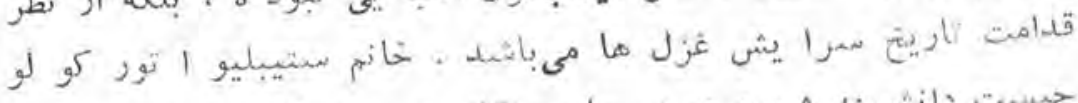

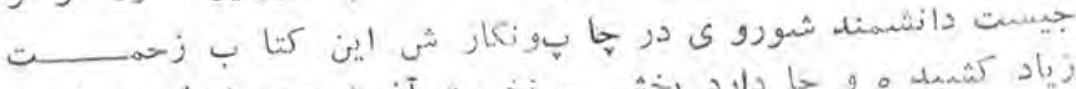

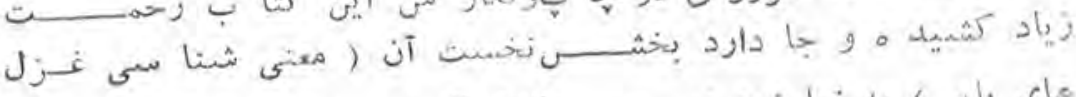

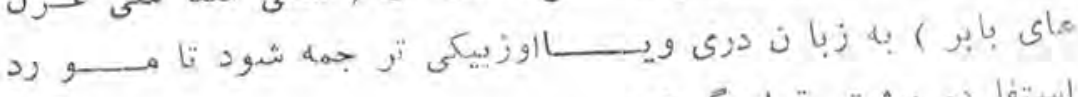

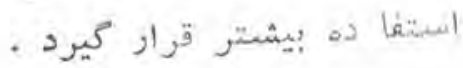

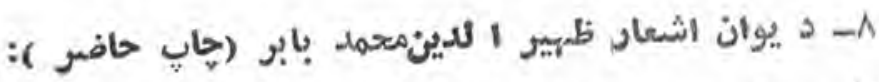

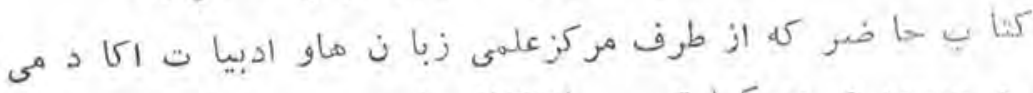

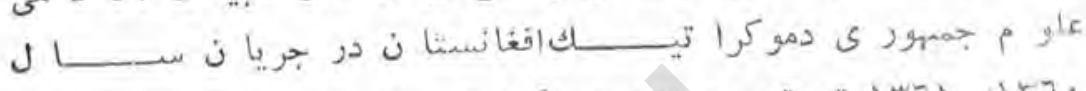
.

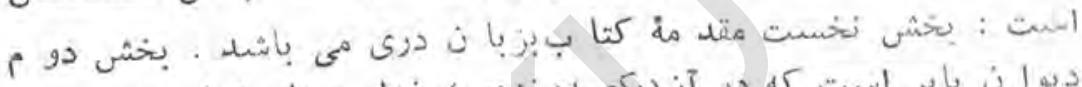

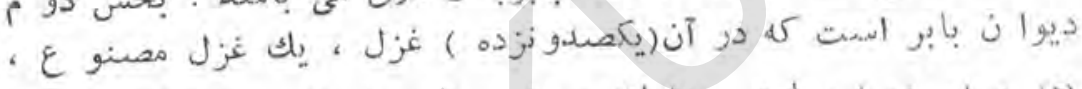

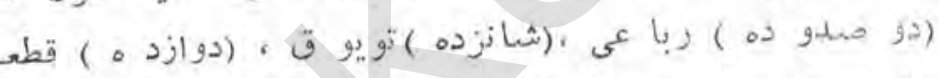

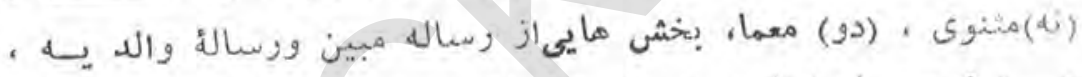

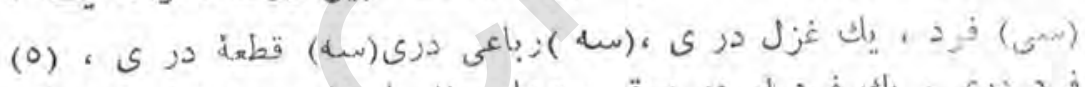

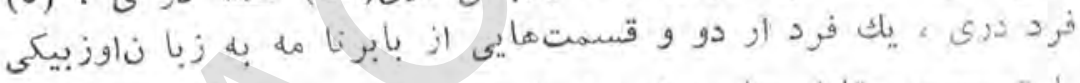

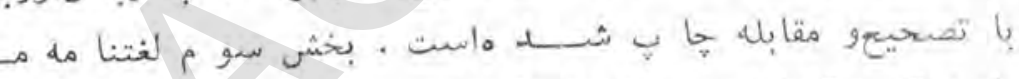

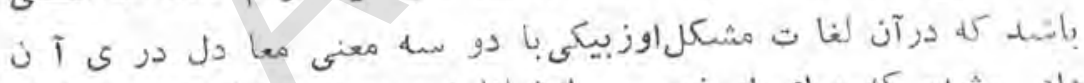

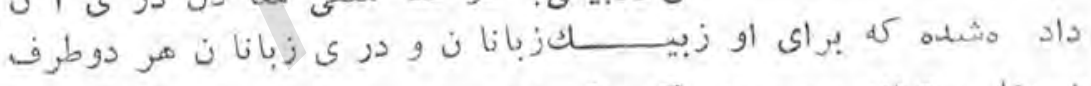

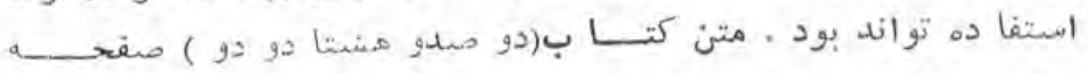

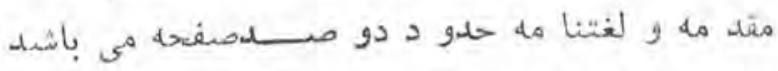

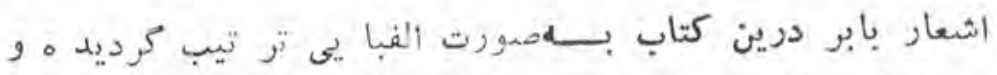

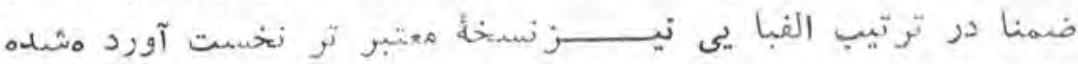

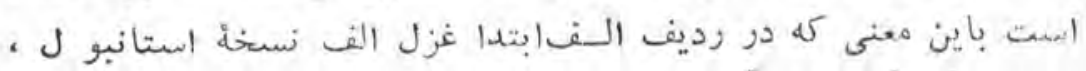

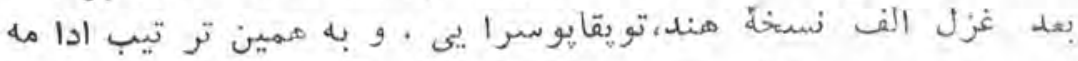

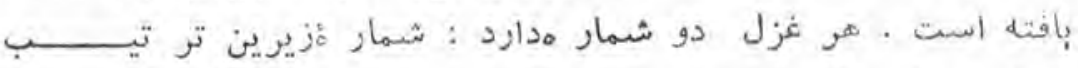

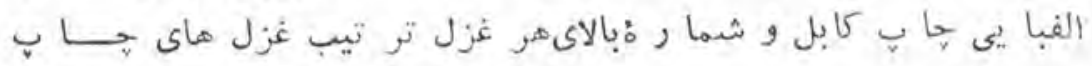




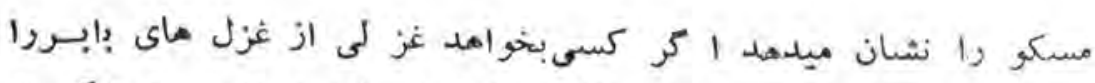

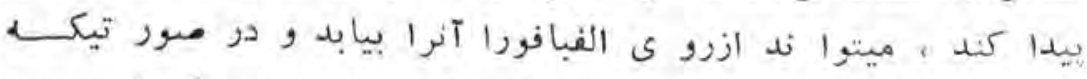

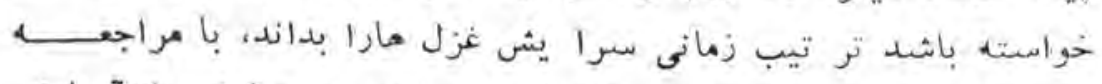

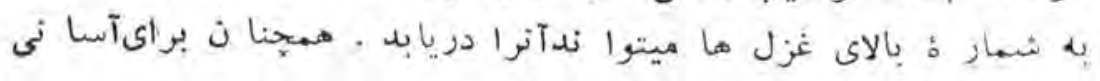

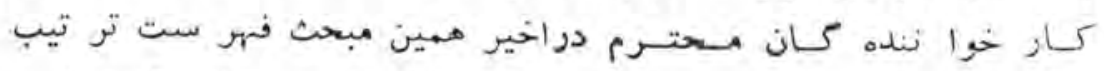

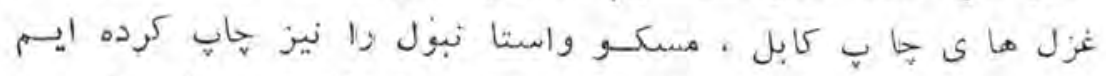

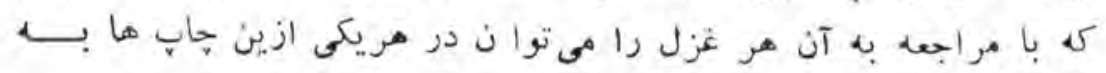
آسا نى يافت با مراجعل

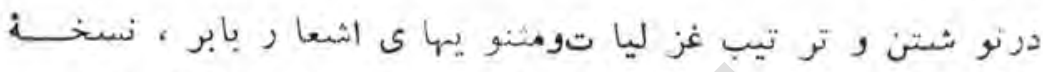

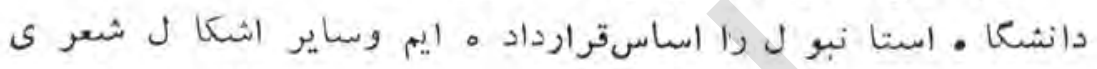

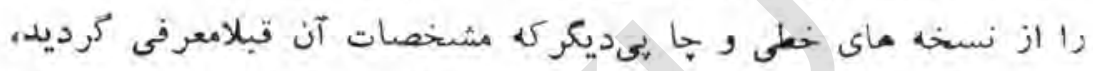

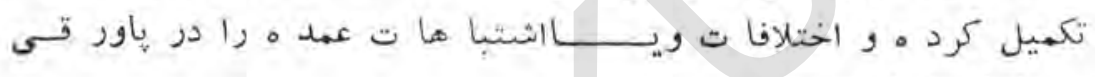

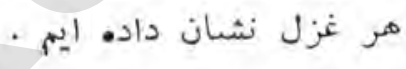

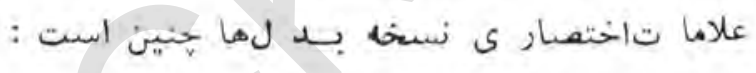

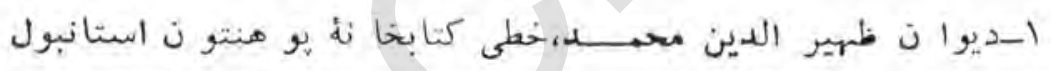

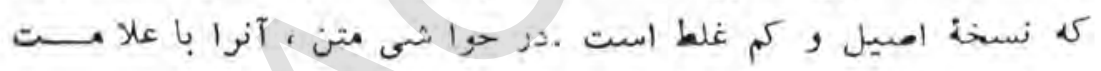

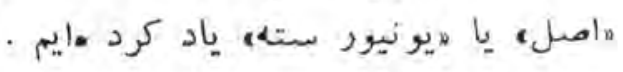

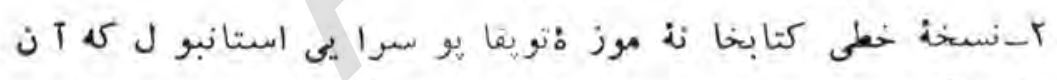

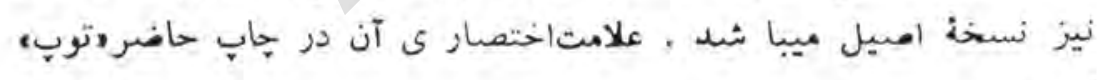

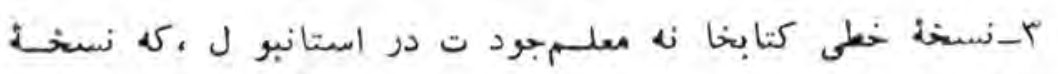

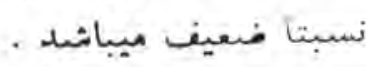

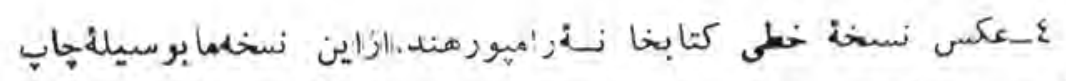

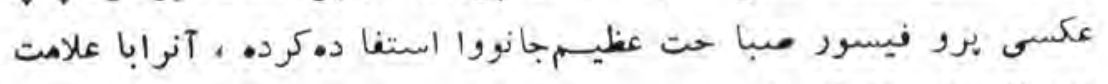

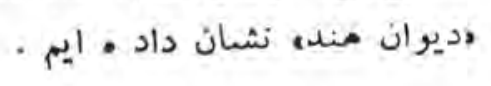

\section{- ريكعلو سيزدم}




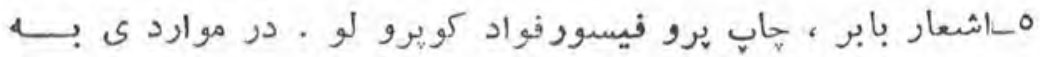

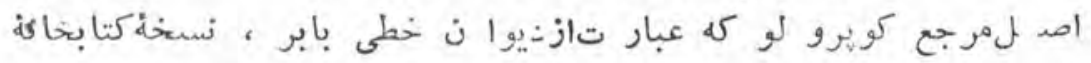

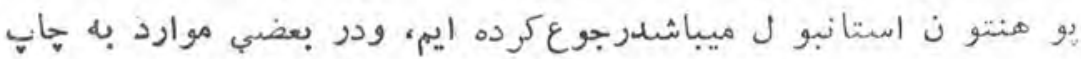

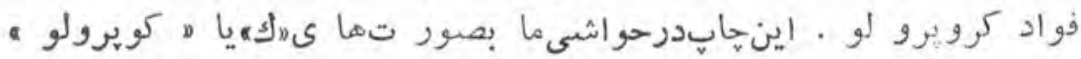

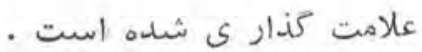

7-(يكصدو هجده ) غزل حا پآفسيت خانم ستيبيليوا ( مسكو )

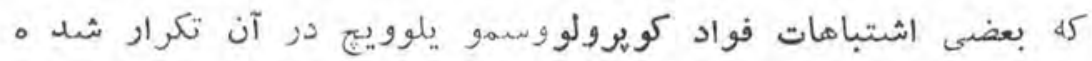

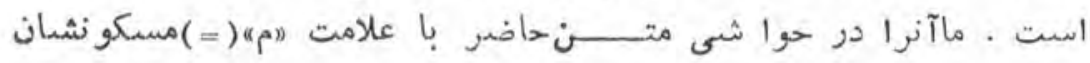
داده إيم

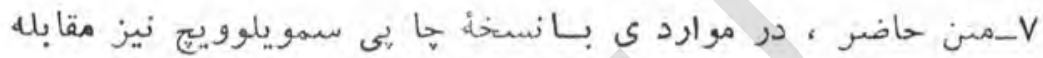

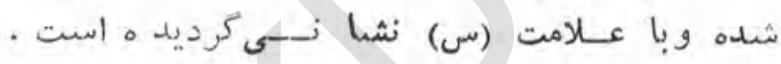
هـديوا ن بابر ، جاب تاشكنـدبالفباى كريلي كه يكعده اشتباهات

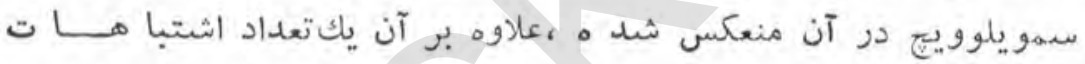

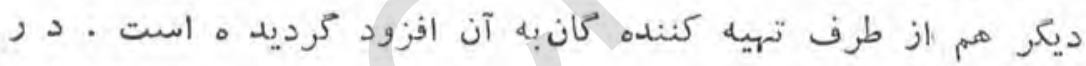
تصحيع متن ، اين خاب با علا متي"ته = طبع تاشكند علامت كنارى مشده است متع 


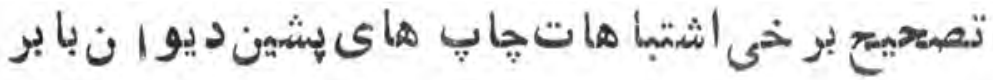

در صفا ت كذشته ياد كر د ى داشتيم از هاب هاي كونه كونديوان

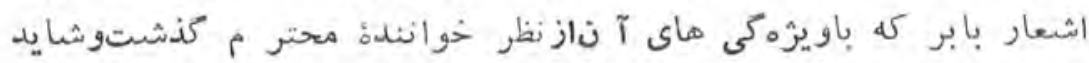

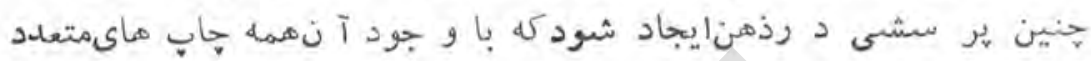

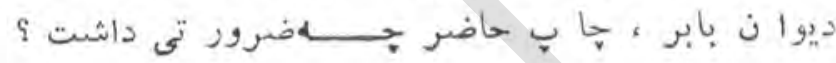

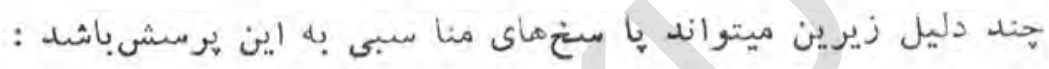

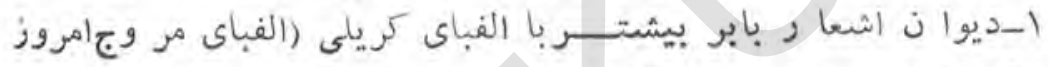

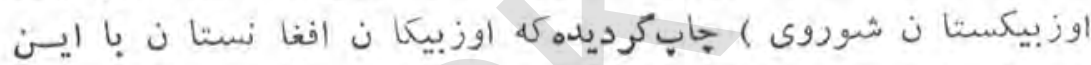

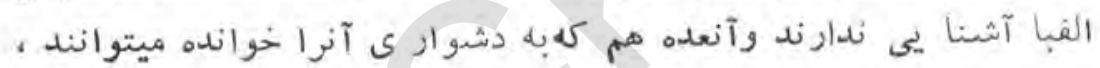
بسيار إند كند آثنا ندار

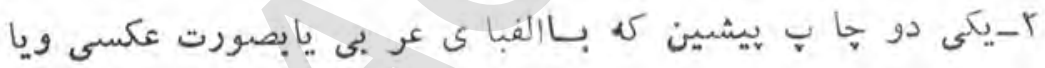

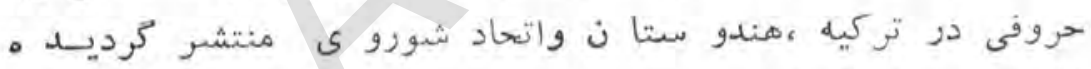

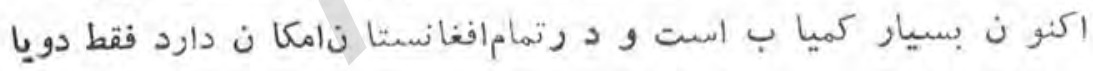
سل نسخة آن موجود باشد .

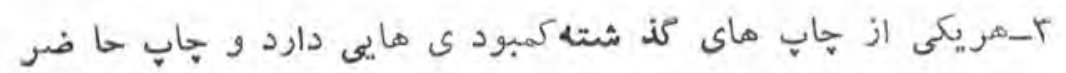

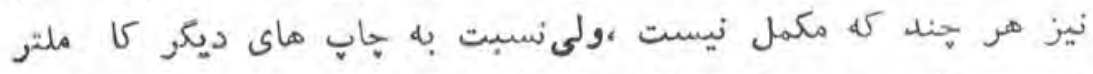

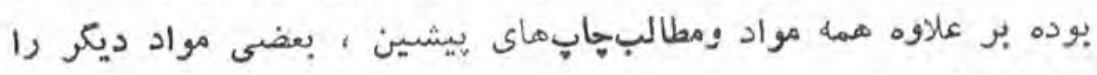
نيز احتوا مى كند . ملن.

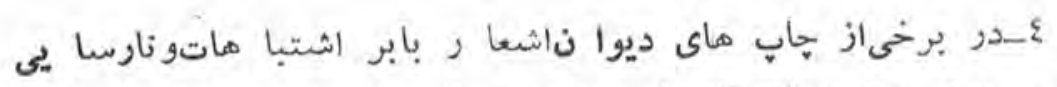

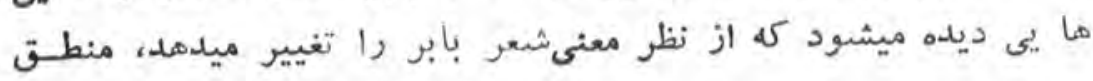
- 


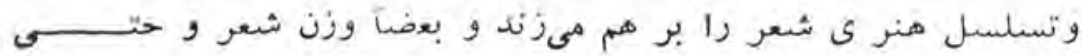

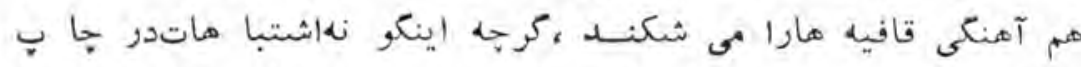

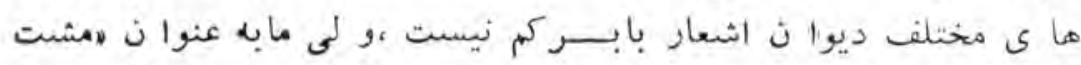

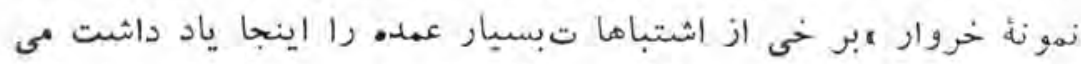

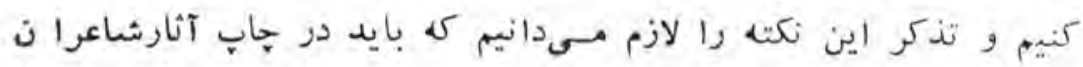
و زويسندمكان كلاسيك كه سر مايذمعنو ى ملتى هستنا ور آثار آنا ن

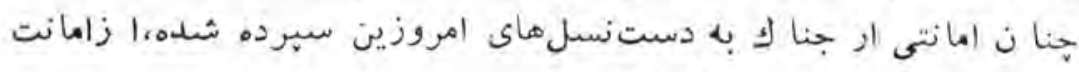

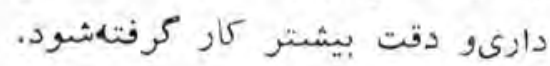

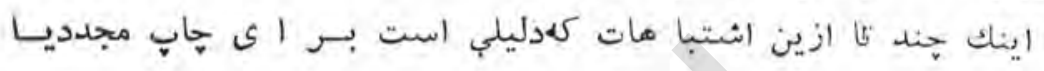
حاضر

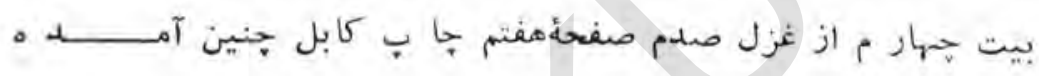
است : خو شتور ورو صال ديار ،اندابولها سا ديار بولسه و صل بى اغيار ، دو لتوسعادت توت ترجمه :

(وصال يار خو شست درصورتىكه اغيار در ميان نبا شلد .اكرجنين

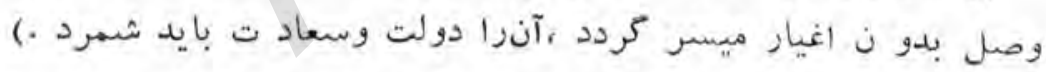
إين بيت در خا ب هاى بيشيسنبينكو نه نغيير يافته است : خو شتوزو روصال ياز،اندابولماساديار

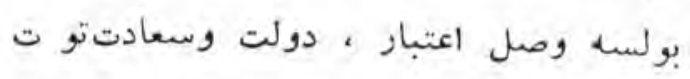
مصرع اول درست است و لسىمصر ع دوم برغلاو ماينكل ازنظلـر وزن سكته كى و ثقلت ييدا كرده ، وعنى آن نيز جنين شده است : ( اكر به وصل اعتبار باشل دولتوسعاد ت بدان !) همجنا ن بيت نيخم همين غز لجنين است : - 


$$
\begin{aligned}
& \text { غم خي يكى بيحد دو ر ء جار هسه بو دو ربابر }
\end{aligned}
$$

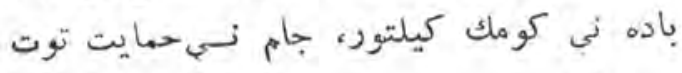

$$
\begin{aligned}
& \text { ترجها : }
\end{aligned}
$$

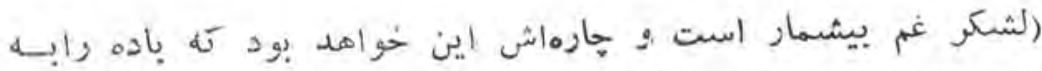

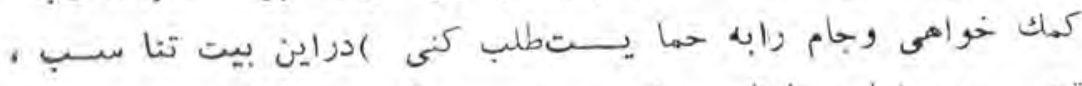

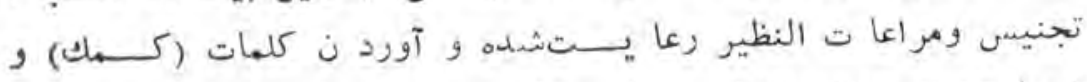

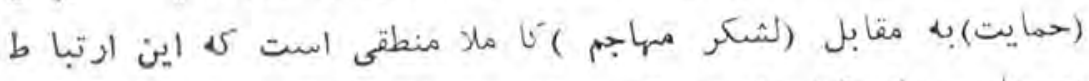

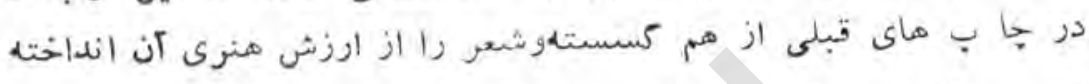

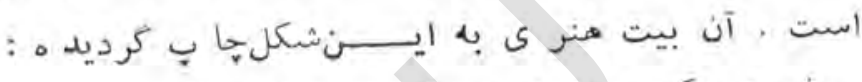

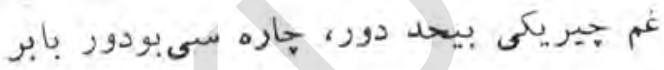

$$
\begin{aligned}
& \text { باده نى قويوت كيلتور ، جام نى حمايت توت } \\
& \text { ودريك خابخ ديكر آمده : }
\end{aligned}
$$

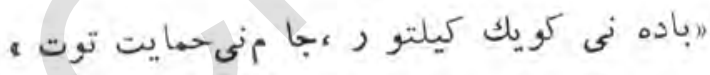

$$
\begin{aligned}
& \text { : }
\end{aligned}
$$

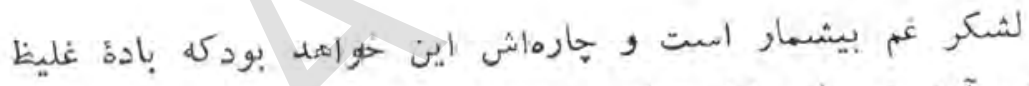

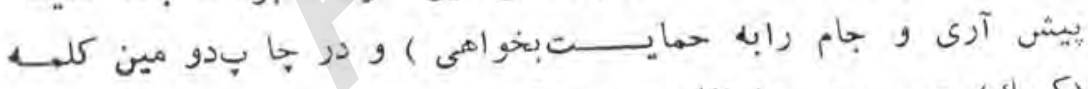

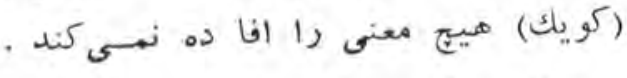

$$
\begin{aligned}
& \text { مثالى ديكر مى آوريم : }
\end{aligned}
$$

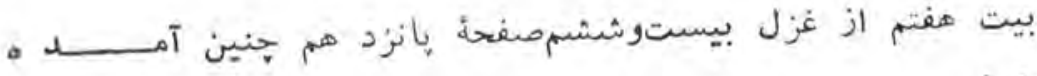

$$
\text { هر نيخه بى عنايت ايسه يـا ربابرا }
$$$$
\text { سينقو يمه خد متينكنى و آنسىاو يا لدور }
$$

ترجمه :

(اي بابر مر جند يارت بىعنايت باشد تو در خد متكذار ى فـر و 
كذاشت مكن واو را خجالت بد ه )اين بيت در جاب هاى كذشته جنين شلده است :

$$
\begin{aligned}
& \text { سينقو يمه خد متينكك نىو آنىاو بالدور } \\
& \text { ترجمها : - 20 }
\end{aligned}
$$

(تو در خد متكذار ى فروكذاشتمكن واورا كناه است ؟؟!)

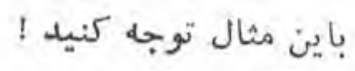

باش كو تار ما ن باده دين جونبار اياغى اور تادا قويما ن ايلكيمدين اياق جو نجلوه كرساقى دورور

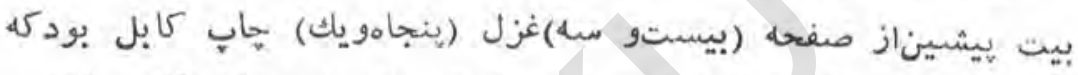

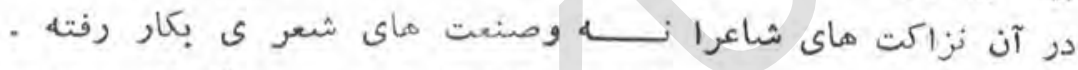

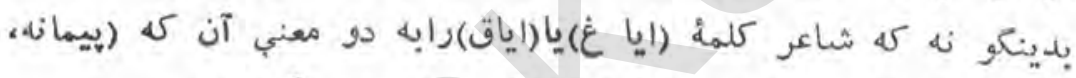

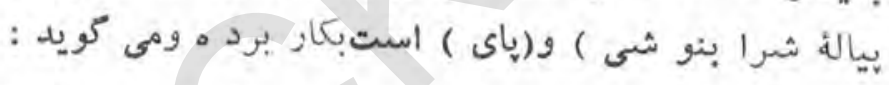

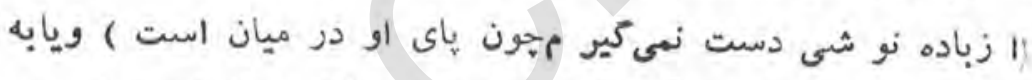

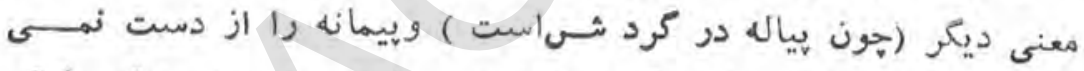

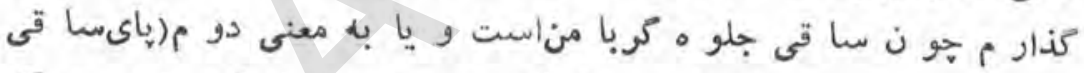

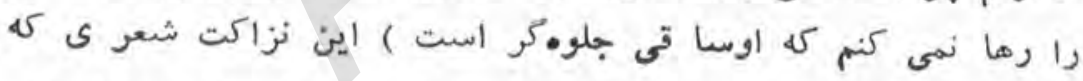

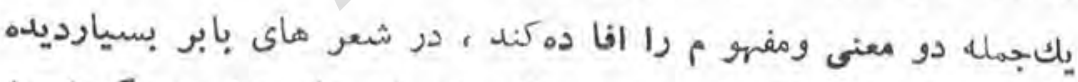

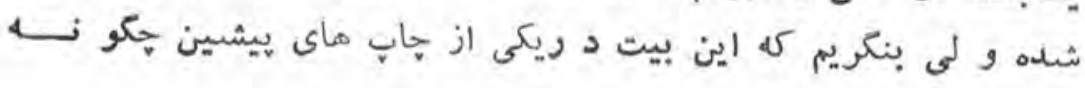

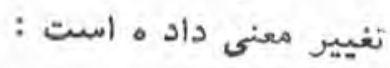
باش كو تار مين باده دين جو نيار ايا غى اورتادا

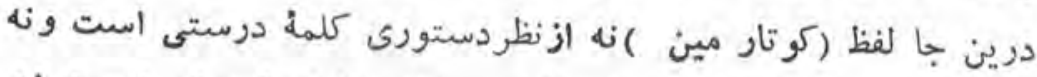

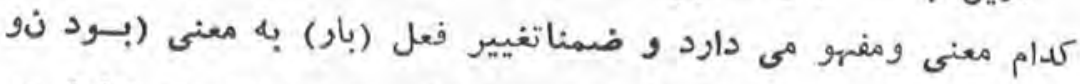

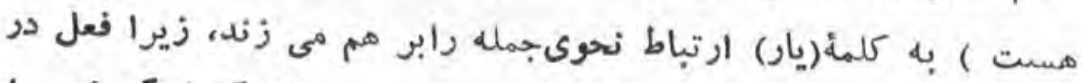

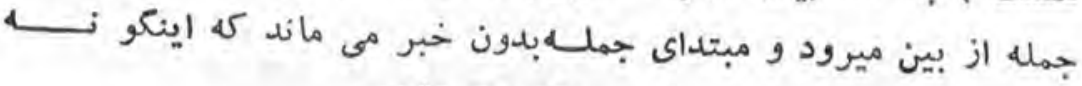




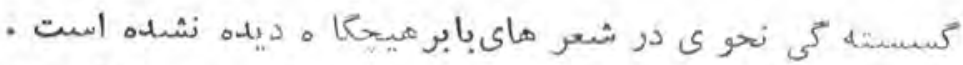
2

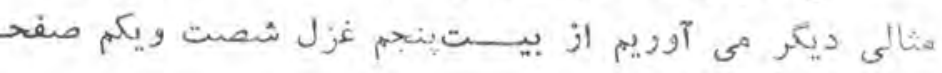

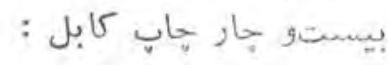

$$
\begin{aligned}
& \text { سيندا بابر يو ت كثله يار نينكتعتا بى كم ايماس } \\
& \text { جرمي سيز دايم عتابايـلار،عجبدلدار دور }
\end{aligned}
$$

دوين جا شاعر مصرع اول را بلهيث مبتدا و مصرع دوم را بهحيث

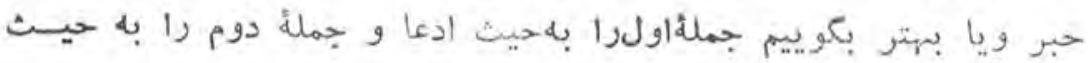

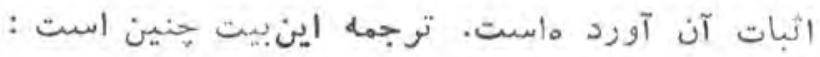
(بابر در تو كنا هي نيست،عتابيار بسيار است . او بدون هيــــ جر مى عتاب مى ورزد عجب دلدا رئست !) همر ع اول اين بيت در جا بهاى بيشين خنين تغيير شكل و معنسى :

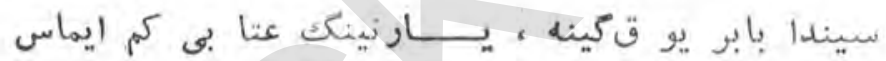
كه لفظ (كينه) به جاى(كنه)درين جا هيت هفهو مى را نمى رساند . به اين بيت ديكر تو جه كنيـلعاز غزل جهها رد هم صفحة سىو نله : ناتو ان جانيم غه عشقىقايغر نى كيلتور كوديك عيش و عشر تنى كونكو ل ديـنقايغو زايل قيلغو ديك. :

(هنا ن مينمايد كه عشق او د رجسم ناتوا نم حرما ن وحسر تهما خواهد آورد واين حر مان، عيشسوعشرت هارا از خاطر مزايل خواهمد

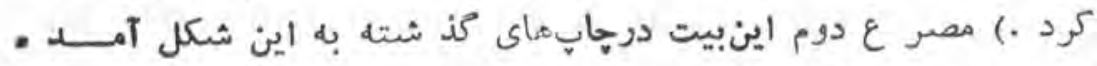
كا هي- معنى ندارد: عيش و عشر تنى كو نكو ل دينقايغو رو رايل قيلغو ديك - 


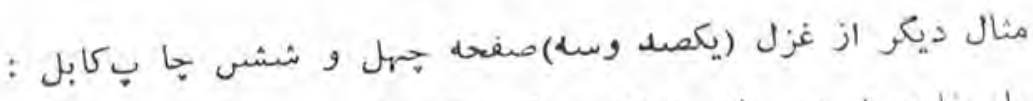
بار غاي ايرديم باش ايلاكو يق كا نيلاى بابرا

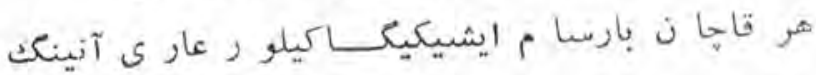
تر

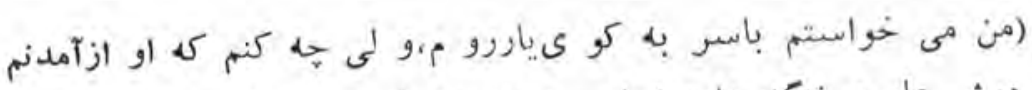

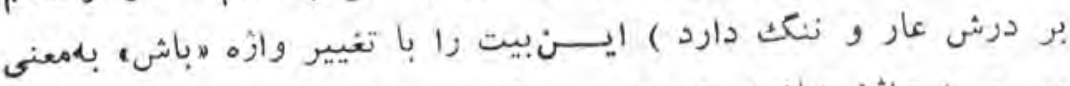

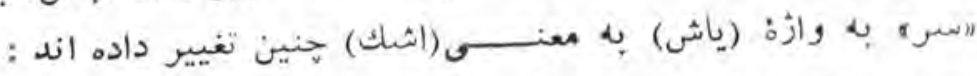

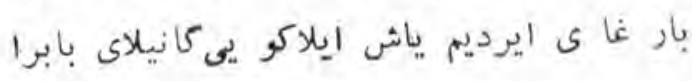

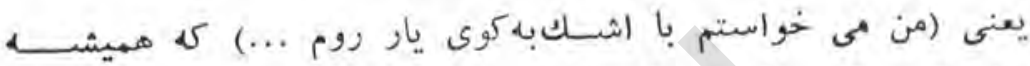

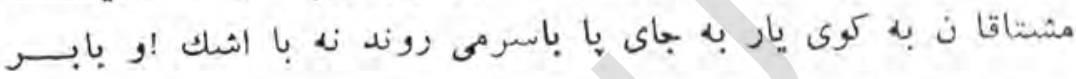

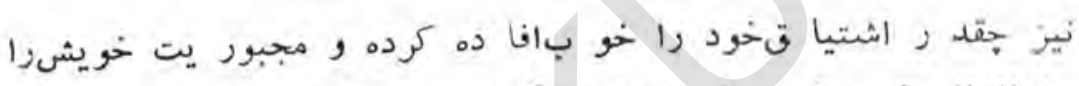
جه اندازه خوب تو صيف نمود هـ وكفته است كث :

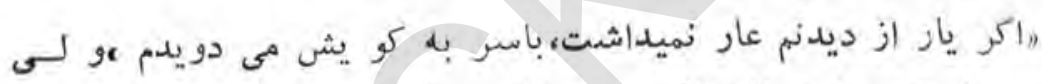

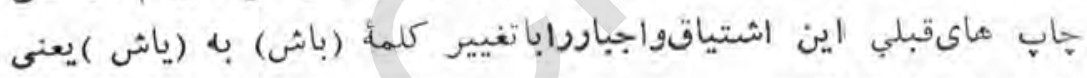

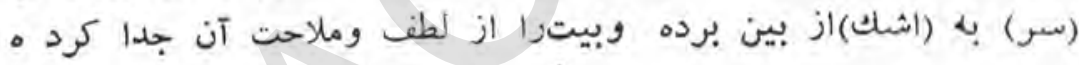

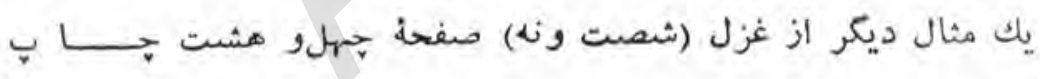
: ك

نى نكر ى كيم سينينك فكر ينكايماس اول فكر ايرور باطل نىعمى كيم اوتار سين سيز ،ايروز اول عمر بى حاصل ترجسه :

(هر فكر ى كه دربارة تونبا شد،انديشه باطل وآن عمر ىكبى تسو

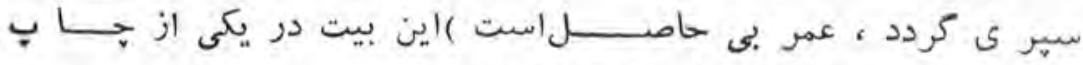
هاى بيشين بدين شكل جاب كرديدهاست: 


$$
\text { نى عمز ى كيم او تار سين تيسز ائرور اول عمر بى حا هل }
$$

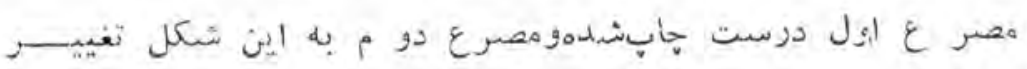

ياقتيه است :

$$
\begin{aligned}
& \text { (آن عمر ى كل بو تيز (!) بكذرى بي حاصل اسمت .) }
\end{aligned}
$$

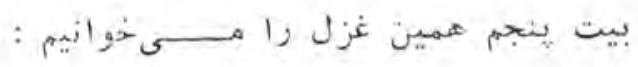

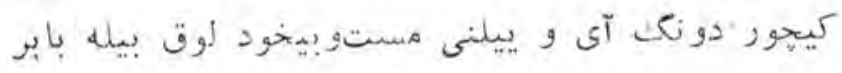

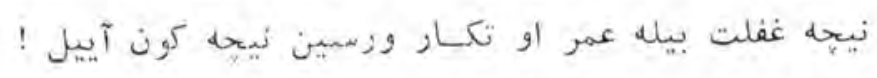

$$
\text { : }
$$

(ماه ها و سال هارا بامستيوبيخبرى كذ ششتا ندى ، اى با بـر

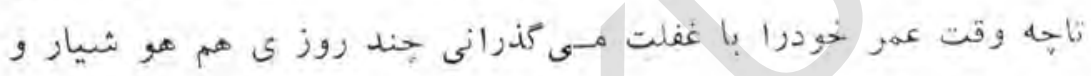

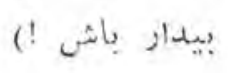

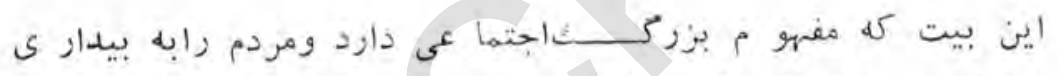

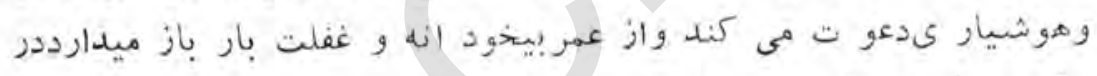

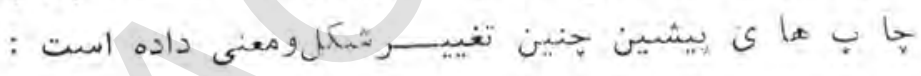

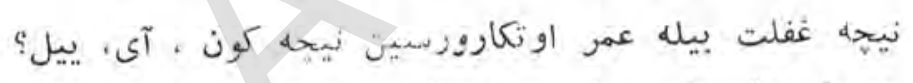

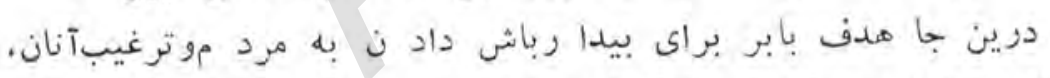

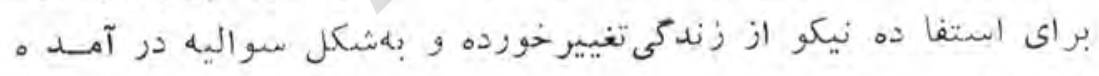
است : براي المتعا

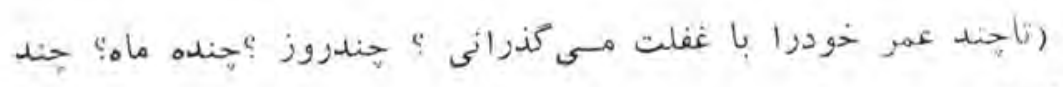
(s) Ih

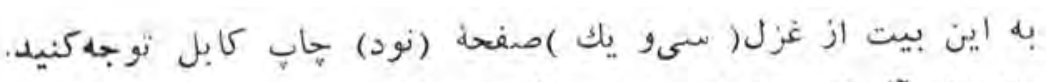

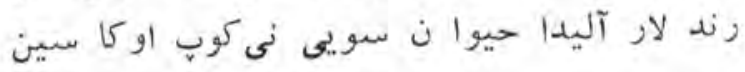

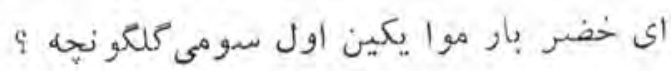

- يكمبادو بيستو يكن - 
( اى خضر! نزد رندا ن تعريفآب حيوا ن مى كنى . آيا آن آب به

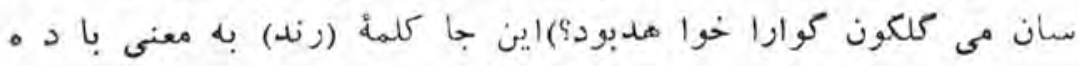
نوش بكار رفته كه در اشعأز حافظوديكر شاعرا ن در عواوزبيكى بسيار

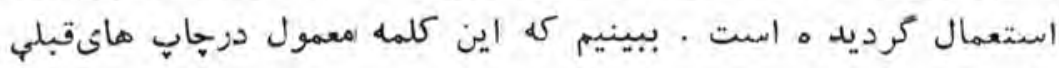
: زنده لار آليدا حيوا نسو ينسى كوب اوكاسين

$: \operatorname{laz}^{\prime}$

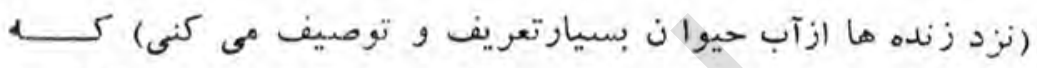

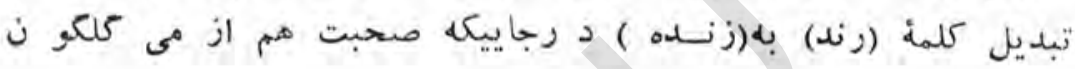
باشد ، بسيار بيجا و بيموردخواهدبود . آخرين مثا ل از بخش غزل ها .ائ نبيت را از غزل (نودونه )صفحه

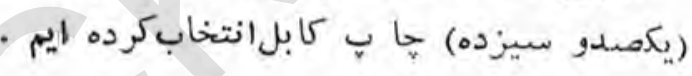

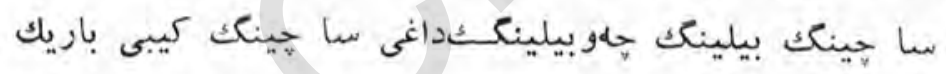
لطا فت ايحر ه يوق فر قــى بوايككى نينك سبر مويى ترجمها :

(كيسوا نت به سا ن كمرتو كمرت به سا ن كيسوا نت باريـك (ندار

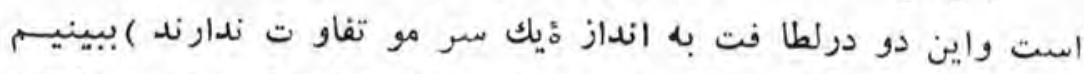

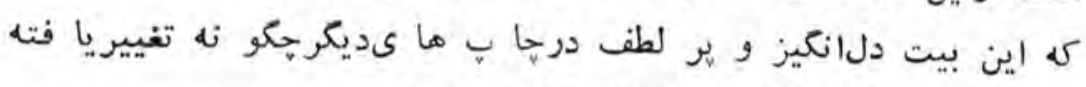
واز ملاحت و لطف شعر ىآن كاستهشده است : ين

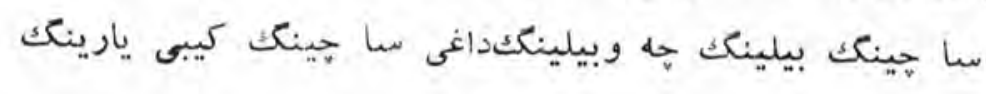
ترجمه :

(كسيوانت به سا ن كمو ت وكمرت به اندازه كيسوا نت يار ت )

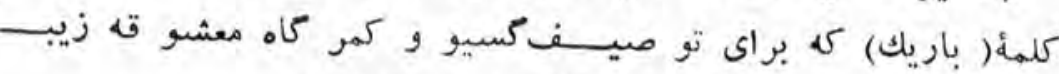
- يكصسو بيستو وو- 


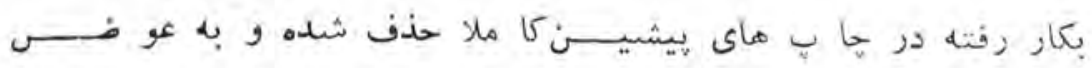

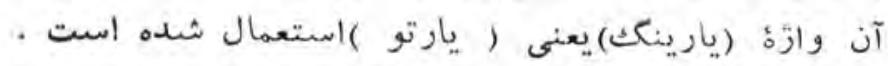

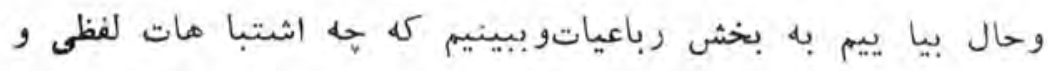

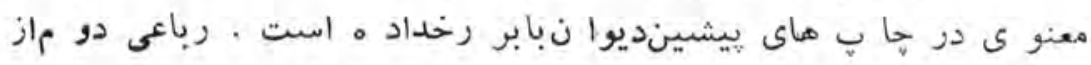

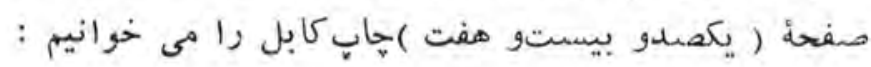

$$
\begin{aligned}
& \text { هجرا ن قفسى داجا ن قو شىرمقيلادور } \\
& \text { غربت بو عزيز عمر نى كم قيلادورب.... } \\
& \text { ترجمه : }
\end{aligned}
$$

(مرغ روح در قفس هجران مسىرمد و غربت عمر عزيز را كو تاميى

مصرع اول اين ربا عى دريكسي از جا ب ها هنين شده است :

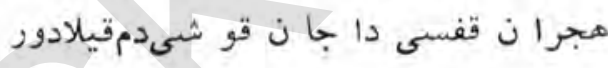

$$
\text { إعنى (مرغ روح در قفس هجرا ندم مى كند !؟؟) }
$$

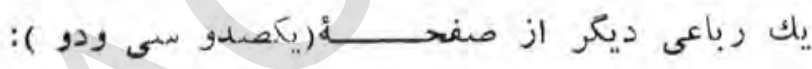

$$
\begin{aligned}
& \text { ديوانيمه نى ربط و نه تر تيـبدورور } \\
& \text { نىجدو ل ونى لوح ونى تذهيبدوزور }
\end{aligned}
$$

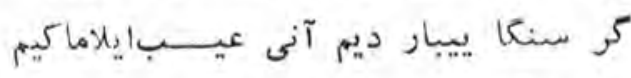

$$
\begin{aligned}
& \text { ديوانينك نى تيلار كا تقر يـبدورور }
\end{aligned}
$$

$$
\text { ترجمه : }
$$

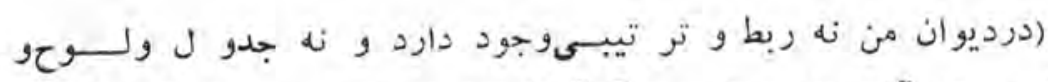

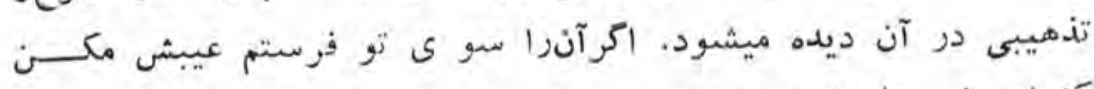

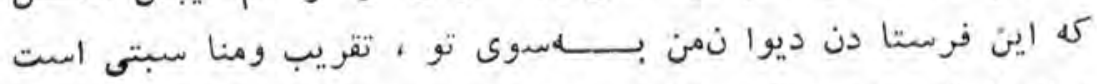

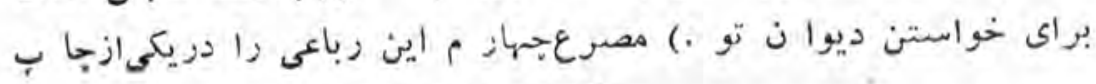




$$
\begin{aligned}
& \text { ماى كذنشتله جنين مى خوانيم ؛ } \\
& \text { ديوانينك نى تيلا ركا تقر يــردورور }
\end{aligned}
$$

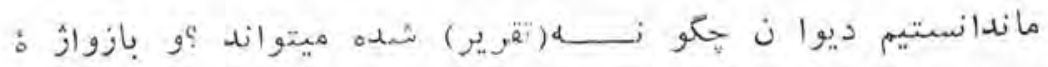

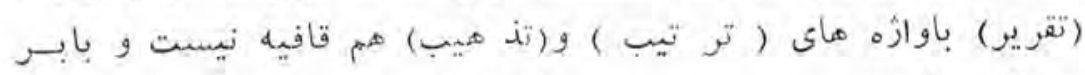

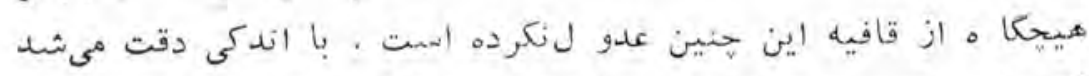

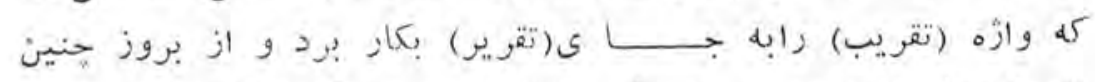

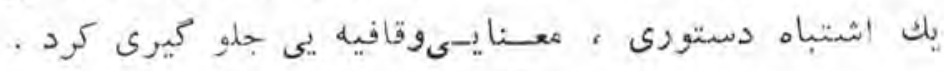

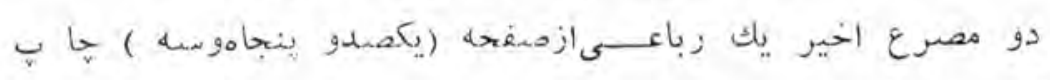
: آس آغز ينغ اونه او بار سوزين بيتتى آلماس مين بارغان كيشى حين آغيز سوزينسوز غاي سين :

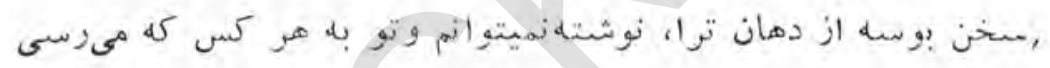

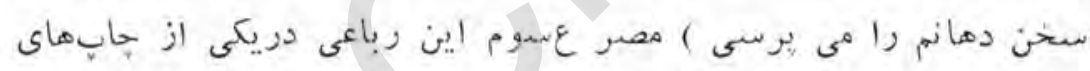

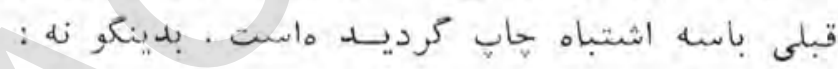
(آغزينكغه اويار سوزين بنـــى آلماس سين) كلهعنى آنرادرنيافتيم.

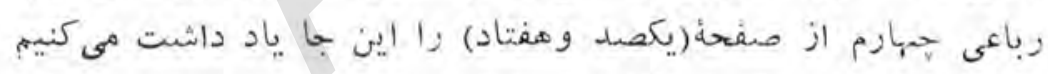

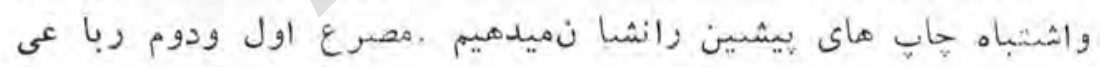
: مينينكث تيلاكيم بودور كه تازندهبولاى

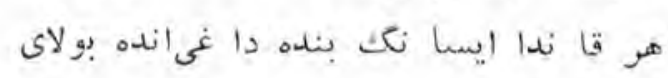
:ترجمه

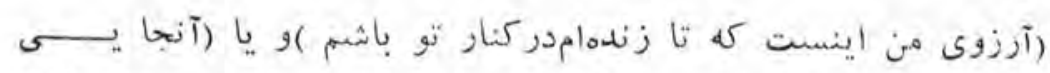

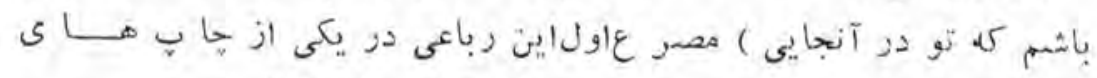




\section{كذشتها حنين تغيير بافتها است :}

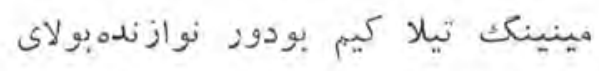

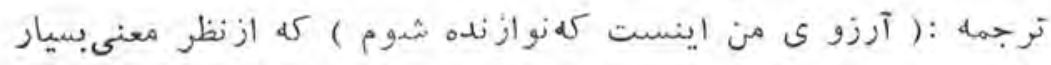

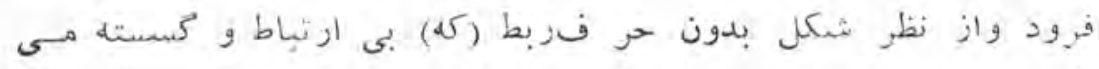

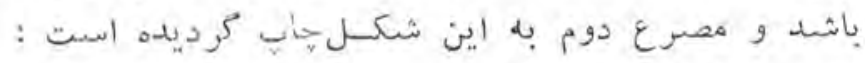

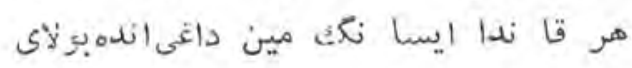

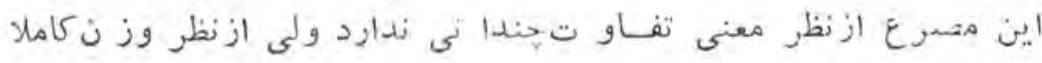

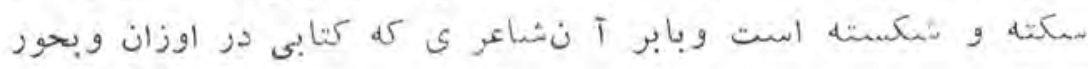

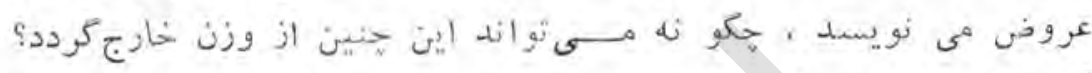

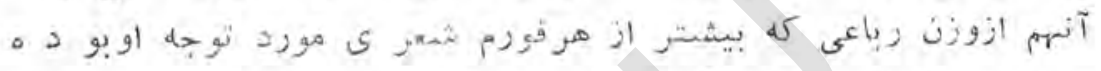

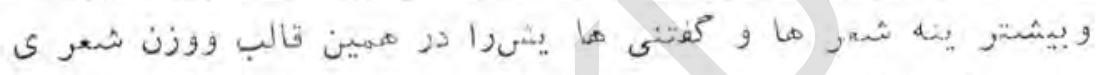

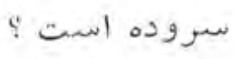

آخرين مثا ل الز از بخشرباعيات

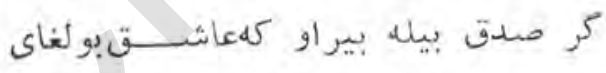

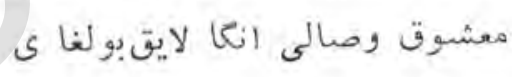

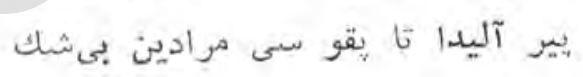

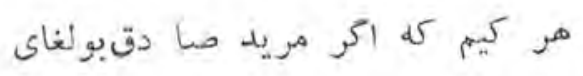
ترجمهاه

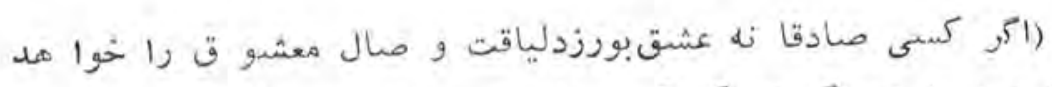

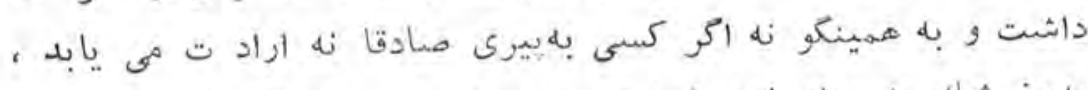

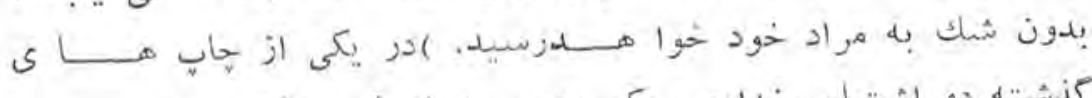

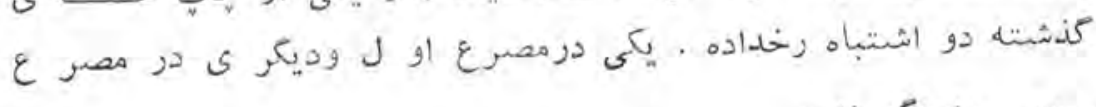
سوم · بدينكو نه :

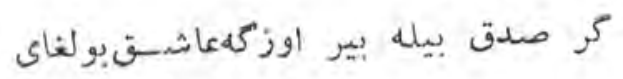
- يكصندو بيستو ينبج- 
يعنى ( ازرو ى صدق اكر يـــكبيكانه عاشق شود )و مصر ع سوم

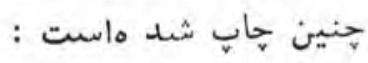

$$
\text { بير آليدا تايقو سى مرادين بسىتنك }
$$

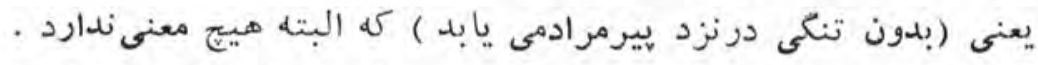

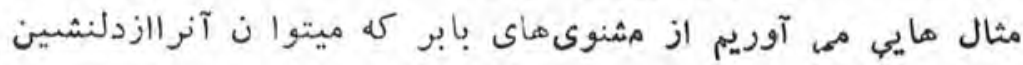

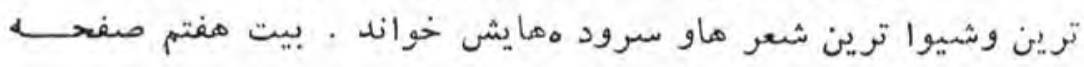

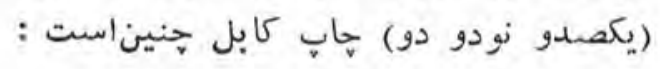

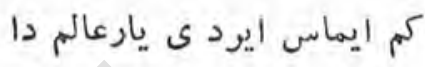

$$
\begin{aligned}
& \text { هر طرف ياربار عالم دا } \\
& \text { ترجمه : }
\end{aligned}
$$

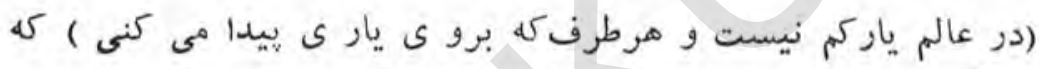

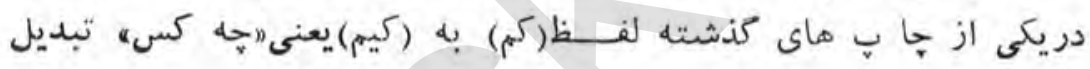

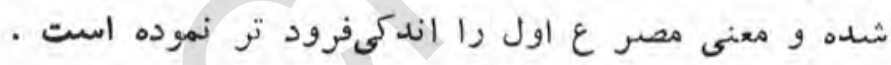

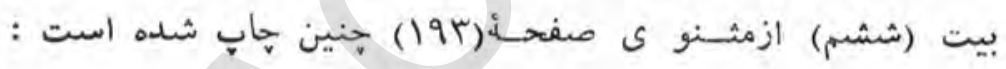

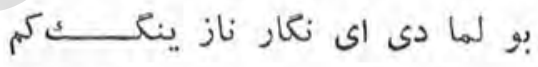

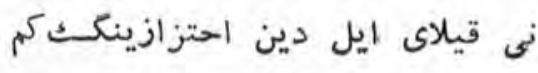

$$
\begin{aligned}
& \text { تر جمه : }
\end{aligned}
$$

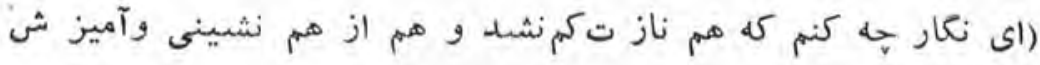

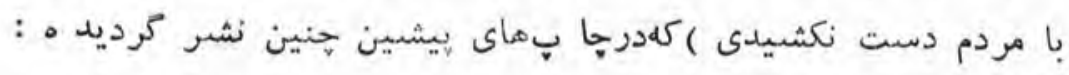

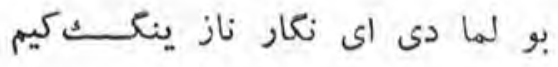

$$
\begin{aligned}
& \text { نىقيلاى ايل دين احتراز ينكــكيم }
\end{aligned}
$$

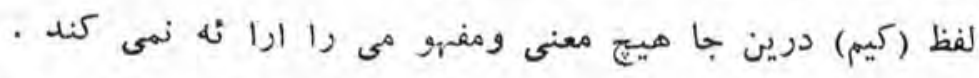

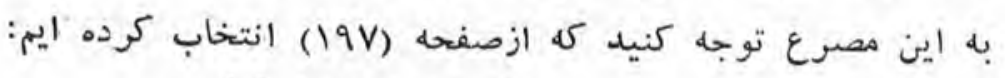
- - 
بو نه استغنا دورور اي جانكم.

$$
\text { : ترجما }
$$

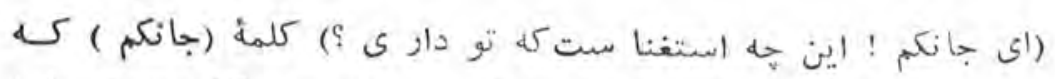

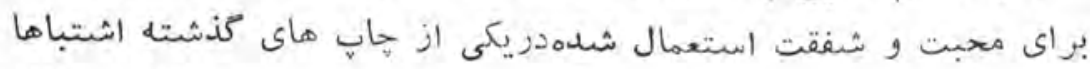

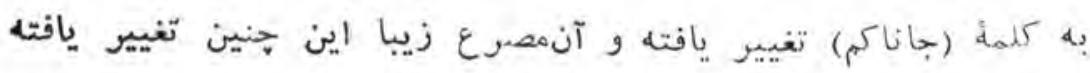

$$
\text { بونه الستغنا دوروز اي جاناكم. }
$$

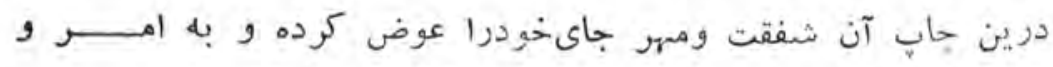

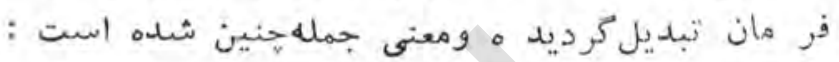

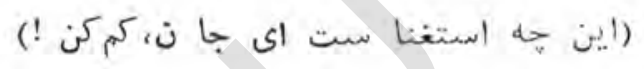

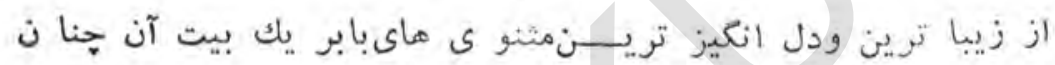

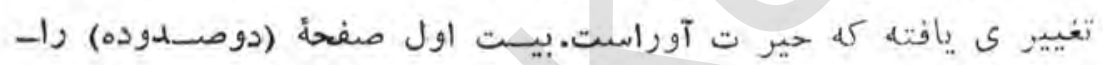

$$
\text { هى حُوانيم }
$$

$$
\begin{aligned}
& \text { هين ديماسب هين كه دودا غينى اوياى } \\
& \text { كر ايليك بيرسه ارياغينى او باياى }
\end{aligned}
$$$$
\text { : }
$$

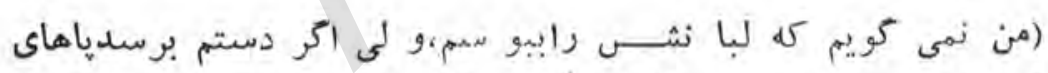

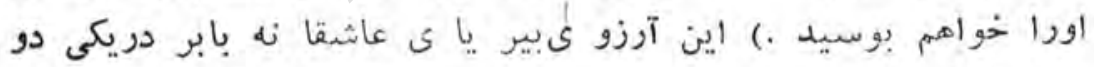

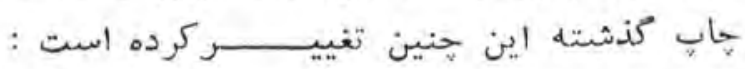

$$
\text { كر انينك بيرسه ايا غينى تاو ياى }
$$

$$
\text { ترجمه : }
$$

(اكر از او بدهد بايش راخواهـمبوسيد .)

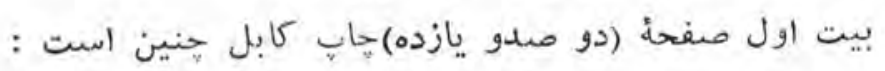

\section{- يكصسوبيستو هفتـ}


خاطريم ساقتلار ايسا نك كيــلـقوقيغيل

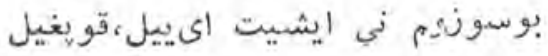
:

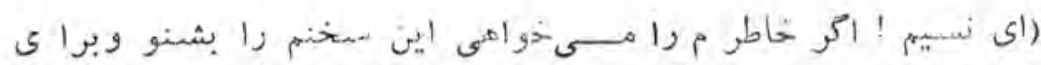

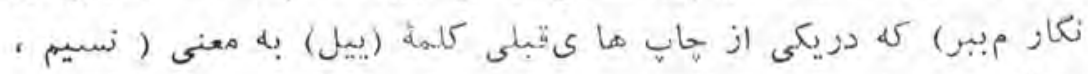

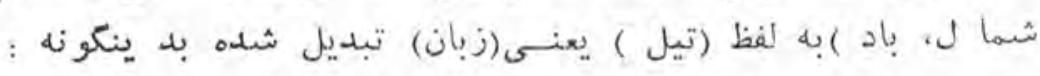

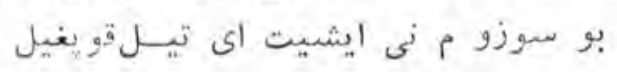
ترجه : (إين سخنم را بشنو اق زبا نعجاه كن وبرو)

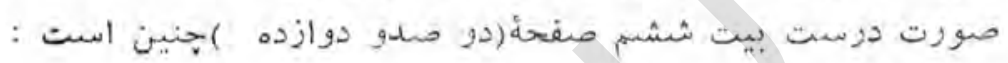

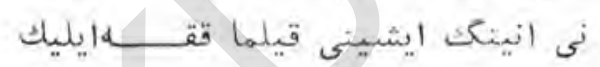

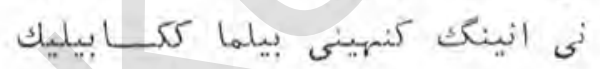
:

(نه دستى كله كار اورا بتوا ندانجام دمد و نه أنديشه بي است كم

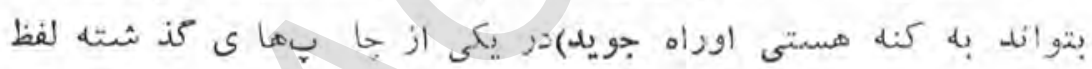

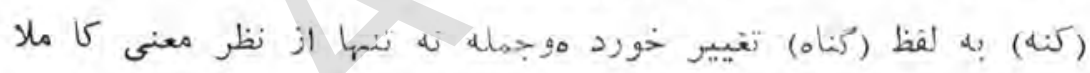

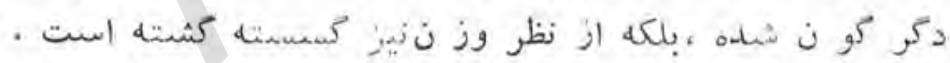

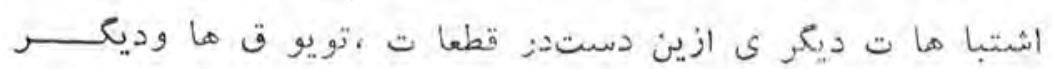

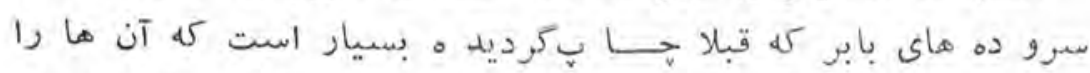

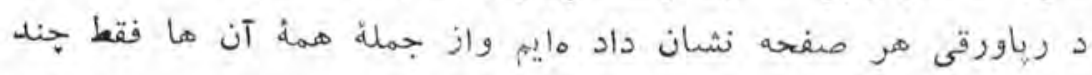

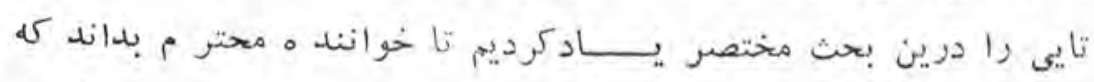

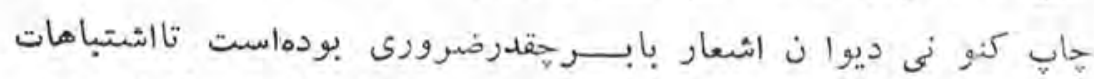

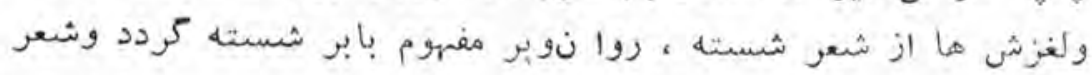

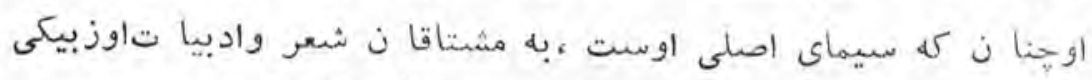

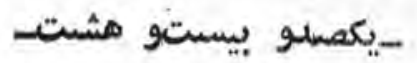




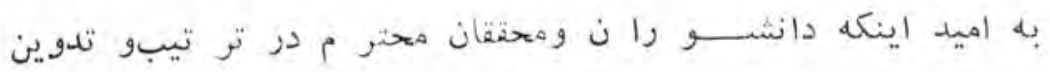

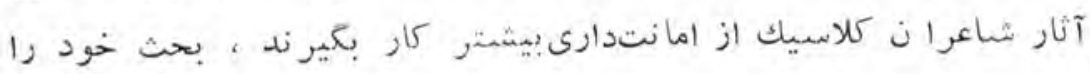

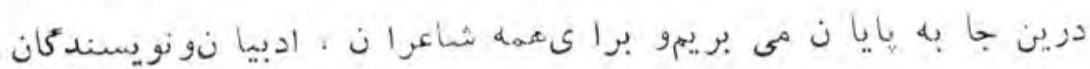

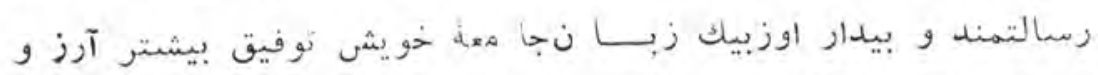

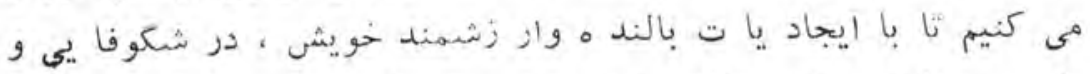

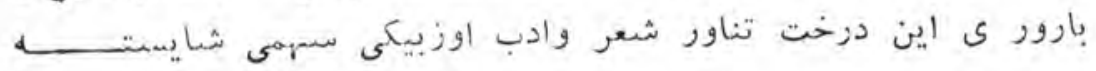

$$
\text { بكير ند . }
$$

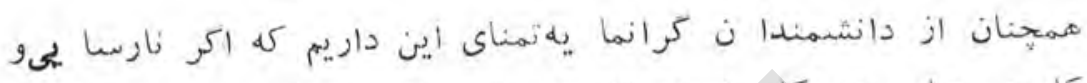

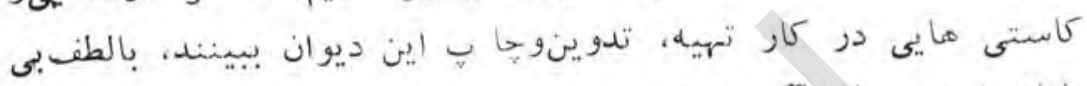

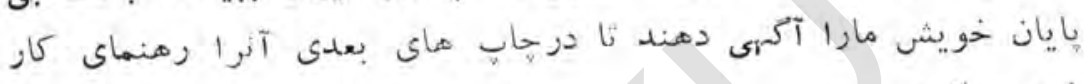
خود سازيم

معاون محقق

شفيقه يارقين 
تر نيبغزل هاى با برد رجا پهاى

مانتلف د يوان

جابابتانبول ل

لجابل

باب كابل

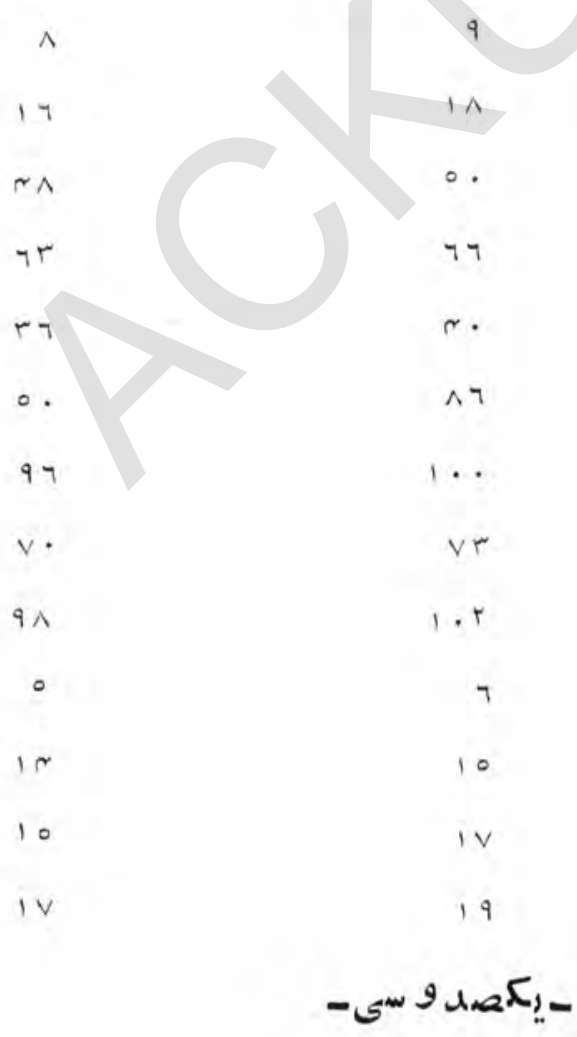




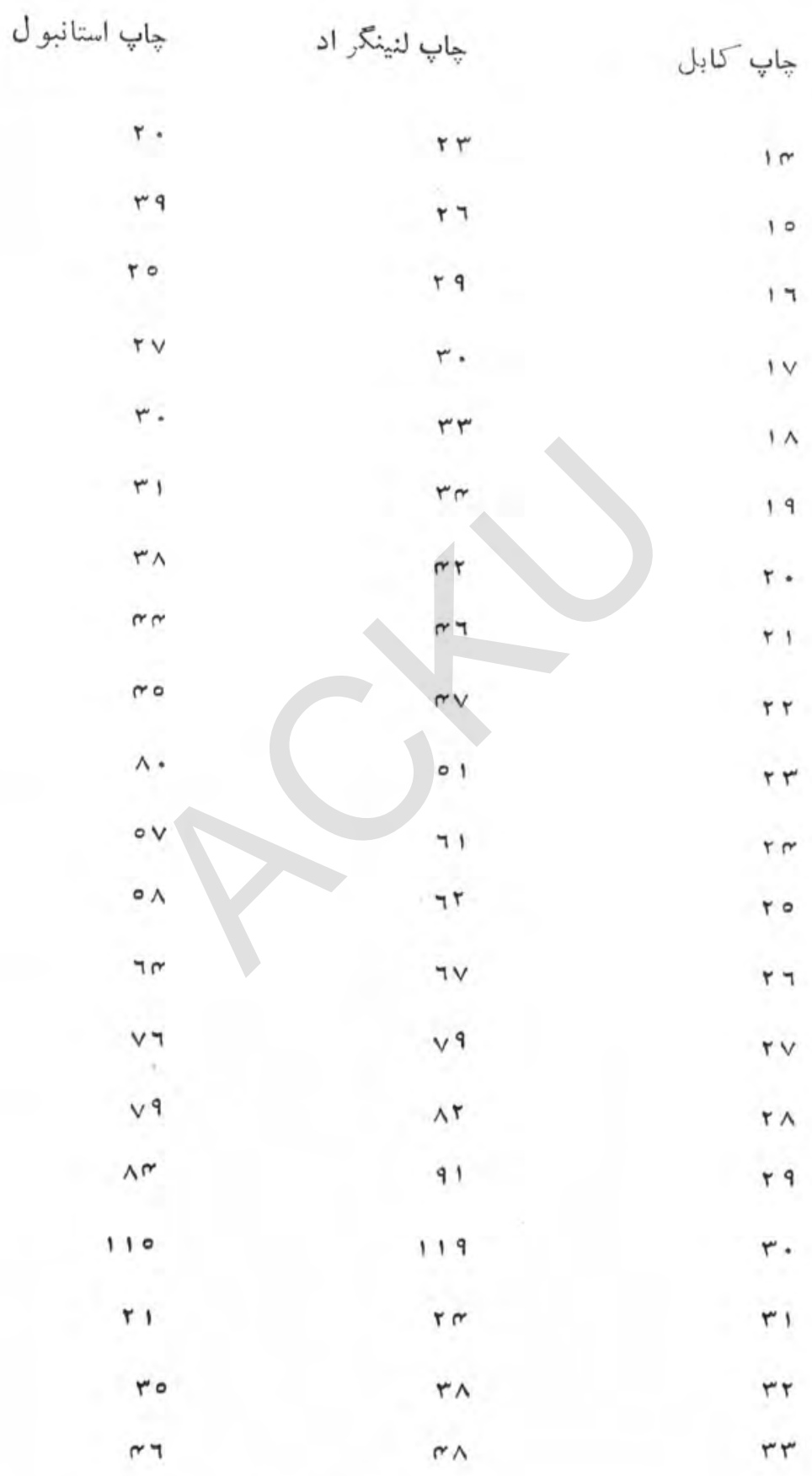

- يكمد و سيى و يكك- 


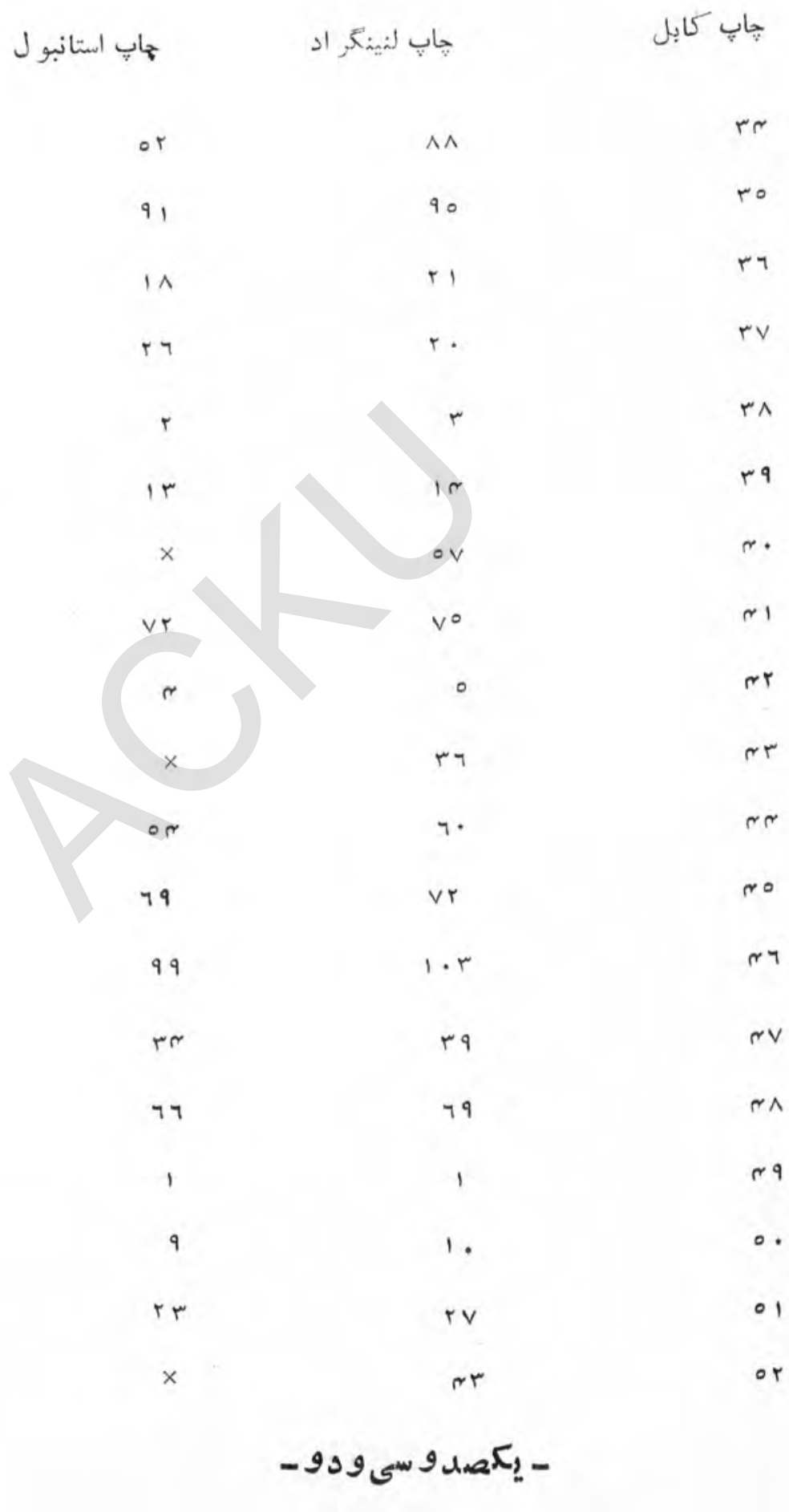




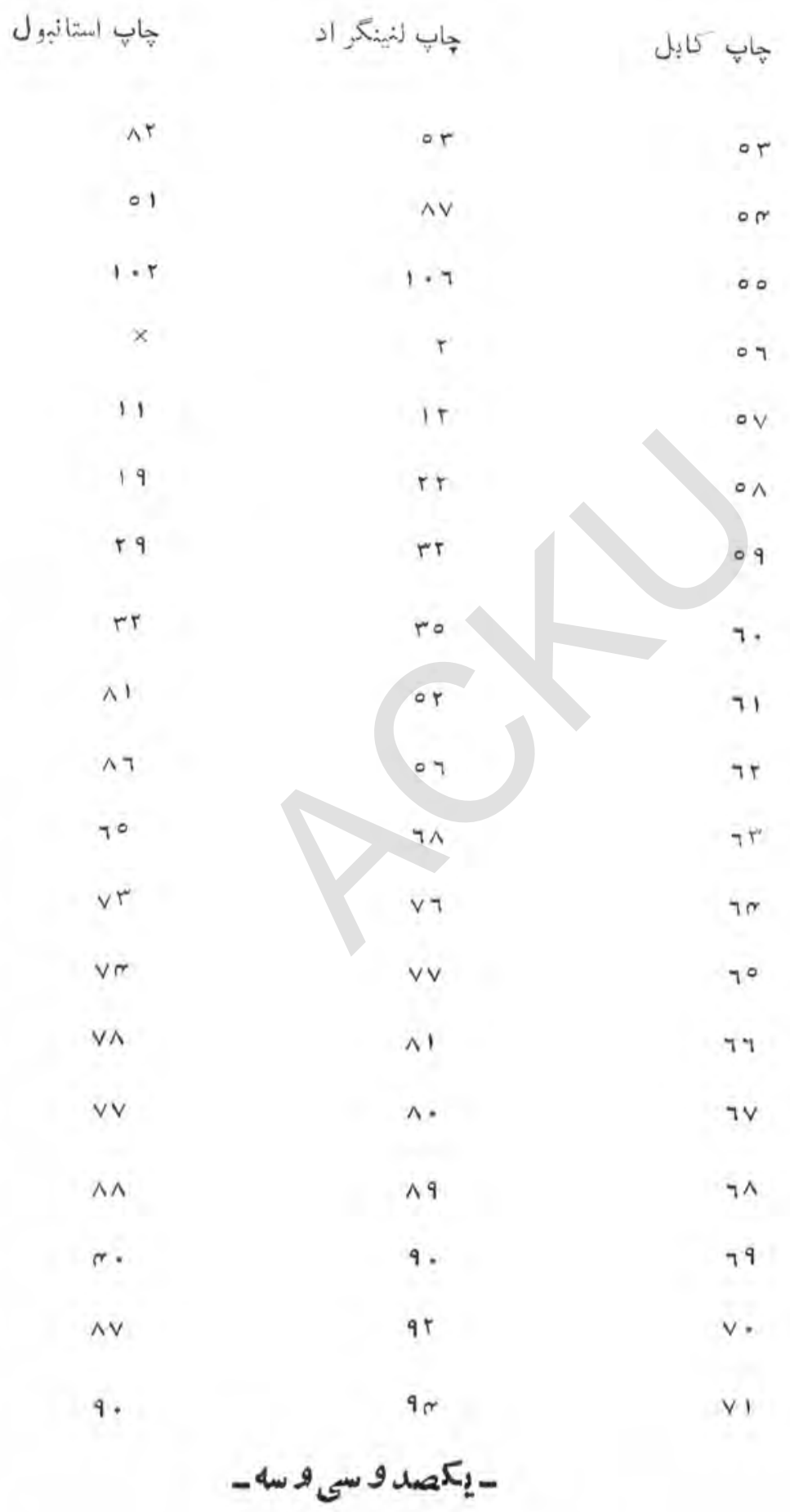




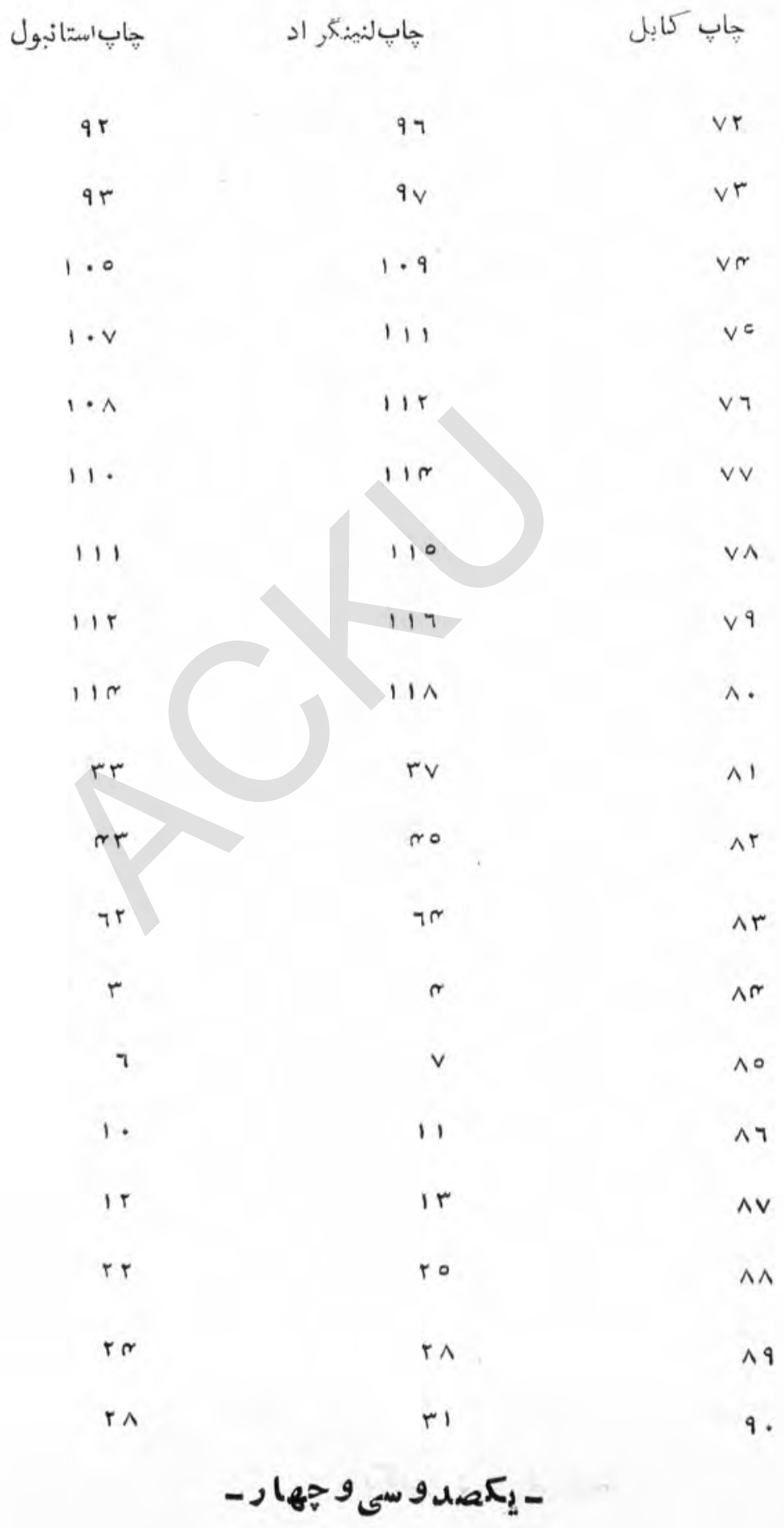




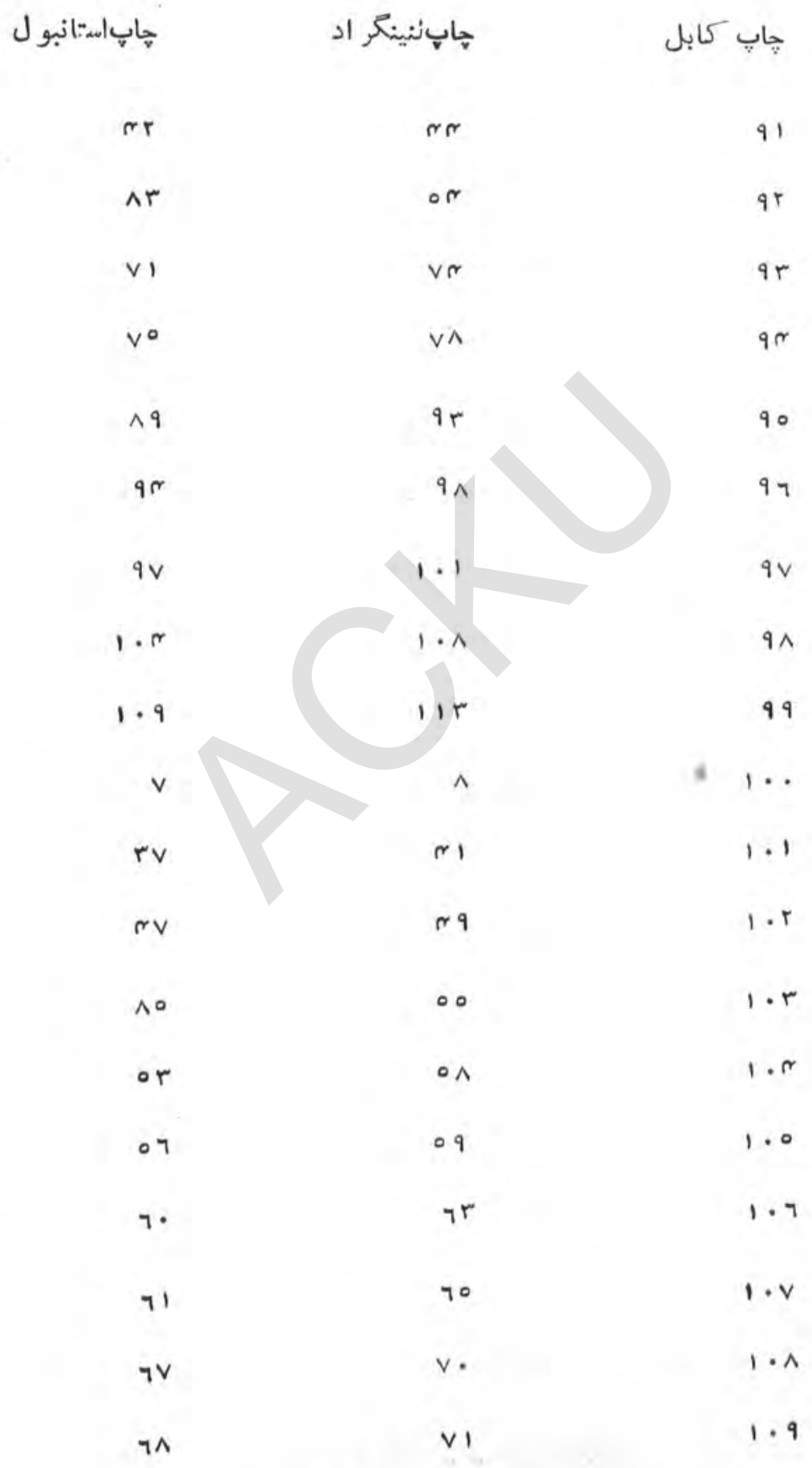

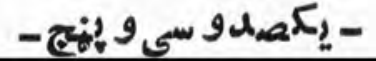




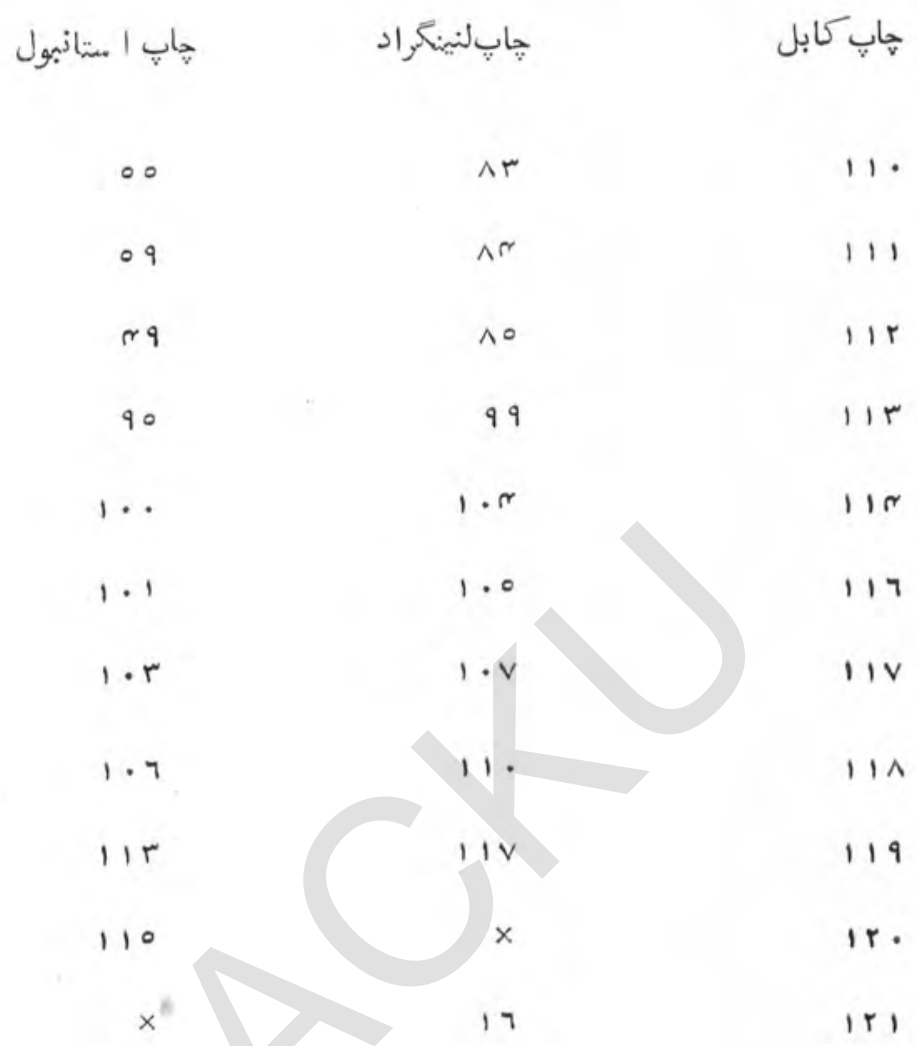

- يكصد و سى و شش - 


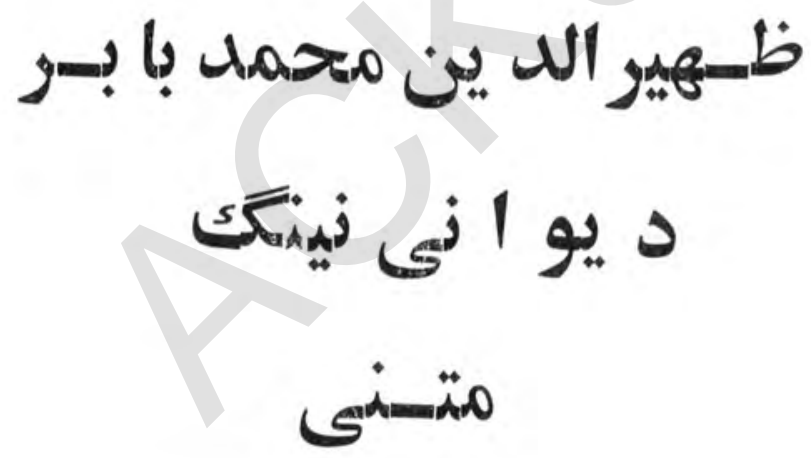


غـرس ل لار 


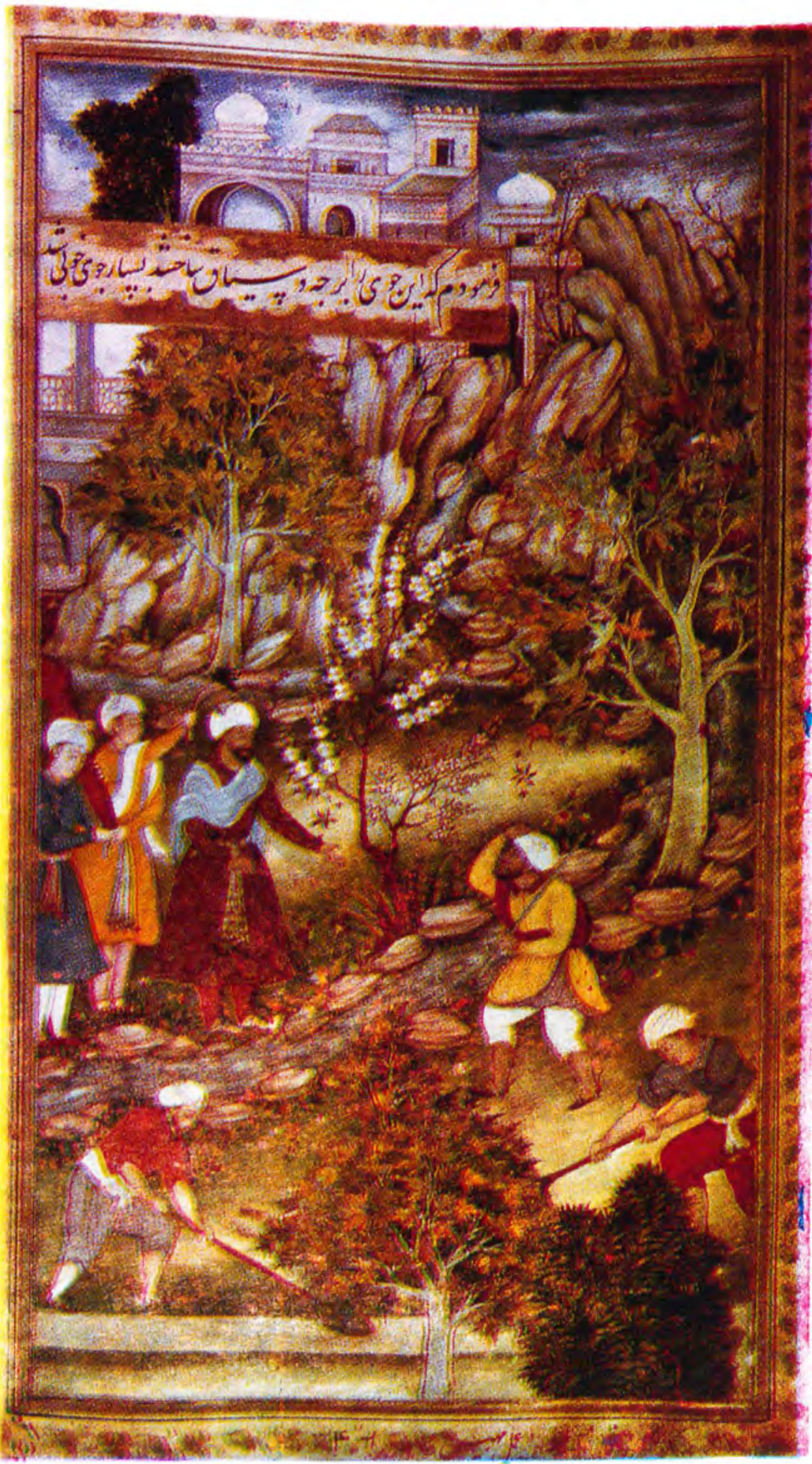

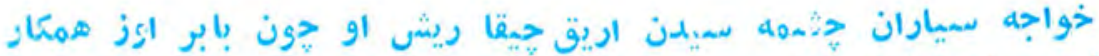
كرى بيلن ايشمله هاقده . 


\section{(9)}

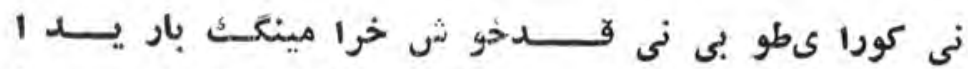

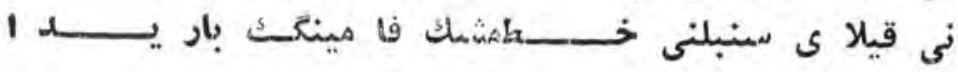
كيرخضر سو يين آغيسـز لانغا ى لبينكف نينكك قا شيـــ

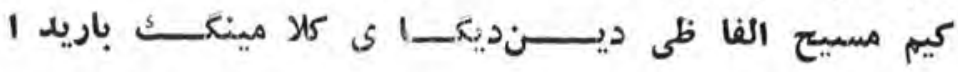

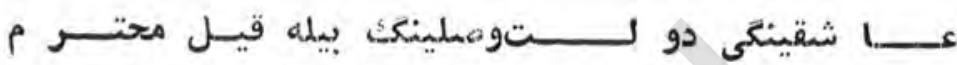

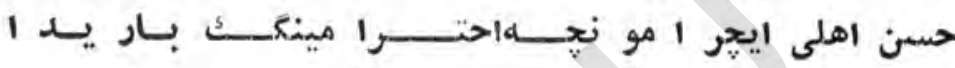

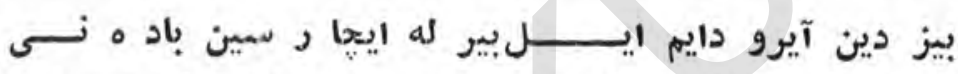

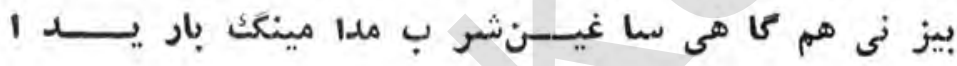

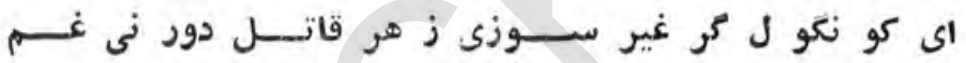

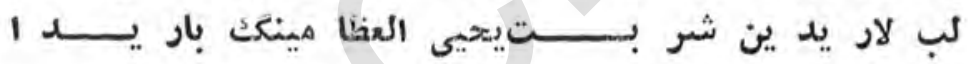

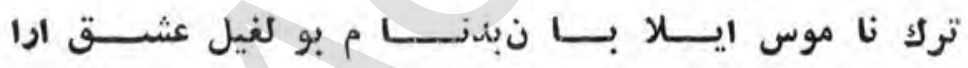

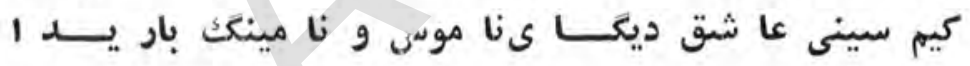

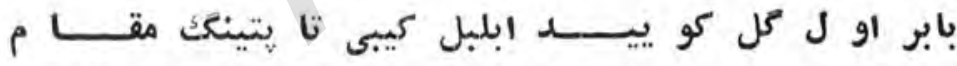

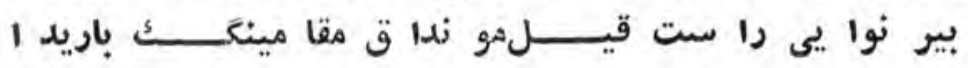


(1A)

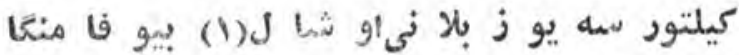

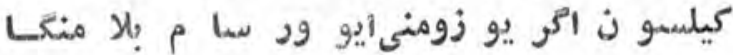
نيتكا ى مين (r) او لوذيق بيلهكيم قيلور بسمى مهووو فا ر قيب غــهجو ر و جنا منك

بيكا نه بو لهمه عتسـله هين تيلبه دين نى تا زعك جون بو كلـــ

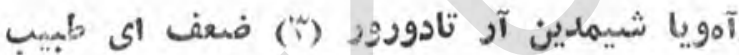
بيلد يم يارا شماسايمدى .و آب و هوا منكــ درديم كورو ب معا لجهده ذها بــــ ايتهه عمهـر

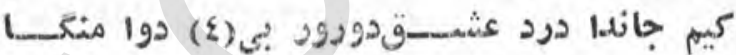
تايار كيمنى ايستا ر وكم نكليكا (0) كيم يا قار تشو يشس بيجهت تسورور (I) آخر لسنكا منغا بابر بو لو ب تسور ورايكى كوذيوميو كيداتورت

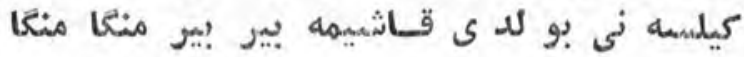

(؟)

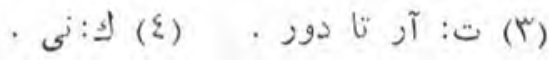

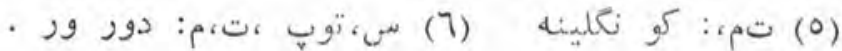




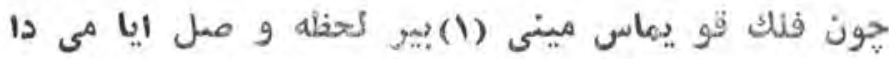

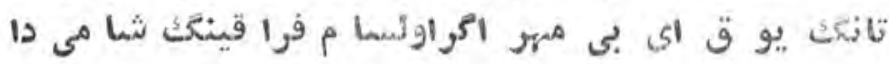

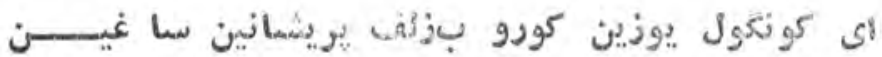

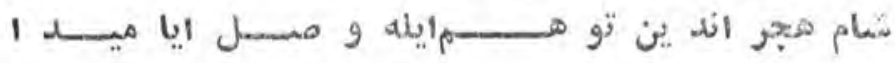

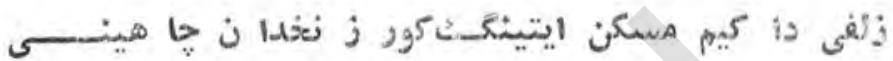
وأقف او لفيل كيم ايسـرو دميمين ازدها زينكك كا ميد 1

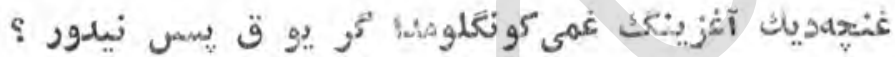
:

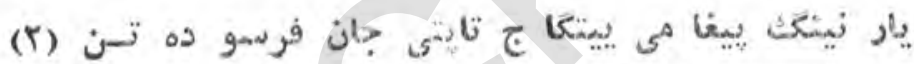

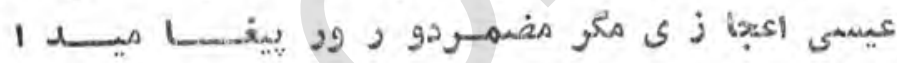

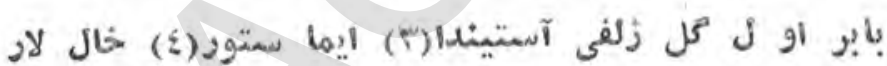

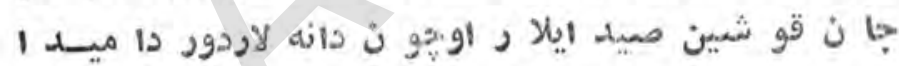

$$
\text { (1) }
$$

.

$$
\begin{aligned}
& \text { - } \\
& \text { (5) تم: إيما سدور }
\end{aligned}
$$


يا غليفينكَ (1) كيمجان بيلهمين خشته دور مين زا رانغا

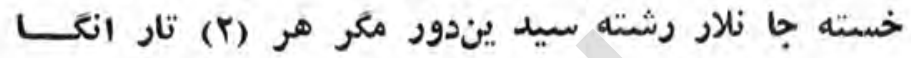

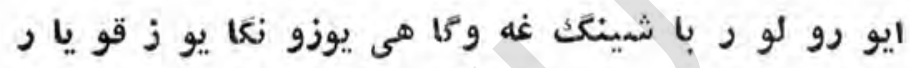

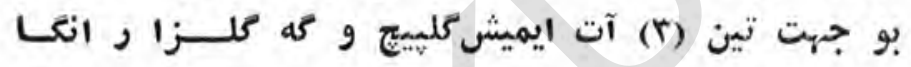

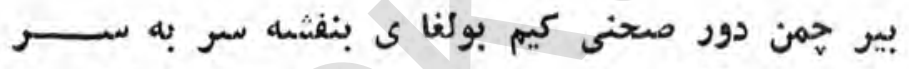

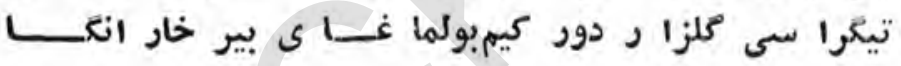

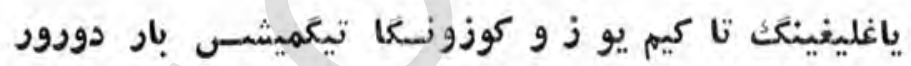

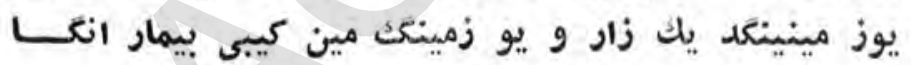

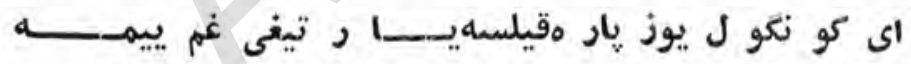

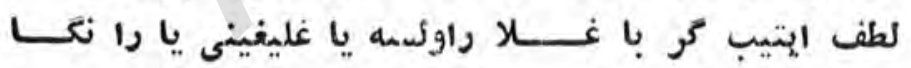
كو نعلو م ايستاريا غليغينك نى بلكه آندين بير نسيـمام

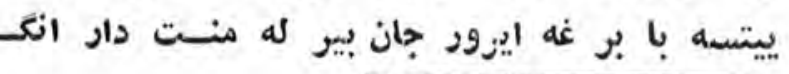

$$
\begin{aligned}
& \text { - (1) : بالغينك } \\
& \text { (Y) } \\
& \text { - }
\end{aligned}
$$




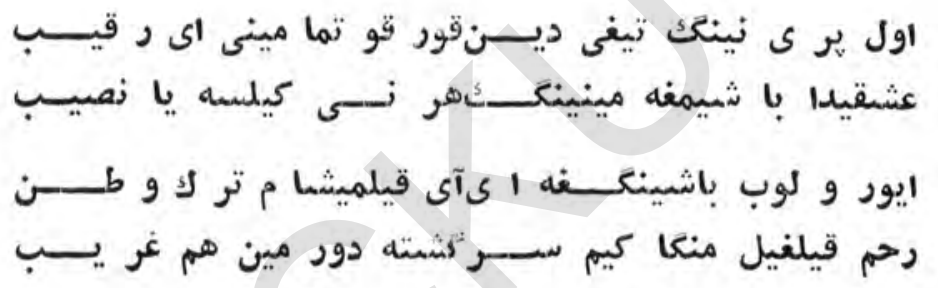

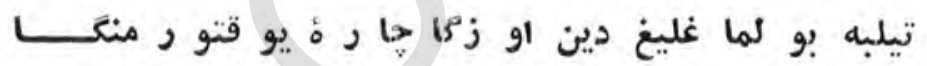

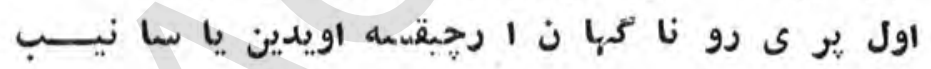
جاندا بير كيتعا ن او قيسنجمكما كو منغا ر نجبى دور ور قو يغيل او ل او قنى، هيكايدبب رنج هيكمه اي طبيسب

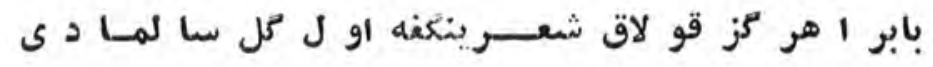

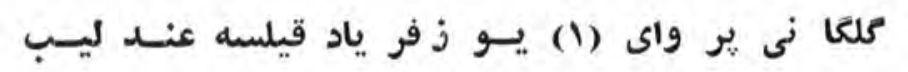

$$
\text { (1) }
$$




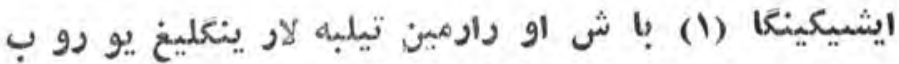

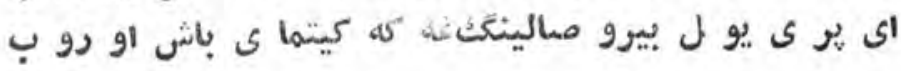

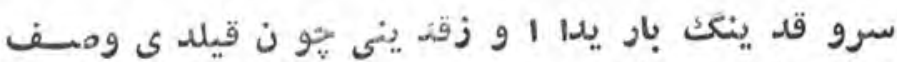

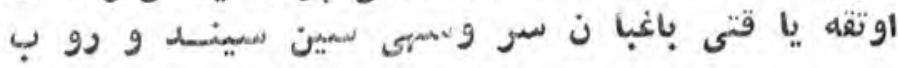

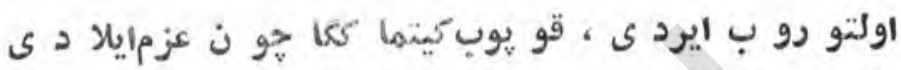

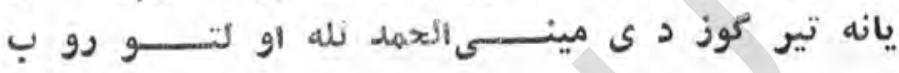

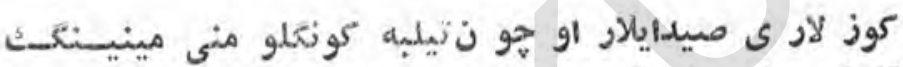

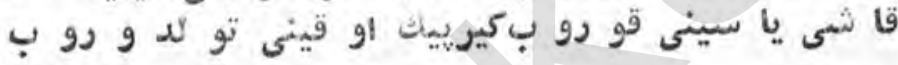

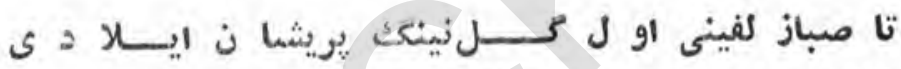

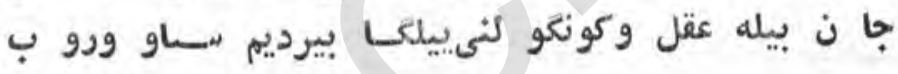
تابشور و ب ايرديم كو نكولنى يار غله جون باردى(ك) يار

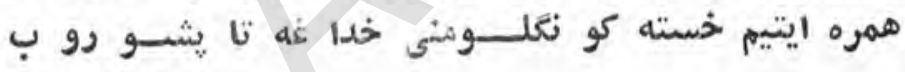

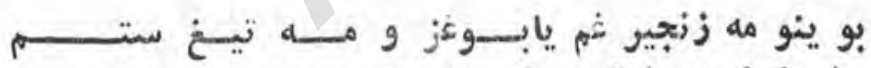

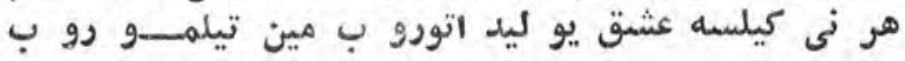
مين بيلور مين كو ز مى قـاتز، كلعلى جانبخش ايو كانين

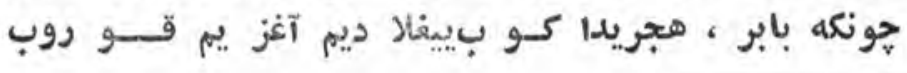

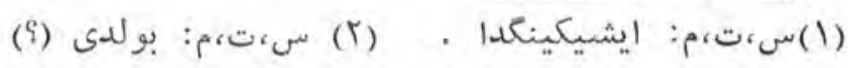




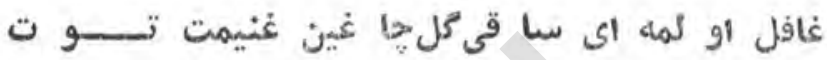

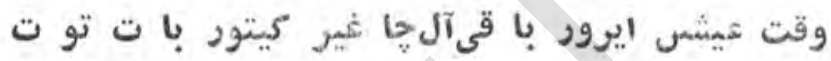

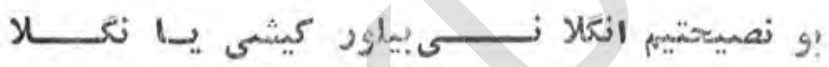

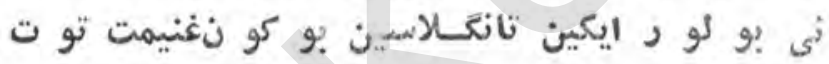

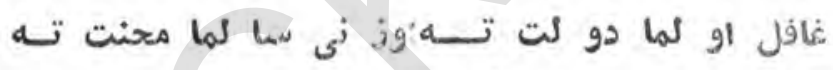

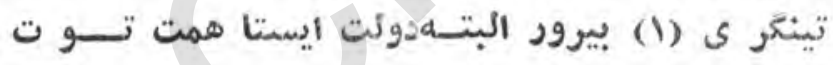

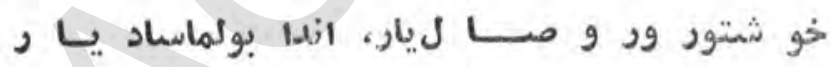

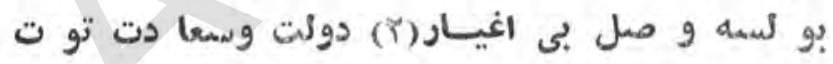

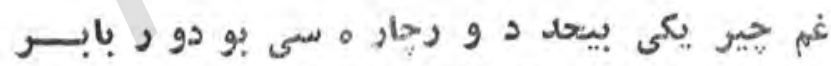

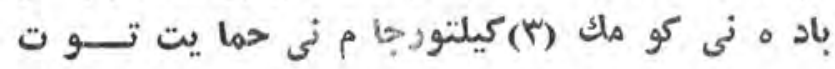

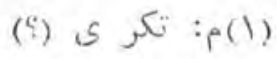

$$
\begin{aligned}
& \text { (5) } \\
& \text { (؟) } \\
& -V_{-}
\end{aligned}
$$




\section{(Vr)}

اى يوزى نسرين(1)، قا متىشمشاد

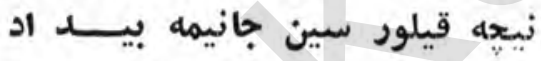

سبين كيبى.

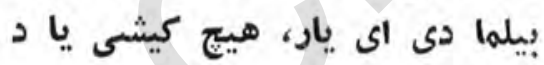

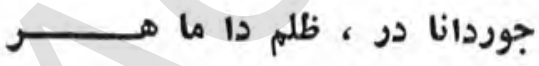

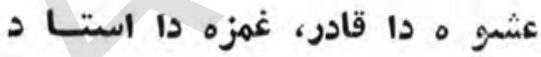

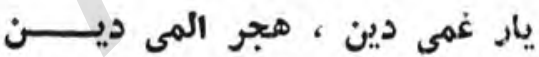

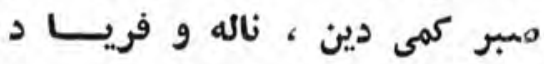

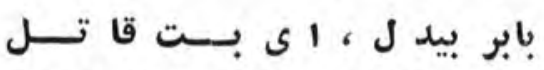

جود ونغامايل ، ظلمو نغا معتـا د

$$
\text { - ن }
$$




\section{$(1+r)$}

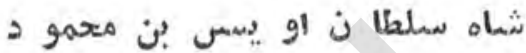

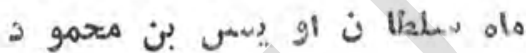
قل و آغزينكدين آيرو تار تار مين

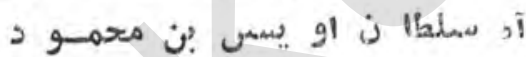

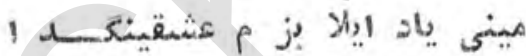

د إ oladav ذواثمتودور همبر هيماكر سمينسين

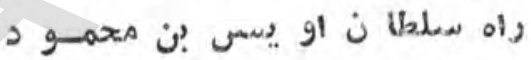

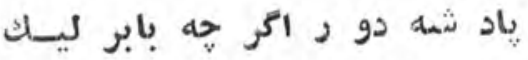
ثشاه سملطا ن او يسمر بن محمسود 
(4)

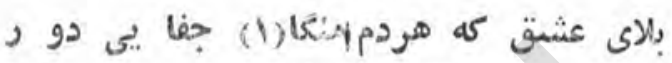

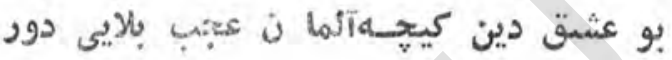

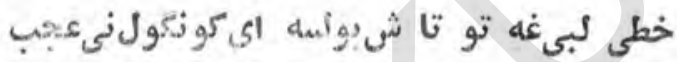

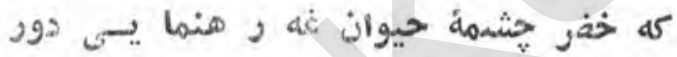

ياراربوختهلكو نغول دردينهاو قين ياراسيى

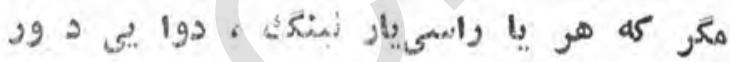

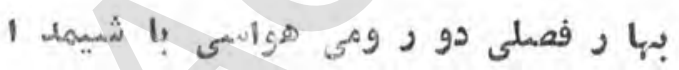

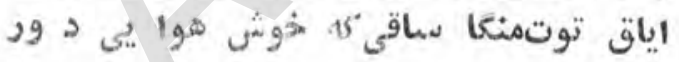

اول آى رقيب غه بولأي رفيقو بابر نينك

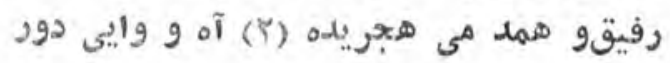

(९) Rim : Vel(1)

(T)

$-1$. 


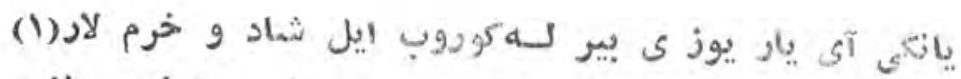

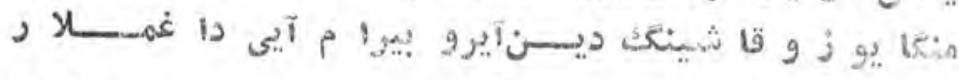

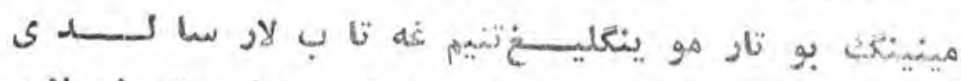

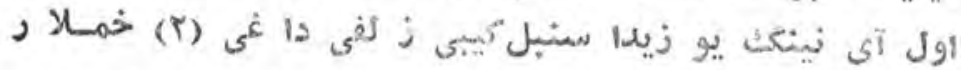

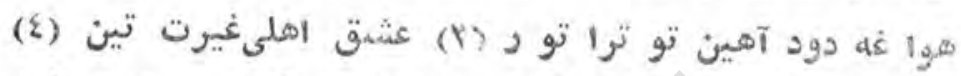

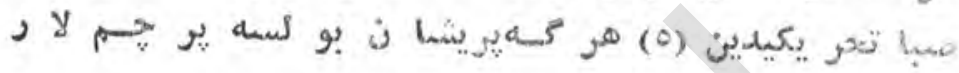

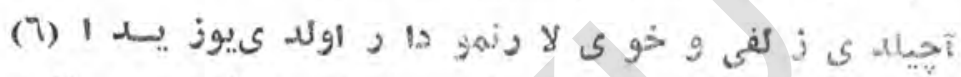
كال او ز آحيا

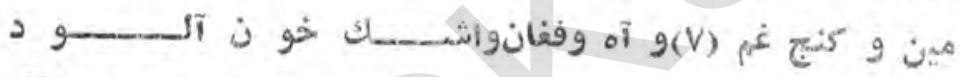

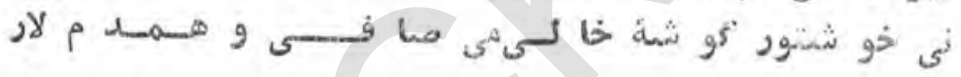

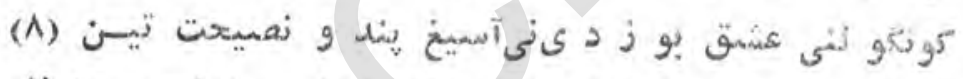

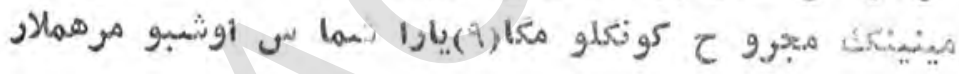

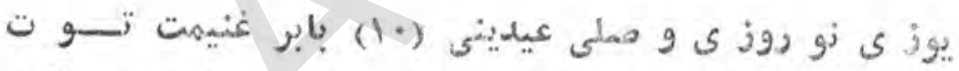

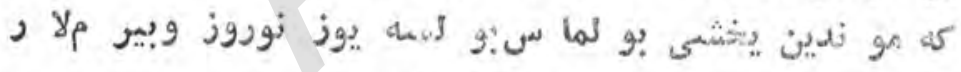

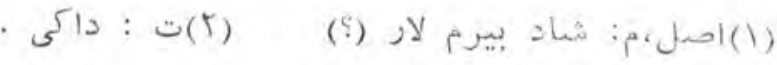

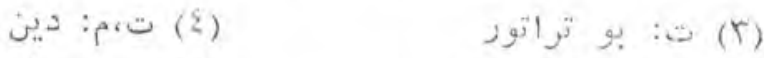

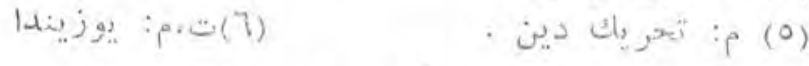

$$
\begin{aligned}
& \text { دين (V) }
\end{aligned}
$$

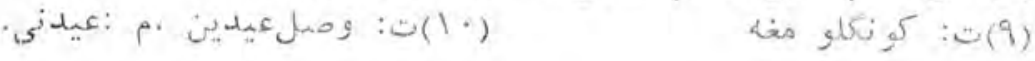

$$
\begin{aligned}
& -11-
\end{aligned}
$$




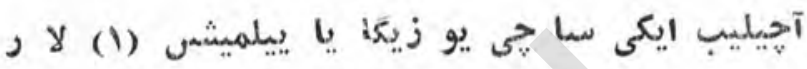

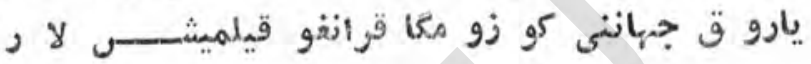

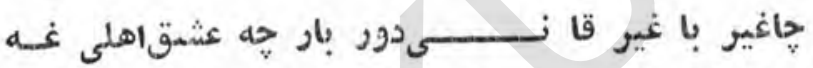

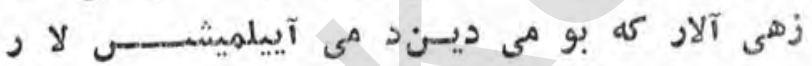

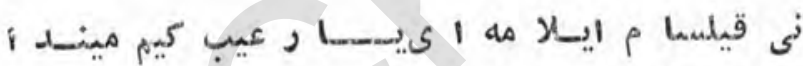
جنون وعشمق و ييكيتليكك بـســا رى قا تيلميشس لار

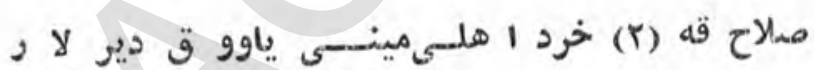

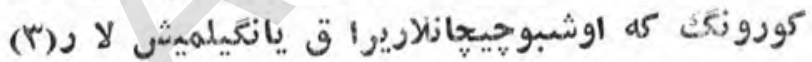
نى سمود عشق نى ايلد ينيســــا شمور ماق اى با بر

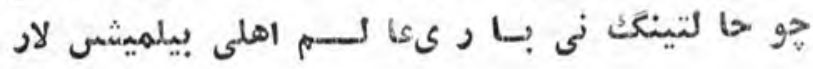

$$
\begin{aligned}
& \text { Aيhol: (1) } \\
& \text {. } \\
& \text { (r) بوبيت زاشكند نشريده يوق. } \\
& -15
\end{aligned}
$$




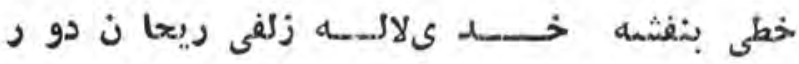

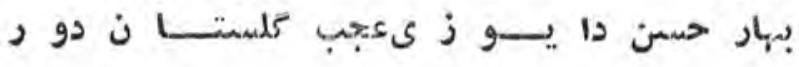
ايكى (1) مينكى آىوداغىيوذى (Y) سموزى ملرو مل

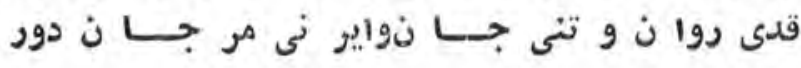

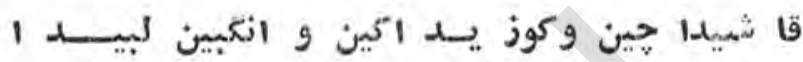

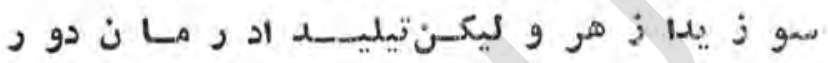

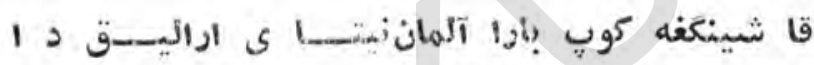

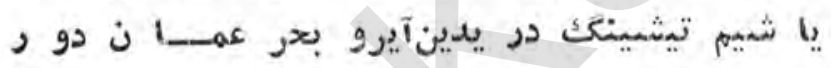

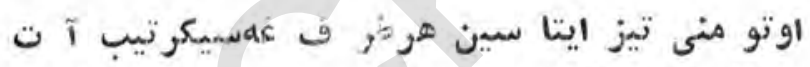

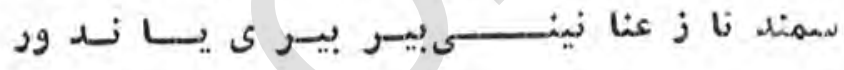

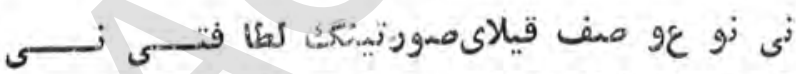
كa

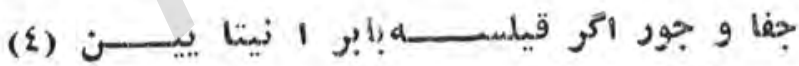

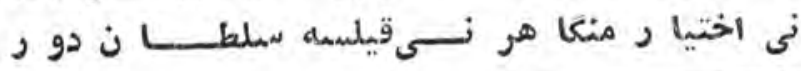

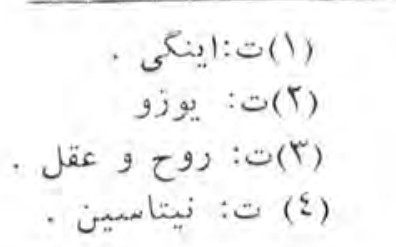




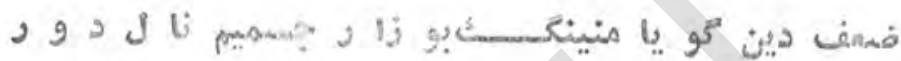

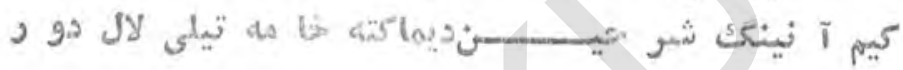

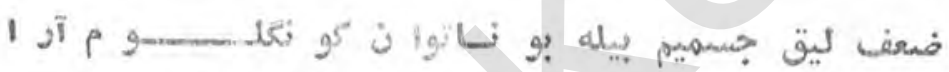

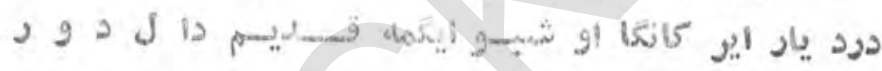

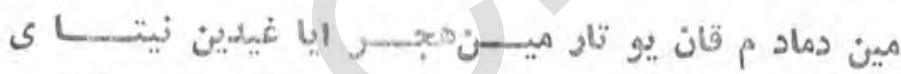

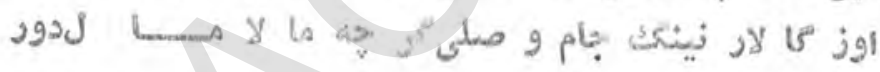

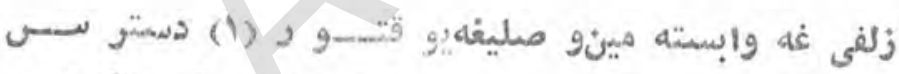

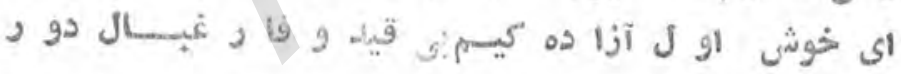

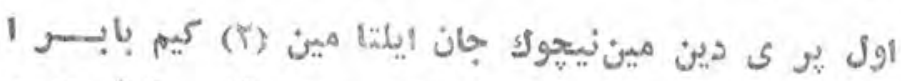

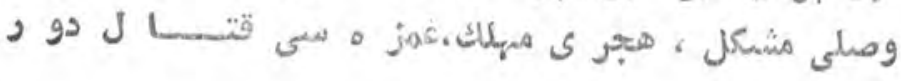

$$
\text { • (1) }
$$

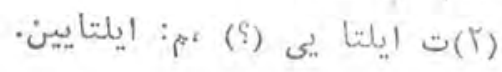




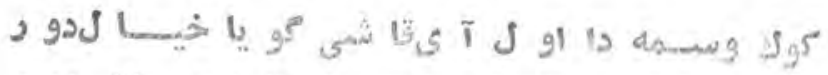
يا

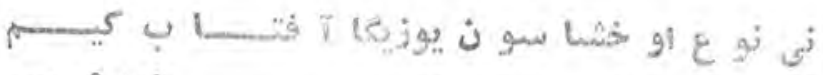

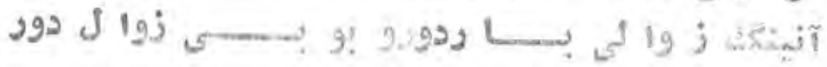

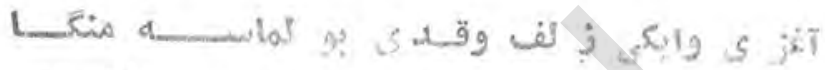

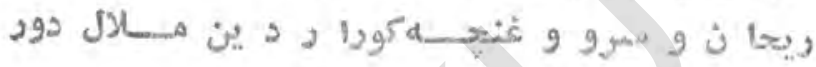
(1)

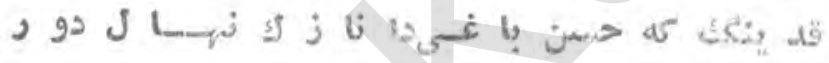

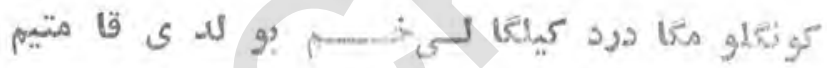

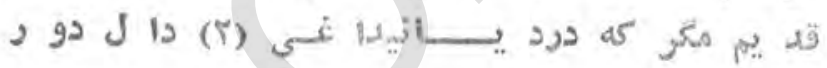

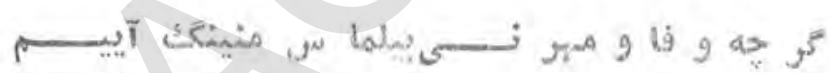

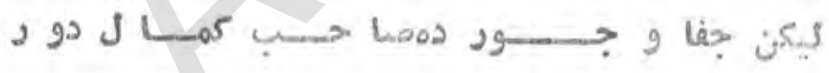
Dر ز

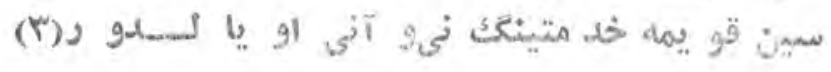
(1) . (؟) : $-10$ 
كو نعلو منى حو او لإنسـسـر ى آليب تسـور

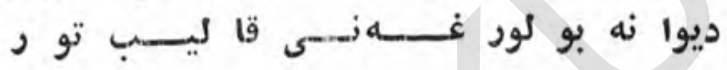

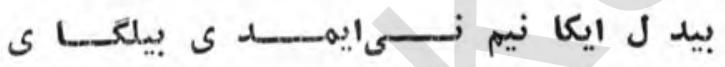

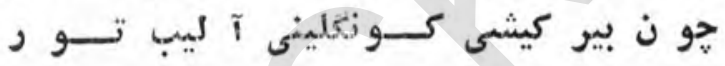
كو نعلو منى آ ليــب تنغا فليهـــن كـــو ر

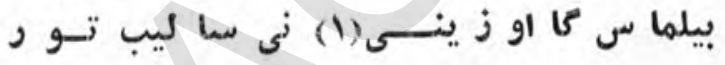

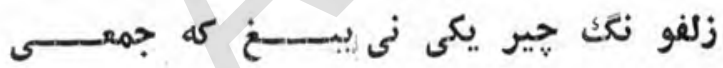
بو فتنه دين آ سـر وقو ز غا ليســبـ تو ر

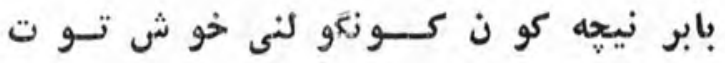

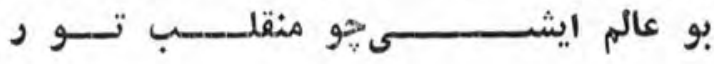

$$
\text { · (1) }
$$


(iv)

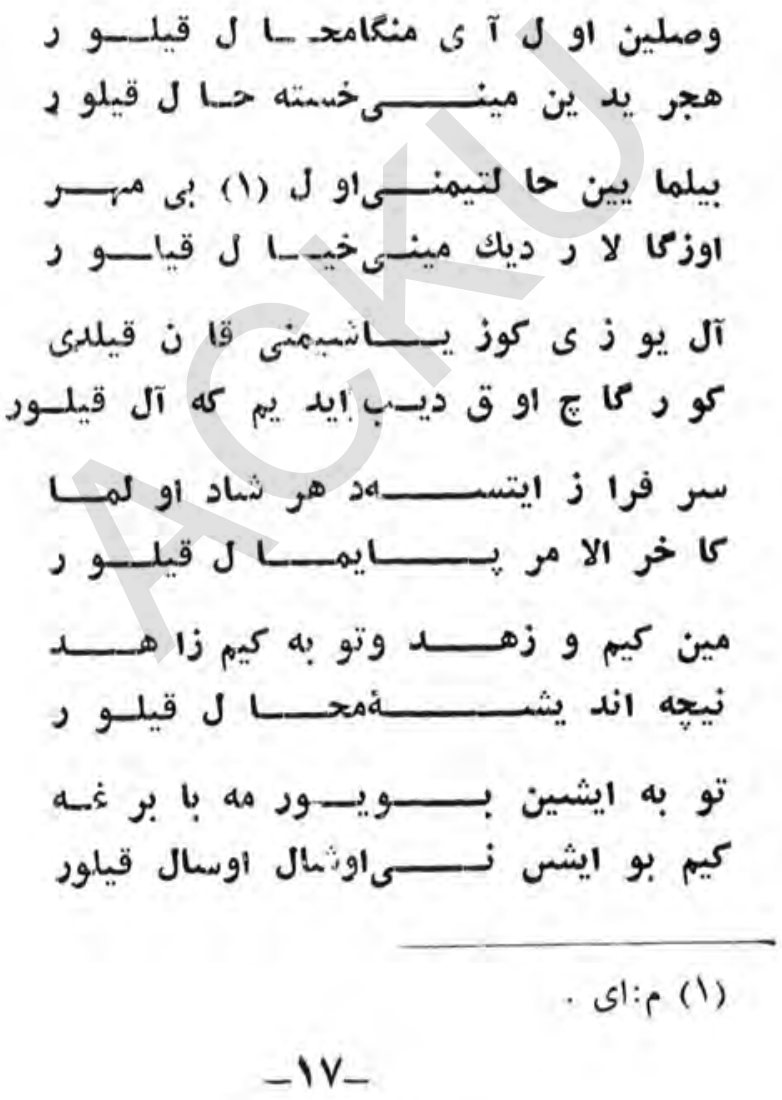




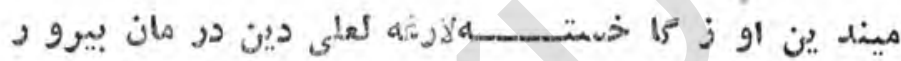

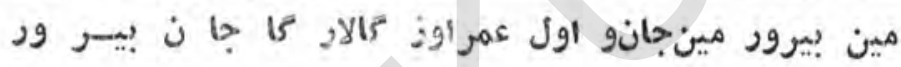

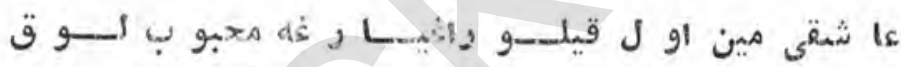

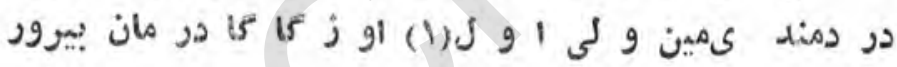

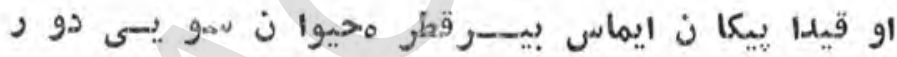

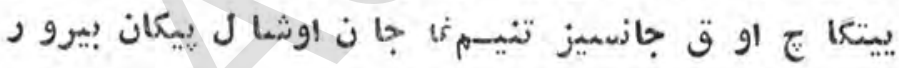

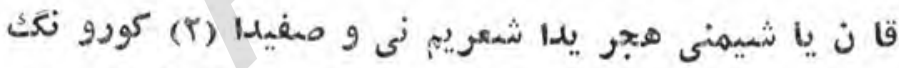

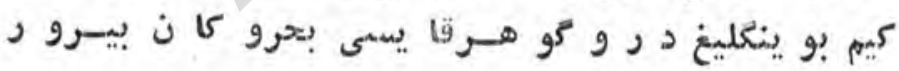

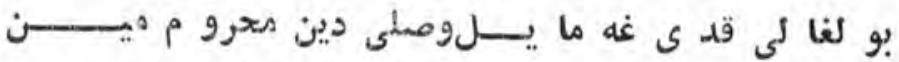

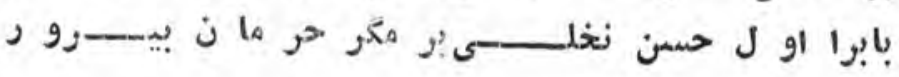

(؟)

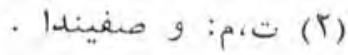
$-11$ 


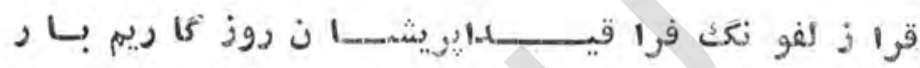

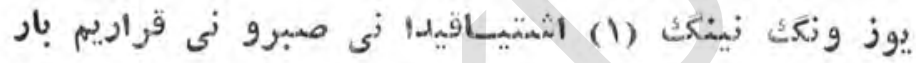

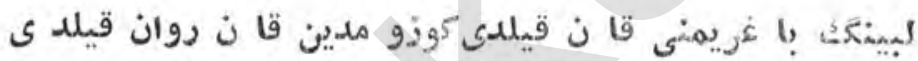

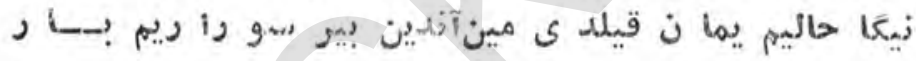

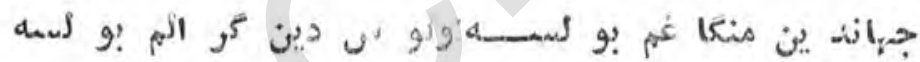

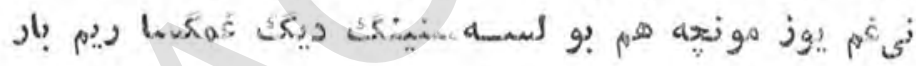

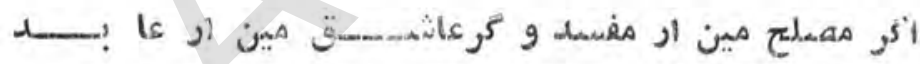

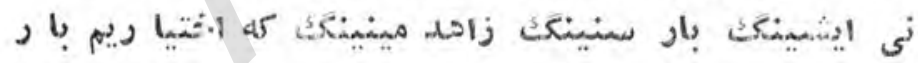

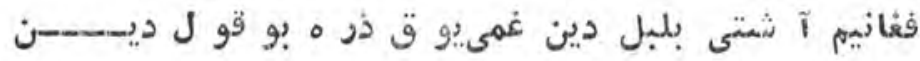

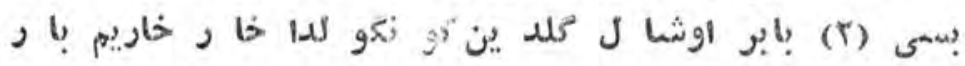

$$
\begin{aligned}
& \text { (1) } \\
& \text { تا }
\end{aligned}
$$




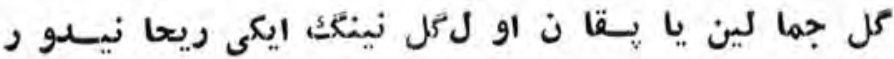

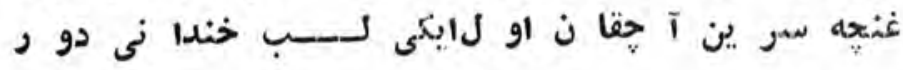
او ل هسماسمسل ايكى ز لفى كل يو ز

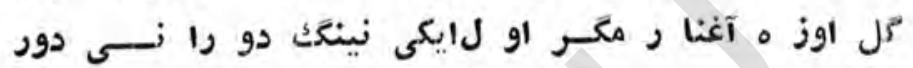

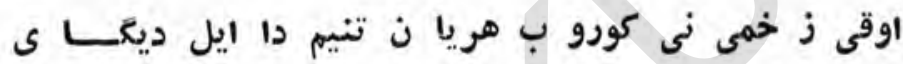

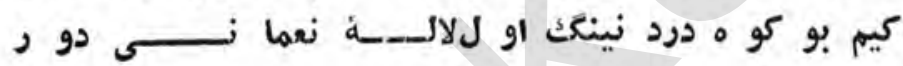
سيل ايماستور (r) يير يو زين تو تقانكوزوم نينكك ياشمىدور رعا- ايماستور(r) كو لكاحير ماشقان كونكول افغا نىدور

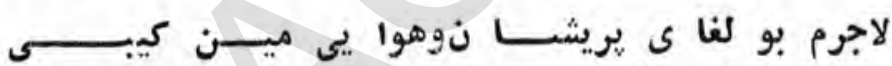

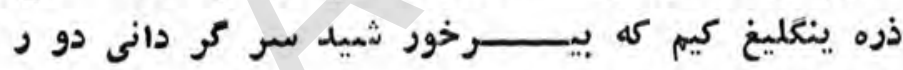

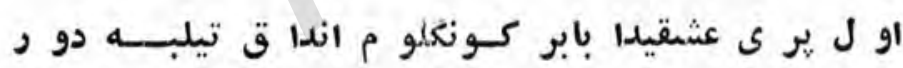

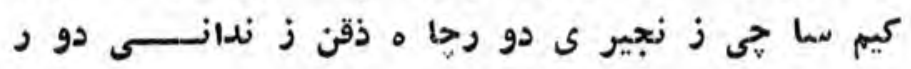

$$
\begin{aligned}
& \text { (1) (1) من.تم: او ستيدا } \\
& \text { (r) } \\
& \text { - }
\end{aligned}
$$


مينينك كو نكلو م كه مل نينكفغنهه سيد يك ته به ته قا ندو ر اكر يو ز مينك بهار او لسـهآحيلما غى نى امكان دور

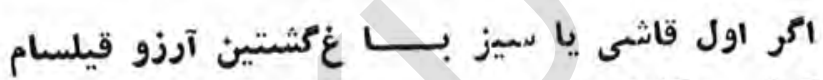

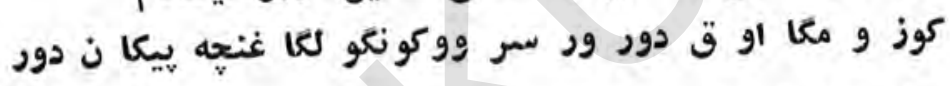

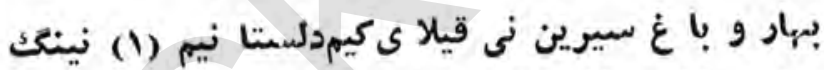

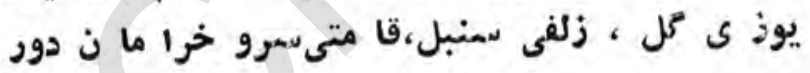
ومها كى لذتى دين دو ح (r) تايما كليغ(r) ايرور دشوار

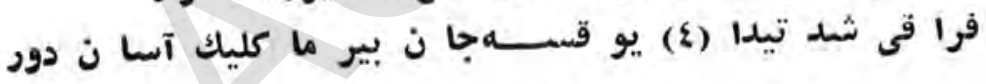

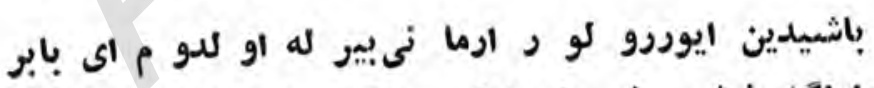

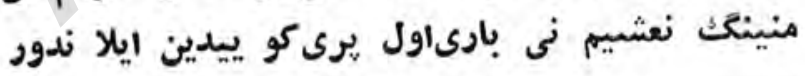

$$
\begin{aligned}
& \text { (5) (1) } \\
& \text {. }
\end{aligned}
$$

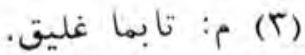

$$
\begin{aligned}
& \text { (ع)تم:م: شد تيندا. }
\end{aligned}
$$


احو حه سين سيز ين صبر ايلاماك اى يار مشكل دور سينينكك بير له حيقيشما غليق(1) دا غي بئ بسيار مشكل دور مزا جينك نا ز لك و سين تندو(r) هين بير بى اد ب تيلبه

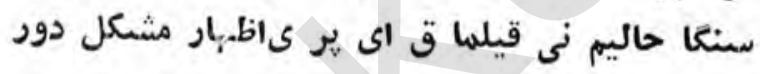
نى آسيغ نا له و فرياد خوا بآلود بختيم دين بو اونلار بير كل حو ن قيلما قآنى بيدار مشكل دور منكا آسا ن دورور بو لسه اكريوز مينك تو ما ن دشمسن ولى بو لماق جباندا اى كونتول بى يار مشكل دورد دور وصالين كيم تيلار سين ناز ينىخوش تار تغيل (r) بابر

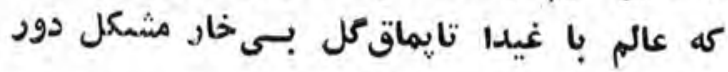

$$
\begin{aligned}
& \text { · (1) }
\end{aligned}
$$

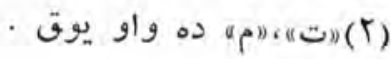

$$
\begin{aligned}
& \text { (ז) }
\end{aligned}
$$$$
\text { - rro }
$$ 


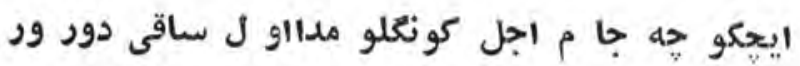

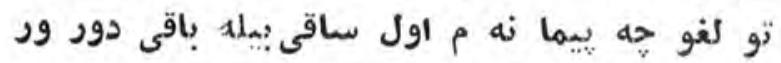

باش كو تار مان (1)با ده ديسن جو ن بار (ץ) ايا غى اورتا دا قو يما ن ايلكيمد يُن ايا ق حو نجلو ه مرسا قيى دودور

ايكمه قديم عيب قيلمه قا شيى آلار عشدقيدا

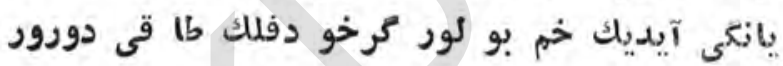
اول هلا لينك بير له خور ثيدينكك صفا تين ياز غالى مختصعر دور فى المثل كر حر خاورا قيى دورور

(ن) عشق ايالامى دين كونكو لنى توزها غينكك نى سود كيم

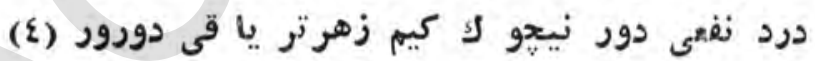
توك لار خطى نصيبينكك بو لمساسهه بابر نى تانتك

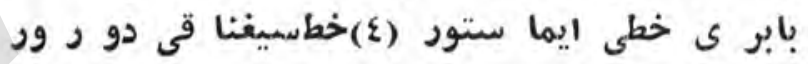

$$
\begin{aligned}
& \text { (؟) (1) } \\
& \text { - يار } \\
& \text { (ז) }
\end{aligned}
$$

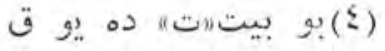

$$
\begin{aligned}
& \text {. (0) }
\end{aligned}
$$




\section{ياردين آزار كونعلوم ايُجر •بسى آند بار دور

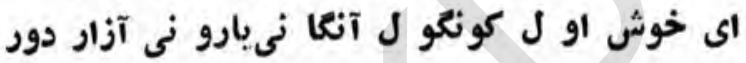

يو قتود و ر كر يار (1) يو قتورطاقت و صبرو وارو شكيب يار اكر باردور جفا وجورومحنتيار دور ورو

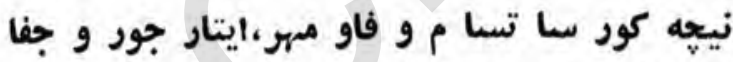

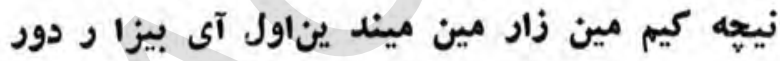

كوز ى هجر يدا ، يوز ى يا ديدا،سوزى شو قيدا خاطريم افعار و جسميمزارو كوزخو نبار دور ، يوز

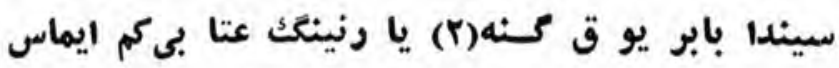
جرم سيز دايم عتا ب ايلار،عجبدلدار دور

(1) (1) ده "(1)

(؟) (r) 


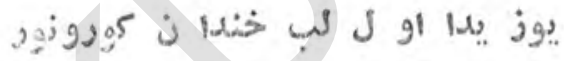
200

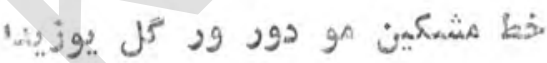

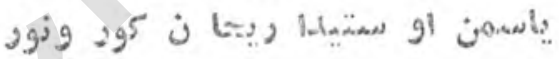

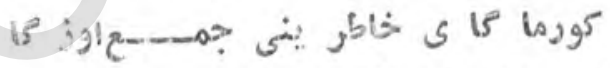

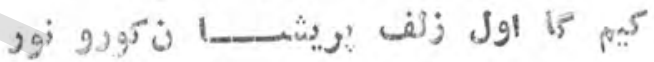

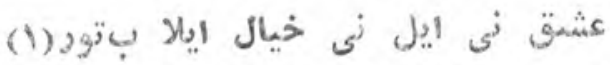
أسمرو مشهل دور ور آسما نكورونور

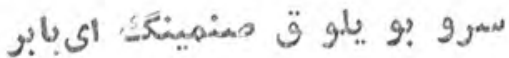

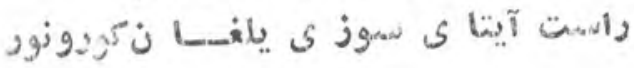


(TV)

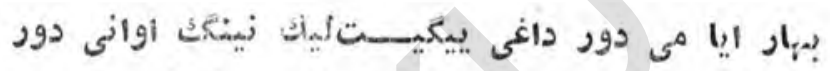

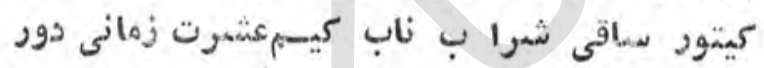

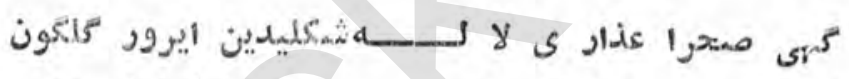

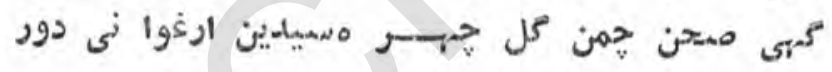

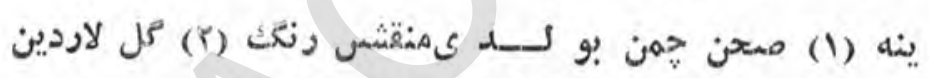

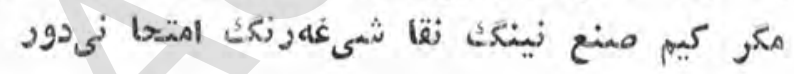

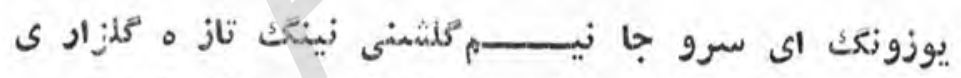

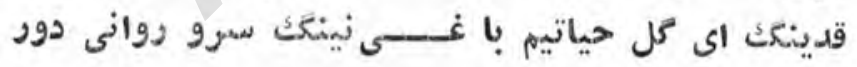

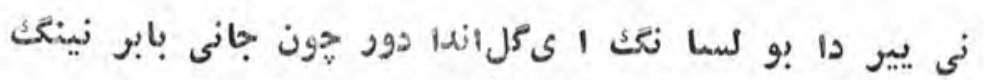

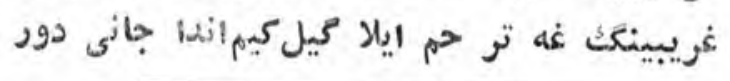

(1)

. di ر : 
(V9)

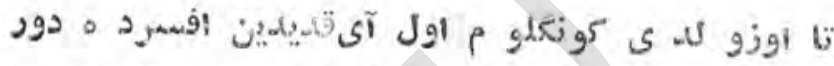

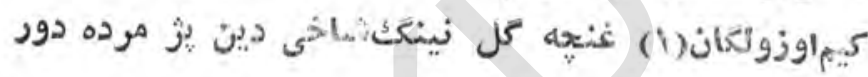

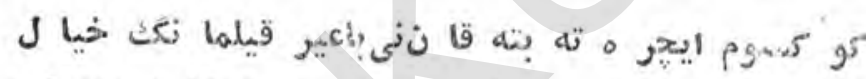

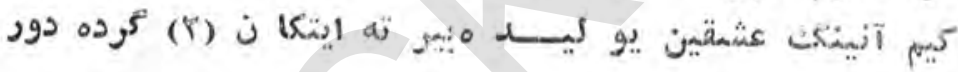

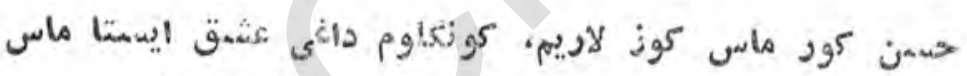

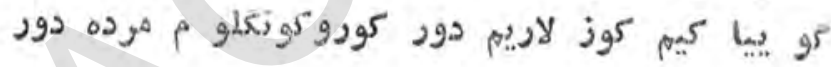

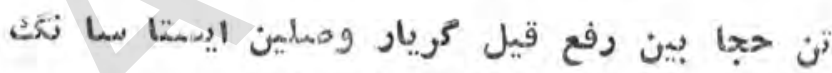

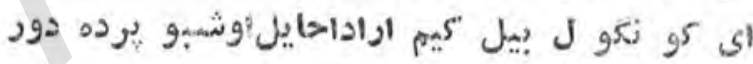

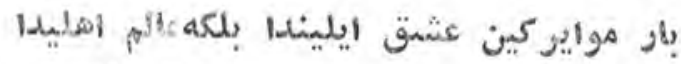

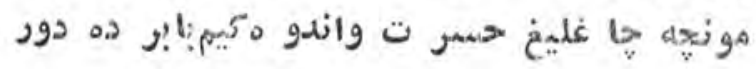

(؟)

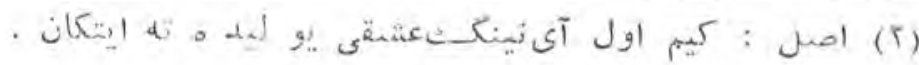
$-r \mathrm{~V}$ 


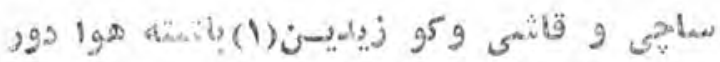
3 قالخ و

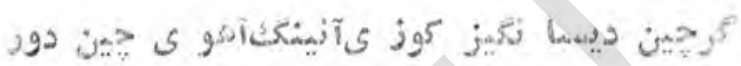

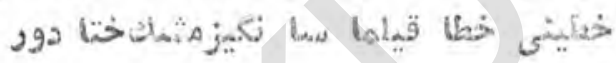

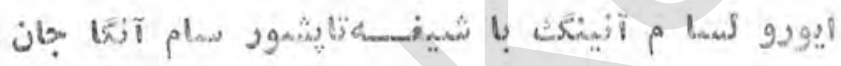

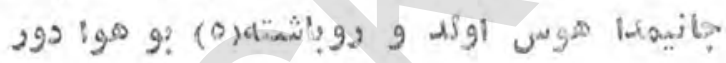

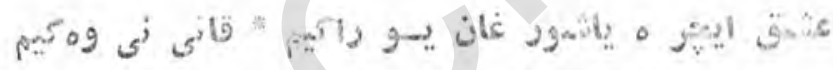

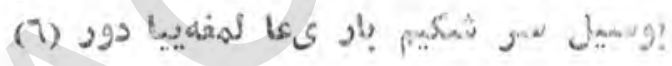

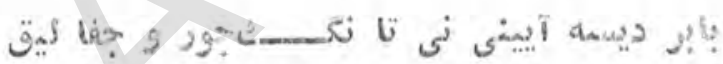

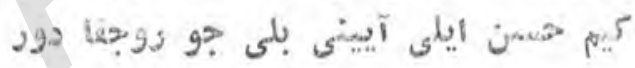

$$
\begin{aligned}
& \text { (1) }
\end{aligned}
$$

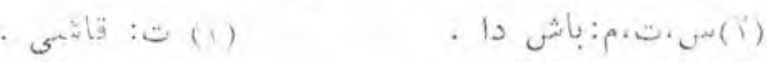

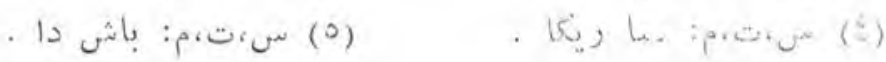

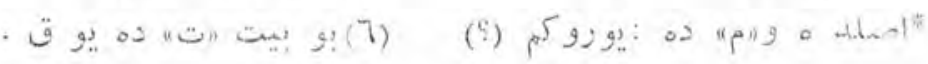

$$
\begin{aligned}
& \text { - PA }
\end{aligned}
$$




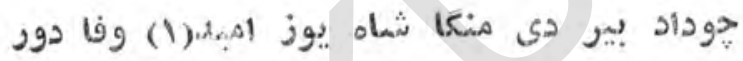

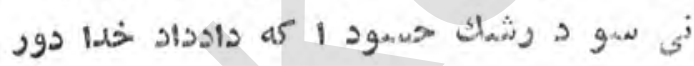
زs

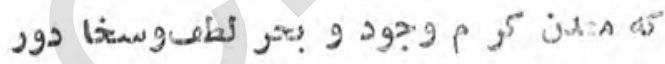
إن

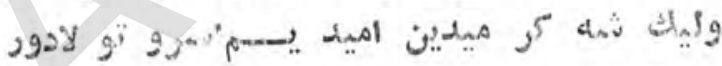

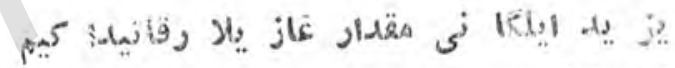

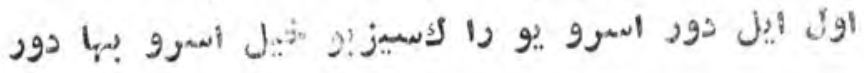

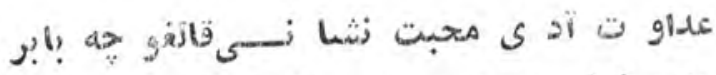
عدو خيل يز ين و محب آل عبادور . (1) 


\section{(119)}

غربت ته اول آى هجر ى مينى بيرقيليب تور

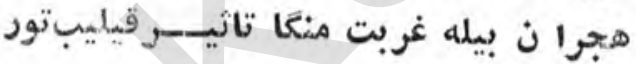

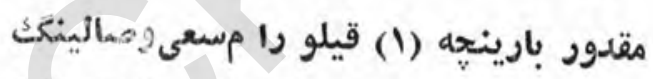

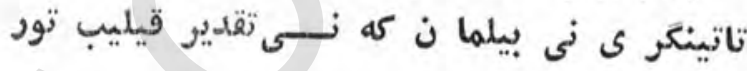

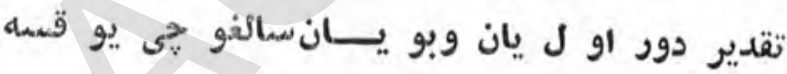

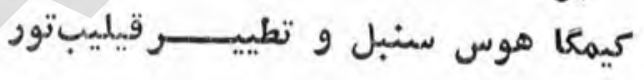
بو هند يير ى حاصلى دين كوب كونكو ل آلديم نى سمود كه بويير مينى دلكيسر قيليب تود دوري سيندين بو قدر قالدى ير ا قاولما دى بابر

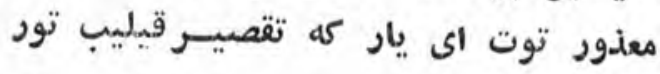
(1) $-r \cdot$ 


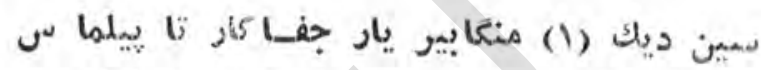

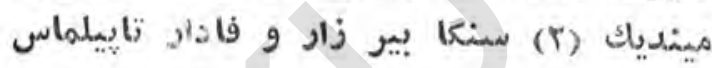

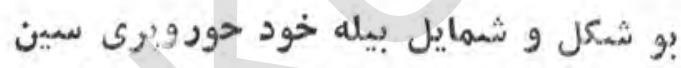

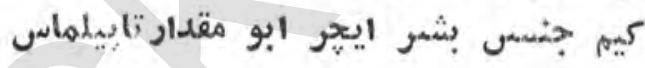
اغيار كوز آليد ه واول يارعيا نيوق

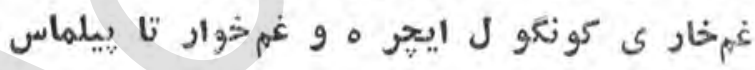

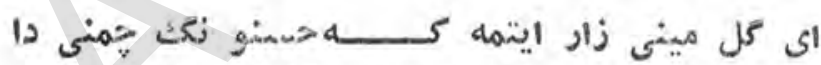

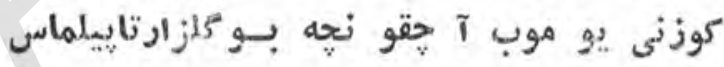

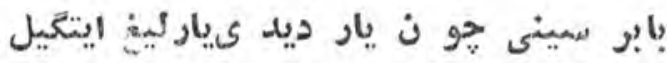
عالم داكيشى كايو ق ايسمه يارتأيشلماس

$$
\begin{aligned}
& \text { - (1) } \\
& \text { · }
\end{aligned}
$$




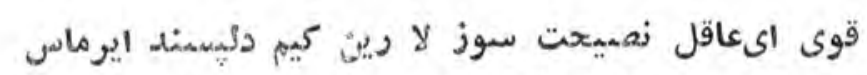

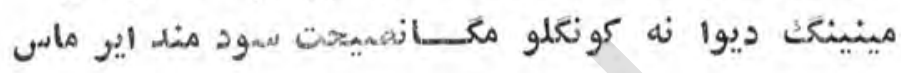
نيسهة ديوانه كو نعلو منى قيلوربنين نفى اي عاقل

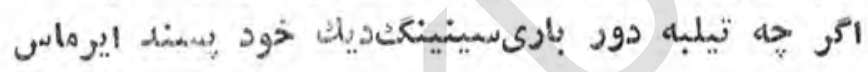
قيلور سمين تلخ عيشيم كا مينى إمبهود ه سموزلا ردين

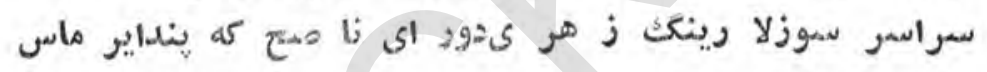

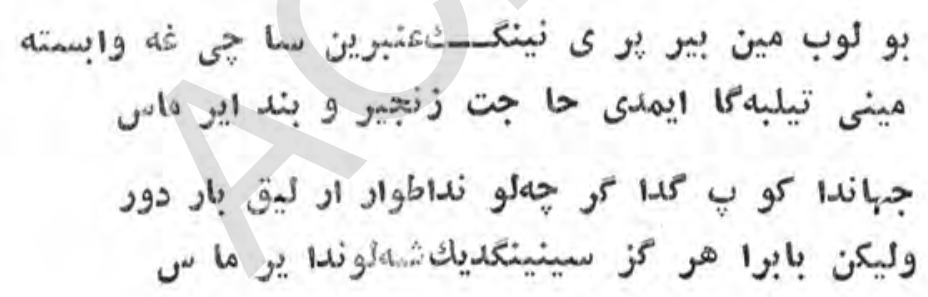


اول آى نينكك اتفا قى نفا قى غه(1) آرز يماس

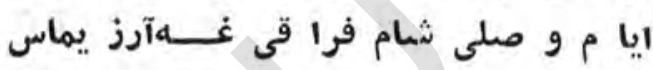

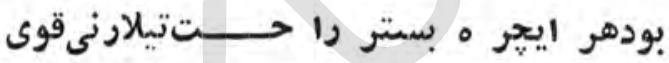
او ل فرش جو ن بو كهنه رواقىغد آرز يماس عيشى كه او تتى اوز كا آنىذكرايلاما

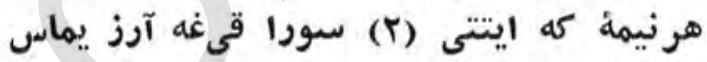
قيلماق اميد و بيم ايلهخد مـتشهه آليده

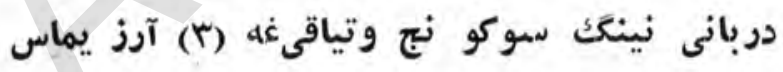
بابر و صا ل نىنى تيلار سيسنجو هجر بار بير لحظه عيشس، محنت با قـى فئه آرز يماس

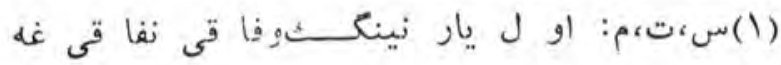

$$
\begin{aligned}
& \text {. } \\
& \text { (r) م: وثاقى غا . }
\end{aligned}
$$


آلد ى كونتلو م نى سا غينديسم كيم منغا دلدا ر ايميشس

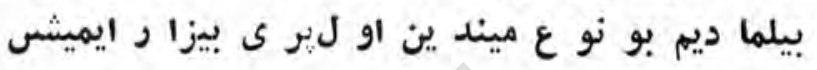
عاشق اولغا ج كور دوم او لشمششداد قد دين يوز بلا

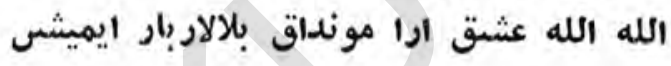
التفا ت ايتماس ليعين بازى خيالايلار ايديم

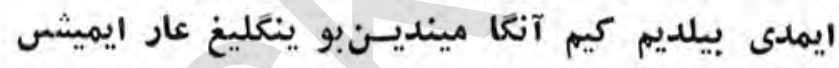

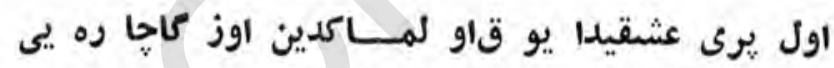

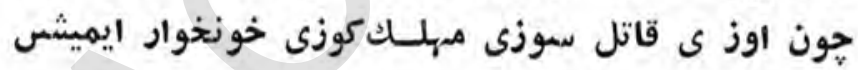
حسن اهلى اي كونكول عالم اراءشق املى نينغك

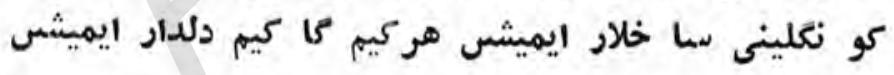

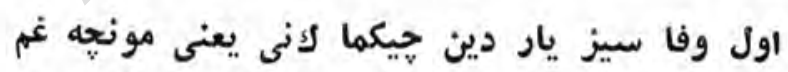
حسن اهلى جونكه بابر دنيا دابسيار ايميش ونس 
نيجهه دورا ن غصه سيو لغا ىمينينك جانيم غه خاص كاششى اولسطا م داغى بو غصهدين بو لسطام خلاص آهوواويلا سرود وم دردو غم همصدحبتيم

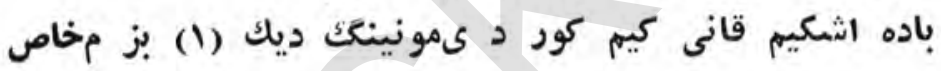
كر شكستيم بو لسه سست (ז)اغبار دين طعن ايتمانغيز كيم شكستى غه سبب الما سـىنينك بار دور رصا ص سئه عاثق اولغا ج بيخود و ديوا نهبو لدو م بيلما ديم كيم ير ى ر خسار ه لار عشقىعه :و اير ميشس خواص خوبلا رنى كوز كورو ب قا نقيلد ايمدى كوز دين قان تو كار مين كيمبو دور انغا قصاص

$$
\begin{aligned}
& \text { - (1) }
\end{aligned}
$$

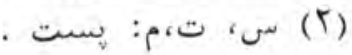


كيم كورو بتو ر (1) اي كونتولاهل جهاندين يخشيليغ

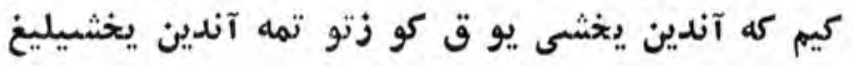
كرز ماننى (r) نفى قيلسا م عيبقيلمه اى رفيق كور ماديم هر كز نيتايين بوزماندين يخشيليغ دلر بالار دين يما نليغ كيلـد ىمتزو ن كونعلو مه

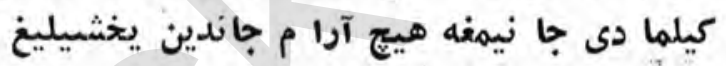

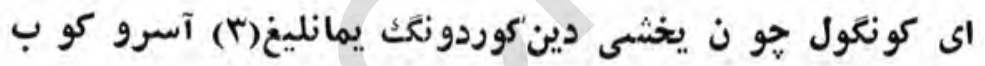

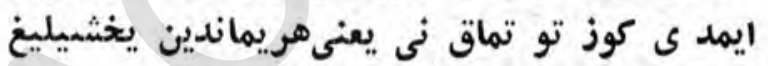

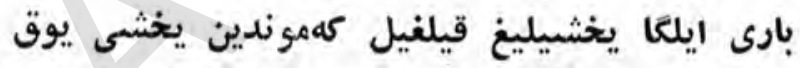

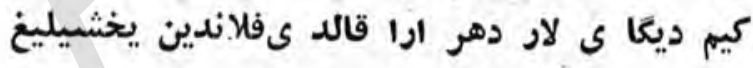

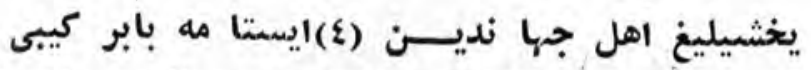

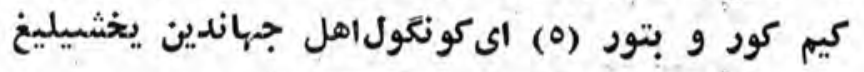

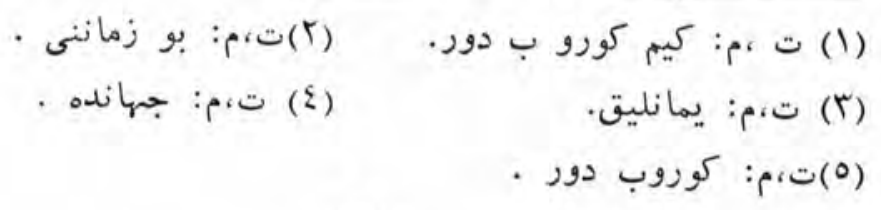




\section{(5.)}

سور مه حاليمنى كه بو لد و مبور ناغيدين زار راق

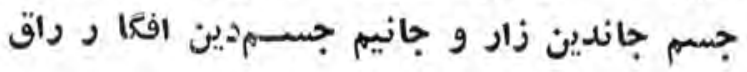

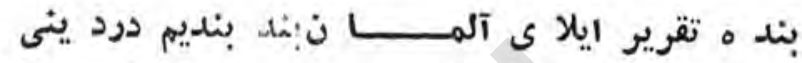

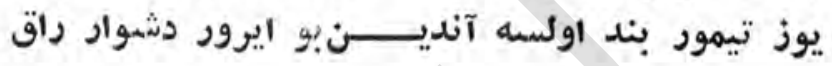
مست و بيخود لوق بيله عمر وزكنى اوتكار دينك دريغ ندي

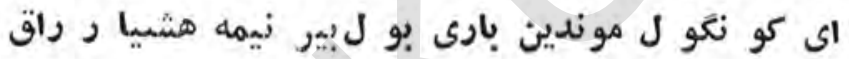
غفلت اويقو سيدين او يغان كرتيلار بو لسمانك مراد

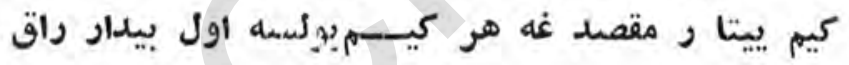

اولكالى ييتقيم هينينك جانيـــمغمين يـى (1) اي رفيق

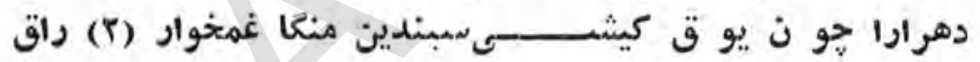
كيلما س او خشا ر زحمتينكــامهلاح غه بابر مكر هو دواكيم قيلد يلاربو لدو نتكثقى (r) بيمار راق

$$
\begin{aligned}
& \text { · (1) } \\
& \text {. }
\end{aligned}
$$

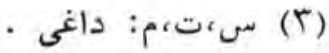$$
-r V
$$ 


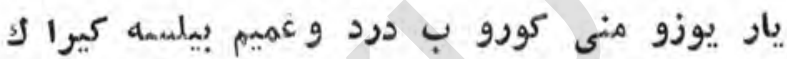

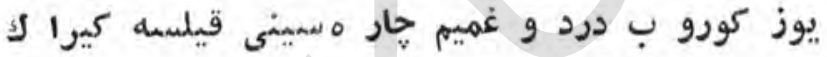
اي صبا جا ن و كونكو لنى اوزىنيمك جو ن قيلد ى

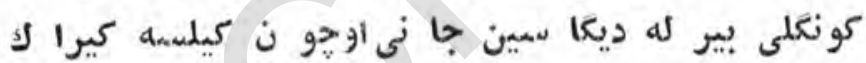
وصلينى نى قيلا يين غير ديسن آير يلما دى هيتح

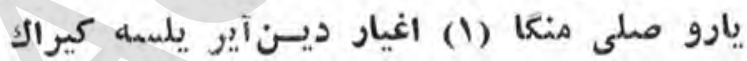

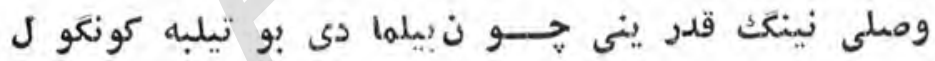
هجر ى نينكك تيفى آنينك يوراكينى تيلسمه كيرا لك

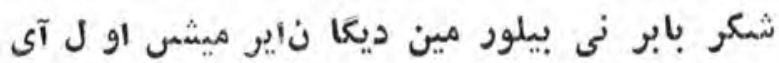
لاجرم بند ه لارين شـــاه لار ى بيلسمه كيراك (1) 
بير مرو ى مين تيلبه نى حسنسى نيه مايل قيلغو ديك

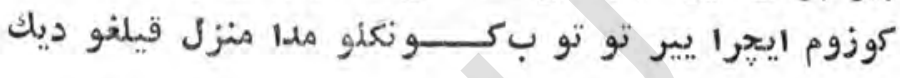

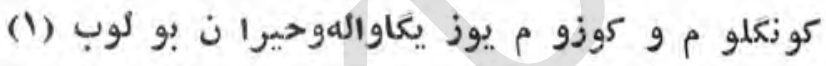
جانيمه يوز مينكت غم و محنت نى حاهمل قيلغو دوريك زاتوا ن جانيم غه(ץ) عشقى قايغونى كملتور كو ديك

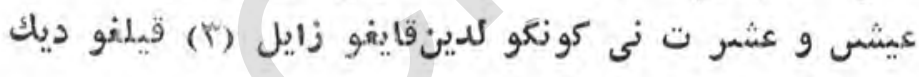

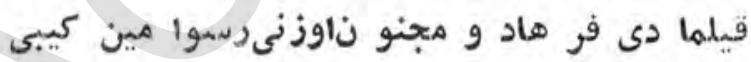

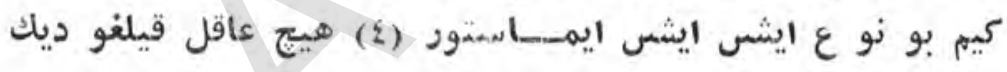

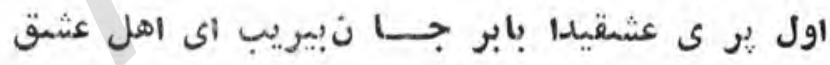

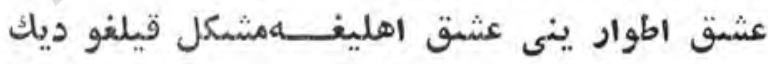

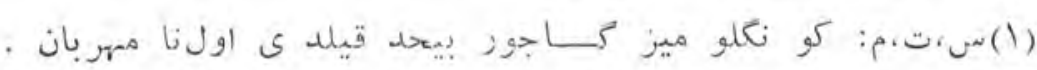

$$
\begin{aligned}
& \text { (T) سيتماتم: ناتوان كو نكلومكا. } \\
& \text { (r) }
\end{aligned}
$$

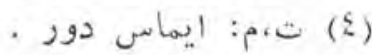


جيكسه قو ياش فلك كا سينآتقه جيقةا نينك ديك ولغا ى مو اولسينينغد يكاولبيرى تو سنينك ديك كوكسوم نى هو ن كه ياردينك، كير كيل كونكو لكا كيم بار اول ياره ايشيكينك ديك ، كوزآند هـ روز

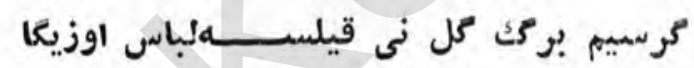
بولغايمو اى كلندام كو نعلا كبيله تنينكك ديك اول يا ر حضمر تينده بسيسـا ريخشى دور غير

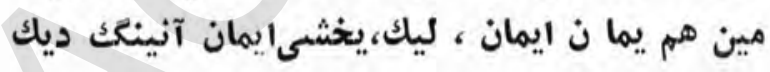
دعو ى عشق ايتيب غير بابر نىعيب قيلمه كيم مين ايديم سينينغد يك ،سين بئ بو بو لغين سين مينينك ديك 
(V०)

اوزنى كوزيكو ل عيشس ايله توزماقكيراك ?يز نى اونو تقا ننى اونو تما ق كيراكي عيشس و طرب تحلبنى غا ســـــوبيريب

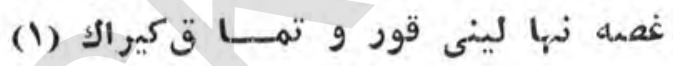
تير م دورور ز هد دمى ديـــن كونكول

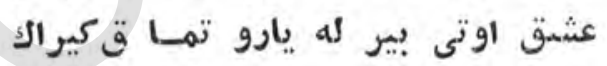

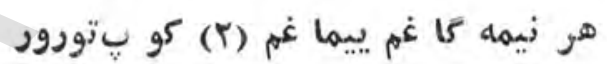
عيثم بيله اوز زى آوو تمسا قيم كير الك قويمه مشقت ارا بإبر كونكو ل

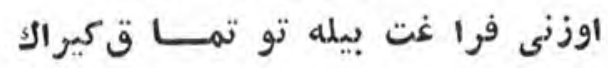

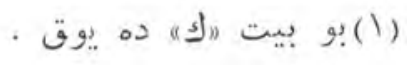

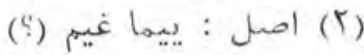

$$
\begin{aligned}
& -21-
\end{aligned}
$$




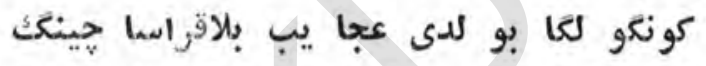

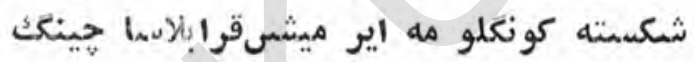
الثمبمغه حيقتى تو تون ر شـاكدين قرا سمات دين

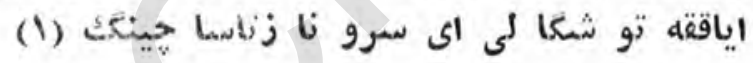
ميسمر اولد ى جنو ن ملكى الى إننون اهلى

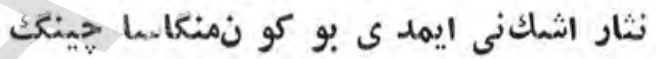
مها حينكك شكستيدا بار دو رئهنيته كونكول لار

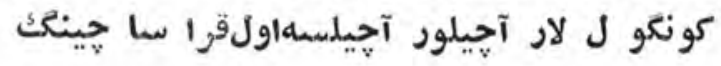

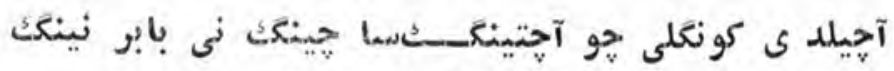
نى عيب اكر ديسمه دلبندودلكثماسما حينكى احتيك

$$
\begin{aligned}
& \text { (1) بو بيت "اته و "مم" دهيوق } \\
& -\varepsilon T-
\end{aligned}
$$


(ry)

أولتو رور كر حه هينى كفتا رينك

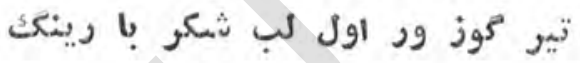
كو يدو رور حسدر تيدا مينـــىنيتاى

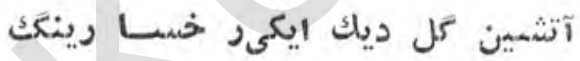
اي كو نكو ل يا خشى ايكى دنيادين

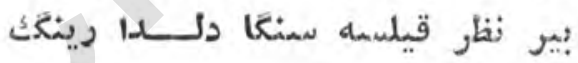
خوار كور ما غمين او ل آ ىنينكك كيم جو دو دور فر قتى دا غمخو ا رينكك قيلد ى تا مّل يوز ى دا ظا هرخطا

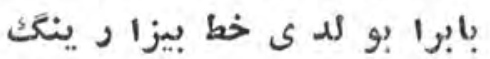
خرد و صبر (1) كيليب البته عشقيدين إيما ى مينى قو تقا رينك (1) $-\varepsilon r$ 


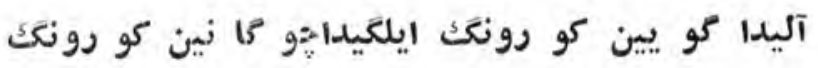
يوز يدا ز لفى بيله كو ىزنخدن ينين كورونكك

سيكرا تيب (1) ييلد وركا نيدهزوسنى غٔه كوز مسالينك يايقا ليب يو ل يو روسه سر وخرامانين كورونك ليك اول ير ى ميدان ارا جو لانسـد ميوز هينكَك نازايله

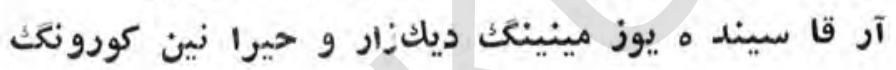

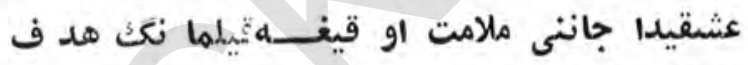

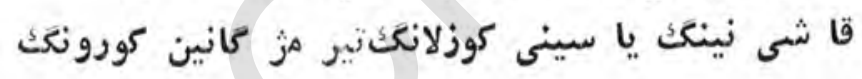
دير كه بابر التفا ت ايلاىسنكايتشكا ن زمان

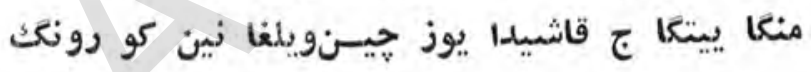




\section{(Vr)}

قايسى بير آزار ين آيتاى جانيمهأغبار نينكَك قايسى بيرآغر يتقا نين كو نعلومنى دى دلدار نينك نئك

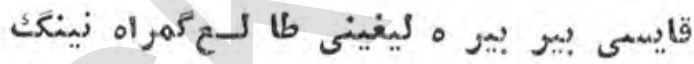

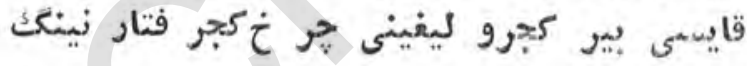

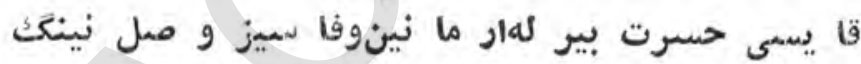

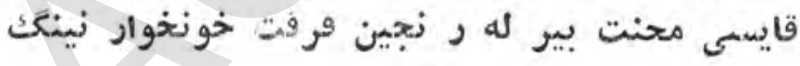
غر بت ايحֶر ه ایىونغو لايلدينوفا ايستا ر نى قوى

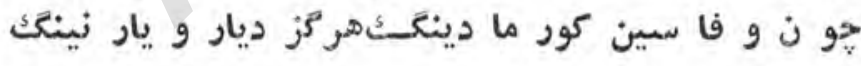
بابو اول مل جود ايتار اغياردين نىيخشميليغ (1) كل نينك آزار ى بوبو لسمه وهنى بو لغا ى خارنينك

$$
\text { (1) }
$$




\section{$(1+\psi)$}

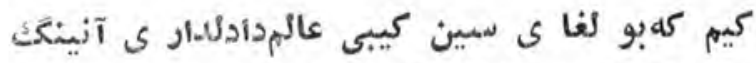

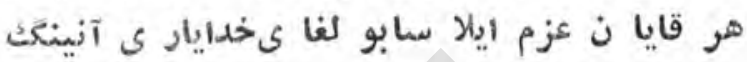
كو يى دين مين عزم (1)ايتارمينقالغو ديك تور خاطريم

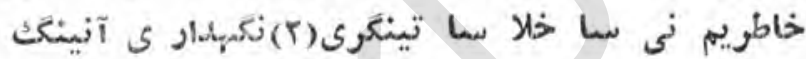

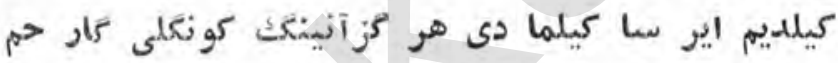

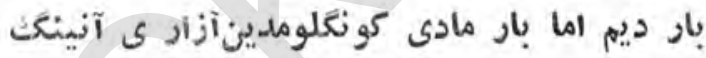

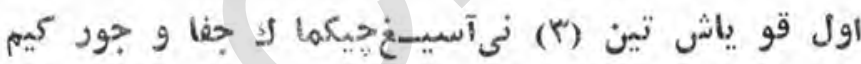
ميلى يو قتور ذرة مهرو وفــــاسأر ى آنينكك

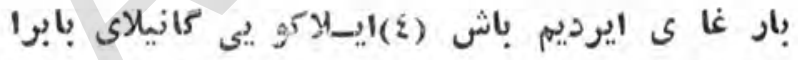

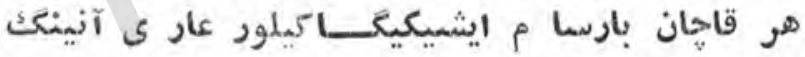

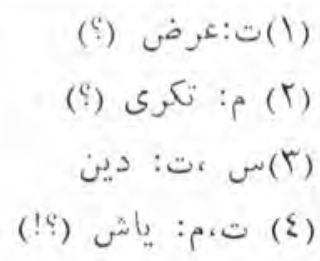


(सq)

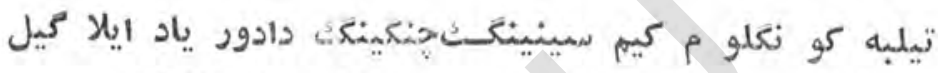

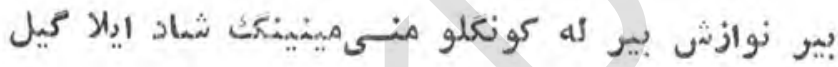

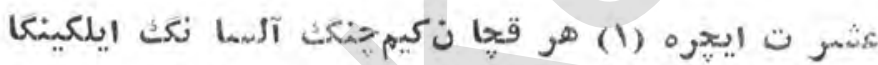

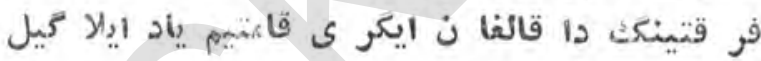

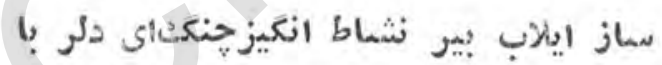

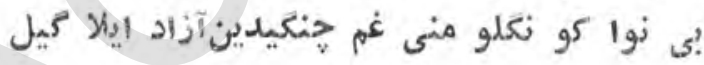

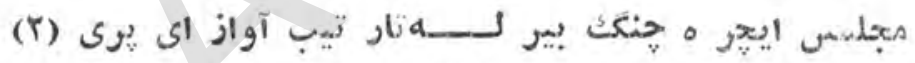
صمبرو هو شيم جزو و اورا قينى.رب بأد ايلا كيل

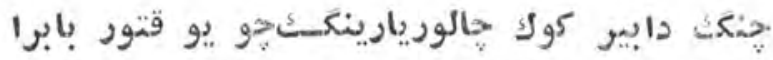
يير كا باشن حا لما ق بيله اوزوزيكنى معتاد ايلا كيل

$$
\begin{aligned}
& \text { (1) (1) (1) م: عشر تينكدا }
\end{aligned}
$$

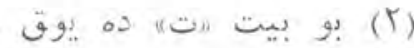




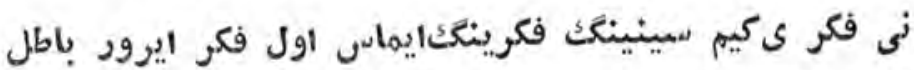

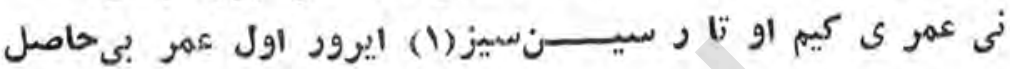
تعالى الله نى كوز و قاشدوروركيم هر قاحها ن كودسام

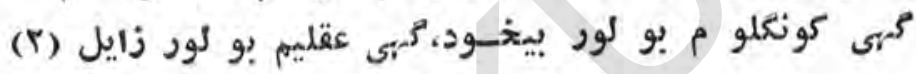

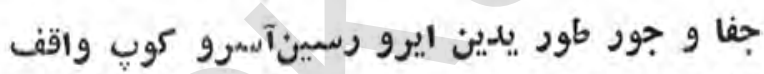

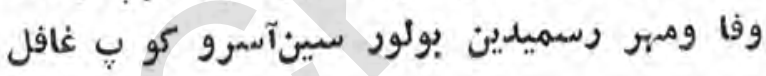

قو ياش ينكليغ يوزو نكا ميسـندور ور مين واله و حيرا ن

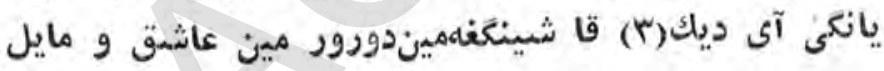

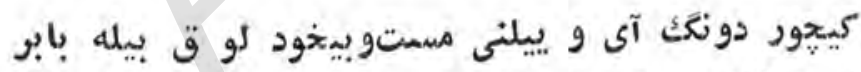

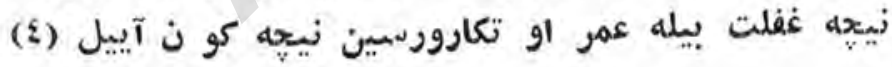

$$
\begin{aligned}
& \text { () (1) } \\
& \text {. }
\end{aligned}
$$

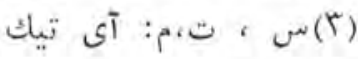

$$
\begin{aligned}
& \text { (؟) (آى ، بيل (؟؟) }
\end{aligned}
$$


جانيه دين اوز كايا روفا دا رتابِماديِم

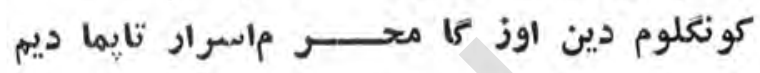
جانيم ديك او ز تا جا ننى د لافكار (1) كور ماديم كونتلوم كيبى كو نكو لنى كرفتار تإِما ديم اوسرو لك كوز يخا تا كهونتولبو لد مى مبتلا هركز بو تيلبه نى ينه هشيار تابِما ديم

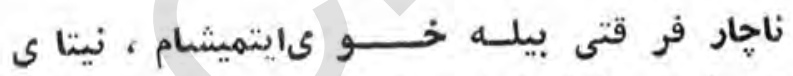
حو ن و صليغه اوز و منى سزاوار تإيما ديم بار ى بارا ى ايشيكيغا بوتو بتأى كونكول نيته كه باريب ايشيكيعا بار تإِماديه بابر اوزو نتنى اور كا تا كو ريار سيز كه مين ايستاب (r) جهان نى مو نجـهـيليب يار تإيما ديم

$$
\begin{aligned}
& \text {. (1) } \\
& \text {. }
\end{aligned}
$$


سينينك عشقينكك دا اي نامهربان بى خانما ن (1)بو لدوم

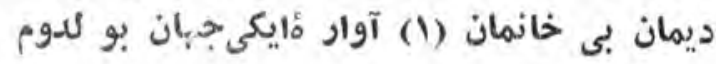

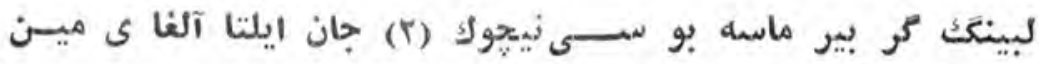

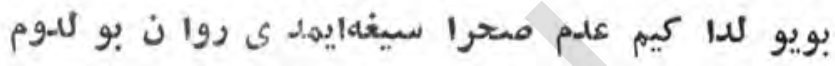
سورو ب اول آى لبى دين آغزىنينك دمز ينى انعلاديم

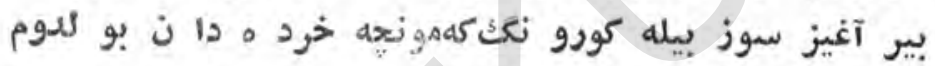

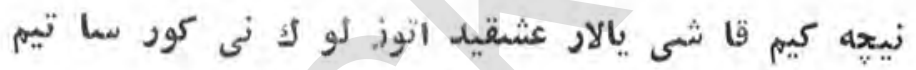
ولى آخر ملامت او ق لاريغه اوق ئشان بو لهو م كولار اير ديم:ودون(r) فرماذهمسكين داسمتا نيغه

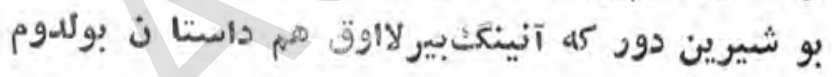

وصالينكَ دولتى غه ييتما سا مبأبر كيبى نى تانكت

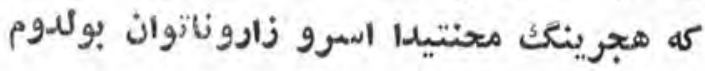

$$
\begin{aligned}
& \text { - (1) }
\end{aligned}
$$

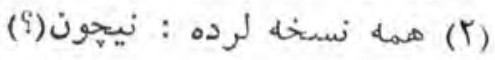

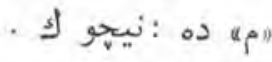

$$
\begin{aligned}
& \text { (؟) }
\end{aligned}
$$


خزا ن يفرا غى ينغليغ مل يوزونكف هنويدا سار غارديم

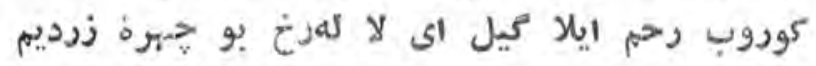

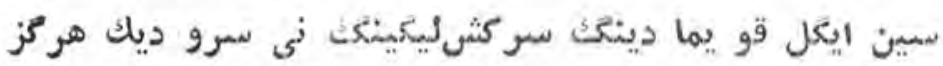

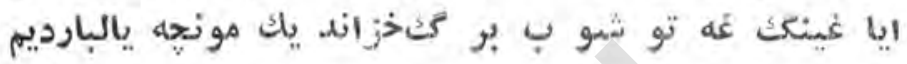

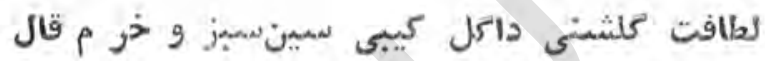

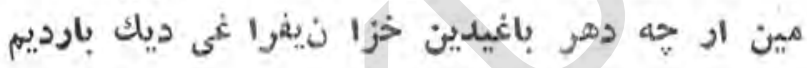

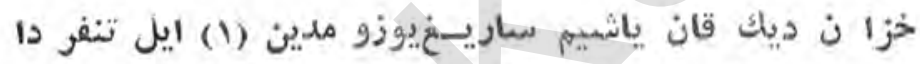
بهر (5) رنكى بحمدالله اولو شيديز اوزنى قو تقارديم

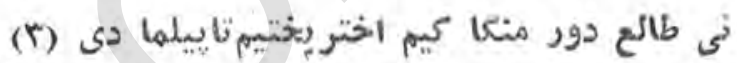

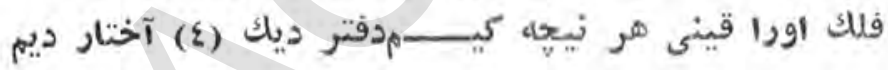
اوكود نينكف طعن و تعريفى منكا بأبر بوابر دور بو عالمدا اوز و هنى حون يمانيتنسمى دين اوتكا رديم

$$
\begin{aligned}
& \text { (1) } \\
& \text { (c) (ب) } \\
& \text { - (r) } \\
& \text { (2) }
\end{aligned}
$$


غير تا شى زخميدين درديم نىاظهبار ايتماديم

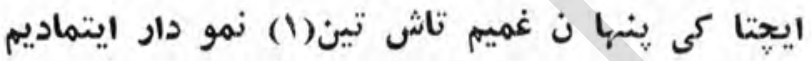

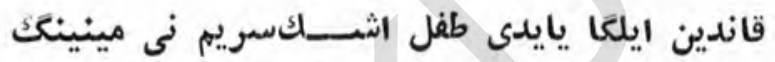
جونكه مين او ل ياش نى هر مزصـاحب اسرار ايتما ديم

يوزى خور شيد ى تيشى دريدينايرو جسم دا. قالما دى بير ذره يير كيم تيشدين افعار ايتما ديم كيلما دى كونكلو مكا عشقـــينكك سمرور و دولتى تا اوزو م نى (r) محنت و غمغهديزاوار ايتما ديم (r) طالعيم دين نى آسيغ بابر فغانوناله اويقو لوق بختيم نى بو او نبيركل بيدار ايتماديم

$$
\begin{aligned}
& \text { · توبه ،س ،ت ،م: تاشدين }
\end{aligned}
$$

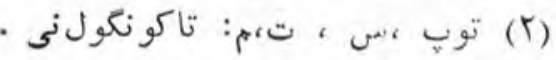

$$
\begin{aligned}
& \text {. } 4 \text { : (r) } \\
& \text {-Or_ }
\end{aligned}
$$


اياغين اويسا م يتيشكا ى عرش ملا قى (1) غهل باشيم دست بير كا ى دولتيم كرتو تسمهايلكيم مهو شيم عريم

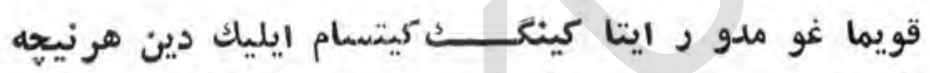
بار ماغو مدو ر آستا نينغد يسناكر بارسمه باشيم اوتتى ايل بو لما قدين ا و لياش ، مين قاريغوم عشقيدا اولكانيم يخثى بو نو عاراوتسمايليكدين ياثيم دوستلار كو نغلو مدا كينقبريمتا ثمى غه ياز غا سيز

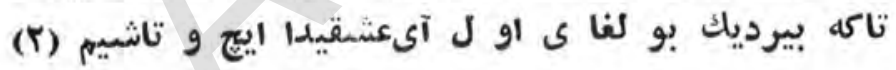

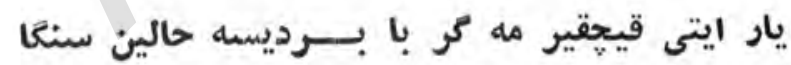
نيلا يين بو غر بت ايتحراسينديناوز كايو ق كيشير

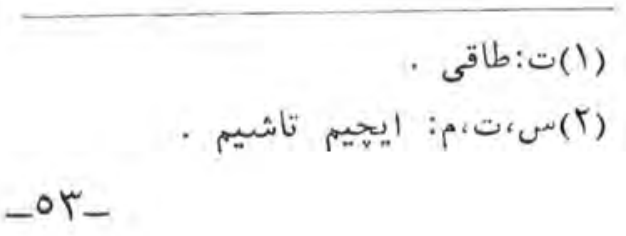


(AV)

نى خو ش بو لغا ى كهبير كو ناويقولوق بِختيمنى اويغا ثشام (1)

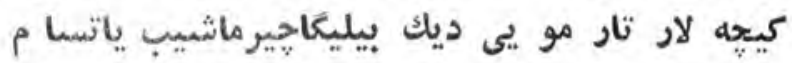

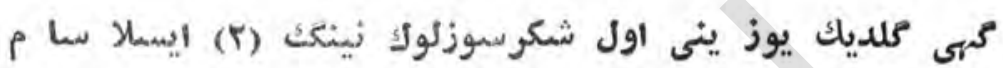

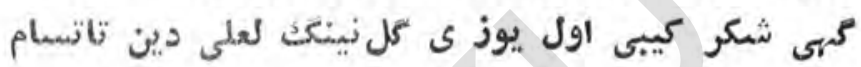

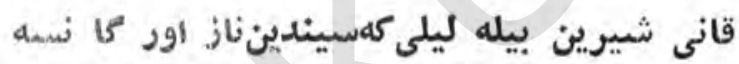

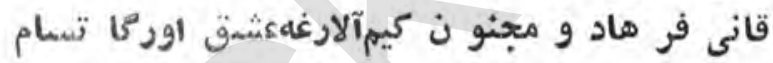

يارو ق كو ندو ز قرانغو كيجهدالنجم كيبى بو لئا ى

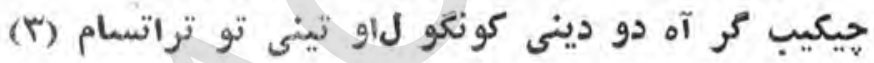

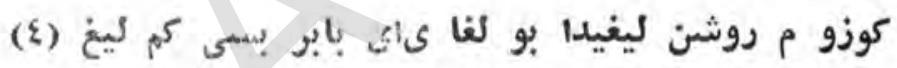

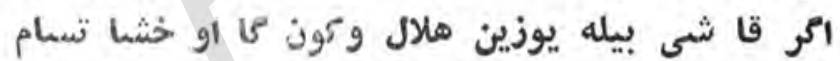

$$
\begin{aligned}
& \text { (1) م: اويقا تسا م: م: (1) } \\
& \text { (ז) } \\
& \text { (9) (צ) }
\end{aligned}
$$

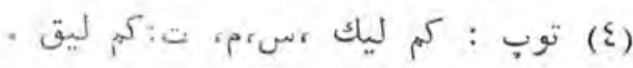

$$
\begin{aligned}
& 0 \leqslant
\end{aligned}
$$




\section{$(1+7)$}

هجرا را عشبر ت اياغين بار مونوش ايلار حاغيم

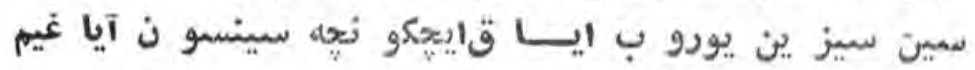

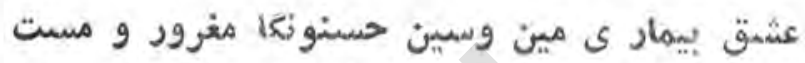

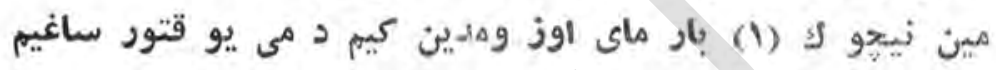

داغلار قو يد وم درم لار كيبى كو كسوم (r) نى ئى ياريب

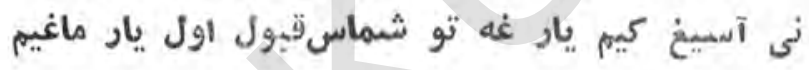

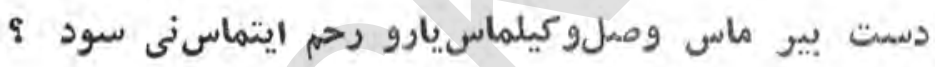

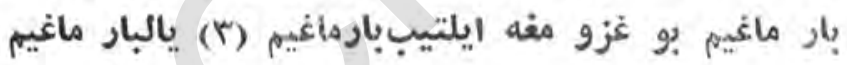

ايستارا م اي عشمق ميندينقالهاغاي نام و نشان

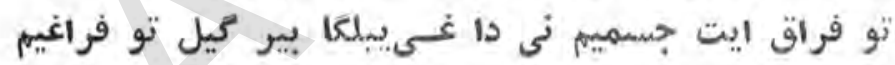

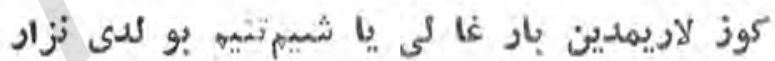

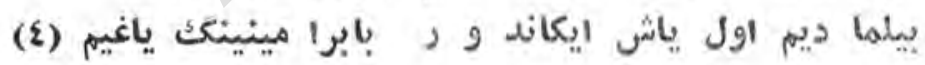

$$
\begin{aligned}
& \text { - من (1) }
\end{aligned}
$$

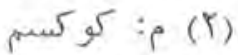

$$
\begin{aligned}
& \text { - } \\
& \text { (ع)م:بايرا مينكتياغميموبو غز لهاته ده يوق . } \\
& -00
\end{aligned}
$$


غربت و هجرانغه قالديم آه او لجان ايلكيدين جانغه ييتتيم ايمدى غربت بيرلههجرا ن ايلكيدين كورسما تور تهه تيغ و كةه او قدالتيمنى بيلمايين نى بلا لار كورا دور مين يارنادانايلكيدين

ايل فغانيمدين ببا ن و مين بوجاندين ، اي اجل قيل خلاص ايلنى و مينى جا نوافغان ايلغيدين بابر اول آى هجريد ه ايشينكـــبسى دشوار ايدى شكر كيم قو تقار دى اولو م ،سمينى آسان ايلكيدين 


\section{(IT)}

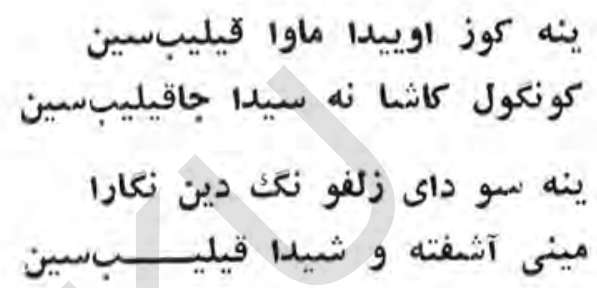

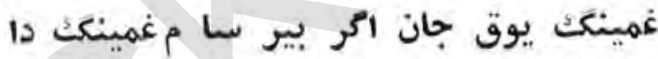

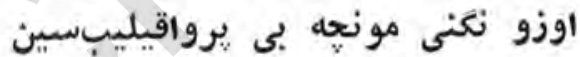

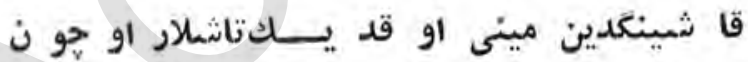
يانغى آ ى ديك قا شينكنى يـاقيليب سين لين كوزو هدين ياشو نو ب اي بحرالطاف

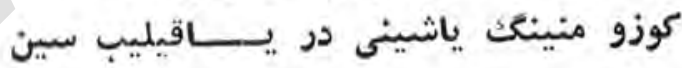
ساغينما س جنت الماوا نى بابر آنينك كو نكليدا تا ما واقيليبنمين 


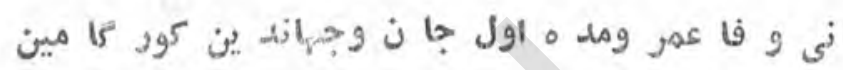

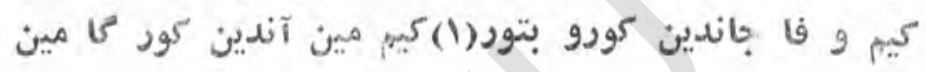

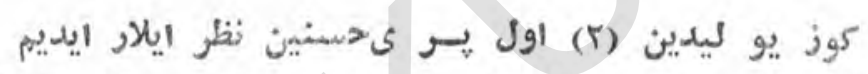

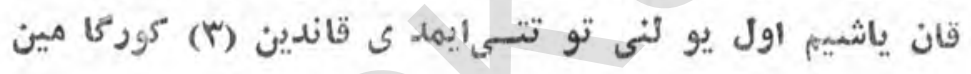

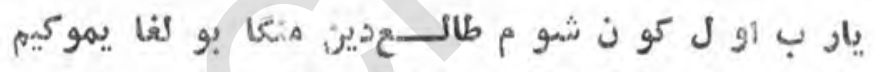

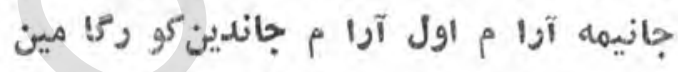

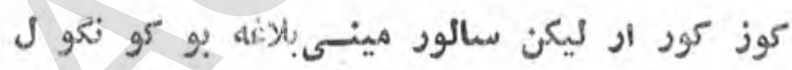

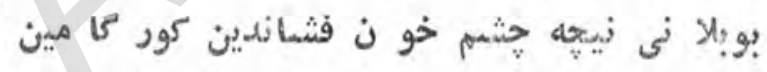
برطرف قيلغيل و فا ايستا ر نىايناه ين بابرا

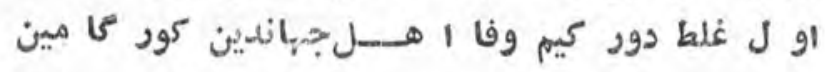

$$
\begin{aligned}
& \text { · (1) } \\
& \text {. (r) } \\
& \text { · }
\end{aligned}
$$


تكلف هر نيجه مسور تاهم(1) بولسما آندين آر توق سين

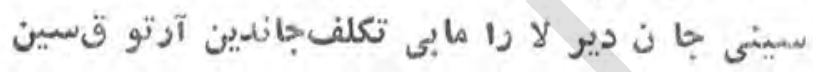

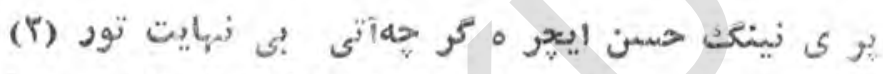

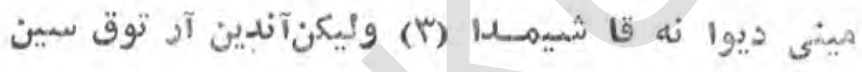
بوى بو حسن بير اله كود بسهيوزو نكنى بو لورو تيلبه

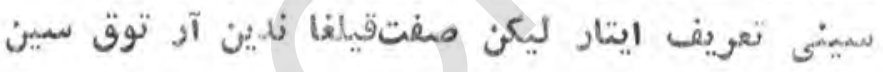

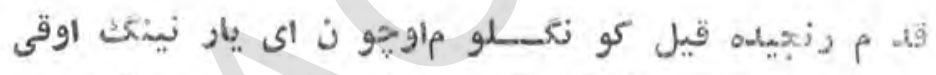

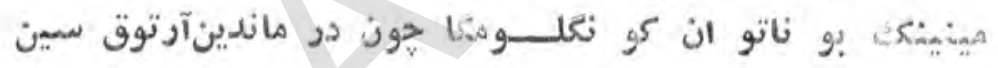

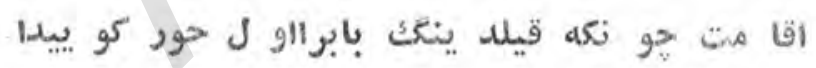

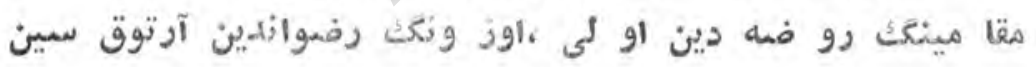

$$
\begin{aligned}
& \text {. } \\
& \text { • } \\
& \text { (r) }
\end{aligned}
$$


بو ينكليغ بيلسا م اير د وهجر نينكت مهلك قرا شا مين

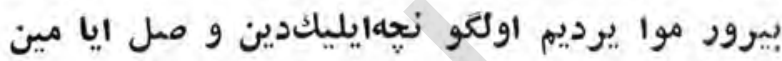

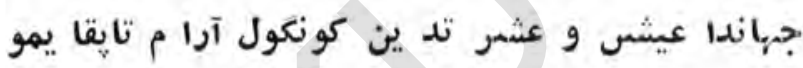
كيشى تاكور ماكو نجه يانيدممهوش دلا را مين

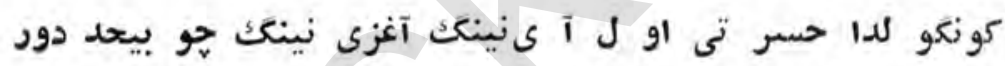

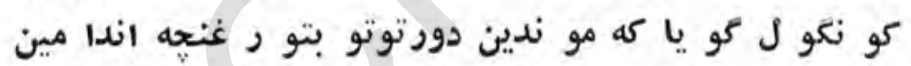

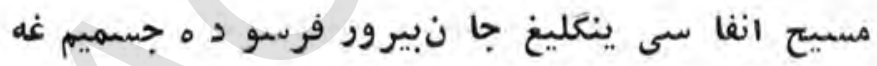

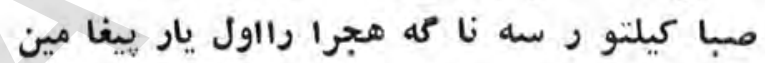

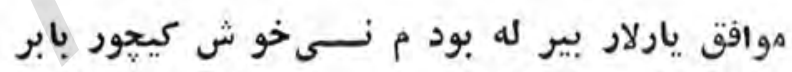

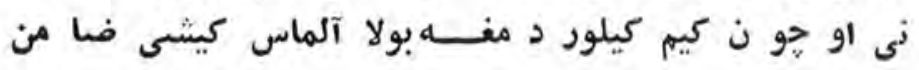


سوزلاب اول لعل شكر خا نسىشكر ريز ايتا سين

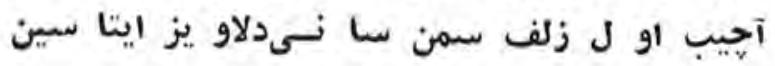

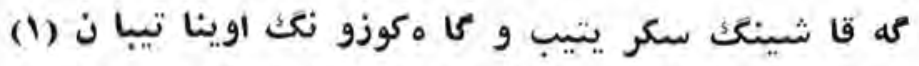

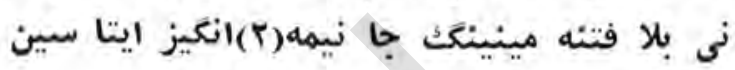

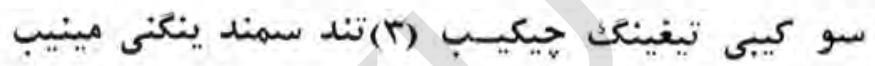

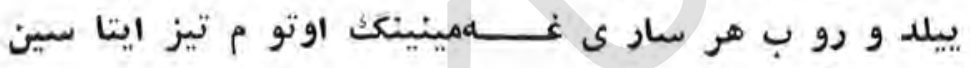

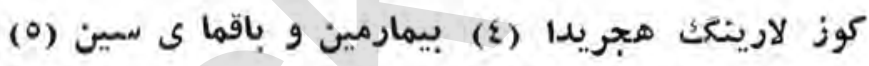
مينى آغريق قه مكر ياققا لى (T) لارير هيز ايتا سين

هجر شا مى المى دين (V)قوتولآلما ى سين المين

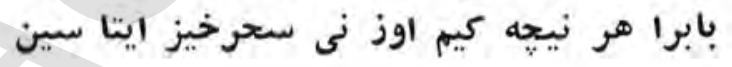

(1)

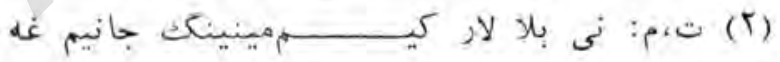

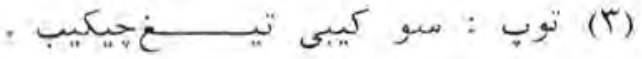

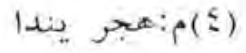

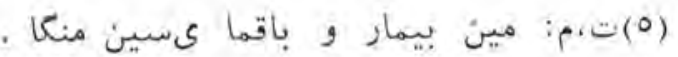

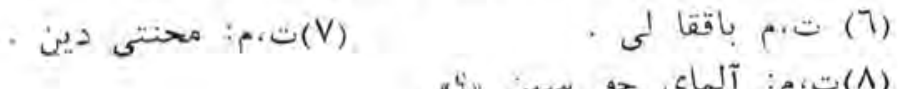
(1) 
خور شيد يوز ونكك بير لهبوكوناى هله تابان

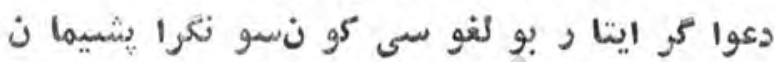
سين كل كيبى تا غمزه دا سين-حسنو نكا مغورد

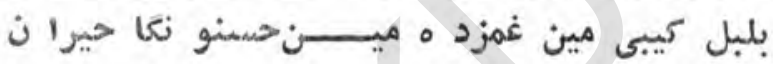
"مل يوز ونكك ايرور لاله ، و لى لالة خود دوى

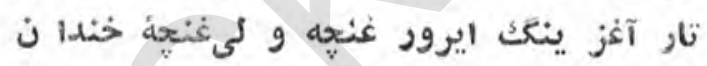
ما هى قو لا غينك تو لغا دم ىكهيوزو زكا كيله ى

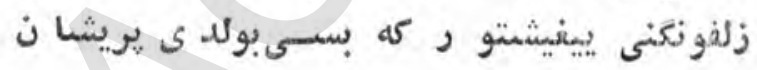

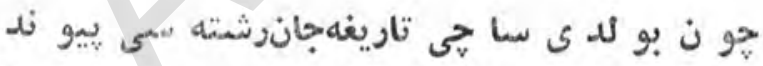

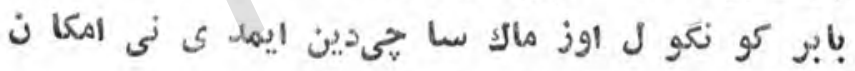


قدو خطينكك بيله كوز ويوزونكك(1) الى سرو سيمين تن

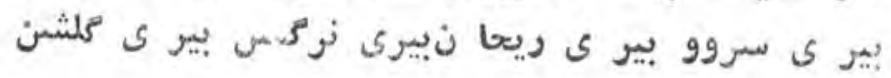

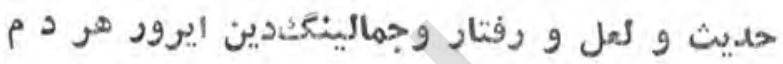

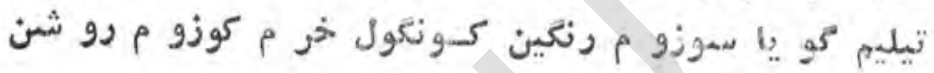

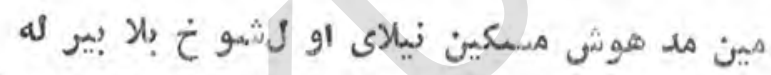

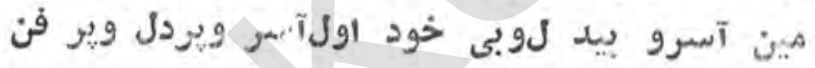
فلإ جور و جفا سميدين اول آكدرد وبلا سيدين

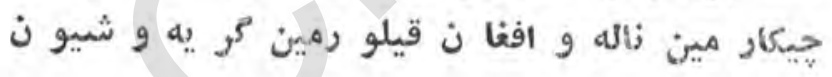

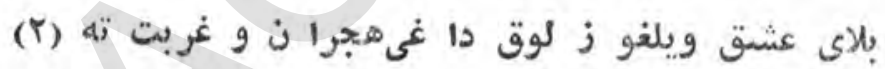

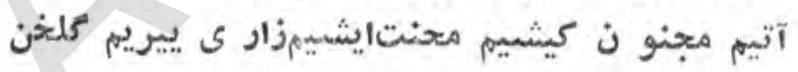

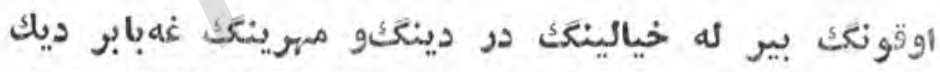

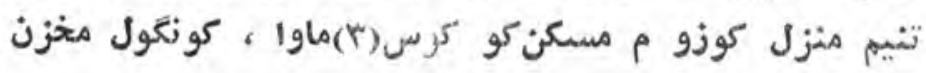

(1)س،ت: قد و خطينك بيلـهيوزونك

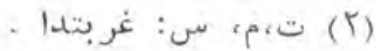

$$
\begin{aligned}
& \text { (r) ت: كو كس. }
\end{aligned}
$$

$-7 r$ 
عشق ايلى نينكَ آهى دين او لسرو قد خم بو لها سمو ن

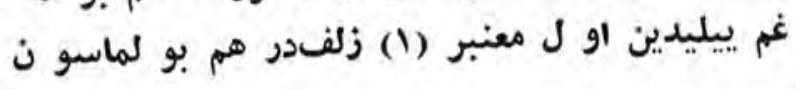

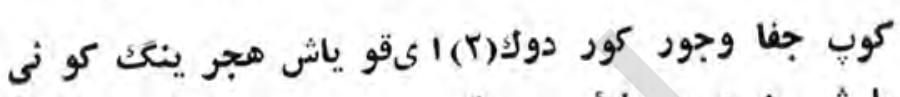

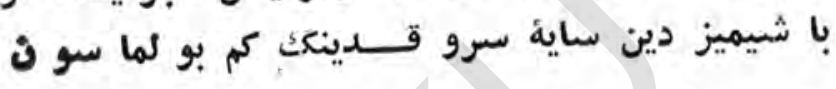

دهر دو ن دين تيكما سو نآزارناز كا جسمينكا

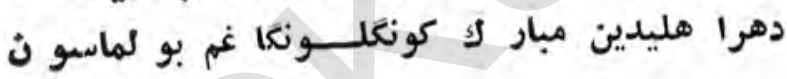

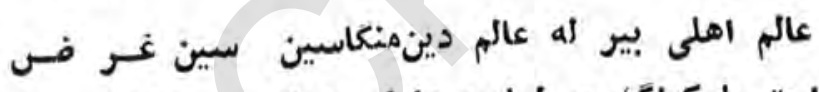

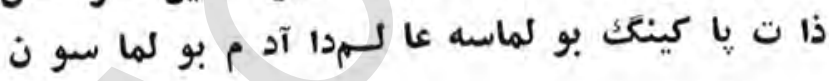

كر هوا داريم ايرو رسين ائصباعرض ايلاكيم :

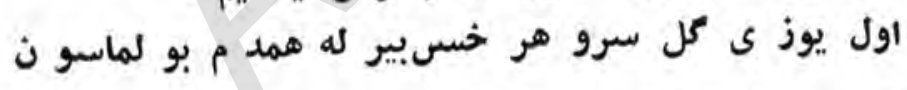
كر حه عاشق لاز مى عالم دا رسوا ليق دو رود

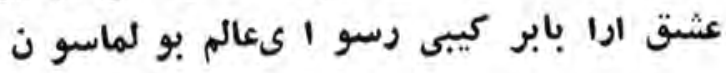

(1) (1) (1) تو بיسיمיت: كور دوم . 
تو شمومدا جو ن قو يا شن ديكعار ضمينكنى كور دوم اوترو دين تيلا ر مين تاقيا مت آحمغاى هين كوزنى اويقو دين دين

سينينك و صلينك دين آير وتو شكا لى بار غا ن سا يق آرتار

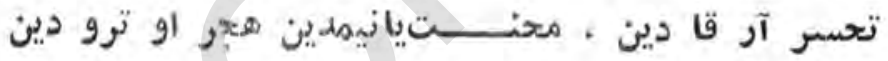
كو نكو لد ين قطع اميد ايلا ديماول و قت كيم يملديم

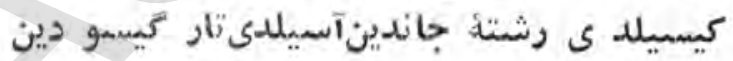

تيا آلما ن ييغينى كور كا ج او ليا شنشى ولى اولى هم

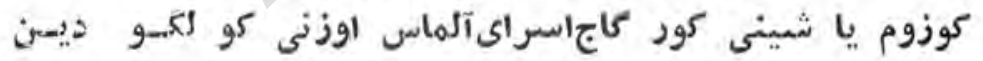
كوزوم يا شَى كه ييمرو لدى(1)شَكيب و م.بر او يبى آندين

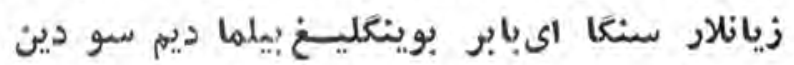


قو يا شيم هر سا ريغه عــز مقيلسه ذره قالما ن

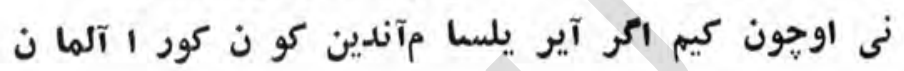

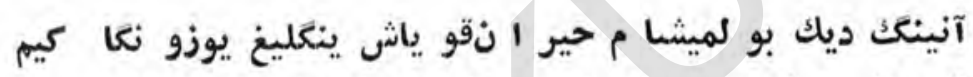
قو ياش ديك نيز ه لار تيكســهوزو مكا كوز آلا آلمان اكر حه يار عشقى ناتوا نكو نعلومكا (1) او ت سالدى

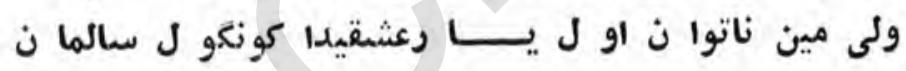
عباد ت و قتى بو لسه هرنيجهمتحرا ب اوترو مدا

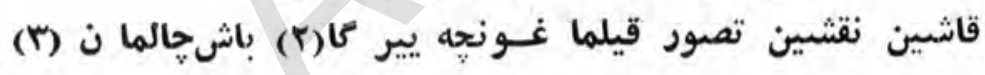

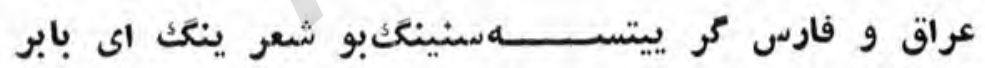
آنى حفظ ايتكو سى حافظ مسلمتو تقو سى سلما ن نست

$$
\begin{aligned}
& \text { (1)ت:كو نكلو م غه. }
\end{aligned}
$$

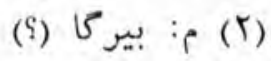

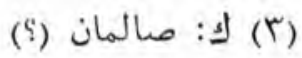


مينينغ كو نغلو منى هر د مآغريتيب يروا ى (1) قيلما يسين

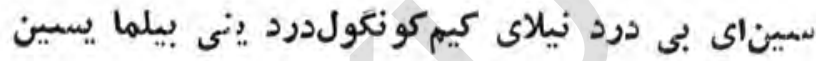
نى بيلكا ى سين مينينكك درد وغميم هرسا عت و هردم

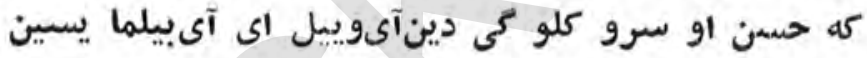
وفا مكتو بى بير له غمزه او قينهيج ياز ها يسين جفا رسمى و جور آيينينى هركزيانغيلما يسين

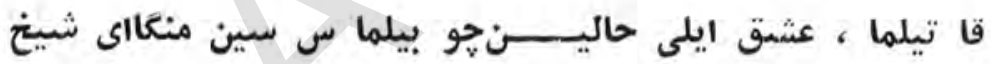
نى بيلكا ى سين كه هركز .بسوجماءت قه (r) قاتيلما يسمين

بو لو بتور عشقينك ايجر مكرحه خس ديك جسمى بابر نينك

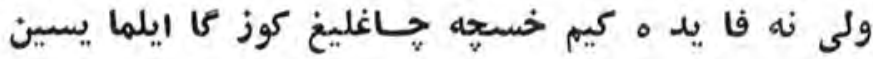

$$
\begin{aligned}
& \text { (1) } \\
& \text {. }
\end{aligned}
$$




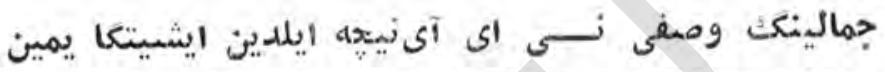

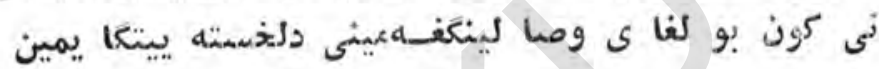
ثر حم يوز يدين يوز و نكنسي كور ما ككا بويور غا ى سين خو ش او لكيم عار ضينكنى كوركا مين سوزو نكك ايثميتكا يمين

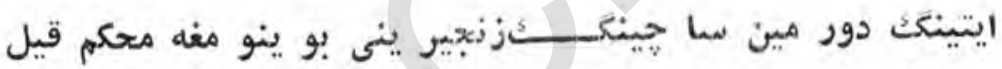

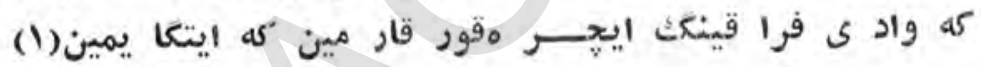

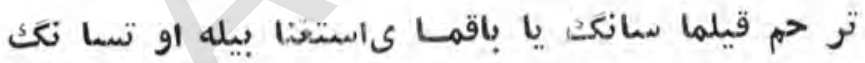

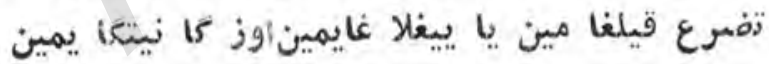
ميسمر بو لهمانسه با شيمنى قو يماغليغ (r) اياغى غه باشيمنى آليب اي بإبر ايسا قييتغانجه كيتكا يمين

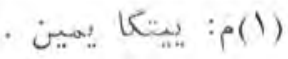

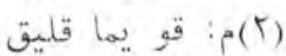


بو كيxنه كلبه م غه كيلد ى او لقو يا شميم يا شورو ن قرن لار ده كيلما دى هركز مونينكد يك (1) كيج قودو ن

آغزى ديك تار .فرصت و صلىولى هجر ى تو نى (r)

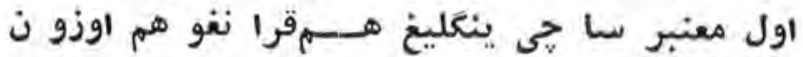
تا خيا ل عار ضينك تو شتى(م)كونكو لكَا اى قو ياش بو لدى كو نكلوم بير يا ناراوتوسو نكا كلاريم اوتو ن بو لدى كونعلوم ده كر محسرت آنينكَ تار آغز يديئ بار مكر جسميم هينينك تار وكونكول آنده تو كو ن آلغالى جانيم زى (ع) هانجرا نغه حواله قيلدى يار

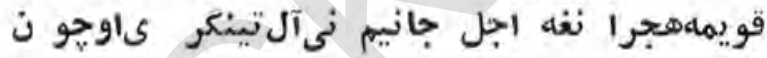
سوو ديك (0) قدى فراقيدافغانيمدور بلند كل كيبى د خسار ى هجر يداياشيم دور لاله كو ن عشق ايلا ديوانه ليغ دابولميشامصاحب كمال عشق اهلى ايمد ى بابر نىديكائبيز ذو فنون - (1) (T)

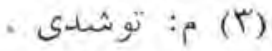

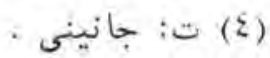
(9) (0) م: سرو دين (2) 
شاخ مل و نستر ن ياد بيرو دبويى دين عطر نى مشك ختن كسب قيلو رمويى دين نين مل يوز يدين منفعل ، سرو قديدين خجّل

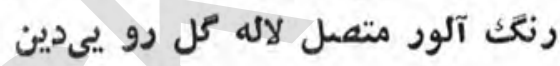

جانغه قيلور يوز ستم كو نغلومهبوز آنجهاه هَم

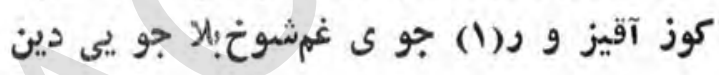

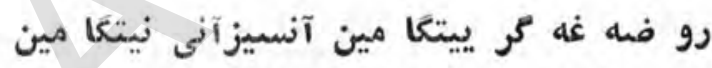

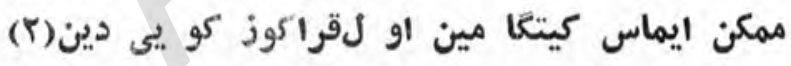
كر حه قيلود يوز كر م و صلى صايتار معترم

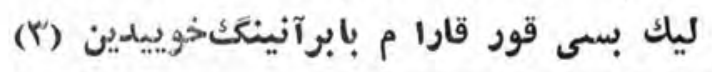

$$
\begin{aligned}
& \text { · م) }
\end{aligned}
$$

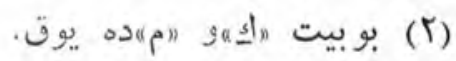

$$
\begin{aligned}
& \text { (Y) بوغزل (اته ده يوق. } \\
& -V \cdot-
\end{aligned}
$$


قايا نغه بارسا نغك ايتينتك (1)مين اوز و منى ييتكو رايين (r) يتيشما سا م سينكا با قيب دعـاقيليب هورا يين إنين يوزوم بوسما غأ نغا سمور سا منى يخشيى عيشس دورور عنايت ايت ايشيكينها (W) بوزيشيس نى سو رايين

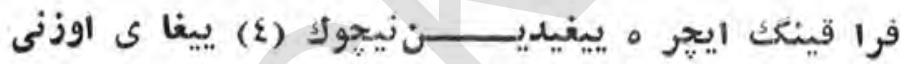

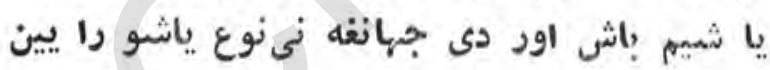
زيجهه تنافل ايتيب منكا باقمسـايين (0) يودور اول

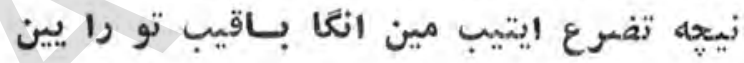

قو ياش قه (ج)ذر ه نظرسالمـاغا ى سيو و نماك دين قو تو كسمه غم تو نى دين كورسه يانه بابو آيين

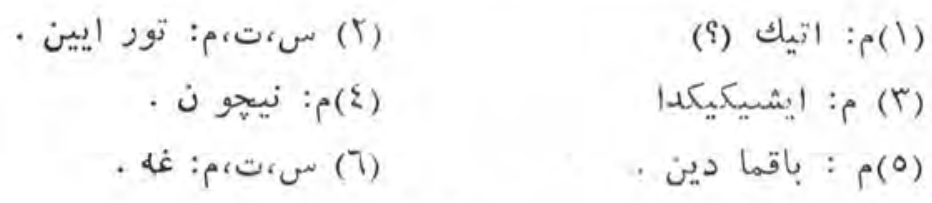


نيجِه حسن اهليدين مجنزو ن كو نكول آزار تايقا يسين

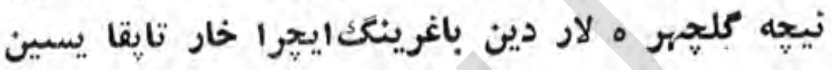
نيجه عشق و فرا ق ورحم سيز اغيار ايلكيدين اوز و نكنى خوار و جاننى زا رو وكوز خو نبار تايقا يسين

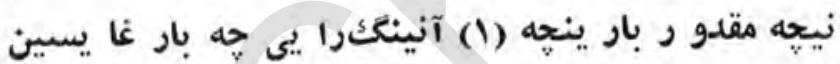
نيحه بار غا نسا يى (r) اوز ونكنى بى مقدا ر تايقا يسين تنيم غه نيجهه كيم نظار مقيلسـانكع داغ كوركا ى سين كونكلدا هر نيته كيم ايستاسانكک آزار تإِقا يسين

بو مهوش لارغه كونكلو نكك بيرماكيل كيم (r) اسما ى آلماسلار. كونكولنى اسراغيل بو لغا ى كهبير دلدار تايقا يسين

(؟) (ب) (1)

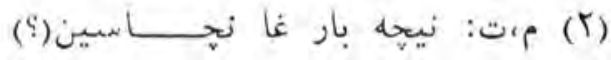

$$
\begin{aligned}
& \text {. } \\
& \text {-Vr_ }
\end{aligned}
$$


خطينكك بيله يو زو نكى و كاكلو نكى سينينك الىجان بير ى بنفشه ، بير ى ياسمن ،بير لى ديحان

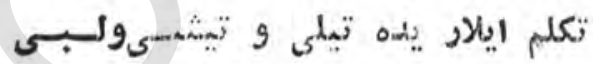
بير ى عقيق و بير ى اينجو وبيرى مرجان

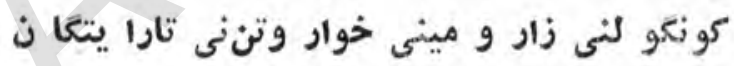

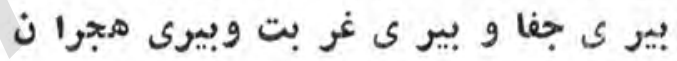

تن و كونكو ل بيله كوزو صل ونازو حسنى او جو ن

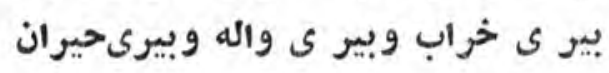

تمام عمريدا بابر غه او ج سوزآيتيب تور (1)

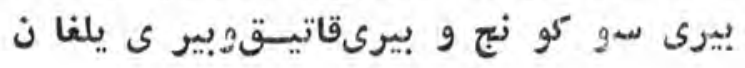




\section{$(1+9)$}

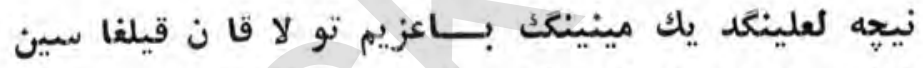

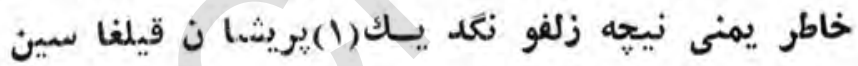

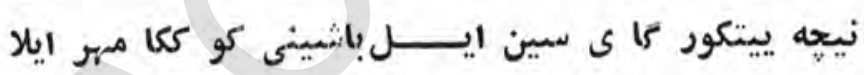

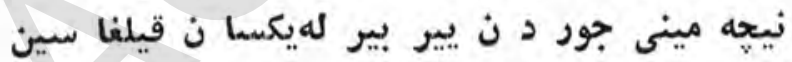

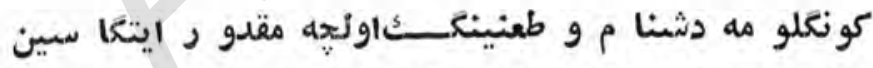

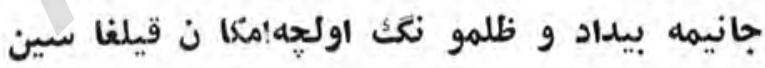

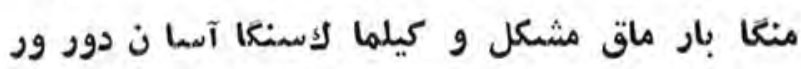
اوشبو مشكل نى منكا ياربسين آسلسان قيلغا سين

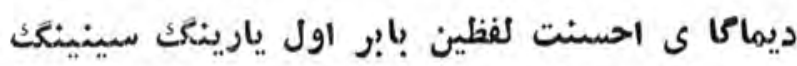

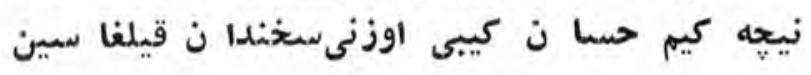

(1) (1) (1) م: (؟) مين 
كيلد ى اول و قت كه با شيمنى آليب كيتشا ى مين

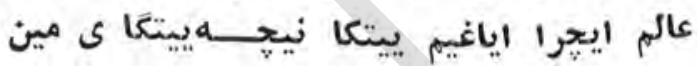
ايستا را م اوز نى عزيز ايلكاكورو نماس ليك تين

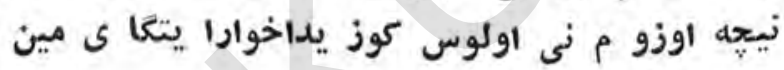
خلق يوز جو رايلا ايشس لاربويودور كاشى ايل نينك

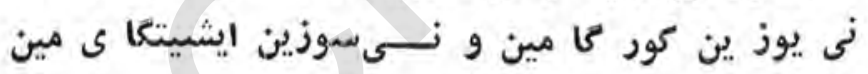

هونسار ى بارسه بو ديوا نه كونكول عيب ايتما

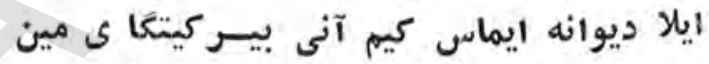

ديمه بابر كه (1) نيتا رسينباشرآليب كيتماك نى زينكر ى (ץ) نينكك خوا ستـــىموندا ق ايسه مين نيتغاى مين

$$
\begin{aligned}
& \text { (1) } \\
& \text { (؟) }
\end{aligned}
$$


بو غمدا مين كه ايشيم فكر ينى نى نوع ايتا يين

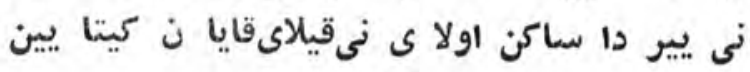
نى دير دين ايشيكيم آ جيلود ، نى مسنجد تين

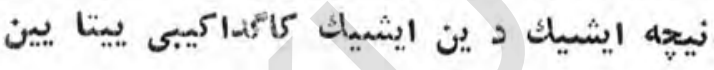
جهان ايلى بيله كفت و شنو دتيلماس مين

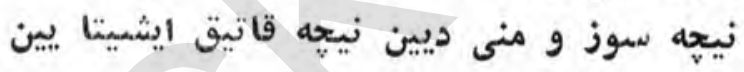
(1)

اوزو منى كو ج بيله بو دنكــــايلكا نى قاتا بيين ؟ ديمه نى بو لد ى ايشينك فكرقيلغيل اى بابر

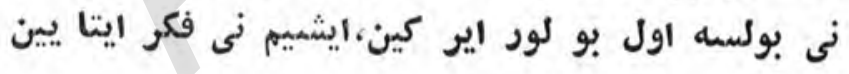

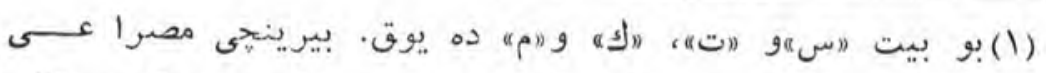

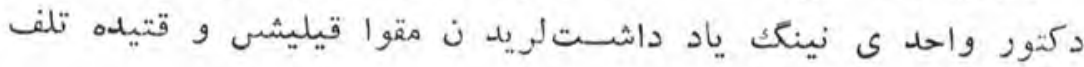
بولكن . 


\section{(IIE)}

غير غه زيجها و فا قيلغا ى سمين جانيمه نيتهه جغا قيلغا ى سين

بى خطا ايلكَا آتيب (1) غمز ماوقين

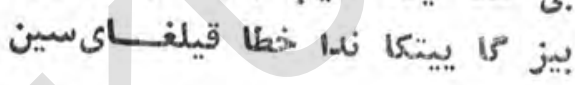

كور ماكأ ى سين الم و دردي-وزين

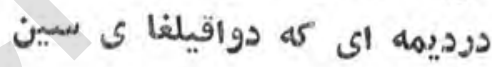

تيلارا م سمرو روا نينكَك روشين

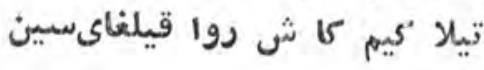

بابو اول عمر سينى سو ككـا ناوجو ن عمر بارينهه (Y) دعا قيلغـا ىسين

$$
\begin{aligned}
& \text { · (1) }
\end{aligned}
$$

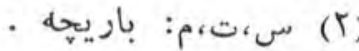

$$
\begin{aligned}
& -V V_{-}
\end{aligned}
$$




\section{(110)}

سيندين نفسى (1) موادتابما ن عشقينكدا كو نكو لنى شادتابمان عشمق اهليغه التفا ت كور مان حسن اهليدا اعتقاد تابمان قيلسط م مسنغا هو نيجه تظلم فرياد و فغا ن كه داد تايمان فرياد كه دير كا عشق دازين بير كيشتى نى اعتما د تإِمان

قا شينك غمى شمر حينى يازارغه كوز قار ه سيديك (r) مراد تـايمان مين بنده جزا نقياد بيلمان سين شا ه دا جز عناد تإيمان - نفس (1) · 
خو ش او ل كه يا نا مبار كل يوزونكنى كور كا يمين

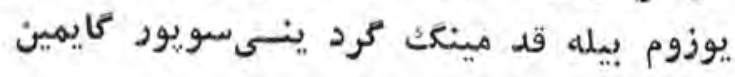

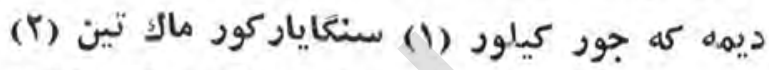

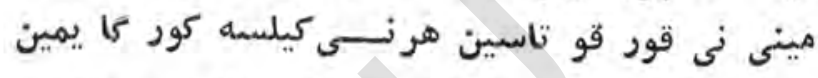

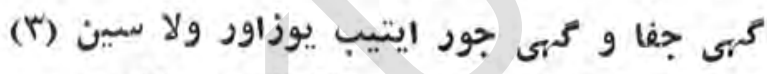
مين اول ايمان كه بولار بيرلايوزاويور كايمين

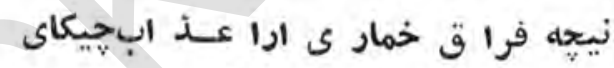

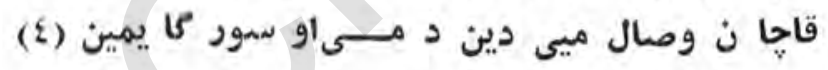

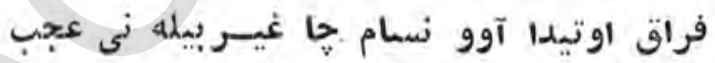

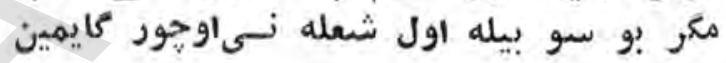

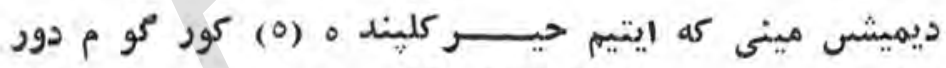

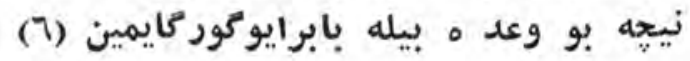

$$
\begin{aligned}
& \text { (1) } \\
& \text {. } \\
& \text { (ك) ت: ايوراس }
\end{aligned}
$$

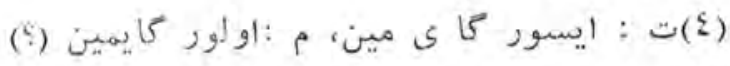

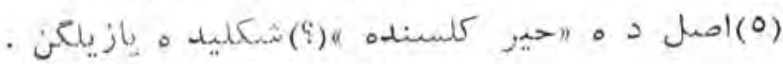

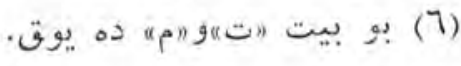
- va 
كيل كاه سين سيز تا بكيمقتول هوجرا ن بو بو لفا مين

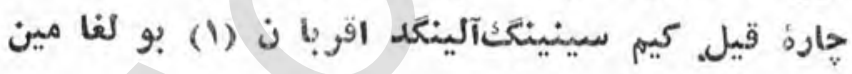
اي خوشاو ل كيم تورغا سيسن كيليب (5) كوزوم اوترو سيدا

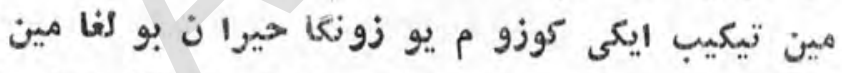

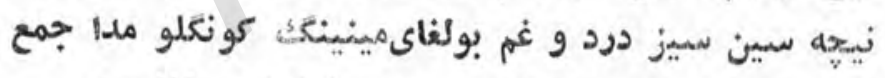

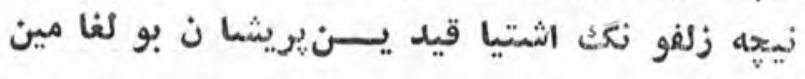

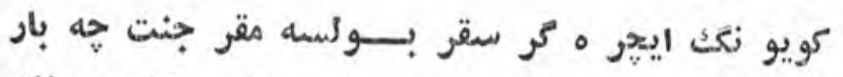

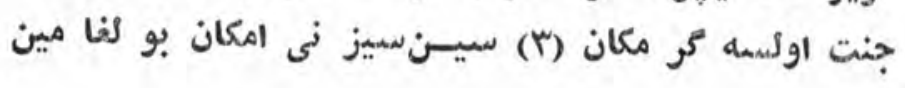

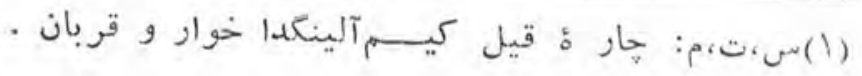

$$
\begin{aligned}
& \text { • (r) } \\
& \text { (؟) } \\
& -\Lambda \cdot-
\end{aligned}
$$


بيك نا كه كوزو مكا او حرا باوترو مينى ديوا نه قيلد ينك ایى ير ىرو جها ندا هر كيشى كا بار مرادى مينينك يو قتور مراد يم سيندين آيرو ميني مكر او يقو دايوز ونكك كوركايايرديم ولى هجر ينغدا كوز دين او جتى دواويقو

ايكى سا حينكك بيله يوز و نككقو يا شين

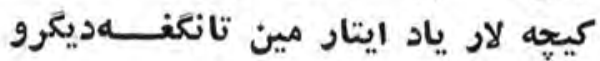
توحم ايلاكيم بيجار ه بابر

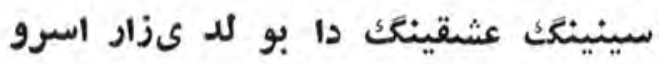


حرخ نينك مين كور ما حا نجوروجفا سى قالد يمو

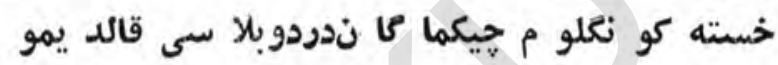
مينى خوار ايتتى و قيلد ى مدعىنى(1) يرورش

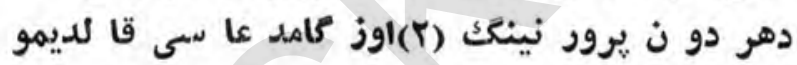

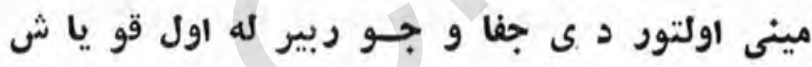
ايمد ى تير كوز ما لك او حو نمهيو ووفا سمى قا لديمو عاشق او لغا ج كور دو م اولومنى اوز و مكايى رفيق اوز تا كونغلو م نينكُبوعالمدههر اسمى قالديمو

اي كو نكو ل مر بابر اول عالمنى ايستا ر ، قيلما عيب

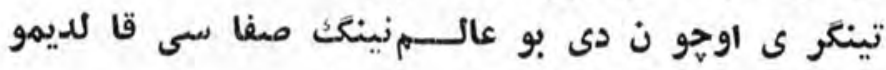

$$
\begin{aligned}
& \text {. } \\
& \text { · }
\end{aligned}
$$


تا(1) آلغا لى كو نعلو منى او ليوز بيله اول كيسو

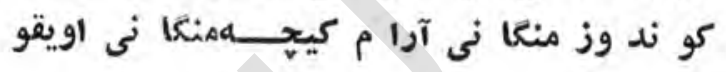
هريانغه كه عزم ايتسا ميانيمدابارور محنت

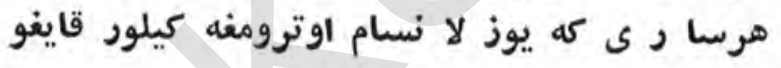
يوز جود و ستم كور كان مينكَكدحنت و غم كور كان

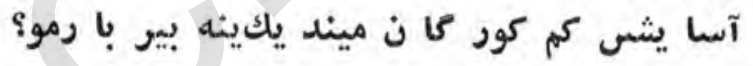
اول يوز ى قو ياش هجر ى بوهمب بلا دردى

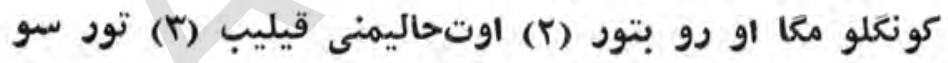
هر نيجه كه مهيك دور دردينغنىديمه ايل كا

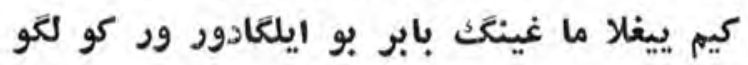

$$
\begin{aligned}
& \text { (1)(1) ده 》تاه يو ق. }
\end{aligned}
$$

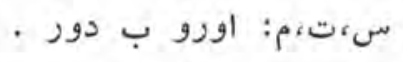

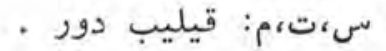


سا جى نينك سودا سى تـــوشتى باشيمه با شتين ينه تيره بو لدى روز كاريم او لقراقا شتين ينه

مين خود اول طفل يوى وش غه كونكول بير ديم و لى

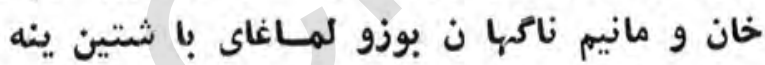
يوز يما نليغ كوروب آندين تيلبهبولدونكك اي كو نغو ل يخشيليغ نى كو ز تو تا ر سيناول يو يو شدين ينه تا ش او رار اطفا ل مينى، اويدافارغ او ل يو ى تيلبه لار ديك قيجقير و ر مينهرزما ن تا شتين ينه

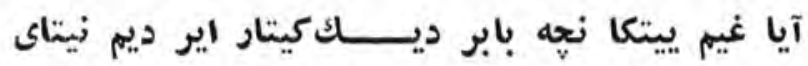
سا حى نينكك سودا سىتو شتى با ثميمه با شتين (1) ينه

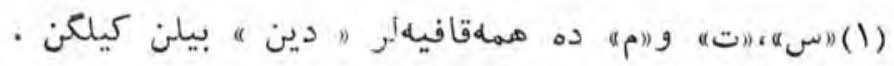
$-\Lambda \varepsilon-$ 


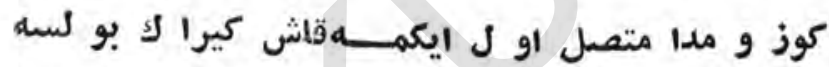

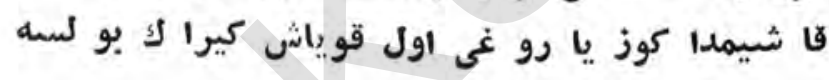
سجو د و قتى دا مترا ببولمهاسمون هر كز كه باش قو يار دا اوشا ل ايكمه قاش كيراك بو لـو لسه حبيب عشقيدا باش دين كيج ایىونكو ل يوق ايسه بو يو لغه قو يمه اياق سنغاباش كيراكيداتو لسيه قويو ب ايا غيغه (1) باش سورسم لعليدين هركيم باشيغه تو فرا ق و آغز يغهتاش كيرا كائ بو لسه سينينك بيله بار ى ايلناخو ش اوكسيه اي بابر

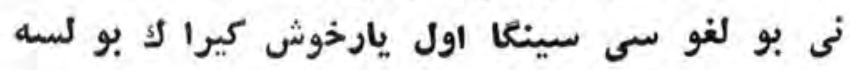


كيم كو دار خور شيد نى او لماهميما بو بو لماسه كيم سو رار شكر نى اول لعـلشيكر خابو لماسه كل تيكان دور كوزلاريمكا اول يوزى كلدين يراق سرو اوق تور (1) باغريمه او لـسرو بالا بو لماسه جنت الما وا نى اى زاهد نيتا ىمين زار كيم ايستا را م كو يى دين اوز كمامنكا ما و ابو لماسه

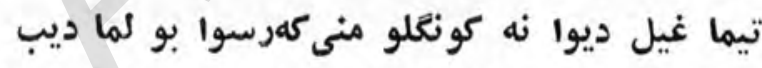

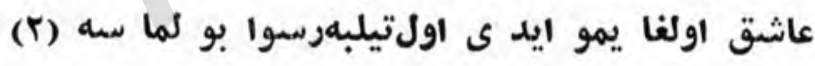

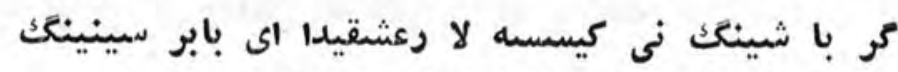

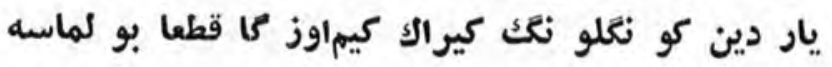

$$
\begin{aligned}
& \text { (1) }
\end{aligned}
$$

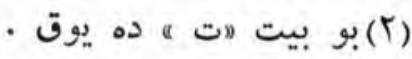




\section{(Ir)}

$$
\begin{aligned}
& \text { جانيمه او ت سالد ى اولرخسارئ زيبا ينه }
\end{aligned}
$$

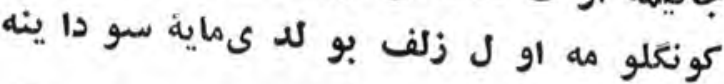

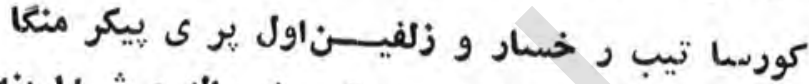
جا ن و كورنيل تيب منى قيليب تود(') واله و شيدا ينه

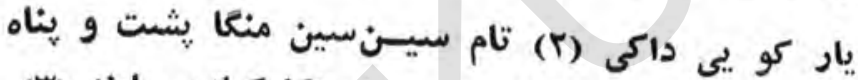

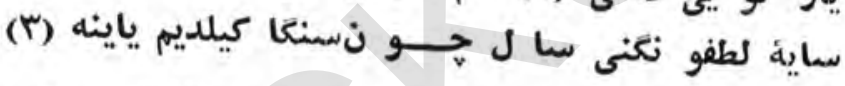

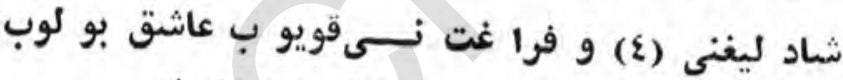
هحنت و غم نى قيليب مين اوزوعه يِيدا ينه يار غه قول مين ديعا ج بابرنى

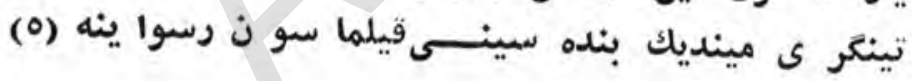

$$
\begin{aligned}
& \text { - (1) } \\
& \text { • } \\
& \text {. }
\end{aligned}
$$

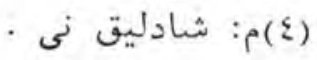

$$
\begin{aligned}
& \text { (0) بو غزل "اته ده يوق مئ }
\end{aligned}
$$


اوكو م اويقو سيغه باريب جهاندين بو لدو م آسود هـ

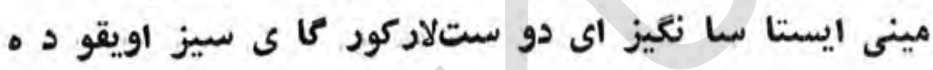
نى كيم تقدير بو لسه اول بولورتجفيق بيلكا ى سيز

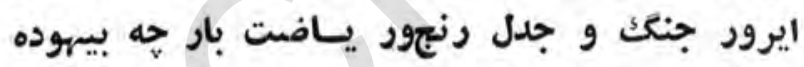
اوز ونتنى شاد تو تغيل (1)غمبيمه دنيا اوحو ن ز نهار

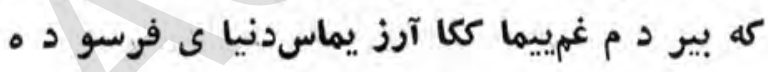
زمانه اهلى ايتجره ای كونغو لآياتاييلغاى مو ؟

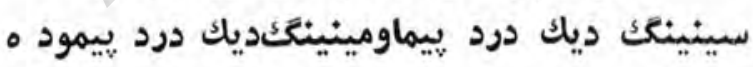
اولوس دين تينما ديم عمرو مداهركز لحظة بابر

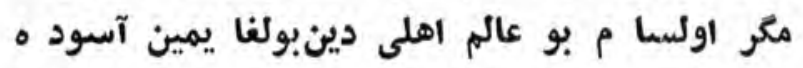




\section{$(r \wedge)$}

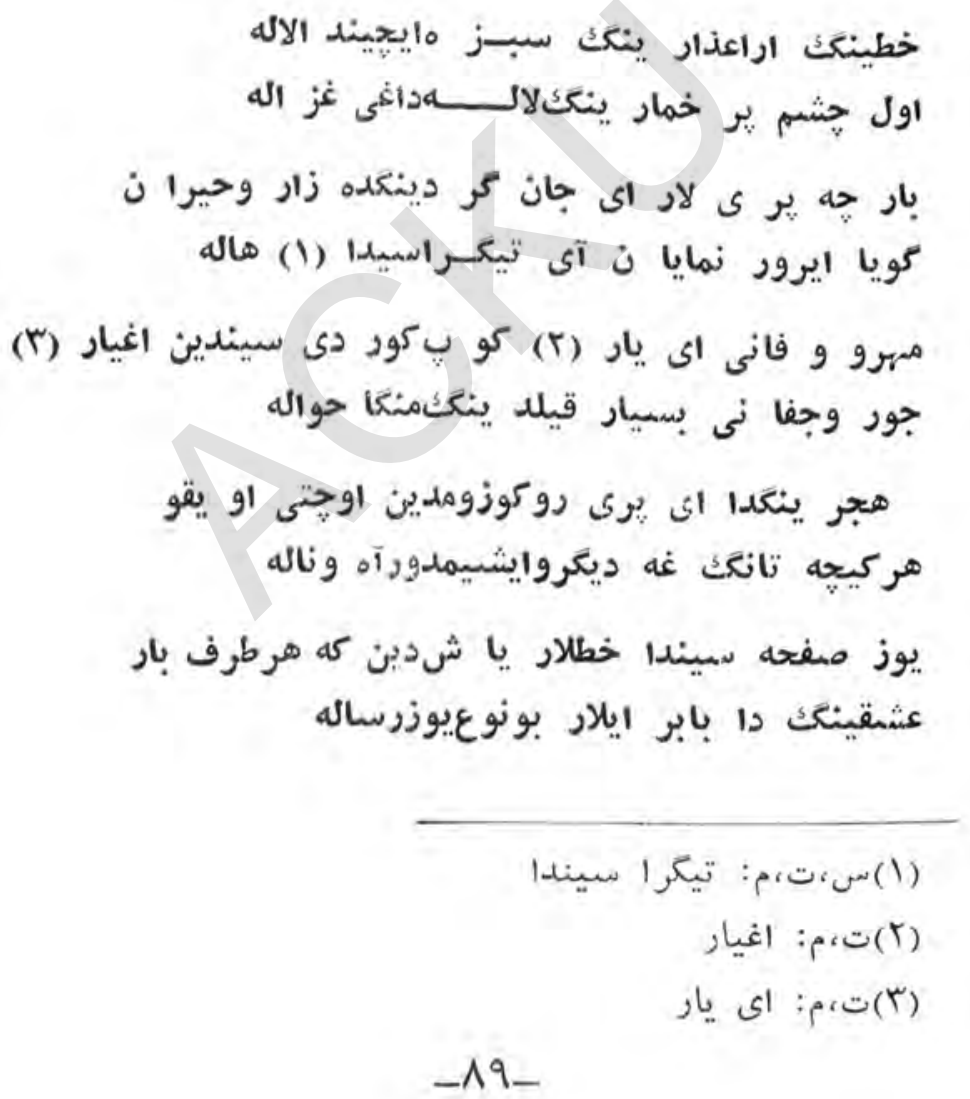


هجرا ولتور دى مينى انعلا ساماير دى مونتهه

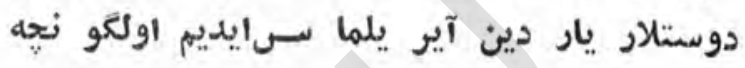
زاهدا دوزخ اوتى دين (1)مينىنى قور قا تا سين هجر اوتى قاشيدا كور ماسمين آنى اوحقونيه اول قوياش مهرينى بير ذره منعاكور كوز ماس كوكب اشك تو كوب بو لسا ماكتر كردو نجيه

حسن دآر توق اكر بو لســــيـئيـى ليلى دين

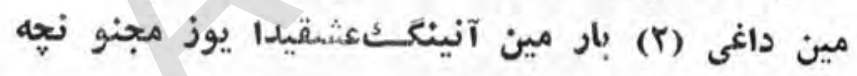
رندلار (r) آليدا حيوان سمويك، نى كوي اوكاسين

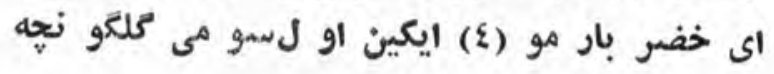
بابرا شعر ينغا كر سالساقولاقاول شا هينك بو لغو سى دور سوز و نغا قدردر مكنو نها ئه

(r)

(ع)
· (1)

(؟) (؟) 


\section{$(\varepsilon \varepsilon)$}

قا شى و قدى و آغزين او لكاه

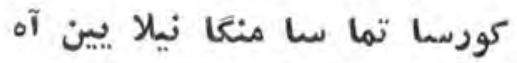
تو تتوم سا حينى ،يو زين كودايديب تون اوزو ن ومين غريبكمراه قدى بيله ايكى زلف و آغزى جانيمغه بلا بولوبتود الله خواه ايستا كونكولنى خــــواهقاوله جون سين سين بو كو نكو لكادلخواه ايل بيلما سمه حالتيم بيلــــــو ديار حاليم دين ايرور خداى آنا هال

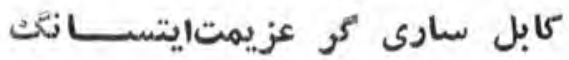

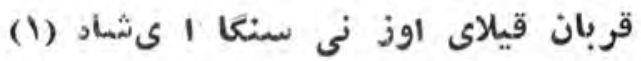
بابر ينه اوتلوق آه جيكتينكـــــ كويد ور ماسو ن ايل نى آه ناكاه

(1)(بو بيت كويرو لو نشر يد هيوق."(م) دن آليندى .

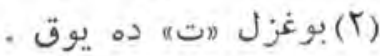




$$
\begin{aligned}
& \text { خطينك يورانه كيلتور كا ج تيرينّى اوشبو ديوانه } \\
& \text { آنى تير كوز ما لو اوحهو نكويياكيلتوردى يروانه }
\end{aligned}
$$

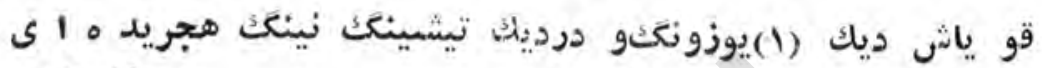
(r) جان

كوزوم نيمكك يا ثمى دور يو زوحأره و هرقطره دردانه

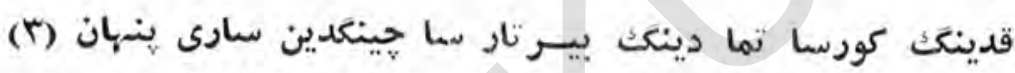
عنا يت تو غر ى كر يو قتورنى بولدى بو للمسه تولغا نه آنينك اوسروك كوز يدينبارد جيون دينيم اويى (ع) بوباد مين و اي دوستار مو ندين نارىمى بيمر لنه ميخانه جمالينك شمسى هجرانيدابابسر (0)اور تانيب باردى

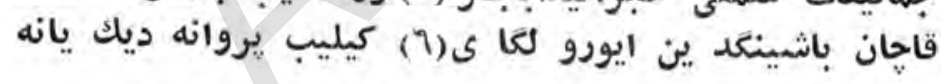

$$
\begin{aligned}
& \text { (1) } \\
& \text { · } \\
& \text { (r) }
\end{aligned}
$$

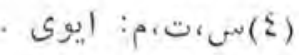

$$
\begin{aligned}
& \text { (0)س (2) }
\end{aligned}
$$

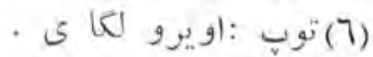




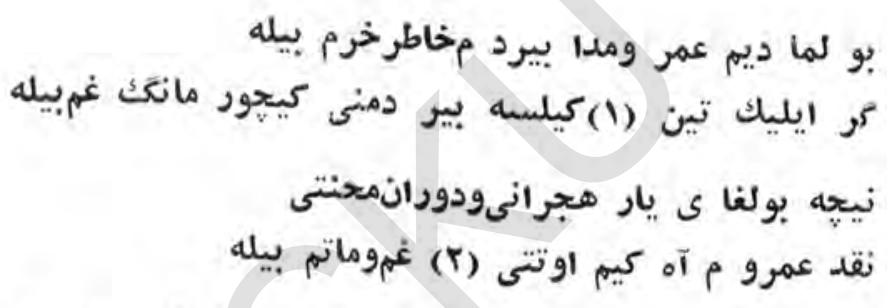
ظاهر اولغا هي هر نفس بيرتون،سماحينغك نينكَ هجريدا

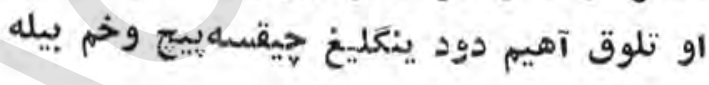

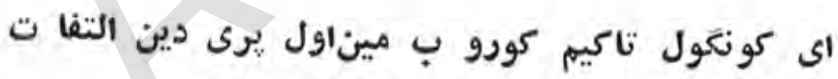

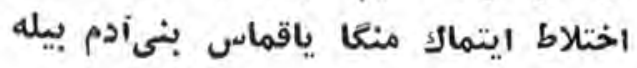
قطع ايتيب بابر بار ى دينجو نسنغا كيلتور دى يوز

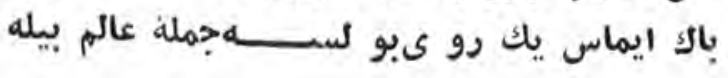

$$
\begin{aligned}
& \text { (1) (1) (1) } \\
& \text {. }
\end{aligned}
$$


(VA)

نيحه رسوابولغا مين عشق ايحرهشيداليغ بيله هيج كيشى كور ما يد و رور عاثيقبورسوا ليغ بيله

$$
\text { هونيجهه كيم تو تتوم اوز نى هاردشانيغ طوريدا }
$$

مين كه هجرا نينك داقانيوتماقبينه معتادمين منغا يوقتور هيج نسبت عيشسو(1)صمبا ليخ بيله شيخ شعريم منع ايتار ييتما ى بلاغت(r) لكفنى غه نيلاماى يار ب كيشى بويير نـاباتغبيله بابر بيدلنى عشقى تيلبارا تسهنى

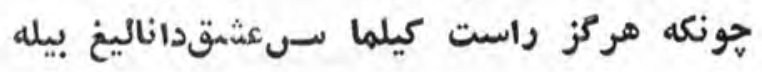

$$
\begin{aligned}
& \text { (1) (1) (وهده يوق. } \\
& \text { (؟) (ז) : بلاغات }
\end{aligned}
$$


قاجان بو لغاي مشرف بولغا مين جانا جمالينك غه

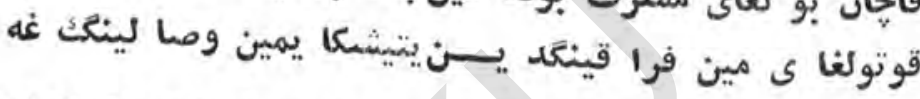

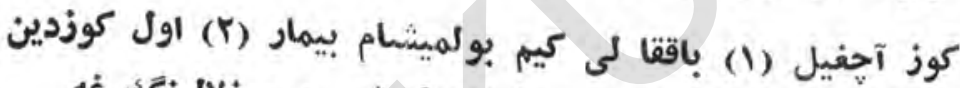

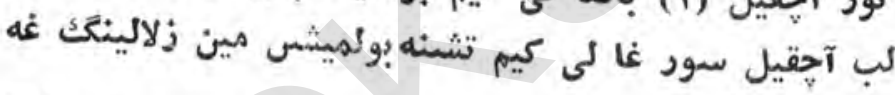

اول آى نينكك يوز

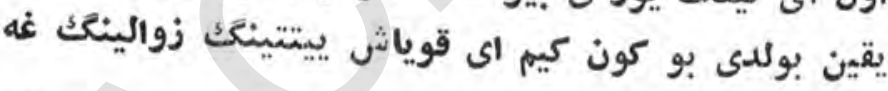

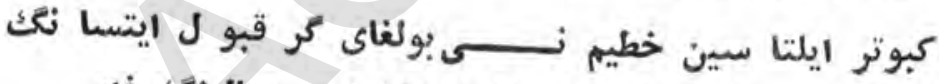

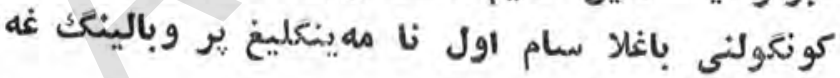

بيلينكك دين كيم خيا لى دو ديرأق دور مين مينى يادايت

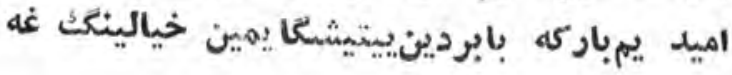

$$
\begin{aligned}
& \text { · } \\
& \text {. } \\
& \text { (Y) } \\
& -90
\end{aligned}
$$




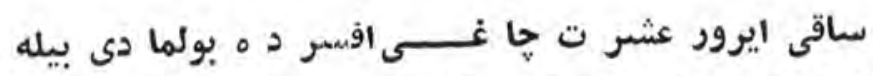

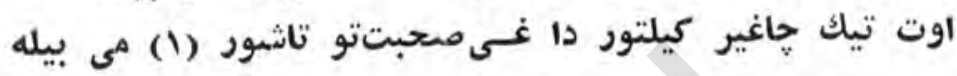
كيلتود شراب ناب نى آما دمقيل اسباب نى

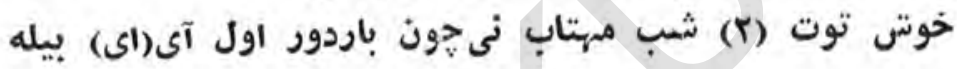
دورا ن غمين برباد قيل عشر تاوبين آباد قيل جان و كونكو لنى شاد قيل آواز جنك ونى ونى بيله

(r) مجلس دا بارد ور سربسر مى نثشئه سيدين شور وشر بارينى مست و بى خبر قيل جام بيى دو بي بيله همدرد يار ى قانى كيم بير (ع)غمكسشار ى قانى كيم

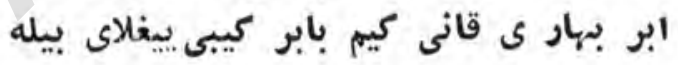

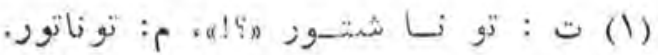

$$
\begin{aligned}
& \text { (r) } \\
& \text { (؟) } \\
& \text { ( ) }
\end{aligned}
$$




\section{$(1+1)$}

اول كه ييل لار آيلار اوتكا ركائمو ماتم بيله شاد وخرم بو كماغاي نوروز ايلا بيرام بيله اول كه دوران نينكَ اياغيدين دمادم قان يوتار

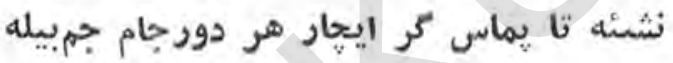
ديمه اي همدم ديارو يار سوز ينكيم مينينكك

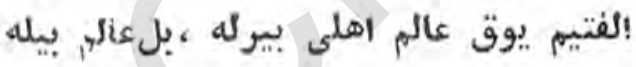
سيندين آيرو نيلا كايمين عيدايله نوروزنى

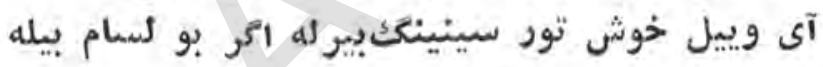

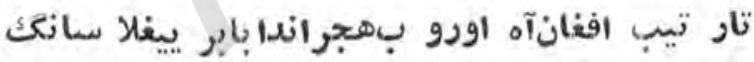

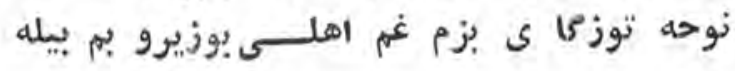




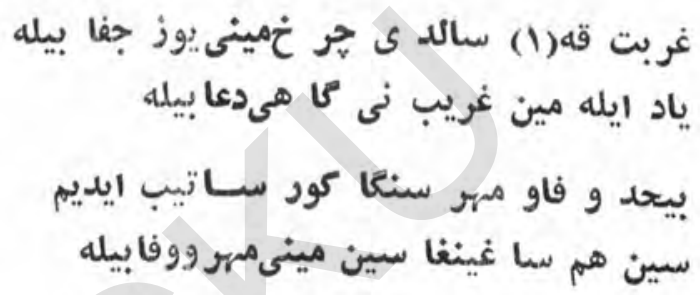
حون قيلدى مينى اول بت حينزارو مبتلا ايشيم مينينگك (ץ) قاليب تورور ايملى خدابيله كور مان فرح نى (ז) بيردم اكر إندين آيرو مين

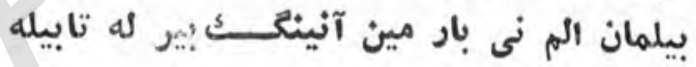

اول سرو غه كرم قمليبان ييتكورائ بابر نياز ينى يير او يو بخو بادابيله

$$
\begin{aligned}
& \text { (1) } \\
& \text {. } \\
& \text { (r)م:مرنى }
\end{aligned}
$$




\section{$(114)$}

خوش اول كيم ياردين قطع ايلا بإن ترك ديار ايتساك

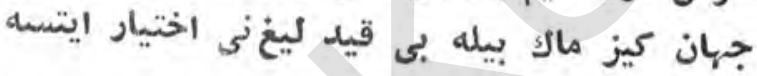

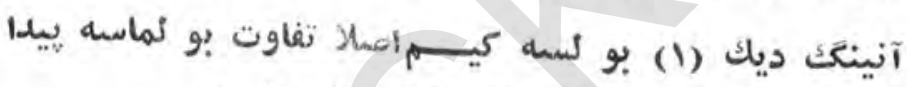
اكر بو دهر دو ن خوار ايلاساكر آنتبار ايتسه دئه جفا دور جانغه بو كما غليغ مقيدعالم اهلى غله خوش او ل آزاد ه كيم ايلنينكار دوار سيدين كنار ايتسه كيشى نينتك جانى غه دشمهــن بلادور با ششيفه بو ايل اكر با شين طفيل ايلاب و مرجانين نشار ايتسه

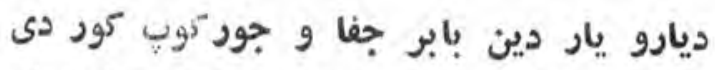
خوش او لكيم يار دين قطع ايلا بأن ترك ديار ايتسه • 


\section{(A)}

إول كه منعا ياردلنوا ز كسو روندى جورنى كور سل تتى كوب و آز كوروندى

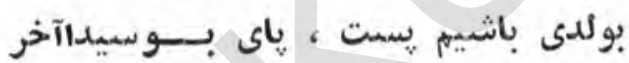

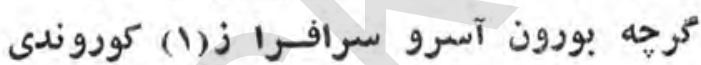
سمينينك اوجو ن اول كه باش (ب)اوينا ماد ىهيح

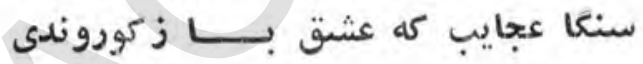
عشق باريدا صلاح وتو بــه و نقوى

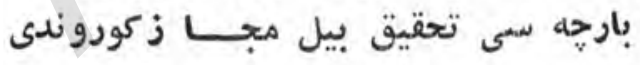

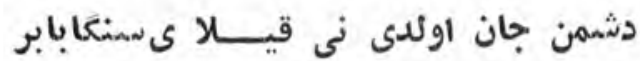
اول كه منغا يار دلنوا ز كور وندى

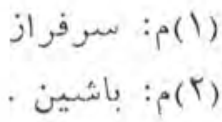
$-1+\cdots$ 
زى حهن داسرو بار اولقا مترعنا كيبى

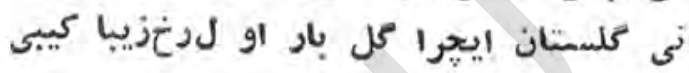

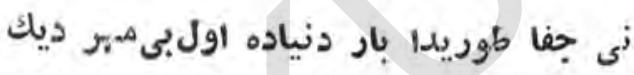

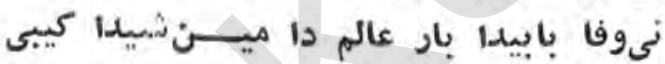

دانه خالى مسبيح آسا لبى نينكســاوستيدا

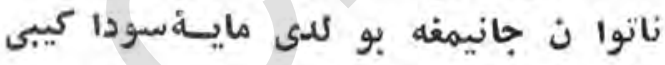
ايلاسام كو يى دا ماوا، نيلا يين جنت نى كيم

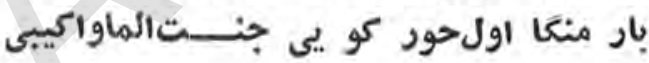

بزم ارالى دوست لارنى مى كهةقان ايجماك دور ور

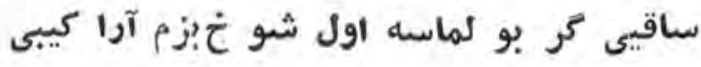

مينسه ابرش اول قو ياش ،كويمالى نيتا كي كيم بابرا مينى كويدور ماككا ييلدو دمر كب،اوت دور راكبى (1)

$$
\text { (1) }
$$




\section{(₹q)}

قدى شاخ ملديك نتاريم قانى ؟ كبى غنتجه ديك كلعذاريمقانى نى تانتكَ يوز نكار اولسه قا نيُش بيله كه اول يوزى كل ياش نتاريـــمقانى ؟ قرا كيحه لاردا كوزوم يارو تور اوشال شمع شبهاى تاريمقانى

ياريم كيحه لاركيلود اير دى بودون بوتون كيلمادى آه ياريم قانى

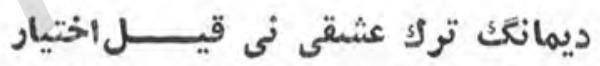

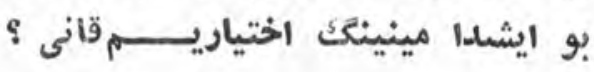

فرا قينكَك دا(r)كونتلو منى قانايلا سانكَك سنغا بولغاى اول بى قراديـــمقانى

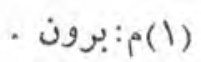
) $-1.4-$ 
شام هبرانين منعا اول بيو فاكورسها تماتاى

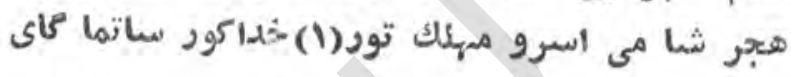
وعده ايلاب و صل كورساتعا ى زيتيّه جانيمنه هجر

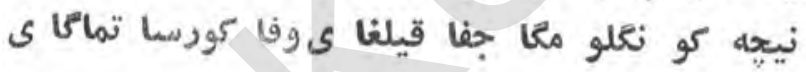

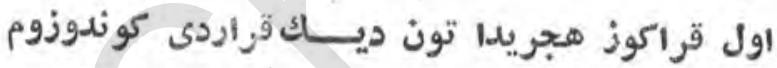
يارب انداق كون نى اول كوز ى قراكورساتماتا ى

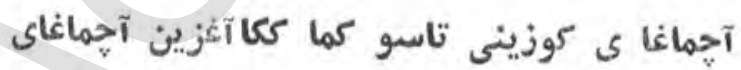

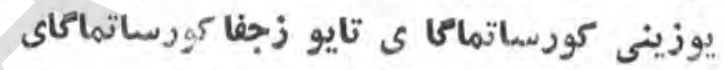
كشُقايستار بو كسه مجنون ايلا يوكنى نى بيلكاى كيشى تارهنما "وردساتماتحاى

اوحقو ديك (r) دورجان قو شى هجِراندا بابر آهى دين كيليرى تعجيل ايلا جانيم هواكوردماتماتحاى

$$
\text { (r) }
$$


$(\circ \wedge)$

يوز كورساتيب اولتور و رسينایى يوق سين كيبى خود نماو خودراي

قدينكَك الف و قا شينكَ ايروريا ديسام نى عجب اتر سينى آى آى هم لاله يوزونك قاشيدا بىرنك

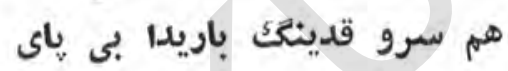

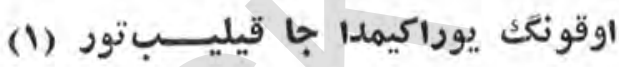
تارتيب يثه اوقنى قيلمه بى جاى بئي سيندين منعا يوز هزار حسر ت

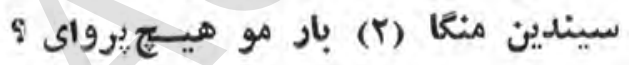
اول يار اكر ياشور سهيوز آه

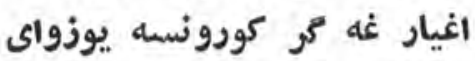
كولماس منغا صبح وصل بابر هر نيجه كه شام هجر (r) هييغلاي • (1)

(ई) (r)

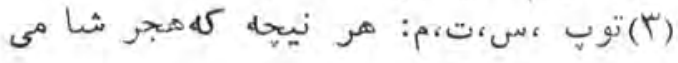

$$
\begin{aligned}
& -1 \cdot \varepsilon_{-}
\end{aligned}
$$




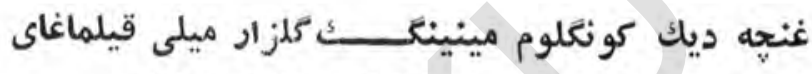

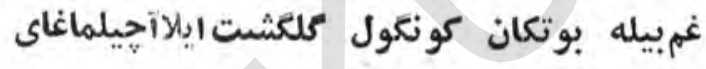
رنكهرنكه كلالار ينغنى باغبا نعرض ايتما كيم

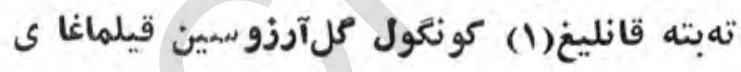
يوقتور اول كيم عل يوزونغديسن أيروباقسام كل سارى

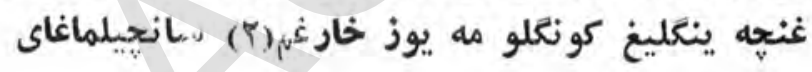
عارض و قدينكنى تعريف ايتسالاريوزييل هنوز

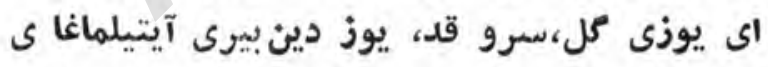
سيندين آير يلديم ايسهبو لد نم نصيبيم خارغم

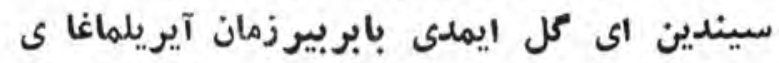

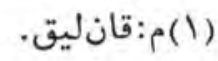

·

$$
-1.0-
$$




\section{(94)}

كمى ساغين نى بولدى زارلار نى اونو تماغيل بورو نغسى(1) يارلارنى

سينى كورماى ييرا قدين زار بولدوم (r) سارد بيرارياد ايت يير اقدين زارلارنى ئى

يوزونعدين آيرو مين خوار 1 ى كزيزيم كيشى حلدين آيير ماس خــ رلارنى

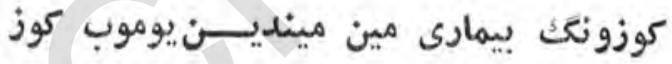

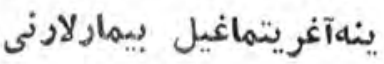

سنكا بير يول ييتار فكر يدادو رمين اونوتمابير يولى افعار لارنى ينى يلى بير رسنكا كونغلو منى آلد و رديــم جبهاندا كوروب هين كر حه كوي دلدا رلارنى سبى قدلارغه بابر عاشقاولسـانغك بورونراقكوزلا عاى سيــن دارئ عالارنى

$$
\begin{aligned}
& \text { (1)تم:م:بوزونقى } \\
& \text { (T) }
\end{aligned}
$$


(90)

ياقاشمينكك ينكليغ ايكيلكان جسمرأريمنى مودى

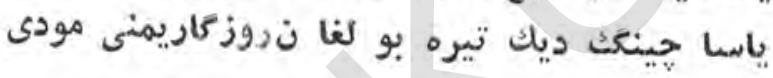

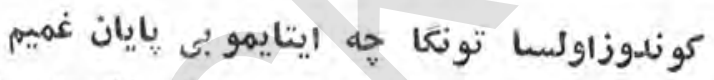

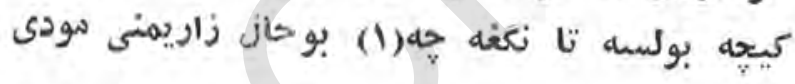
هجر قاتل بيركه كونغلو مج بـاكتين مو شرح ايتالى

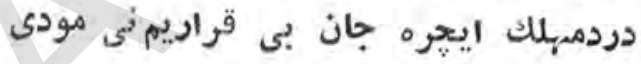
تيلبه ومدهوش وبيخود ديمه كيم قيلمدى سينى

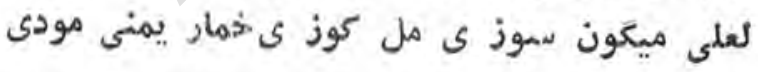
بابر اول آى نينكف قوياش ديك عازفمى هجرانيدا تانكغه ديكر وهر كيجهيو لسدوز ليساناريمنى مودى

$$
\begin{aligned}
& \text { •(1) } \\
& -1 \cdot V_{-}
\end{aligned}
$$




\section{(V.)}

زهد كيتنى ايسه كرم قيلدى عشق كيلدى و محترم قيلدى إسى كيلي اول الف بويلوق آى نينكثعشى

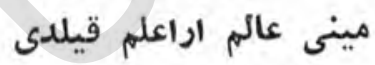

كوزى وزلف وآغزى فرقتى فلك آخر مينى عدم قيلدى وزئ كونكلوم اور تاندى هر د مآهيمدين

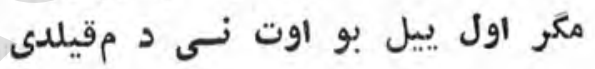
قاشى يالار جفا سيدين بو حرخ مينينكَك آتيم غه اوق رقم قيلدى جنكَك غم دين قوتو لمادى بابر

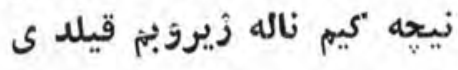


كورماناى ايرديم جمال عالم آراكاشككى

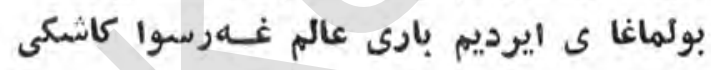

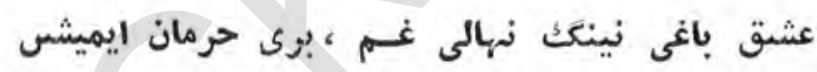

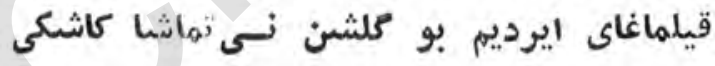

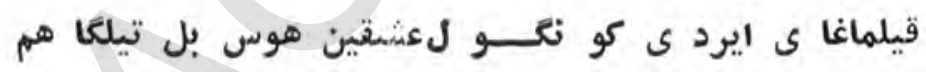

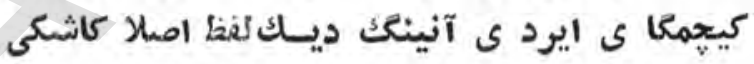

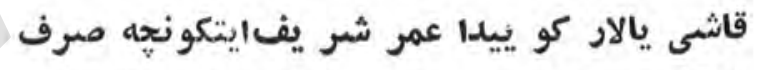

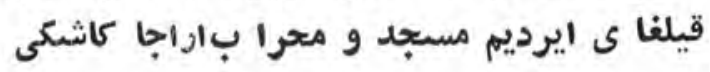
اختيار ايت اوز كا ايشس بابركه.حاصل بولماغاى عشقو وصل وعيش ايلا عشرت تين (1) الاكاشكى ائى إنى (1) $-1 \cdot 9-$ 


\section{(Ar)}

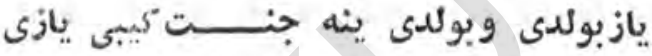
خوش اول كيشى كيم عيش ايلهاوتكأى قيشس و يازى

دوتاره اونى عيشس وفراغت نى بيزور ياد دطرب قه(1) قولاق توت كه نى دير نغهل داسازى

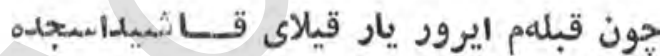
ناصح سوزينى نيلاى ، ايما س سبوزي نمازي بوتيلبه ومدهوش دل وجانغه نى ئوش تور(ك) كه قهر و عنابي بيله

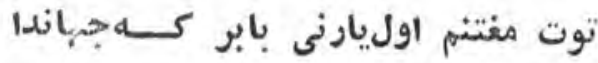
محمودكيم ايودى ،نى كيشى ايردى ايازي ؟ ؟

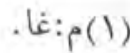

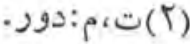




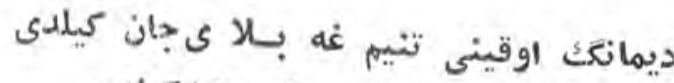

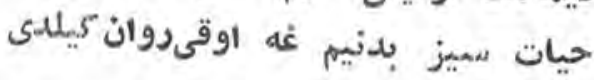
حيات سو يينى قوى كيم لبيدين آنديمير كام

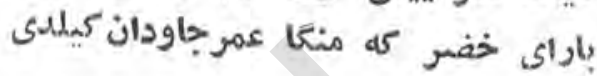
سميهر كو يينى كولك ايورو لو دكيليدهر كون

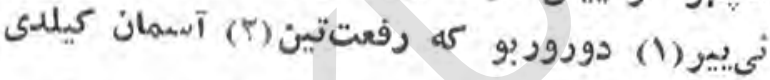

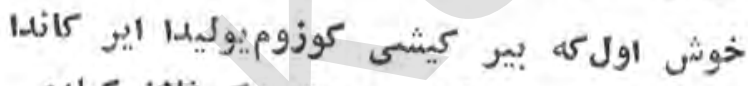
سيوينجى ديب يوكوروب ييتسه كميرفلان كيلدى فراقارا اولا ريمدا يبتيشتى (r) اول جانان خداغاء ش.عر قيلاى إكيم اولار زمان كيلدى

عدم يوليفه كونكول كيردى عشقداغى بيله بويولدين اوتمادى هركيم كه بى ثشمانكيلدى

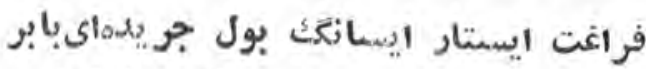

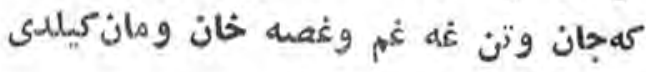

$$
\begin{aligned}
& \text { (؟) } \\
& \text { - (r) } \\
& \text { · (r) بيتيشتى }
\end{aligned}
$$


باش داحر يوقتور جلالتموهوى دين افسرى يانيمهسب دور مذلت توفراغيدين بسترى

كير عالى كوكسوم ارا كونكلوم، ايشيم كويماكك دورور مين نيحوك كويماى كهو كسومائجره باردوراخترى صبر وهوش وعقل و دينيم نسى آليب تور (1) نيلايين سروقدى تحلر خى ريحان خطى زسمرين .برى كيرييكى ديك (r) خنجرين ايل كو كسيعا كوركان زمان كوزومه هر كير ييكين يارب كهقيلغيل خنجرى

ابو شينى ييلد وروب ييتــا جييقيلديم دو ستلار

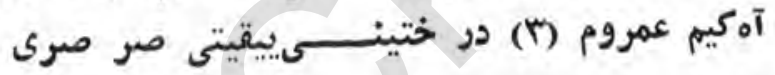
كنج حسنى داكورونك زلفى بيله كلكونه سين

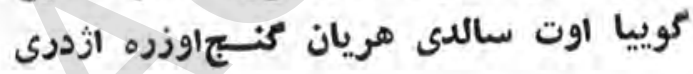

هجرشا مي دين مينينك قان يوزماغيم نىيادايتينك

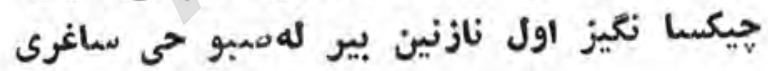

هرنيجوك تور (ع) عمر نى بابو مخوش اوتكار ماك كيراك كيمبو بيش كون عمر غمكين بولغالى قيلماس كرى

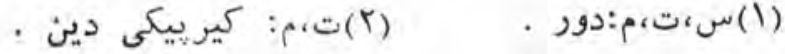

$$
\begin{aligned}
& \text { (ع) } \\
& -115
\end{aligned}
$$


بحمدالله كه اول كل داوفا دين بارايميشس بويى

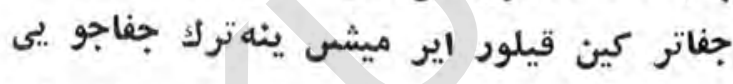
قدم رنجه قيليب باشيمغه كيلكا يمو ديبان (1) اولئي

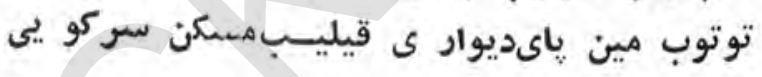

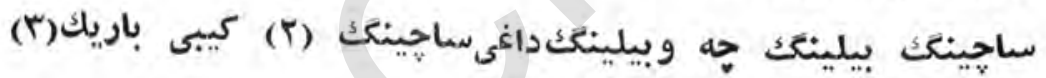

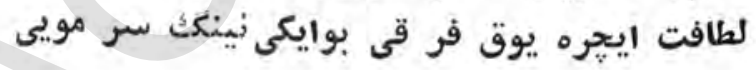
ميسر بو لسه بيلكيل كيم بارىعالم دين آرتوقدور

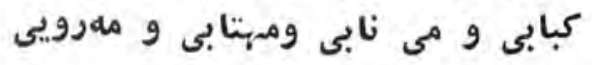

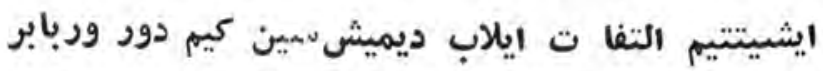

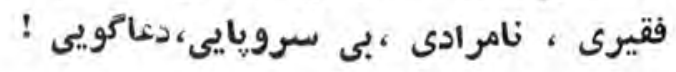

$$
\begin{aligned}
& \text { (1) مبكاك: ديب } \\
& \text { - } \\
& \text { (ب) }
\end{aligned}
$$




\section{$(1 \cdot \varepsilon)$}

توناكون بيرلهبو تون (1)مجلسى اسرو خوش ايدى مجلس اهلى بارى دلخواه وبارى دلكشس ايدى

بارى نينكَك سموذى ايدى خوب ولطيف ورنكين

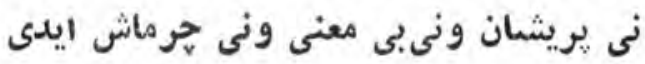

يخشى مى يوق ايدى و نسشئهَمى يخشى ايدى ناخوش ايل يوق ايدى و اسروهواىخوش ايدى ايلى ليدى بارى احباب ايدى حاضر بار ى الدباب ايدى جمع سازو خواننده بيله نقل و مىبى بنس إيدى

كاه يرخنده ايدى ايل بسى سر خروش لوقتين

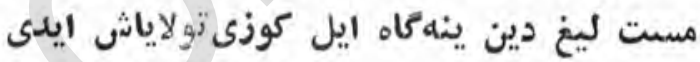
بارحه تعظيم قيليب بير بير ىنىمشمتائه

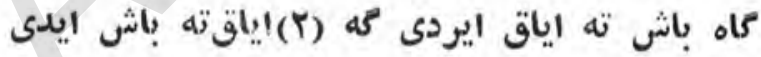

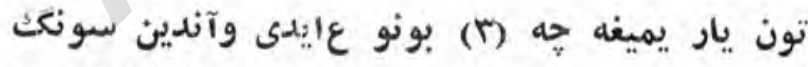

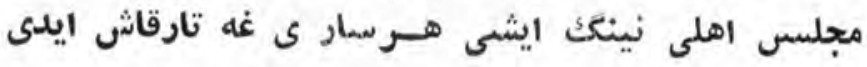

(1) $.018:-(r)$

(؟) $-11 \varepsilon-$ 
مين ايليك تين (ع) باريب اليرديمثرنوب ايلكيمنى بير او اودي

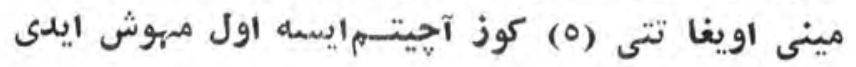

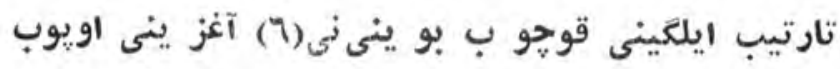

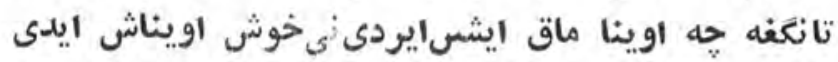
بابر ارهرزه ديدى مجلس ايلسىيب ايتمانك

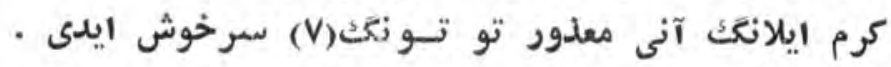

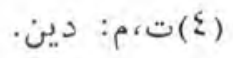

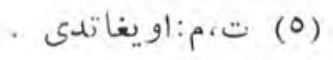

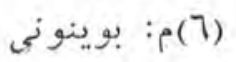

(V)

$-110-$ 


$$
(1 \cdot 0)
$$

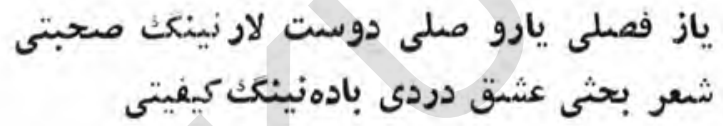
ياز فصليدا حاغير ايحما كو نينك اوز 'ماحالى بار كيم حابو زشئه مينير بولسابار دوردولتى لئي عشق دردينى جيكيب هر كيم كه تأِبسمه وصل يار اول زمان بو لغا ى اونوت يوزييلغى هجران شدتى

دومست لارنينك صسبتى دا نسى خوش اولغاى بحث شعر

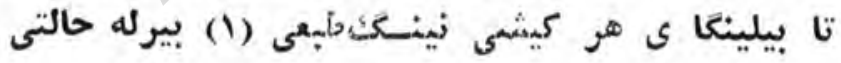
كربو اوج ايشنى موافق تايسـانكـ اول اوج وقت ايله

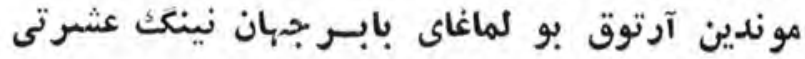




\section{$(1 \cdot v)$}

اول عهد ايله بيمان قانى اى يار نى بولدى ؟ إنى

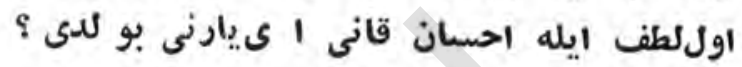

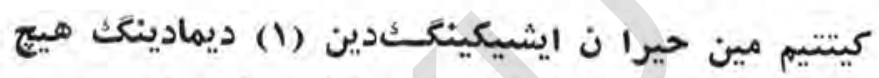

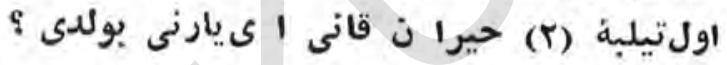

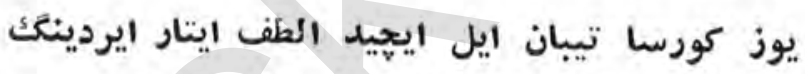

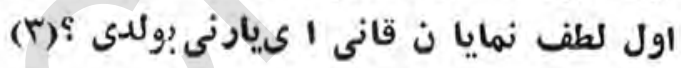
سينينكث سار ى بارى كونتو لايستاب تإيا آلمان

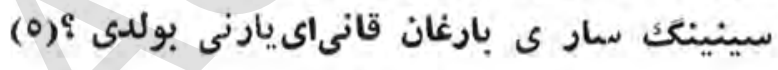
جانيم غه دوا سوز ينك (ع) ايدى سوزلاهادينك آه

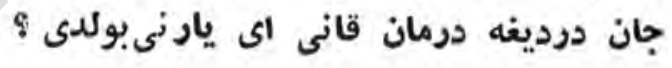
مونداق موايدى عهد كه بابر نى اونو تتونكَ

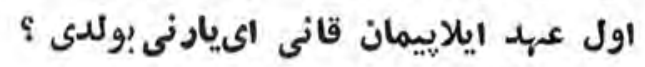

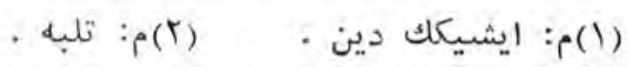

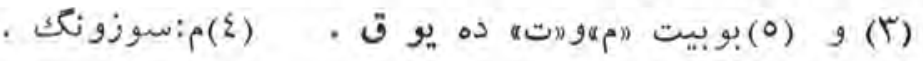
$-11 V_{-}$ 


\section{(11*)}

شكر لله عيش يوزلا ند ى ومحنت قالمادى ييتتى ايام وصالو (1)شامفرقت قالما دى لئ

يوزلانيب امن و فرا غت غصه وغزم بولدى رفع(ז) عيشس و عشر ت كيلد ى و رنجو مشقت قالمادى

محنت هجرا ن كه آندين حا لكهائ ايردى كونغَول بولدى راحت قه مبدل اول جراحتقالمادى مرتفع بولغاندا هجران كيل تسوقفقيلماكيم انتظار ينك نى هيكا ر ما اوزكا طاقتقا لمادى

وصلينكا ييتـكو د دى دورا نعاقبت بابرنى شكر

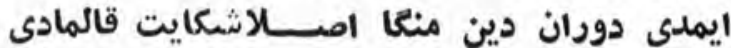

$$
\begin{aligned}
& \text {. لهاله (I) } \\
& \text { (T) }
\end{aligned}
$$


ينه بير كوز غمى دين خستــه كورارمين اوزنى ينه بير زلف غه وابسته كورا رميناوزنى دين خدون

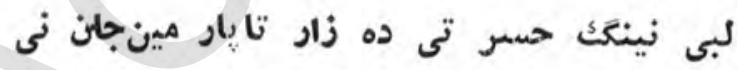

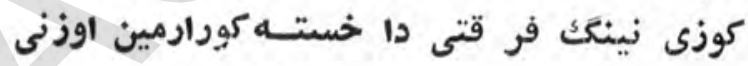

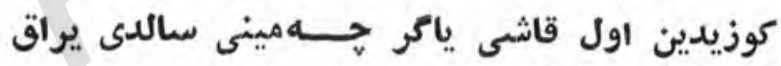
ليك اول آى قاشيدا (1) يِيوسته كودارمين اوزنى زلفى زنجير ى غه تابو لدى كو نكول وابسته

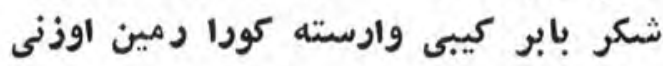


حبيب بو لسه ايدى يار قيـــبـاولسه ايدى إيلى

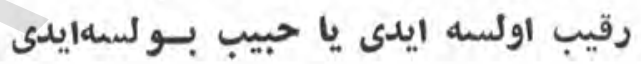

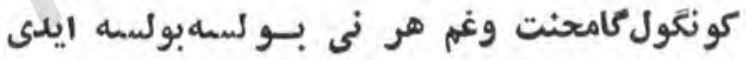

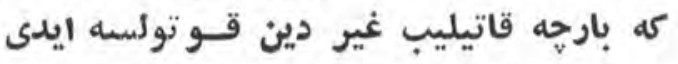

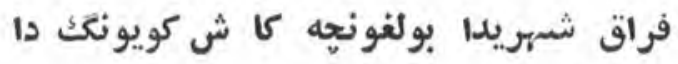

(1)

(1) بوتو كه تيلمه كن غزلناتعده يوق . بو هصراع دكتور واحدى نينكك ياد داشتى دن صحاف آرقسه كيسيب تشلنكن. - 


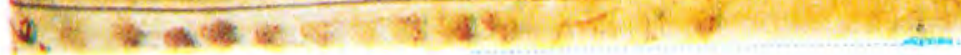

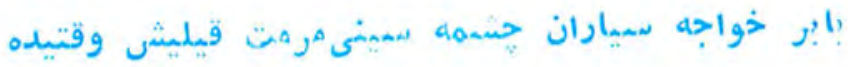




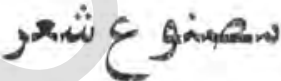

\section{(17)}

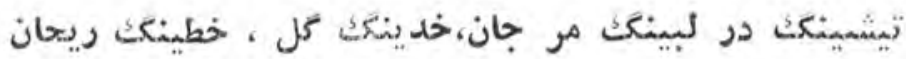

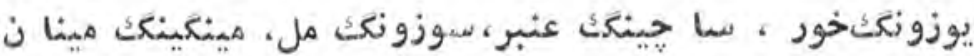
مينان مينكينك ، سوزو نككمل،عنبر سـا حينكف يوزونكك خور

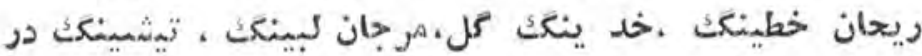
-IrI- 
تفاخر كوزو م مو نعلو م قيلورلاز هكر باردور

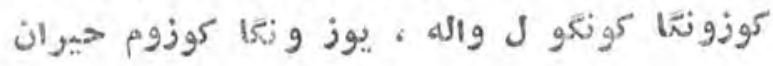

حيران كوزوم يوزينكا ، واله كو نكول كوزونغا

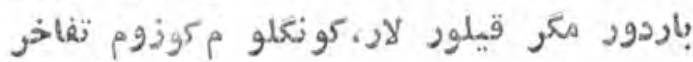

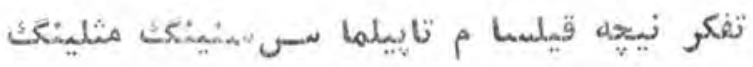

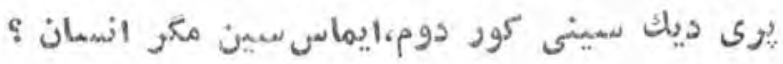
انسمان مكر ايماس سمين كوردومسينى ير عديك

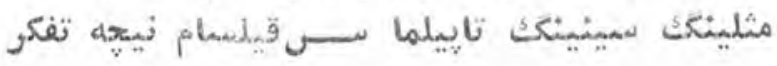

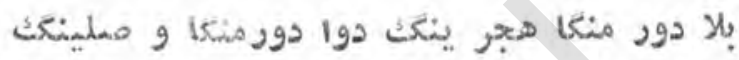

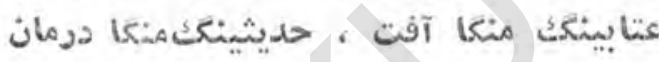

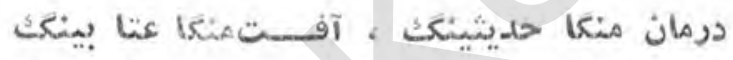

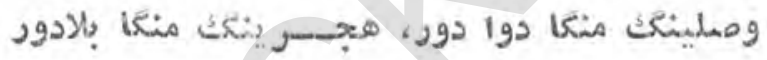

بابر جو (1)سنكا قو ل دور، نظرقيل انكتا زنهاد

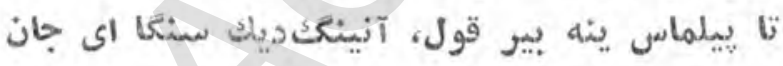
ائ جان سنكا آنينكك ديك بيسر قول ينه تالييلماس

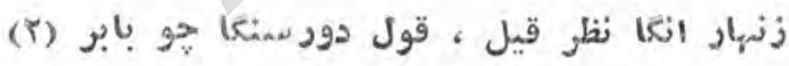

$$
\begin{aligned}
& \text { • } \\
& \text { (T) بو شعر "اته ده يوق . } \\
& \text { - Irt - }
\end{aligned}
$$


ر بـاعسى لار 
gis

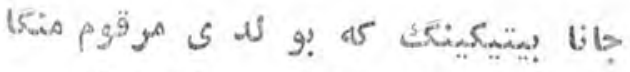

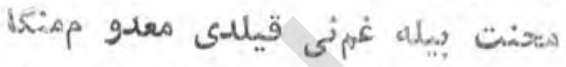
مضو $2 و^{5}$

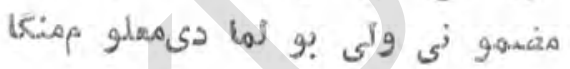
wg

نى عشمرت و عيش أوجون مسى ناب منَّا

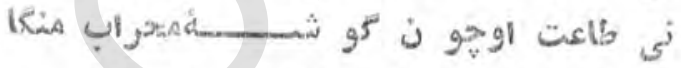

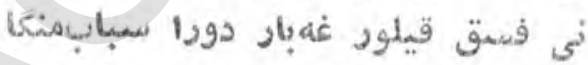

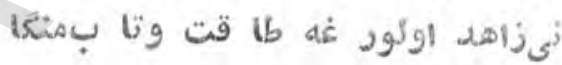
و'

تابولفا كي ديلهار اوشارآ ومنغا

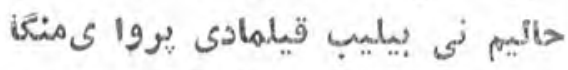

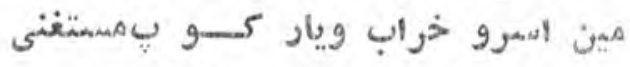

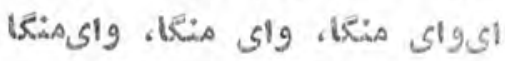
$-1 Y H=$ 
4)

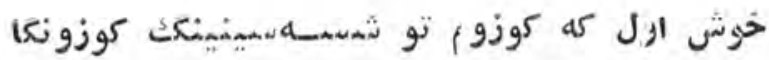

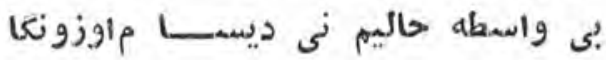

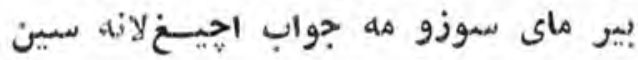

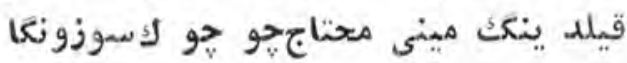

..

اسروكوب إيمشن جراتو همت منيز

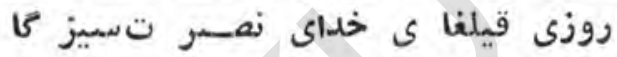
هردانه ليفينكيز نى.بارى اي-سل بيلدى

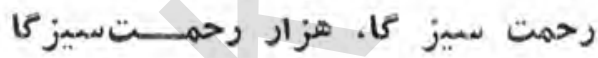

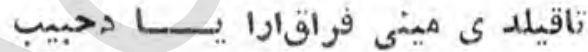

مه:جور كونكو ل نى ايرلا دى شماد بيبب

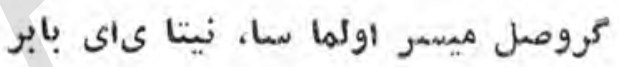
فرياد حبيبوآهو فرياد حبيب : as

اى قا متى سمرو ولب لارى آ ب كيات

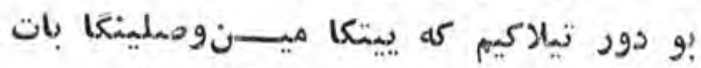
ثنجر ينكى دا منكا نى مسبرقالدىنى ثبات يإكيل .و سلاريغه يا مينى او زونكاقات - Irs - 


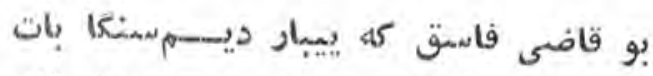

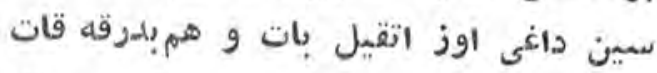

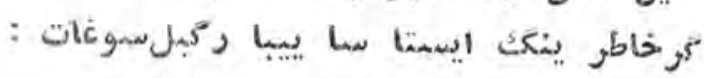
معتون وشمراب وآب نارنســيج ونبات.

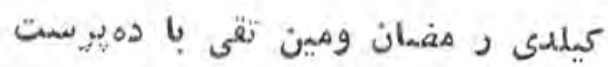

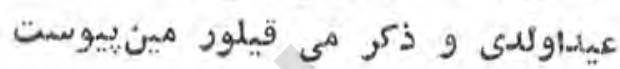

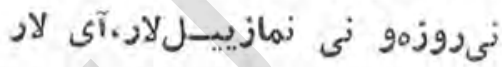

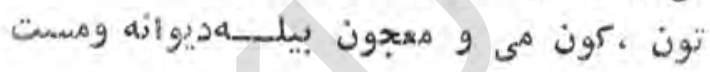
49

بوليدوم مين آشفنة حثرانهردود قيلغيل هدد ى كهبو كلى امكانंابود

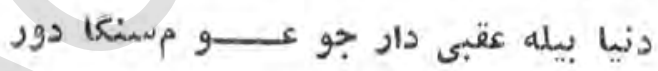

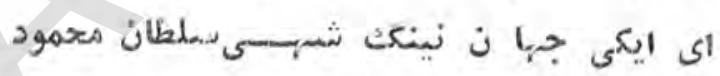
ولـه

مطرب كه اونينى هو كيشسى كوشقيلور جان بيركله كو نكو لنى زارو مدهوش قيلمور

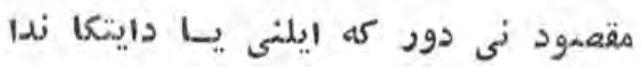
اول دايره د!بيز نى فرا موشقيلور - Iro- 
ajg

دشمهن نى كهبود هر زبو دسستققيلور زخوت مبيى دين بير نيخه كو نمسمت قيلورد

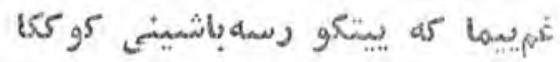

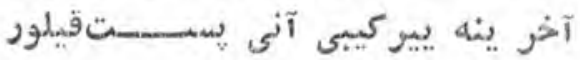

Sg

كوزونكث بأر يايل كو نكلينسي(1) مسمت ايتكو سميد ود

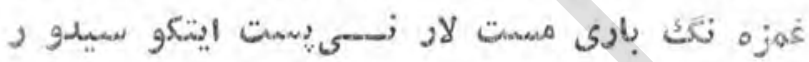

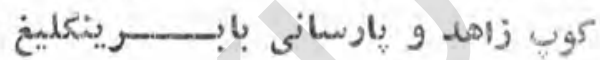

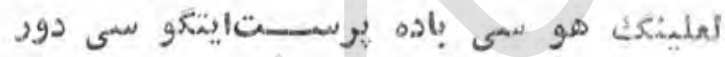
dg

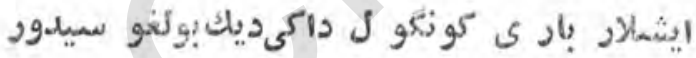
انعام وو ظيفه بار ى بويرو لغوستيلور

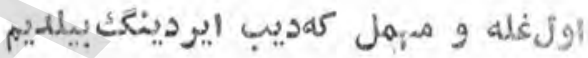

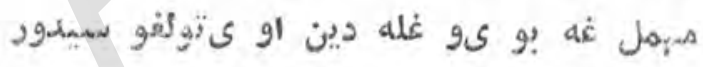
g) هر كيم كه وف قيلسمه و فاتإيقو مسىدور

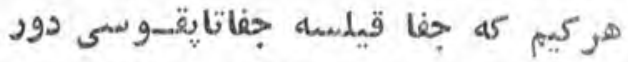

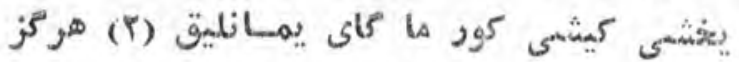

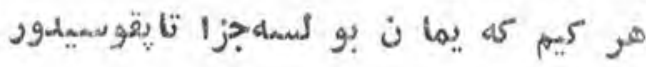
inlon: ت (T) رنى 


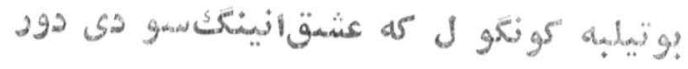

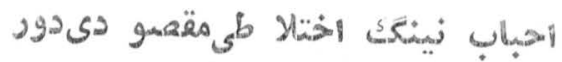
ها:

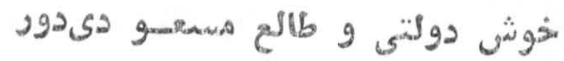
asg

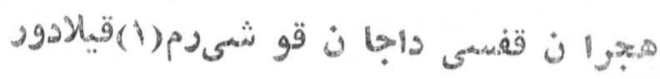

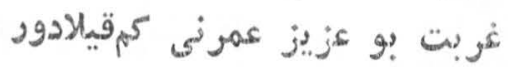

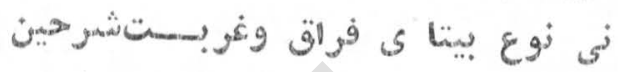

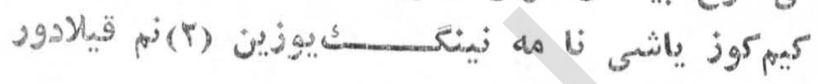
4g

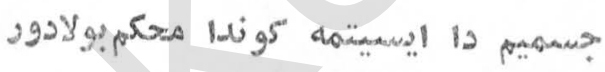

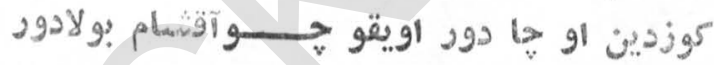
هو

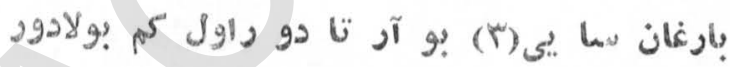
dg

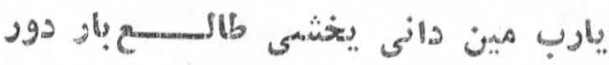

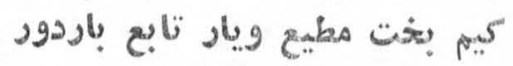

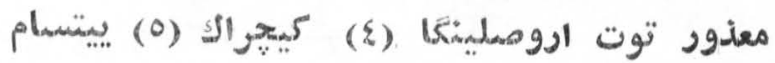

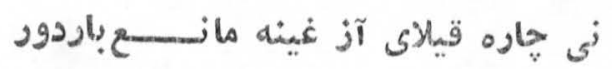

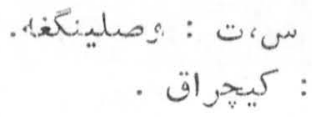

(!) (1)

· (Y) . 
وله

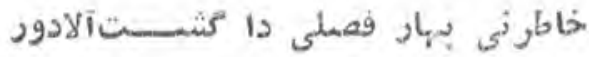

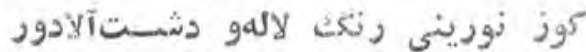
خوش اول كم تلالار دايودو بمسيرا يتسمشك وفعسل داكيم لطميف و دلكشم تالأدور

g)

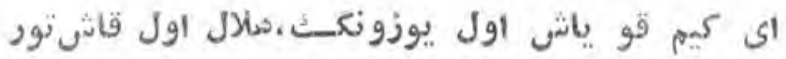
يولاد دورور (1)كونكلو نكك وباغرينك ناش دور

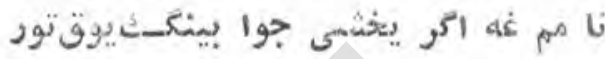

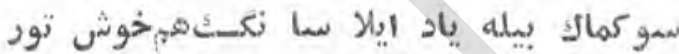
ald

آهجرىارأ آرام وقراديه يو قتور

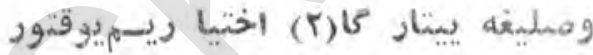

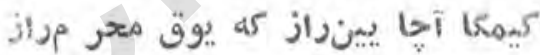

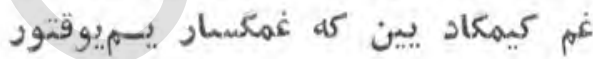
و

اولكيم إنكا علم (r) ايتره غالب يوقتور

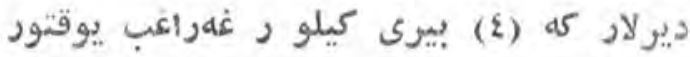
ديبيم كهبوسموز راستت ايماستورد(0) نيكاكيم

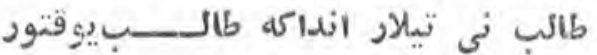

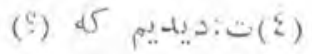
(1) . إ. (r) مالم: (r) 


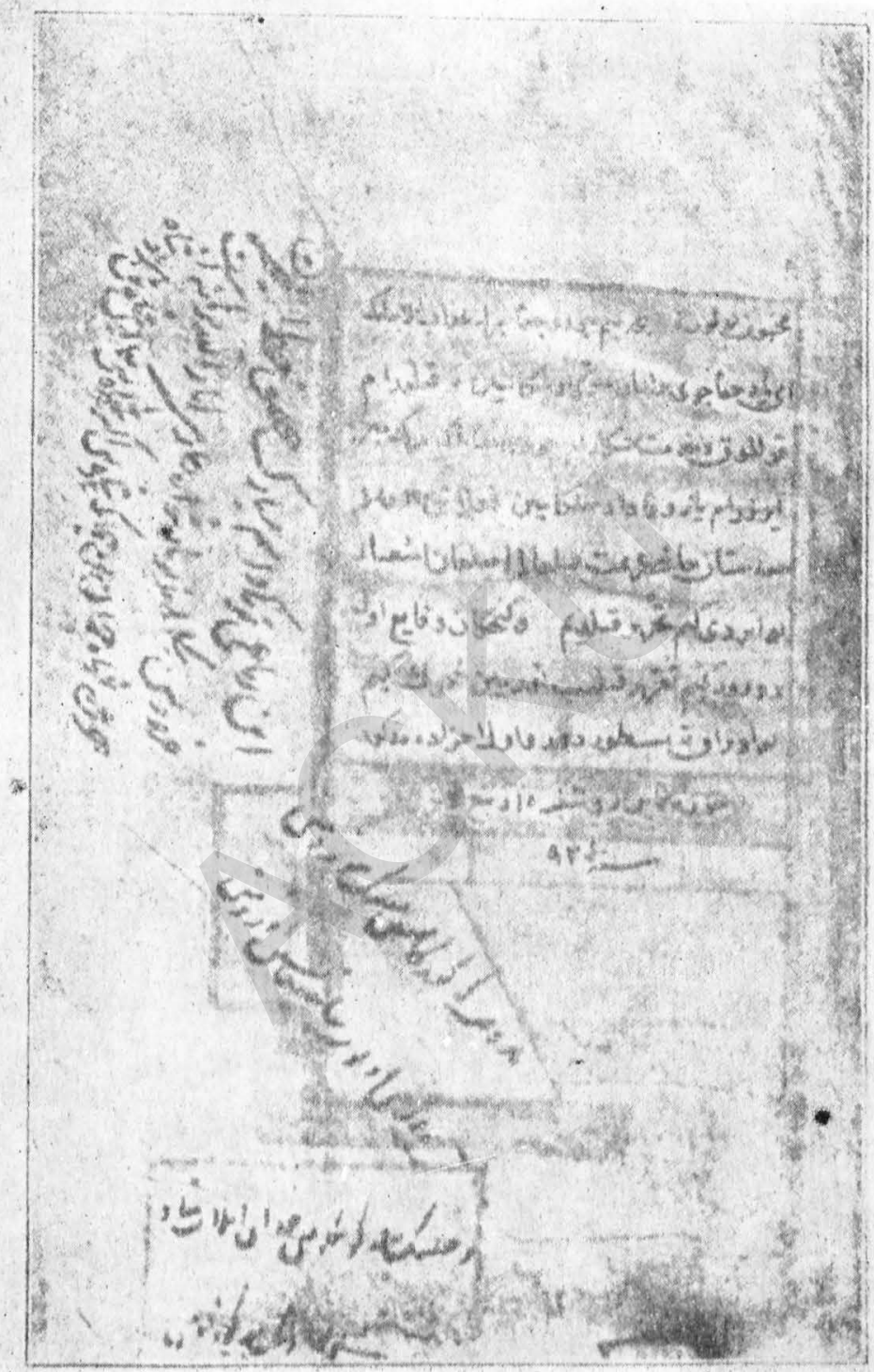

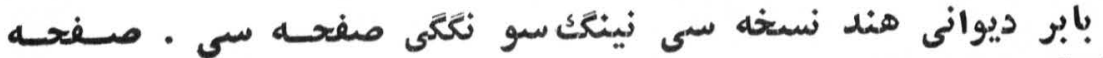

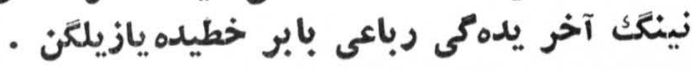




$$
\begin{aligned}
& \text { و } \\
& \text { زوزآه ظبهر دين هملمد بأبر }
\end{aligned}
$$

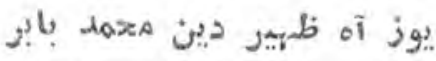

$$
\begin{aligned}
& \text { سمر رشمته عيشن دين كونكولنىزنبهار }
\end{aligned}
$$

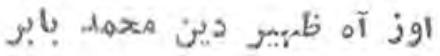

$$
\begin{aligned}
& \text { alg }
\end{aligned}
$$

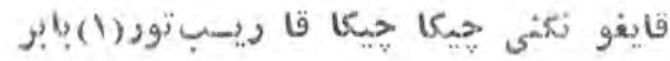

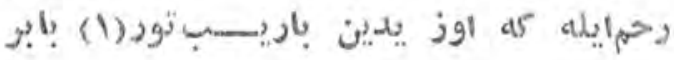

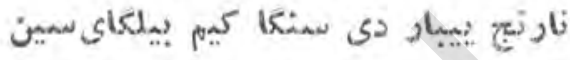

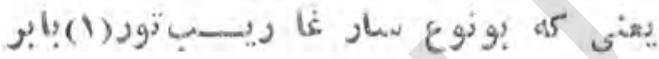

$$
u_{g}
$$

$$
\text { ب!. }
$$

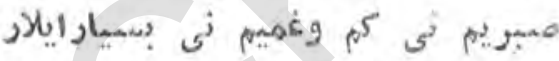

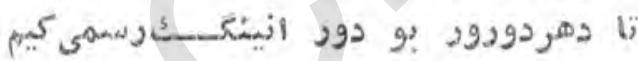

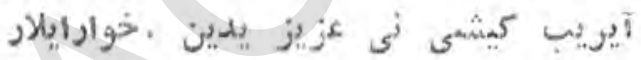

dig

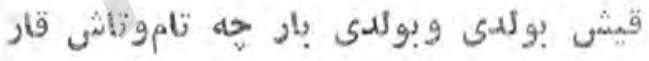

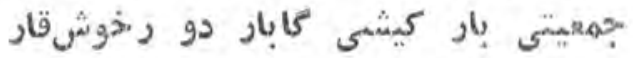

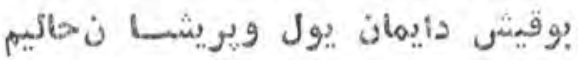
يأرب مينى يخشئى ليخ(Y) سماري بانشقار

$$
\begin{aligned}
& \text { (1) } \\
& \text {. }
\end{aligned}
$$




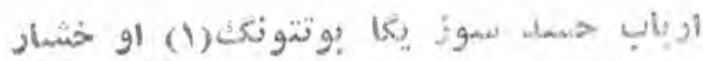

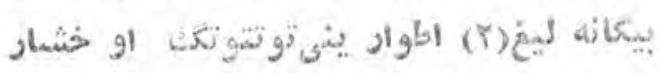

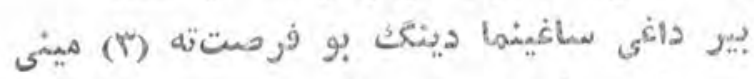
هين خسته نى إى يار اوزو تقونكي اوخشمار وله

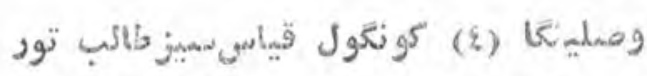

$$
\begin{aligned}
& \text { هجريثكن ارا أختيار سيز قاليمبئور }
\end{aligned}
$$

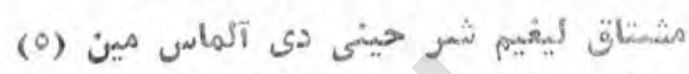

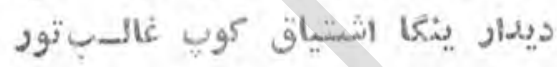

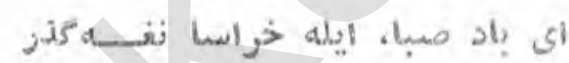

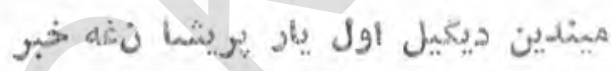

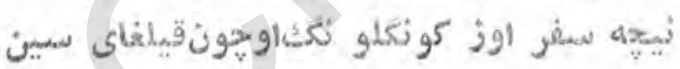

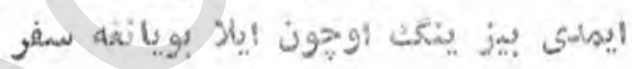

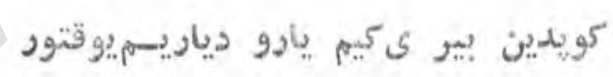

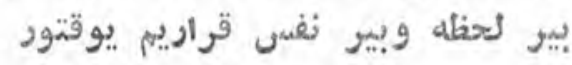

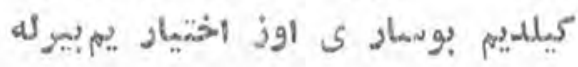

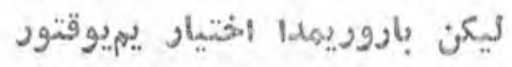

$$
\begin{aligned}
& \text { (ع) س، ت : وصلينغغه. } \\
& \text { سن: (1) }
\end{aligned}
$$

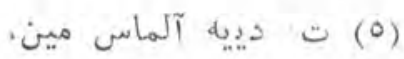

$$
\begin{aligned}
& \text { س. (T) سي: (r) }
\end{aligned}
$$

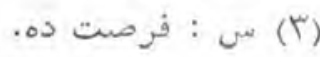

$$
\begin{aligned}
& -18+
\end{aligned}
$$




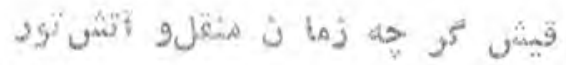

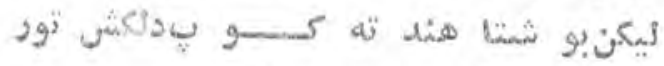

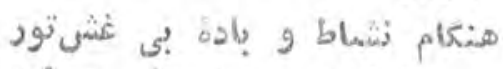

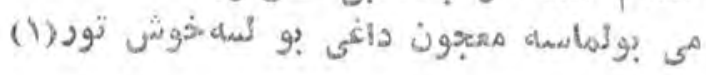

$$
\text { as g }
$$

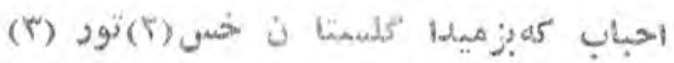

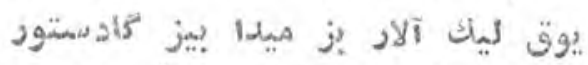

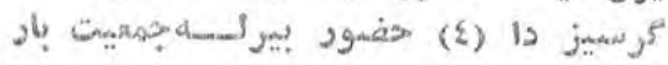

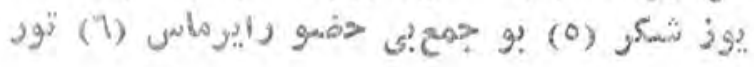

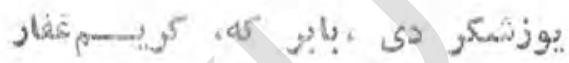

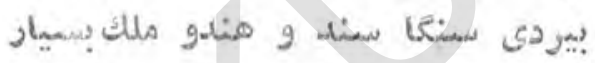

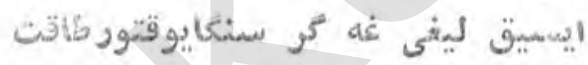

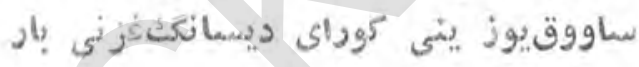

كونكلو هدا او ت وايكى كوذو مداسسو دورد

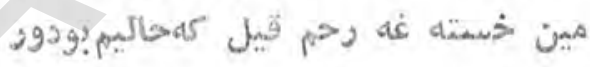

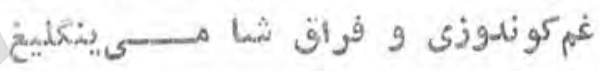

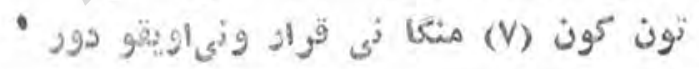

$$
\begin{aligned}
& \text { (1) } \\
& \text { (r) } \\
& \text { • } \\
& \text { (2) }
\end{aligned}
$$

.

(؟)

. : (V) 


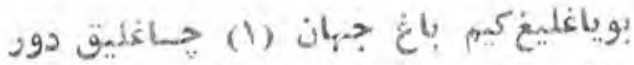

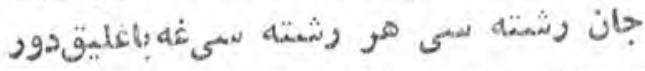

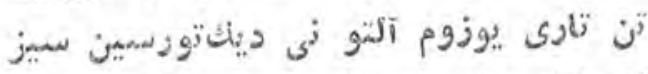

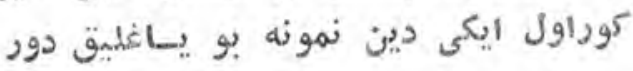

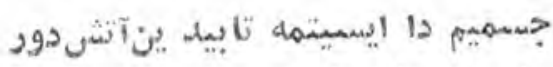

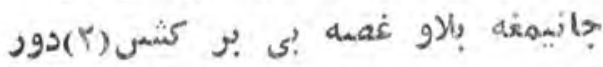

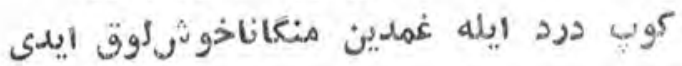

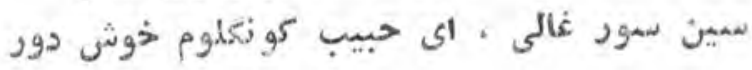

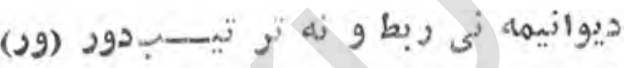

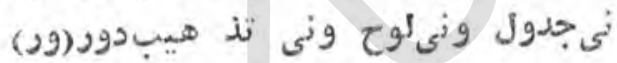

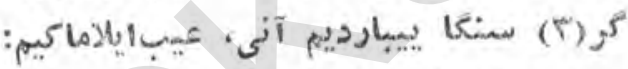

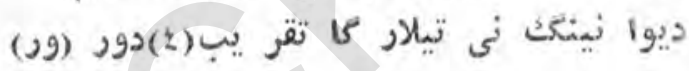
d)

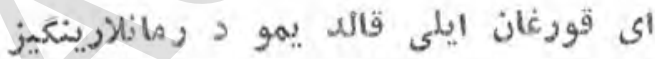
حيقماى ، زيد ورور (0) بوجنهل قيلفا زلارينكيز

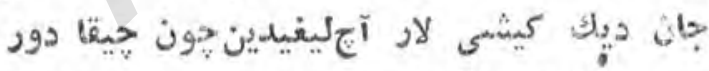

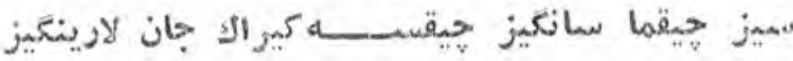

$$
\begin{aligned}
& \text {. } \\
& \text { (?) (ب) } \\
& \text {. } 4: 0(4) \\
& \text { (؟) (乞) تصن } \\
& \text { (0) ت: هيد: روز } \\
& -1 H 4-
\end{aligned}
$$


afg

احباب يبغيلما ق نى فرا غت توتونكيز

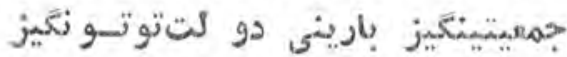

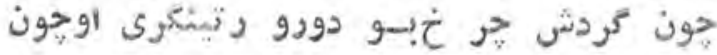

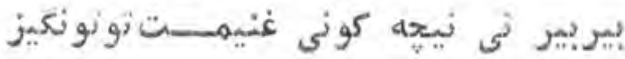
is

ثنجرينك غميدين عا قيتاولكومقراكوز يوزغصسه واندو م ايلا باركو مقرواكوز.

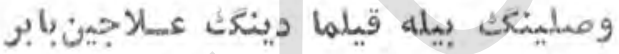
مشمكل كه فرا قهينك داتيريلكو مقوراكوز اظظهاد لطافت و ظرافت قيلاسيز مونكته دايوز توها نكتا بتقيلاسميز

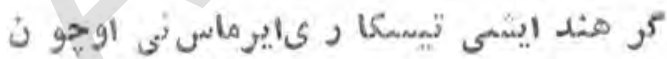

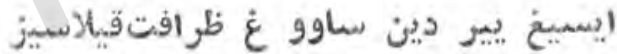

آزار ايله زيمه كفتكو قيلغنا ع مهيز ؟ آذرده بوكور نى جسم:جو قيلغاي سميز

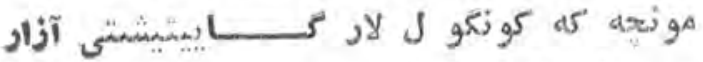

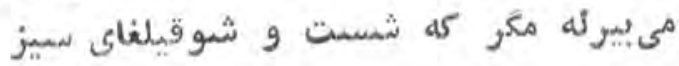
-IYK- 


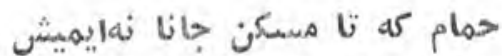

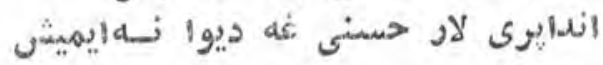
اول خودير ى دور بارحه مالخاز ملأرى هم

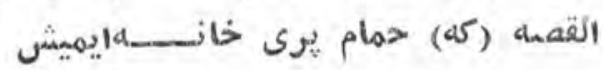
ag حسمن الهليفه زار و مبتلاكو زابيرميش

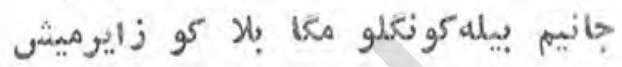

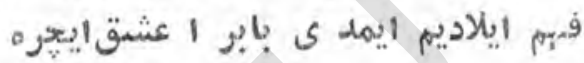

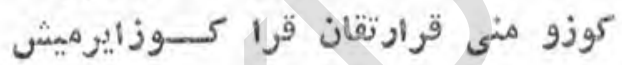

هو حظ كه خلايق اند ين إبريلماسى اليمشي

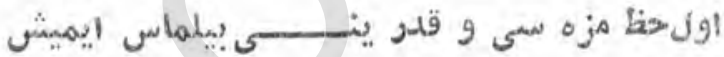

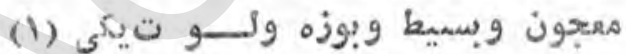

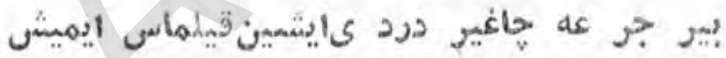

بو خسته كو نكو ل ايوور وصمالينكك بيله خوشن

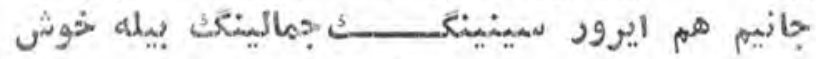

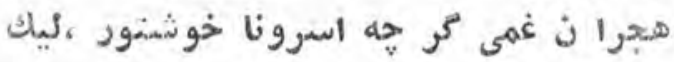

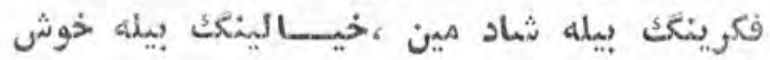

(9) (ب) : (1) 
?ون إردي

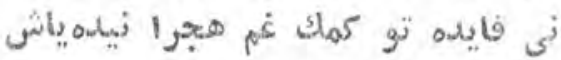

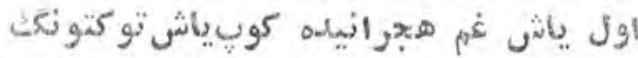

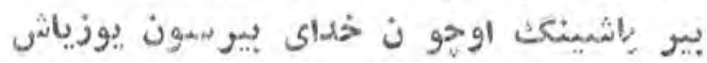

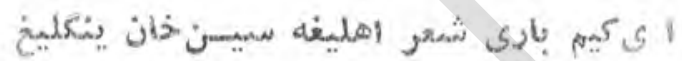

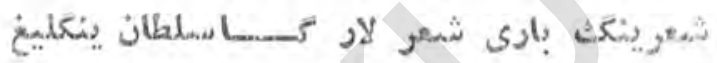

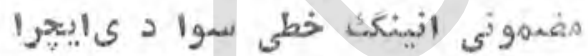

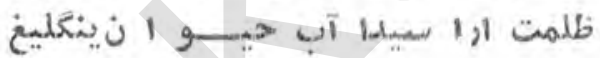
459

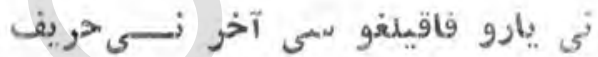

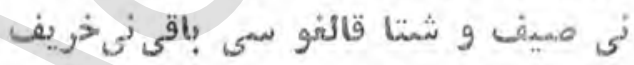

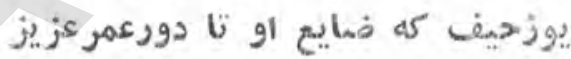

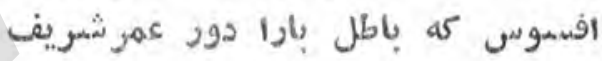
dg

الكفت توتاي اربار ايسهة تاليفشَّريف

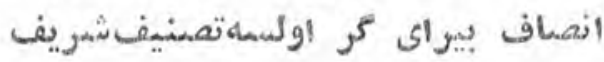

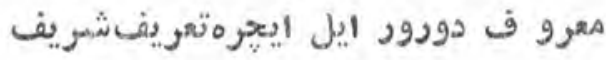

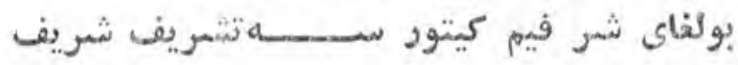
$-1140$ 


$$
\begin{aligned}
& \text { وله } \\
& \text { اندين بيرى كيم قوصديم او حونتوندى فراق } \\
& \text { يوز درد والمز نى هنغاييتكور دى فراق } \\
& \text { هينى ايضشيكينكادين ، نيتا بيســن سمور دي فراق }
\end{aligned}
$$

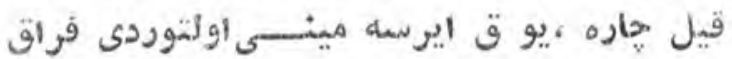

$$
\begin{aligned}
& \circ \div \\
& \text { مى تركينى قيلغا لى ايرور مينغم ليثت. }
\end{aligned}
$$

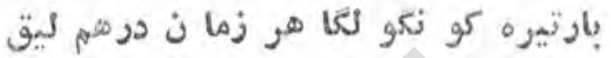

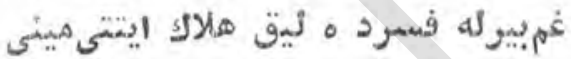

$$
\begin{aligned}
& \text { مى بيركه ايميش شماد ليغو خر ملئي } \\
& \text { آلوده .يوز زو مان معاصمى بـــولماق } \\
& \text { كوزرنج وتو مان عذاب خا صمسى.بلماق: }
\end{aligned}
$$

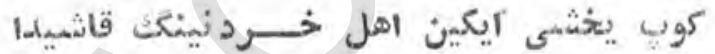

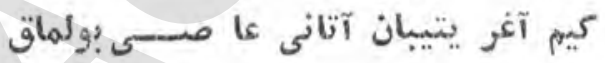

$$
\begin{aligned}
& \text { وله }
\end{aligned}
$$

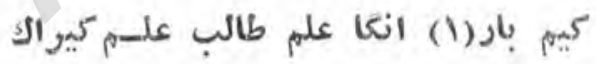

$$
\begin{aligned}
& \text { اوركا نكالى علم طالب علمكير الك } \\
& \text { مين طالب علم و طالب علمى.يوق } \\
& \text { مين بار مين علم طالبى ، علهـم كير الك } \\
& \text { - (1) } \\
& -1+4
\end{aligned}
$$


وله

يوزونكف بيله لب لارينك ايرودمك-مل (1) ديك

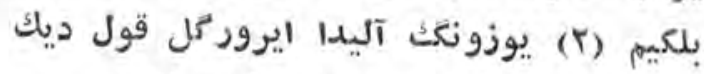

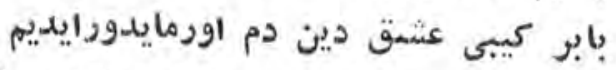

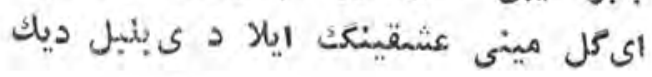

g a

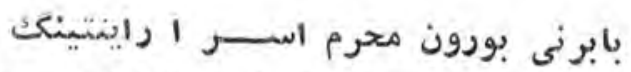

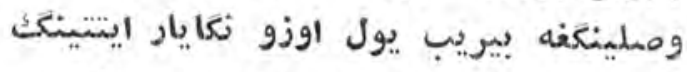

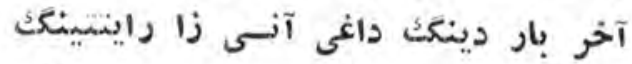

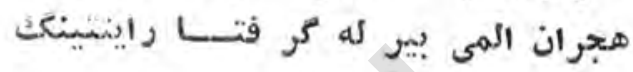
asg

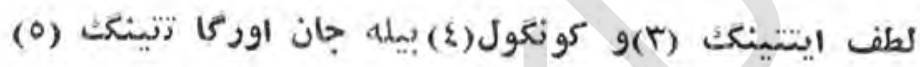

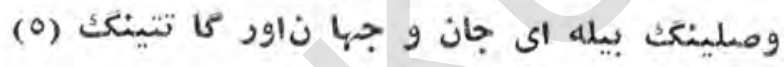

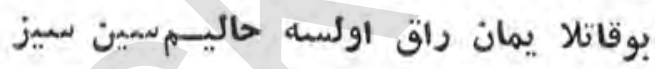

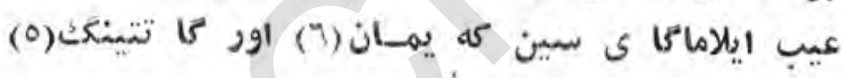
g

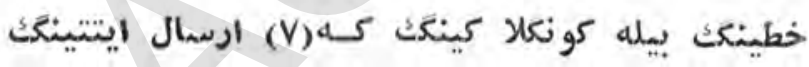

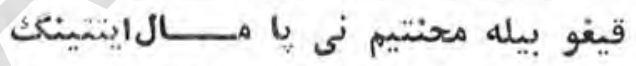

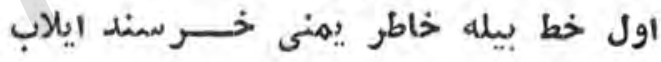

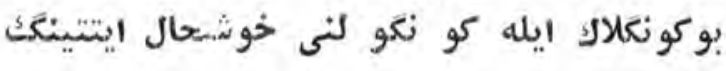

$$
\begin{aligned}
& \text { (0) } \\
& \text {. } \\
& \text { : (V) }
\end{aligned}
$$$$
\text { (1) }
$$$$
\text { (r) }
$$$$
\text { (ك) }
$$

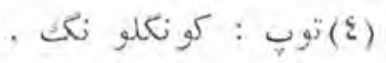

$$
-I r V-
$$


كوز شمعيني يازو تقا كي مهوش كيلدينغك

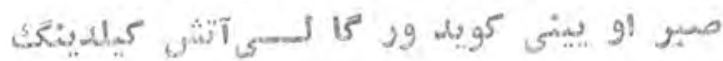

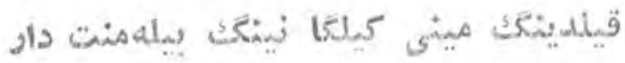

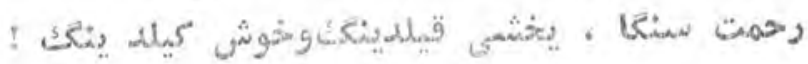

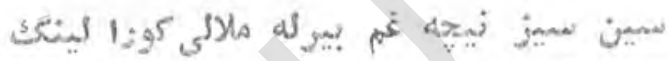

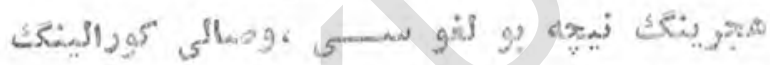
هـ

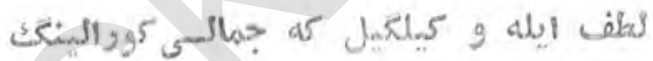

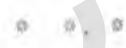

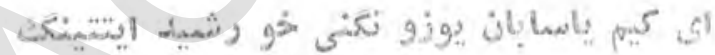

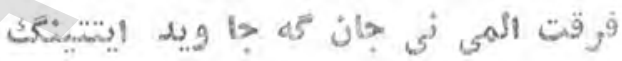

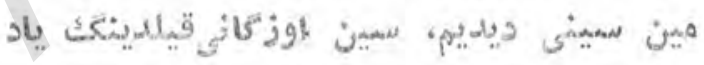

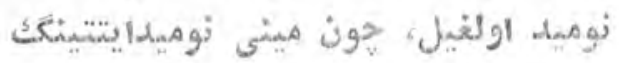

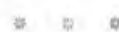

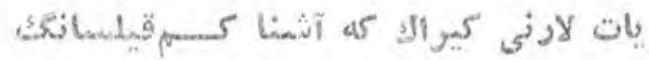

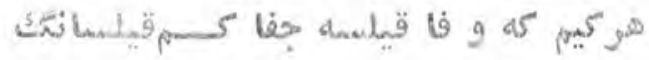

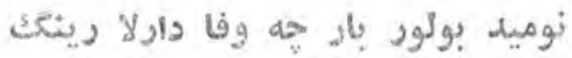

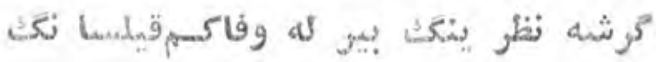
$-151$ 


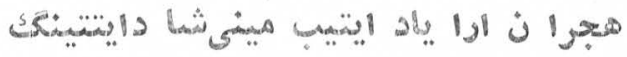

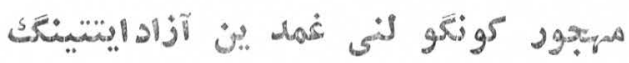

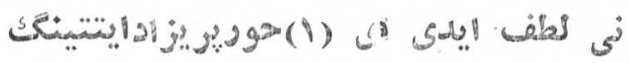
(i) * * *

هو يميو

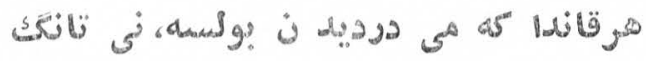

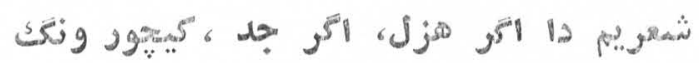

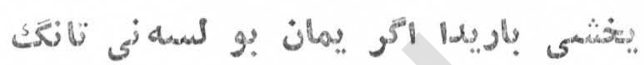
alg

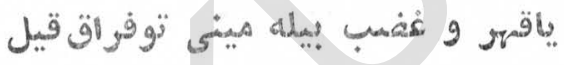

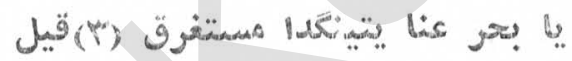

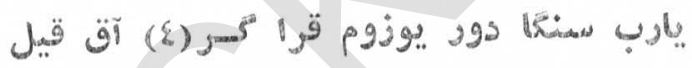

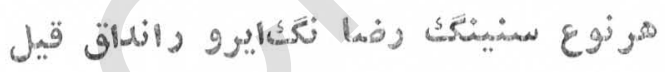
ass

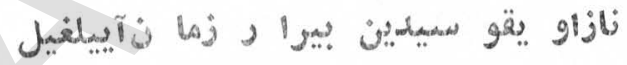
تأل

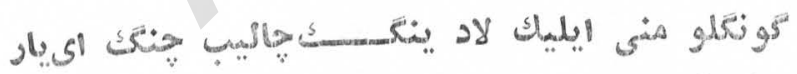

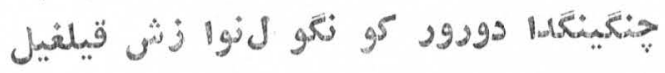

$$
\begin{aligned}
& \text { (1) س ، ت: اول. (1) }
\end{aligned}
$$

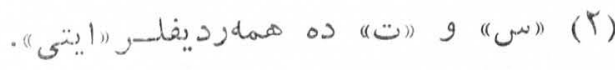

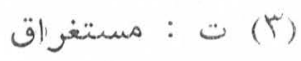

$$
\begin{aligned}
& \text { خو : (ع) } \\
& -149-
\end{aligned}
$$




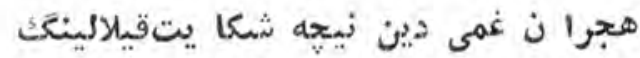

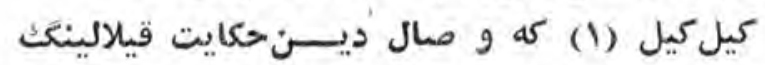
تينكر ى حقى بيز نى ديب الكر سمين كيلسها نك

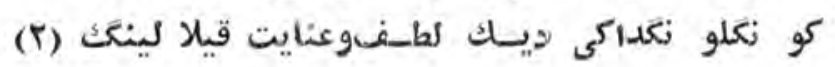
sg

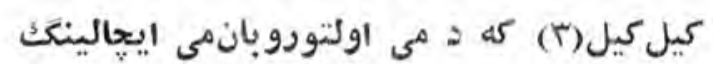

$$
\begin{aligned}
& \text { دنياغم ورنجى دين زمانى كيجإلينك }
\end{aligned}
$$

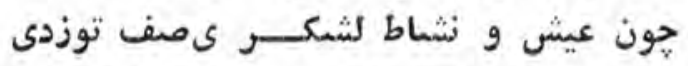

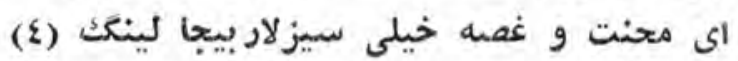

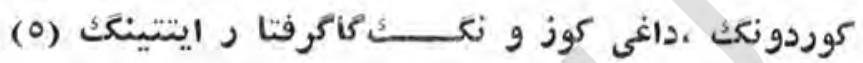

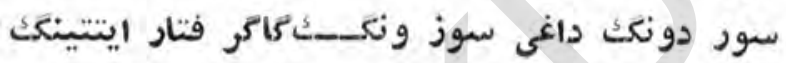

بوطبع و كلا مينكك بيله او ز باشينكغ اوجو ن

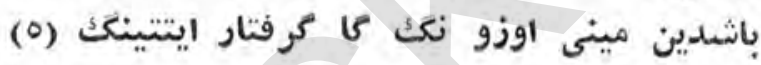
as

اي ايار، حزين كونكولنى ياد ايلادادينك

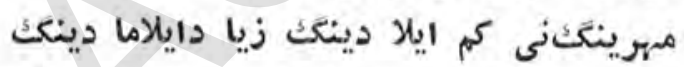

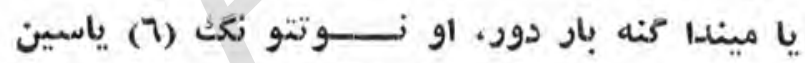

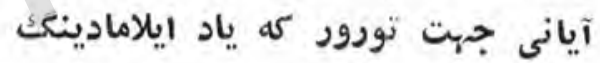

$$
\begin{aligned}
& \text { (1) } \\
& \text { (T) } \\
& \text { (5) }
\end{aligned}
$$

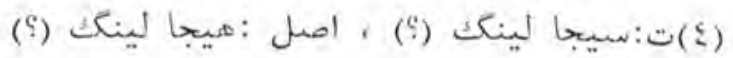
(0)ت:ايتد ينك . . (7) : او نو تدينك. $-1 \varepsilon \cdot-$ 
وله

دايم سا غينيب كونكو ل نى نآل خوش قالغيل

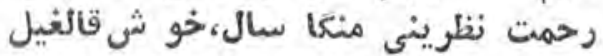

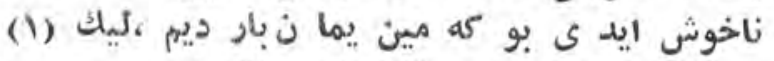
سينلاله عذار يخشى قال خوش بر بالفيل

وله

ايييل باريب احباب قه نا ميمنى ديغيل هركيم مينى بيلسه، بو بيا ميمنى (ז) بديكيل

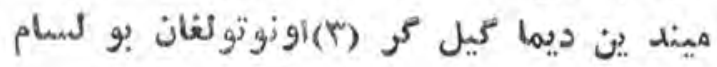
هر كيم كه مينى سورسه سلاميم نىديكيل وله

نقاش مينينغك حاليمه ثن بيسر ايتكيل بير ياغليغ اراكشميده تحر يـــــايتكيل

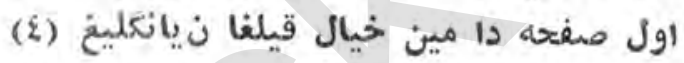
اول يارغه مشُمليم نى تقريــر ايتَيل و

تاقيلغا لى ذكر ، طبع نا مينى كو نكول ورد ايلادى طبع اهلى كلا مينسى كونكول

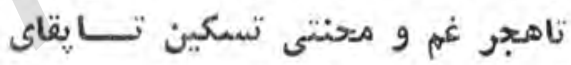
ايستاى دورور احبا ب ييا مينى كونكول

(1) توب: ناخو ش بو ايد ى كلمين نهانعزم ايتتيم (r) (S)

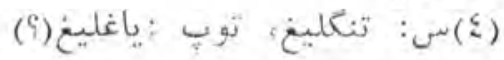
$-|\varepsilon|-$ 
g)

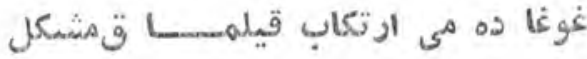

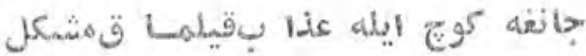

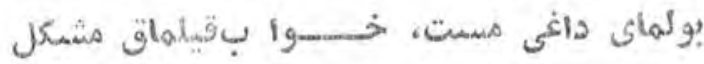

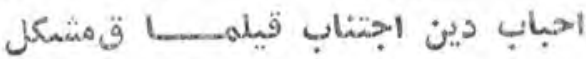

$$
\begin{aligned}
& \text { g }
\end{aligned}
$$

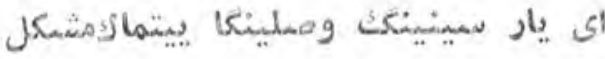

$$
\begin{aligned}
& \text { ؤرخأله }
\end{aligned}
$$

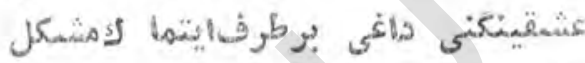

$$
\begin{aligned}
& \text { بأشنى آليبان يبر سـار ى (1) } \\
& \text { as }
\end{aligned}
$$

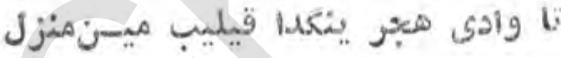

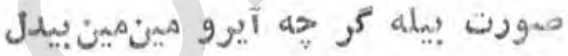

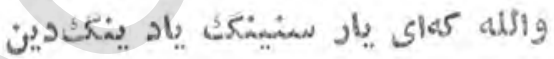

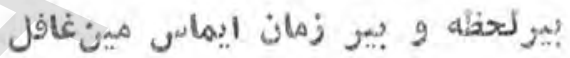

$$
\begin{aligned}
& \text { ag }
\end{aligned}
$$

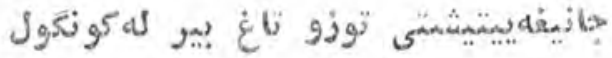

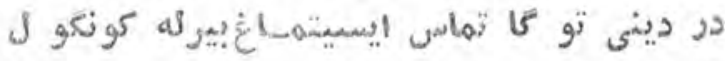

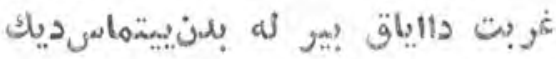

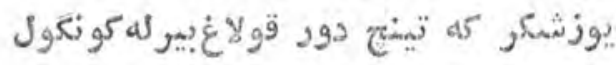

$$
\begin{aligned}
& \text {. (1) } \\
& -1 \leqq Y-
\end{aligned}
$$




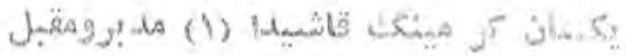

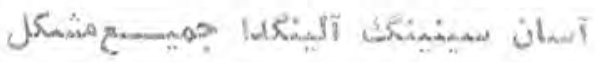

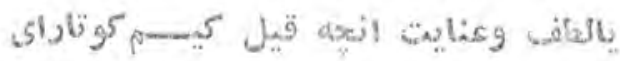

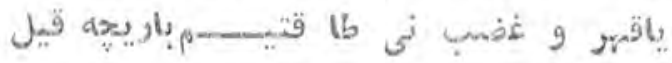

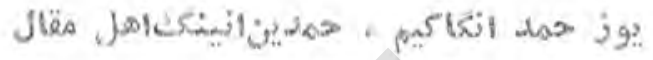

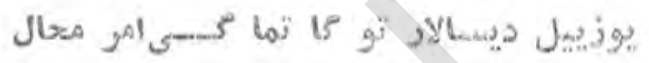

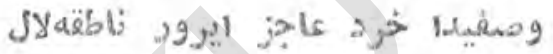

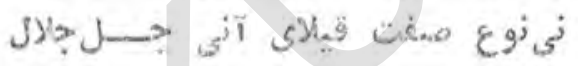

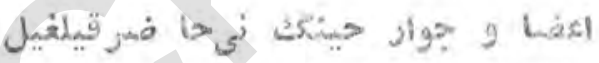

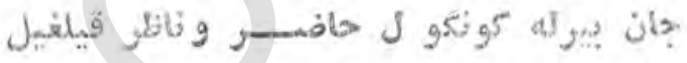

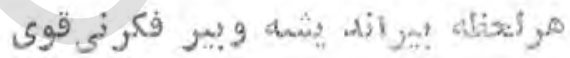

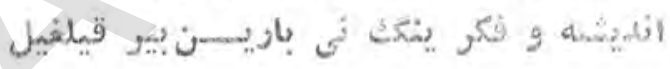
of

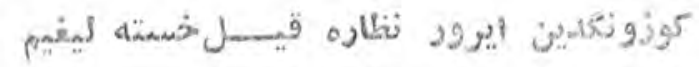

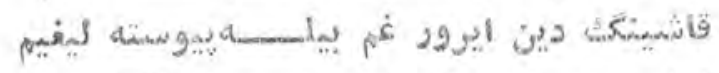

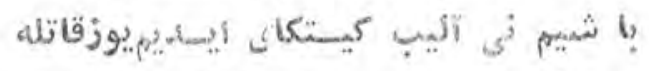

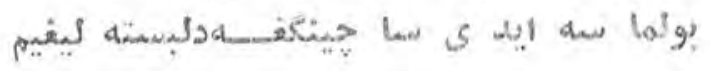

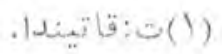
$-1 \varepsilon r_{-}$ 
وله

سينينكك بيله مين كه آشنــــــاليغ قيلديم

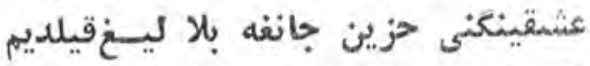

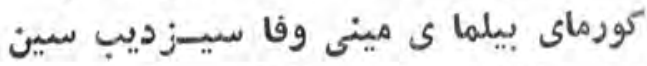

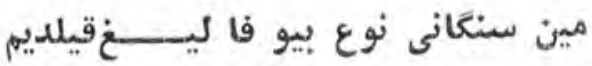

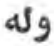

كو زكلوم تيلاكى وصالايميشتوك (1) بيلديم

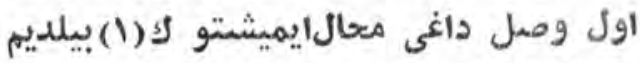
هرقاندا كه بولسه مهربان دورديوايديم

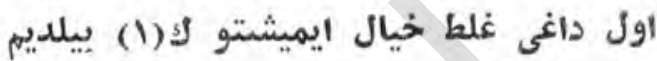

زَّفى غنه كونكول قويوبِيريشان بولدوم

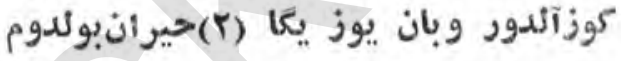
ئين

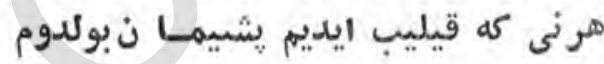
وله

حسنو نكك صفتينى ايشيتيسبزار اولدوم

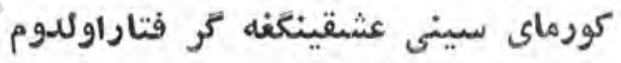
سورغيل كه لبينكَ فرا قي بيحال ايتنى كود كيل كه كوز ونكت هجريدابيماراولدوم

$$
\begin{aligned}
& \text { (1)توب: ايميش توك . } \\
& \text { (Y) } \\
& \text {. } \\
& \text { (ع) } \\
& -1 \leqslant \varepsilon-
\end{aligned}
$$


a)

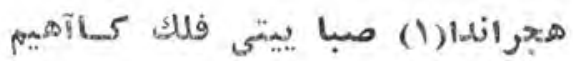

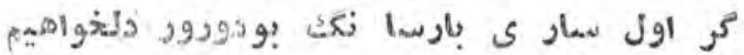

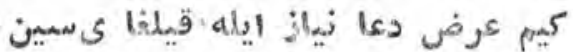

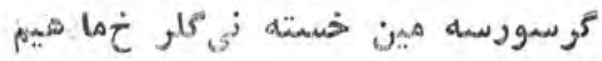
ag

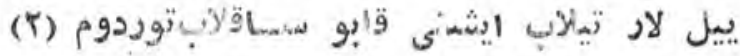
يوز جهها بيله اليثشنى مو نغيـايمتكود دوم

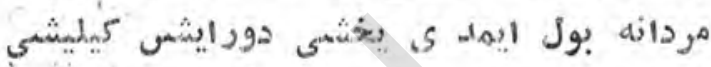

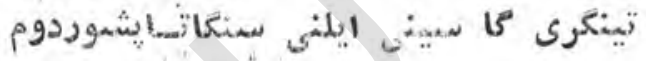
a)

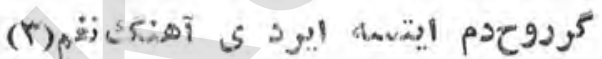

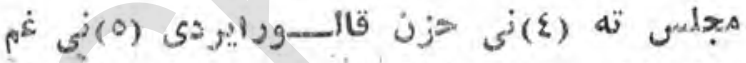

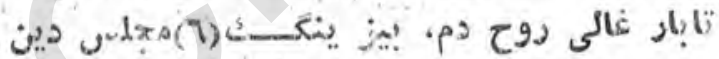

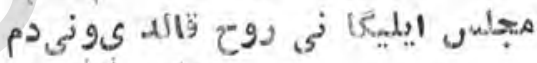

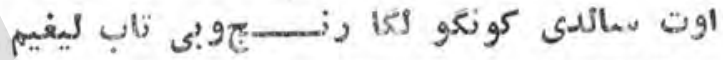

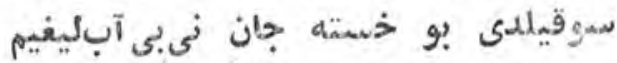

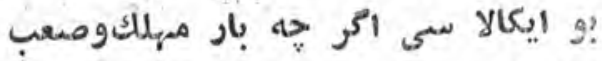

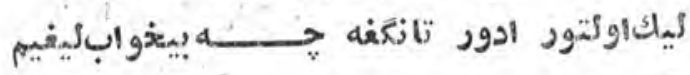

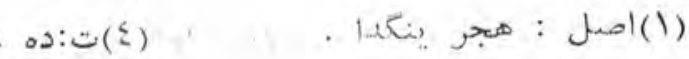
(r)

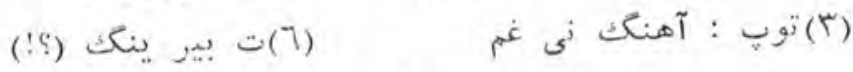
$-1 \leqslant 0$ 
s'

ايكل نى اوخون قا شينكدا مينخوار اولكوم يوز محنت واندوه بيله ياراولدون لئوم

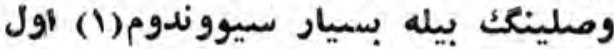
هجر ينكك بيله عاتبت مرفتا راولدوم سيله

و a

يوزنا مة اشمتياق تعرير ايتتيم

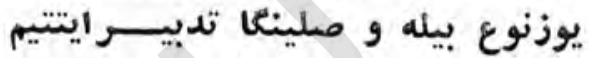

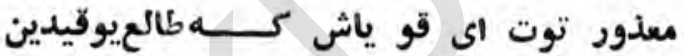
وصلينكك غه ييتار معل نوداتقصير ايتتيم وله

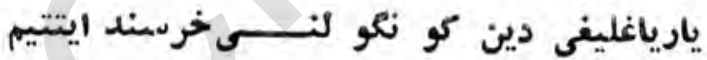

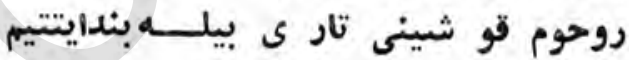
كونعلو منى نى نوع اوزا ىاوشالياغليغ دين جان رشته سينى تاريفه ييو ندايتتيم - $\bullet$

بى مهر ديسه أيل سينى مينبوتماس ايديم.

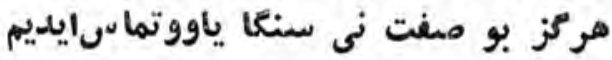
ناحق آغريب مينى اونو تتونكَّآخر والله كه سيندين بو طهعتو تماسايديم · (1) $-127$ 
اسملام اوحون آوارذيازى بولدوم كفار وهنود حرب سازىبو للدو م جزمايلابايديم اوزنى شمهيد بولماقونه (1) الهنةلله كه غاز

هركوندايوزو نتنى كورماك ايرورهوسيم هركيعه سا جينك خـ خـيالى دور همنفسيم عيسى د دمى دين روح بــيرو دجسويم غه نهائ

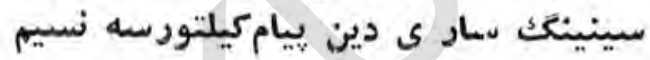
قاتينك دا'ير كناه كا هىقيلديم يوزقاتلاندا مت بيله آ هيقيلديم قيلديم يمان و اسبرو ثبا هـــي قيلديم لمفو نكث بيله سين كيجــــور،منامى قيلديم - -

احباب اونو تماسه كيرالك عهـدقديم ييتكور دمه كيراك خبر كهىييك نسيم بابر حو اميد ايله قيلور عر ضيد فيلهاز

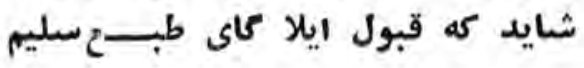

(1) هندوستا ن نسخغه سى وبابو نامه دن آليندى $-1 \leqslant V_{-}$ 
بوكائم ارا كجبهالم لاركو ردوم

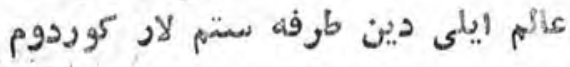

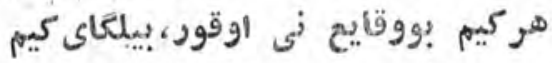
نى نىنجونى Aتحنت ونى غملار كوردوم $\therefore$

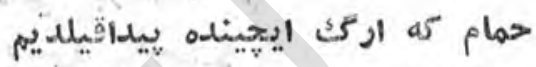

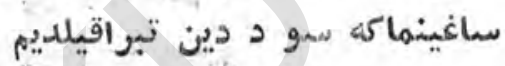

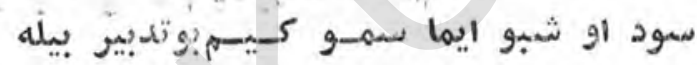

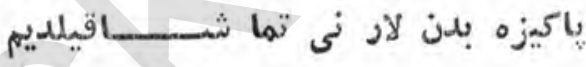

يوزشمكر قيالى كه يانا عا شـــقبولندوم

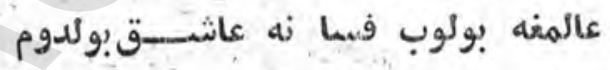

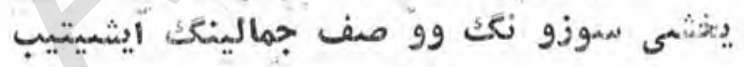

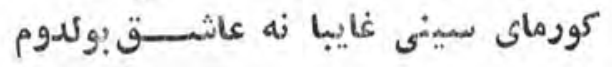

حمام كه قيلديم كورو نكيز كيم، ايام اوخثا تتى انينكك بار ك ايشمىمنكاتمام

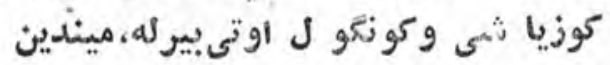

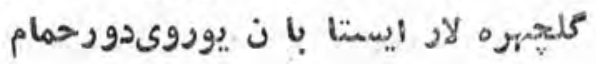
$-1 \varepsilon \lambda-$ 


$$
\begin{aligned}
& \text { اوليوزى ووياش كه بار دورآ ىدين افزون }
\end{aligned}
$$

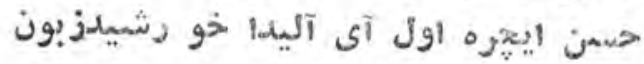

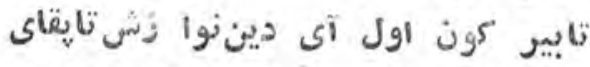

$$
\begin{aligned}
& \text { كوك دايره بولدى وجلاجل آى وكون } \\
& \text { alg }
\end{aligned}
$$

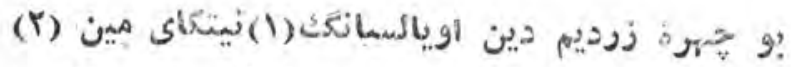

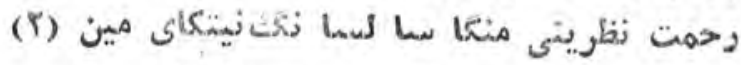

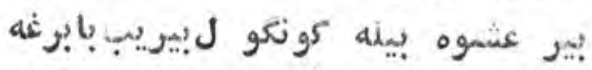

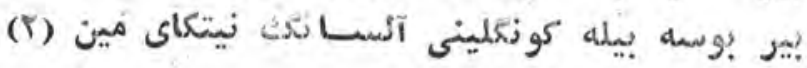
$\omega_{g}$

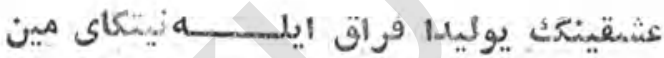

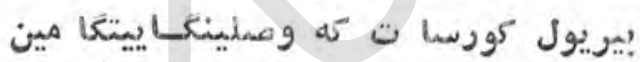

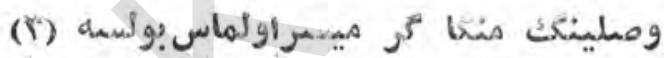

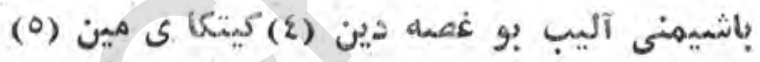
ug

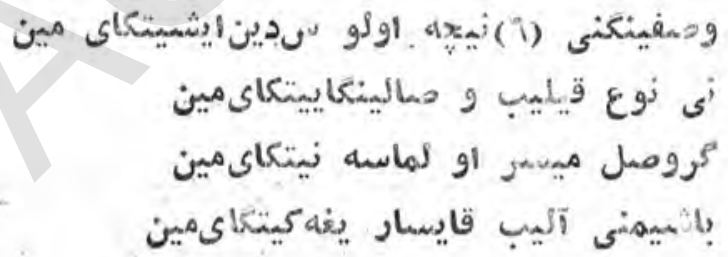

$$
\begin{aligned}
& \text { (؟) (9) (1) }
\end{aligned}
$$

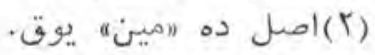

$$
\begin{aligned}
& \text { · }
\end{aligned}
$$

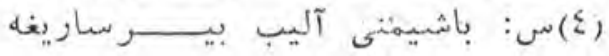

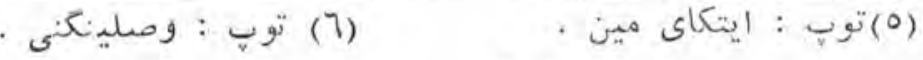

$$
\begin{aligned}
& -1 \varepsilon 9-
\end{aligned}
$$




\section{ولـه}

اول خط كه مين اندا سينى(1)يادايتكاى مين

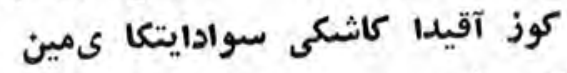

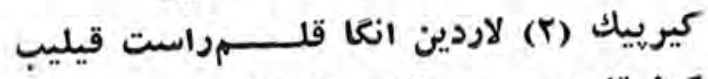

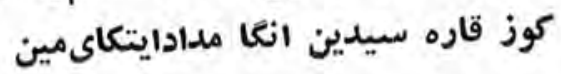

وله

بير كوشة باغ اولسه و سيسنبولسانك ومين

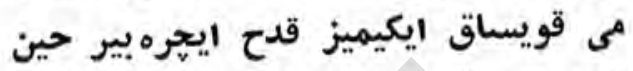
اندين سونعر ه اياق ايليك كسآليبان

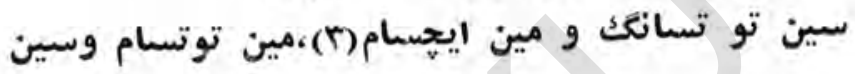
وله

بىقيد مين و خراب سيم ايرماسمين هم مال ييغيشتودور لئيم ايرماسمين ائرماسين

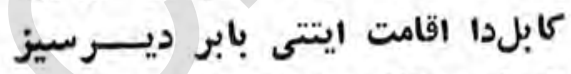
انداق ديمانغيز لاركه مقيم ايرماس دئ دين وله

مهر ينكَ نى دورود بورونجوبار (ع)جوركيين

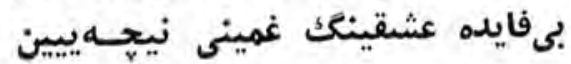

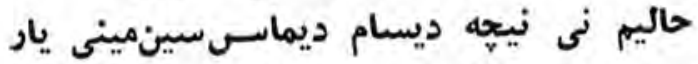

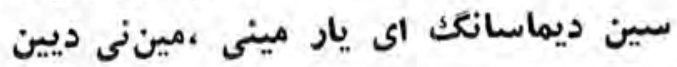

(ז) · (1)

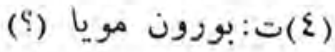
. 
هبرينكدا نى قان قالد ى كهيوتمايدورمين

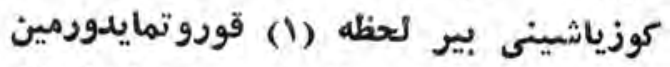

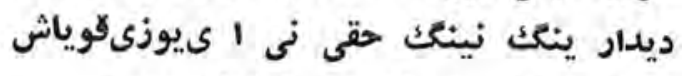
تينكرى حقى بيرذر ماو نوتمايدورمين نين وله

سين "مل سين ومين حقير بلبلدود مين

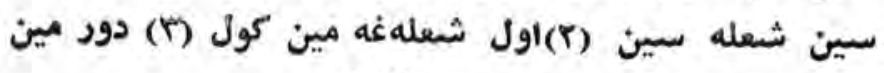
نسبت يوقتور ديب اجتناب ايلاماكيم شه مين ايلكا و لى سنغا قو لدورد مين اجناب الداكير وs

خطيم نى كوروب سون و منى يون نييلكاي سين

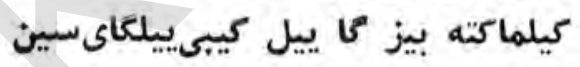

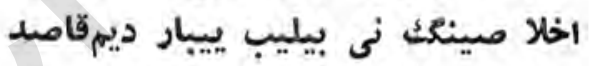

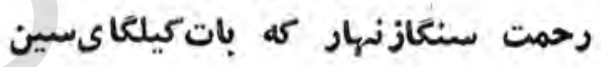

وله

اولباردى كه عشرت آرزوقيلفاى سين

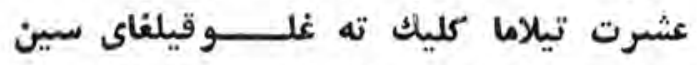
حون عيش وفراغ ممكن ايرماسزنهار

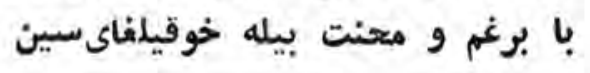

. (1)

 ,

101 
أحباب غه (1) هلو خط كه سوا دايتشاي سين بيزي داغي اول بيتيكدا يـا دايتغاي لمدين

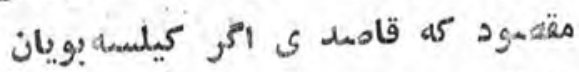
بيرنا مله بيله كونغلو لثى شا دايتشاى سمين وله

هجران دانهاغينيب مينى شا دايتكاي سين مين خسته نى منخلص اعت_قا دايتكاى مدين

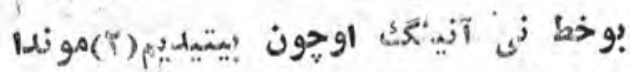
كوركاج بو خطيمنى مينى يا داريتكاى سين إنى os

نيجه منغا جور متهمل قيلغنسا ي سمين

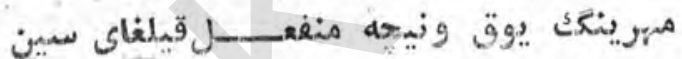

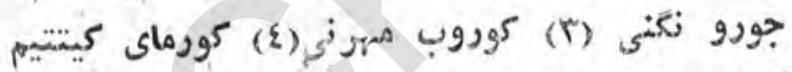

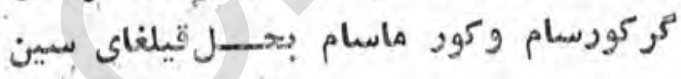

ig

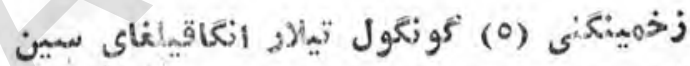

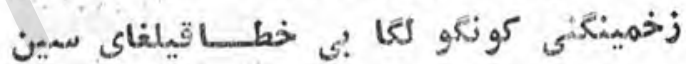

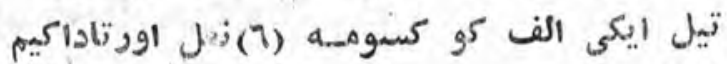
كونغلوم تيلارين حقين اداقيلغاي سين

$$
\begin{aligned}
& \text { (1) اصل : (1) } \\
& \text { · (ז) بيتد } \\
& \text { (0) : رحمينكنى } \\
& \text { · } \\
& \text { تزي : كو نكلومه }
\end{aligned}
$$


ag

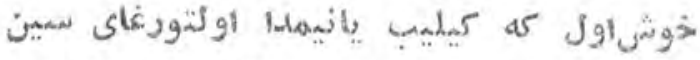

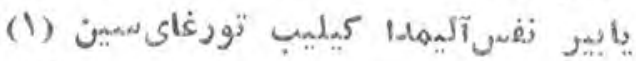

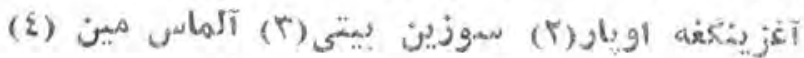

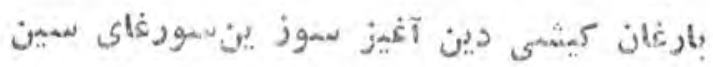

\section{a.s}

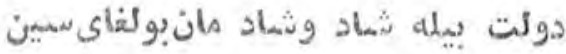

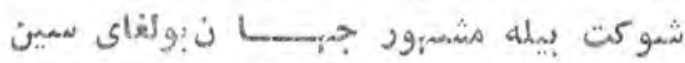

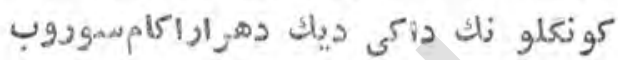

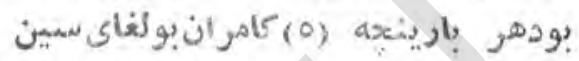
$\omega_{g}$

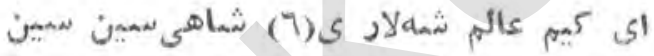
s

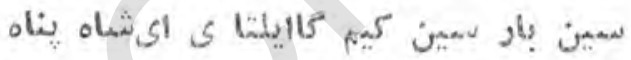

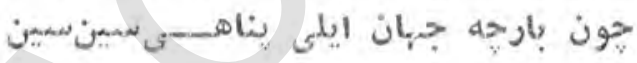
وله

زنهار كه دوستلو قونى اونوتمغانسين

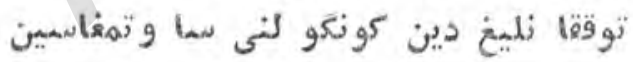

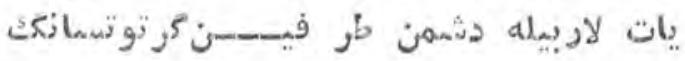

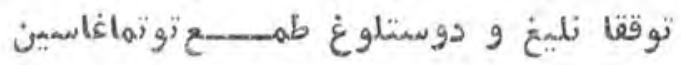

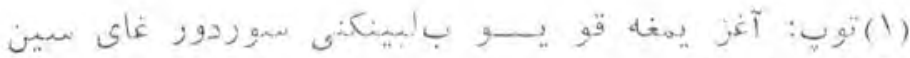

$$
\begin{aligned}
& \text { (!) (ب) } \\
& \text { - dreste: (0) } \\
& \text { (19) } \\
& \text { s,yohite(7) } \\
& \text { (2) } \\
& -104
\end{aligned}
$$


asg

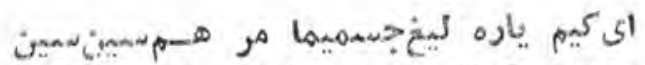

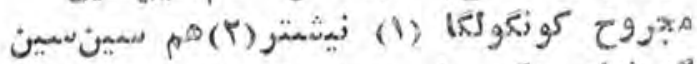

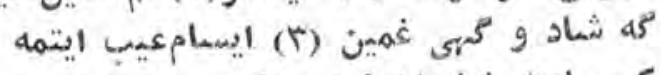

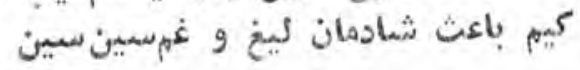

$\omega_{g}$

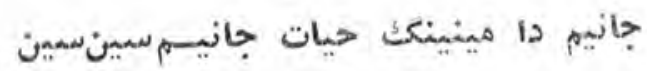

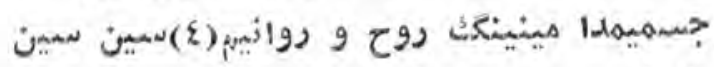

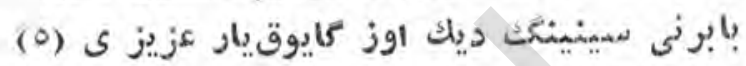

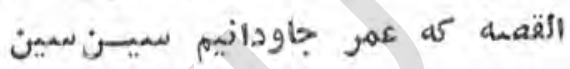
$\mathrm{s}_{9}$

اي كيم هنكا مزده :بير دينككاول جانان دين

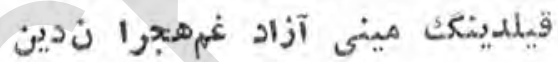
و مزده نى نى نوع مشفتقيلغا ىمين

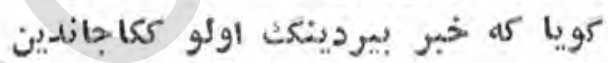
is

دوران مينى أوتعار دى سر وسماهان دين

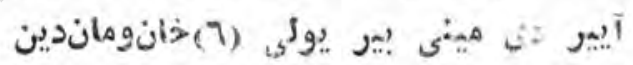

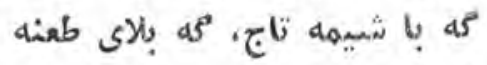
نى لاركة باشمبمغنه كيلماديدورداندين

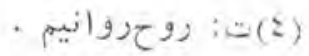

$$
\begin{aligned}
& \text {. } \\
& \text { · } \\
& \text { (7) ت: آيبر دى بير يولى مينى } \\
& \text { (T) } \\
& \text { (r) } \\
& -102
\end{aligned}
$$


as

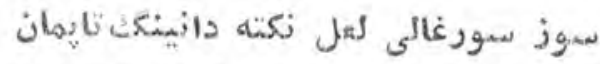

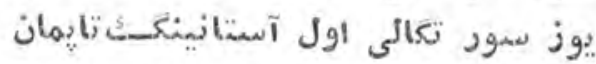

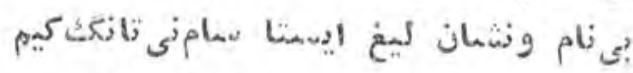

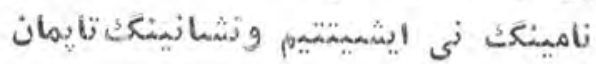

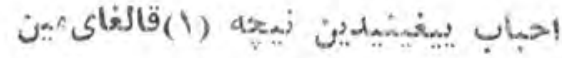

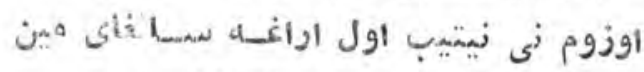

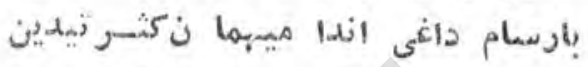

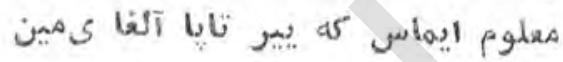

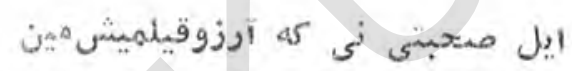

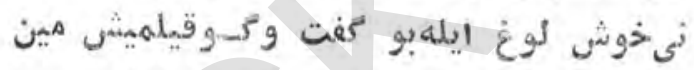

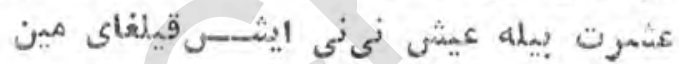

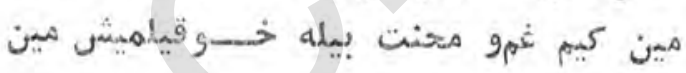

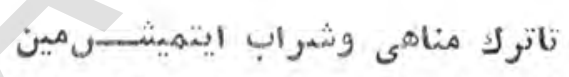

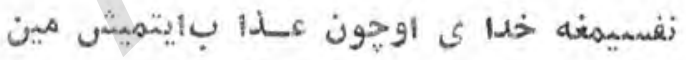

$$
\text { توبه ايشيميكى هنوز آحوق (r)ايبردى }
$$

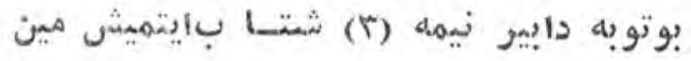

$$
\begin{aligned}
& \text { - مئن (1) } \\
& \text { - آحيق }
\end{aligned}
$$

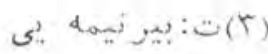




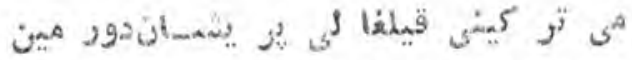

$$
\begin{aligned}
& \text { بيلمان قيلور ايشميمنى وحيرا ندوردمين }
\end{aligned}
$$

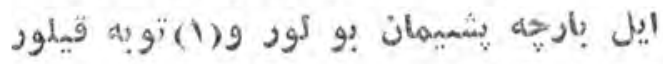

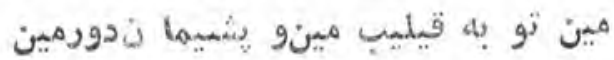

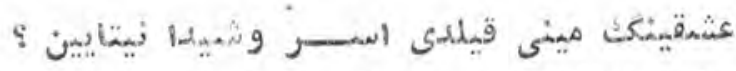

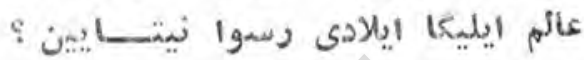

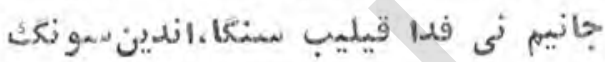

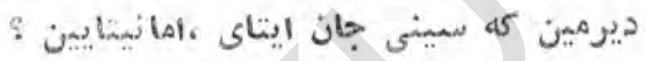

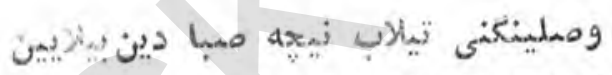

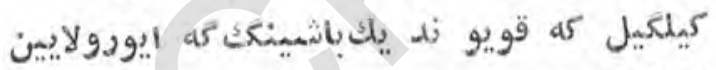

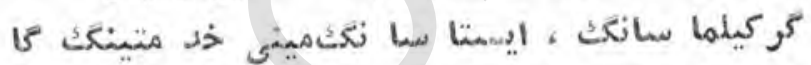

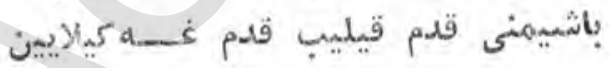

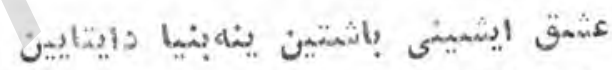

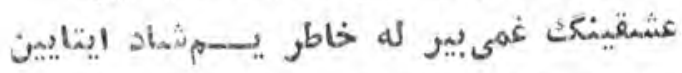

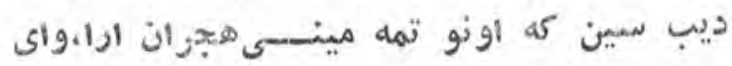

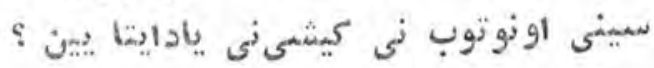
(1) $-107$ 


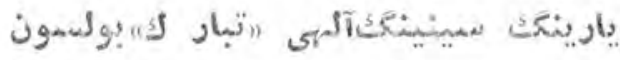

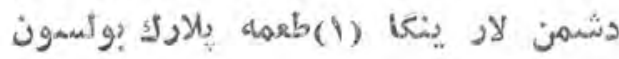

$$
\begin{aligned}
& \text { ملكو نغدا فراغت بيله خان كيكانلارقيل }
\end{aligned}
$$

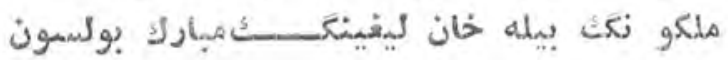

$$
\begin{aligned}
& \text { * * }
\end{aligned}
$$

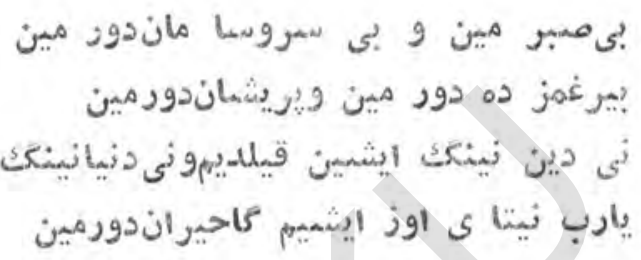

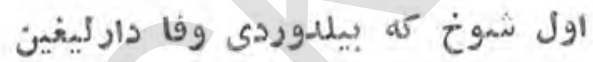

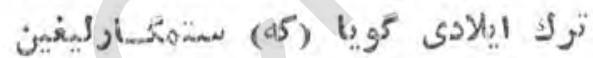$$
\text { كطف ايلاذدى يار كيق قه فرمها ن بيردى }
$$$$
\text { اعدابيله ياردور ، نيتاي يأركيغين }
$$$$
\text { *) }
$$

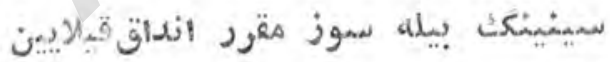$$
\text { عالم داسينى متتبر انداق قيـلايين }
$$

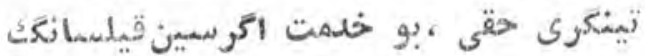

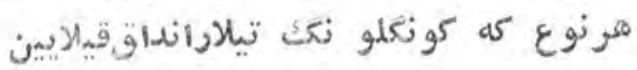$$
\text { . (1) }
$$$$
-10 \mathrm{~V}-
$$ 
نسيان قيليبان (1) نيجه هنعاكور مايسمين

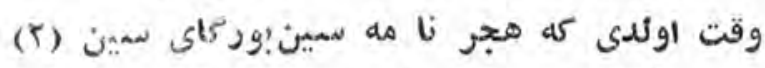

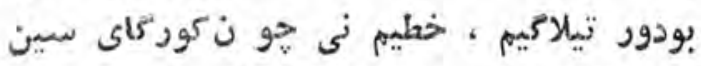

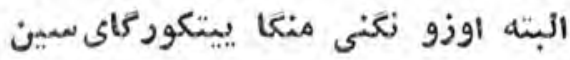

$$
\begin{aligned}
& \text { يارب منكانيتد ى بو لدى شاهيم بيلمان }
\end{aligned}
$$

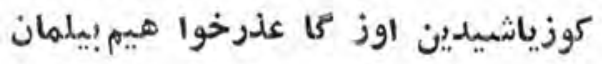

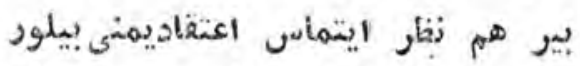

$$
\begin{aligned}
& \text { هرلحظه عتاب ايتار كنا هيــــم بيلمان اعنمان } \\
& \text { وله }
\end{aligned}
$$

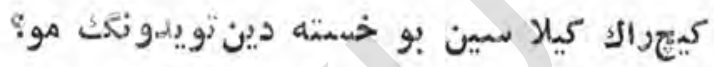

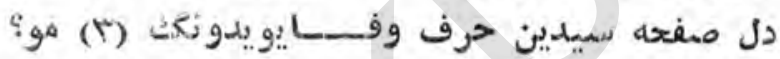

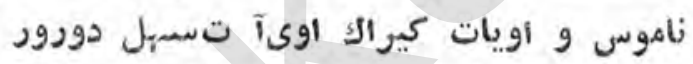

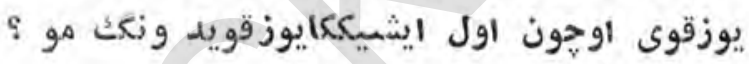

$$
\text { g) }
$$

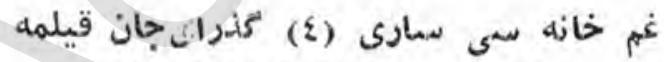

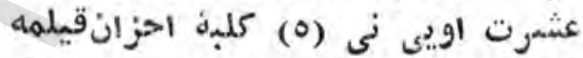

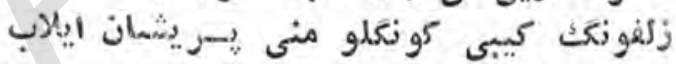

$$
\begin{aligned}
& \text { لعلينك كيبى باغر يمنى تولهقانقيلمانه } \\
& \text { (؟) (1) } \\
& \text { (5) }
\end{aligned}
$$

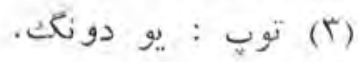

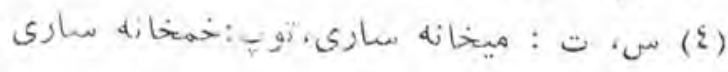

$$
\begin{aligned}
& \text { (0) س : ايوينى } \\
& -101-
\end{aligned}
$$




\section{وله}

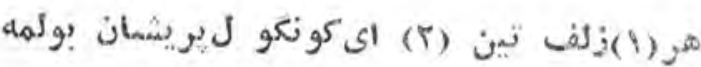
هر

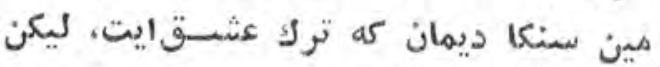

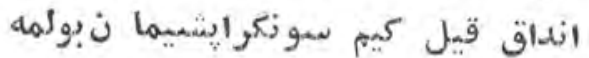
وله

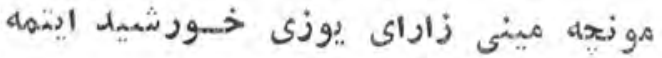
ورقت المينى منكا جاويد إيتها

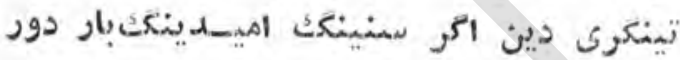
تينكرى اوجون اي آى مينىنومهيدايتمه a g

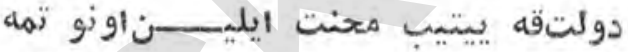
وإيش كون اوحون اوزو نكنسى المروتو تمله

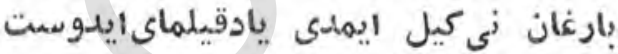

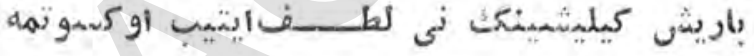
وكه

$$
\begin{aligned}
& \text { هجران ارا ياد ايتيب مهنى (غ)ششادايله }
\end{aligned}
$$

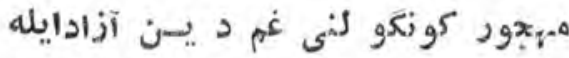

$$
\begin{aligned}
& \text { وخطا نى أنيذك او حونبيتيديم هوندا. } \\
& \text { كوركان سايى خطيه نى مينىيادايله } \\
& \text { (r) } \\
& \text { (1) بير. }
\end{aligned}
$$

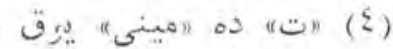


49

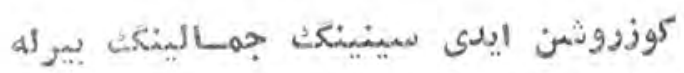

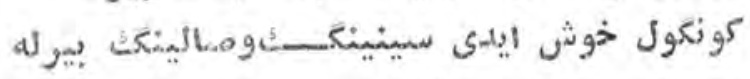

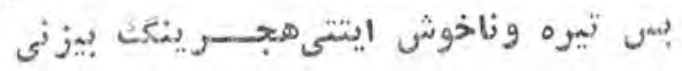

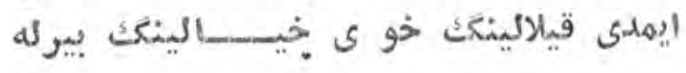

$\omega_{g}$

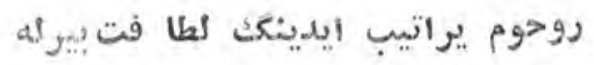

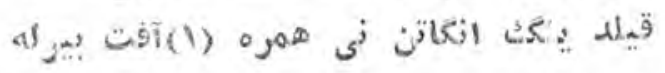

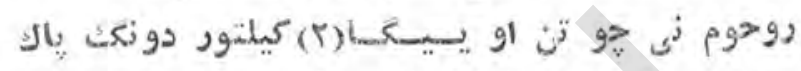
هوندين بارى ايلتمه كثا فت بيمركله dg

سمين اندافراغ وعيش وعثمر ت بيرأله

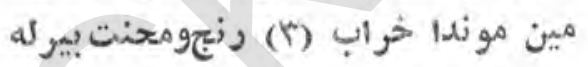
أسراد هين اوزوم بيم له سينى نقتش قيليب

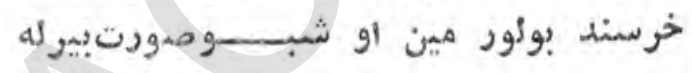
g

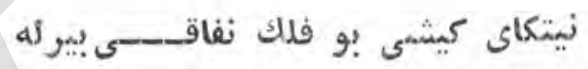

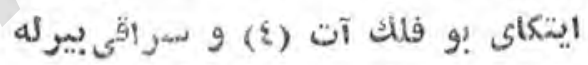
كأه تير كوز ادور وصمال اياميدين

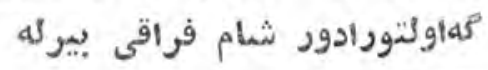

$$
\begin{aligned}
& \text { (1) (1) (1) إس، (1) }
\end{aligned}
$$

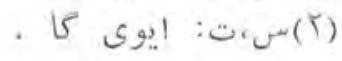

$$
\begin{aligned}
& \text { (r) ت: فراق و. } \\
& \text { (๕) } \\
& -19+-
\end{aligned}
$$




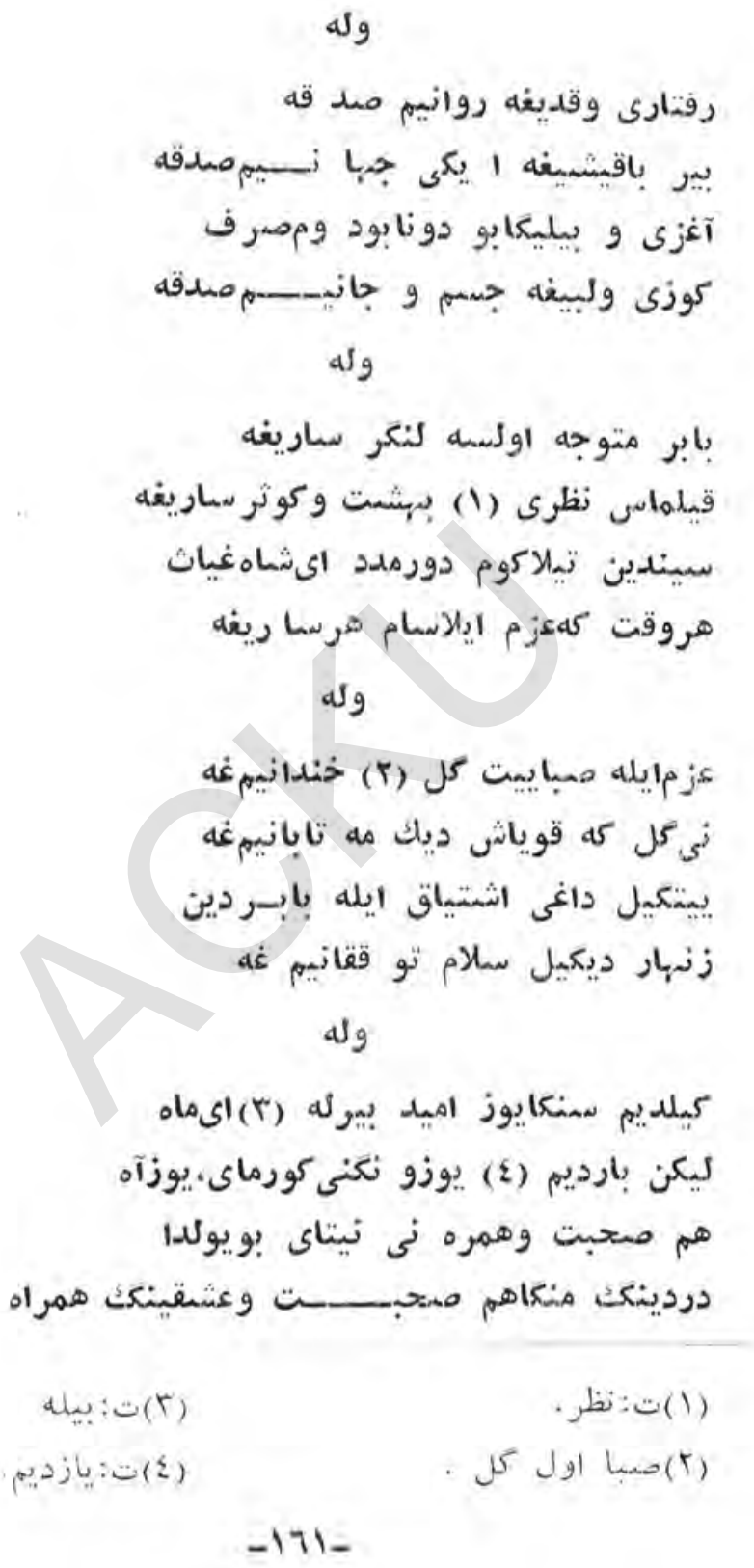


نىخويش مينى خوش لارو نسـى بيكازه

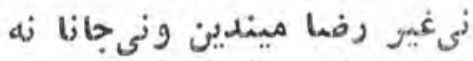

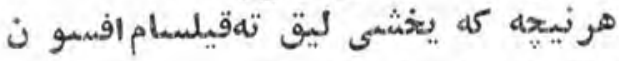

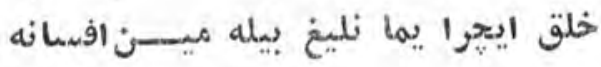
g

$$
\text { بودهرارا كر احتمالى بو ليمه }
$$

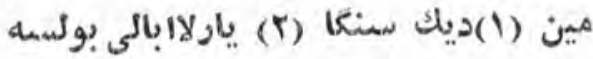

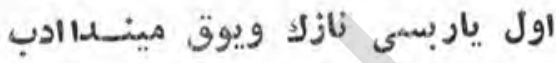

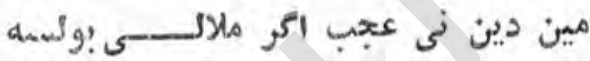
و

ياراول دوركيم ثمعر غه ميلتسى بولسيه

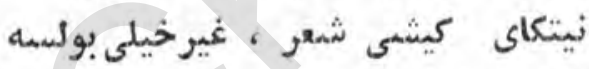

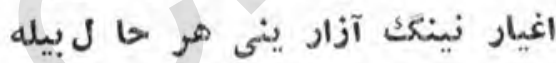
جيككاي مين اكر يار (r) طفيلى بوكسه go

$$
\begin{aligned}
& \text { منيا باريسى منكا مسبسخر.ولسمه }
\end{aligned}
$$

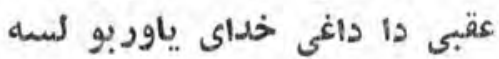

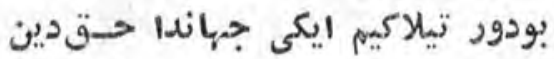

$$
\begin{aligned}
& \text { هونى تيلا سام بارى ميسر بولسه } \\
& \text { (1) } \\
& \text { Kنم: : (T) } \\
& \text { (؟) }
\end{aligned}
$$


وS

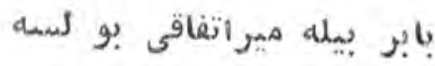

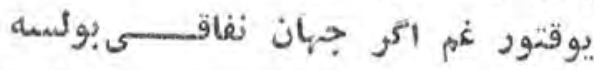

(1) (1)

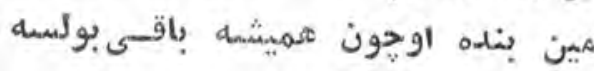
وله

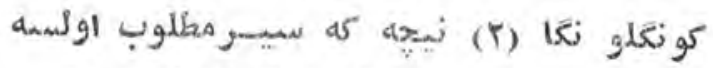

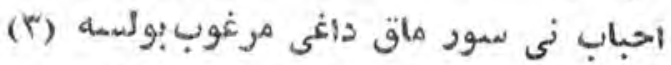

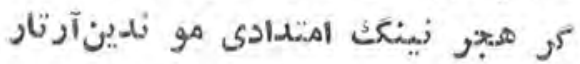

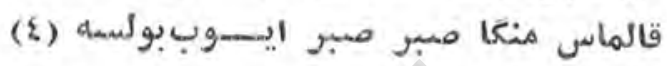
atg

خوش اول كه بيهار فهملى بـ بـودنياده

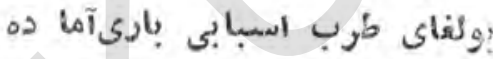

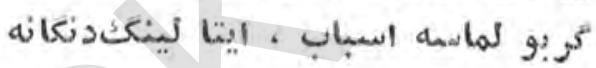

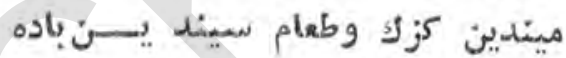
as

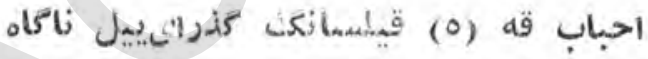
اول جمع نى بو سموزوم ديس-سـن إيمكل آكاه

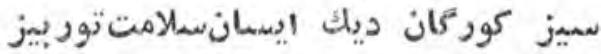

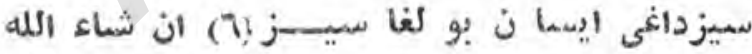

$$
\begin{aligned}
& \text { (1) } \\
& \text { }
\end{aligned}
$$

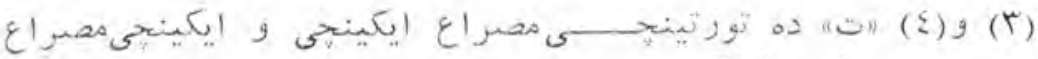

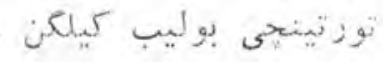

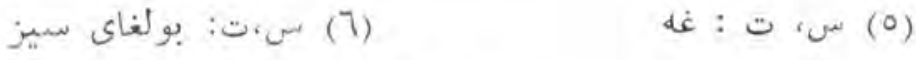




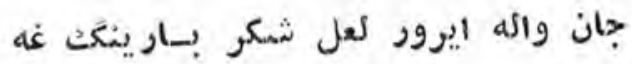

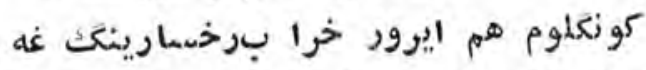

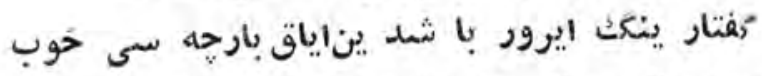

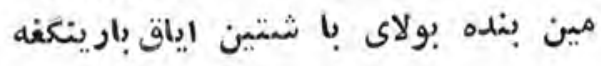

اي آىيوز ونكف آليدا وو يا ش شّرهنده

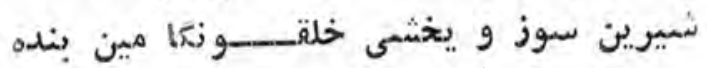

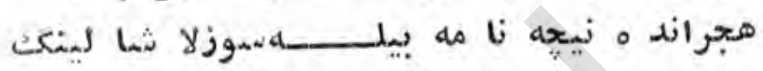
ياسمين بير ى كيل .يابارا يي-نهمين النده وله

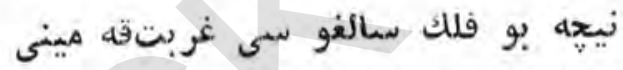

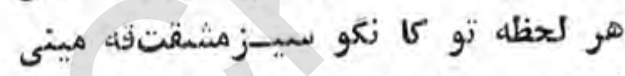
نى حاره قيلاي نيتا ى كهنتينكرى كويا

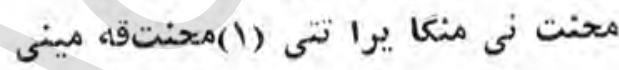
و

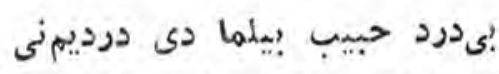

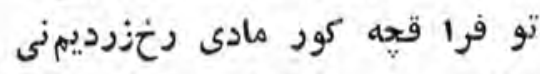

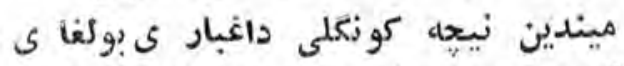

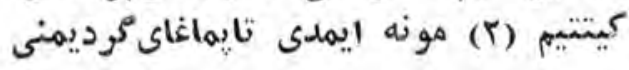

$$
\begin{aligned}
& \text { (1) } \\
& \text {. }
\end{aligned}
$$


dig

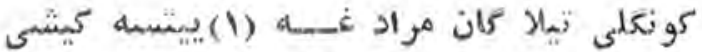

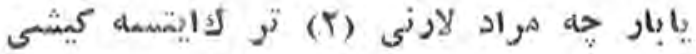

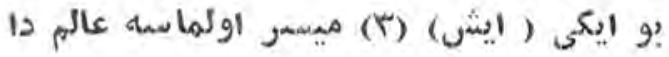

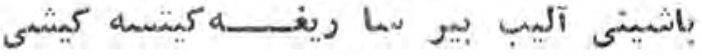
وله

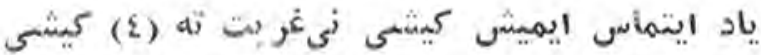

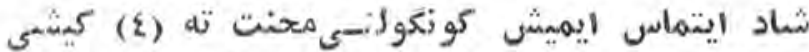
كو زعلوم بو غريب ليق (0)داشئد اولما دي آه

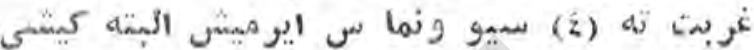
os

آواره ليغ (7) اسبرو خانوماندينيختثى

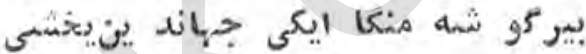

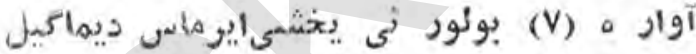

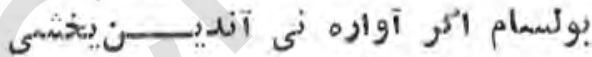
وله

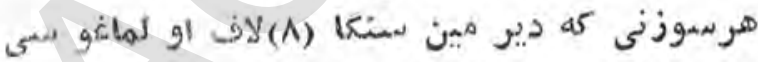

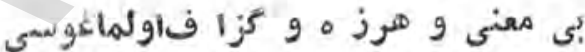

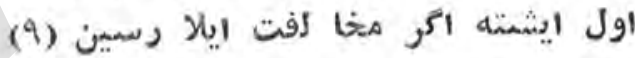
تينكر ى حقى بو لدوز دا يخلا فأولما غوسيى

$$
\begin{aligned}
& \text { (7) } \\
& \text { dis } \\
& \text { (c) ل्र } \\
& \text { (r) }
\end{aligned}
$$

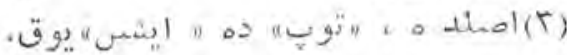

$$
\begin{aligned}
& \text { (1) } \\
& \text { oD:inu (ह) }
\end{aligned}
$$

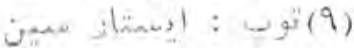

$$
\begin{aligned}
& \text { U }
\end{aligned}
$$


g

ايى يار جغا رسمى جيقار ما قنى ايدى ؟

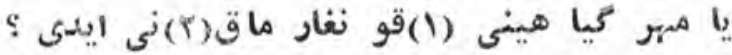

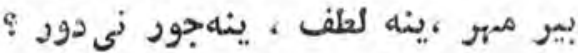

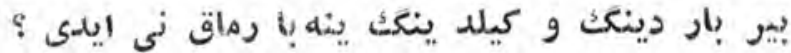

Sg

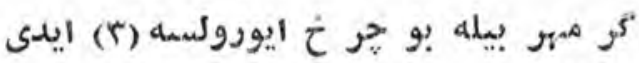

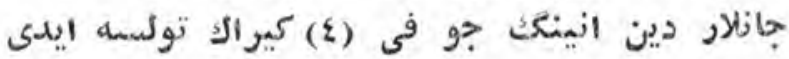

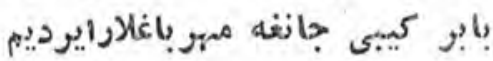

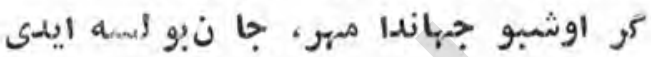
وله

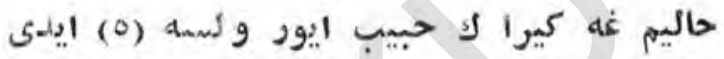
عثشرت قد حى حبيب دينتو كلماه ايلدى

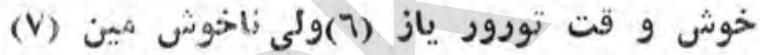

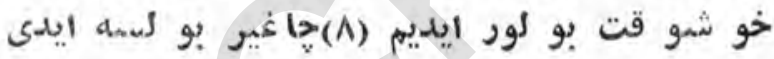
وله

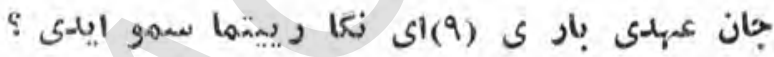
اول عهد بيله قرار ييتما سم-ـوايبدى ؟

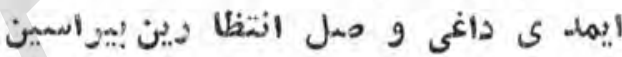

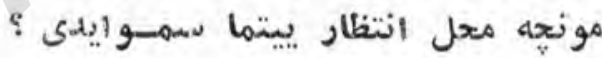

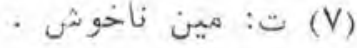

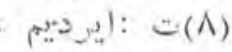

(9) (9)

$$
\text { توب : كيا : }
$$

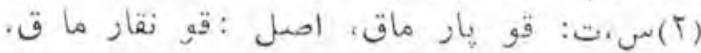

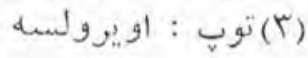

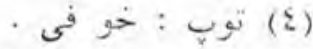

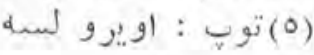$$
\text { (7) ت: يار اولت }
$$ 


$$
\begin{aligned}
& \text { ولهa }
\end{aligned}
$$

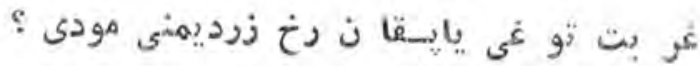

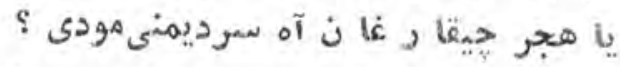

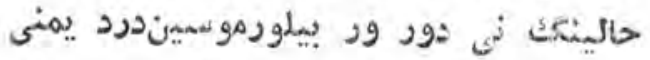

$$
\begin{aligned}
& \text { حالينكي نى سمورا ى مويو قسمهدرد يمنى مودى ؟ } \\
& \text { as }
\end{aligned}
$$

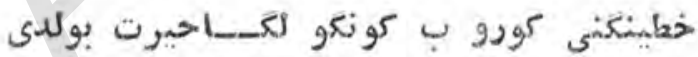

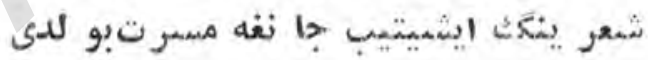

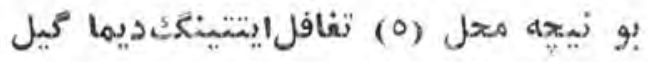

$$
\begin{aligned}
& \text { ن (r) }
\end{aligned}
$$

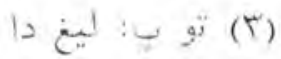




\section{وله}

اى بيك باريب رنما بيله قو للو قدى

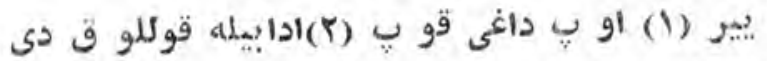

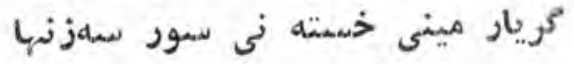

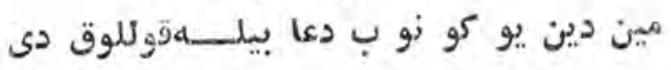
as

$$
\begin{aligned}
& \text { ألا منكَ كه تير يكليكيم نشا نى ايودى }
\end{aligned}
$$

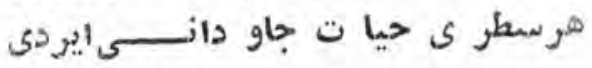

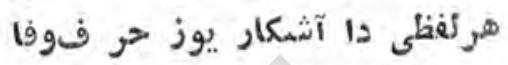

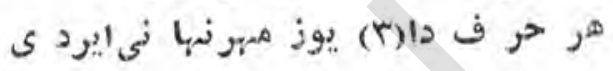

$$
\begin{aligned}
& \text { - •. }
\end{aligned}
$$

هجر ينكدا بو تو ن كونكو لداقايغو ايردى

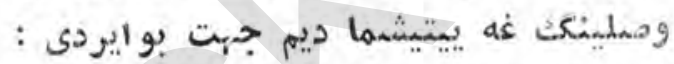

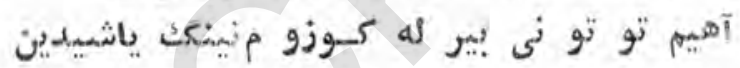

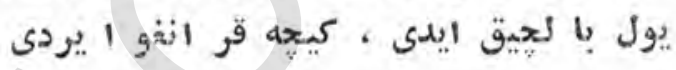

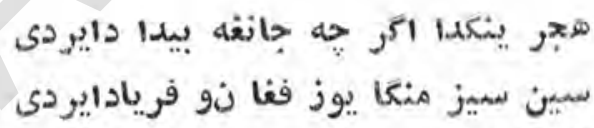

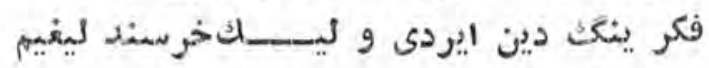

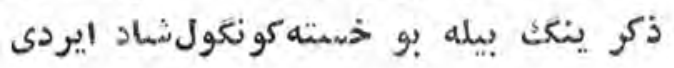

$$
\begin{aligned}
& \text { (1) } \\
& \text { (9) }
\end{aligned}
$$

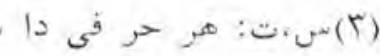


atg

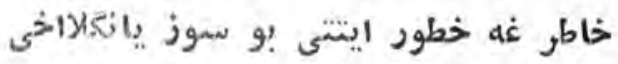

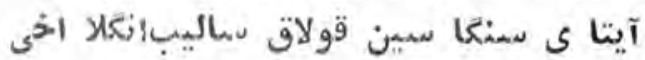

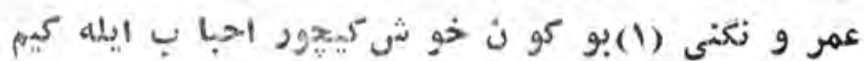

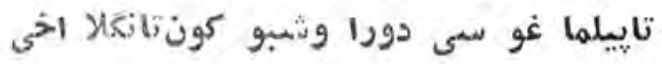
dg

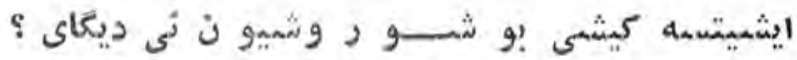

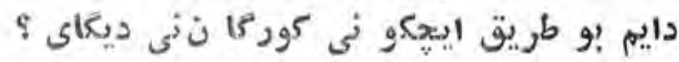

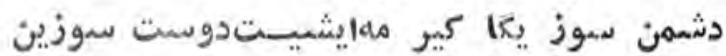

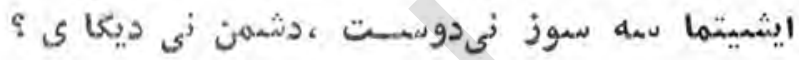
alg

عشقيش:خدا كو زنكو ل خراب دو رمين زي قيلاي ه

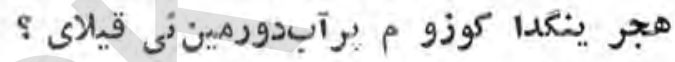

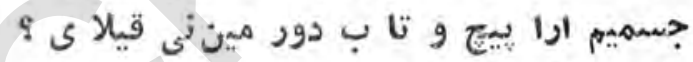
جانيم داكو ي اضطهـــر ا بدوردمين نى قيالى ؟ asg

شاهيم سنكا معلو م إيماستو رنى قيلاى آهيم سمنيكا معلو م إيماستور نى قيلانى ؟ هين يوز و قا شينك دير مين وسمين بدر و هلال

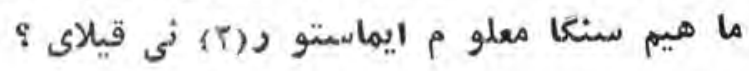

$$
\begin{aligned}
& \text { · تمر ينكنى } \\
& \text {. } \\
& -179
\end{aligned}
$$




\section{af}

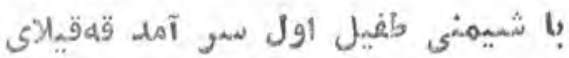

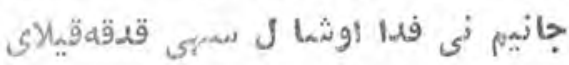
كو خ خسته كونكو ل

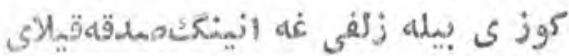

4ig

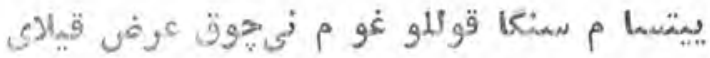

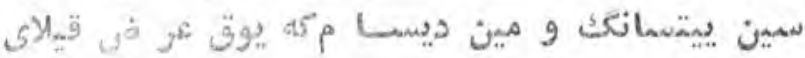

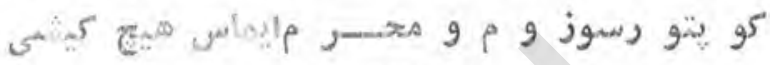

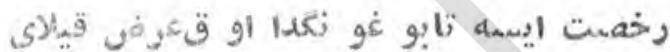

$$
\begin{aligned}
& \text { als }
\end{aligned}
$$

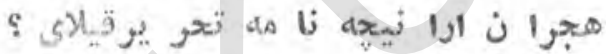

$$
\begin{aligned}
& \text { خا مه تيلى بيركله حا ل }
\end{aligned}
$$

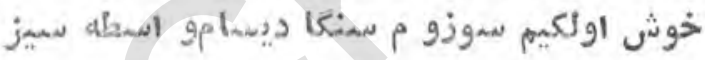

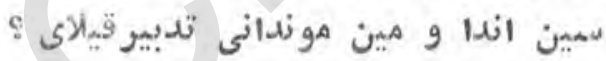

$$
\begin{aligned}
& \text { as }
\end{aligned}
$$

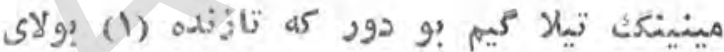

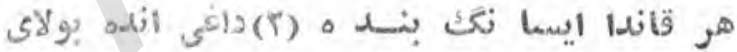

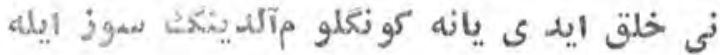

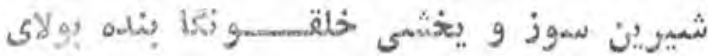

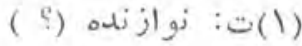

$$
\begin{aligned}
& \text { - ت }
\end{aligned}
$$


49

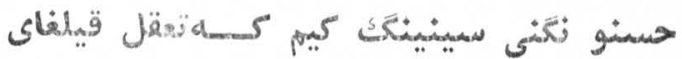

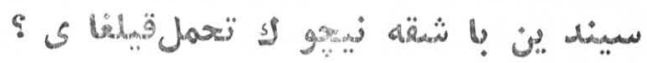

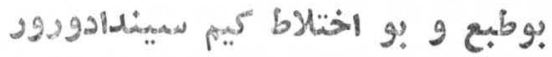

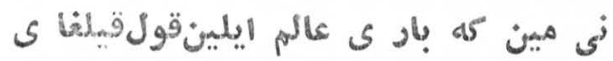
dg

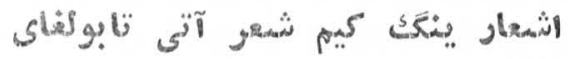

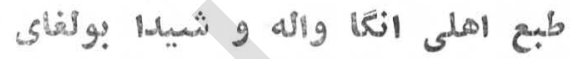

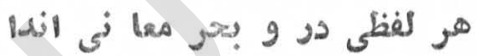

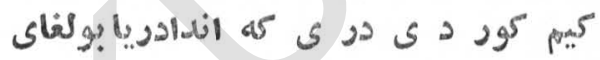
4ig

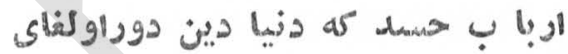

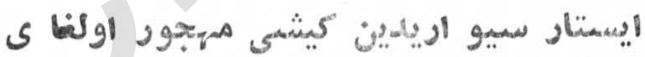

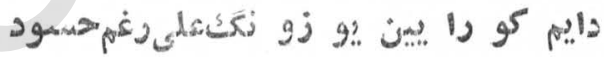

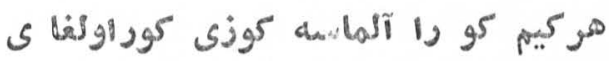
$\mathrm{dI}_{9}$

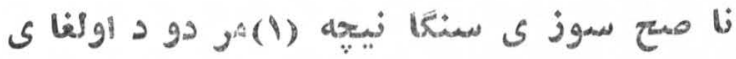

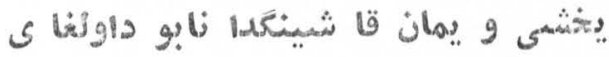

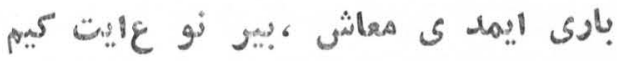

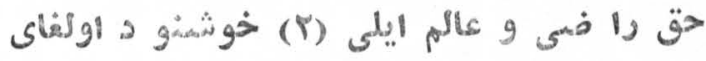

$$
\begin{aligned}
& \text { - Kier doj: : : (1) }
\end{aligned}
$$

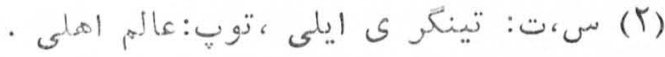

$$
\begin{aligned}
& -|V|-
\end{aligned}
$$


يوز جبد ايله ييتماى (1) دمنكائى آى نيتاى ؟

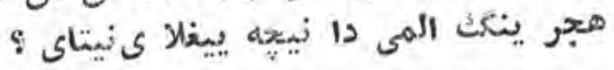

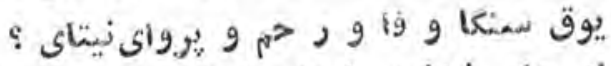

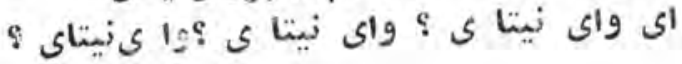
وله

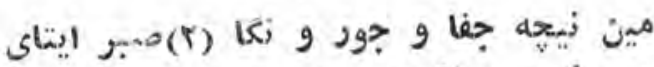

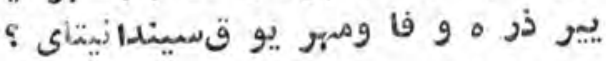

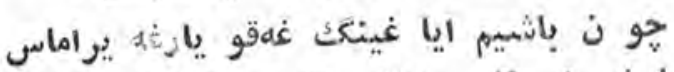

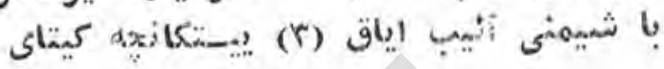

احباب ، فرا قينكيز بيله ايسـلـ نيتكاى ؟

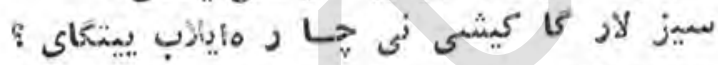

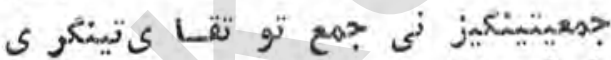

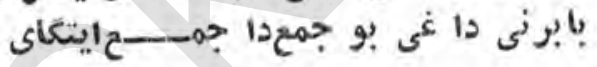

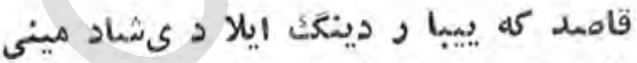
دايم بو يو بمو نلو ق ايلا كيل دياد مينى

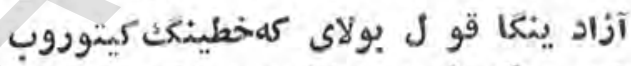

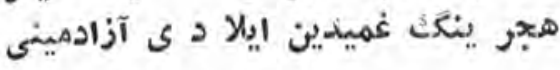

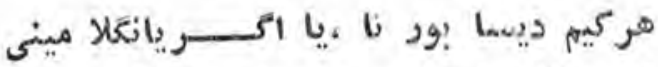

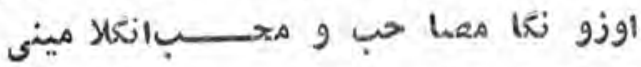
بو كو ن مينى ياد ايتيب ،اونوتما تانعلا معاد

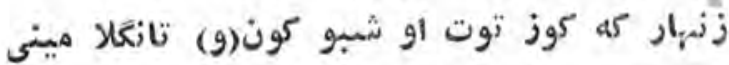

(Y)

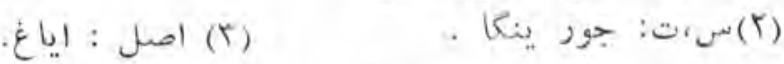


شمعرينك ايشميتود فكر ينى بابرقيلدى نىفكر خوش و يخشَى تصو رقيلدى كوزنى يارو ق إيالدى سواد ى في فيركله

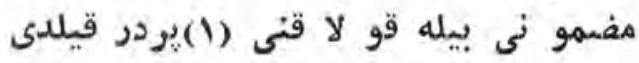
قديمنى فرا ق محنتى ياقيلد

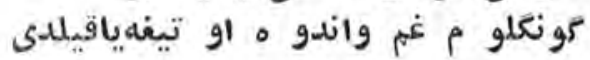

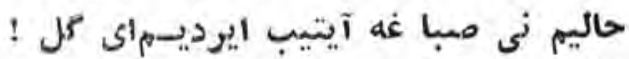
(r) بيلمان سنغا شر ح قيلما دى ياقيلدي

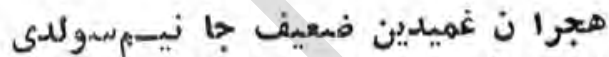

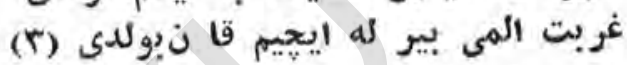

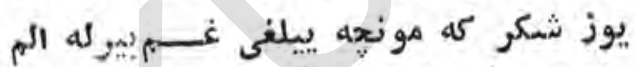

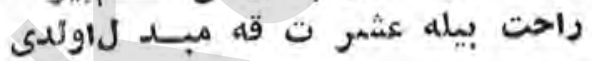

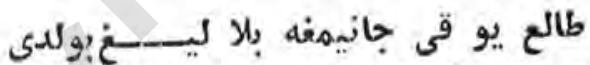

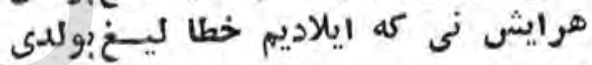

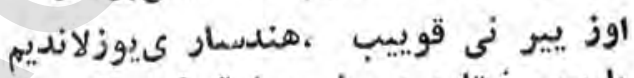

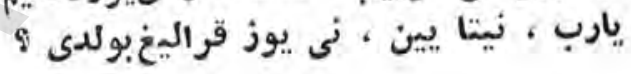

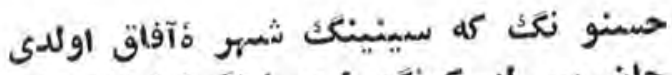

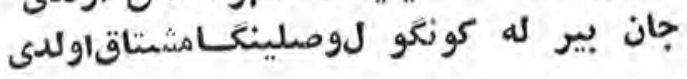

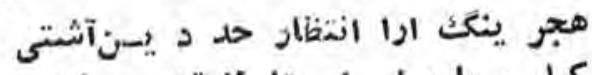

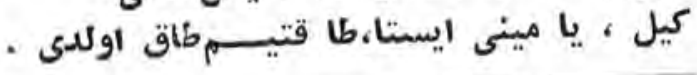

$$
\text { · (1) }
$$

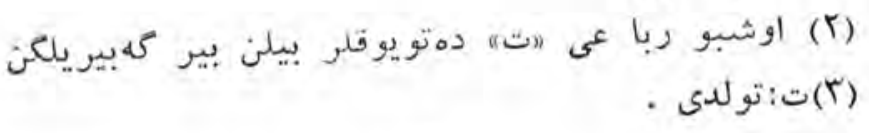




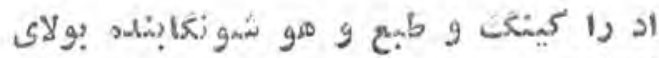

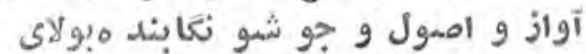

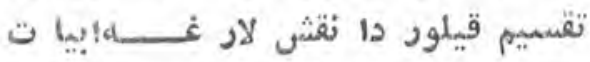
تعريب بيله اوقو شبو نغا بثد مبولائ -

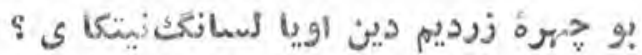

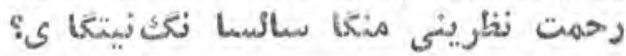

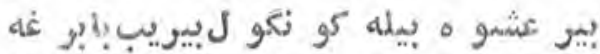

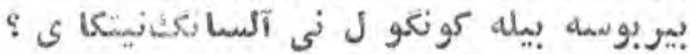
क \& $\$$

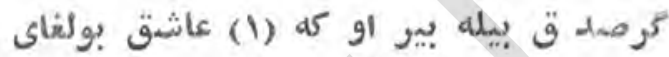

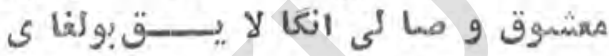

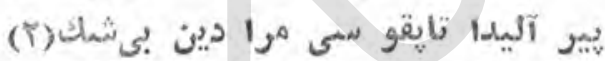

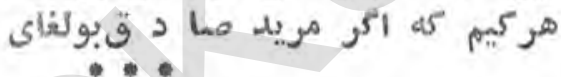

عشمقينك نيتا ى ، اختيار سيز قيلدى مينى

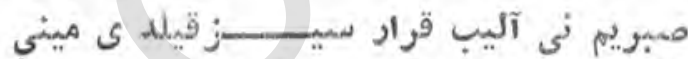

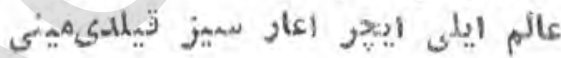
زهد اهليغه اعتبا ر سيز قيله ىمينى

هرو قت كه كور 15 سين منينكك سوز و منى

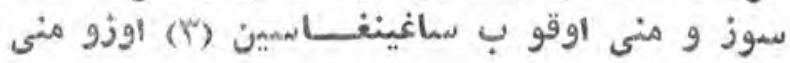

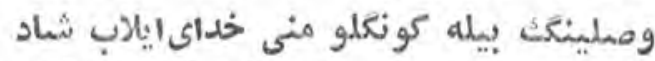

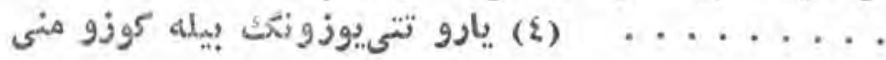

(!) (1)

•

(19) (1)

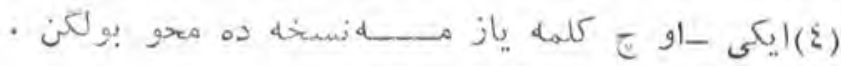


تــو يــو قلار 
g g

وصمل دين سموز دير كا يو قيار امثنكا

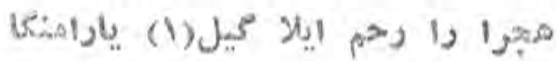

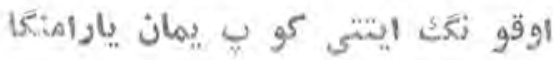

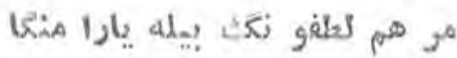
وله

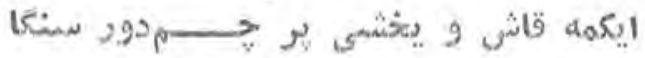

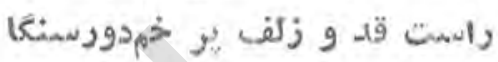

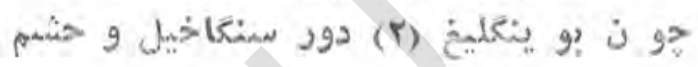

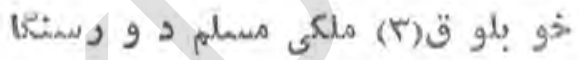
و له

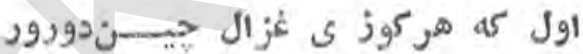

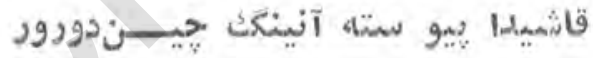

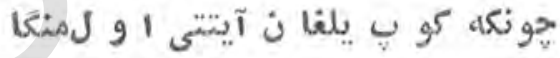

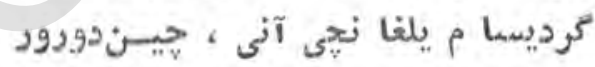
وله

مينى بى حا ل ايلا كان يارآ يدودور

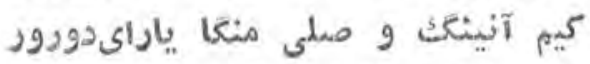

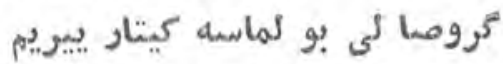

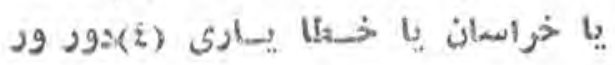

(1) य!S" -1 Vo- 


\section{ولسه}

عشق اهلى عشق در دينى تـانيشكى كو ي يما ن دور درد عشقى دين تانينك هر نيحه كوزوم آتج ايو سه كوزتو يار كر آحيلسه سيم ديك نســـا ز لكتينك وكه

ههر كيم كو ككا قيلور آ هنكـكتانك

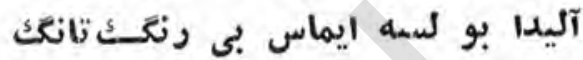
خالى وايكى لبى ديك بو لماغاى هند وار كيلتور رسه شكر تنعكتىك (1)

بوولا يت قه مقيد بو لماغيل. كيل خراسا ن جا نبيغه عـــز مقيل نوليل كر با دوربو لسا نك ايرورمينهمر هينك ور تو را رسين ، مين بارور مينجزم قيل olg

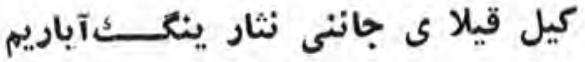
نقد جا ن نى بار موسيند يــــن آباريم بوسه بير سا نكك كر تمســا مآغز ينكك بيله كنج آغزينكَك دين آلايين ايازيم (1) (1) (تنك تانك. 


\section{g}

مين كيبى بير دلر بانىبيلمانام

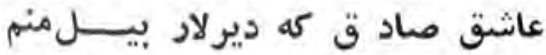
قيل تصور كوز يا شمنى بيــرتينكيز

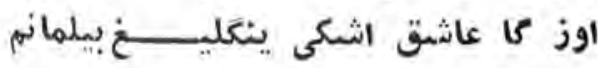

$$
w_{9}
$$

تا هيقا ر دى خط عذار هإكى دين

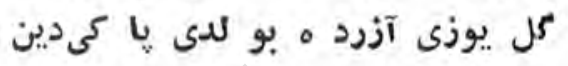

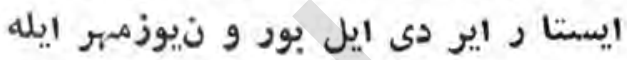
ايمدى اول يوز مهبرى (1) كيمتى ياكبدين

$\omega_{g}$

تا كونغو ل بيرديم اوشال قــــيسا ريغه

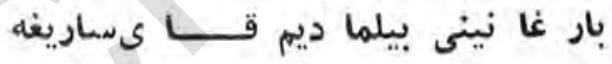

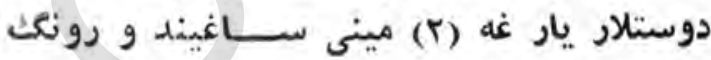
سمالسا نكيز ناته قو لاق قايساريغه

شهه ميو يورا ى آستا نينكـــــــيوز إيله تيمنك دين نيجهه اوراى يو يو زايله

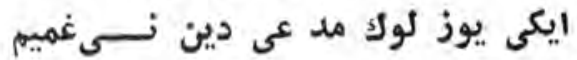
كر ايشيم تو شسسه الار دين يوزايله

(؟)

. 
نى بلا بيمك تودور (1) دو لت نتاغى

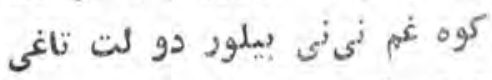

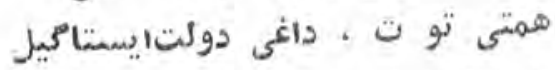

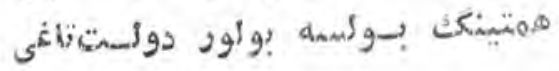
وله

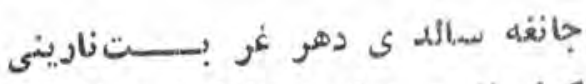

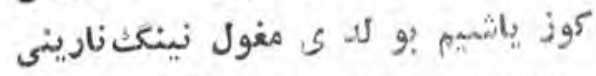

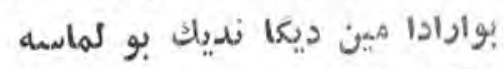

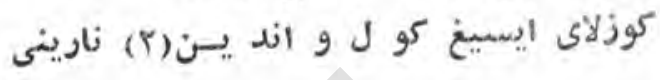
و o

قيلما سه او ل آى نظر منكا نى تانكك ؟

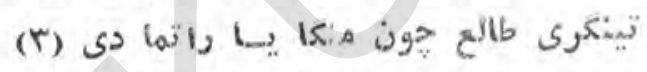
او قى يارار (ع) ايردى كونكلو مدردديغه

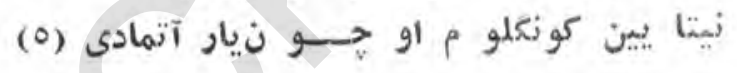

يو قتو دور ناز ينكد ين آزا د ىمنكا

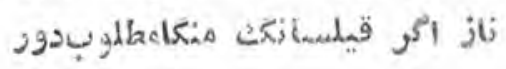
خواه كور سما ت لطف وخوا هي بحورقيل

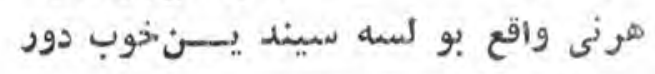

$$
\begin{aligned}
& \text { • (1) } \\
& \text { (r) } \\
& \text {. (Y) }
\end{aligned}
$$

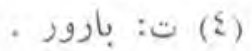

$$
\begin{aligned}
& \text {. } \\
& -I V A-
\end{aligned}
$$




$$
\text { i L La }
$$


اله آلار كيم بوهند كشوريدين

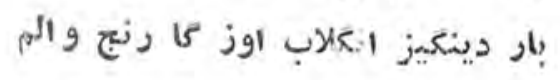

كابل وخو ش هوا سينى سيــاغيئيب

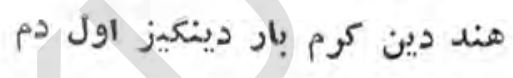

كور دونكيز · تايتينكيز (1) ايكين اندلا

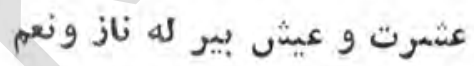
بيز داغى اولما دو لئبحمدالله

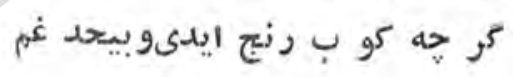
حظ نفسى (T) مشمقت بدنى

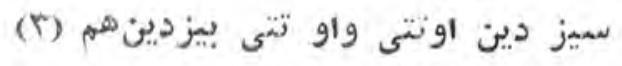
(1) . و

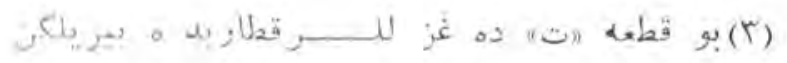
$-189$ 
دوران غمى بيله ستمى نى اونوتتورور

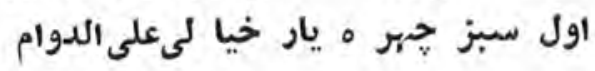

هجرانيدا خيا ل ايتا آلمان بوطرفه كيم

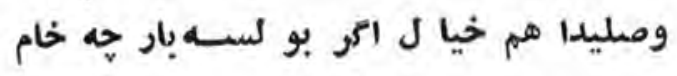
وصفيدا خام ليق اكر اولسه نىغم دورور

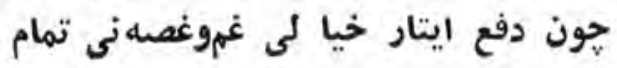
جون يار راز دار قيلور مين سينىخيال

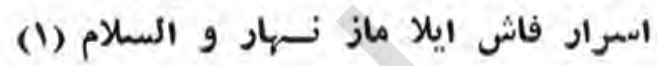

بابر نياز و مد حينى ييتكور كيلاى صبا

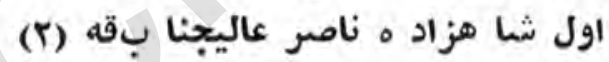
بول آى و ييل فراغت و خو ش باشليغ بيله بولغو نجه ما موسا ل آىوآفتابقه هجرا ن حو ليدا جهد بيله يويهلار اوروب

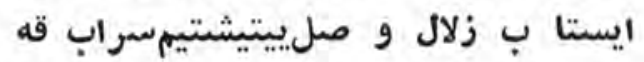

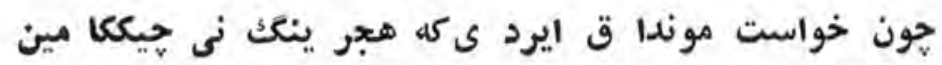
بىخوا ست ر جعت ايلا ميشاماندراب قونه

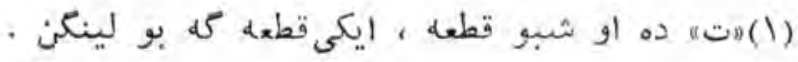

$$
\begin{aligned}
& \text { (T) } \\
& -11 \cdot-
\end{aligned}
$$


اي كه تر غيب قيلور سين خاغير ايجماككا مينى

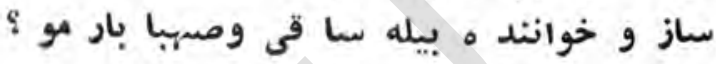
باو جود يكه اوتوبتور vاغير ايجماك و قتى

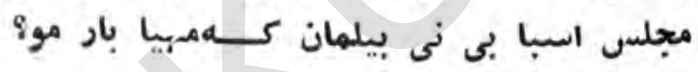

نا اميد بولدوم ، اي مغولسيندين تا ايشيتتيم كه : اند جان باردين النعك آيتغان سوز كا كيلديم، اماسين

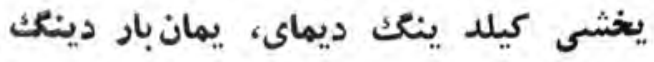

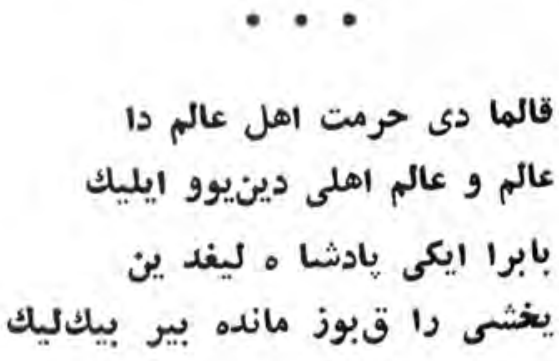
$-|1|-$ 


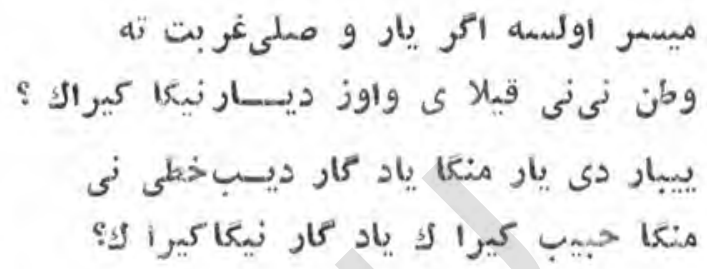

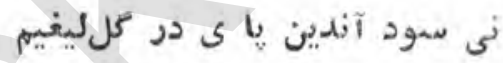

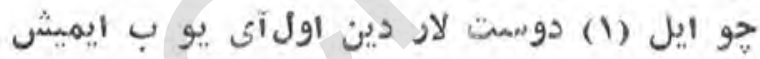
اوزين فارغ و بيز نى قيلغـا ناسمير كيم اير مشش بو ينغليخ اولايوبالبميشن -

تمام حسمن ايلى سا غوهو شيار ايكاندا

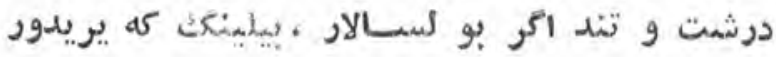

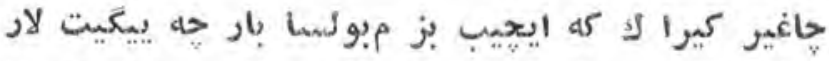

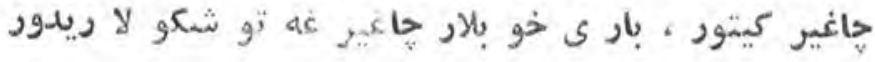




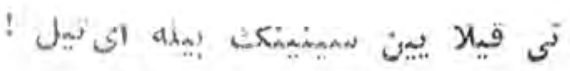

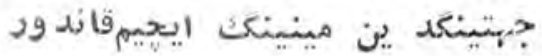

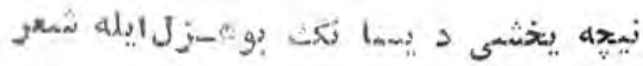
بريسمى فحشس وبير كيلغاندور كرديسا نكف قو يمايين موجر مبيله

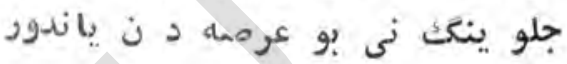

كرواد ى هـجر ينكع ارا بو للدو مزاقوى

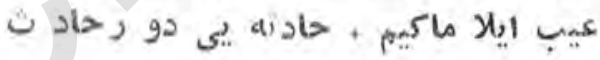
قو مى عنجبى حا غيو غهقيلد ى توغيب

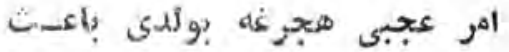

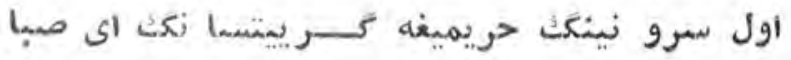

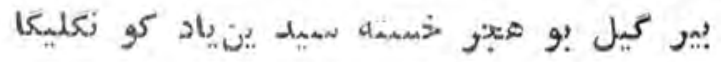

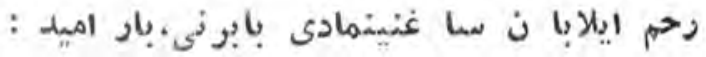
مالغا ى خدا ى رحم ني فولا دورنكليعا -inr 
مـمهـا لار

بابر

ايشيكينكك آستا نيغه لويو با نايكى يوزو منى

اويا ى كا هى تواضع بير له ،سور تاى كاه كوزو منى

شاه

هجر شامى مهاجسى سمو داسهى هيكار هر يان مينى وهكه بو ين بانى يوق تون قيلدى بمركردان هينى $-1 \Lambda \varepsilon$ 


$$
\text { م-تستسموى لار }
$$




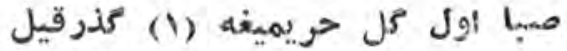

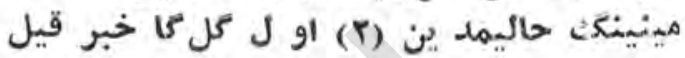

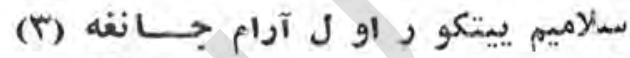

يوزو نكنى كور سا تيبكو نعلومنى آلد ينكك

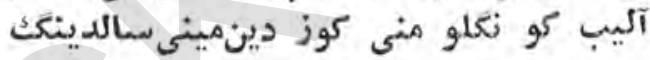

ديكيل دلدأر ليغ (ع) مو نداقبولود مو؟

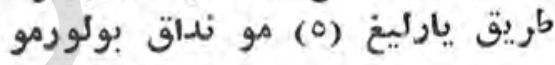
سبنى موندا ق تصدور قيلما سيايرديم

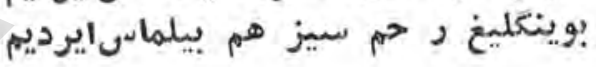

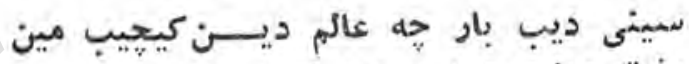

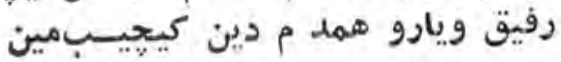

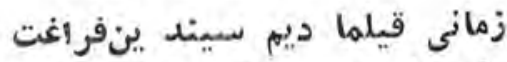

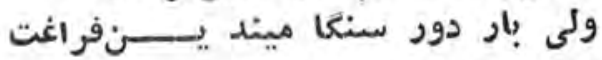

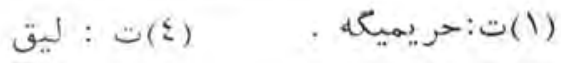

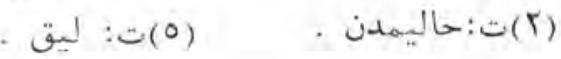

$$
\begin{aligned}
& \text {. }
\end{aligned}
$$




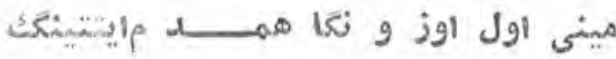

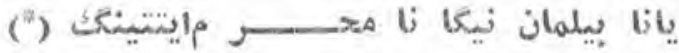

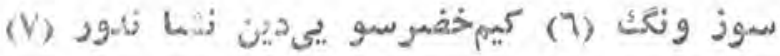
ولى اول دمو كيبى ميند يـســنهنهان دور نى يعنى مونجه بيز دين سموز ياثمور ماق جا آيينى نى حائ دين آشمورماق

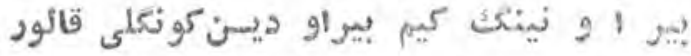
كيشى يوز سموز بيله (A) كو نكلينى (9) آلور

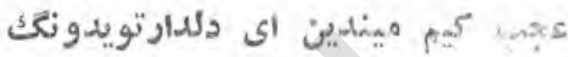
منينكت كو نملو منى بير سو زبيركه قو يد ونكك

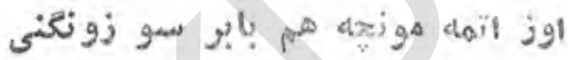

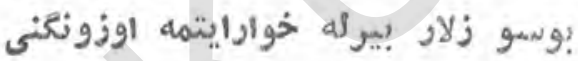

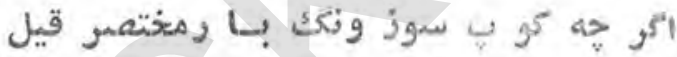

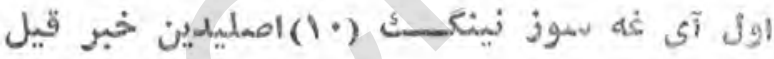
كر او ل سموزيم يا شور دونك آيتماس سعين

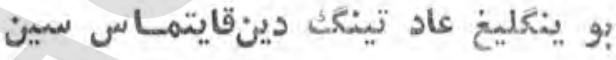

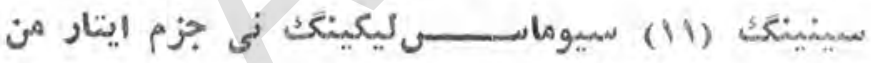
باش آليب اوز كا بير سار ىكيتار مين اكر باترا ق ييباد ماس سين جوابيم

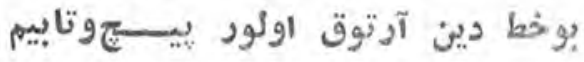

$$
\begin{aligned}
& \text { - (9) } \\
& \text { (·) سوزنو نكك . (1) } \\
& \text { (1) }
\end{aligned}
$$

$$
\text { "بو بيت التاده يو ق. }
$$

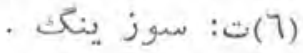$$
\text { (؟) (V) }
$$$$
\text { ( ) }
$$ 


$$
\begin{aligned}
& \text { اي يياك مبا قا تيمغه كيل كيل }
\end{aligned}
$$

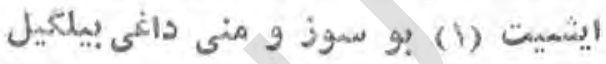

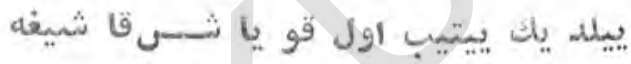

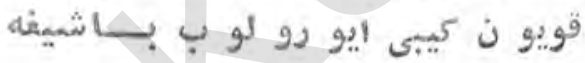

$$
\begin{aligned}
& \text { يوز حمهر ت و اششتيا ق بيركه } \\
& \text { يوز مينك أم و فواق بيركه }
\end{aligned}
$$

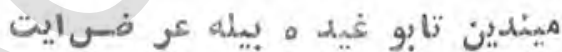

$$
\begin{aligned}
& \text { بو(Y) خدهت نى اوز ونكا فرضايت }
\end{aligned}
$$

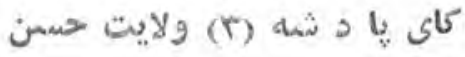

$$
\begin{aligned}
& \text { شما نينكَك دا كيليب تور (ع) آيت } \\
& \text { سين حسمن سر ير ى يادشا هى }
\end{aligned}
$$

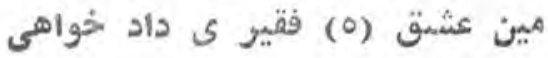

$$
\begin{aligned}
& \text { (5) } \\
& \text { (0) } \\
& \text { (1) } \\
& \text { (r) } \\
& \text {. } \\
& -11 V_{-}
\end{aligned}
$$


هجر و غمينك ايتتى ظلمو بيداد اى جان و جها ن فثا نو فرياد آير يلغا لى آى نغار سيندين آير يلد ى هش و قرار هيندين كوزومدا اتر حه يو قجمالينك

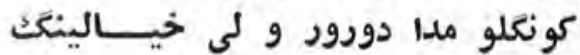
فكريم بو دورور كه سنكاييتسام ذكريم بو دورور سوز و نكســـايشيتسام بار ما دى كونكو لدين اول سآجويوز ياد ايتتيم آلارنى كيجههوندوز جون يو ق قا شينعا (ך)ييتا ر كا(V)حديم

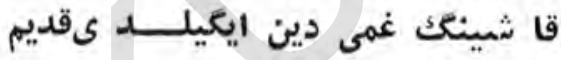
زلفو نكك تمر هى غه بسته دو رمين كوزونك هو سيد ه خسته دورمين

تآق يوزو نغك يرا قتو ثتى ايكى كوزوم ايحِر آ آق تو شتى

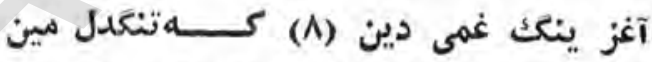
او لما ى يورورا م نى سنكد لـين لطف ايت كه خرا ب بو لــد ىحاليم رحم ايلا كه قالما دى مجاليم

(T)

.

- تا:غميده 
خو ش اولكه يوزو نكنى (q)يانه كورسطام

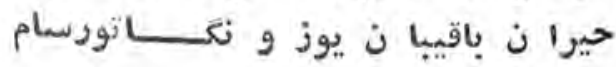

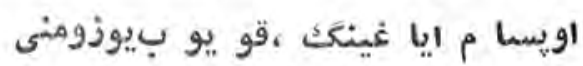

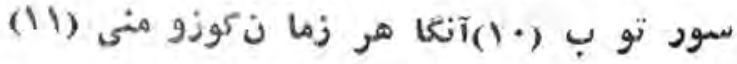

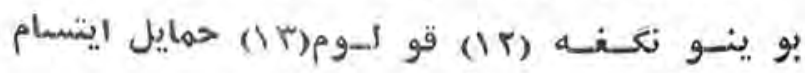
سرو يتُكنى او ذ و مكا (ع أ)مايلايتسمام

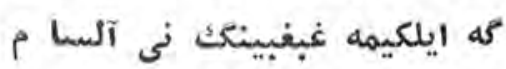

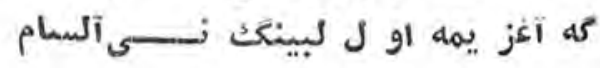

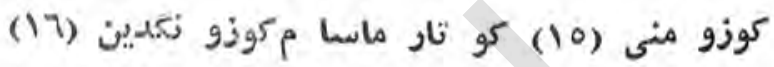

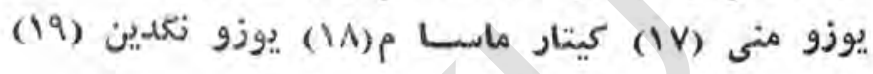

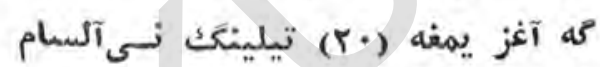

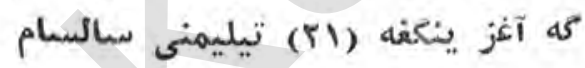

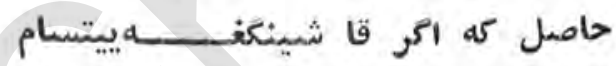
كونكلوم (Tr) تيلا كانجاهعشمرت ايتسام يوز ونكف ينه كورسا م اير دىائ لئان اولسمام داغى قا لما س اير د د عار مان دائ

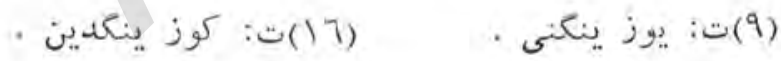

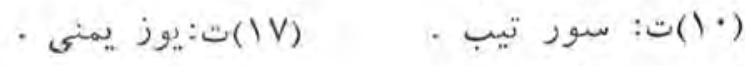

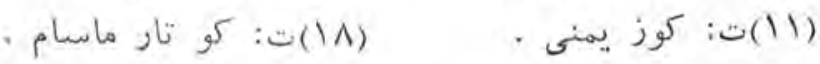

$$
\begin{aligned}
& \text { (IT) } \\
& \text { (Ir) }
\end{aligned}
$$

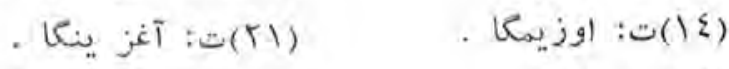

$$
\begin{aligned}
& \text {. . ل } \\
& -119-
\end{aligned}
$$


يوز مونجه خيا ل لار قيلور مين يادينك بيله حال لار قيلور مين لار فيلور مين

مين او شبو خيا ل لاربيله شا د سين مينى قيلور سين اوز تاجهياد مهجود كونكو لنى شاد قيلماى يخشى سوز بير له ياد قيلماى يالغا ن سوز ايلا عتا ب ايتا رسمين يوز قهر بيلا خطا ب ايتار سين

كريالغا نى بو لسه ظا هر ا ىدوست شر منده بو لورسين (Yr) آخراىدوست اى يار سين ايلاما تصور

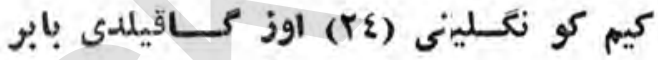
يوز حور صفت قا شيم غـــــــــــيلسمه يوز تيغ جفا با شيم غهكيلسه كونكلو مدا هنوز اوشا ل وفـادور باشيمدا دا غیى اوشا ل هوادور فكريم اوشا ل و خيال اوشا لدود درديم اول وزار حا ل اوشيــالدورد كر مو نده تر ددايتسه آييم بو سوز ده كوا ه ايرور خداييم دوايتهه ايم

$$
\begin{aligned}
& \text { ( } \\
& \text { · }
\end{aligned}
$$


حال او ل ايدى كيم حكا يــت كايتتيم (Yo)

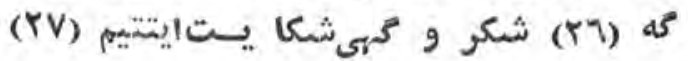

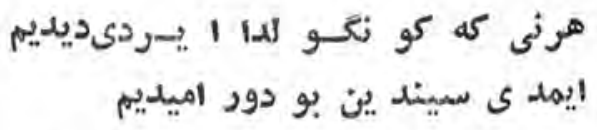
هو ايشته (YN) شتا ب قيلماغاي سين بوطور عتاب قيلما غاي سين قالغا ن كونغلو منى آلغا سيسنبات

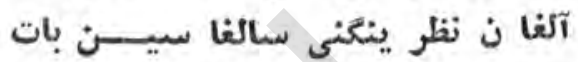
كر يخشى و كريما ن قيلـــو رسين

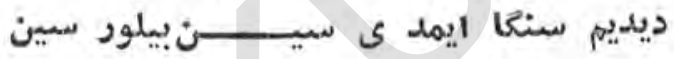
تا دهر دور ور سلامت اولغيل خو شلوق بيله تاقيا مت اولغيل

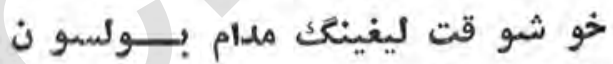

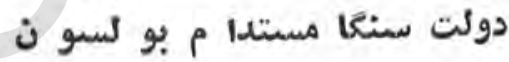

$$
\begin{aligned}
& \text { - } \\
& \text {. } \\
& \text { - } \\
& \text {. }
\end{aligned}
$$


خاطريم نى تيلا را يسا نغك ميل

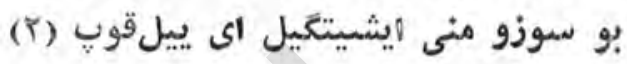

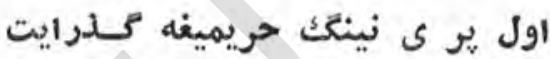
مين ديوا نه حاليدين خبر ايت نين

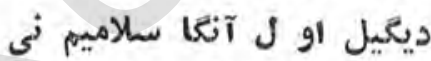

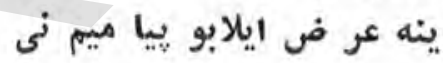

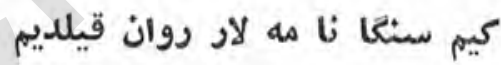
حالتيم نى بارين بيا ن قيلديم سينى ديديم اميد ايلا ایى يار كيم آليب كونتلو م اولغا سيـنديندار

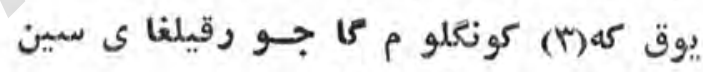
يار ليغ نى بو طور قيلغاي سين كم(ع) ايماس ائيردى يار بو عالمدار هر طر ف ياربار عالم إنمان 12

$$
\begin{aligned}
& \text { (צ) } \\
& \text { · }
\end{aligned}
$$

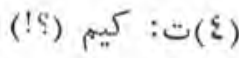

$$
\begin{aligned}
& \text { · (Y) : قويقات } \\
& -197
\end{aligned}
$$




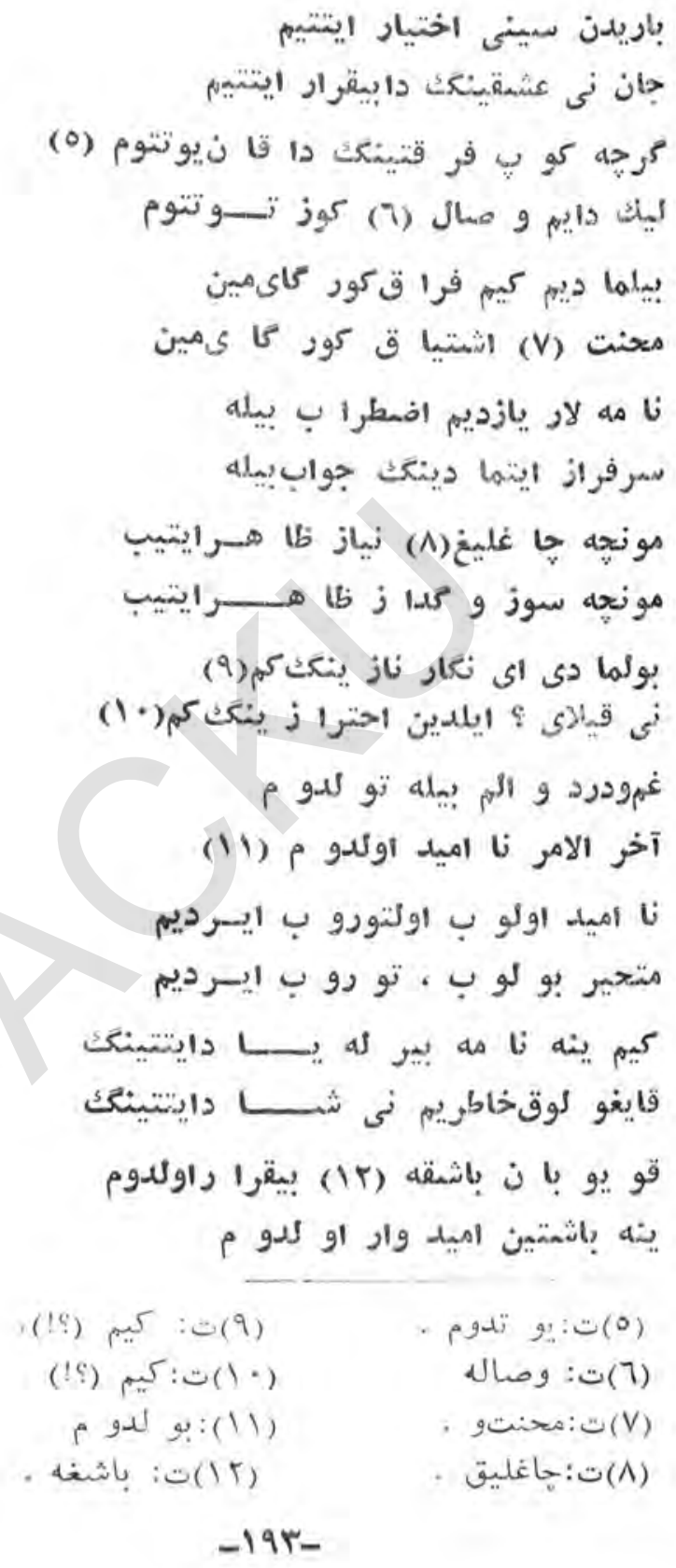




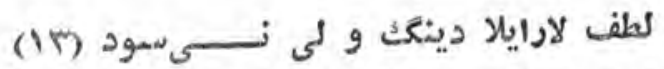

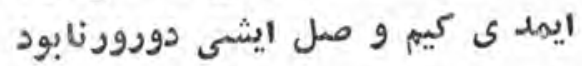

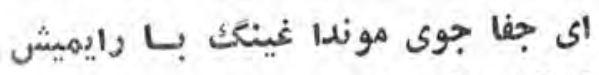

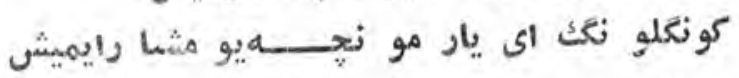

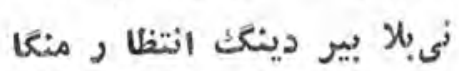

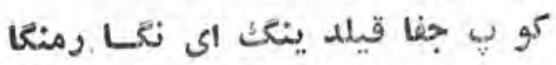

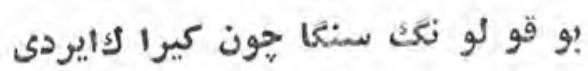

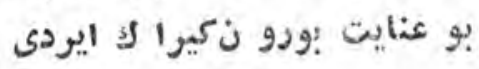
ايمد ى كيم و علدهُ وفا قيلدينكك تونك

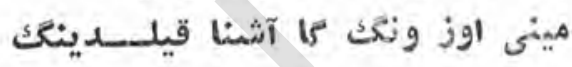

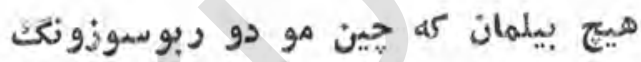

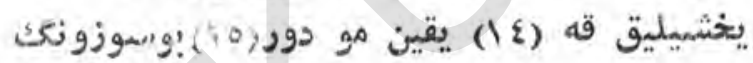
يابو هم عشموه و فويب مو دور دوستلو قته بولار حسيب مودور في مور دور يارليخ نى اكر قيلو ر بو لسـانك دولك

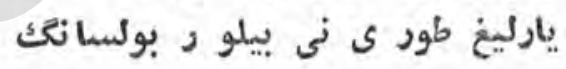
عهد و قولو نكك (17) درست ومنكمي قيل

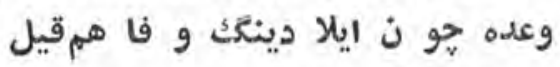

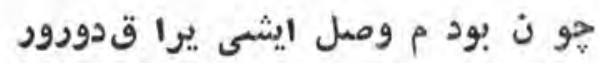

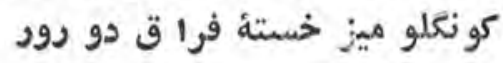

$$
\begin{aligned}
& \text { (Ir) }
\end{aligned}
$$

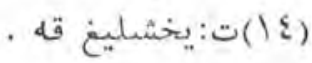

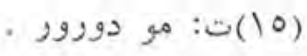

$$
\begin{aligned}
& \text { (7) (17) }
\end{aligned}
$$


هر قاحا ن و صل ايشَى يا ووقالاشسشه

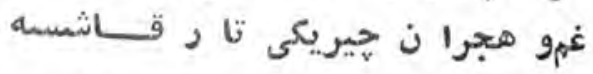

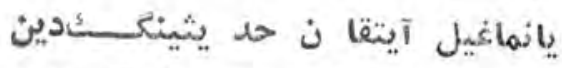
تا نماغيل آيتقا ن حلـ يثينكسكدين شاد ما ن قيل مينى ومسار بيله اختلاط ايت بو خسمته حال بيله بند ه با!برنى محتر م قيلغيل هـرم ايت و صلينغا (IV)

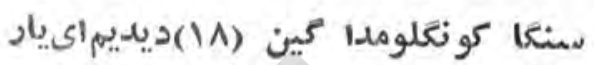
ايمد ى سميندين جوا ب اميديمبار خط جوا بينه يو للدا بو لـــــ ىكوزوم

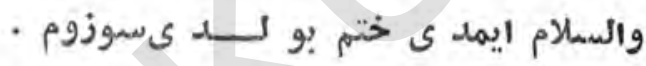

.

·

$-190-$ 
اى صبا ييلما كنى قو يغيل حزمقيل سرو نازيم كو يیى سار ى عزمقيل ييل كيبى ييت سرو نازيم قـــاشيغه

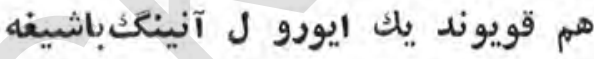
باشقويو ب يير كا ، نيازيم عرضمقيل

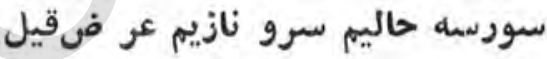

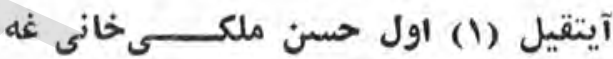

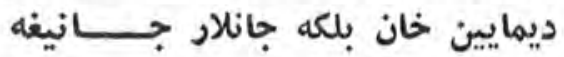
كور مايين يوز و نكنى بيمار اولميشام غا يبا نه عاشق زار او لميشام هيجيلما ن كيم بيلور سين ا ىنغار

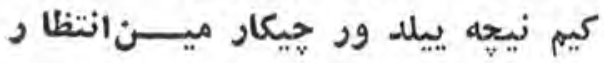

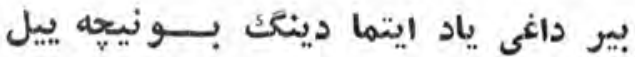

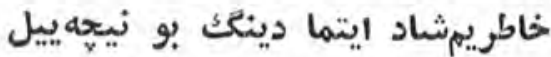

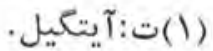




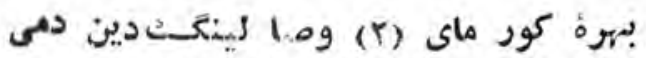

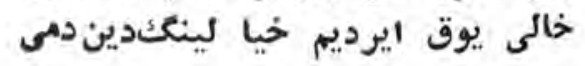
فكر ينكت اير دى دوستـدار وهمدميه ياد ينك اير دى غمكسار ومحريم ميه

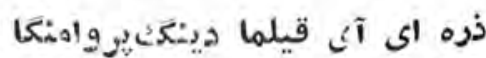

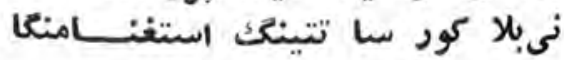

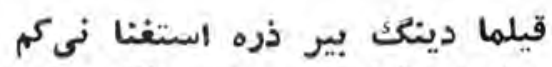

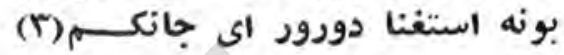
سين بو ينغليغ مست حسنونككاجاهى دين مين مونينك ديك آيرووصلينكك كامى دين

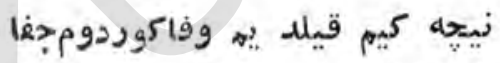
نيجه كيم كور دوم جفا ، قيلديموفا ياوو شوب اير ثيم كه نوميد اولغامين عشق دين بيكانه جأويد (ع)اولغإمين

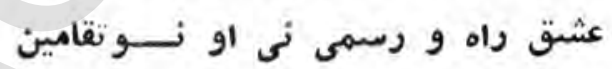

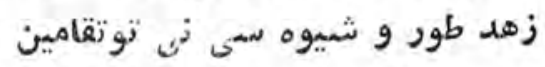

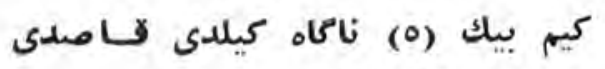
يار دين آكاه كيلدى قاصد يل

وصليدين (7) بير مثده بير دىاول منغا جاندين آرتوق مزده اير دى اولمنكا

$$
\begin{aligned}
& \text { (r) ت : بهره كورماى : (T) } \\
& \text { (s) (s) : (s) } \\
& \text { (ع) ت : : جويد : } \\
& \text { (1) }
\end{aligned}
$$

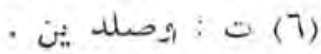

$$
\begin{aligned}
& -19 v-
\end{aligned}
$$


وصفينى نيجوك(V) قيلاى بومزده نينكك حينى نى قاندين بيلاى بومث دهون نينكى بولسه جين بير نامه كيلمـاسموايدى ليدي

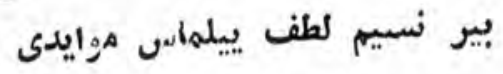

قويغيل ایى قاصد بولار يا لغاندورور ههر و حسن اهلى ، بونى امكا ندورور 9 مين كوروب مين خو بلار جورينىكوب مين بيلور مين خوبلار طور ينىخوب لين دوري كر سوزو نكك جين:ورينه بيلماكيكيراك ياردين بير خط آليب كيلـما كوكيراك ييتكيل اول خدمتى (^) غه يـارنينك

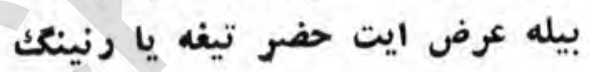
يخشى يِيغا مينك نى ييتكو ردىرسول

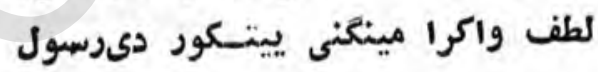
كر حه قيلد ينكّك لطف اى دلبرمنكا

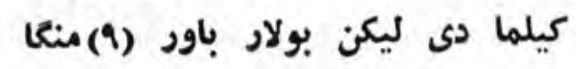

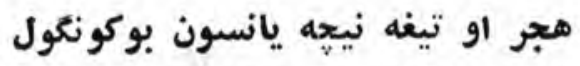

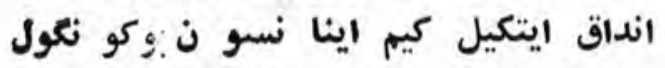

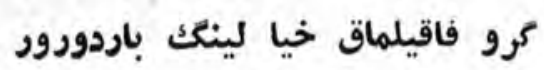
قوى جفانى كيم كونتول مضطردودورد بنافي باردورو

(§) (V)

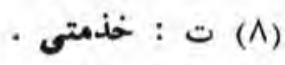

(§) (9) : (१) : (^) 
بير عنا يت نا هه بير له يــا دقيل

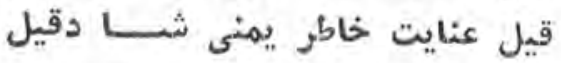
يا مينى قا شينغنه ييتكو ر،قيل كرم

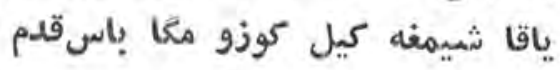
هر نى كيم كونغلو نما كيلسهاى يري

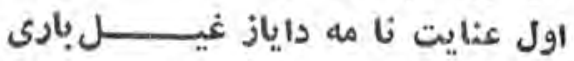
كر سينينك و مسلينك اميد ى بولماسه وصملينكا (·(1)ييتما لو نو يدى بولماسه

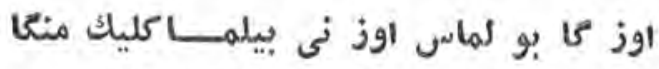
بلكه مشكل دور تير يلما كليكمنكا وصمل ايلا فرسود ه جسميمزندهقيل كلف ايلا بابر نى با شتين (11) بنده قيل

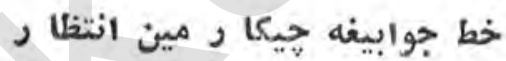

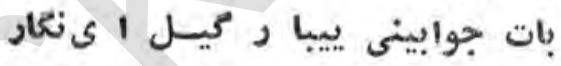
هر نى كو نكلو مدا ايد ى ديديمتما م ختم بو لدى سوزوم (r) ايمدى كوالسلام

$$
\begin{aligned}
& \text {.) (1') } \\
& \text { • } \\
& \text { - }
\end{aligned}
$$


بير كيجه خاطريم مشو شايدى

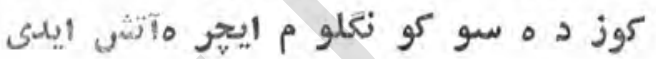
دهر ايشى دين فغا ن قيلور ايرديم خاطريم نى يما ن قيلود ايرديم فيم هر زما ن دهر نى خطا بقيليب اولتو د وب كه قو نوب دي شتا بقيليب ديو ايديم اي وفا سى يو قظالم ظلم دين ييتتى اولكَالى حائيم ظلم دين اوز ما ايشنى بيلما ى سمين

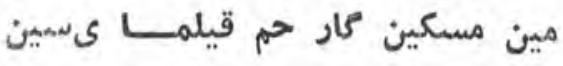

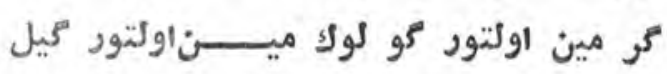
يوق ايسمه سور كو لو كايسامسوركيل هر نيجو ك (1) طور قيل بو جورايتهه هر نيخو كل (ז) جور قيل بو طورايتمه

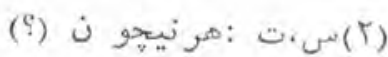

(؟) (1) -r.?- 


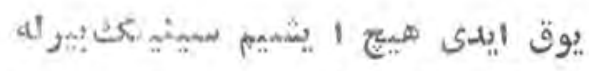

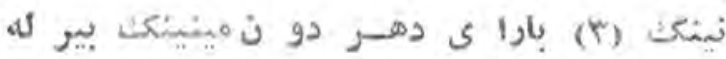
كنج عز لن ثله دو قيليب ايرديم.

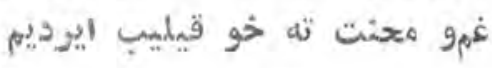

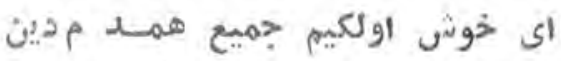
ديمه همل م كه جمله عالم دين فارغ ايرديم قنا عتيم بارايدى قانع ايرديم فرا غتيم بارايدى كو شه بي اختيار قيلغان ايديم

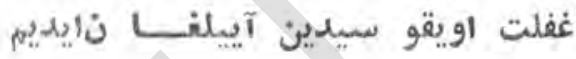

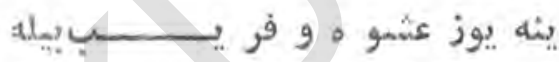
هيج بيلما ن كه ني حسيب(ع) بيله دولت اوتر و سيغه مينى سالدينكي غفلت او يقو سميفه مينى سا لدينكك بأرى احبا ب نى قيليب (0)مسرور

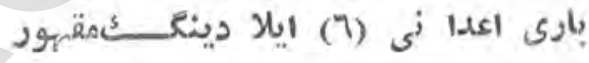

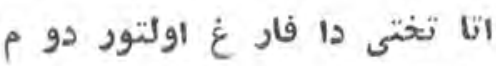

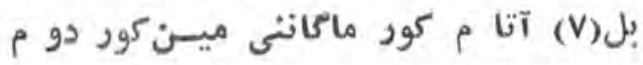

$$
\text { - مكات }
$$

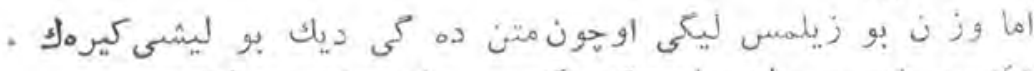

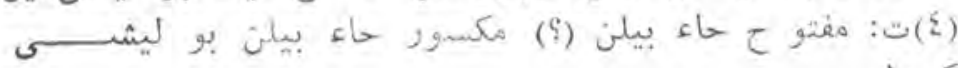

$$
\begin{aligned}
& \text { كير هـ } \\
& \text { : (0) }
\end{aligned}
$$

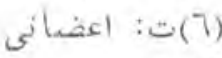

$$
\begin{aligned}
& \text { (S) }
\end{aligned}
$$




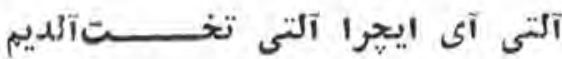

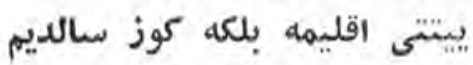
ديديم ايمد ى مراد يمه ييتتيسـم بيلما ديم كه غلط خيا ل ل ايتتيم عشرت و عيش و قتى ييتكا نهاغ

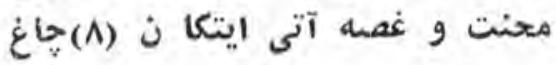
ينه محرو م خان ومان قيلـــدينكت ينه آواز هُ جبا ن قيلد ينك

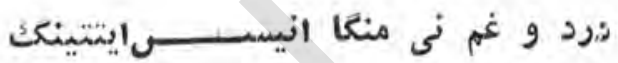

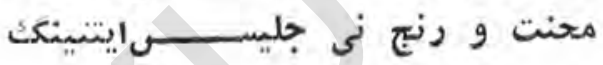
عيشس ايلا عشر "تيمد ين آيسـريلديم دولت و عزتيمد ين آيريلديم دولت و تخت و عز وجاه قانى؟

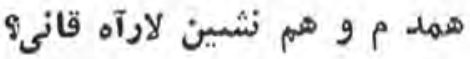

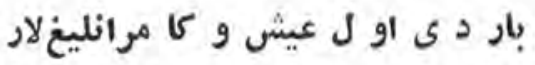
ايمد ى كيم كورسه جا لتيـــم، ييغلار

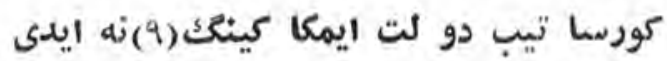

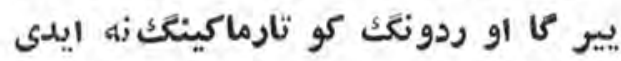

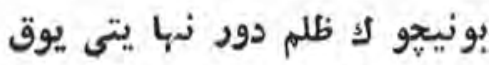

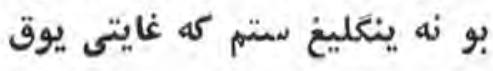

(1)

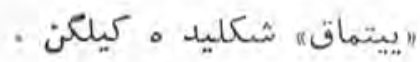

(9) 


$$
\begin{aligned}
& \text { دهر غه نى و فا دور ونى دحم }
\end{aligned}
$$

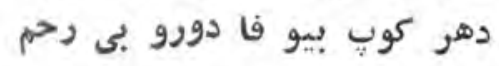

يو قتودو ر مهر ى هيج كيشيكآنينكن

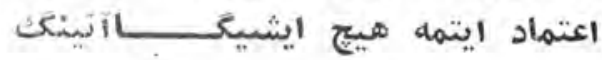

5اه كفر اهلينى مسشلط ايتار اهل دين نينك ايشينى منحطا ايتار كاه יير قولنى يادشاه قيلور شا هنى بنده ، كاه كاه قيلور كاه جا هل نى سر بلند ايلار كاه عاقل نى هاه جان و كو نكليدا جز جها لـــتئي

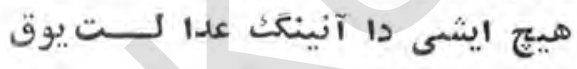
نىو فا قيلغا نينى بيلسه بـــوني

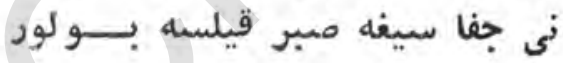
نىقيلا ى ، نى كيشيى دين ايستاى داد كيم 15 دهر ايلكيدين قيـالك ى فيرياد دهر دوندين شكا يثيم كو يتو د (.)

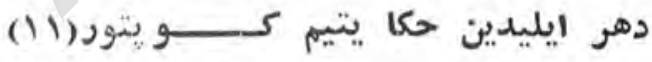
اوشبو حا لت تله نا توا ن كو زكلوم غصه دين تايما غا ن اما ن(rال) كو نغلوم اوز قاتيق حا لتى غه بيفـــا رايدى

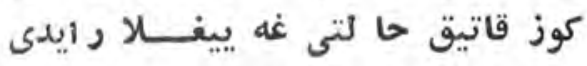

$$
\begin{aligned}
& \text { (•) (1) (1) س، ت: كوب دور. } \\
& \text {. آن } \\
& -r+r-
\end{aligned}
$$


كيلد ى با ثميمغه صبحسجــــد مآخر مهردين اور د ى صمبح ،دم آخر ميد مينى اوز دينى مهربا نليغ دين

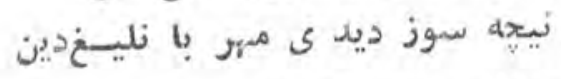

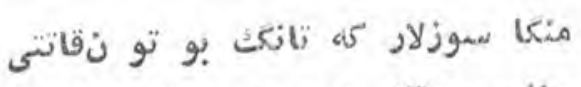

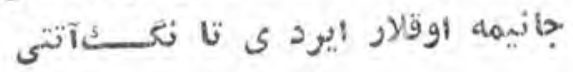

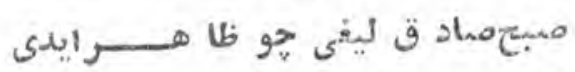

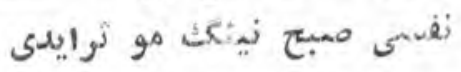

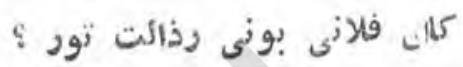

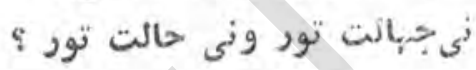
زيجها دونيا غميدين ايتها كليك

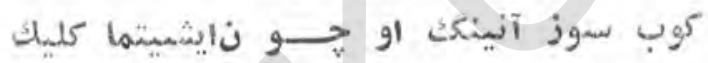

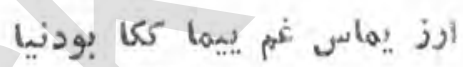

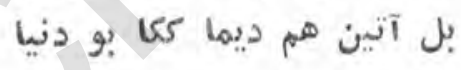

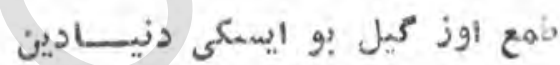
خاطار ينكك دين حيقا د بو د و ون نيادين دولت اوجيجو ن كونكو لنسى زارايتمه

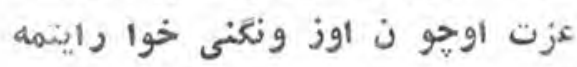

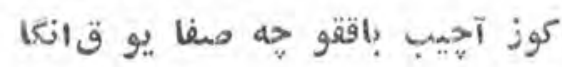
كوز يو موب آحقو حهه بقا يو قانها دهر دين كيمكا بولسمه ملتمسى آنس بيش ايماس آرزو بيله هوسى دئ ملئ نفس نينك كسبى دور هوا وهوس دوح آليد ه دور بو لار يارا ماس دور وموس -r. 


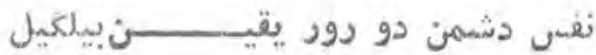

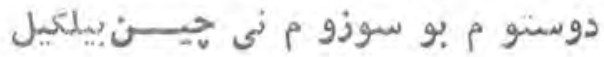

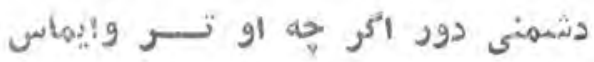

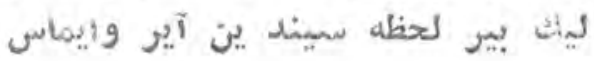

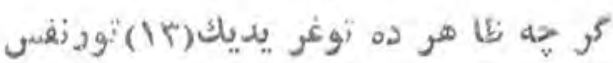

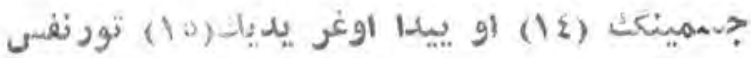
بورنا غي لار سوزين (17) نظر تي إفيل

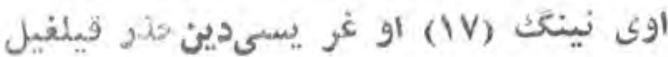
نفس تو مسن نى (1) (19) رام قيلاوز ونغا

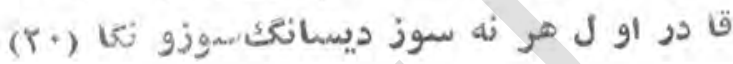

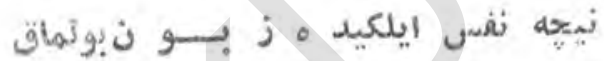

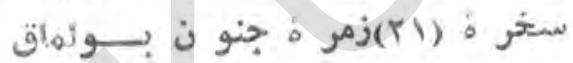
نى ديسا نكف نقس نينكك رضالمى بيله نى كه قيلسا نك آنينكك هواسى بيله

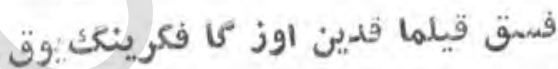

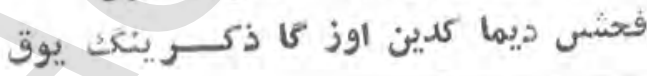

(S) (S. . . (1)

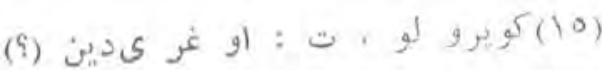
(17)

(s) .

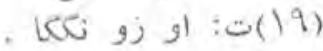

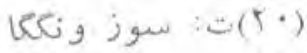
(9) : سجوز :(Y) 


$$
\begin{aligned}
& \text { ايلا رذل ولو ند او لو ب سينكيم } \\
& \text { خلق ارا ريشنخد اولو ب سيسن ونيم } \\
& \text { هر زما ن بير لو ند مسخره يى ديى }
\end{aligned}
$$

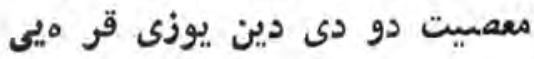

اوز نى ياندا شتو رو ب اوز ونككبير لله

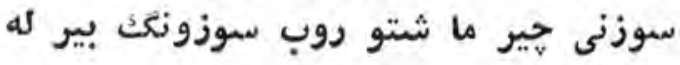
آنى اوز ونكا سين بيليب همدم

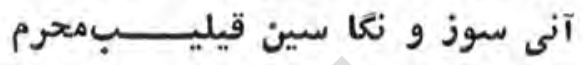

قيلغا سيز خلق نى تو مانغيبت

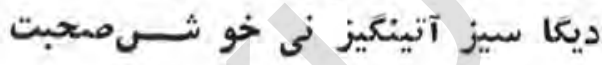

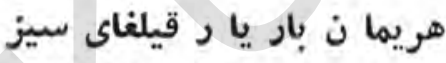

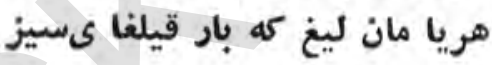
ناكهان بير جوا ن مدار ايلاب آليد ه اوز نى بيقرار ايلاب

هر ييگيت كيم كور و نسه حا لاقيليب كيينيده (Tr) يوز تو ما نيت خور ونيا لوقيليب

بونى عمرو بونى بالكيغ دور ؟

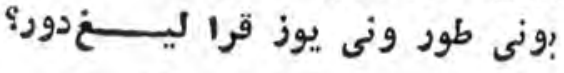
يوقتورور هيج اعتهيد سنكا ينا

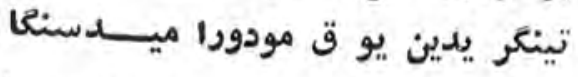

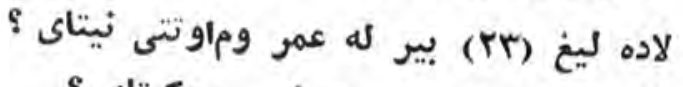

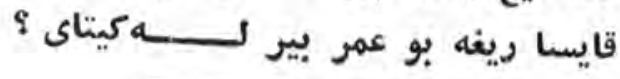

(Tr) 
عمر غُفلت ته (عَ) او تكا ريسبباراسين اي ييكيت واقف او ل قاريــبـبارابمين

حق تعا لى نيعا يارا تتى سينى

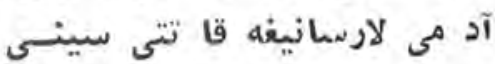

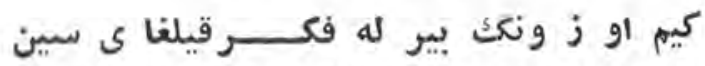
غفلت اويقو سيدين آييلنـــــ كسين ايلغا سين جهد ايلا بارىصفتين قيلغا سين در كو تينكر ى معسرفتين

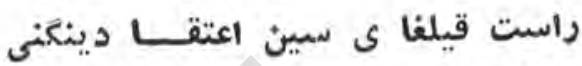

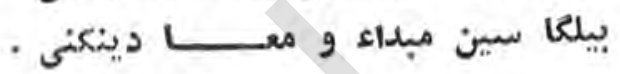


جسمينكا (1) ضسف ايسه جانيم مهل قه

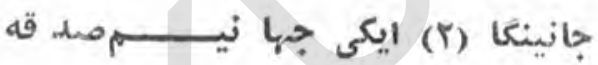
كوز ونكا (r) بو تن بيمار فدا

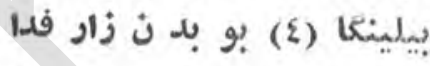
سمين سيز ين جسم بيلا جانتـى نينا ى ؟

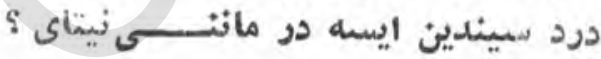
منكا سين سين بو جها نديـــنمقتمود

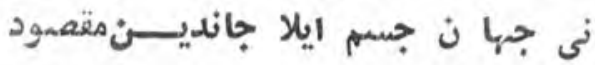

قا متينك ينغليغ اوزو ن يا شتإيقيل (0)

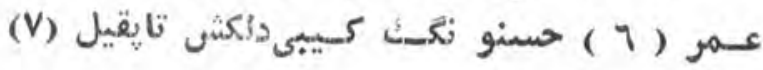

$$
\begin{aligned}
& \text { - (1) } \\
& \text { - }
\end{aligned}
$$

.

· . (乏)

- تات: تانغيل

- عمرو 


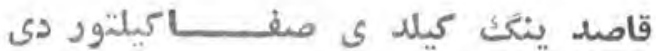
خبر مهرو و فا كيلتود ديل

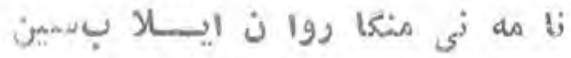

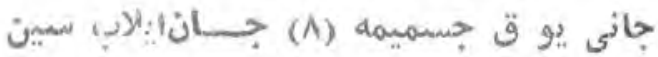

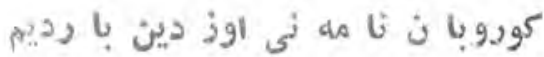
اوقو بان سموز ينى سموز د يسن بأدد.بم كور كات اوق كوزو مه سودتوباوبتوم اويكا ج اوق باشيمله قو يو بوقوتيتوم

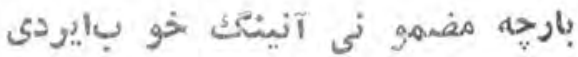
بارى الفظى دا غي مرغو بإيردى يار دا مهروو فا بار أير ديشس لله الحمل وفا دار (9) ايوميش له تون و. كو ن فكر و خيا ليســـــــودودود

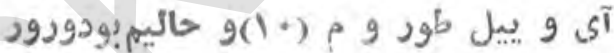
هجر نينك كلبه سيدئ كيتغائيمين

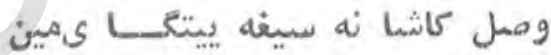
وصملينكا (11) تينكو ى مينسيكي لتكور سه لكلف ايتيب منغا سينى ييتكوربسا ييتكاج اوق ايور ولا يين (I) بالشينكدين غايب او لماي نفسمى قاشينكسدين

(9) \&s proman: : $:(\Lambda)$ . (9) -

(() (ايورو لورسه (1) 
مين ديماس مين كه دو دا غينىاويّاي

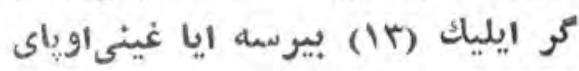
يبر زما ن خالى ايمان فكر ينك فيدين

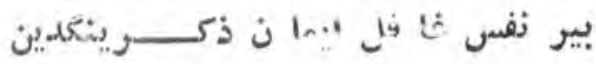
كرديسا م جسم ايله جانديســن سمين سين غرضيم ايكى جهاندين سميــــنمنين آى يوزونكَ يو ق داقوا كـو ن بولسمون يير وكوك آستين و اوستو ن:ولسمون

$$
\text { هر نى كونكلو مدا ايد ى ميسنديليديم }
$$

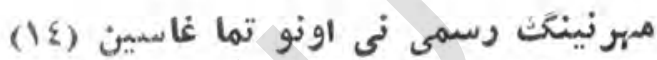

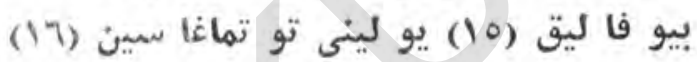
بور ناغى ديك مينى ياد ايتغا ي بمين. خاطر خسته نى شا د د إيتغا ى غير اخلاص و دعا بير له سلام نى ديين اوز كا ، سوزو مبو لدى مالم .

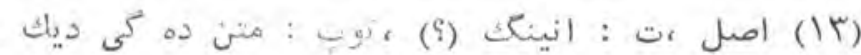

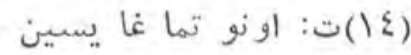

$$
\begin{aligned}
& \text {. } \\
& \text { · } \\
& -41 \cdot
\end{aligned}
$$


خاطويم ساقار (1) ايسا نعــكبل قويغيل

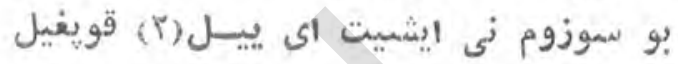
اهل دل آليدا سر عت بيلـــــيته

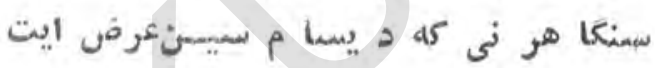
هشمكيم آليدا تقرير ايتكيل

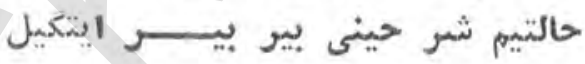

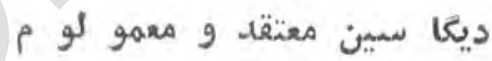
روش و طور وسملو ك ويو لو م مونم بار دور اندا قكه عيانايلا بمين

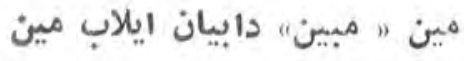

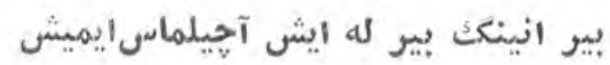

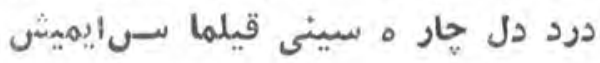

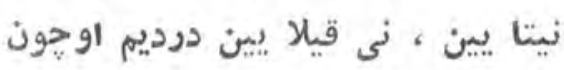

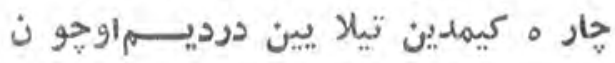
- (1) (1) 
حار ه درديم غاره مكر ليير ايتكا ى حار ه سيز ايشيمه تدبيرايتكاى دئي نيلايين مر شد و نيثا ى ارشاد قابليت قا نى و استعداد مستعد بو ل و قيل اوزنى قابل فيضلار تاسنكا بو لغاي واصل

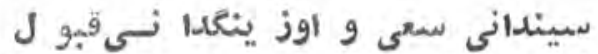
نى ايشينكَ يخشى ، نى سوز و نكَّ هفبو ل نى ايا ق كيم طلبيدا يود و كاى نى كونكو ل كيم هو سيدا جورو كاى

نى انيينكَكايشينى قيلما قتهايليك

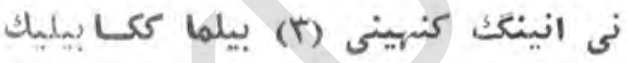
شسو ت ونفس كر فتار ى سين ددبيله ديو نمو دار ىسين شهرو ت و نفس قو ى دشمهــندود

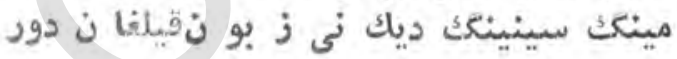

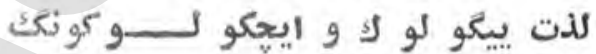
خو شئى كيفيت و ايجكو لو كونكَ

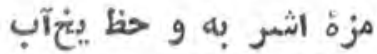

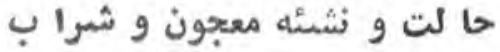
حورو ش لار بيله همد ســـتاولماق مى كث ايل بير له ايجيبمست الوألماق نشئهة صبح و صبو حى نشئه مى كش ايل قو ت رو حى ثشئه (!) -rIT- 
تند ر خشينك نى مينيب ييلد ودوبان ايلكا إوز نى تا نيتيب ، بيلد وروبان حكمو نك اولما ق بارى ايلكاجاجى

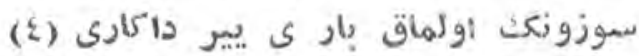
نابعينك (0) ملك خراسا ن بولماق هئل و جين آلما غينكك آسا نبولماق قوللوق و خد متينك ايتما كئييلوآث زمل جو ج"ى و الودوغ حنتا ى بار حه ايش كابو لوبا ن دسترسمينك

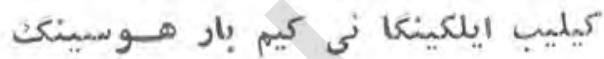
بأرىفانى و بار ى هيع تورور

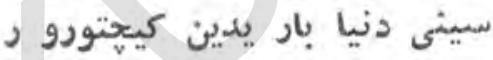
بيلميشـا م هر نى كه قيلد ينغــت تحرير فهيم قيلديم غر ضينكنى بيربير بو ديما لك تين بو بيتيك(7) تين نى سمود ؟ طلبى كيم كيرا لك اول دور نابود تينكو ى قيلفا ى موا يكين طرفه سبب

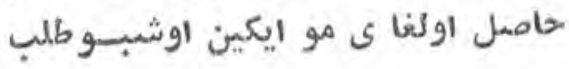
تينكر ى تو فيقى مككر يا ر) راو لفناي

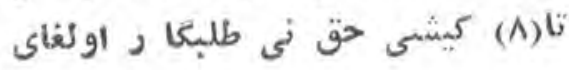

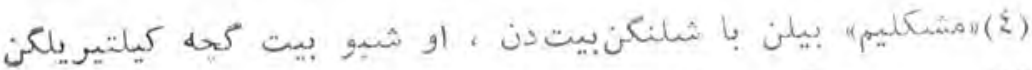
(1)
(؟) (T) (0)
(؟) : (V) 
تينكر ى تو فيقى دى و تيــــتوروايين

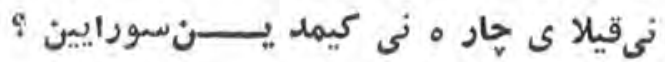
تو ت قو لاق كيم بـــــــو دورورتحقيقى

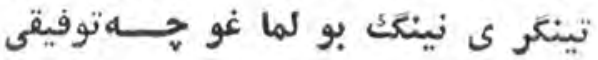
ممكن اير ماس بو لا آلماق هيجايش

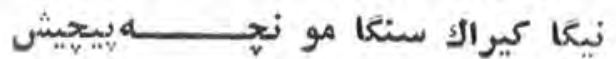
كرد كارا !منكا تو فيقى بير يورو ماك كا رهتحقيقى بير عمر غفلت بيله اوتكا ر ميشـــين مين نفس بويرو غى بيله بار ميثـس ميلين نفس ياغى سينى مغلو بايتكيل

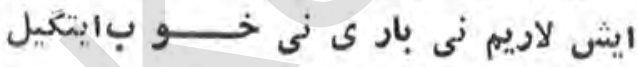
بارى حظ دين مينى آسان اوتكار لاريم

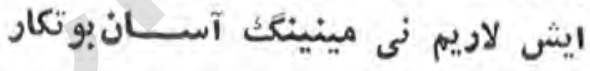
كوش وهوشوم نى سوزو نغـــسارى قيل

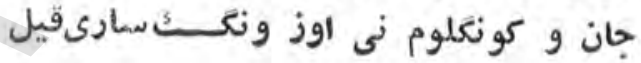
غملارينكك بير له آووت كونكلومنى

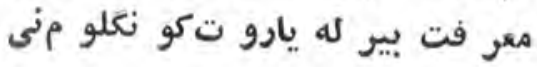
قويمه بابرنى بو حا لت بير لله

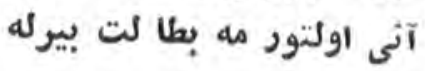
بير كينَينى انكا غمخوا رايتكيل همتين بدر قه و يارا يتغيل تاكه درديغه دوا ييتكور كا في

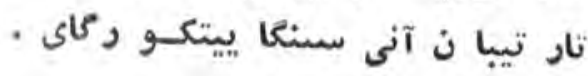
$-Y 1 \leqslant-$ 
نيجهه عصيا ن بيله آلود مليغينغك

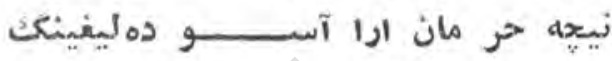

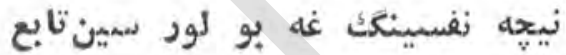

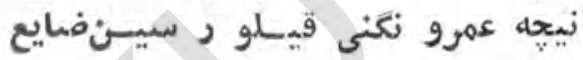
نيت غزو ايله كيم يوروب سين اوأما كينكنى اوز ونعا كورو بيسمين

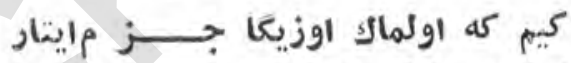

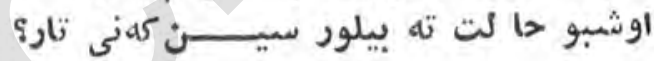
دور ايتار بارجه منا هى ديسـناوزين

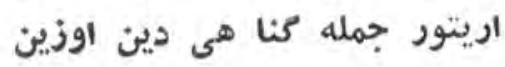

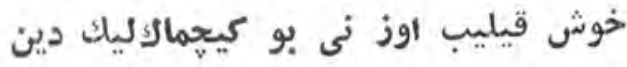

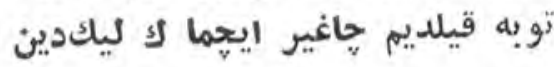
آلتون ونقره صرا حى واياغ

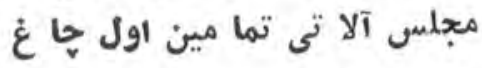

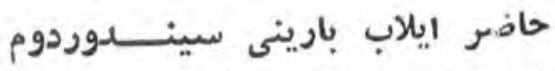
(1) ترك ايتيب مى نى كونكو ل تيندوردودين (1) - rlo 
قرا سين ياغى نينك كورو بتورلار

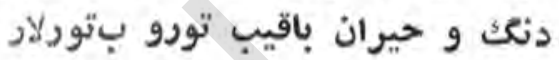

مينييتيب تيز او ل سيـ ر ميوردو دوم يورويورو ديب ايلكا رى يود ودوم لئي غرفيم ايل نى تيز قيلماق ايدى ياغى بير له ستيز ه قيلماقايدى فيلماق اليدي

تيز ايتيب ايل نى، تار تتيم اوزنى

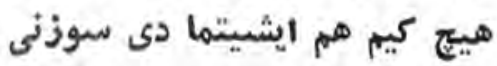
يوق ايدى جيبه و كيجيمويراق

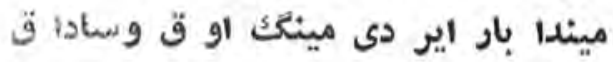
توردوم ايرسه تمام ايل توددى

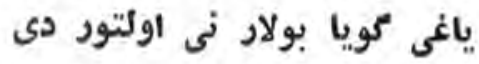

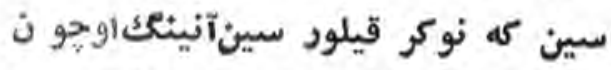

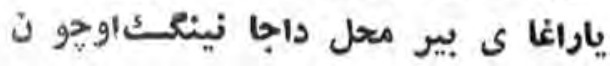
يوق كه نوكر تودو ب بيعى يودو مأى

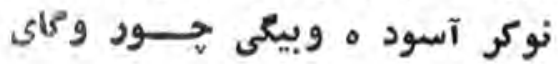
- rIT_ 


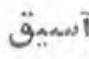

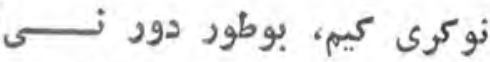

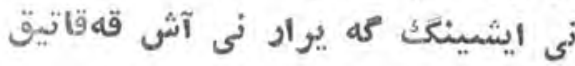

آخر آت سالديم ايلغار ى يودودوم

سمودو بان تاغقه يوقار ى يودودوم يوريم

مينى كوروب يورو دى ايلدداغیى قالدى ايلدين كيين كه قورقاغى

ايتيبا ن تيز تاغ قه تار ماثتوك

او قى كا با قما بين يـــو دو بآنشيتوك

ك.

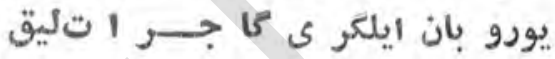

ياغى هم تاغدين اوق قو يارايدى

زور كور كاج ساليب يورو بيردي لئ

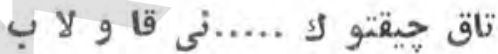

قيرو قولدا كييك كيبى آو لاب

داريغا ننى كييك ديك آتقـــــــلاديك نالابان مال و قو بيى نى بـــــادئ قير يبان ............. ايلادوك بثد كيشى قارهسينى اير اتاغليق نى دستكير ايتتوك إك اهل و اولادينى اسير ايتتوك 


\section{رساله و الديه تو جمهلى}

حقتعا لى غه ديين حمد وسياس كنهى غه ييتما س آنينك ونه وهموقياس خالقوقاهر و سبحا ن وعظيم

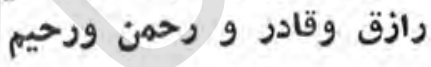
اولى دور كه بدايت انغايوق

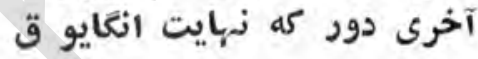

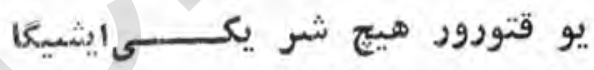
اوخشا هاس هيجنيمه كا هيسـع كيشيكا احتياجى كيشيكا يو قتور آنينك يارو ياور ايشى كايو قتــــــو رآنبنكت كينك آرتمايدور هم بو كما يدور كم يلم

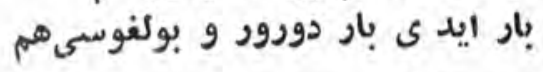
تيل انينك حمديلدا قاصر دو دوبيل بيل بيل آنينك حمديدا قا صر دو وتيل

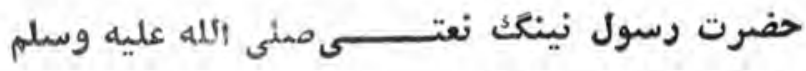

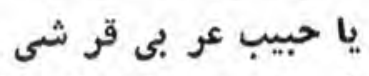

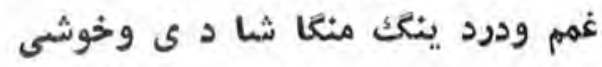
-ris 


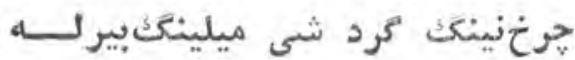
بارى خلق اولد ى طفيلينكَ بيركله انبيا خيلى غه سرور سينسين جملة خلق قه رهبر سين سين مين بسى كا هل ويول اسر ويراق عمر كوي قيسقه ويول اوزو ناوزاق مين كمراه قه كورسا ت بيريول مينى هقصود قه ييتكود كـــاىاول قويمه بابرنى بوحر مان بيركه هاره قيل درديغه درما ن بير له بله رساله نظمى نينكك سببى

حضرت خوا جه عبيد الله دين ايشميت اول سر خدا آكه دين خواجه لار خواجه سى اول خواجهعبيد خادم وحاكر ى شبلى و جنيد حالت ومرتبه سى ظاهر دور وصف وتمو يفى داتيل قاصردور آتاسى قيلفا ن اوجو ن تكليفى قيلدى آنينك آتى غه تاليفى طالب ايل تيليكا مذكور دورور والديه بيله مشسيور دورور هر سوز انداكه انكا مين ييتسا م

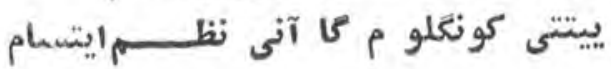


تاكه بولغاى منغا هشيار ليغى

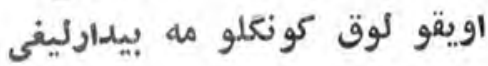
ينهبو نظم اوقو سه هر طالب

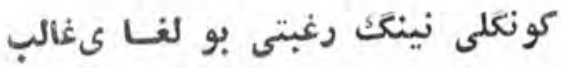
رغبت ايلاب انعا فيضى ييتسه لئكي تيره ليك ،كونكلى دين آنينكــك كيتسه فيضى دين منكا ييتيشكا ى اثرى

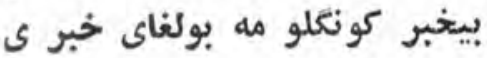
ينه اوقو غو حيى لارغه اول آن

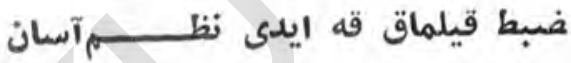
بو ديكان لار منكا بو لدى تقريب

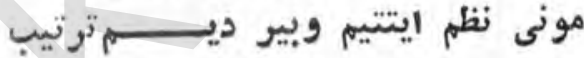
باقما غيل سوزلا كو حيى نينكسك واوزيكا اوزينى قوى ، نظر ايتكَيلسوزيكا سوز مينينك اير ماس الارنينغكدوربيل

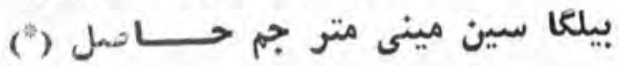

$$
\text { رساله شرو عى }
$$

$$
\text { خواجهُ محرم اسرار الكه }
$$
ديدى اول مونى كيم قا لالله وما خلقت الجن والانســـ 1 لاليعبدون ظاهر و با طنينكك اعما ليغه بيل بو عباد ت متنا ول دور قيل

" د يوان هند : مينى بيلكيل مترجم حاصل - RT. 
بيل بو صوفيه نينكَك اقوا لىدود

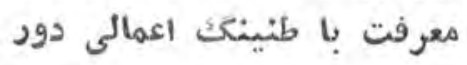
هتق دور بارى تحقيق ايلى

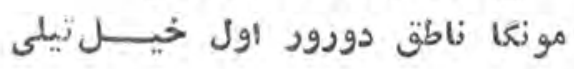
معرفت بى تبعيت بو لماس

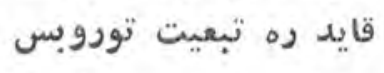
بيلنبى غه تبعيت قيلماق قايسمى ايشملار داكيرا كي، سوزومهباق فيلمات

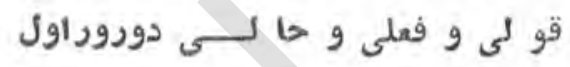

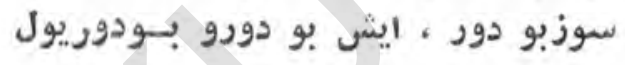
قولى تيلكا متعلق بيلكَيل فملى ظاهر غه تعلق دوربيل بولدى باطن غه تعلقحالى

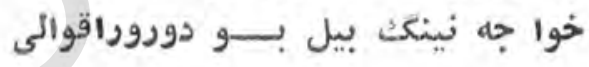
بيل كه قوليدا نى دور بييروليق ديمه هر سوز كه " ايرود نا لايق دور بيق بولسه كر شرع خلافى هرقول ديما تيل آنى و قيلغيل لاحول غيبت ويالغا ن و موذى سوزدين احتراز ايت يواق ايتكيل اوزدين هريما ن قول نى اوز دين دورايت تيلينكا بير نيمه نى مذكور ايت اؤ دين دورايت

$$
\begin{aligned}
& \text { * ديوان هند:قايسى سبوز دوركه } \\
& \text {-ITI- }
\end{aligned}
$$




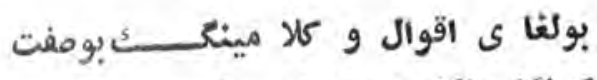

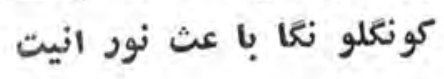

مثلرآن و احاديث ودعا

امر معروف كه بويور دي خدا نهى قيل هرنى كه منكربو لسها

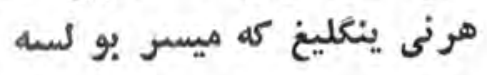
بيل كه او قود دا دعا وقرآن جدو جهد ايلا تاسين كيم اولئ دآن هرنى كونعلو نكدا ايسه آندين بيل

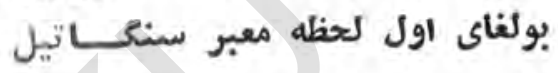

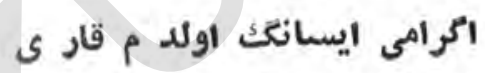
بيلكا سين مونى كلام بارى المي

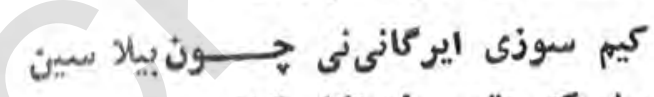
بيل كه حقبير له تكلم قيلاسين تبعيت نى دور ور فعل دا، بيل

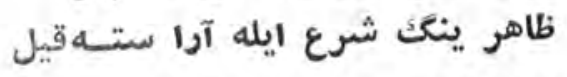
ترك قيلمه اد بو سنت لار

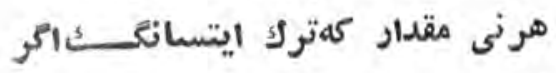
آنحه نقصان سنعا بو لغاى واقع

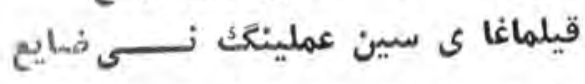

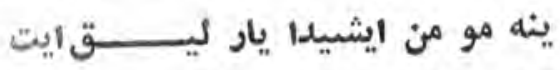

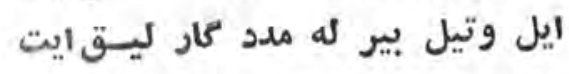
خاصه اول كيشيكابير مالك يار ى كهتوجه انغابار حقسار ى -rrt_ 
نيعا كيم بو كيشى لارنى قادر

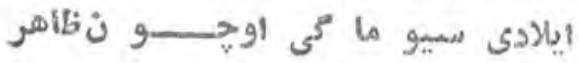

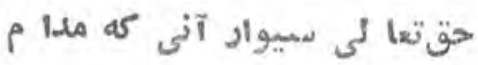

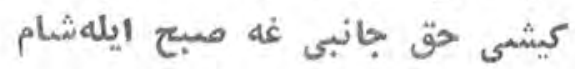

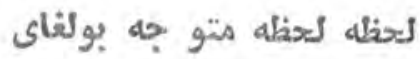
زهى اول كيم متنبه بو كناى

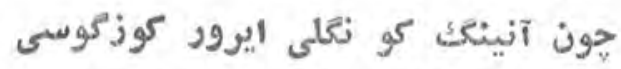
بو لماسه كوز كو نى سود اوتروسى آنى بشريت جهتى دين نظرى تول

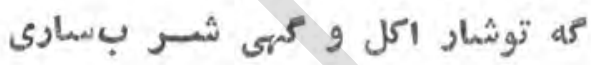
نظرآنجه كه بوسار ى دور بيل

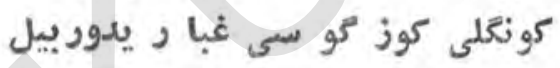
كونغلى دابو لسهه نى مقدارغبار حق شمهود يدين اوشانجه بويراد

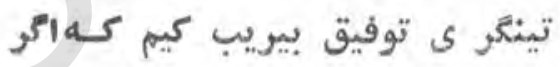
ايش لارين قيلسه كفا يت يكسر توفي

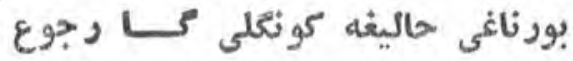

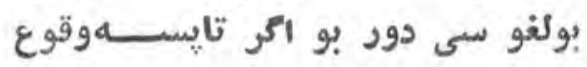

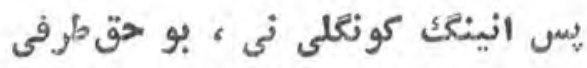

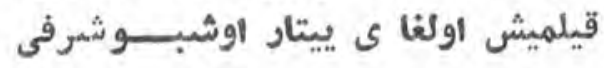

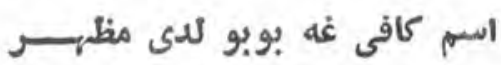
بودورور شرط كه او ل شعــــــايلار نيكاكيم شكر ى بولور مو ندا دليل

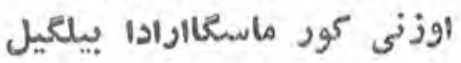
-trte 
متخلق ايسه دير خلق الهى غه بيغمبر بير

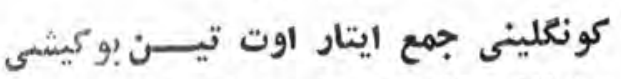

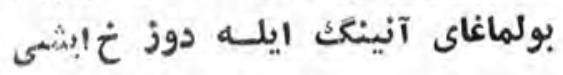
حالى ييرو ليفينى كونكلو نعـآل باطنيغه متعلق ايدى حال

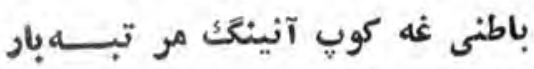
مثلونفس و دل وسر غيربونلار هربير يدا انعا حق جل جلال نسبتى بير له عطا قيلدى مما لـ لهال هر نى ايثته تبعيت قيلسه كيراك اول ايش نى متابع بيلسه تيعيت تبعيت انعا بو لماس حاصل بيلما كو نجه كه نى ايشس تهدور بيل بلماصل معنو 5 مر تبه سينى به كمال

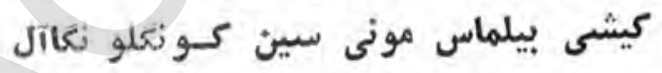
ظاهريغه تبعيت نى قدر بئمان هركيشى قيلسه بو دور انتـــاثمر فئر بو كمالاتى دين اول اول مقدار بهره وربو لغو سى بيلعيل أى ديار تبعيت نى دورور نفسيغه بيل نفس حظى دا خلا فين تو تقيل هر نى كيم شر ع خالا في دودوراول

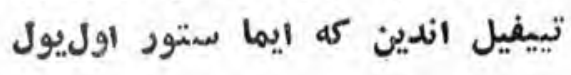
-TrE- 


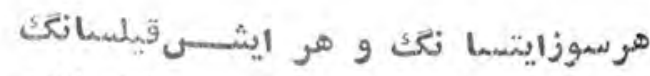

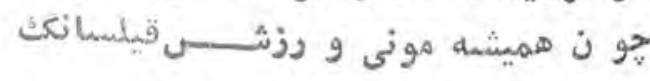

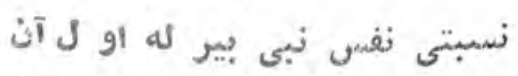

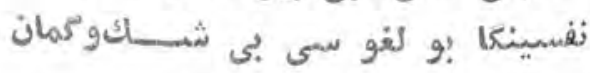
صمفت نفسيدين او شبو فرصت جذب اينار نفس بقدر نسبيت ازنَا اوخشهار كه فتيلهتوتونى جذب ايتار او ت نى كودوبشيسين مؤمونى

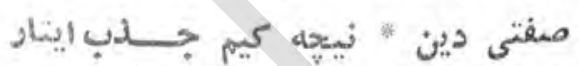

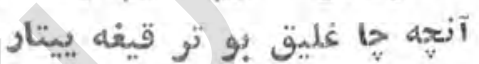

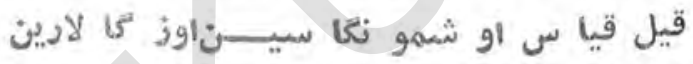

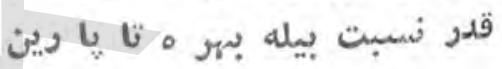

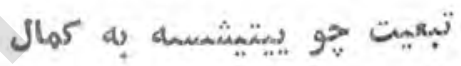
دوست تو تقا ى انى "حى متعال اوزينى متحر م اسمرار ايتغا ى

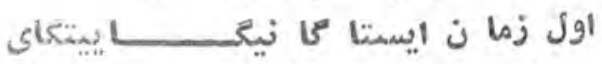

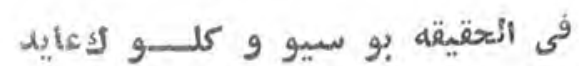
اول حبيبى غه دورور اي عابد

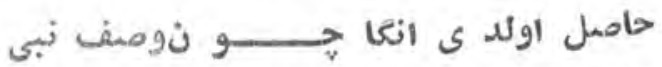

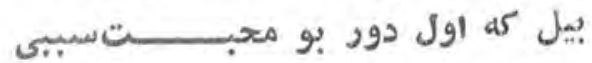
بيل كه بار دور بو ديكا نلا دبارى ه:حض فضل و كرم جبار ى

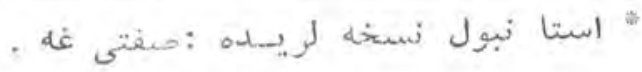
-rTO 
بلكه هر دتبه دايخشى با ققيل اوزيدين اوز كانى سيو ها يدوربيل

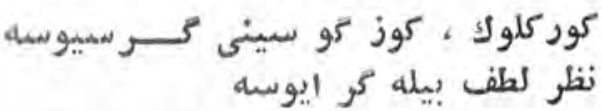
بيلكا سين كيم إو تيمود حبتسى إيماس

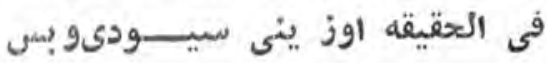

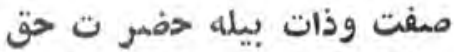
قيلدى كوز كو داتجلى اندا ق

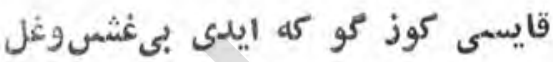

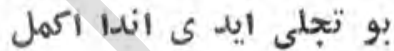

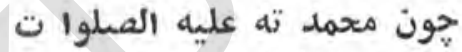
روشن و اكمل ايدى بو مر آت تله

باريدين اندا تجلى ايدى كو بـ

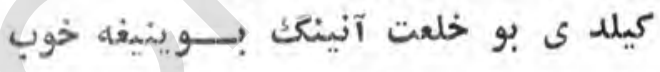

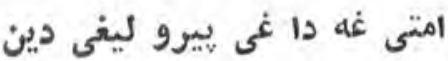
ييتكو سى بهر ه بار يد ين ين اول حين

رتبهُ غه مونى بيلفيل بى شك لك

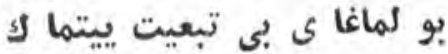

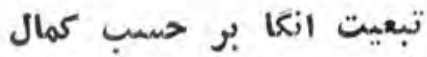
قايدا دور ، مين سنغا آيتــاى ياد آل تمال

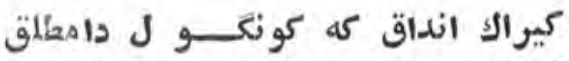
قالماغا ى " هيج تعلق جز حت حت

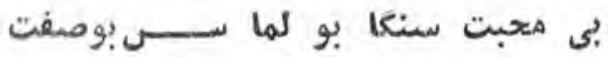

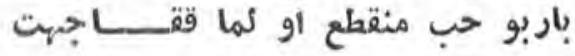
" استانبول نسخه سيله:تقالمادى 


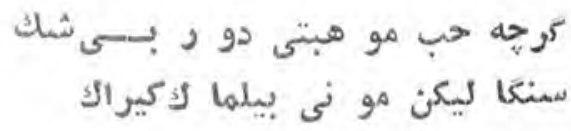
بار ظهود يغه شرايط حاصمل

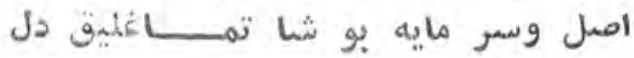
بار طريقى مونكا ميثن آيتـــائى بيل اول اول يار نينكَ آثنينى ديكيل كيم نينكَ آتى ايكا نين انديششه

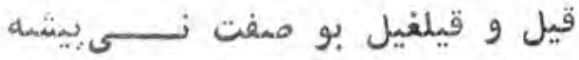
ولمه هر كلظه بو ايشس تيــن غافل بولور آسان بارا بارا مشكل لونل بولفاى اول نوع آثينى ديو يدا.

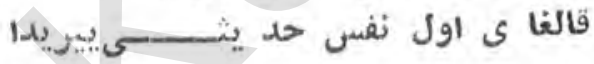

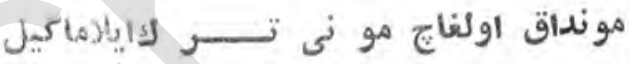

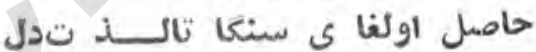
ناكونكو ل دين بار ى لــــــا توهوس

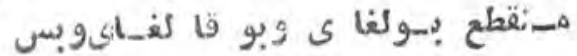

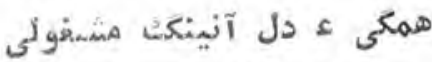
بو محل بولغا ى و اول مقبوكى بولور انداق كه تكلف بيله د J هيتج نيمه حبى غه بو لماسمايل قيلسمه بو هر تبه نى حق حاصل

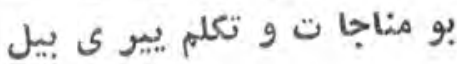

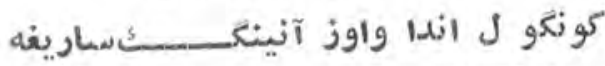
سموز آنينكك بير له، كوز آنينك ساريغه 
انغا بو رتبه دا بـ غيبت بيل

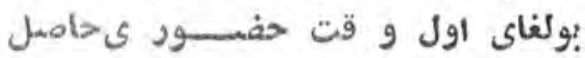

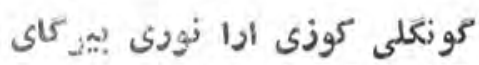
كوز و كونكلى كا سمرود نى بير كأى

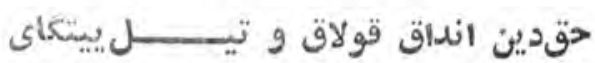

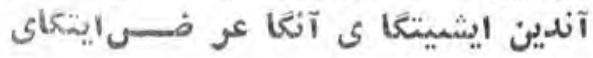

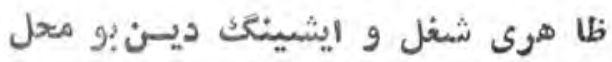
تايما غا ى معنو ى ايشّ سنغاخلل ظاهوى خلق قه با طن حق قه بالغ ساكلك آنا اندا ق قنه آشنا ايج سار لى، تاش بيعانه بوروش هاجه دوش اوكلما سيانه دنيى دا هركيشى كاك تينكريكأدل اوشبو ينكليغ متعلق ايسه بيل

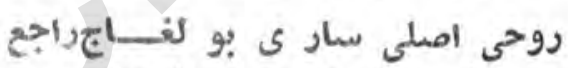

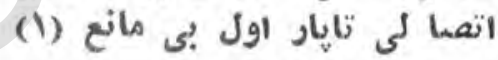

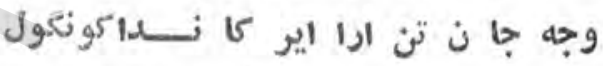

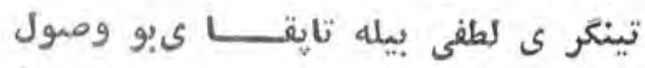

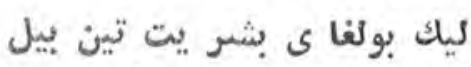

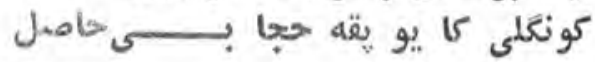

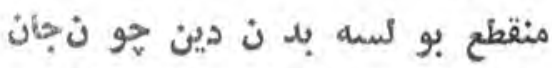
بريت حجبى قالما س او ل د آن

* : استا نبول نسخه سيده: كيم كلدنياده انكا .

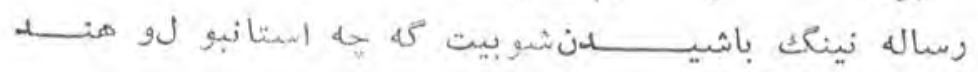
نسته لريد ن نياله نينك آلينكن 


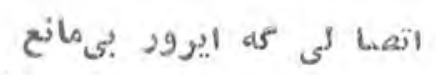

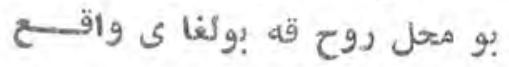
مثلا بير كيثمينى بير

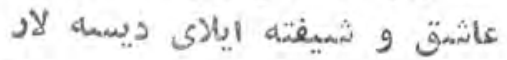
بويو سمونلو ق دى طر يقينسي إيشميت

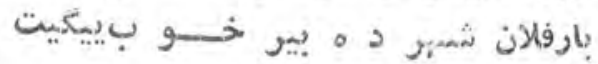

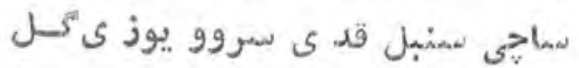

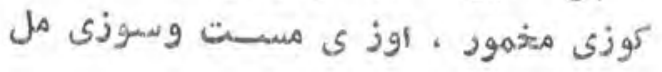

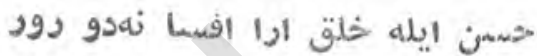

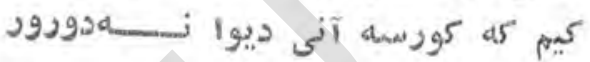

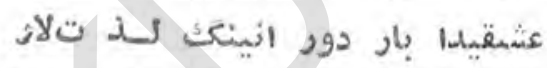

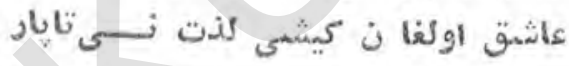

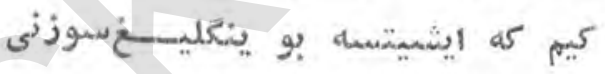

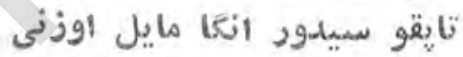

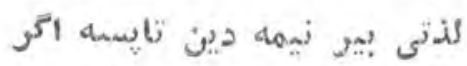

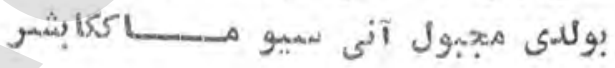

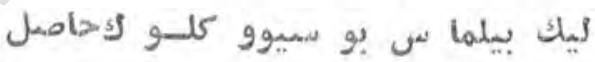

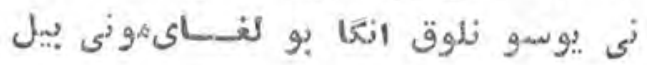
بيل كه بو أيشته طريقه بـ بـــودود

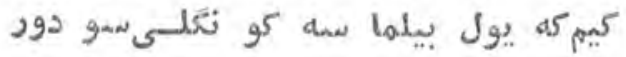

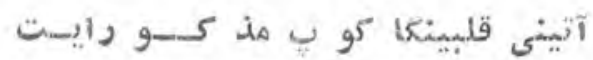

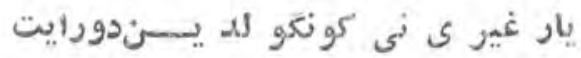

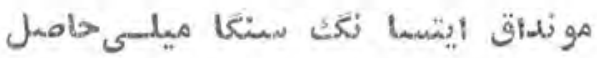

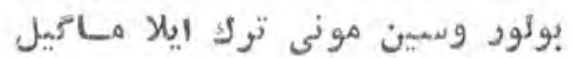
-rra 


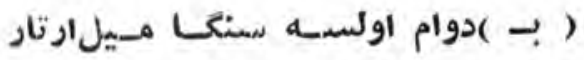

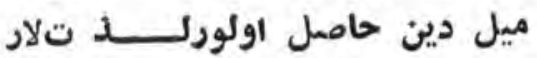

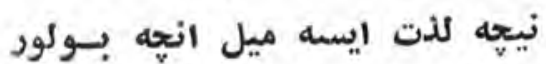
هيل لذات نى تا يقانجهبولود قويما ى ايلدين مونى قيلسانكت تكرار اختيار ى سنغا قا لماس اي يار خواه وناخواه تو تار سين آنىدوست بو كثشس بير له بو كو ششرقانى بردوست

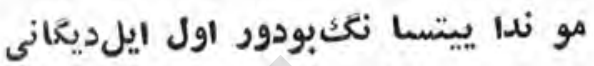

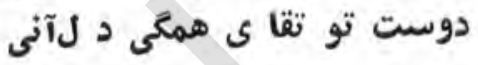
قالماس انديشة غير ى اولدم اونو تولغا ى سنغا محبو ب آتى هم النم

ايلتور ود اوشبو محل استيلا

سنغا سلطا ن محبت ،يارا ؛ (طر) فينى ايدى محبو بومتحب تبن

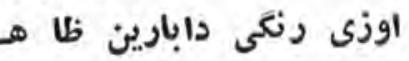
وحدت صرفنى ظا هر قيلغا ى لئ ايكى ليك آتى بود م آيو يلغاى سنغا معلوم حو بولدى بو بويول آنى مشغول لو غى اير ميشاول وردو اذكار ايحِيدا اي آكاه افضملى : لااله الاا لله موندا دصراع بو صورت بولدى لونى

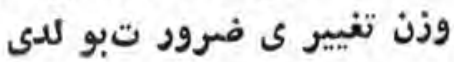


بيلكا سمين بو لدى مركب بو ذكر

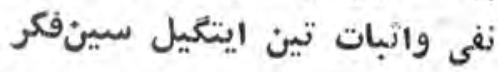

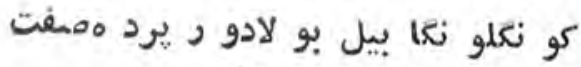

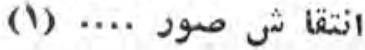
منتقش بو لسه كونكو ل مرآتى بولدى حق نفيى و غير اثباتى

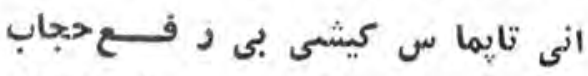

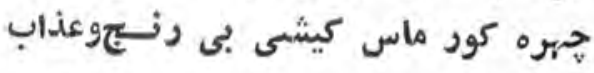

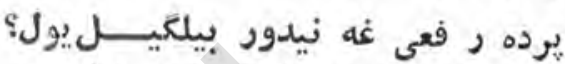
غير نفيى و حق اثباتى دور اول نيل بار دور انداق كه قيليب ميــنمعلوم ذكر مذكور تا اولدور مفهو م

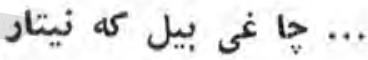
املى نى بارى دين كوته ايتار دم آخر كه جيقار سيندين بيل هرنفس نى دم آخر بيلكيل مال ونقد ينه وبار ى ايل وكون زن وفرزند بيله شسهر ومدن

خاطر ينكدين بارى سى محســـوبولورد خاطر اولد م بار يسيدينقو تولود هرنفس نى دم آخر بيليبان اندا بونوع تعقل قيليبان

ذكر مذكور كا بو لغيل مشغول

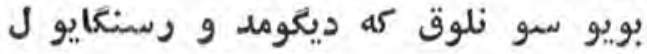

- الم قيلمه دى (1) 
نفى دا هرنى كه بار دود بـــر إنق

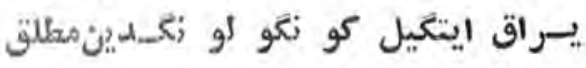
نفى دين سونكر اكه بــــا رالألله

مو ندا ييتكا ندا ايشَسيت بودو روراه بيل كه محبوب ايلا معبو د اولدور بارى ايل ساجد و ، مسبجــــو داولدور

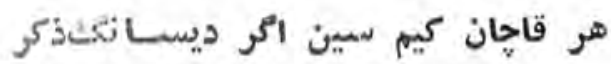

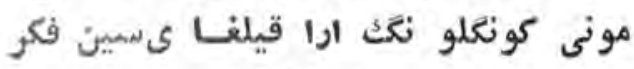

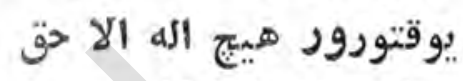

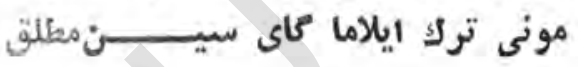

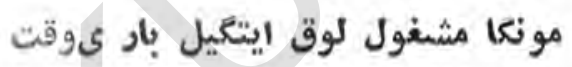

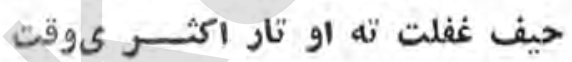
غافل اولغا ندا كيرا كل بو كسهـ بوسيق

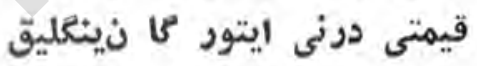
در ايتور كان كه بولور اندا نى حاله بو كيشى كاكيرا كو انداق احوال

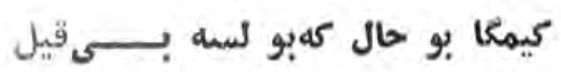
متاثر ليغى غه بولدى دليل هر قاحان مونى ملها م ايتكـا ى سمين

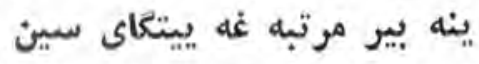
ترك قيلسانعك سين اكر، ليـكاكمين نكول

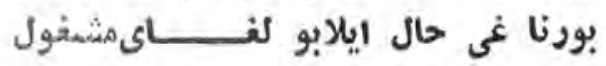
تمين بو حا غليق بيله بس قيلما غاسبين

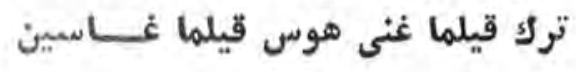
- rrt 
انعا ييتار كه بولور اي طالب ؛

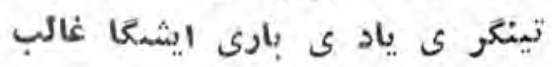

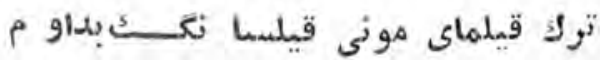
همكى دلينكَّ اول وقت تمام تمام حقتعالى بيله مشغو لاولغاي

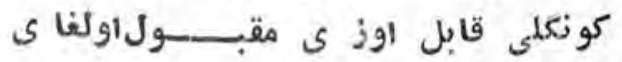
بوبولور اندا كه حب مولا

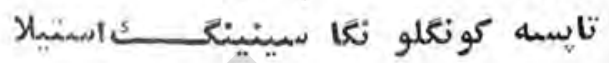
غير دين كونكلو نك اويينخالى ايتار

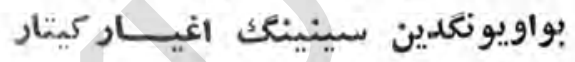
كونكلو نعا هيج تعلق قالماس

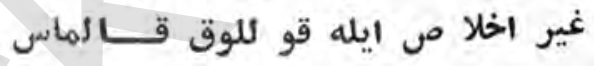
(بو)زمان بو لغو سى حقبير لهدوست

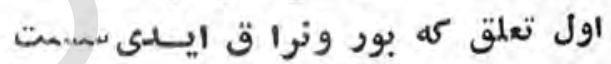

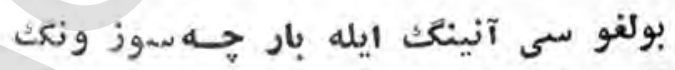
آنى سا غينغو سى نى كور سه كوزونكي آنى

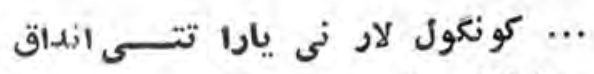
بو لماغاى غير تعلق مطلق لارو في غير دين منقطع اولغا ج بو كـو نكول تينكر ى بير له متعلق بو لـو اولفا جو داول

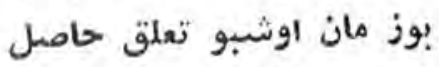

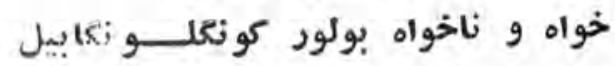

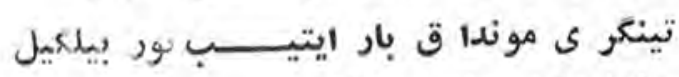

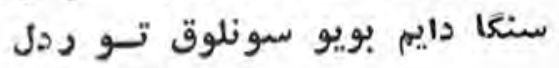
- rrre 
متكلم دور و ايشميتكو جيى دور

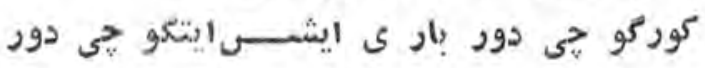

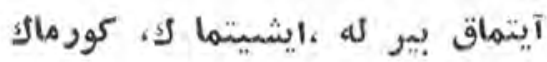

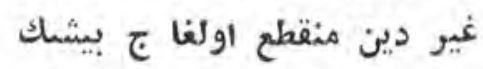
ديوو ايشميتور و كو دار حاصل

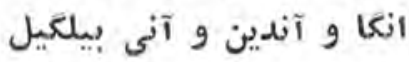
بيل كه بو مر تبه دالاو ل هنغام بار مناجا ت ته حق بير لله مدام بيل كه بو مر تبه دا اي سايل

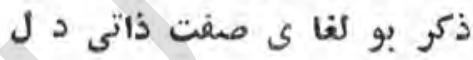
بيلكا سين ذكر حقيقى او ل حين يبل مثز ه انى حرف و اونى ديفي اودين

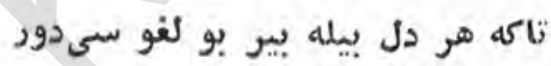

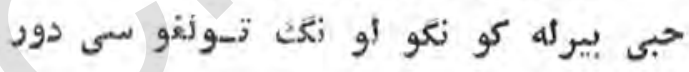
همكىء دل دآنى دوست بر تار

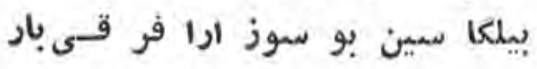

دوست تو تما غليق ايله اي دانا

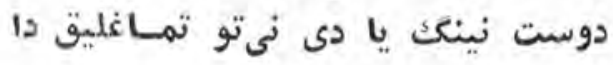
اول كه توتقاى همكىء دل دوست هنتج فرط محبت بيل دوست فمكي دول دول سيين قولاق توت كه مونكا عشقدور آت

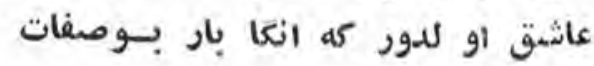
هوندين اول يير كا تر قىقيلوداول

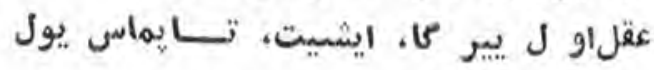
- Trs 


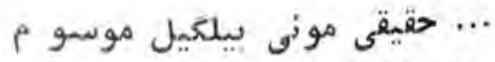

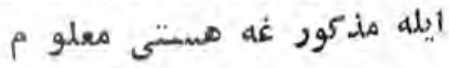
بيل كث بار هستى ذاكرمو هوم

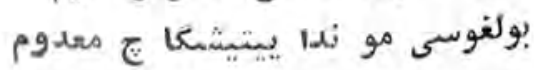

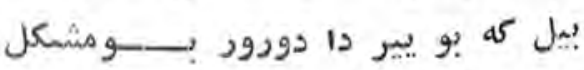
حين مذكور بو لورذاكر تيل

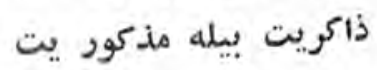

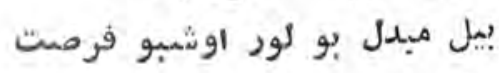

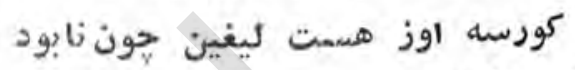

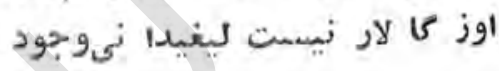

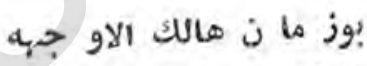

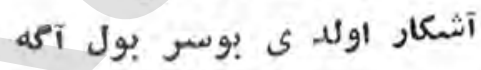

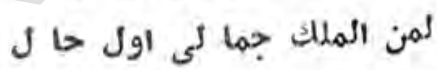

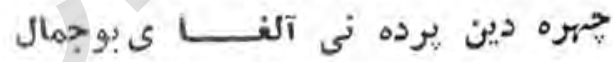
بولدى دعلو م كه تبعيت تين

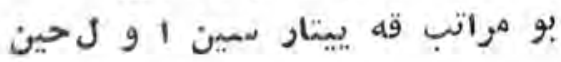

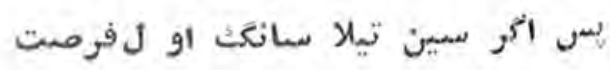

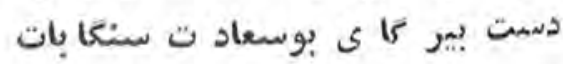

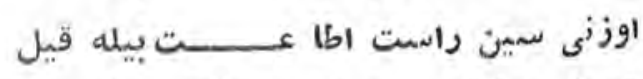

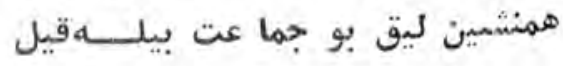

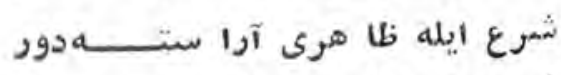
غير دين باطنى يير استه دور آنها ! و كيشى صا حب حالات اولغاى

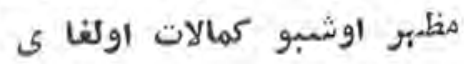
-rro_ 


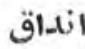

تينكر ى كونگو لنى يارا تت

بو صفت نى انكا قا تتى انداق

همنيشن هر كيم ايله بو لسسه كونكول

صعبتيدين متاثر بو لور اول

اوشبولار مو ندا كه مر قــــو مدورور

ذوق ايلى بار حه غه غله معلــــــومدورور

كيم كه ماتم زده بير له تورسه

يانشاط اهلى بيله أولتور سه

غمو شمادى انغا قيلغا ى تاثير

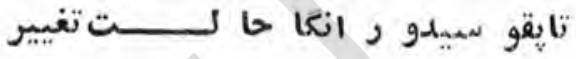

قابليت .و كما لات ايله حق

يارا تيب تور كو نكو لو نكسـ المونداق

بو قبو ل اولماسه ايرد ى 1 و ل حال ممكن اير ماس ايدى بو كسبب كماز كيم كم بو طا يفه بيركله بئوالم همنشسين ليق قيـلود اول او لهنهام بيلعا سين كيم متاثر او ل حين

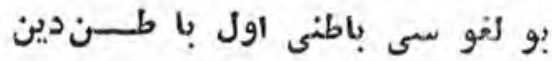

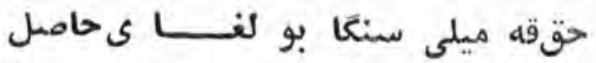
همل حه منقطع اولغاى سنتًا دل انقطاعينك حهينه ميل ارتار ميل حه منقطع او لما غليق بار نيسه اول كو بِينه بيرى داغسى كوب

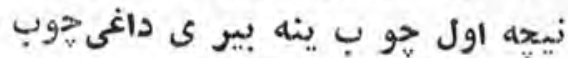




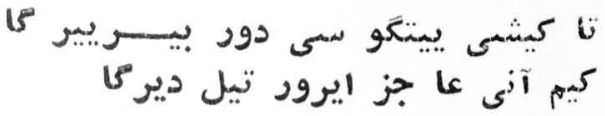

$$
\begin{aligned}
& \text { بو دور ور حال مونغا ييتغاندا } \\
& \text { قالما غا دو هيج تعلق اندا مور }
\end{aligned}
$$$$
\text { بارى اوز لو كى بيله بــــــ دورايشمى }
$$$$
\text { حققه بولغا لى متو جه به بو بيشى }
$$

كيثّى بولغا ى انغا بير صححتهته

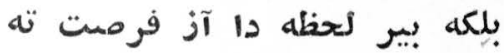

بارى دين منقطع اولغا ى باطن

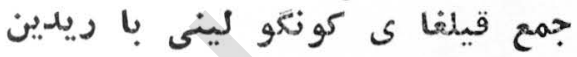

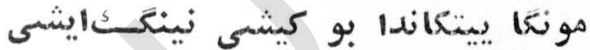

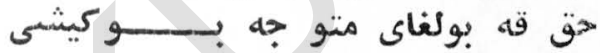

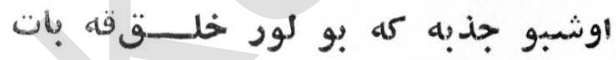

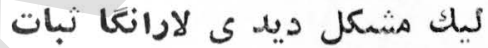

نيكا كيم حضست حق لطفى دين

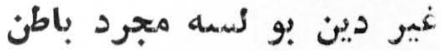

بولغو مدى دور انغا حقبير لسهوهمول.

تينكر ى انسيا ندا بارا يتنى بـوقوقيول

آد مي كونعلى تعلق سيز ايماس

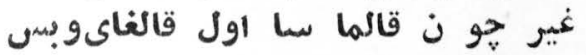

زيك هر كيشمى كا كيم الستعداد كر ضعيف اولسيه مونى توتسمونياد

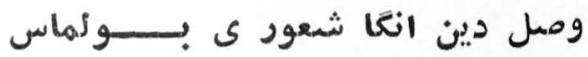

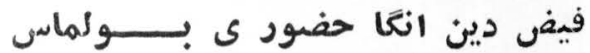

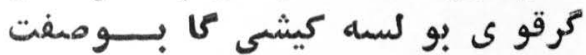

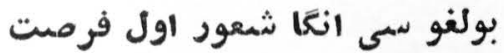

- THV 
كرثبات ايستار ايسما نكك 1 و ل لفرصت

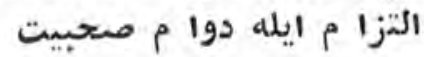

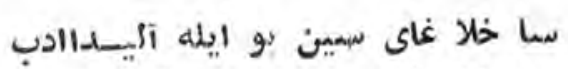

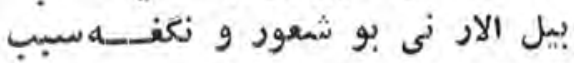

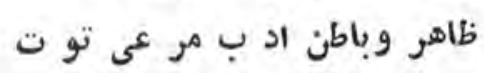

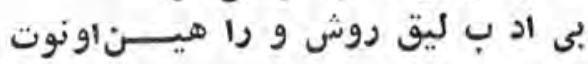

$$
\text { بير اد ب نى كيثىى كر تســر لكقيلور }
$$
اوشبو ايل كو نعليدين او ل توشيثي تمكو سميدور

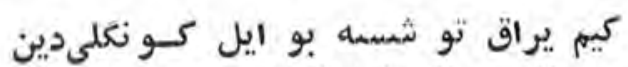
بور ناغى حال انغا قالماس او لـ لين

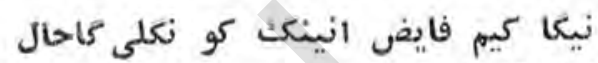
اول كونكو ل لاردين ايدى كونكول لبحال

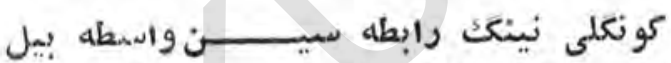

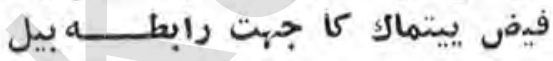

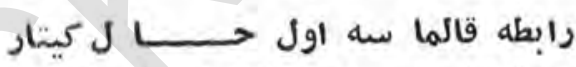

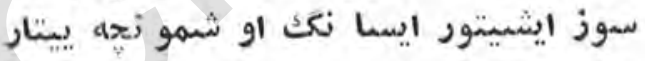
?ى عنايا ت حقو خاص حق

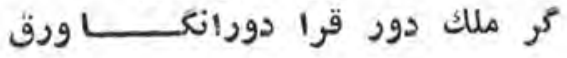

رساله خاتمه سيى

لله الحمد سوز آيتيلدى تمام

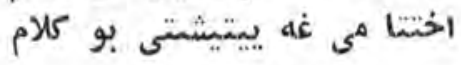

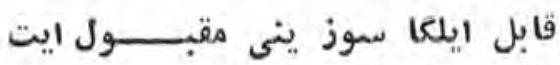

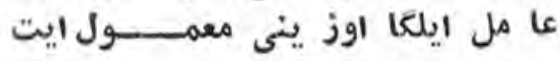
ييل تو كا تكاندا بوميوز بى كم وبيشي

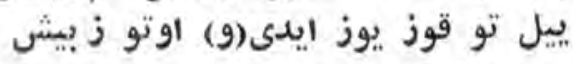




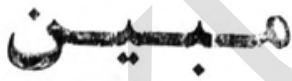

( d. Jus 


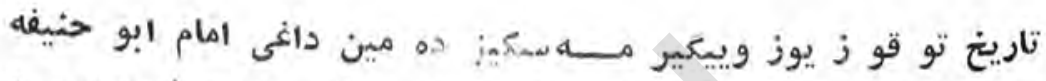

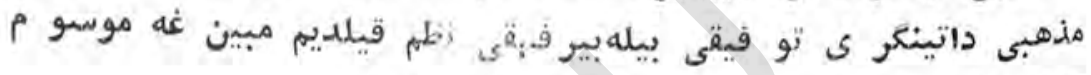

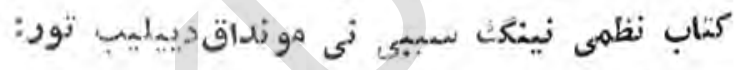

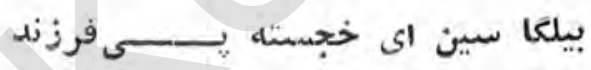
جكريم بير له جانيمه بيوند

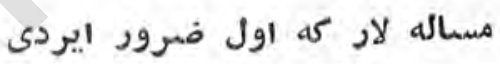

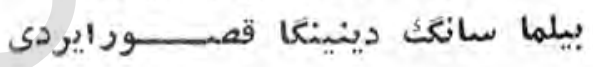

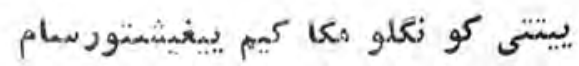

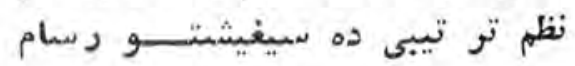

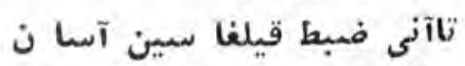
اول مسايل نى بيلكا سينيكسان

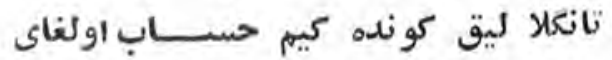

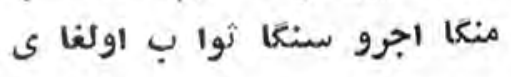

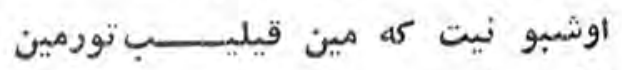
اول مسايل كه مين بيليب تو رمين فين فيليت

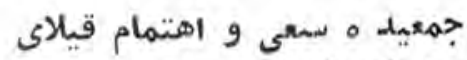

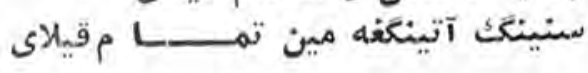
-rrq_ 
?ى بقا دنيا ايشى سهل دورور?

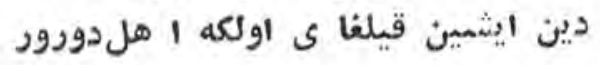

$$
\begin{aligned}
& \text { دين ودأنش ده هر كو ن افزو نبول } \\
& \text { دولت وبخت ايلا هما يون بود دون }
\end{aligned}
$$

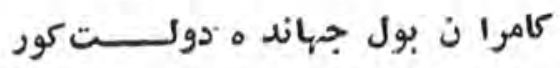

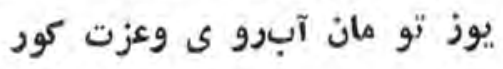

حون بو مختصر سفر ده بيا ضنغه باردى اول منا سبت بيت بيلهمسافر مسايلينى بيتيلدى :

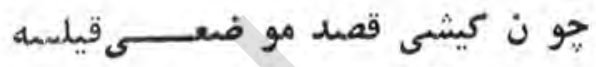

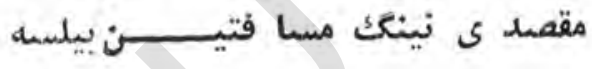

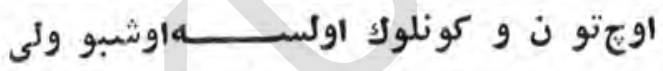
دير سفر مدتى شريعت ايلى بو مراحل ده ثرع مختارى

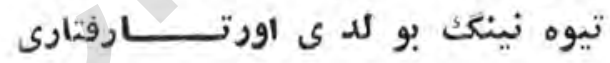

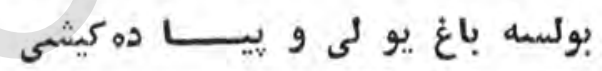

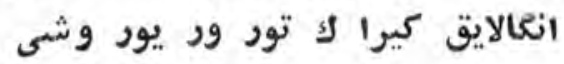

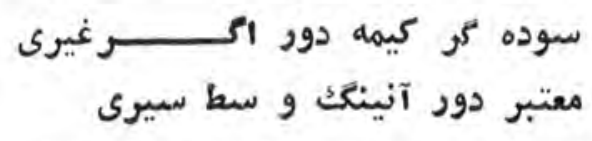
كريغاج بير له ايستا سانكــــمقياس دون اون سيكيز ييل كه ديدى شمرعشناس لئاس هريغاتج بيل كه باردورور اوجييل

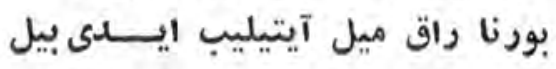
هيقسه كر نيت سفر ايتيبا ن وطنى نينك سواد يدين اوتســو بان 


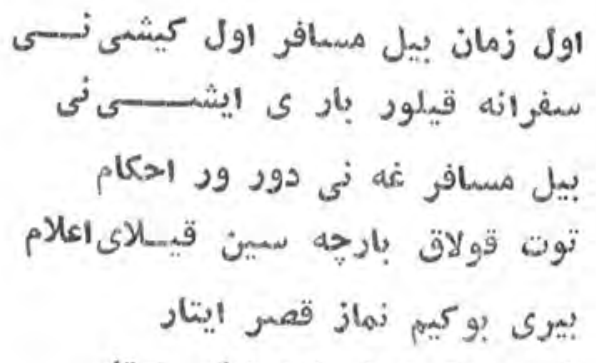
تورت ركمت فريضها ايكى اوتار لمار كر قضفا بو لسماه بو نماز يبنار اول قضط نى داغى همين اونار لـ سيك سنت لارينى دى ايى يار قيلور و قيلما سميخه سبين sختار بيلينكيز او شبهو سموز زيى ائعلما

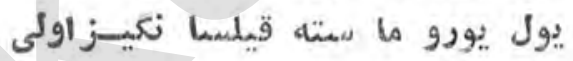

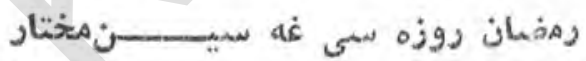
كرتوت ار تو تمه اختيار ينغـــار كيك اولى سمى دوز ه تو تمـا قتور

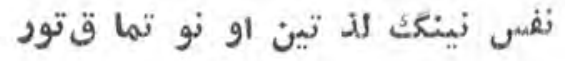
روزه يبكا ن كيشى قضا قيلسمون بير حابير دوز ه سين اداقيلسمون ينه بو كيم مسمافر ى كمهيلور اوتتو ن وكو ن اوتو كعا مسبسحقيلور

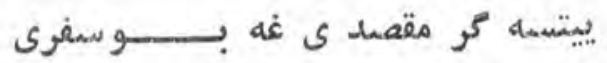
آتى ?و لد ى مقيم شمرع دير ى

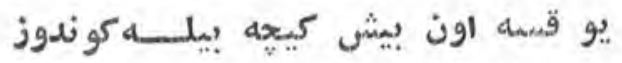
تور ماغين نيت ايتسشه ب-سو دورسوز $-r £ 1-$ 


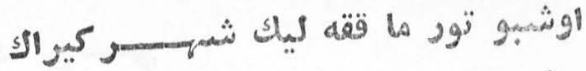

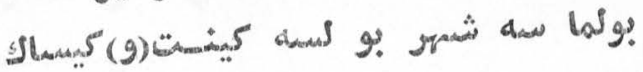

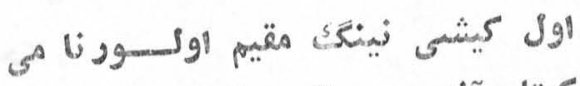

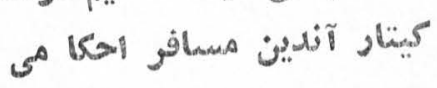
يأزيل ه نيت اقال مت ايله

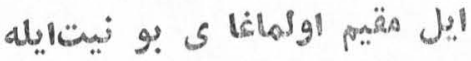

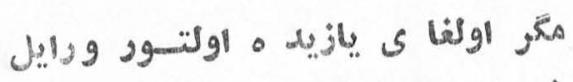

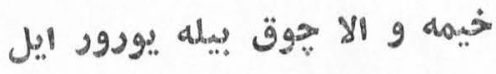

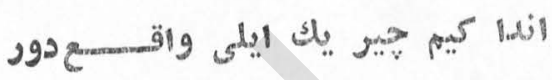

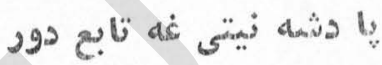
ك مام

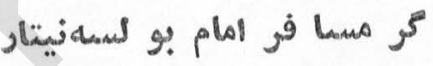

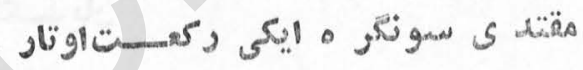
$\ddot{0}, 5$ j $\int 1 \operatorname{lom} 1.5$

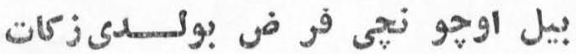

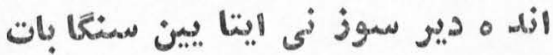

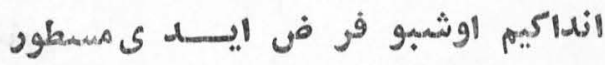

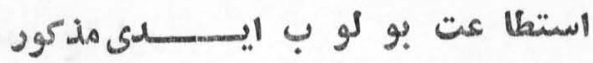

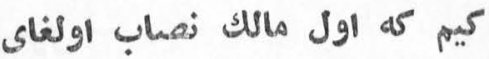

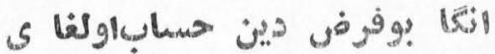

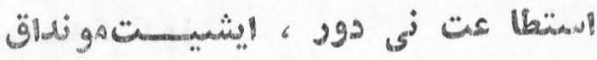
بار دور اول ماكلك نمساب اولماق -rEr- 


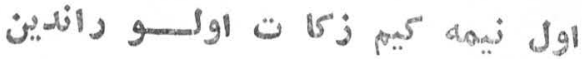

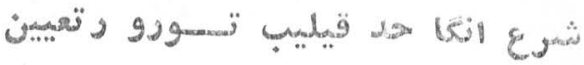

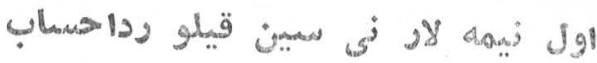

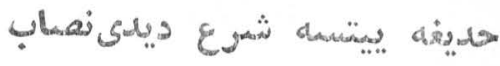

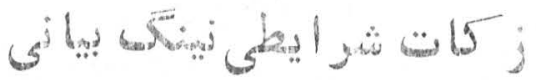

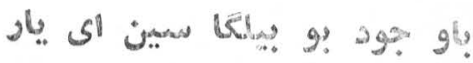

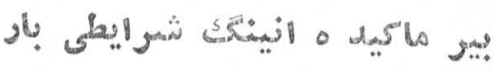

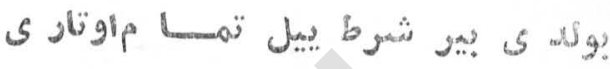

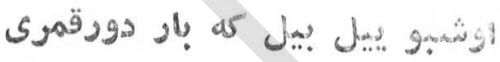

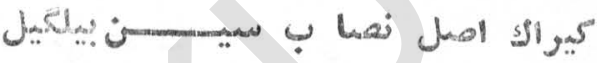

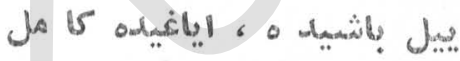

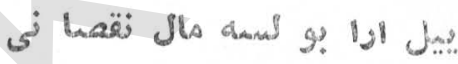

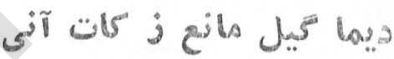

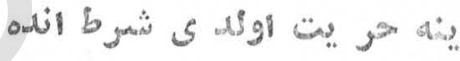

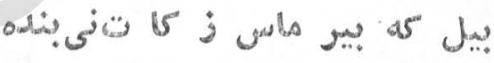

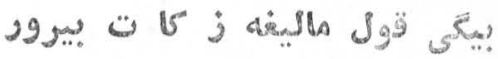

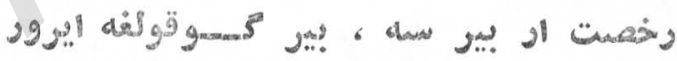

$$
\begin{aligned}
& \text { 管 }
\end{aligned}
$$

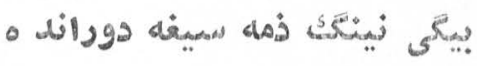


ينه بير شرط ملك تام دورور

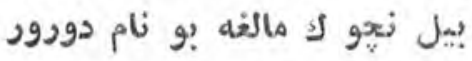

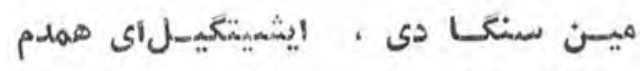

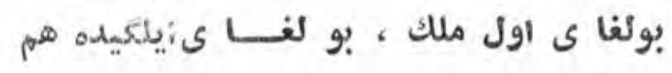

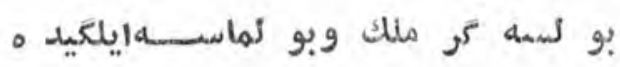

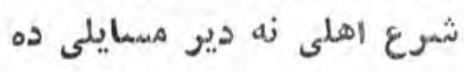
بو لسه ايلكيد ه كير ما مسى دشموار

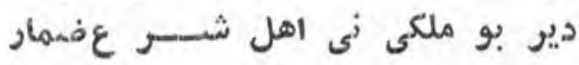
مثل ملكى كه بو لسمه يــــــو ق بولغان ياد فينه ايسه اونو تو لغا نو لنه يابيراو ذهه سى ده قرفمينككبار

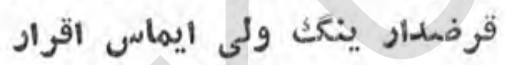
يوق كوا هينك كا كه آنى آلغـاى سين آنسين

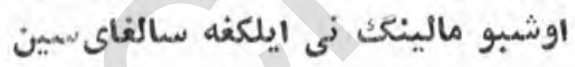
ينه مال و ديعت ومغعموبي

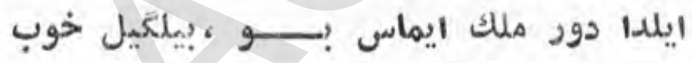
يوقتود ور 1 وثبو ايكى شيقدةزكات

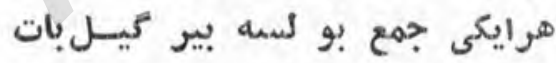

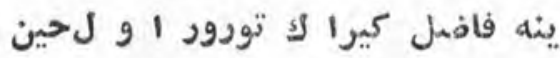
اوثبو مال احتيا ج الصليدين مثلا اول كو موش بيله آلتو ن

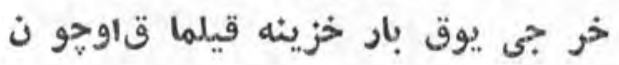
ينه اول قو ى واوى وتيــو هتودور

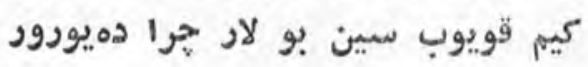
$-r \varepsilon \varepsilon-$ 


$$
\begin{aligned}
& \text { يمر اوجو ن ، قوش اوجو ن يوكاوجون ابملس }
\end{aligned}
$$

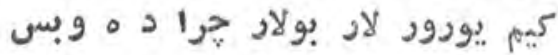

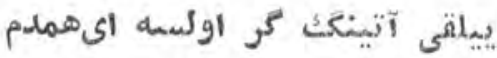

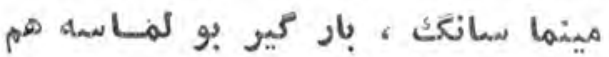

$$
\begin{aligned}
& \text { شرع ايلى اوشثبو لار نى "ســايمهادير }
\end{aligned}
$$

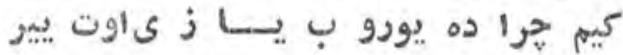

$$
\begin{aligned}
& \text { كريريم يبيلدين آر تو ق اوتسـلانسالار }
\end{aligned}
$$

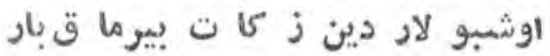

$$
\begin{aligned}
& \text { حاجتيثكدين بو لارنى فا ضسلـل بيل. }
\end{aligned}
$$

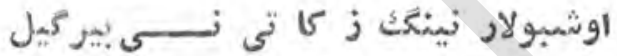

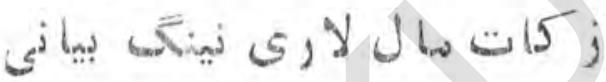

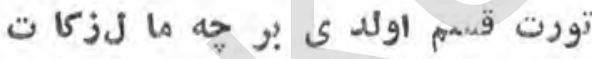

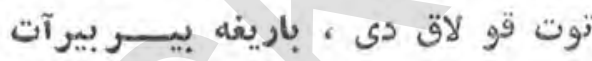

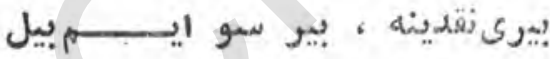

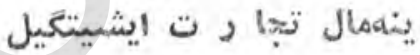

$$
\begin{aligned}
& \text { ينه يير دين هيقار ز كا تيسـن بير } \\
& \text { بيل كه شوع اهلى سموز بو لاردانى ديو }
\end{aligned}
$$

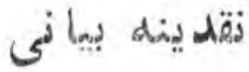

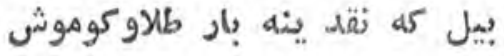
آيتاى آلار نصا بينى توت كوش لئ !و لسمه مثقال بير له آلتسـو ندين

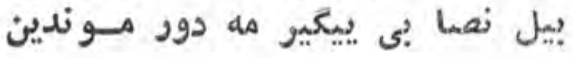

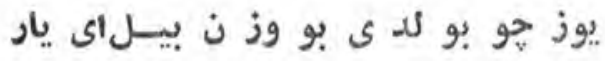
مونى آلتو ند ه دييد يلار دينار $-r \leqslant O_{-}$ 
بير زكاتين مونو نتك ير يــــمثمال

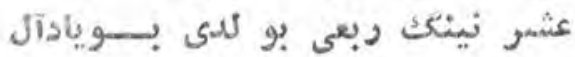

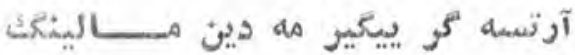
تورث بو لغو نهاه اوشبو دو دمالينكك سين كو موشى نينكك نصا بيسنين سعونى توز بيل درم بير له بار تستو زو دايكي يوز

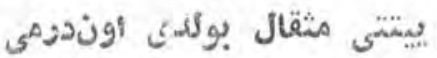

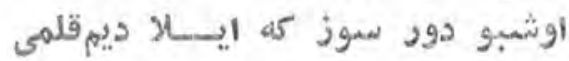
ربح كثبرين حسا ب اتر قيلسانكع

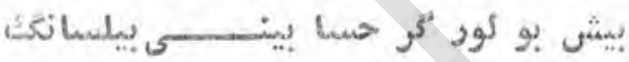

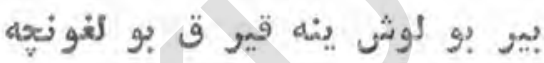

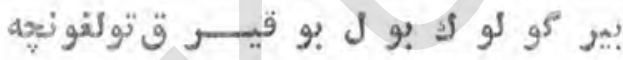
قيرق اكر بو لسهل دبع عثمريسنئ بير

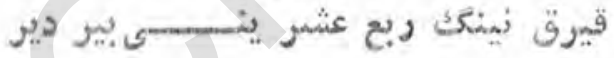
سمينشا آلتو ن ، كو موش حسابي دين

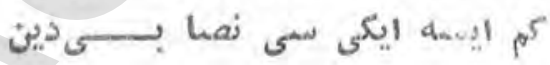
هرايكى قيمتين جمع قيليب

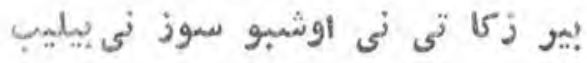

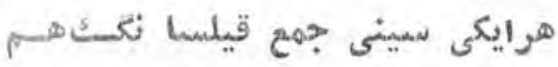

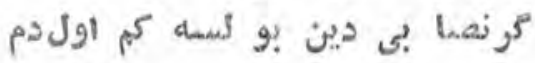

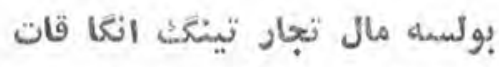

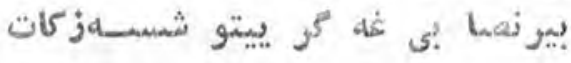

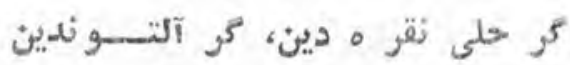

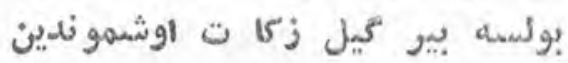




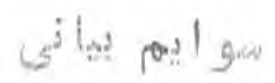

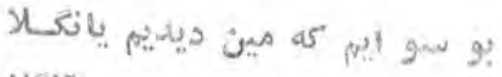

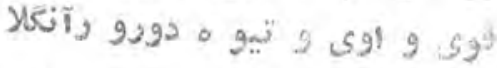

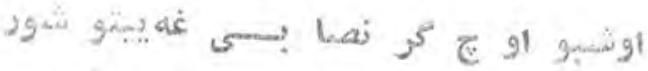

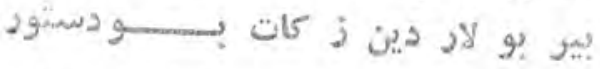

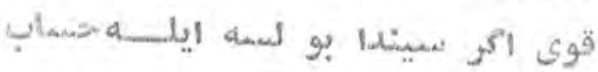

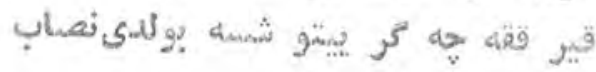

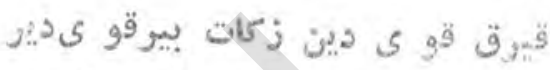

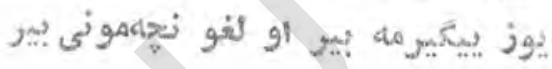

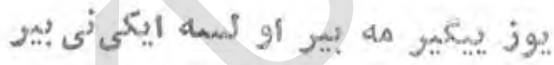
ايكى يوذ بير اولسيه او ع بير،دير تودت يوز بولغو هه بو دور بير يشينكي

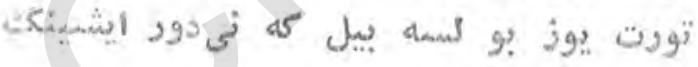

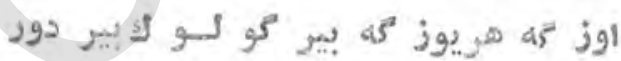

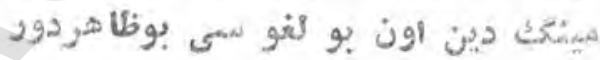

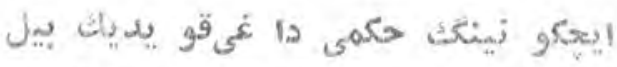
قويد يك آنيغكت ز كا تينى بير ميل

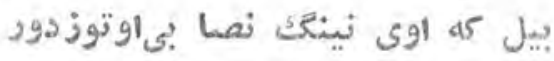

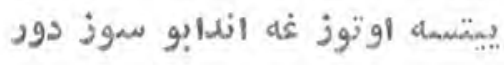
ير يا ثار او ي، مونينكئزكاتين ييل

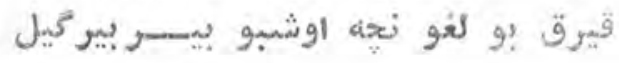

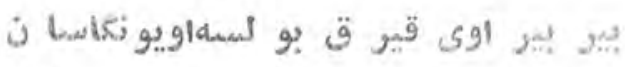

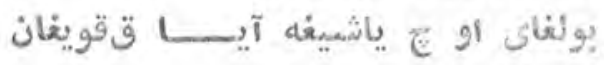
$-r \leqslant V_{-}$ 
آلتميش غه او يينكَك ييتو شسهنى دير

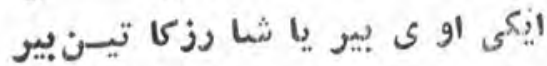
ينها هوقيرق بو لسيه ، يا اوتوز بيل كه اوثبو ديخا ن كيبىدورو سموز

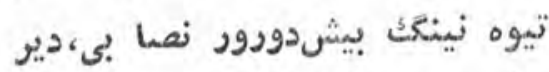

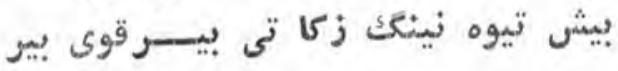
اون دين ايكى و اوج دور او نبيشدين تورت نى بير ييكير مه دين اول دور اونين

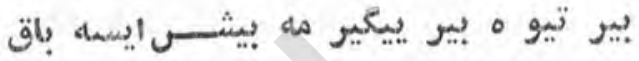

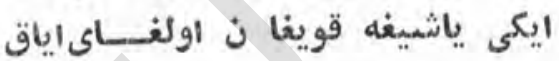

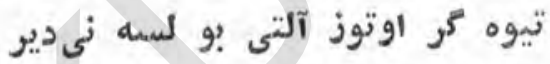
بير تيوه اوج ياشيكه كير كا ن، بير الني

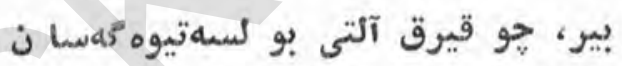
بير تيوه تورت كه آياق قويغان آلتميث بير دابير تيو ه بيـــــركيل

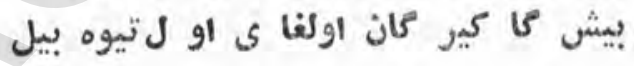
ييتميش آلتى دا ايكى بير ،انداق

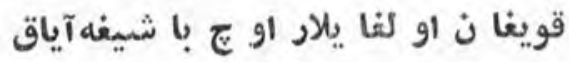
ينه توقسا ن بير اولسه تيوهكه سان ايكي بيو، تور ت ياشيغه كيسـركان بو تيو ه لار كيرا كل كه بو لسه تيشى

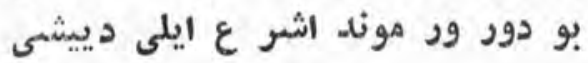

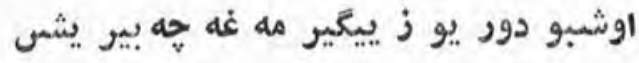
ينه اندين كيين ، نى دور ايش دون $-r \sum \Lambda_{-}$ 
باثسله با ثمتين حسا ب سمو نككموندين

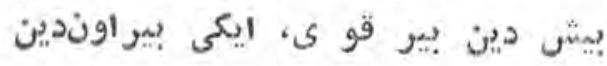

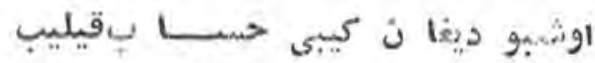

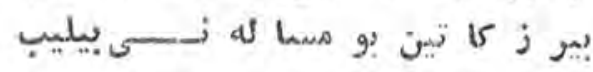

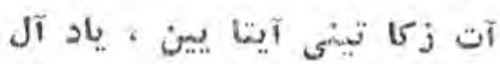

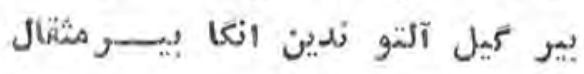
يوق ايسه آت لار ينكنى قيهـت آنيل قيرق دين بير زكا تى نى ييـــر كيل

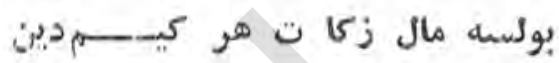

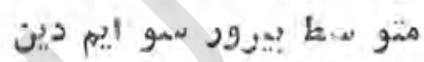

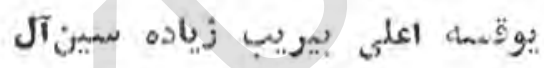

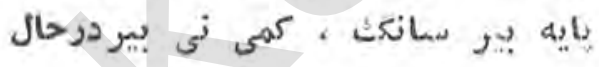
قيمتي نى جيرا ث ديسا نكئهم بير شمرع دوند م سمنى متخير دير

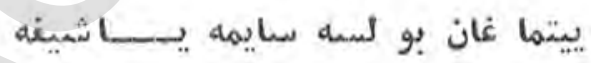

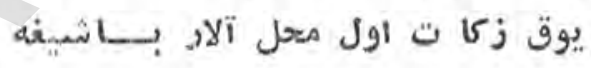
كربولار بير كله بار اولوغ او لدمب سانا ماققه كيرا لك كيجيك لارد الهم

بير ايسمه قير ق دا اولوغ ثثلا

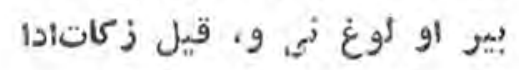

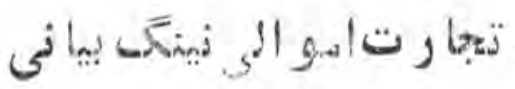

$$
\begin{aligned}
& \text { باراو جو نجّ تجار ت اموا لى }
\end{aligned}
$$

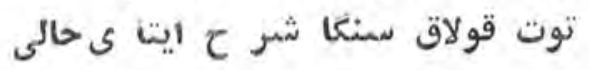


هرنى اندين غرض تجار ت دور جو هر وخوا ه رخت و خواهر آتدور

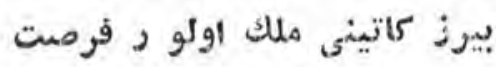

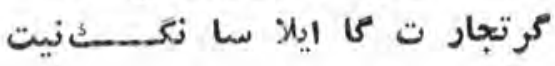

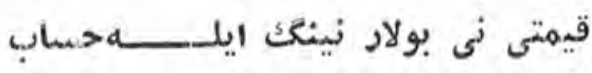

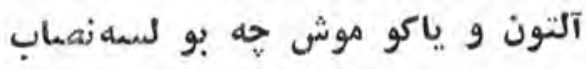
بير كيل آلتو ن ، كو مو ثونس هوحسابى بيله

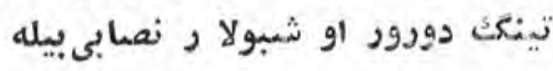
كو موش ، آلتون دا وز ن آيت جواب

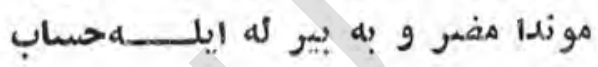

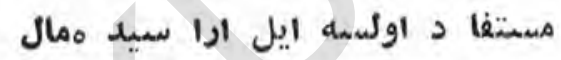

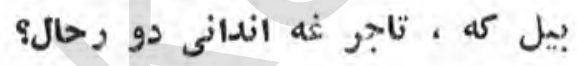

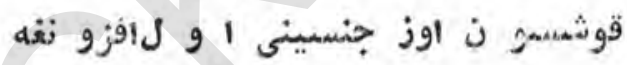
تيوه "s، تيوه ، آلتون آلتونغه

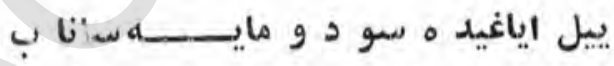

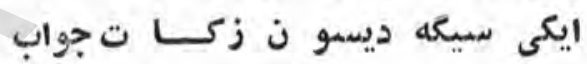
'مود اوجو ن سمايمه كر آلدينكك،بيل

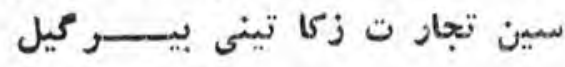

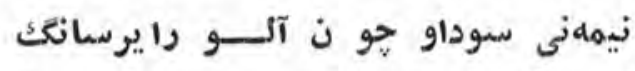

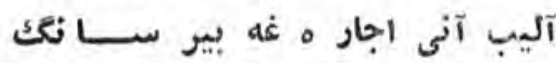

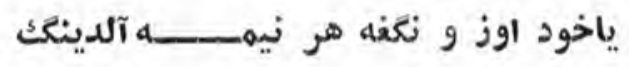

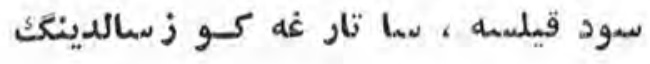

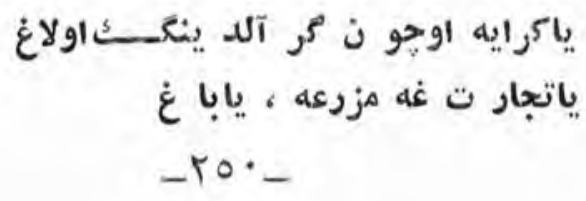




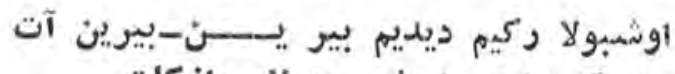

بيل كه واجب ايماس بو لار داز داز

اوتيكا ن اولمسه زكات ما ليغــهـيـل

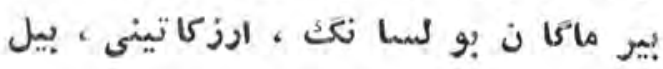

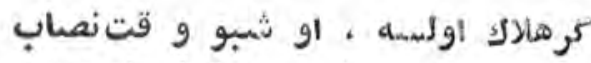

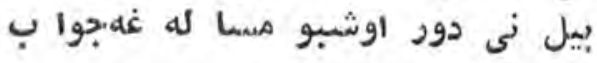

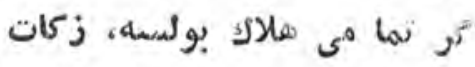
مماقط اوئغا ى تمام اولى لماوقات بحفثى اندين اكر هالاكلبو كور

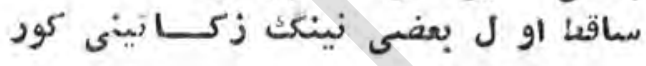
كافر ذهى بو لسمه كر تاجر

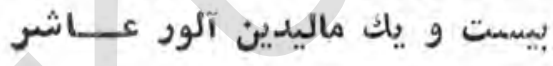
كافر حر بـى اولسه كر تجار

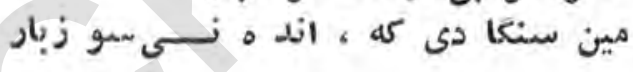
هر نيمه تاجر مسيلمان دين

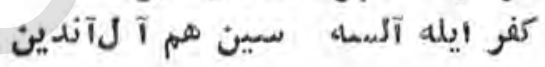

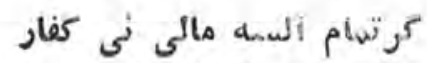

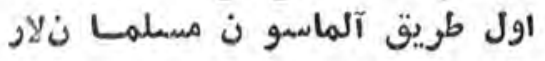

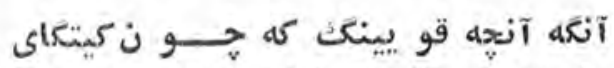

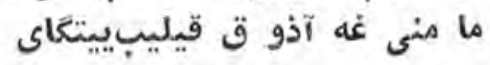
كر آلار آلغا نى ايماس ظاهر

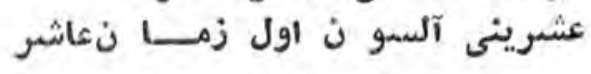

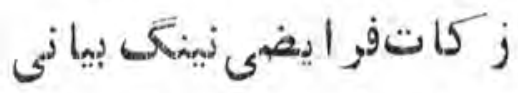

بيل ، اداسيدا بو لد ى نيسـتفرض

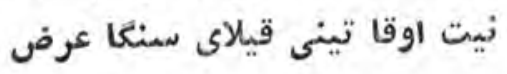
-rol- 
بيرى مالينى آيير ور حا غدور

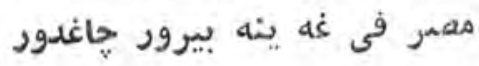

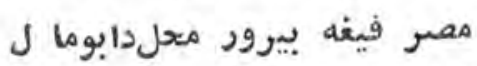

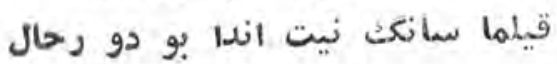

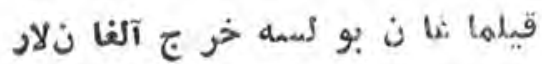

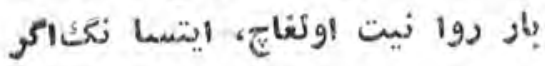

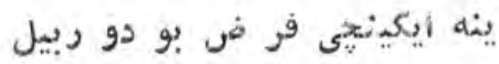

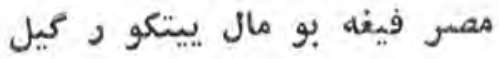
ز همسرفين تينكر ى ديب دورو رسكيز بارينى آيتا يين ايشيتيكا يسهــز

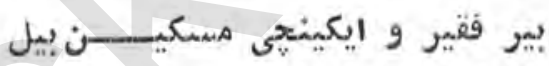
ينه اوحو نجي بار دور ور عامل

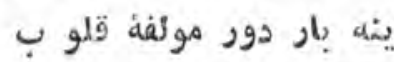

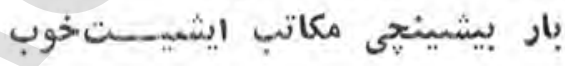
بيل · بار آلتينجى قر ض ليهق م:حتاج

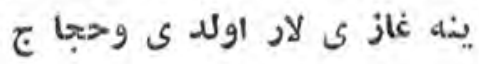

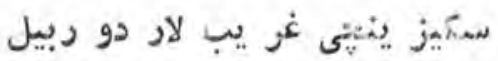

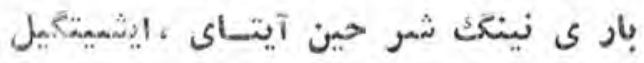
دير فقير آنى شر ع ايلى، يا دآل

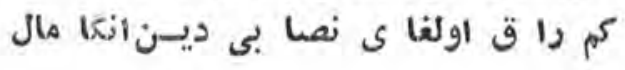
كسب قيلما ققه قادر اولغـــا ىهم خر جدين ليك دخلى .و لغنايكم -ror_ 


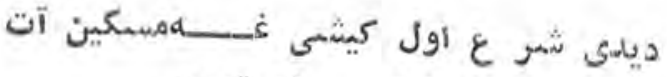

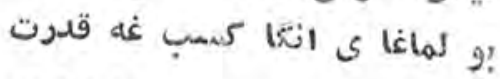

$$
\begin{aligned}
& \text { بو لماغا ى انكا جنس دنيا ليك }
\end{aligned}
$$

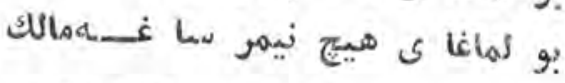

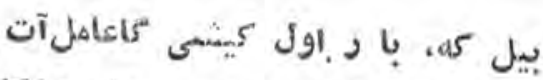

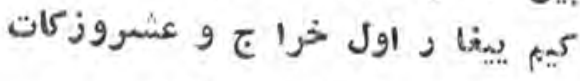

$$
\begin{aligned}
& \text { ?وزما ن جو ن موكفه يو قتور }
\end{aligned}
$$

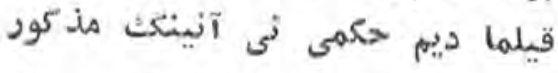

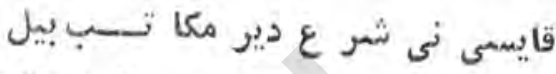

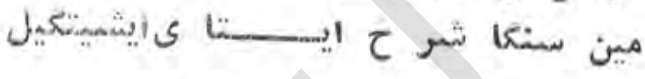

$$
\begin{aligned}
& \text { كر قرار ايتسه خوا جه و بنل } \\
& \text { بير بربا مد ت معين ده } \\
& \text { كر ادا ايلاسمه بو ملد }
\end{aligned}
$$

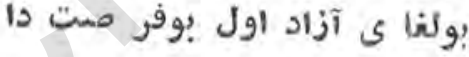

$$
\begin{aligned}
& \text { اوثشبو لاردين بير بسمى بِار مديون }
\end{aligned}
$$

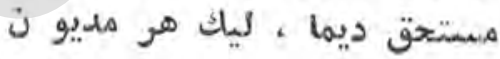

$$
\begin{aligned}
& \text { قرض دين آر ثو غين حســ بايتغيل }
\end{aligned}
$$

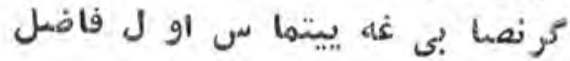

$$
\begin{aligned}
& \text { بو مهغت قر ض كيق كه ديا-ي-مرآت }
\end{aligned}
$$

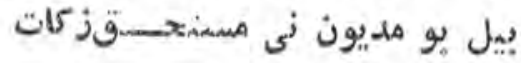

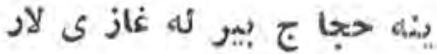

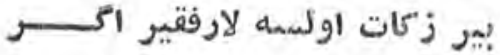

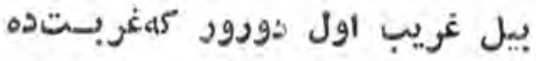

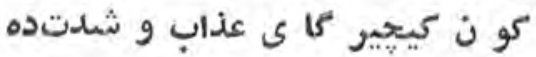

$$
\begin{aligned}
& \text {-ror- }
\end{aligned}
$$




$$
\begin{aligned}
& \text { وطنيدا نيجه كه بو لسمه غنى }
\end{aligned}
$$

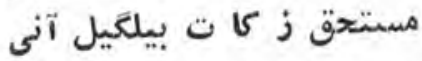

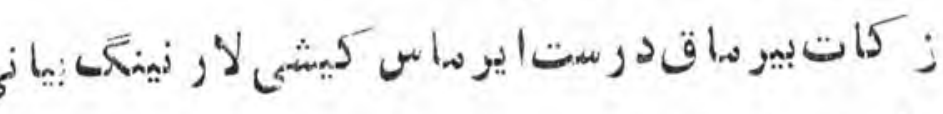

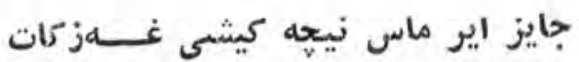

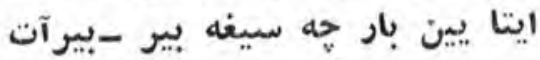

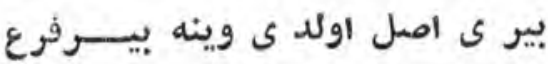

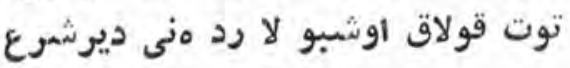

شرع ديو الصلى نى آتا و آنا

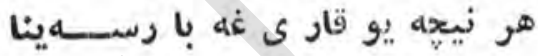

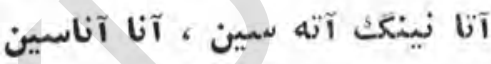

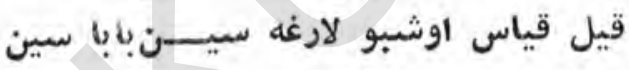
كر نسب بارسه نيخها يو قاريغه جايز اير ماس زكات آلارباريغه

قايسى دور شر ع ايجّر ه فر عديرينكَك اوغو ل و قيز دورور نبيره لا دينك لتك

بونسب بارسه قوييغه هر حند جايز اير ماس تورود جـو با رفرزند اير كا خاتو ن و ايرى خاتـــونغه بير ماسو ن بو انغاو اول موننه

كيم كله بير "كا ى زكاتحقبوليغه بيرسه جايز ايما ستور 1 وزقوليغه هاشهمى و غنى وبنده لارى

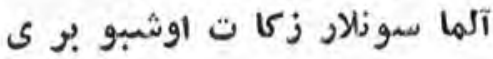
$-r 0 \leqslant-$ 
كفر ايليكا ز كا ت ايماسجايز

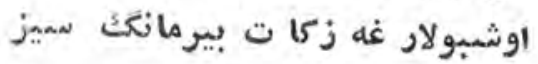

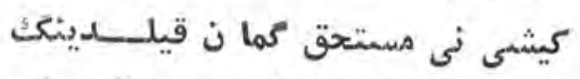

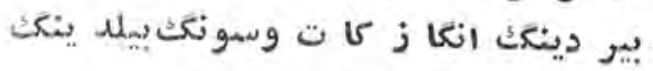
همبرف اير ماس ايكا ندور او لآلفان

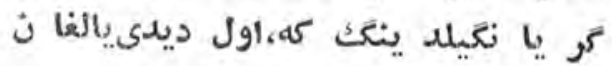
كربو آلغا ن قو لينك ايماستورخوب

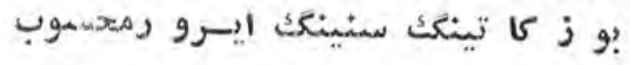

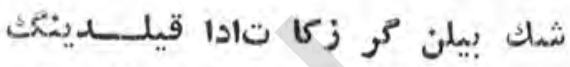

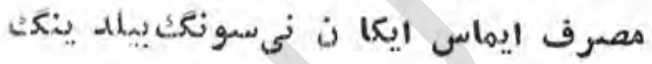

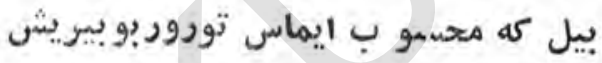
منكا اوشبو محل اعا ده دو رايش ليش قيلمه بيركا ن نى ليك استـــرداد مساله اوشبو بو لدى نى، تو تغيلياد

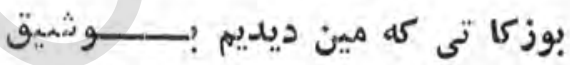
شرط دور غير ملك قيلماق ليق دئ دوريم

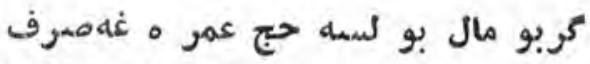
ايل سو ايجما ققه يا خود آلسانكن ظرف

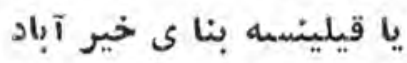

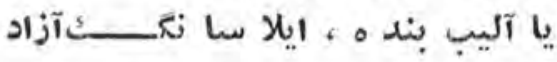
قابل ملك ايماس بو لار ، سيسنبيل

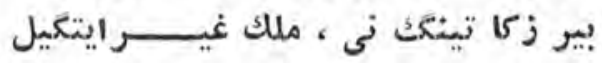

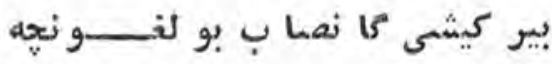

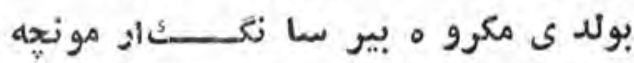
-roo_ 


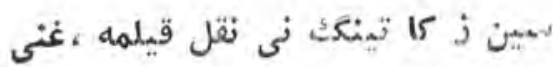

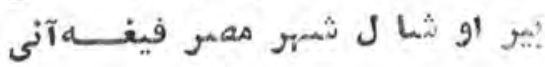

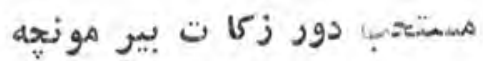

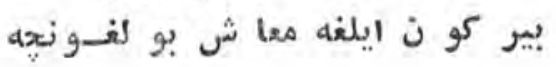

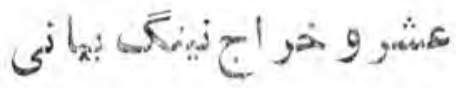

ايمد ى يير دين حيقا ر زكا تين ايشميت

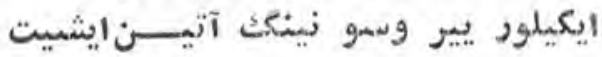
يبرو سمو دين ايكين دوا'بى دور. هربير ى عثمر ى و خرا جى دور ييبر وسو هر ايكى سي عشّسرى ايسه

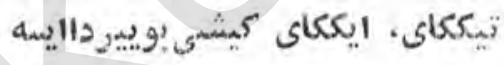
دخل اوجون هر نى كيم ايكيلكوسميدور

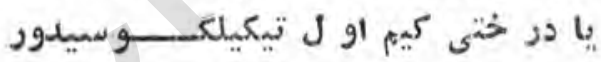
هشلا: ميوة تر و كل ودانه هر نى بو كسمه بو لار كيبى يانه تورثمو نو نخواه تور ما سيـــون ثمره

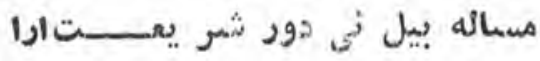
يإييغاج بير كله قيلمسا نكك او تنى نقوروق

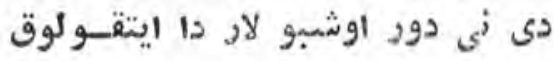
بير بو لار نينك ز كا تى نى نى دهيك

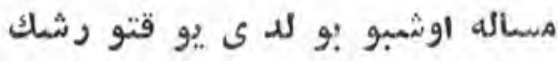
عسمل وميو ه تاغدين آلسها نكك، بيل

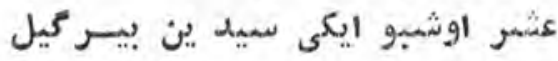
- 107 _ 


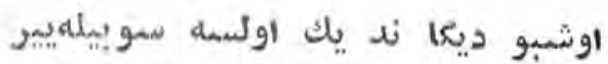

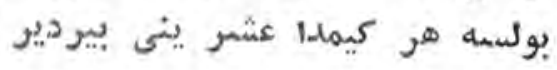

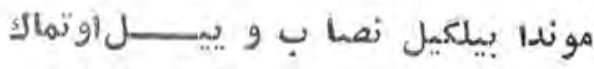

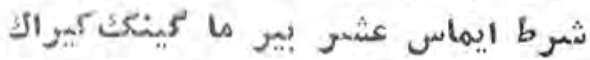
قوروق ايرمان قميش و او تويتنا ج بيلكا ستين يو قتو دور بو لار داخراج هر نى دو لاب ايله ايخحار سو نى نى زمفف ده ياك جوا ب بير مو ني

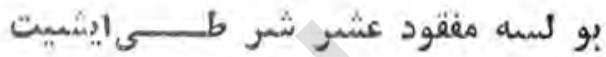
اول حاغ اول يير نى سيبئخراجيى ايتي

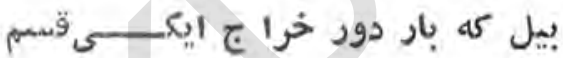

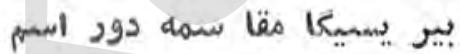

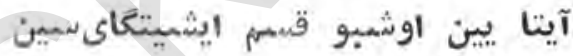
هر قجا ن كيم محين ايتغاي سين إين مال ايكيند ور بو نو ع كيمدييلور

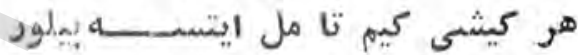
ده سى · با خود سله توده غايتي زمهف

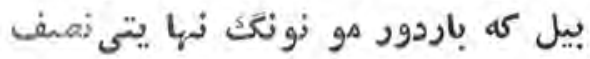
شمرع بو قسمم نى مقالسمه ديسر هر نيجِو ه كيم معين ايتسا نك بيم ييرسه محصو ل نى مكرد يبي سين خرا جينك نى هم مكسر دبير ايمدى ايكينجى سين ديين سنعا بات

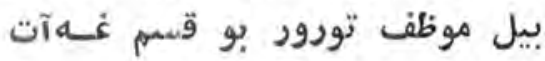
$-\mathrm{rOV}$ 
مو ندا باردور جر يب غه تعيين

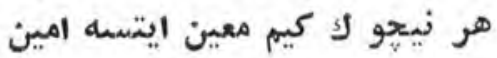
شعصت در شصست كز جريب نى بيل سين هسما حت كز ى بيله تينككقيل بوزراعت غه ، يا ايكين يير يكا. آفتى كر ييتو شسسه هر بير ى

يبر دا ايكين بو نو ع بو لغا ندا ساقط اولغاى خرا ج اول آندا بولسه كر دفع قيلغو د يكآفت صماقط اولماس خرا ج اولفرصت قادر اولسمه اوز ى و صل لك يير ايكماسه · شمرع اهلى مو ندانىدير ؟ واجب اولغا ى خرا ج اول كيشى ديماسمون عذر ايكما كا ن ايشى عاجز اولغا ن ييرين امام آلسو ن ينه قادر مزار عى سالسمو ن كيم انداقيلما يين خرا ج،ييسه مالى دبن يو ق حلال مو نسـا قايسه بو خرا جينك نى كيم آلور سين،بيل. رفع محصو لى دين كيين آلغيل . 


\section{فردلار}

مطلع

حاليم نى سنكا آيتيب هجر اوزئها اورزانديم

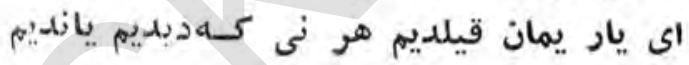

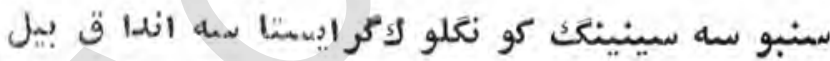

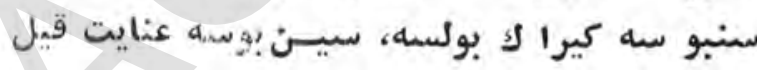

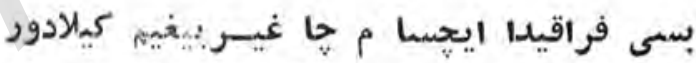

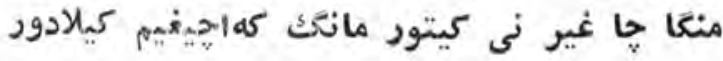

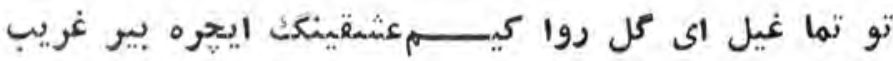
يير كا باشن قويغا ى خزا ن يافراغى ينكليخ سارغا ريب

زهد صحرا نسيغه تو شتوم عشق بوليدين آزيب

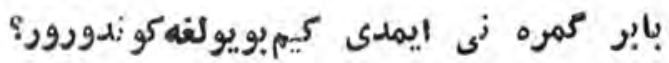


اول ايكى كبى رمزى درد اهليغهةتيلهايدور

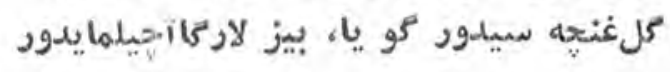
بار ار حه باعث يوز شمورو يو زكناه حاغير حاغير فرا قى هالاك ايتتى مينى، آه هاغير!

$$
\text { مطلع }
$$

فراقينكدين ياو شتو م اولكا كى اي يار كيلكا ى سين وصالينك غه بسمى مشتا ق مينزنهار كيلكا ى سين

$$
\text { - }-
$$

اوليوى رخساره هو كز ناتوا نليف كور ماسون

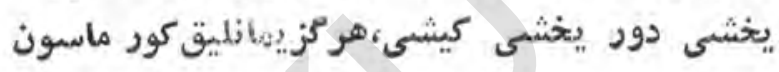

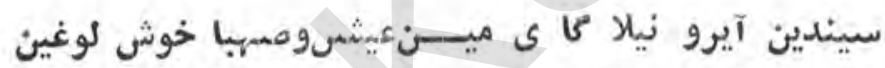
كه سمينينك اوحو ن تيلار ميسن:بازيحه دنيا خوش لو غو غين

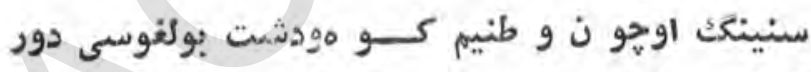

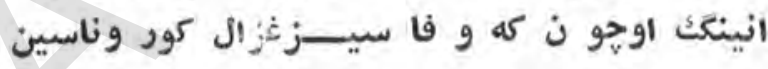

بار مى ايكين هيج نيمه عالم داهيجران دين يمان

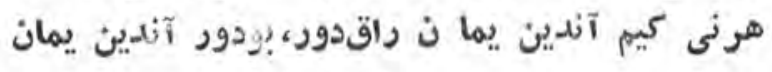
- -

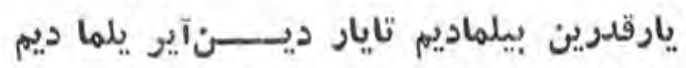

$$
\begin{aligned}
& \text { يار قدر ى مونجه هم دشوارايكاندور بيلماديم } \\
& \text { كوروب هيجرا ن غمين ؛ جانا نغه ييتتيم }
\end{aligned}
$$

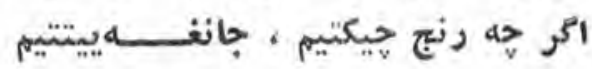

$$
\begin{aligned}
& -r 7 \cdot
\end{aligned}
$$




$$
\text { مطلع }
$$

مينى هجراندا كويدور سما نككونكول سيندين ساوو تماس مين

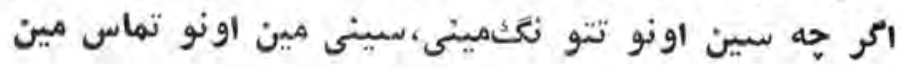

قاوون بيرله اوزوم نينككهريداكونكلومداغم هربو آقار سو نينك فرا قيدين كوزوهدين هردم آقار سبو

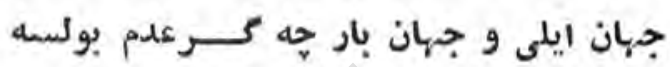

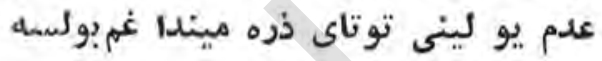

ايستارام ييتسا م قويو ن ديـك كلمذاريم قا ثشيغه

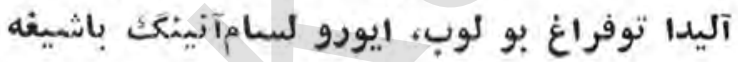

كرحه عالم دا وصا ل ايا مـــي دلكش دور، اخحى

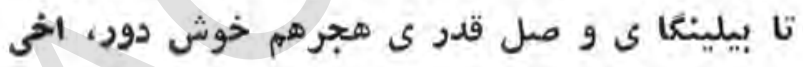

$$
\text { sas }
$$

همربان ساغينغانيم نا مهربا ثاير هيش نيتاى ؟

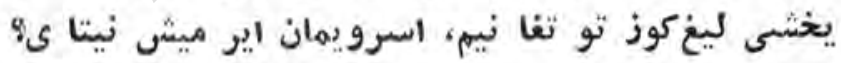
$* *$

نيجهه اول يار ياد ايتماى مينسى اغيار سا غينغاى نى كون بولغا ى مينى دلخستهنى اول يار يار ميا غينغاي

بو دنيا دين فرح يو قتور مينى دتزون غه جانان ميزي

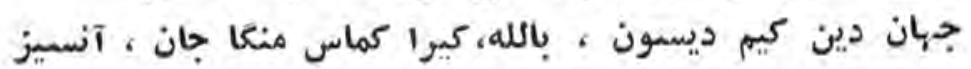




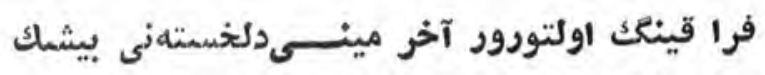
مينى اولتور و صا لينكاد ، نى يعنى اندلك اولتورد مالك دوستلوق نى كر تيلار سين ايلاسانعك البات قيل

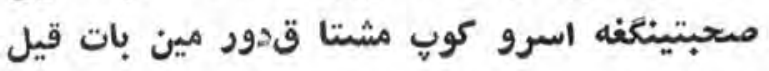

خوش اول بورو نقى زمان لار كهاونتى وبار دى

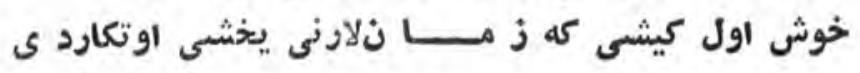
- •

مراد وصلينكَ ايرور ، ايله يا دبابرنى اونو تماغيل يانابو نا مراد بابر نى الئ ..

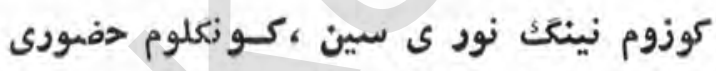

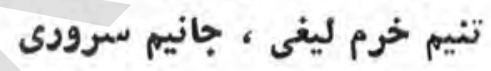
•.

سبزه وكل لار بيله جنت بولو ركابل ، بهار خاصه بو موسم دابارا نيازيسىو وكلبهاد ..

غير غه نيجها اول آى وفاقيلور

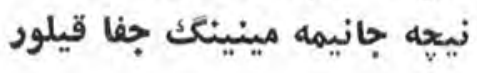
قدى فر قتى مينى دو تاقيلود 


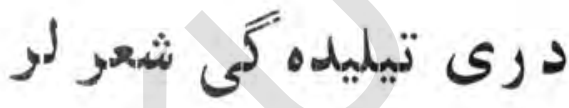

لاله را داغ ازآندم كه بدل حاصل بود

داغ عشقتو مرالاله صفت دردل بود

عمر من رفت ومرا فرقت اوساختهناند

جه كنم عمر من دلشده مستعجل بود

رخنمودى وبمن مرد نم آسا نكردى زيك

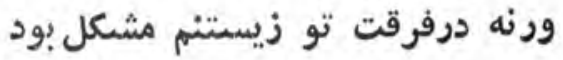

بابر از عقل فرو مانده حهه تشويش كنى؟

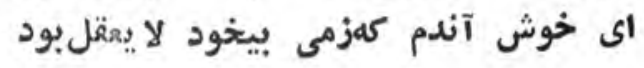




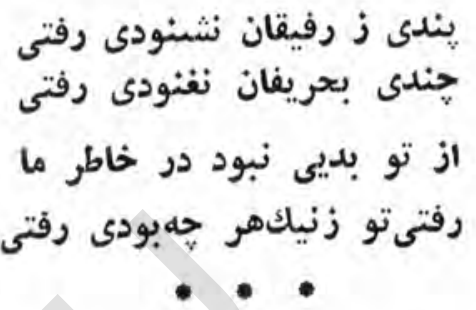

اخلاصو عقيدة تو روشن شد ماست

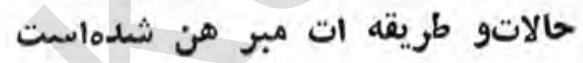
حايل هثو نماند زود بو خيز وبيا

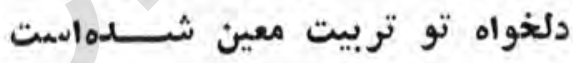

در هواى نفس كمره عمرفايسع كرده ايم ييش اهل الله از افعال خود شرمندهايم يكنظر با مخلها نخسته دل فرما كه ما خواجكى را ماندهايم وخوا جكى رابندهايم

باترك ستيز ه مكن اى ميربيانه؛

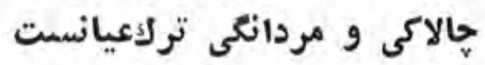

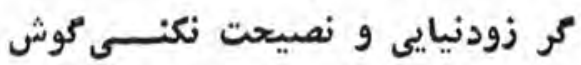
آنجا كه عيانست حه حو حا جت به بيانست $-r 7 \varepsilon-$ 


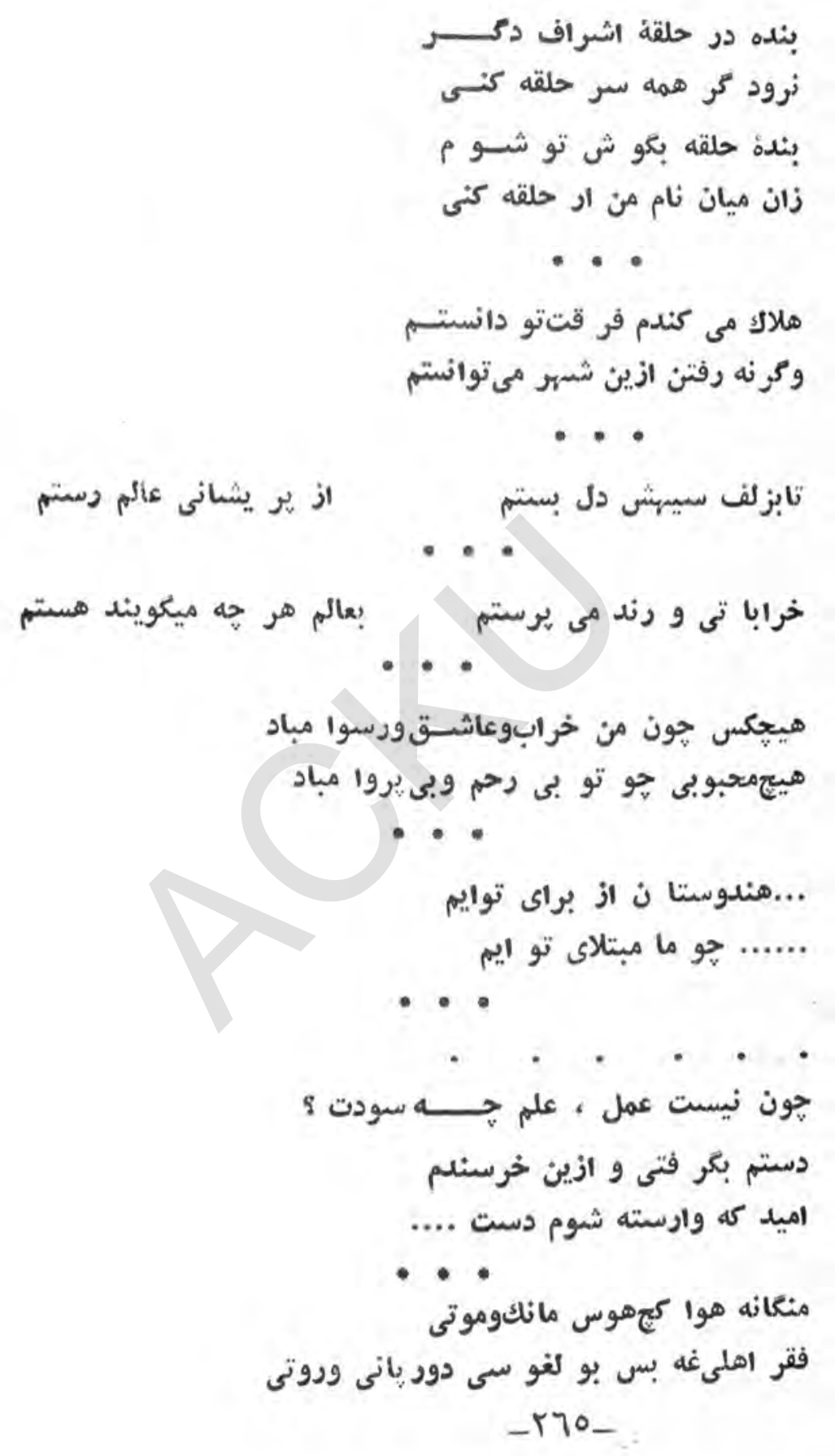




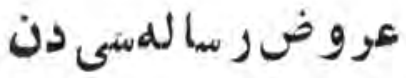

عروض اتما مى دين ايكسى اوجييل سونغك هندوستا ن فتحس

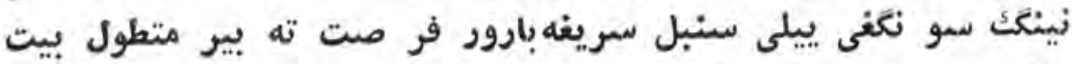
اون آلتى د كن بيله آيتيليب ايدى،دواير مصا ريعى نينكى طريقى بيلى بيله

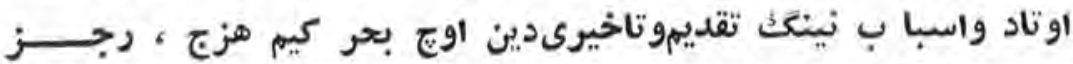

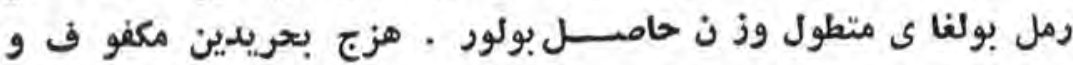

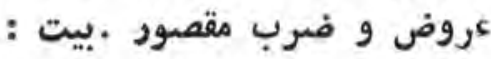

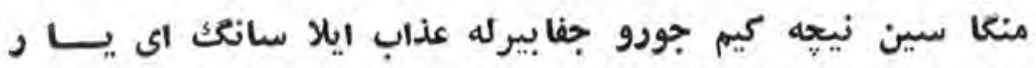

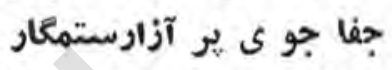

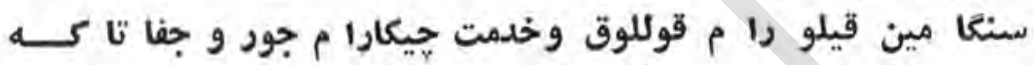

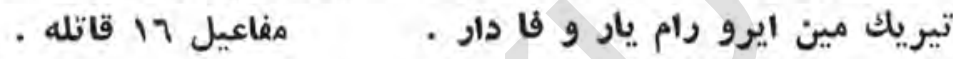

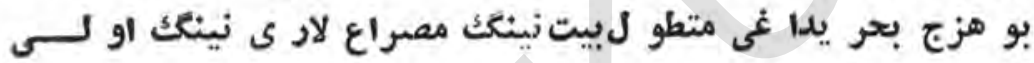

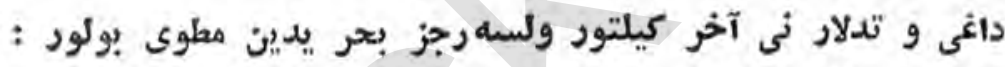

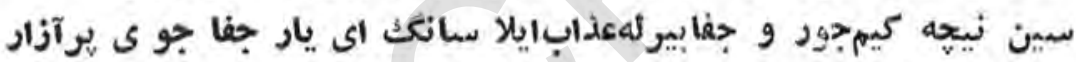

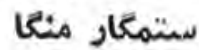

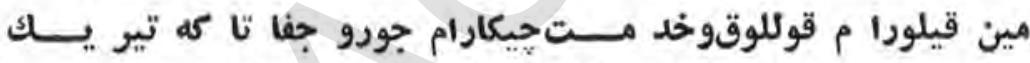

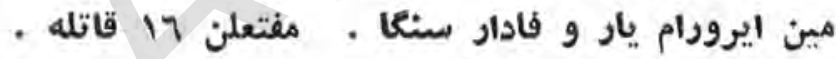

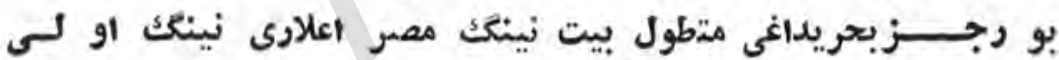

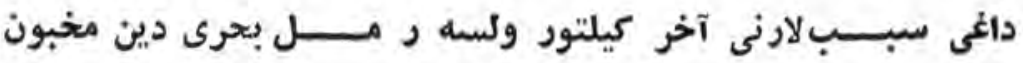
بو لور :

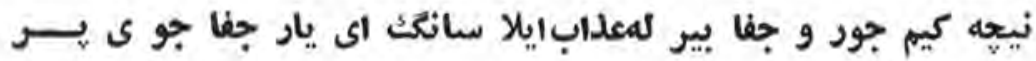
آذار متمعار منعا سين

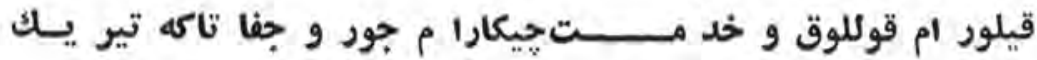

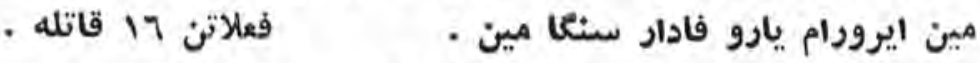

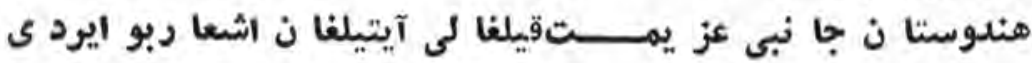


كيمتحرير قيلديم و كيجكا نو قايع اولدورور كيم تقرير قيليب تودمين

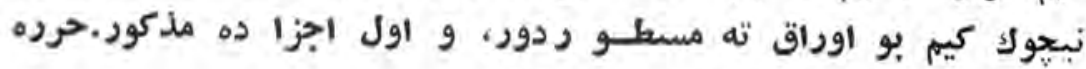

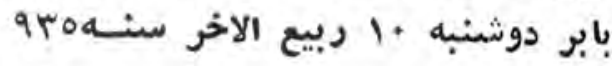

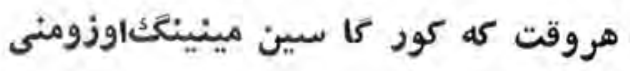

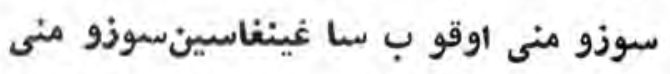

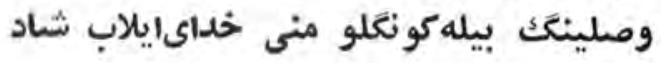

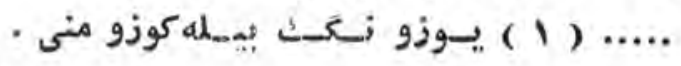

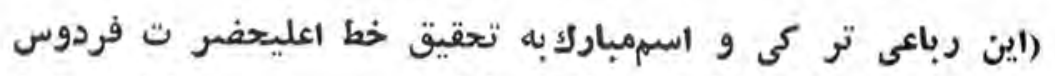

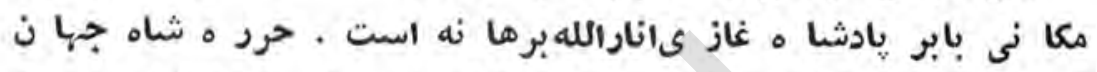

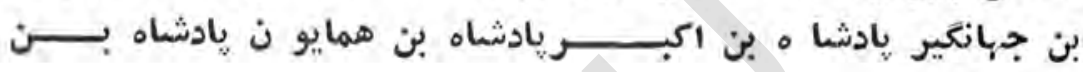

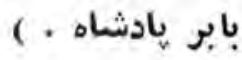

(1) -rTV- 


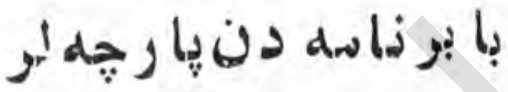

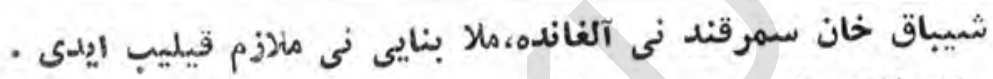

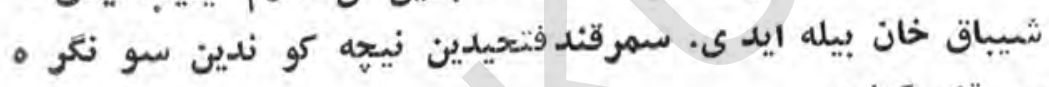

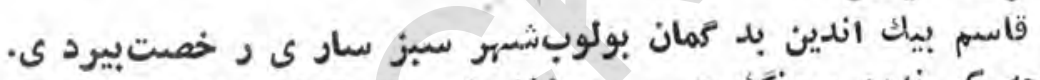

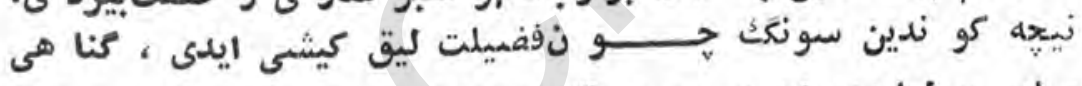

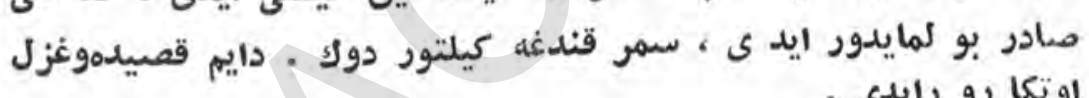

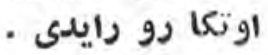

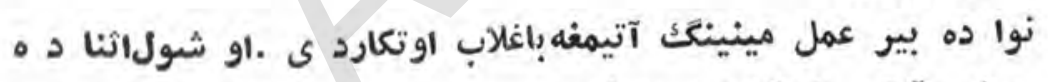
بير رباعى آيتيب اوتكارد ى ،رباعى:

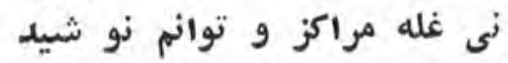

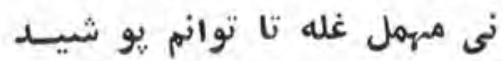

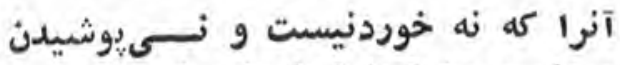
درعلم و هنر كبا تواند كو شيد

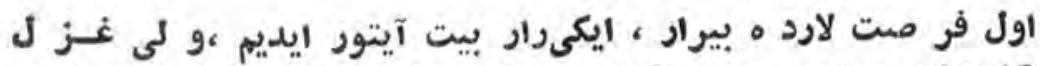

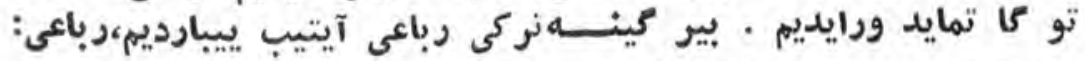

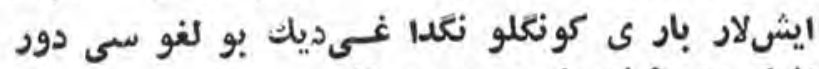

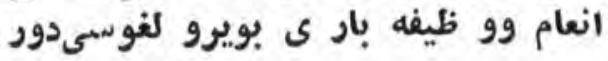
- rרו_ 
اول غله ومهيهل كه ديب ايرديئكن بيرديم

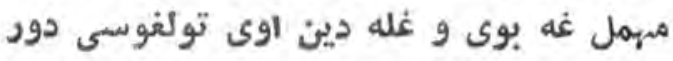

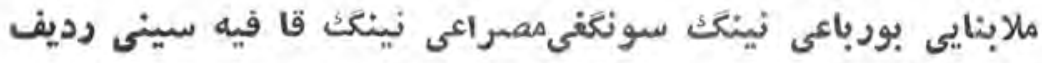

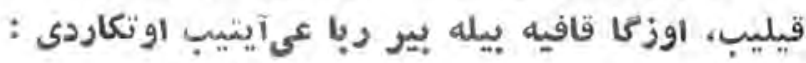

$$
\begin{aligned}
& \text { ميرزام كه شاه بحر و بر بولغوسيى بردور } \\
& \text { عالم ده هنر بيرله سربولغو سيدودي }
\end{aligned}
$$

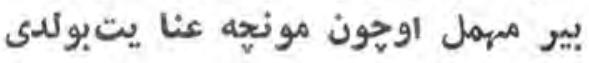

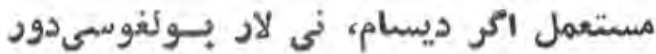

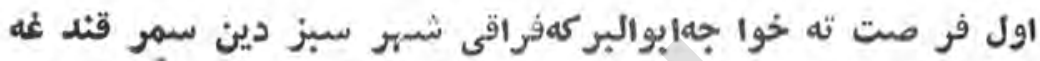

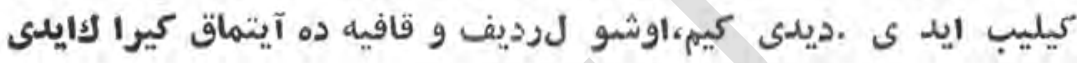

:ودباعينى خوا جه ابوالبر كهآيتدى، بأعى :

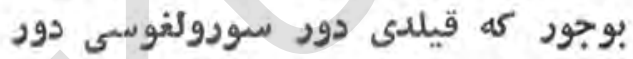

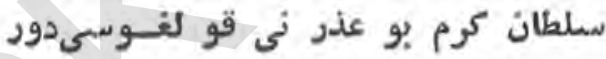

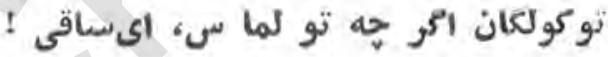

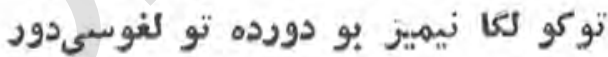

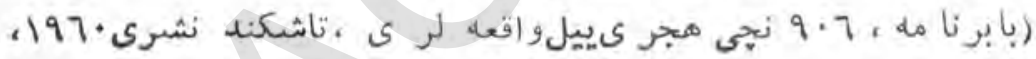

$$
\text { ) }
$$

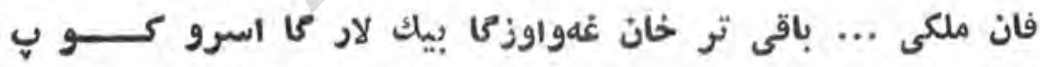

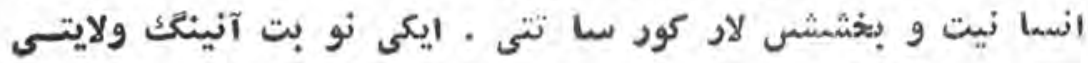

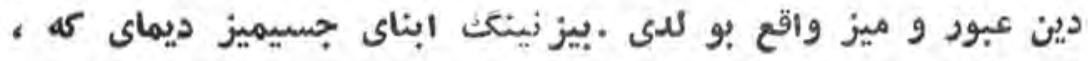

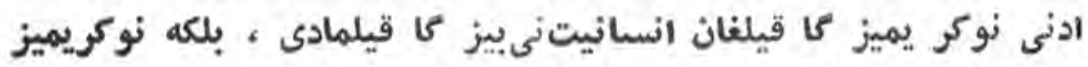

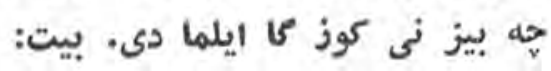

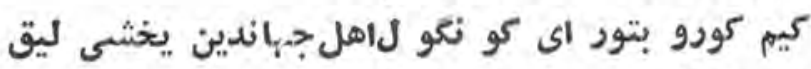

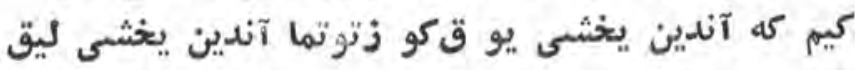

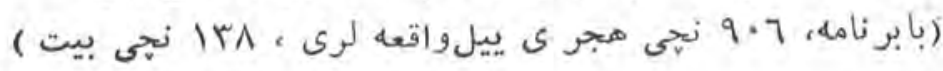


اول كو هستا ند ه ( مسحا كو هـستانيده ) بورسم دور كيم، تاشقه

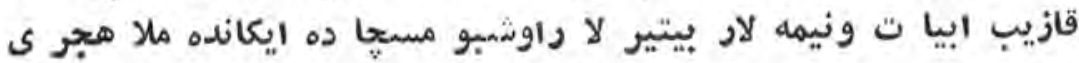

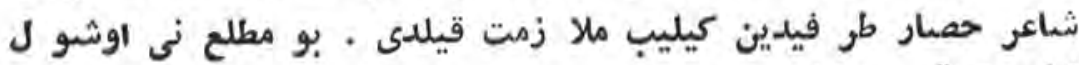

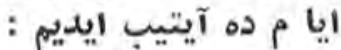

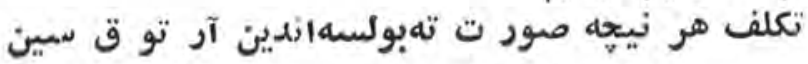

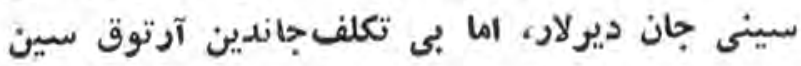

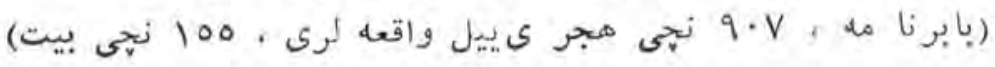

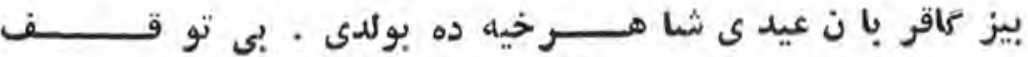

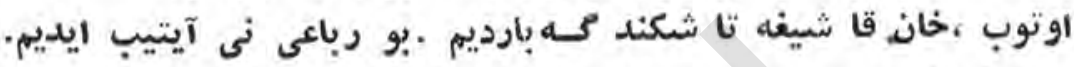

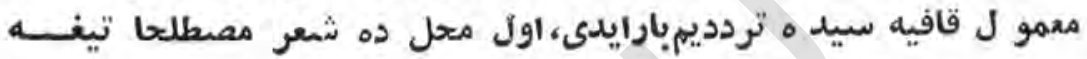

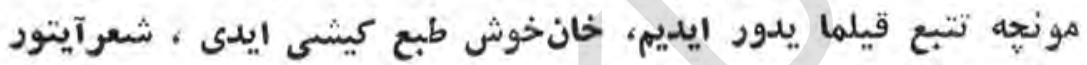

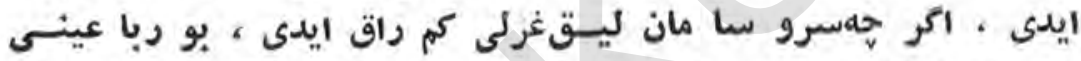

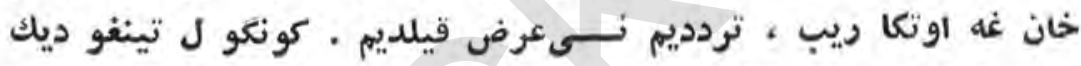

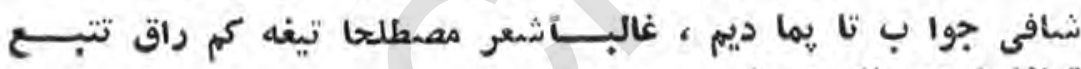

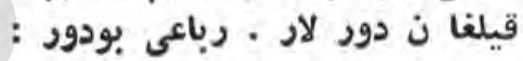

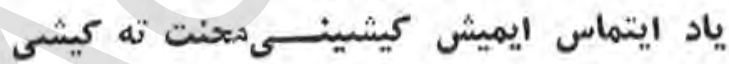

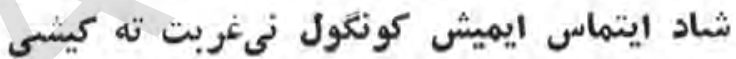

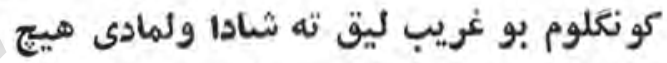

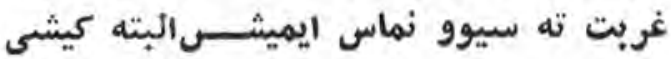

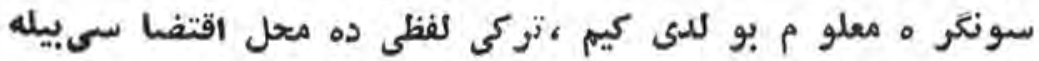
تاو دال يانا غين وقاف و كاف بير بيرلار ى بيله مبد ل بو بول لود لا دات (بابرنا مه ،.V.9. نجى ييل واقعلرى، 107 نجهى بيت )

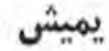

يسكينت بيله سا م سيرا ك نينكارا سيد ه برانغار و جو انغار نسى

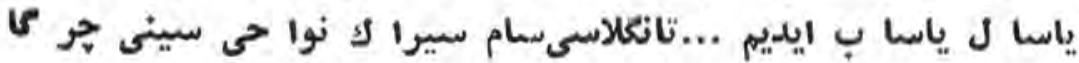




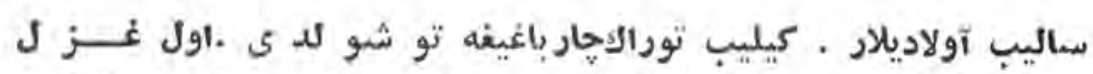

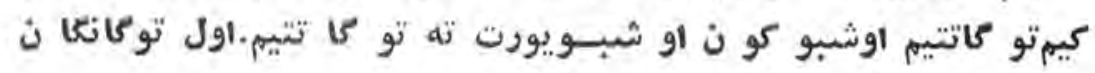
غزل بو دور: جانيم دين اوز ما يارو فا دارتايراديم كونعلوم دين اوزئا هحرم اسرارنا بإنماديم

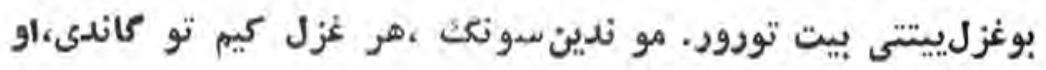

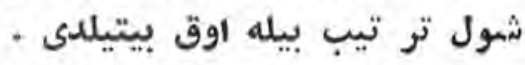

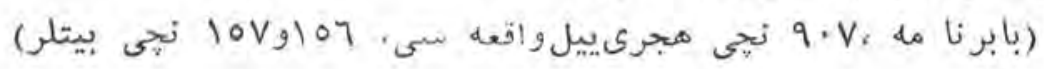

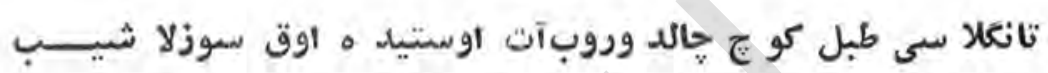

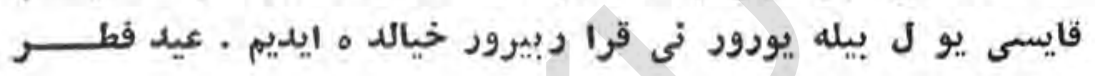
- ايدى

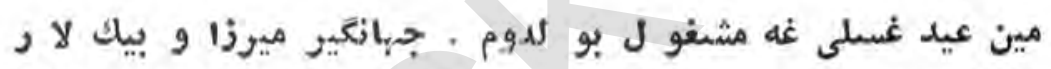

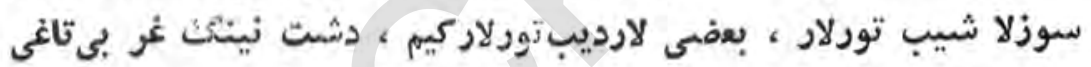

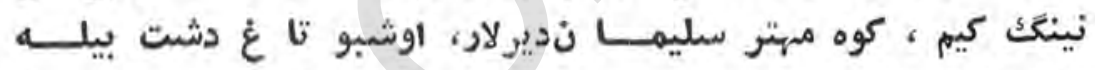

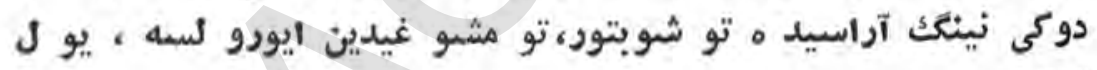
توز دور لـ

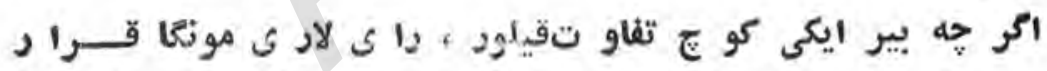

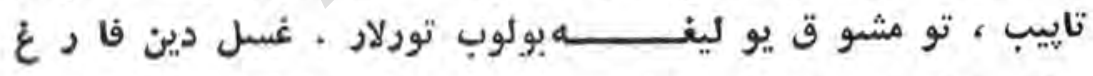

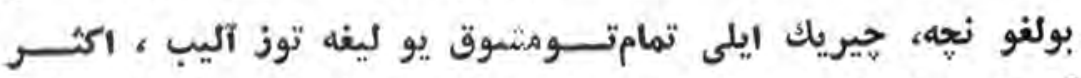

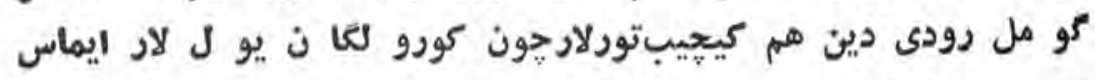

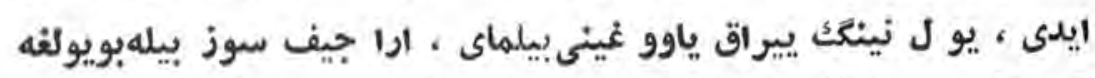

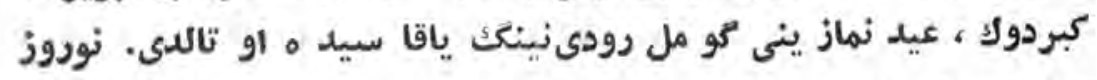

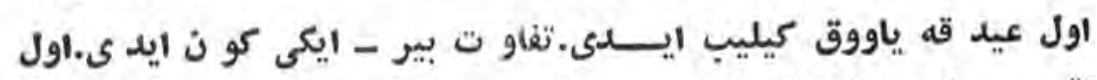

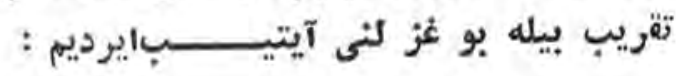
-rVI- 
ينتى آى ياريوز ى بير له كوروبايل شادييرم لار

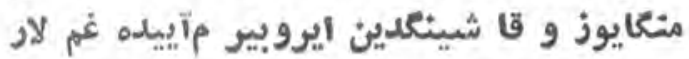

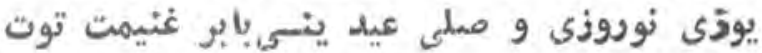

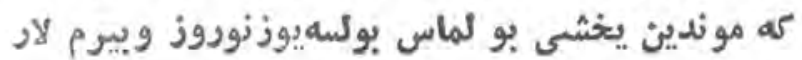

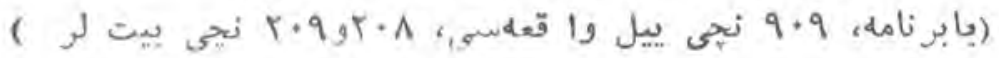

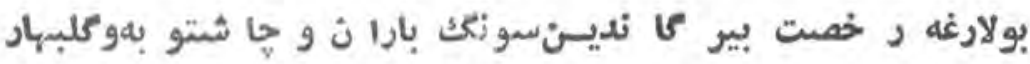

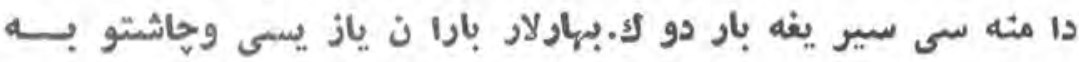

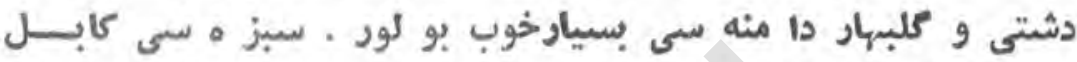

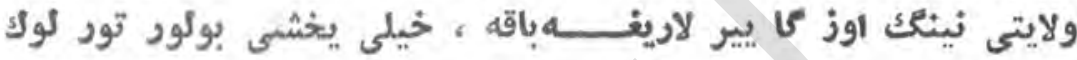

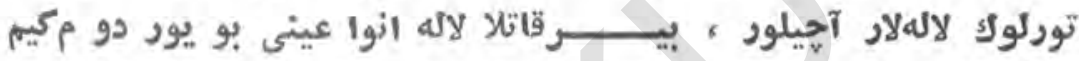

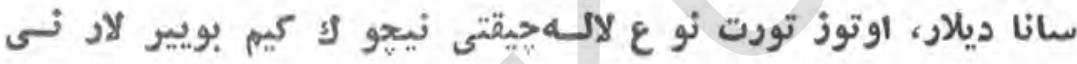

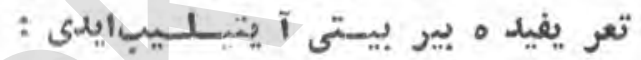

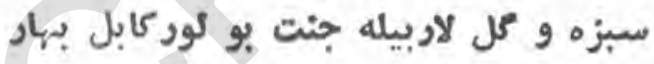

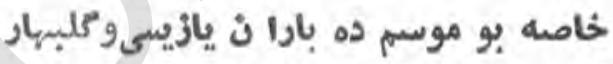

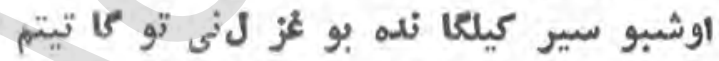

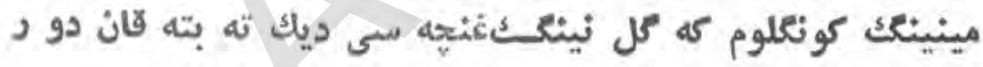

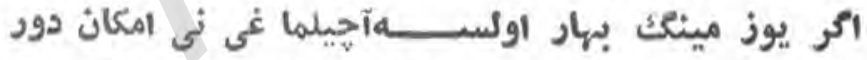

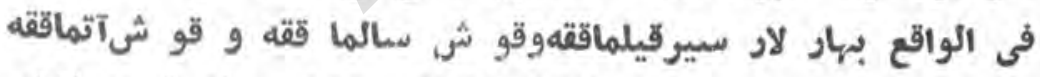

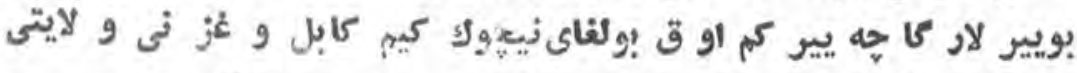

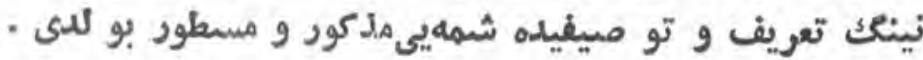

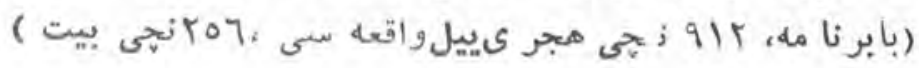

-

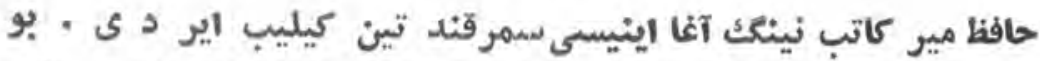

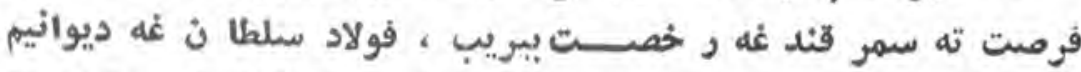

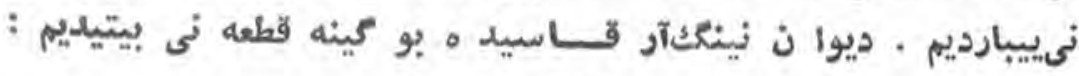




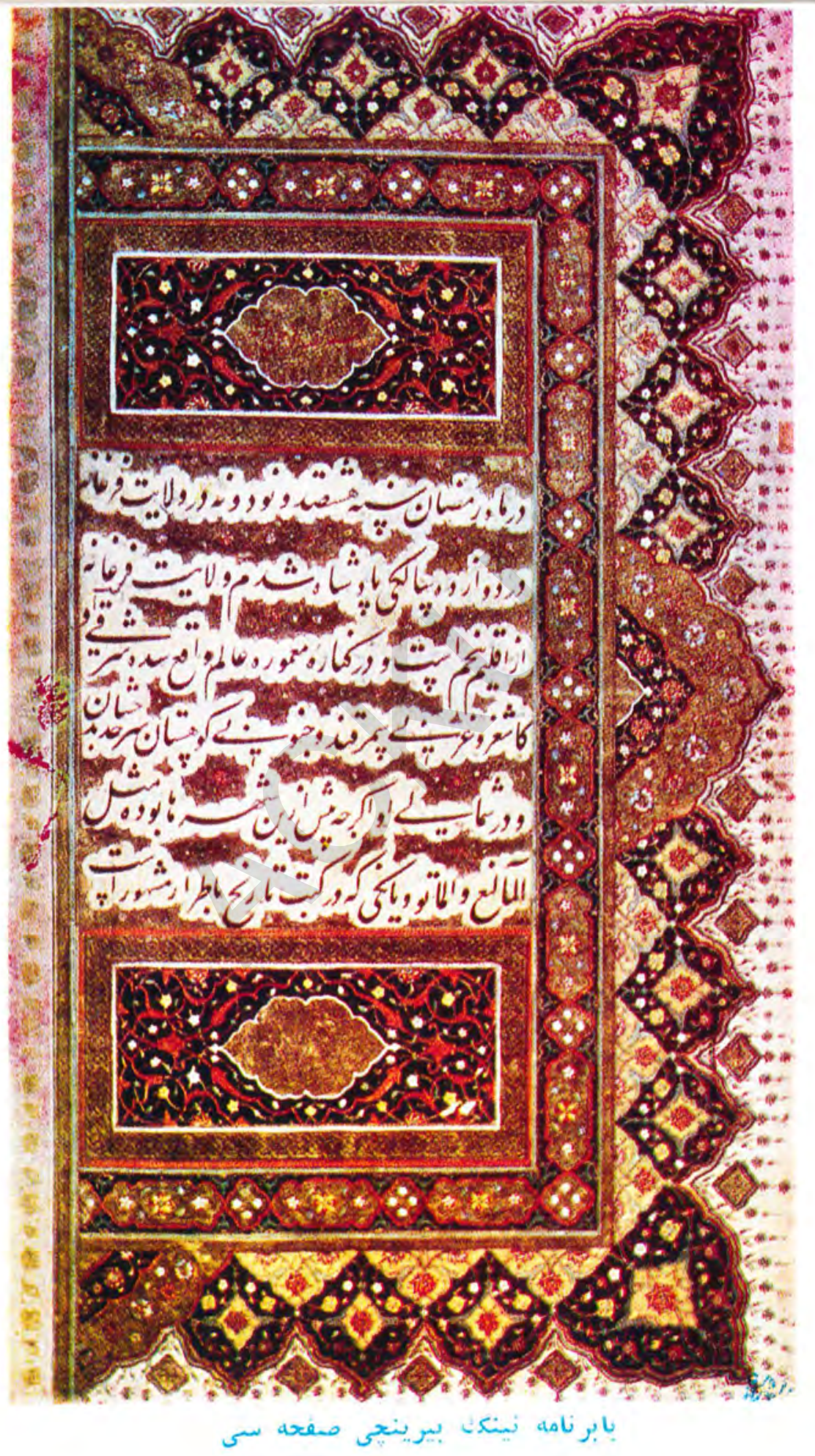




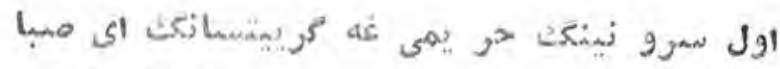

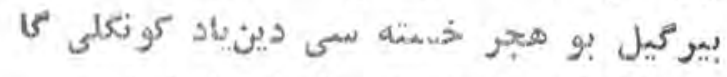

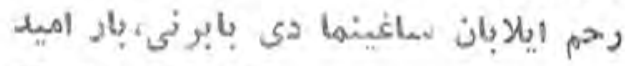

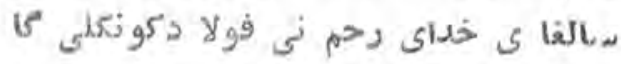

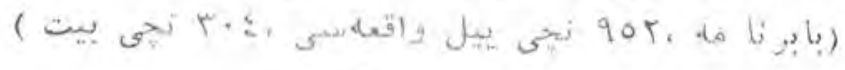

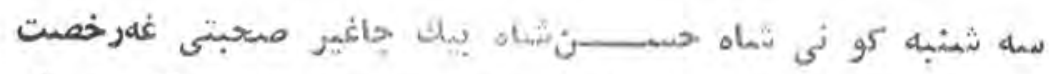

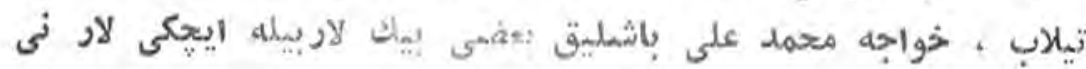

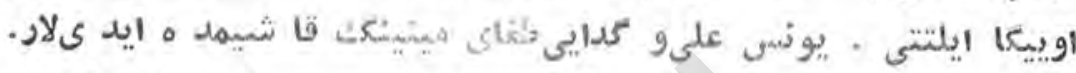

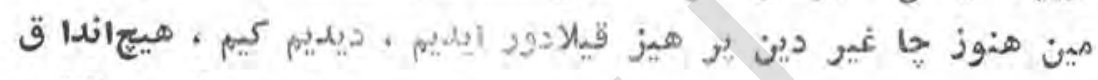

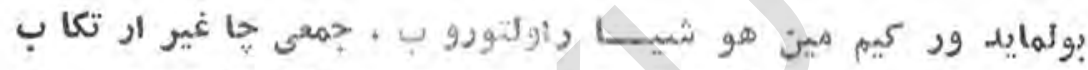

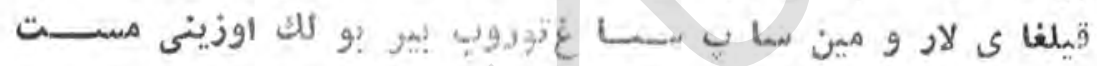

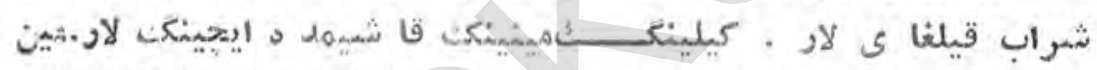

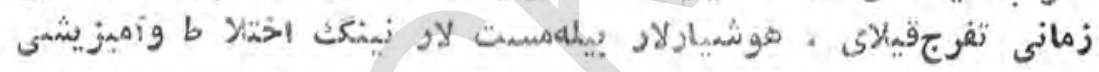

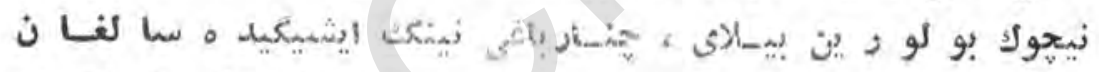

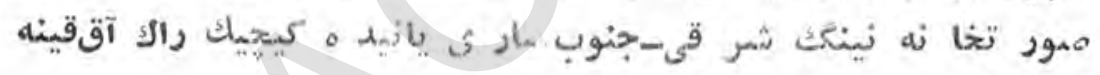

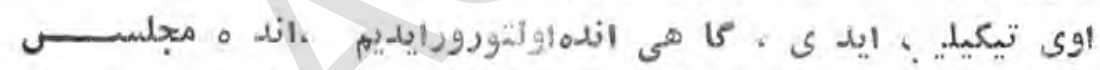

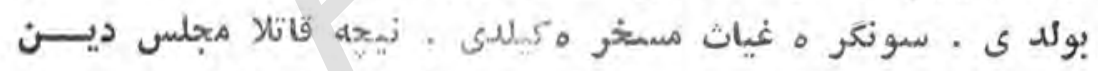

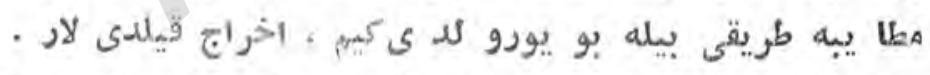

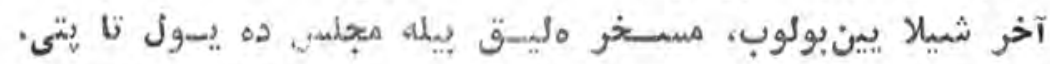

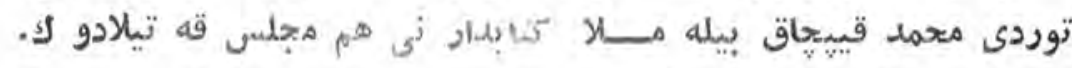

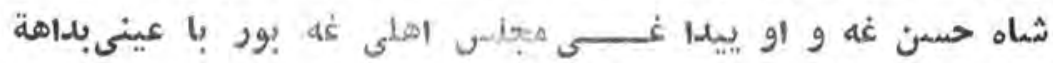
آيتيب يبيار يلدى :

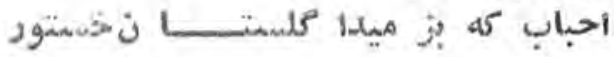
يوق ليك الار ربز ميدابيز مكا دستور

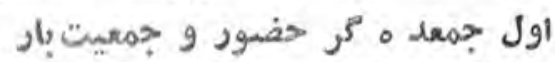
يوشكر بو جمع بى حضمور إبمـاستورد $-r V H-$ 
ابراهيم ههر ه دين بيباريلدى .ايمى زماز ارا سميغه يقينبو مجلس

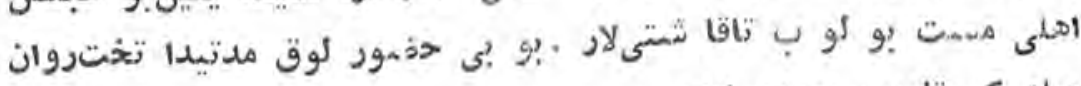

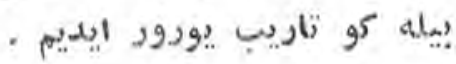

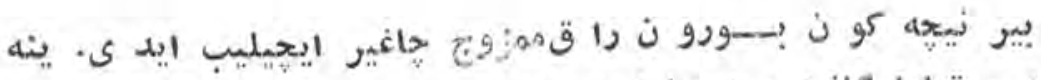

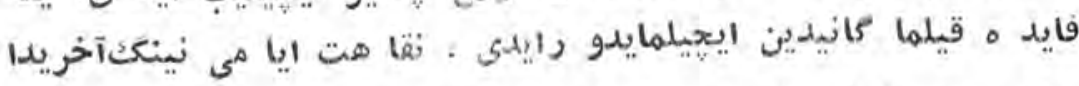

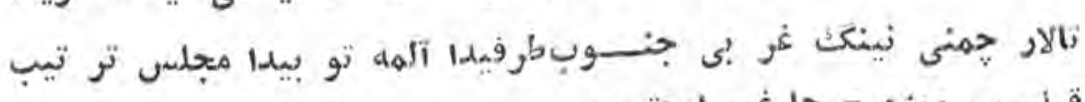

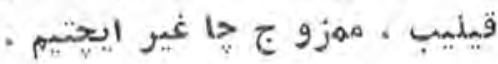

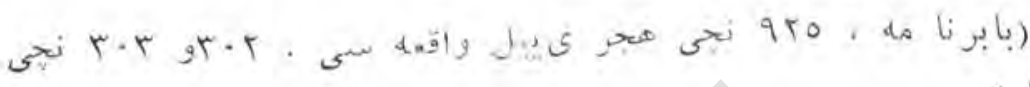

اوشهو ل دوشنبه آقشا مى اوق كوجوب سملطا ن بود بيله خوا جه

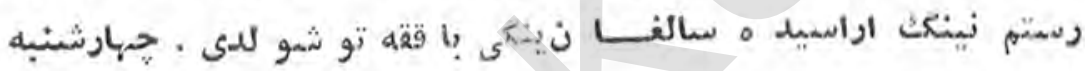

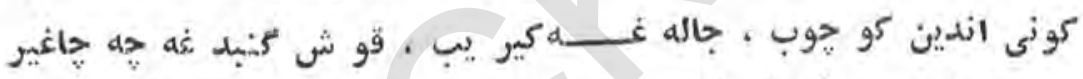

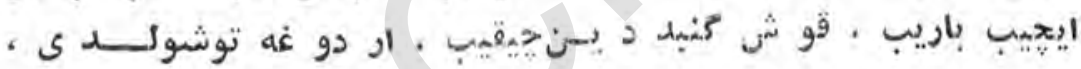

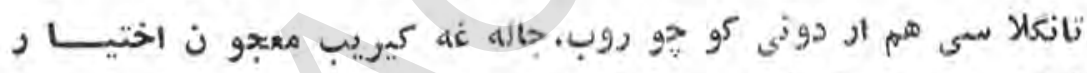

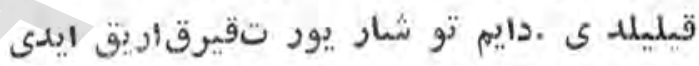
قيرق اريق توغر يسيغه ييتكانده: نميجه مألاخظه قيليلد ى .ار دودين

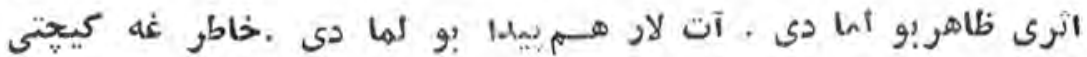

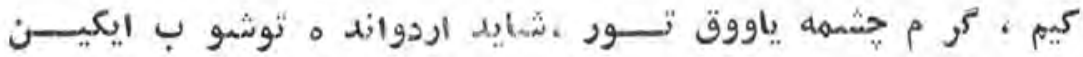

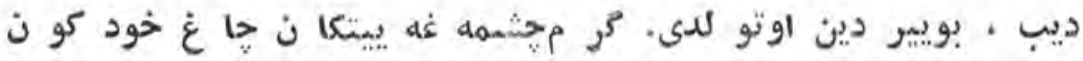
كيج ?و لوب ايد ى، انده همتورماي كيجه سمى هم يودو لدى .

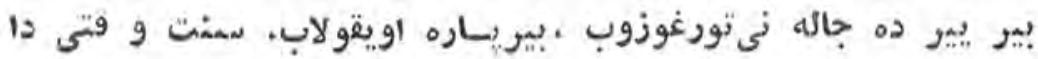
خيريك ايلى كيله باشله دى · ا ردو خود قيرق اريق نوا حستى

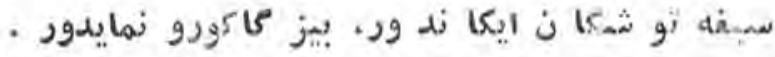




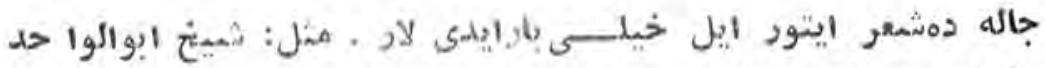

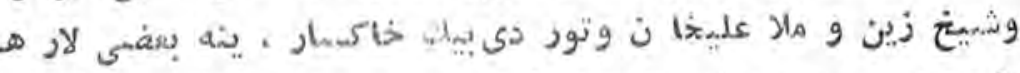

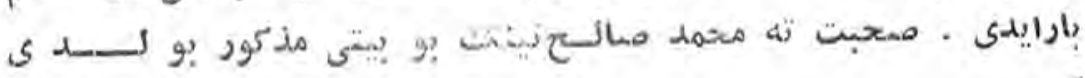
: $6, \pi$

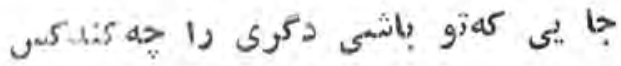

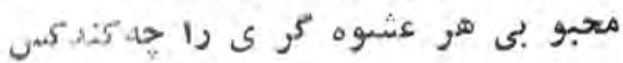

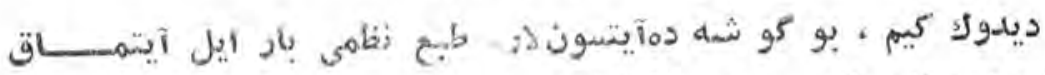

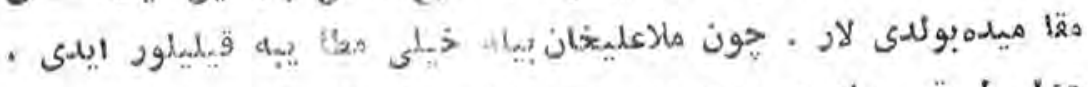

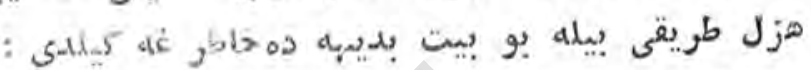

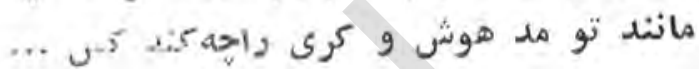

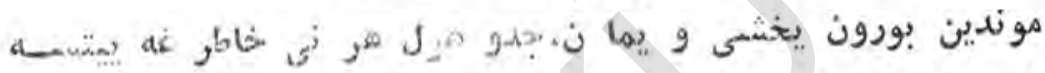

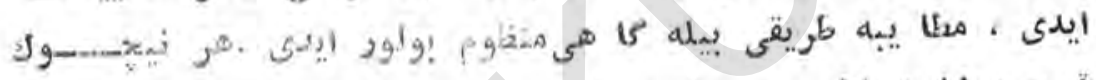

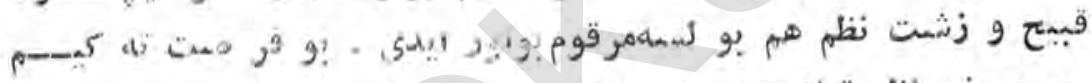

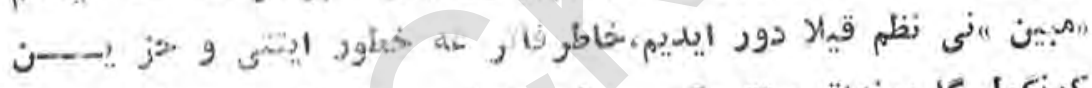

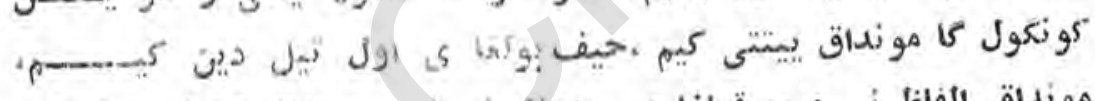

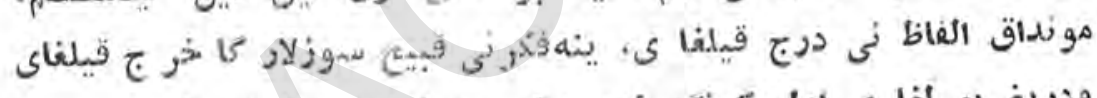

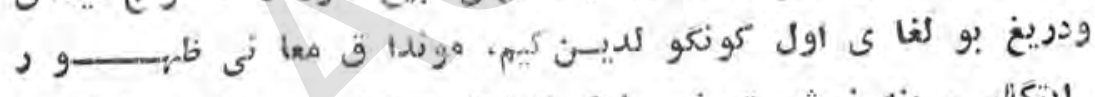

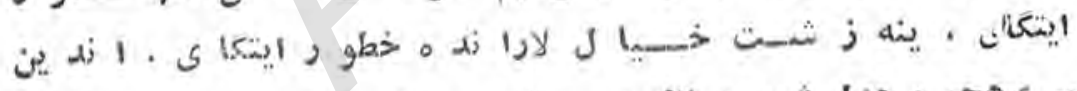

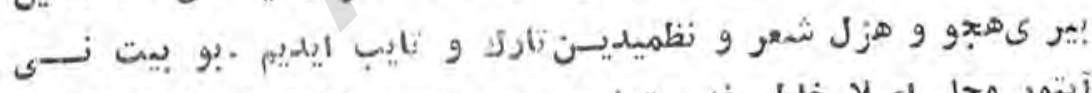

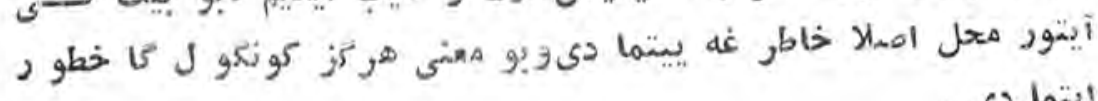

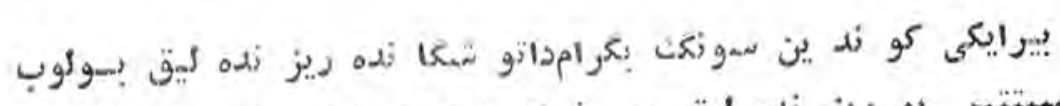

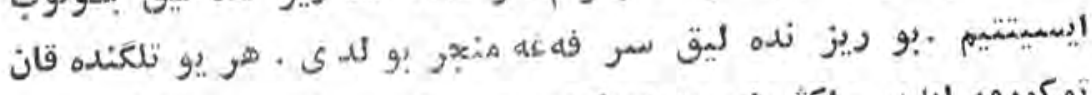

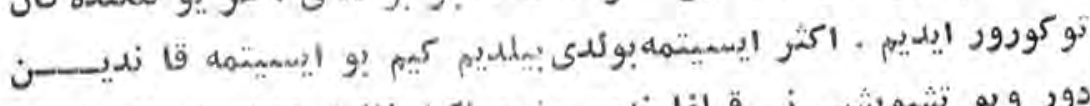

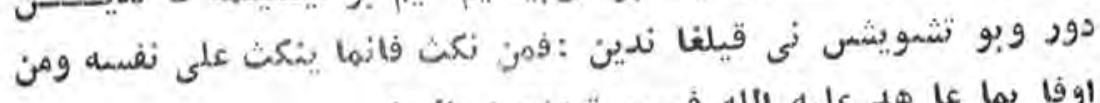

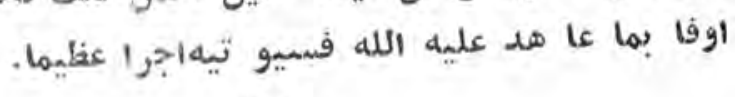


نى قيلايين سمبمينك بيله إىتيل:

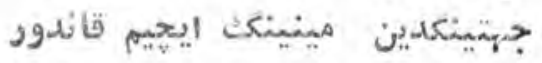

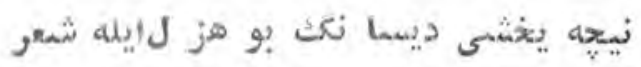

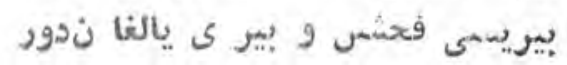

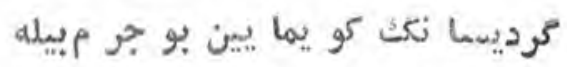

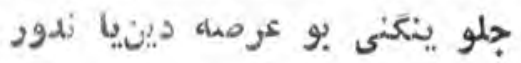

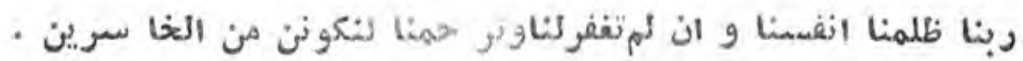

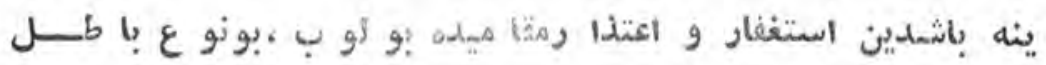

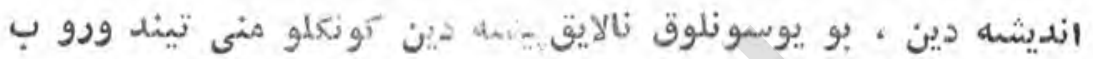

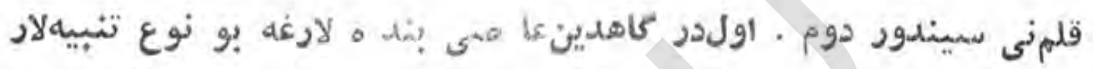

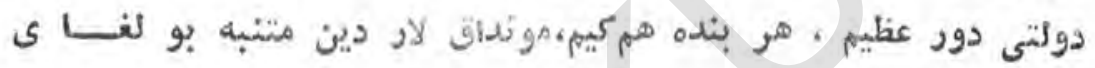

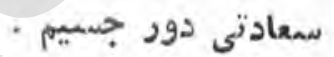

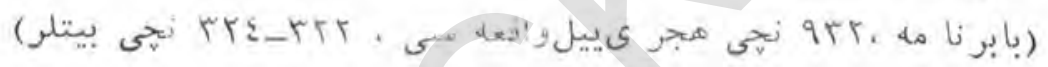
خواجه كالان جو ن هند دينمتنفرايدى . باروز يده اوى نينكگكمارت

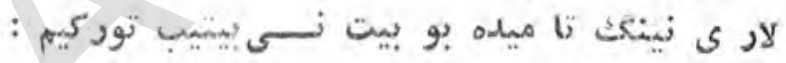

$$
\begin{aligned}
& \text { اكر بذير ومسلامت كذر زسندكتم } \\
& \text { سيا هرو ى ثمومكر هوأىهندكنم }
\end{aligned}
$$

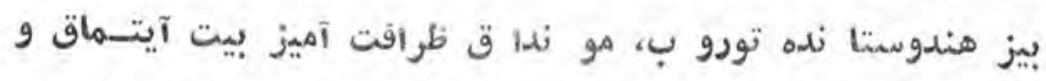

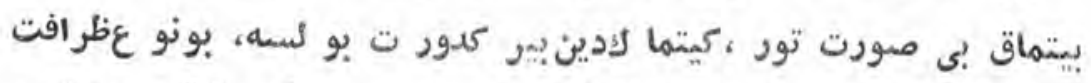

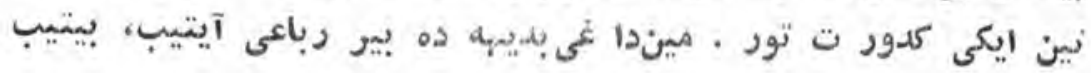

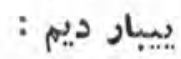

يوزثكر دى بابو كه كريم غنار

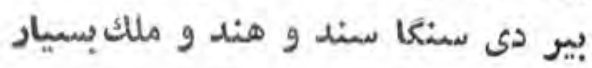




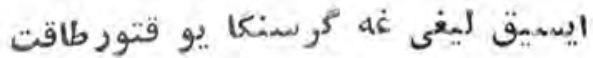

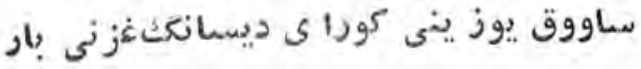

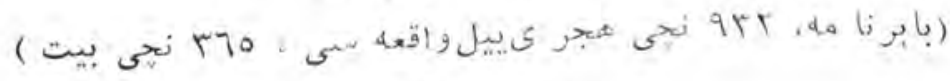

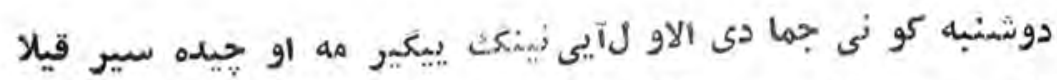

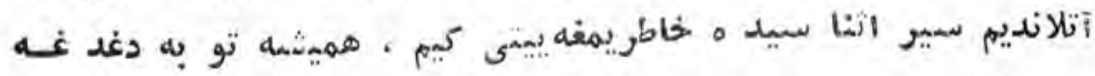

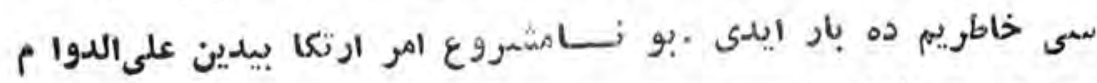

$$
\begin{aligned}
& \text { كونكلوم ده غبار ايدى ديديم كيماي ثغس: }
\end{aligned}
$$

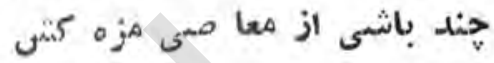

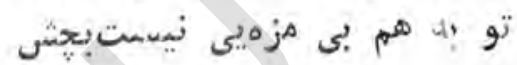

نيحِاعصيان بيله آلودماليفينكن

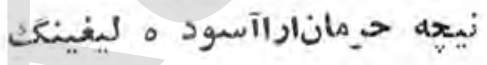

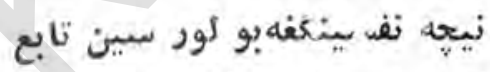

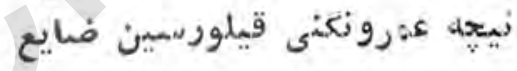

نيت غزو ايله كيم ي.وروب سين

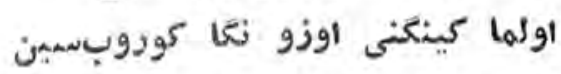

$$
\text { كيم كه اولماك أوزيكا جز م ايتار }
$$

اوثبو حالت تهبيلورسين كهنيتار اوني

دورايتار جمله منأهى دين اوزين

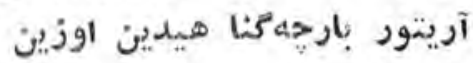

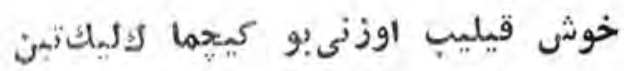

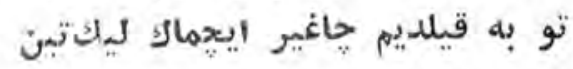

آلتون و نقره صمراحى واياق

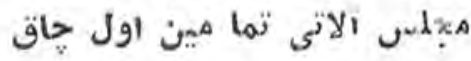

$$
\begin{aligned}
& - \text { rVV- }
\end{aligned}
$$




$$
\begin{aligned}
& \text { حاضمر ايلاب بار ينى سميمالدور دوم }
\end{aligned}
$$

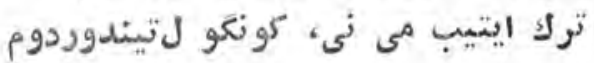

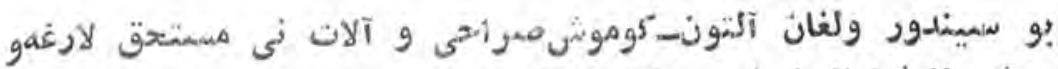

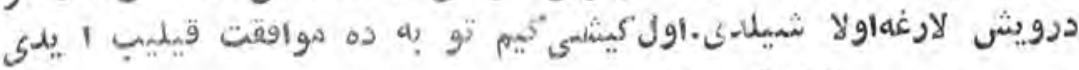

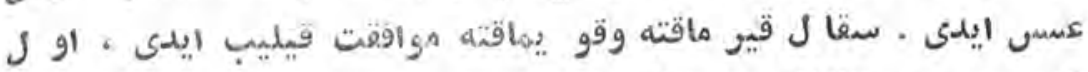

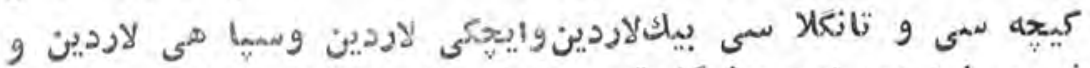

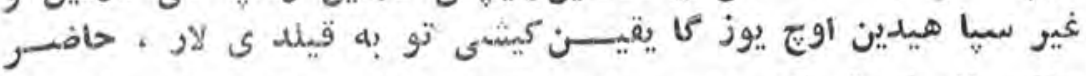

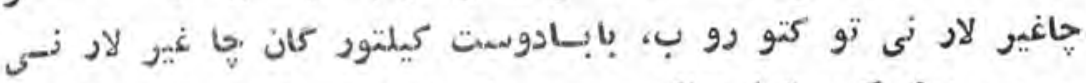

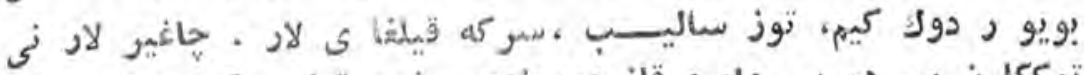

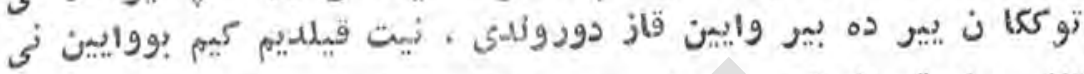

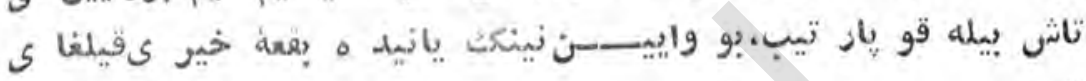

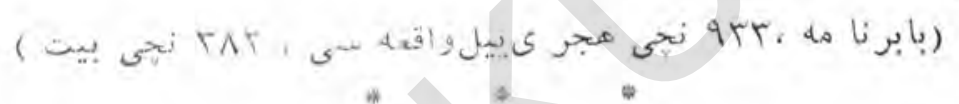

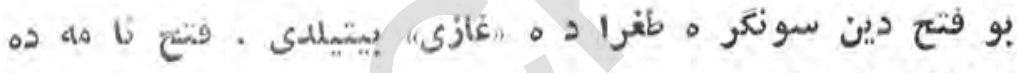

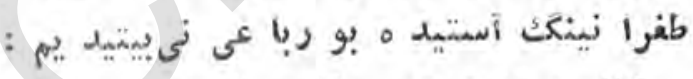

$$
\begin{aligned}
& \text { كفار و هذود حربسمازى بو لندو م }
\end{aligned}
$$

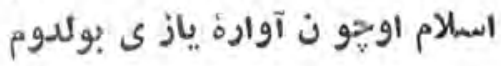

$$
\begin{aligned}
& \text { جزم ايلاب ايديم اوزنى شمهيداوكماقعه }
\end{aligned}
$$

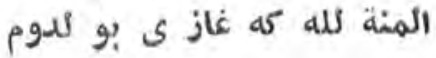

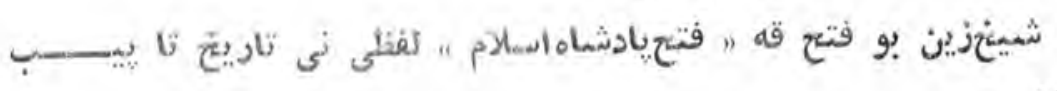

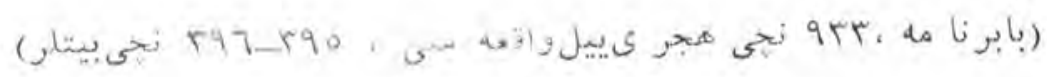

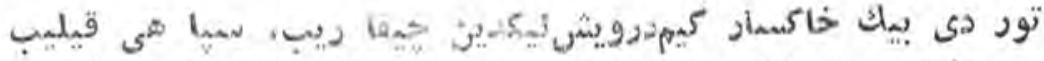

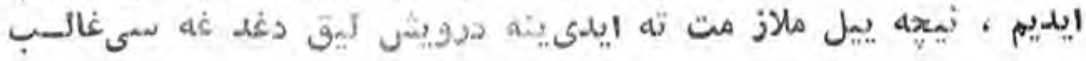

$$
-r \vee \Lambda
$$




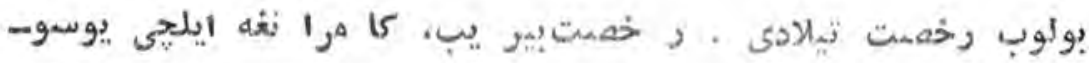

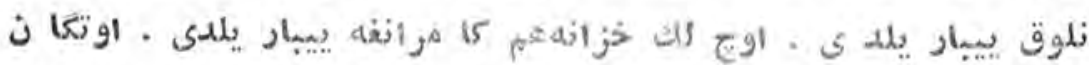

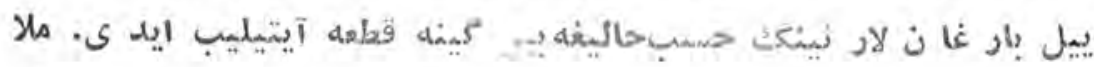

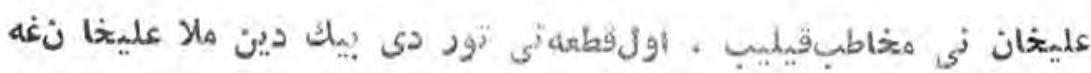
يبيار يلدي . اول قطعه بو دود :

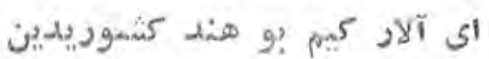

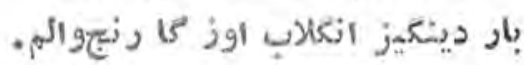
كابل وخوش هواسميني ساغينيب

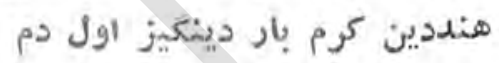

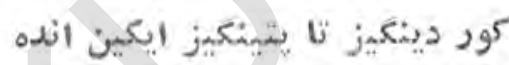

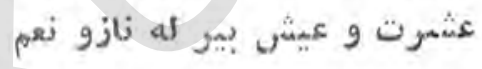
بيز. دائى اولما دوك بحمدالكله

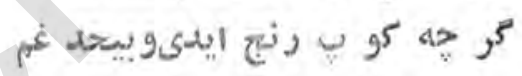

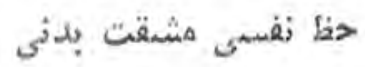

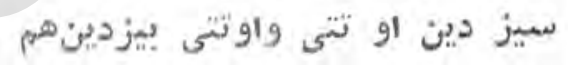

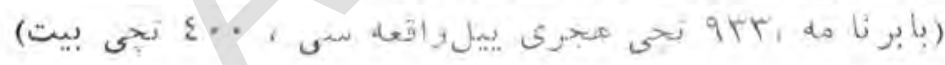

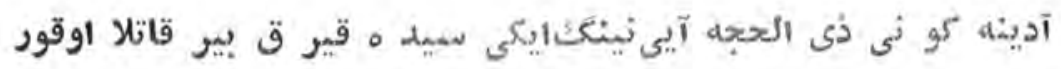

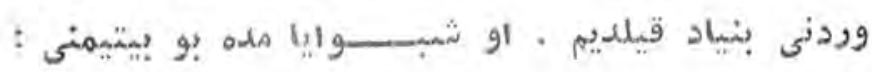

$$
\begin{aligned}
& \text { كوزو قا شمى و سوز و تيلينسى مدودى }
\end{aligned}
$$

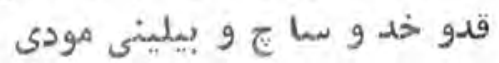

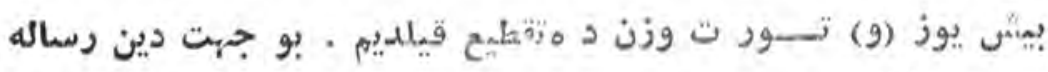

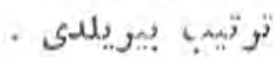

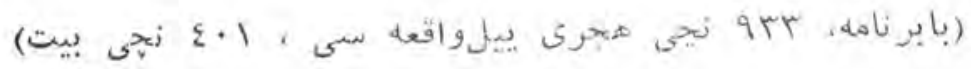
-rVi_ 
يكشنبه كو نى محر م آيى نينككاون آلتى سيد ه ايسميتتيم ، تيترا ديبم

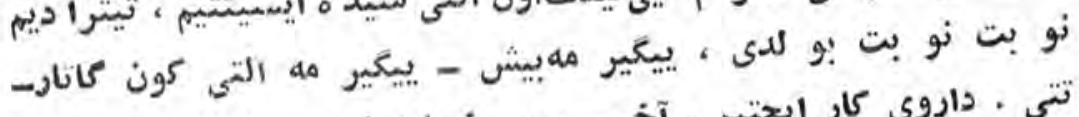

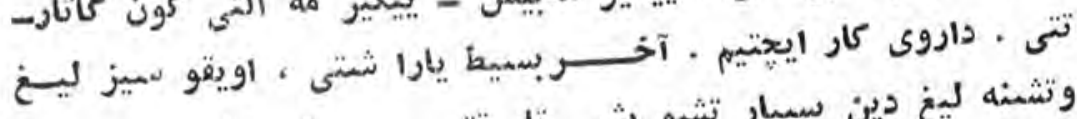

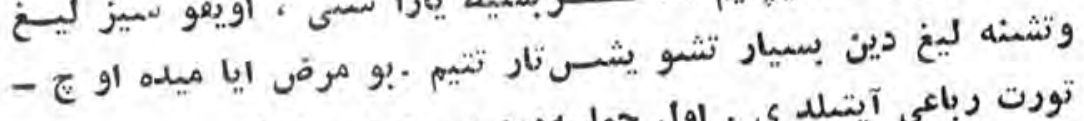

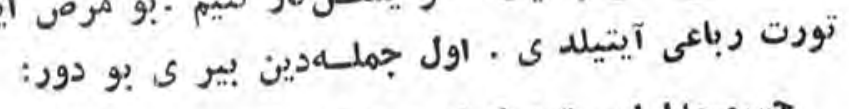
جسميمدا ايسيتمه كوند م محكم بولادور

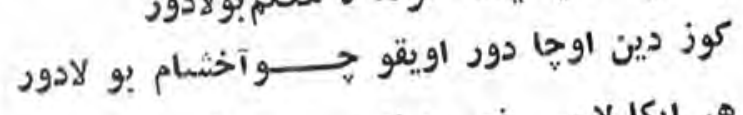
هو ايكا لا سمى غميم بيله صبر يمديك

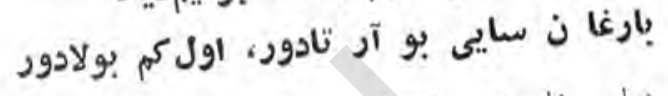

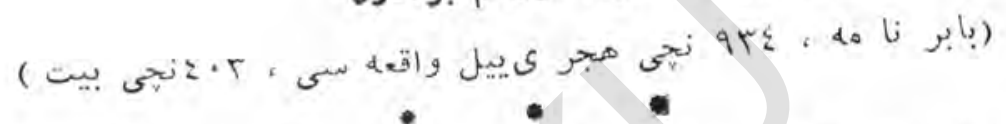

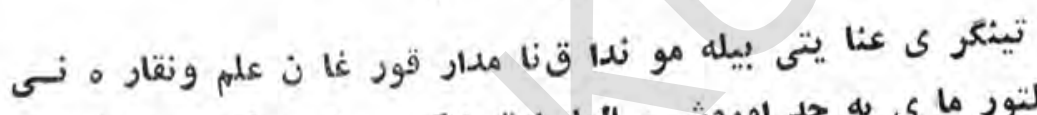

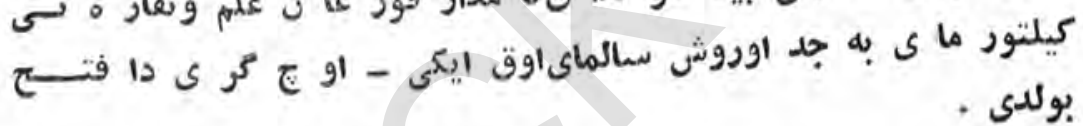

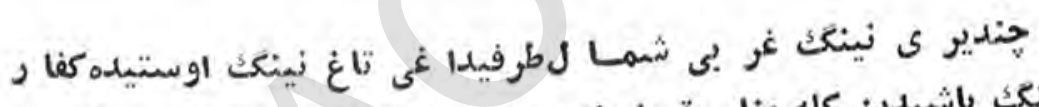

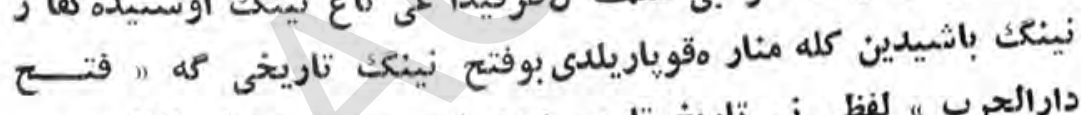
داراكرب " لفظى نى تاريخ تا يبيبايدى لار .مين موندا ق باغيلاديم :

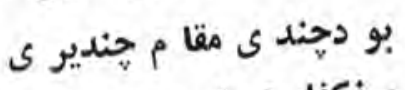

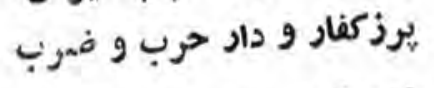

$$
\begin{aligned}
& \text { قتت كرد م به حرب قلعة او } \\
& \text { كشت تاريخ : فتنح دارالحرب }
\end{aligned}
$$

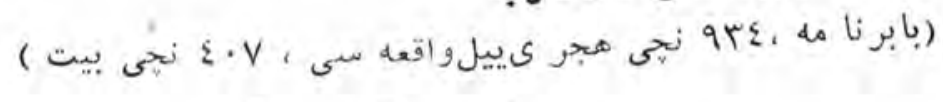
همايونغه مشتا ق ليق لار بيلهسا غينيب سلام ديكا ج، سوزاو ل

$$
-r \Lambda \cdot-
$$


كيم دوشنبه كو نى دبيع الاو ل آيىنينكف او زيده بيك كينه بيله بيانشيخ كيلدى لار .

خط لاردين و عرضه دا شــــــاردين اول يوز دا كمى ،بو يوزداكى

كيفيت و حا لات مشخصو معلو مبولدى .

$$
\begin{aligned}
& \text { شكر، بير ميش سنكا حق فرزندى } \\
& \text { سنغا فرزند و منعا دلبندى }
\end{aligned}
$$

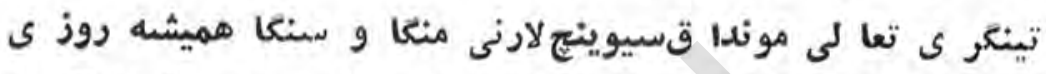

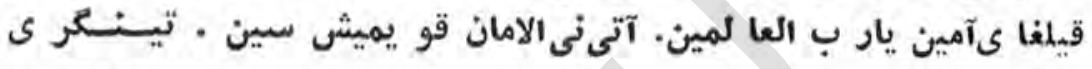

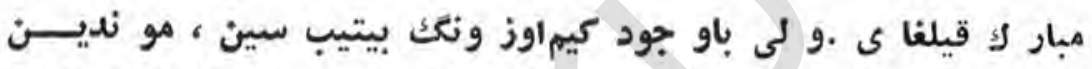

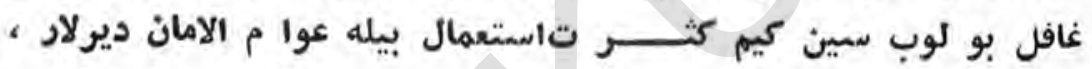

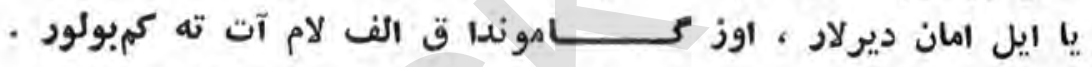

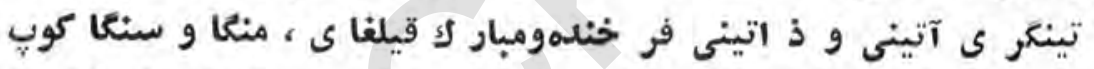

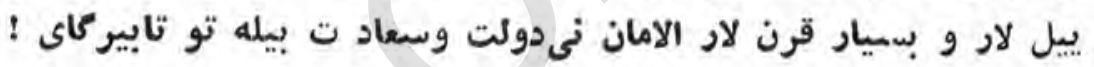

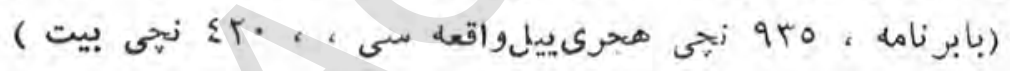

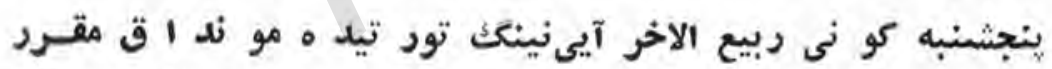

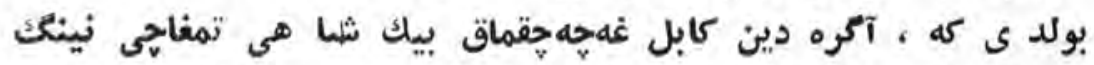

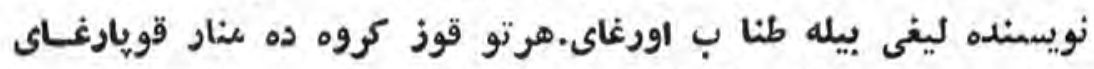

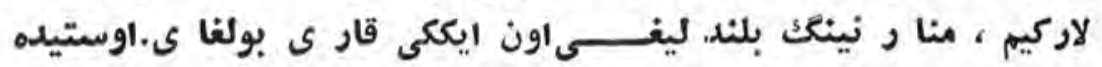

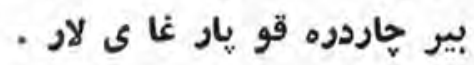

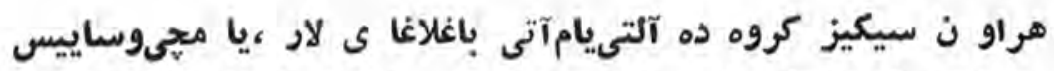

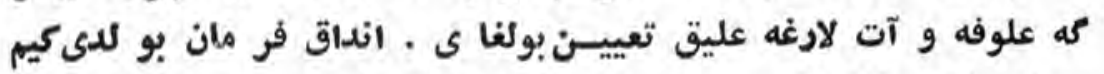

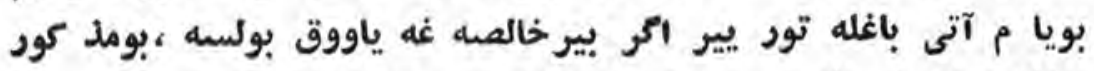

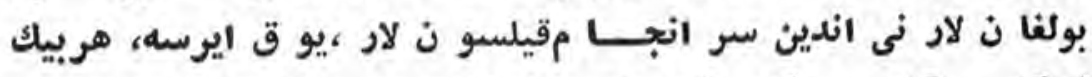

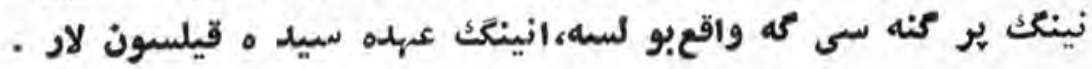




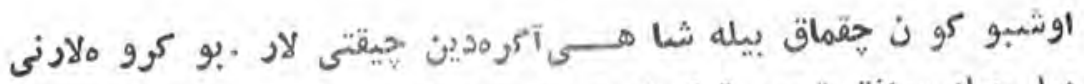

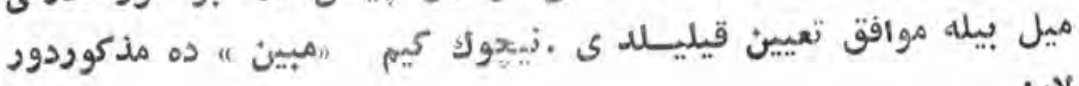

$$
\begin{aligned}
& \text { تورت مينكغ دور قدم بيله بيسر ميل } \\
& \text { بيركوو ه آنى هند ايلى دير دور بيل بيل يدريل }
\end{aligned}
$$

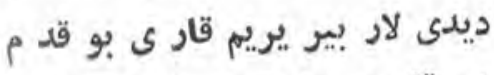

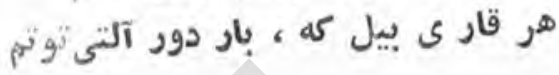

$$
\begin{aligned}
& \text { هوتوتم تور ت ايليك ، ينه هر ائبائك }
\end{aligned}
$$

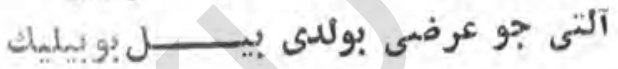

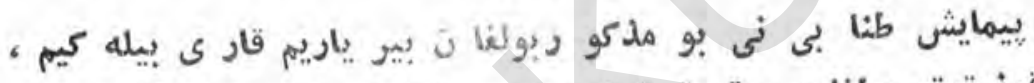

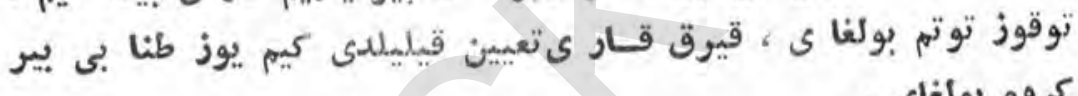

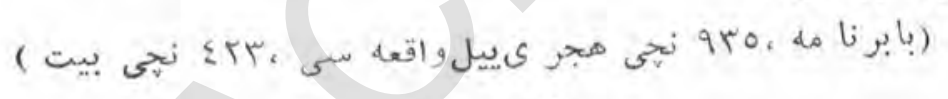

سه شنبه مبا حى ، عيدنمازينى اوتا ب آثلانيلد ى. اون كروه يو ل

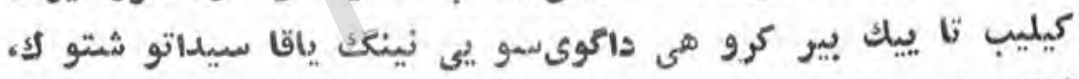

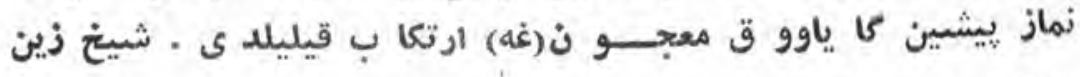
وملا شها ب وخواند امير غهبوغينه بيتنى ييبار يب تيلا دو دو كو :

$$
\begin{aligned}
& \text { شيخ و ملا شهب بوخواند اميسر }
\end{aligned}
$$

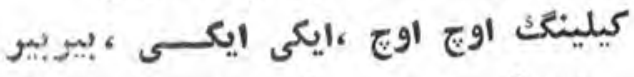

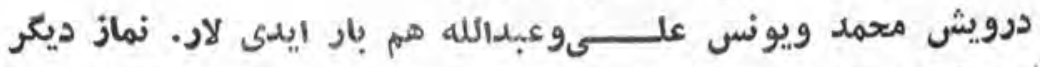

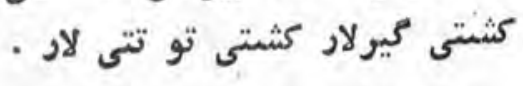

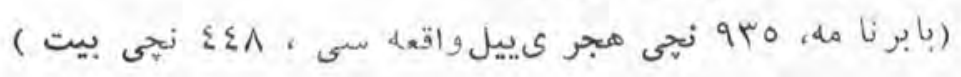


يكشنبه كونى ترلكوهند أمراسينى(إخلوت خانه)) ده جار لاب كينكاـ

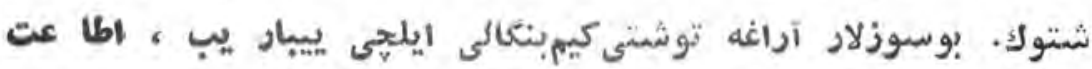

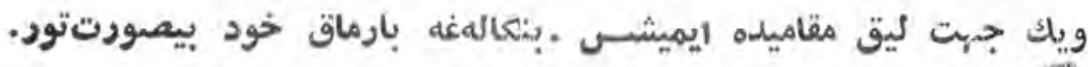

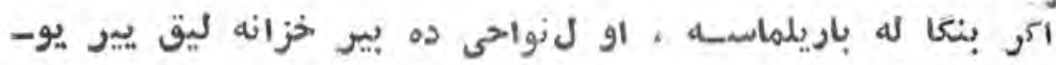

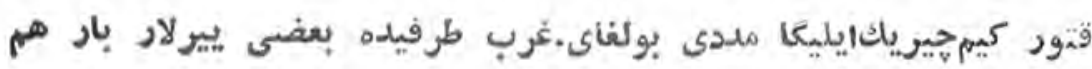

$$
\text { يأووق دورو هم خزانه سيى بازدود. }
$$

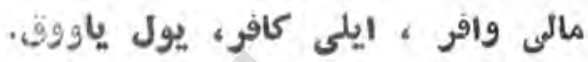

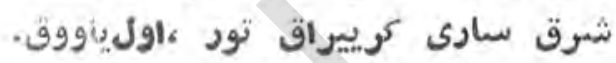

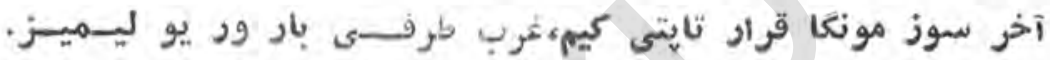

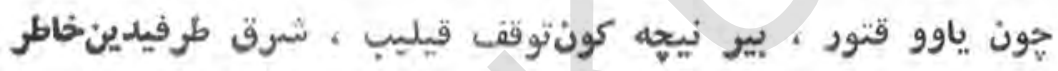

$$
\begin{aligned}
& \text { نى جمع قيليب ، بار يلسهاهمبولودور. }
\end{aligned}
$$

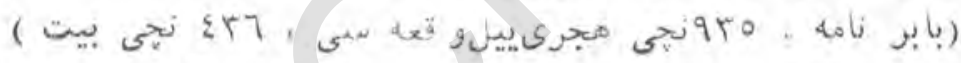

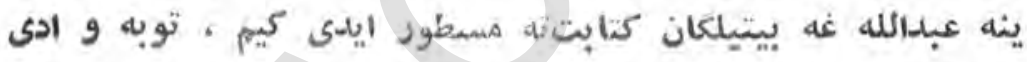

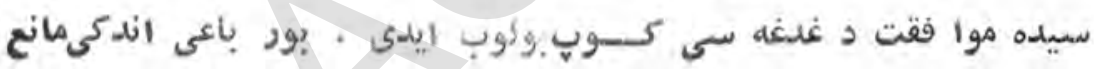
: sis?

مى تركينى ويلنالى يريشان دورمين بيلمان قيلورايسميمنى و حيران دورين مين

$$
\text { ايل بارحه يشيمان بوأودو توبهقيلود }
$$

مين توبهقيليبمئ و هشيمان دور مين

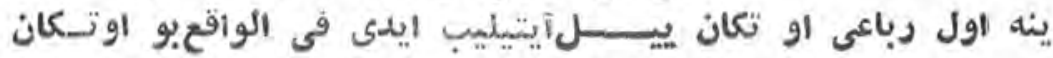

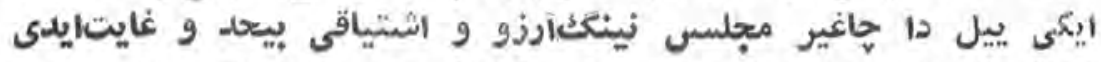

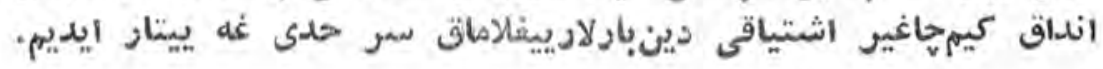

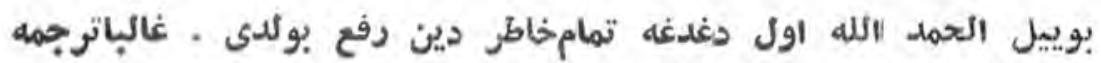

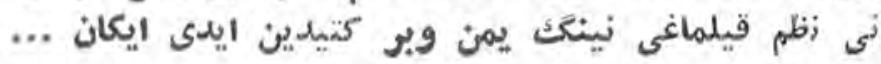

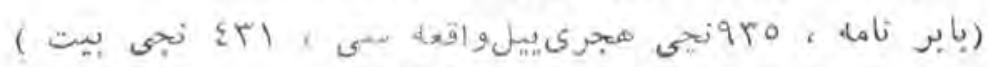




$$
4-0 l \dot{A}=\ddot{A}=\dot{R} \mid
$$

9

$$
\text { فهز ستاسماى خاص }
$$




\section{لغنتفاسئهد يو ان با بر}

\section{(T) (T) ( حرفى}

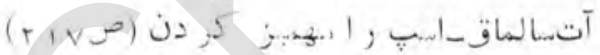

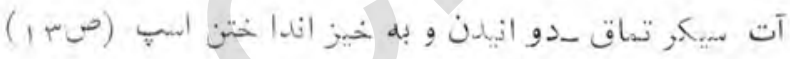

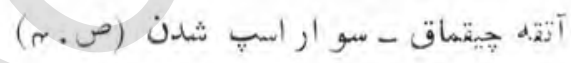

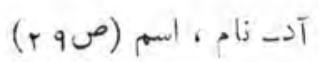

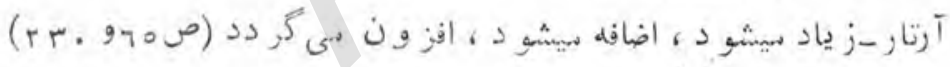

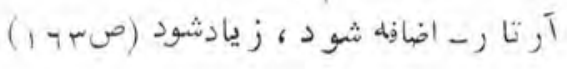

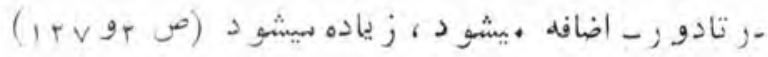

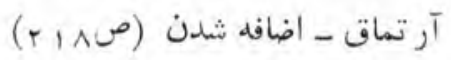

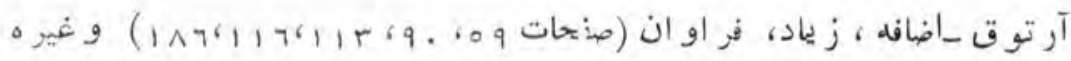

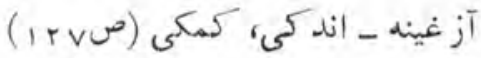

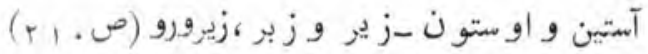

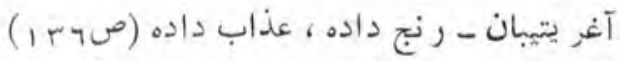

$$
\begin{aligned}
& \text { آغر يق سر يضى، درد دو رنج (صابح) } \\
& \text { آغنار - بىلو لد ، لول بيخو رد (ص. r) }
\end{aligned}
$$




$$
\text { آل - سر خ، احمر (صvivi) }
$$

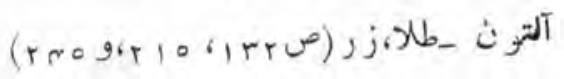

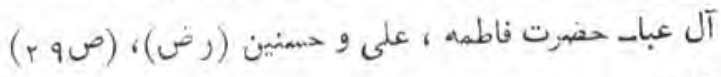

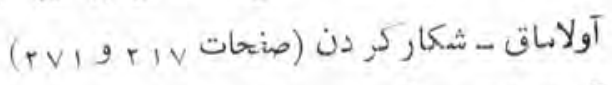

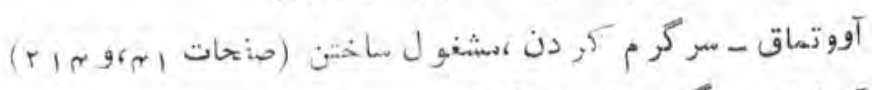

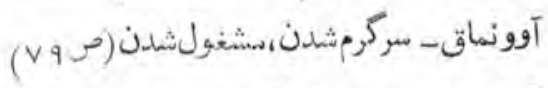

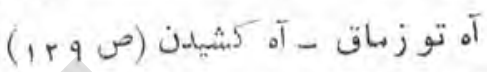

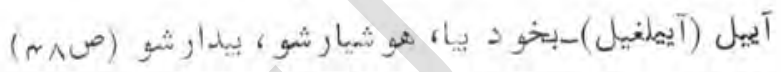

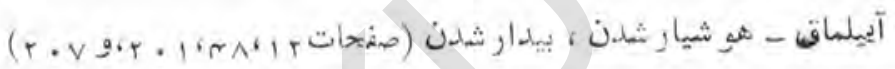

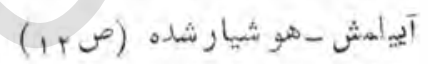

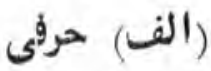

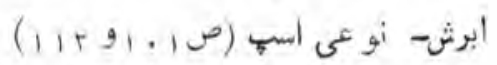

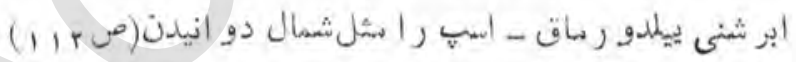

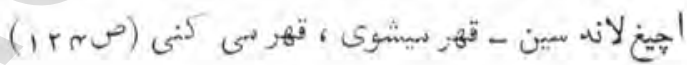

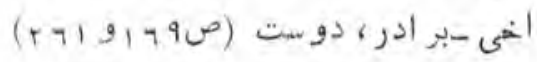

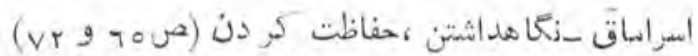

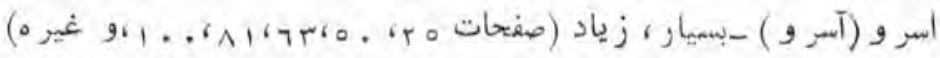

$$
\begin{aligned}
& \text { اشر بله - نوشيدنيها (ص r r r) }
\end{aligned}
$$

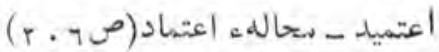

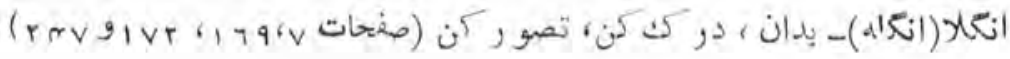

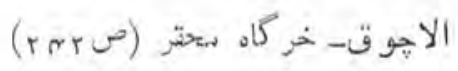

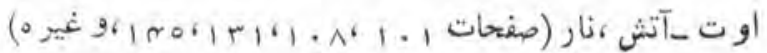

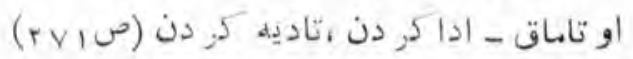

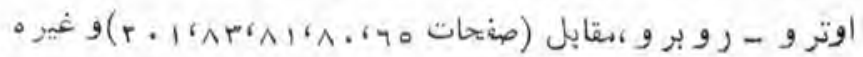




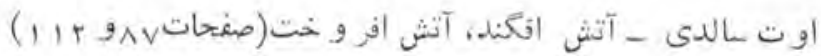

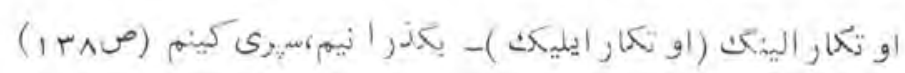

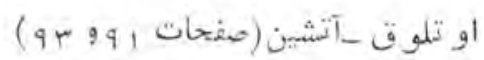

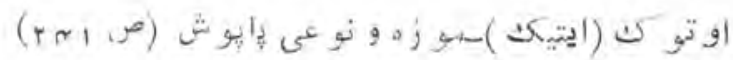

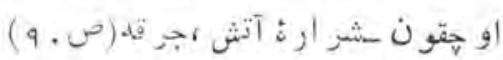

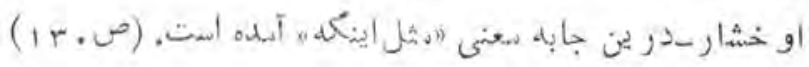

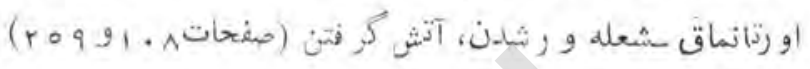

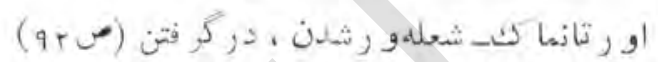

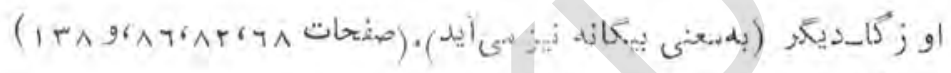

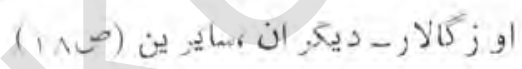

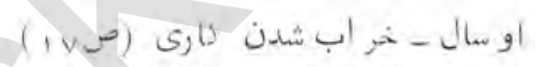

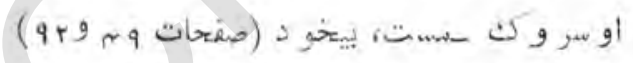

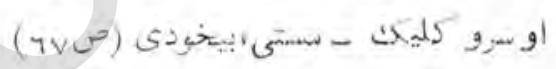

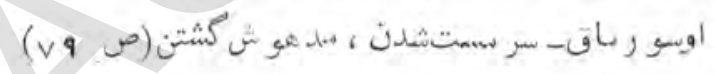

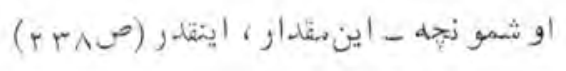

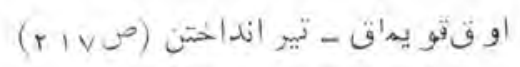

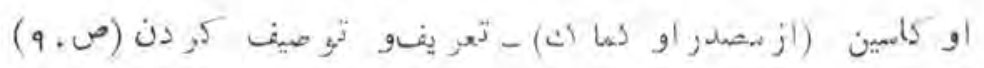

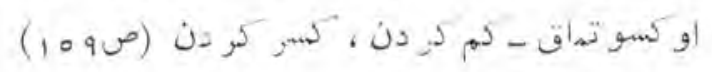

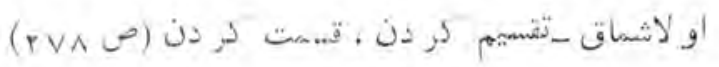

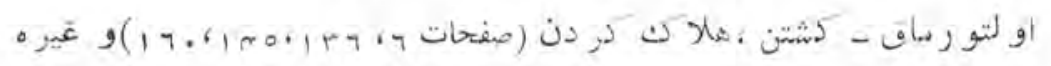
او لتو و و ر-مشيد ، او لماغو سى - :

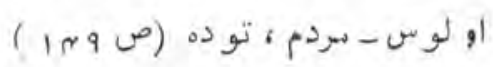




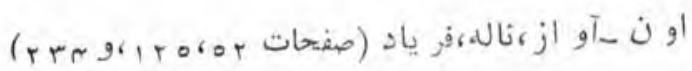

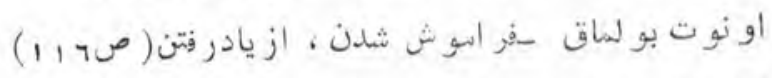

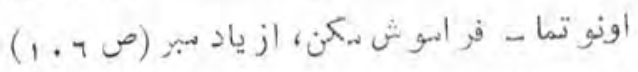

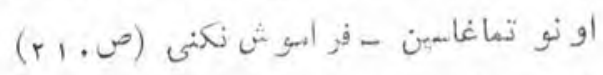

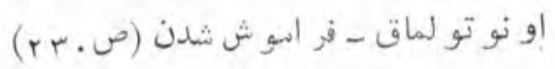

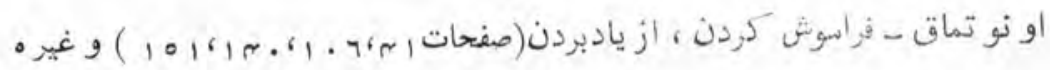

$$
\begin{aligned}
& \text { إd }
\end{aligned}
$$

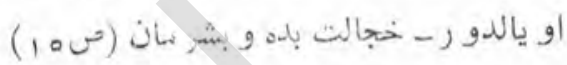

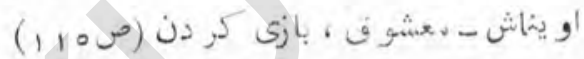

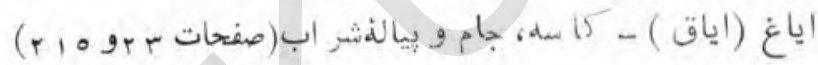

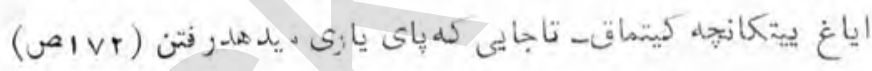

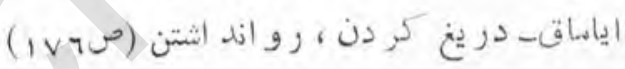

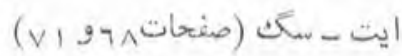

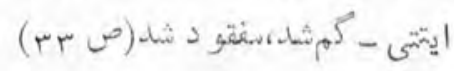

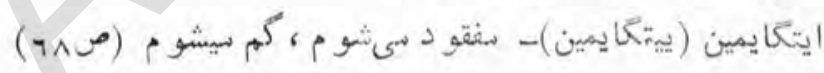

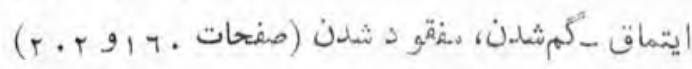

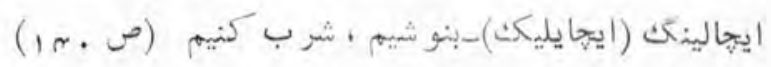

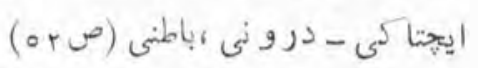

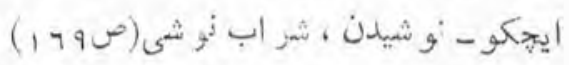

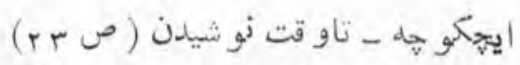

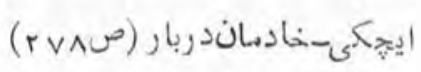

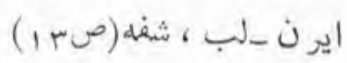

ايسان - سلانت ، صحتمنل (صبr 1 1)

ايسلاسام - بيو يم ، استشمام كنم (ص م مo ) 


$$
\text { ايسيتماق -تب كر دن،تب آلو ده شدن (صنrمر) }
$$

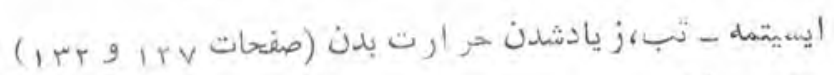

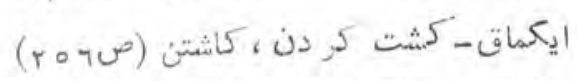

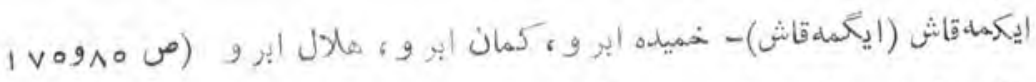

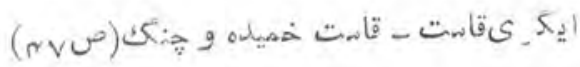

$$
\begin{aligned}
& \text { ايكماقه - خميلده قانت (صسrr ) }
\end{aligned}
$$

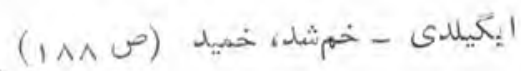

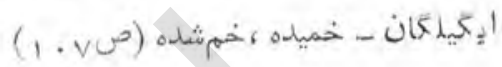

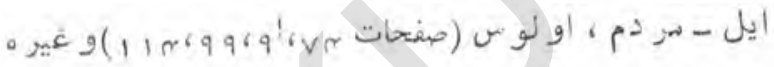

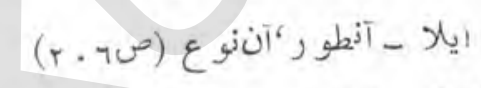

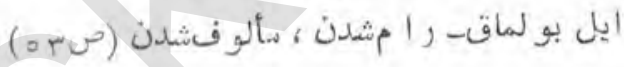

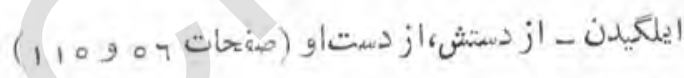

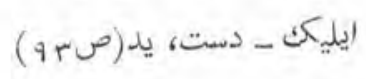

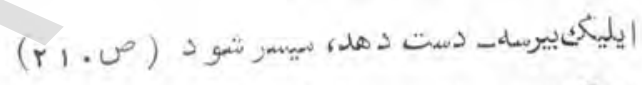

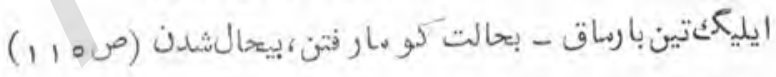

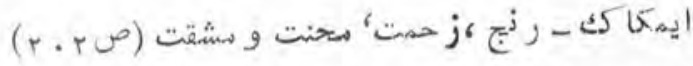

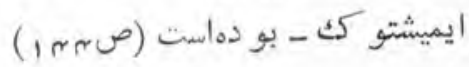

$$
\begin{aligned}
& \text { اينجو - در، كو هر (ص v v (v) }
\end{aligned}
$$

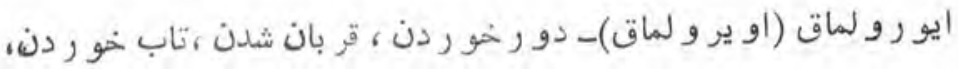

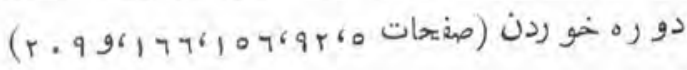

$$
\begin{aligned}
& \text { ايو رو لو ر ـ دو رخوردن (ص ردان) }
\end{aligned}
$$

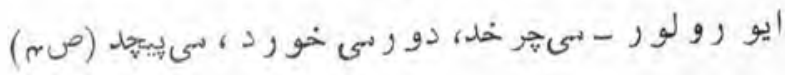




$$
\begin{aligned}
& \text { ايو ساق (يو و ماق ) - شيستن (ص rrr) }
\end{aligned}
$$

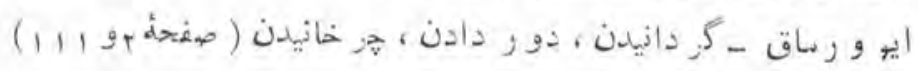

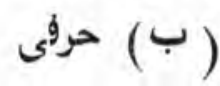

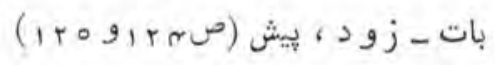

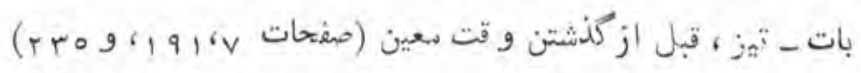

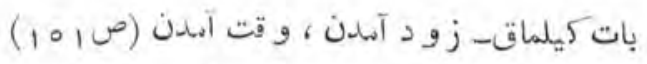

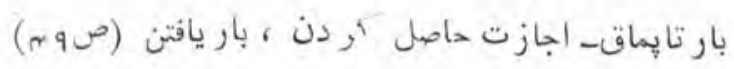

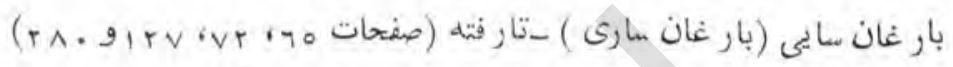

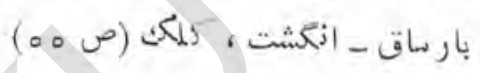

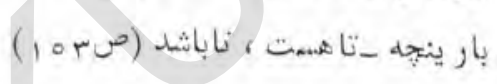

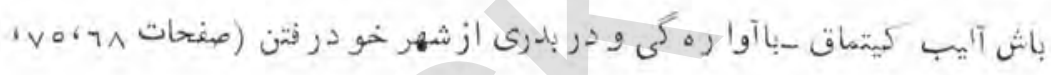
.0.

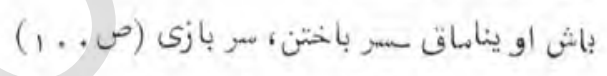

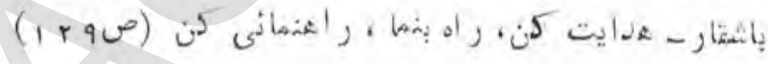

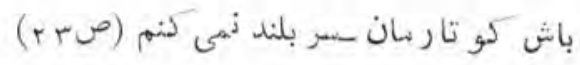

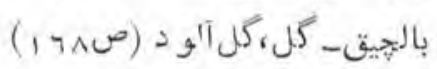

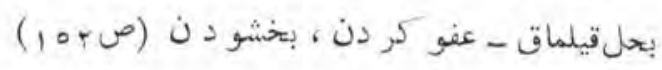$$
\text { بر - ماصل، ثمر (ص م1 1) }
$$

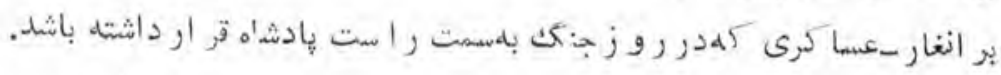

$$
\begin{aligned}
& (r \vee \cdot v)
\end{aligned}
$$

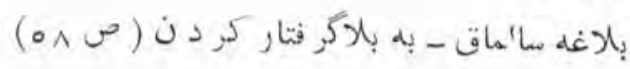

$$
\begin{aligned}
& \text { بهادو ر - دلاو ر، شجيع (صوr) } \\
& \text { بو تتو زكك - تبعيت كر دى ، باو ركر دى (ص . س ا) } \\
& -59+
\end{aligned}
$$




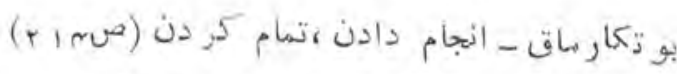

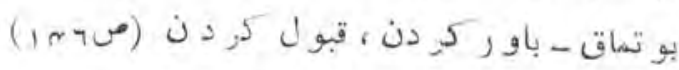

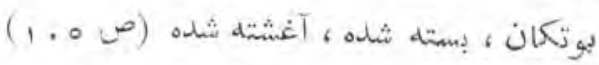

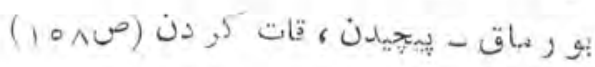

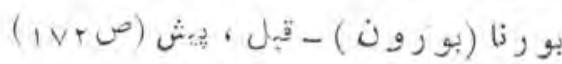

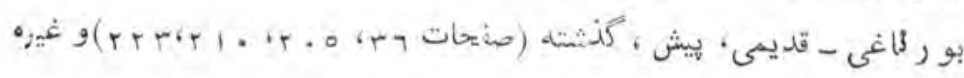

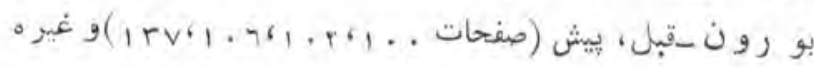

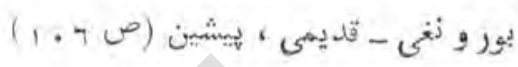

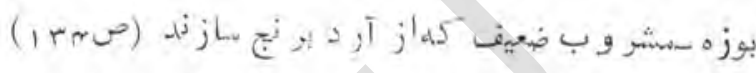

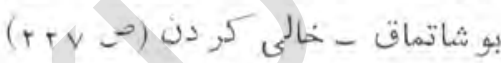

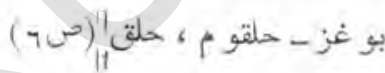

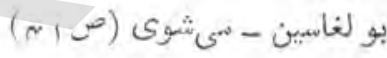

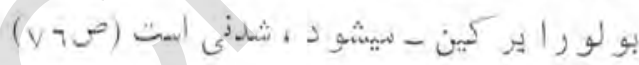

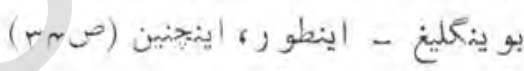

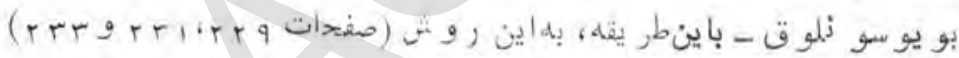

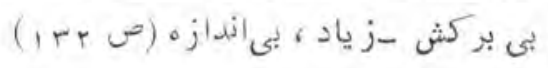

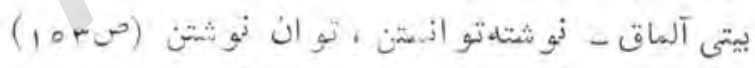

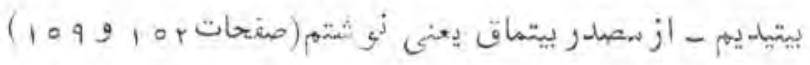

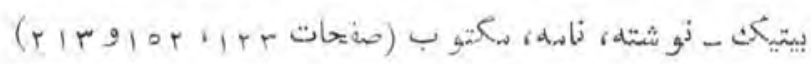

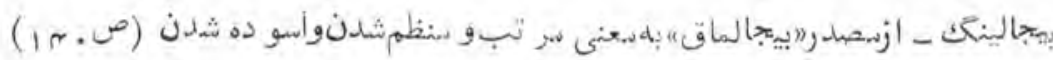

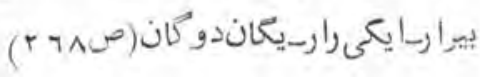

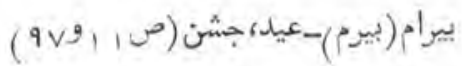

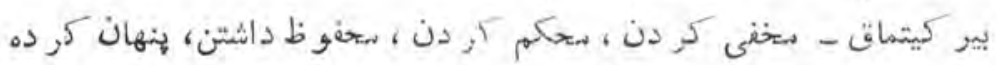
(v०و. (vف) ) 


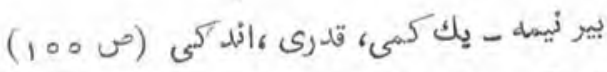

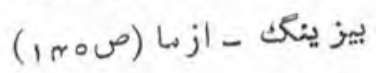

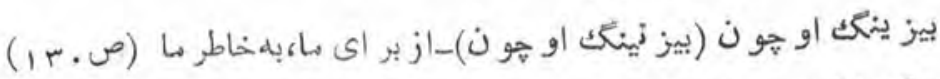

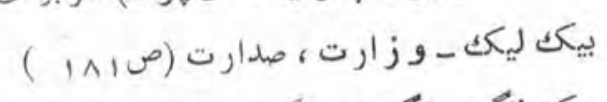

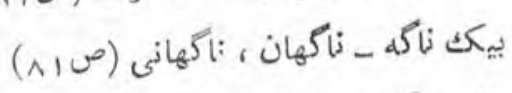

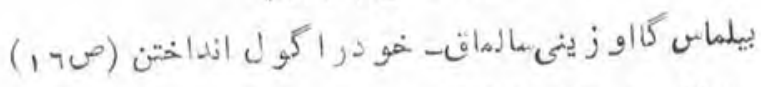

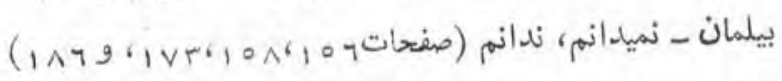

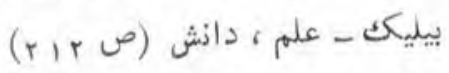

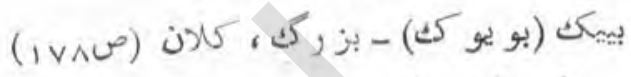

\section{( ب) حرفى (ب)}

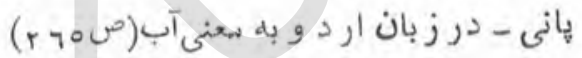

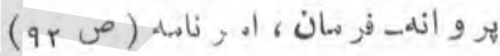

( $)$ ( )

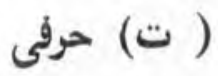

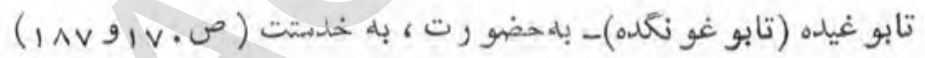

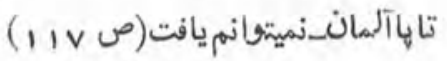
تاتسام - بجششم ، حاشنى كير م(صنمه )

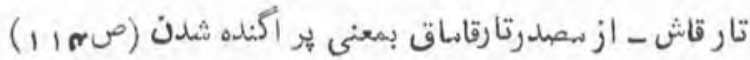

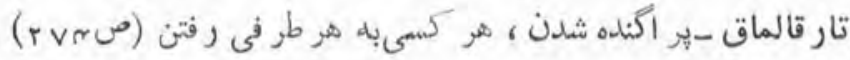
تار ماشتو كثه بيو ست شديم ، نز ديكك ثديم (ص V V r) تاش - بير ون ، خلرج ( صفحات

تام -بام، بام خانه (صvردو و r 1)

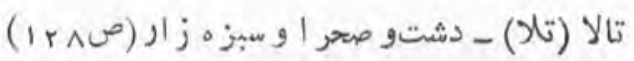

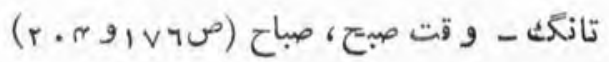




$$
\text { تانغ }
$$

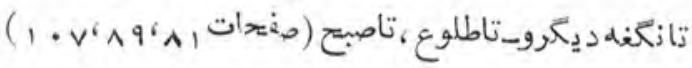
(rtagr

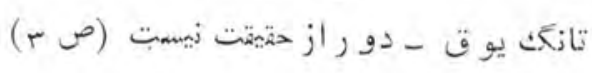

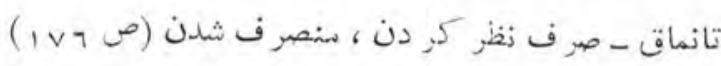
تبار كثـنام سو ره يى است ازقر آن متجيد (صvه 1 ) تبراقيلماق - صر ف نظر كر دن (صدم 1 1) تحسر -حسمر ت،افسيوس (ص0\%) تذهيب -ز يب و ز ينت، زرزكارى (صrrr) تر كعلار-ز يبار و يان (صrr)

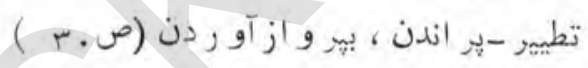
تظلمه- داد خو اهى ، داد خو استن (صیى (ص)

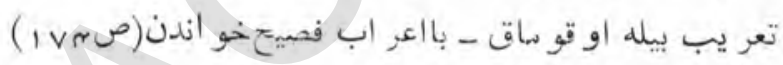

$$
\begin{aligned}
& \text { تنكتنكن - كو زه كو زه (ص I I ) } \\
& \text { تو تاش - بيو ست (ص. 1 ) }
\end{aligned}
$$

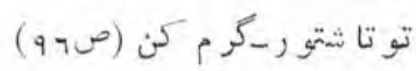

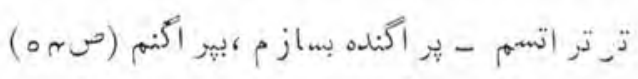

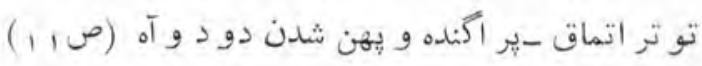

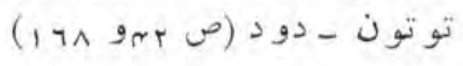

توز- دشت وصحر ا (ص rri)

$$
\text { تو سن - اسبֶ (ص. r) }
$$

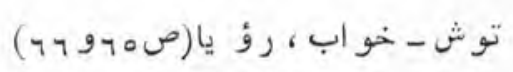


توش عولماق - روبروشدن، تقابلشندن (صrه )

$$
\begin{aligned}
& \text { تو ققان -بر ادر (ص } 17 \text { ( ) } \\
& \text { توققانليغ -بر ادرى ، اخوت (صبه ر) }
\end{aligned}
$$

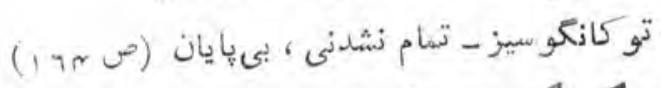

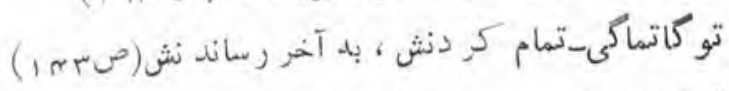

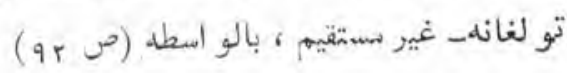
تو لغو خه - تاو قت بر شدن (صrr

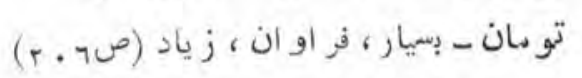

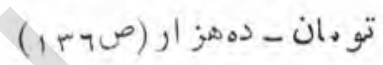

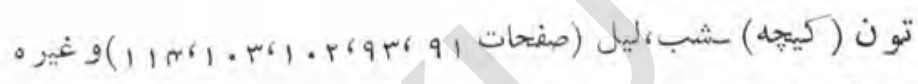

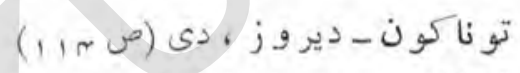

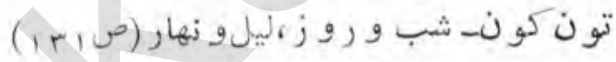

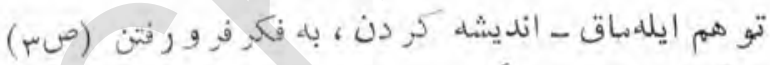

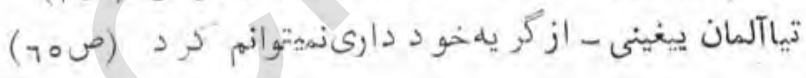

$$
\text { تياق - هو ب ، عصا (صrr) }
$$

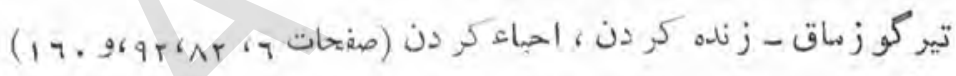

$$
\begin{aligned}
& \text { تيركو زو ر- زنده سى كنلد، احياءنى كنلد (صبrم) }
\end{aligned}
$$

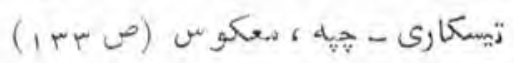

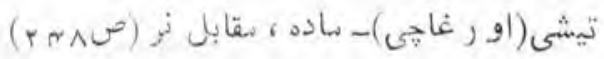

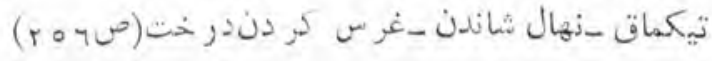

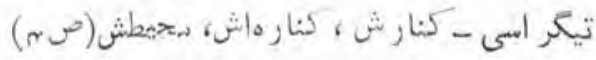

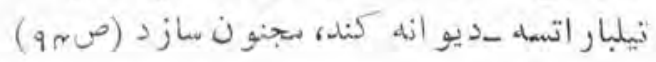

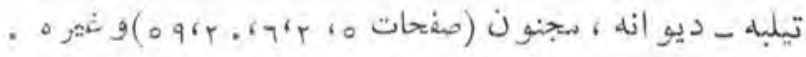

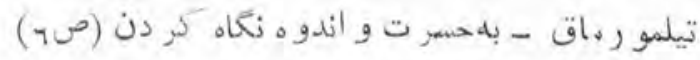

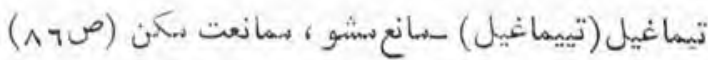




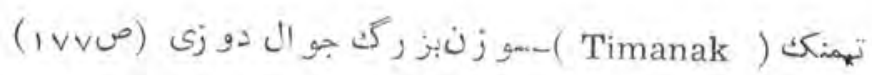

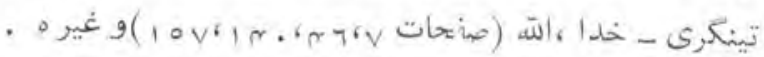

تينميز

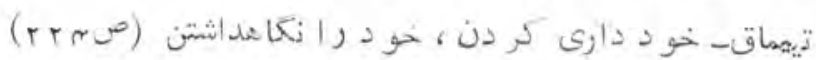

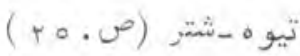
( )

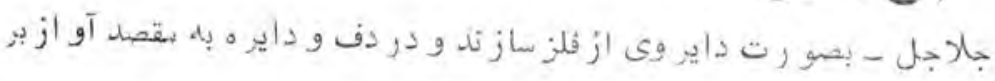

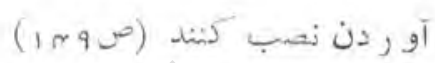

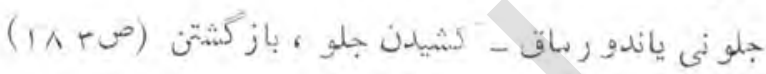

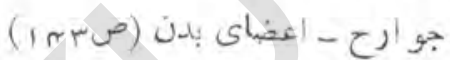

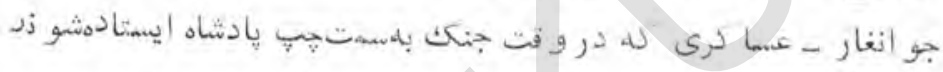
$(r \vee \cdot \omega)$

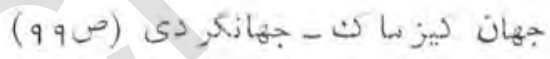

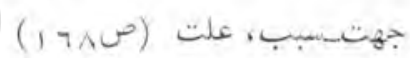

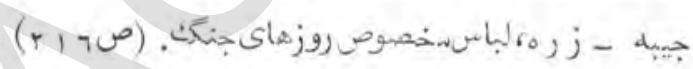
(ج) (ج) (ج)

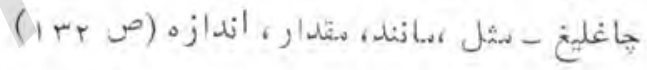

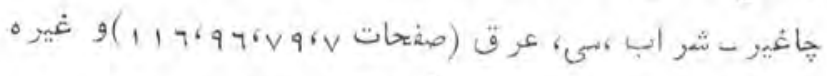

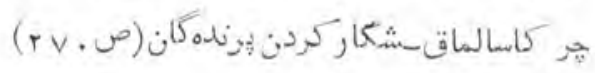

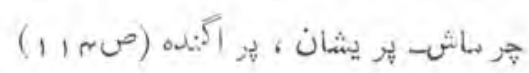

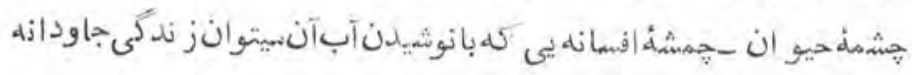

$$
\begin{aligned}
& \text { را نصمب شد (ص . 1) }
\end{aligned}
$$

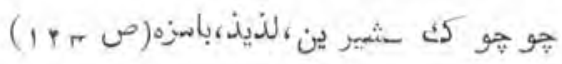




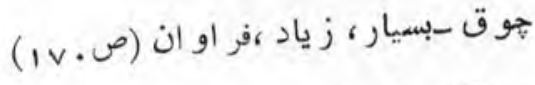

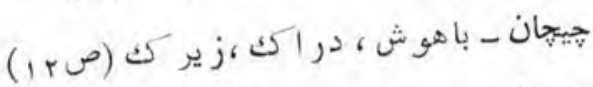

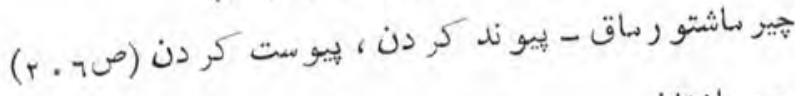

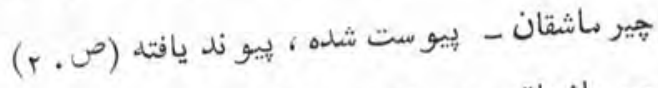

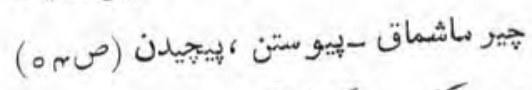

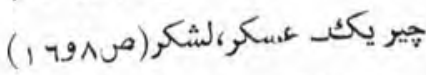

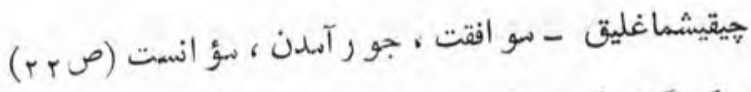

$$
\begin{aligned}
& \text { جيكماك كـ كشيدن ، بير و ن كر دن (ص ه) } \\
& \text { קين - ر است ، درست (ص م. مr) } \\
& \text { (ح) (حرفى } \\
& \text { حدةث - ستخن ، كلايم (صنr } \\
& \text { حيات سو يى - آب حيو ان (ص 1 1 1) }
\end{aligned}
$$

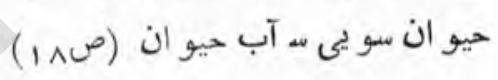

$$
\begin{aligned}
& \text { ) حرفى } \\
& \text { خالى ايمانـ - فارغ نيستم (ص. r r (r) } \\
& \text { خد - رخسار ، كو نه (ص م 1) }
\end{aligned}
$$

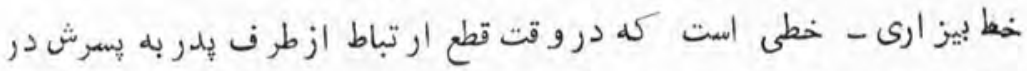

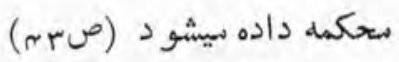

خط سيغناقى - خط سنسو ب به سيغناق و أقع درتر كستان شرقى (صr r)

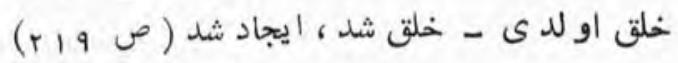

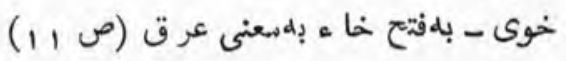




$$
\begin{aligned}
& \text { (د)حرفى } \\
& \text { داد بير دى- عدل كر د ، داد داد (صصو ب) }
\end{aligned}
$$

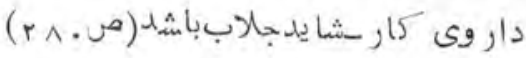

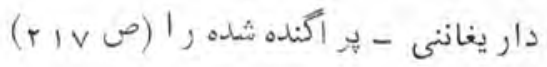

$$
\begin{aligned}
& \text { دنكانه ــ انديو الى (صس 1) } \\
& \text { دزكَك ايل - سر د م ابله و احمق (ص ح V) } \\
& \text { دو تاره (د و تار )-نام آله سو سيقى (ص. 1 1) }
\end{aligned}
$$

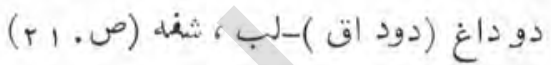

$$
\begin{aligned}
& \text { دو ستلارد ين ايل يو ماق - ازدو ستاندست شستن (مى ميرا) }
\end{aligned}
$$

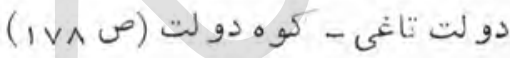

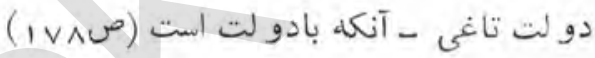

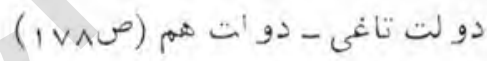

$$
\begin{aligned}
& \text { دى-بكو،حرفبزن(ص اسم } 1 \text { ) }
\end{aligned}
$$

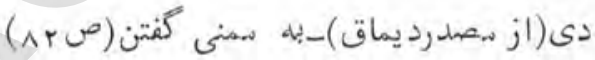

$$
\begin{aligned}
& \text { دى برج جاى وآن ساه د همم سعال شمسى است (صד ه ) } \\
& \text { ديار- - ز نده جان (صv) } \\
& \text { ديز سمعبد ز رد شتيان(صجن) }
\end{aligned}
$$

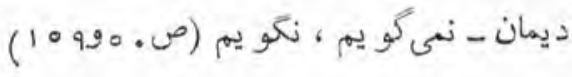

$$
\begin{aligned}
& \text { ذو فنون - صاحب فن ، صاحب كمالات (صو ح) } \\
& \text { (ر) حرفى }
\end{aligned}
$$

ر است - بدو معنى : ا-ددرست كر دن م - سقام ر استدر سو سيقى (ص م)

$$
\text { رصاص - ارز يز، قلعى(صهم) }
$$




$$
\begin{aligned}
& \text { رم قيلماق - ر ميدن ، و حشت ز زه شدن (صv r 1 ) } \\
& \text { روتى - دورزبان اردو بلهعنى نان (صهمجr) }
\end{aligned}
$$

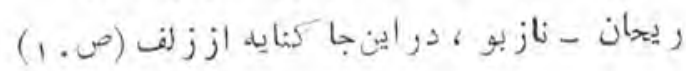

$$
\begin{aligned}
& \text { ( س) حرفي }
\end{aligned}
$$

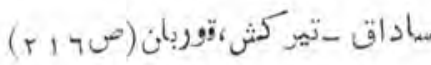

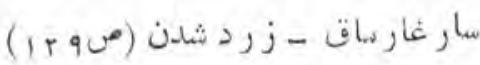

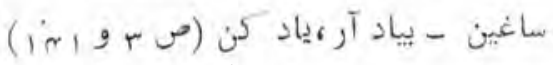

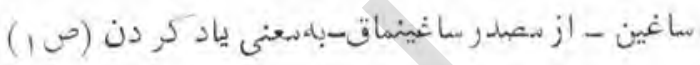

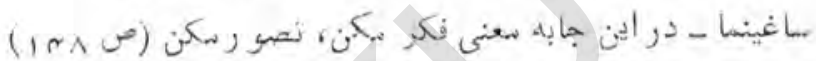

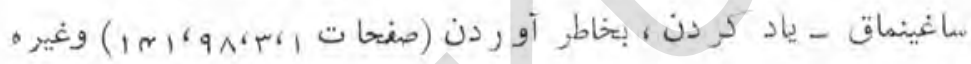

ساغينغاسين- ديادخواهي

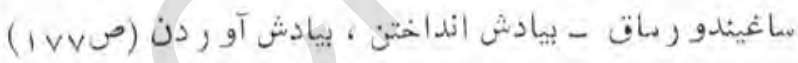

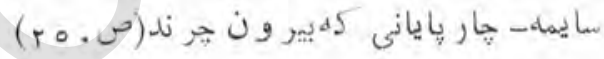

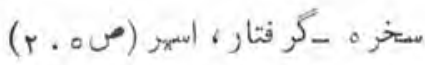

$$
\begin{aligned}
& \text { سو رار - مو الل ، بر سش (صو 1) }
\end{aligned}
$$

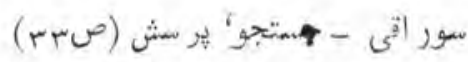

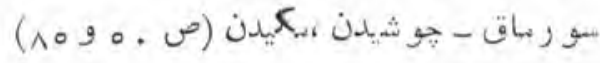

$$
\begin{aligned}
& \text { سو وو رماق - رو فتن ، جارو ب كر دن (صون) }
\end{aligned}
$$

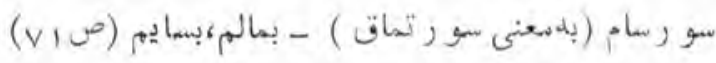

$$
\begin{aligned}
& \text { سو زلاشالينك - صتجبت كنيم(صسم1 1) }
\end{aligned}
$$

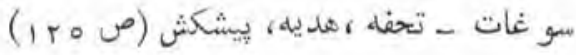

$$
\begin{aligned}
& \text { سو كو نج- دشنام (صفحاتr موبr) }
\end{aligned}
$$

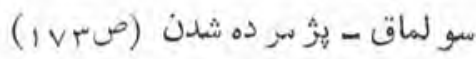




$$
\begin{aligned}
& \text { مو نكاكك - أستخو ان ،عظم (صوح) }
\end{aligned}
$$

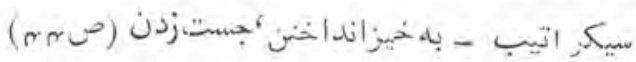

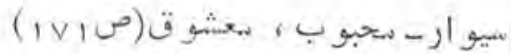

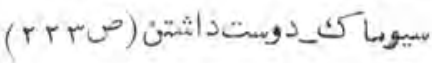

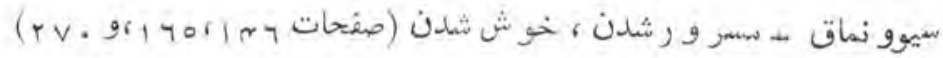

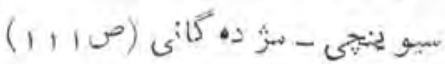

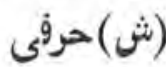

$$
\text { مئl }
$$

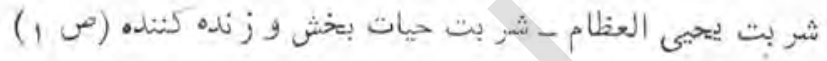

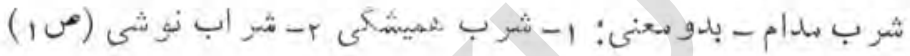

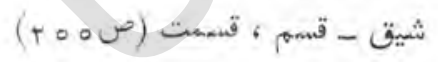

شيلايين -

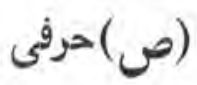

صبر اليو ب - صبر ايوب ب إيانبر (صبr (1)

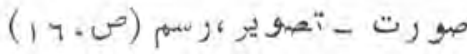

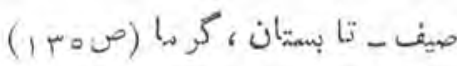

$$
\begin{aligned}
& \text { (ع) (عرفى ) بونى }
\end{aligned}
$$

عذرقو لماق - نذيزفتن عذر، قبول كر دن عذر (صوبrr)

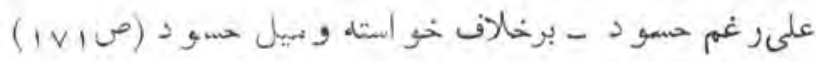

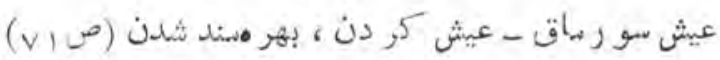

$$
\text { (غ) }
$$

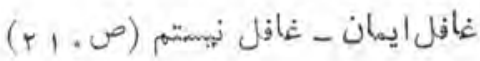

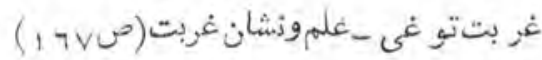




$$
\begin{aligned}
& \text { غلو - مبالغه، از حد زياد (ص } 101 \text { ) } \\
& \text { (ق) حر فىى }
\end{aligned}
$$

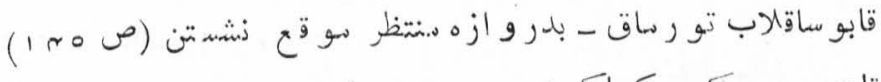

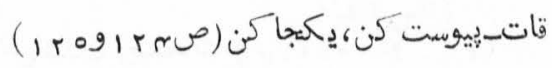

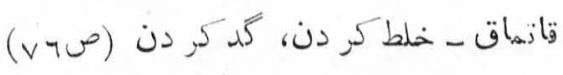

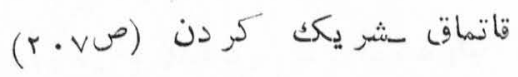

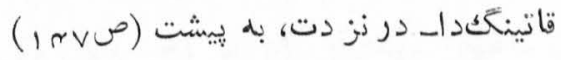

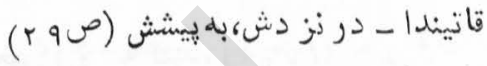

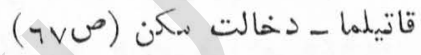

قاتيلماق - بهم ريبو ستن (ص. r r)

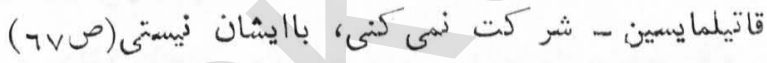

قاتيلميش - تر كيب شلده (ص مار)

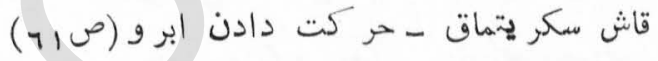

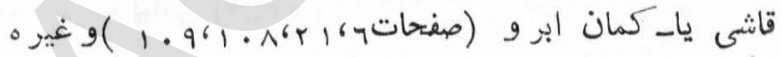

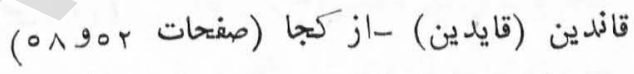

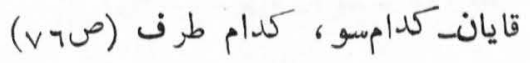

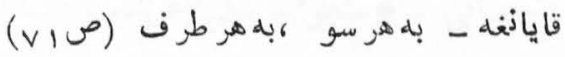

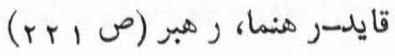

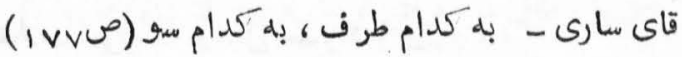

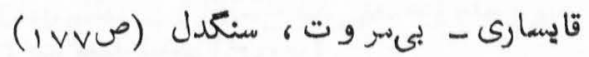

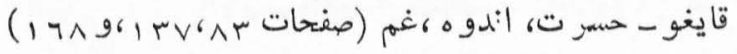

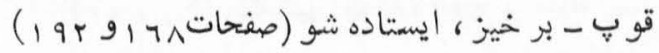

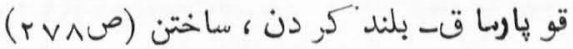

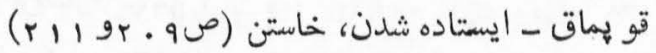




$$
\text { قوتقار دىـ نجات داد، امان داد (صحه ) }
$$$$
\text { قو تقار ديم -نجات ددادم (ص امه) }
$$

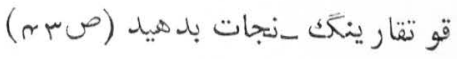

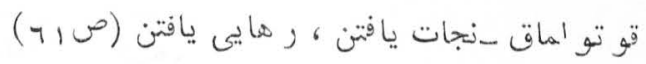

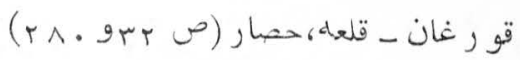

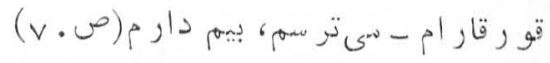

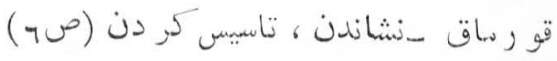
قو زغالماق - جنبش ، طنيان (صه ر )

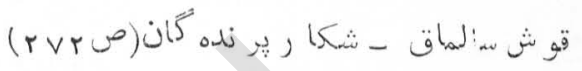

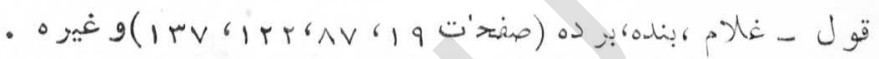

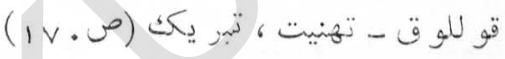

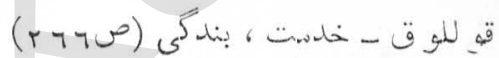

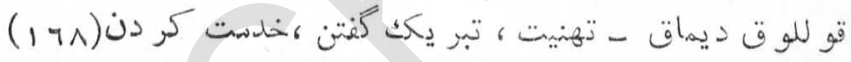

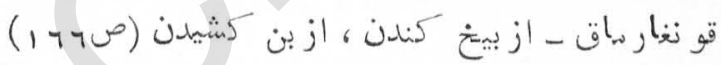

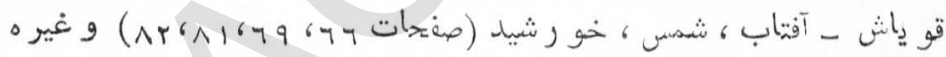

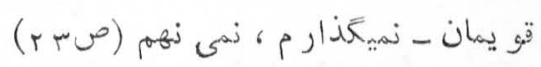

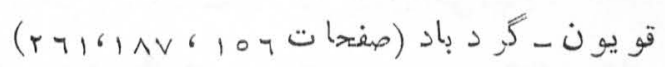

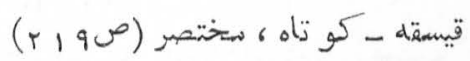

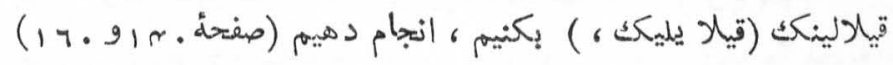

$$
\begin{aligned}
& \text { قيلمهاس كرى - نمى ار زد (ص r ا 1) } \\
& \text { (25) }
\end{aligned}
$$

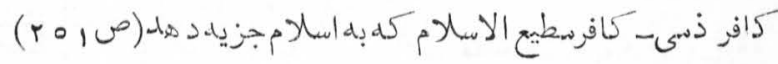

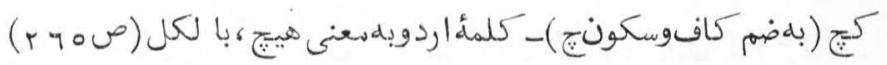

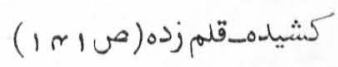

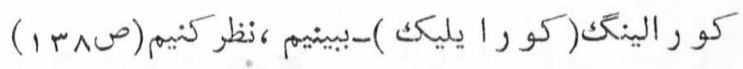




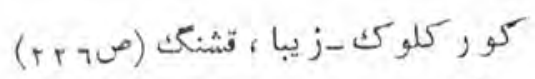

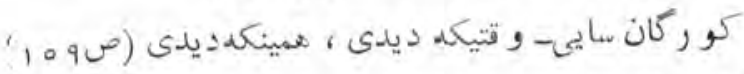

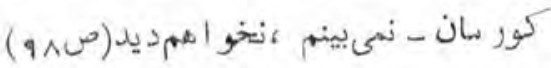

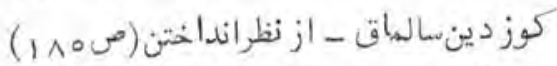

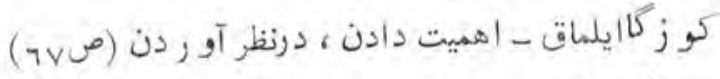

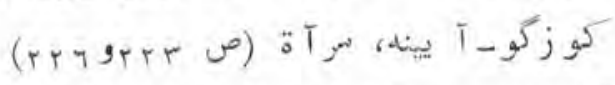

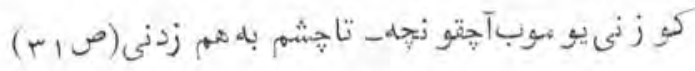

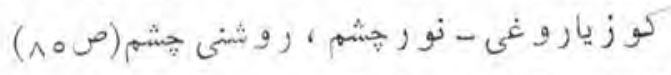

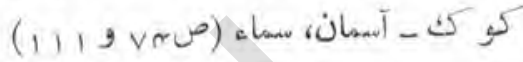

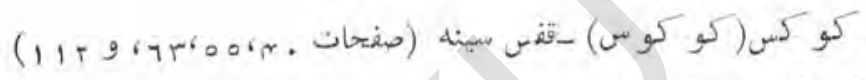

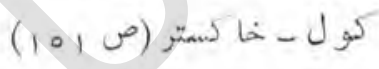

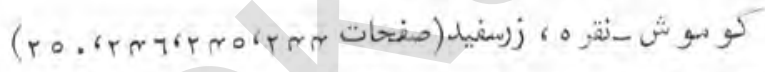

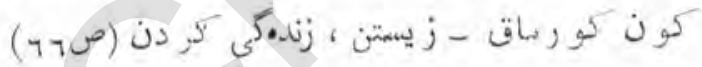

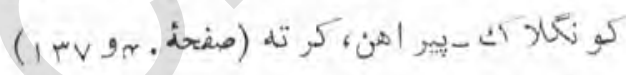

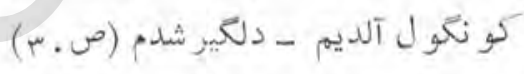

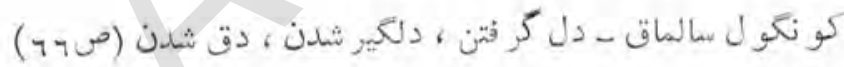

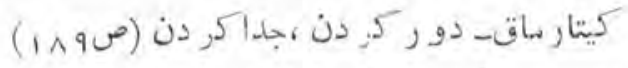

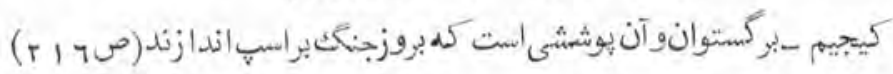

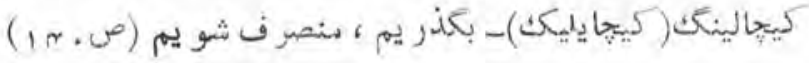

$$
\begin{aligned}
& \text { كيع قو رون - شام، بيمكاه (صوهب) }
\end{aligned}
$$

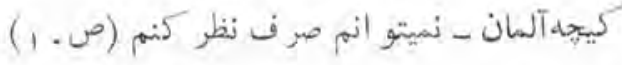

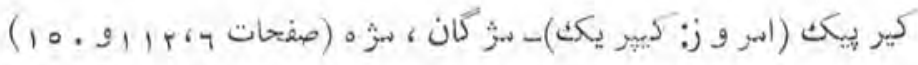

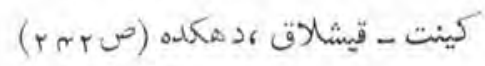




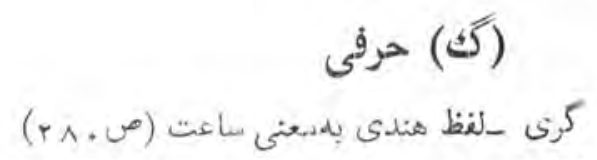

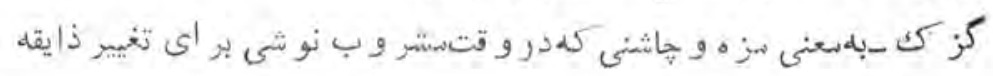

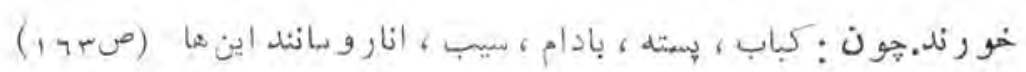

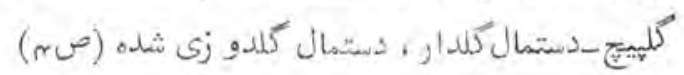

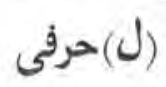

$$
\begin{aligned}
& \text { لاابالى-بىير و ا، لاقيد (صr 1 1) }
\end{aligned}
$$

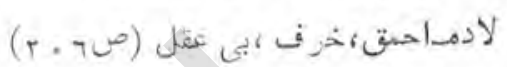

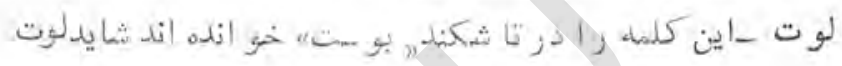

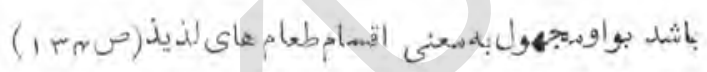

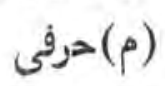

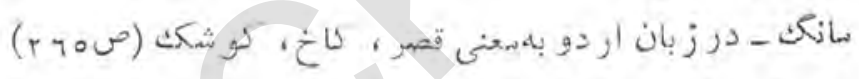

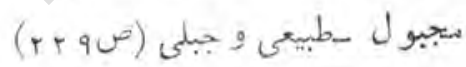

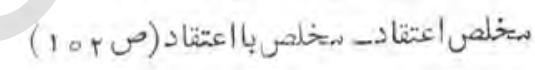

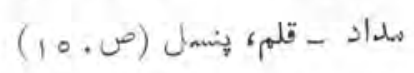

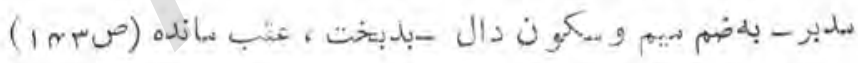

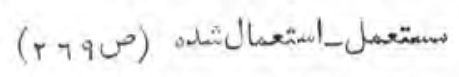

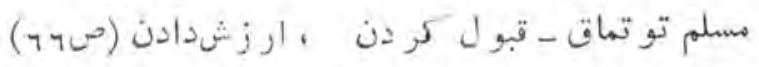

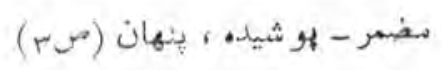

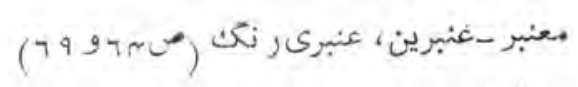

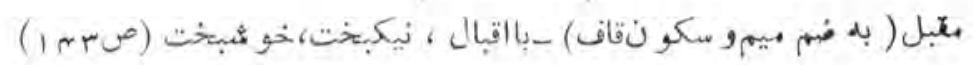

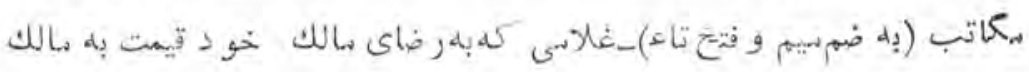

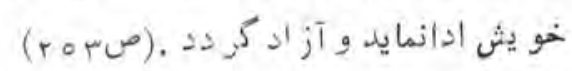

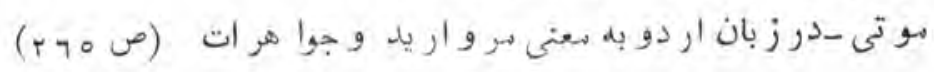




$$
\begin{aligned}
& \text { مو نهه حاغليغ - اينقدر ،اينمقدار (صv r) }
\end{aligned}
$$

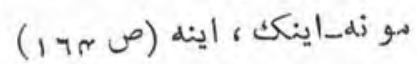

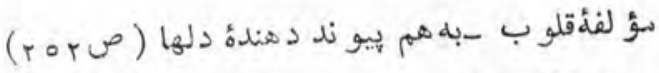

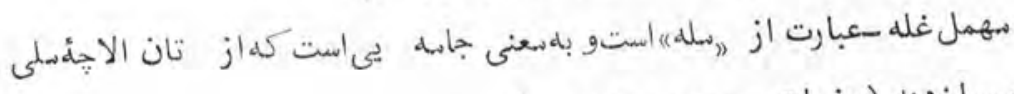

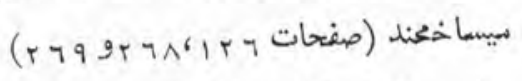

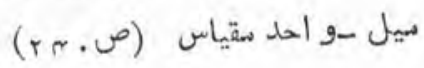

$$
\begin{aligned}
& \text { مينان - آلو (صir) }
\end{aligned}
$$

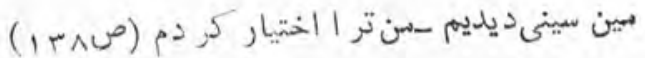

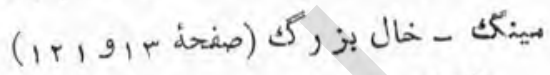

$$
\begin{aligned}
& \text { (ن) حرفى }
\end{aligned}
$$

$$
\begin{aligned}
& \text { نازتارتماق_نازبر داشتن(صrr) } \\
& \text { نال- رودةقلمنى(صمس) }
\end{aligned}
$$

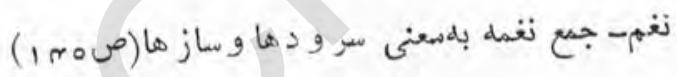

$$
\text { نو ا- بلمعنى آهنكك ، مو سيقى (10) }
$$

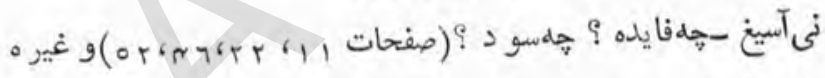

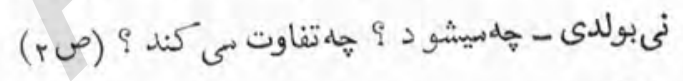

نى تانكك - عجب نيست، جاى تعجب نيست (ص بو. 9 م 1)

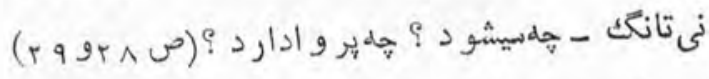

$$
\begin{aligned}
& \text { نيجهو كك- }
\end{aligned}
$$$$
\text { نى يعنى - حddevنى دارد ؟ (صفتحات rrr }
$$$$
\text { (و) }
$$

وايين-حوف،حفره (ص^ر) 


$$
\begin{aligned}
& \text { (ه) }
\end{aligned}
$$

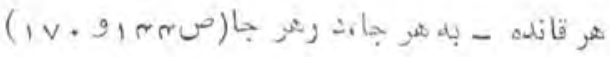

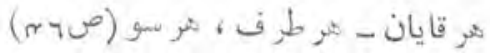

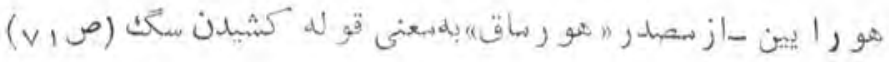

$$
\begin{aligned}
& \text { (ى) }
\end{aligned}
$$

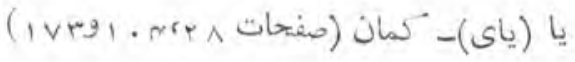

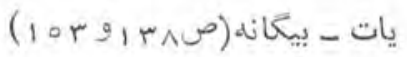

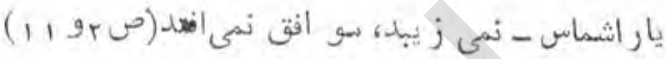

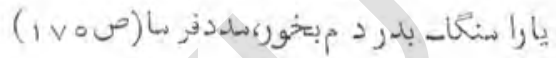

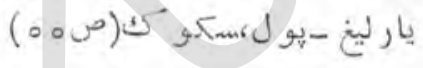

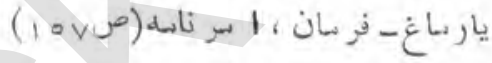

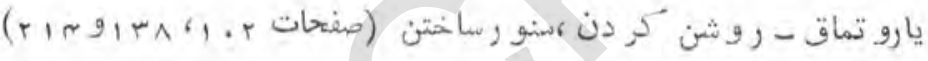

$$
\begin{aligned}
& \text { ياروق - زخمب، جر احت(صنr) }
\end{aligned}
$$

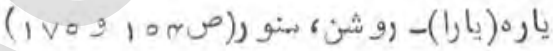

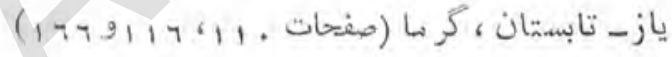

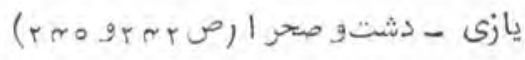

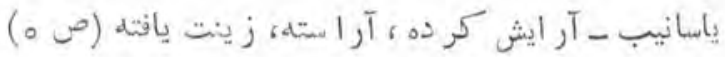

$$
\begin{aligned}
& \text { ياسال ياساساق -صفبستن، صفآرايى (ص • rv) }
\end{aligned}
$$

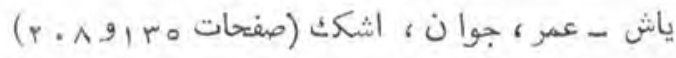

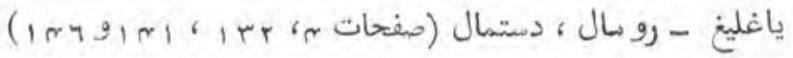

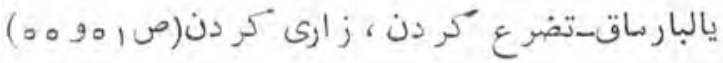

$$
\begin{aligned}
& \text { ياندا شتو رماق -نز ديكك كر دن ، در بهلو قر ارد ادن (صب • r) } \\
& \text { ياندو رماق - رخ كر دن ، دتو جه ساختن (صس ر) } \\
& \text { ياندو رماق - جلوكر دانيدن - سنهزم شدن (صrvr) }
\end{aligned}
$$




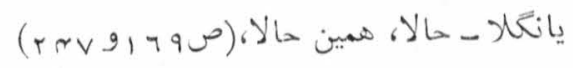

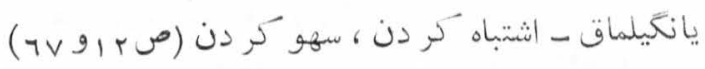
ياو و شماق - نز ديكك شدن ، جيمو ست شدن (ص. . r ) يا يقالماق -خراديدن،خرامانر اهوفتن (صrم)

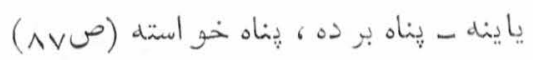

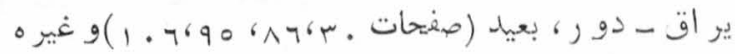
يراق ، اسباب و سامان (صه ان (r) يراق سالماق ـ دو ركر دن ، بدو را نداختن (صو 1 1)

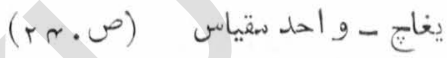

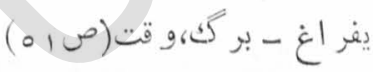

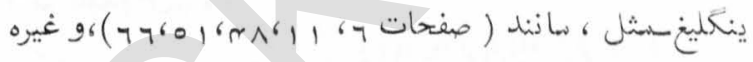

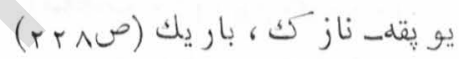
يو ز ايو رماق - رو كشتاندن (صونه)

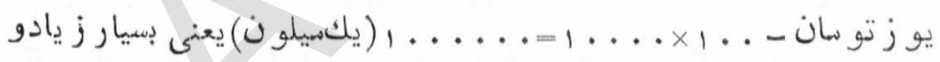

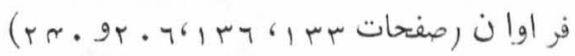
يو زقو يماق- روىنهادن،روى آو ردن (صم)

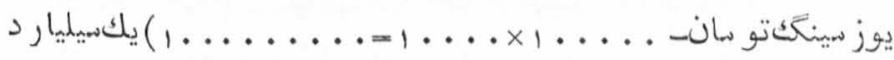
يعنى بسيار ز ياد (ص r r r) يو ز ياش-صدسال عمر (م) 1 ) يو سو نلو ق-طر يقه، طور، نوع (صr I )

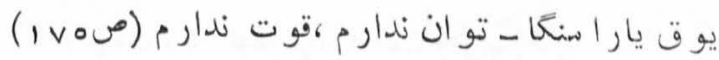
يو كو نماق - با تعظيم سرفوود آوردن رصد1 1 )

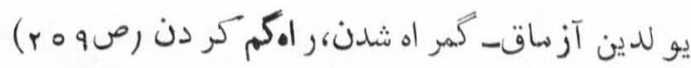




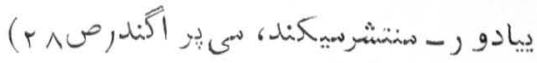

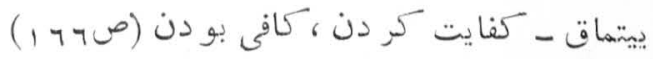

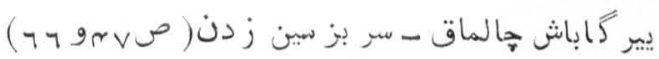

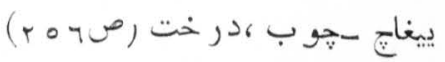

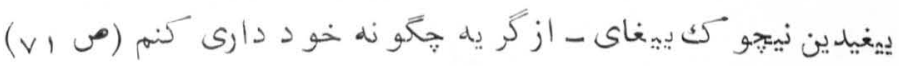

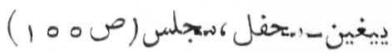

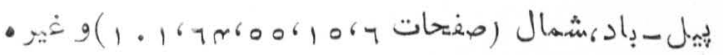

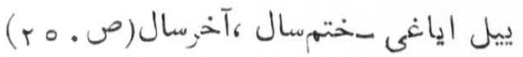

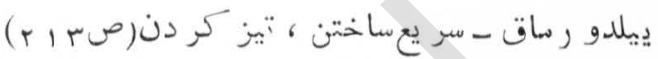

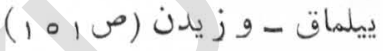

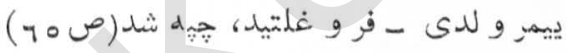

$-r+v-$ 


\section{فهو ست اسما ى مخاص}

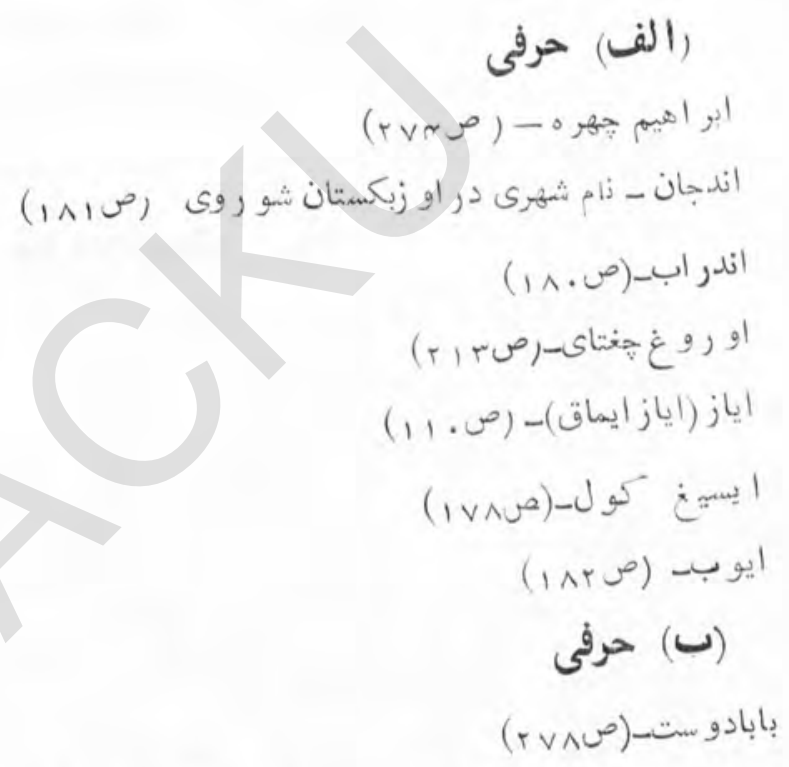

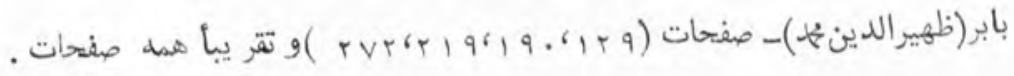

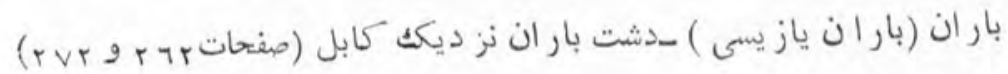

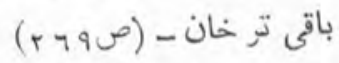

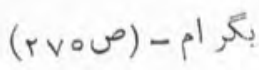

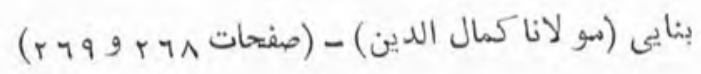




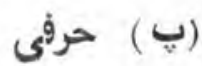

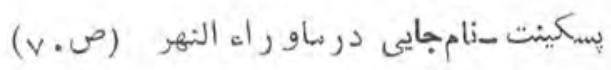

$$
\begin{aligned}
& \text { (ت) حرفى } \\
& \text { تاشكندا (ص. rv (r) }
\end{aligned}
$$

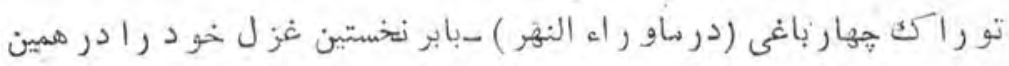

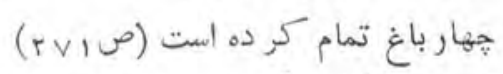

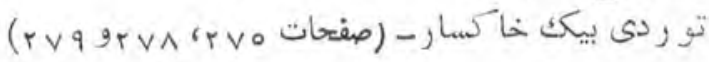

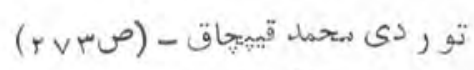

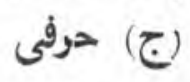

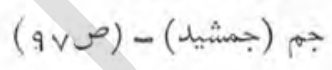

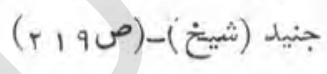

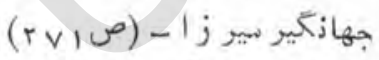

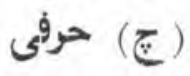

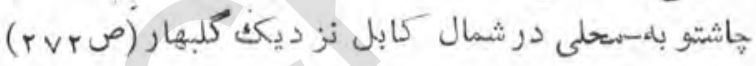

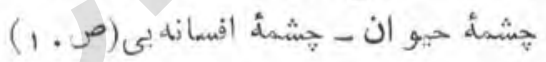

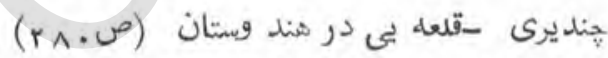

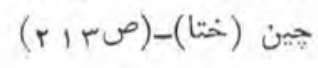

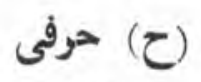

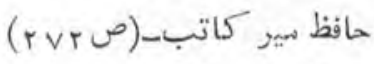

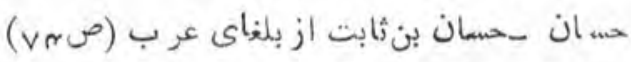

$$
\text { حوفى ) حانى }
$$

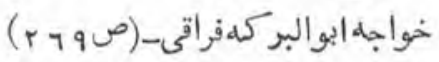

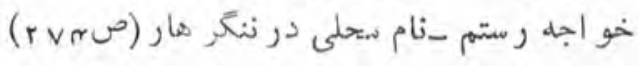

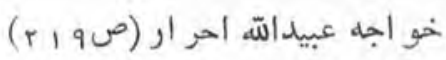

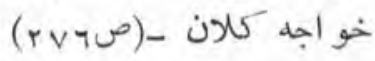

$$
\begin{aligned}
& \text { خو اجله مخمدعلى -(صrver) }
\end{aligned}
$$




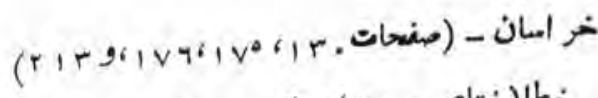

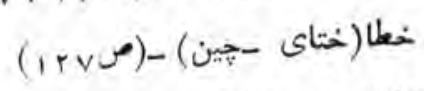

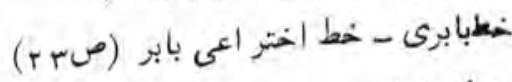

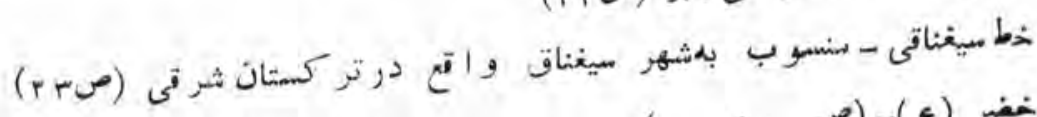

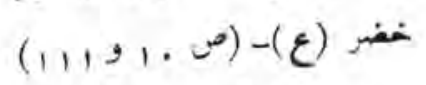

$$
\begin{aligned}
& \text { (2) حرفى ) }
\end{aligned}
$$

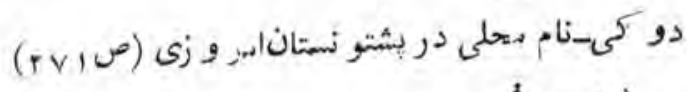

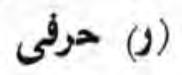

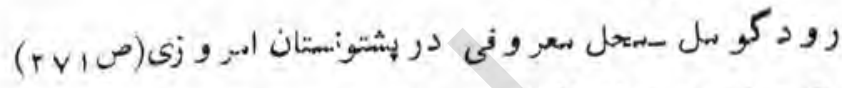

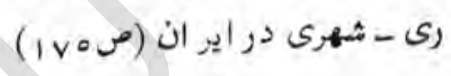

\section{(ب) حرفى )}

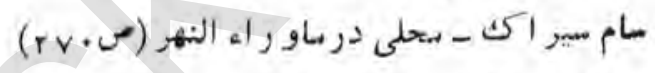

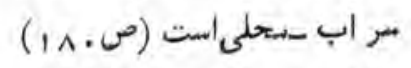

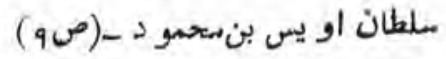

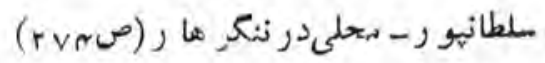

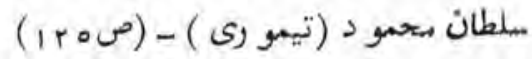

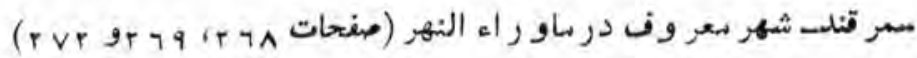

سنبل (سنبهل) _-نام شهرى ودر هندو ستان (ص ح ح r)

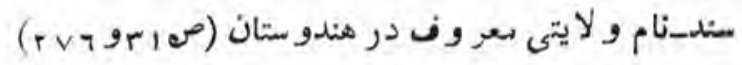

\section{(ش) حرفى}

شامر خيهـ نام شهرى درشمال تاثشكند (ص.rver)

ثامجهان - بادشاه تيمو ري مثند (صV T r)

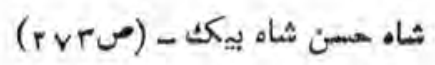

ثاه غياث - (ص, 1 1) 


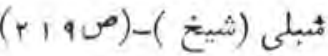

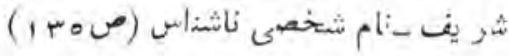
$($ (r)

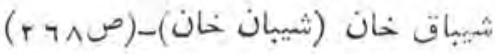

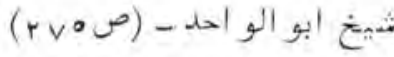

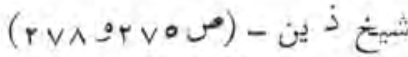

$$
\begin{aligned}
& \text { (ع) حرفى ) } \\
& \text { عبيسى - (صبr) } \\
& \text { ( ) حرفى ) }
\end{aligned}
$$

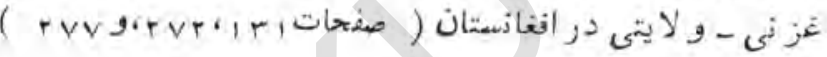

$$
\begin{aligned}
& \text { غياث سمخر - - (صrV) } \\
& \text { (ف) (فرفى }
\end{aligned}
$$

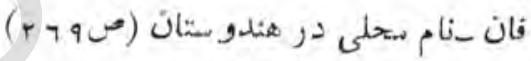

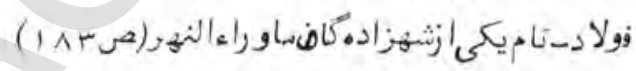

$$
\begin{aligned}
& \text { فو لاد سلطان - (صrvr) } \\
& \text { (ق) (حرفى }
\end{aligned}
$$

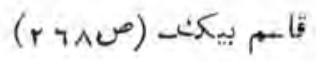

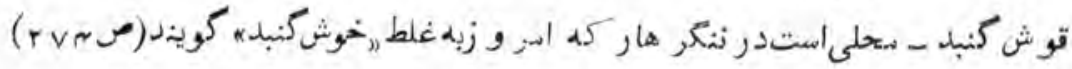

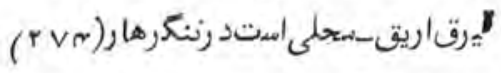

$$
\text { ( ك) (حرفى ) }
$$

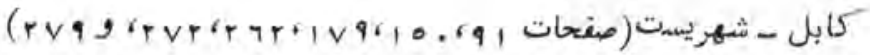

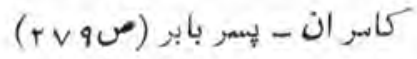

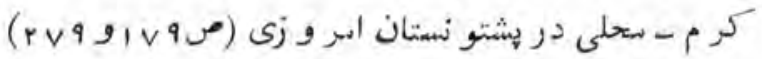




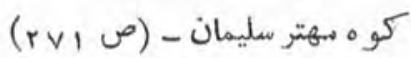

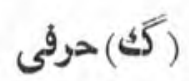

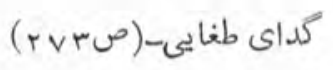

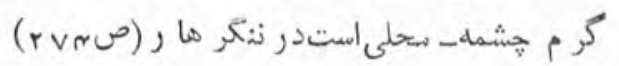

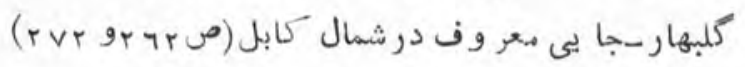

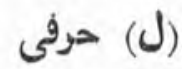

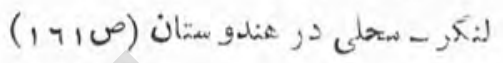

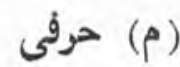

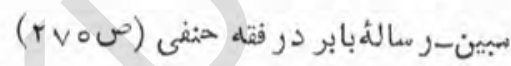

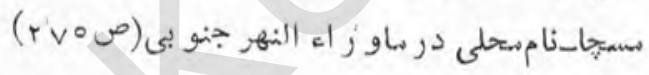

( ص) - ש

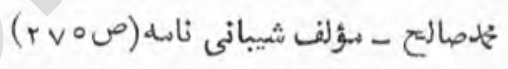

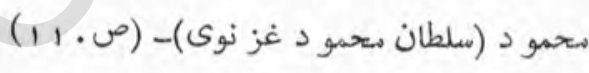

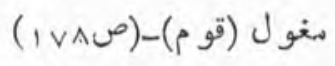

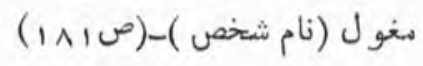

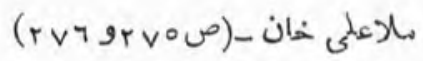

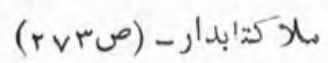

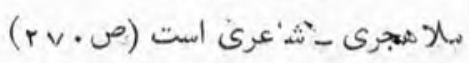

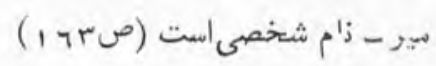

(ن) حوفى (ن)

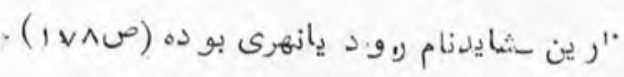

ناصر ششاهز اده يى است (ص.

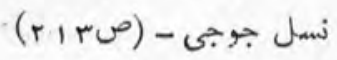

- 


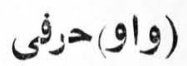

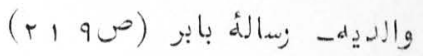

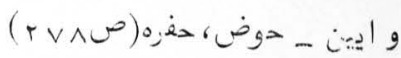

(ه)

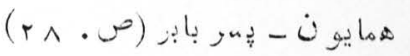

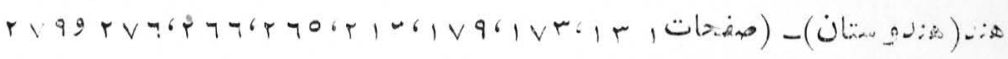

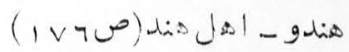

जing (s)

$(r \vee r)-(s)$

- PIF- 
كا: 


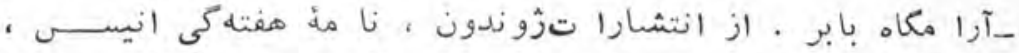

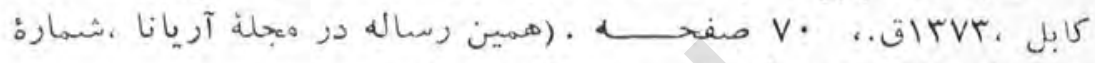

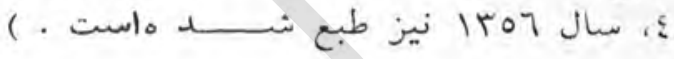

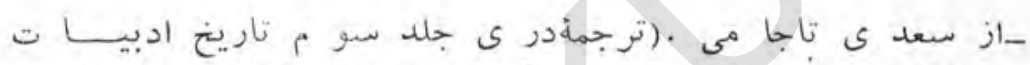

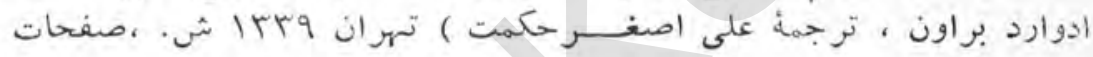
.001_-0 V V

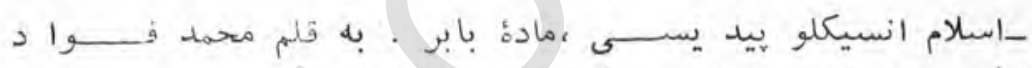

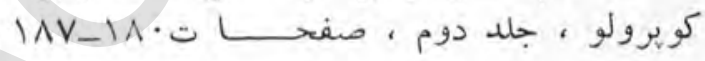

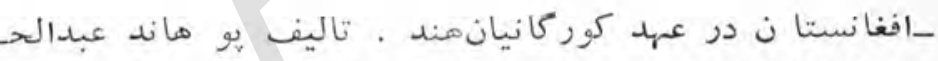

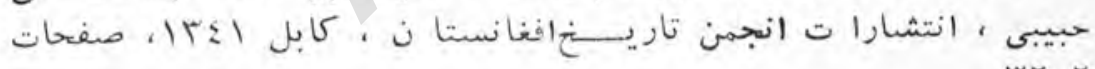
$. r t-r$

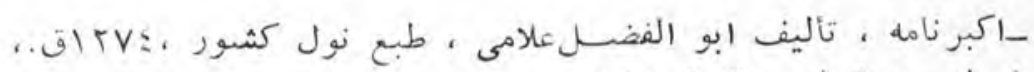

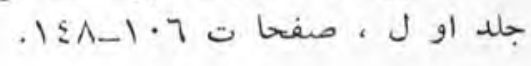

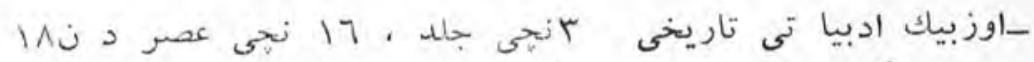

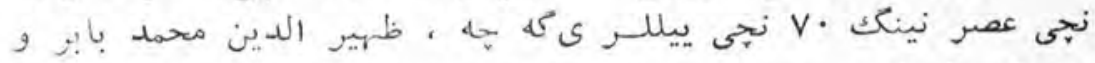

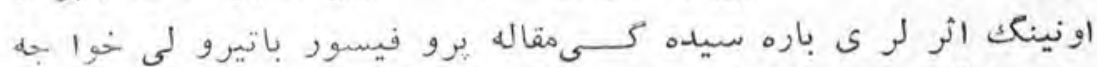

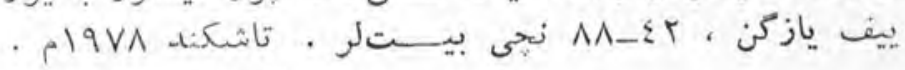
- rlo- 


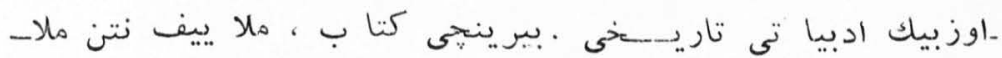

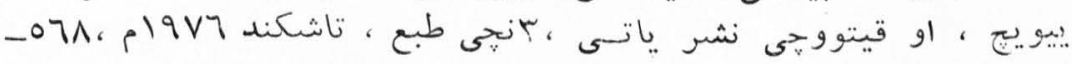

- .

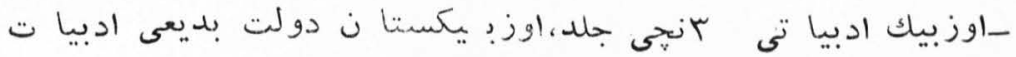

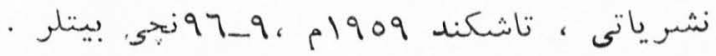

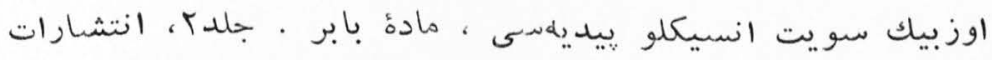

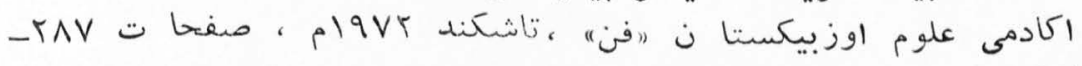

. rav

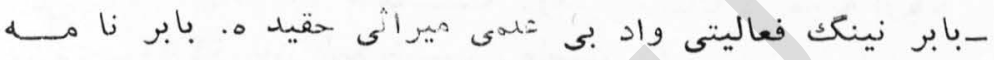

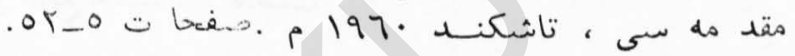

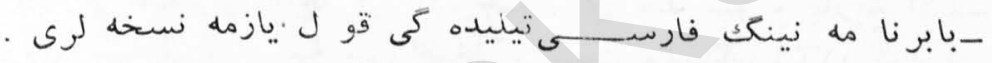

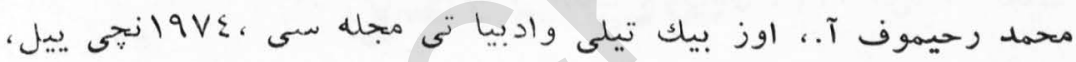

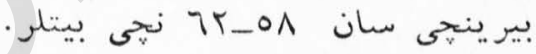

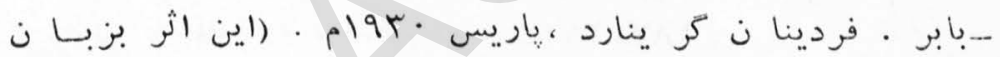

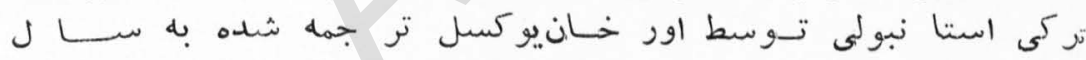

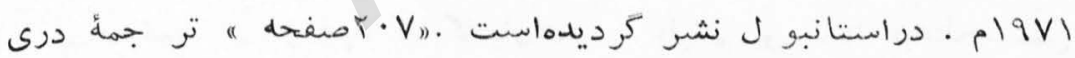

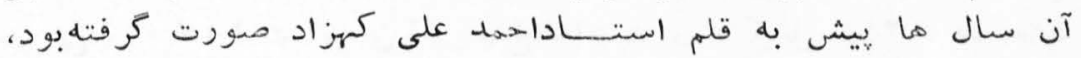

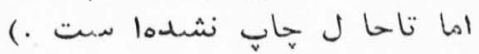

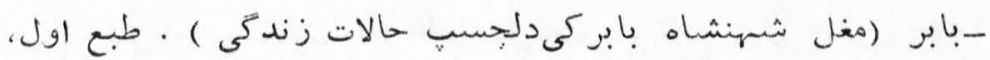

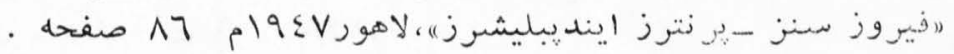

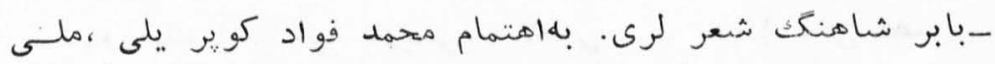

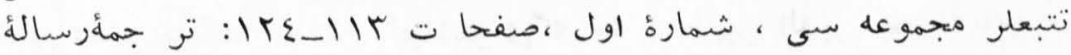

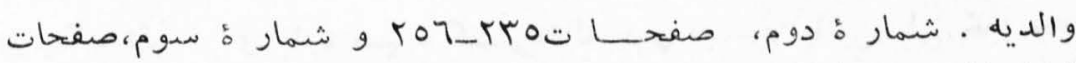
. $-117$ 
ادامؤ مثنو يها و رباعيا ت وسايسراشعار در شمارؤ هنجم همين مجلـه

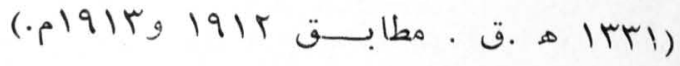

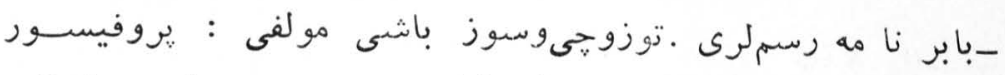

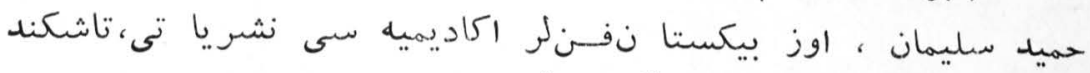
·

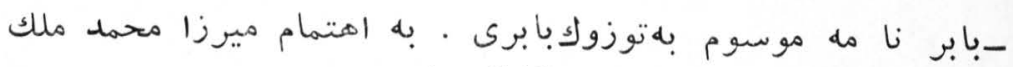

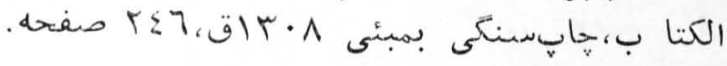

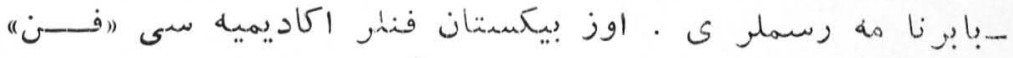

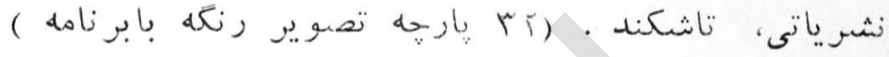

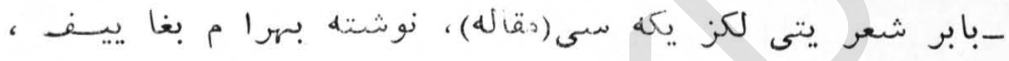

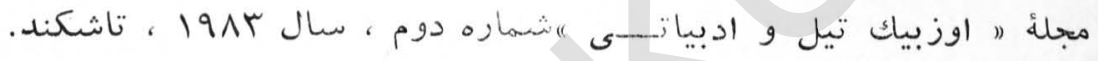

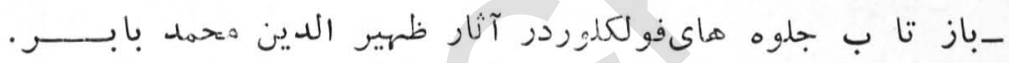

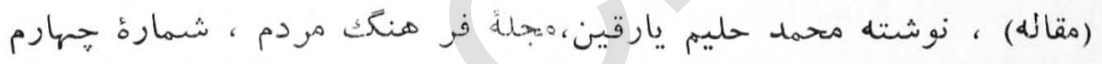

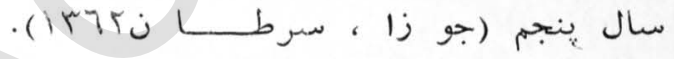

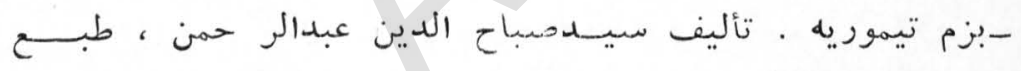

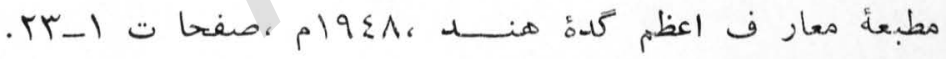

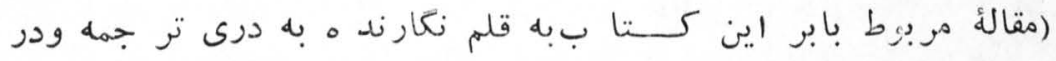

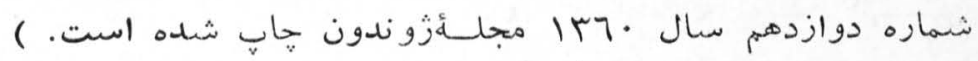

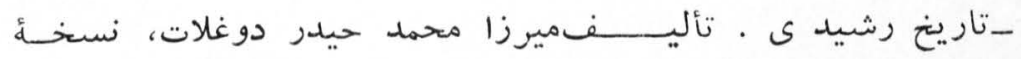

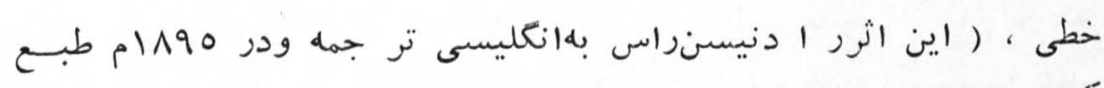

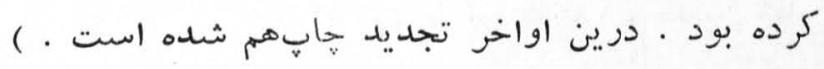

_تاريخ فرشته ، تأليف محمدقاسم ، لكنهو ابr| ق. -riv_ 
_تحفله سا مى · تأليف . ساميرزاي صفوى ، بله تصحيح وحيد

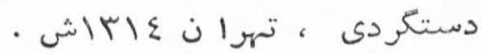

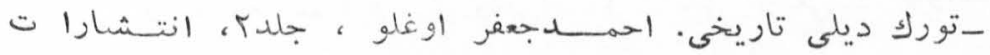

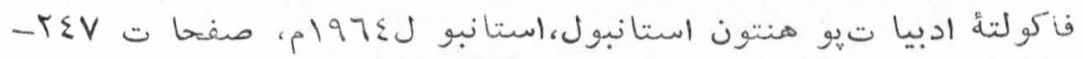

.507

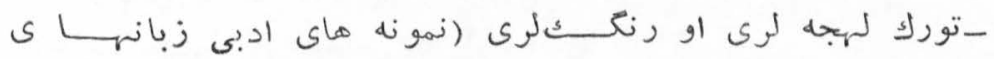

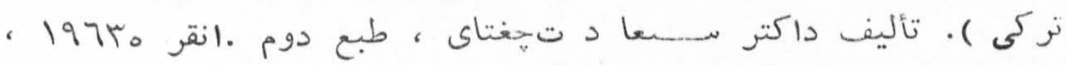
صفها ت

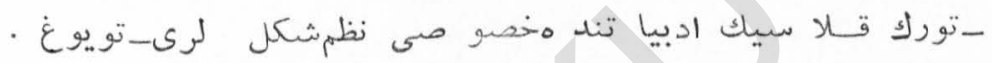

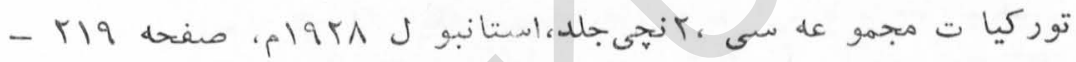

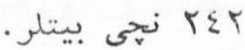

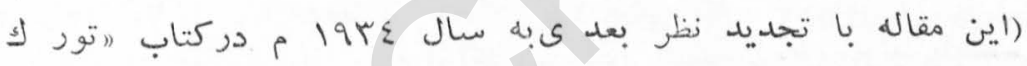

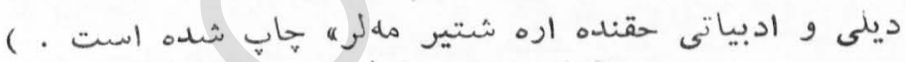

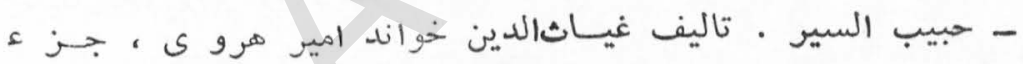

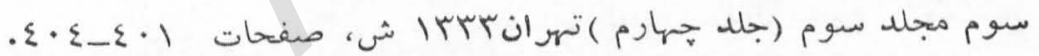

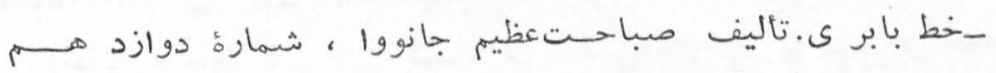

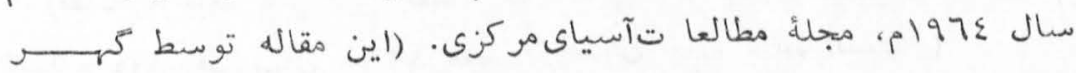

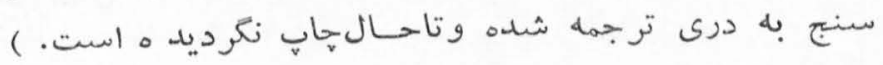

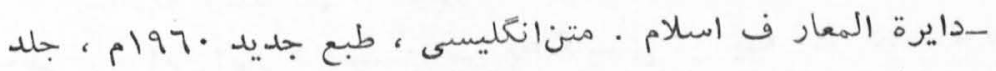

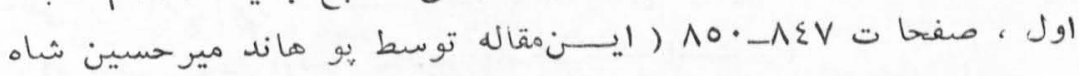

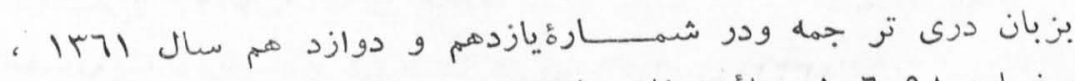

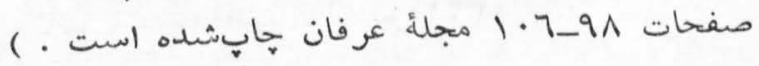

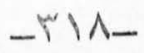




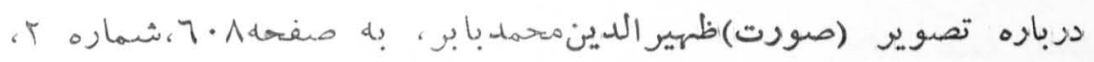

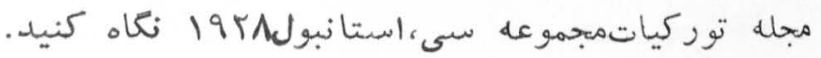

-روضة السلا طين · تاليـففخرى؛ ن امير ى هروى ، بلهنحيح

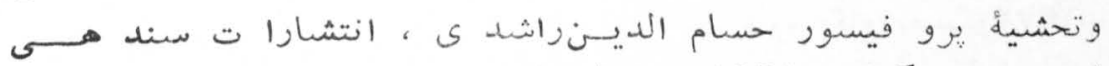

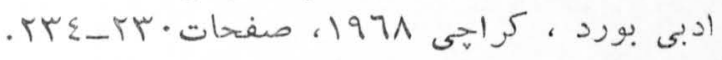

ـظهير الدينمحمد بابر ، بابر نا مله . اوزبيكستا ن فن لر اكاديميه

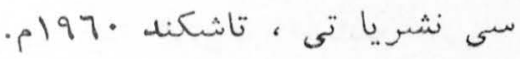

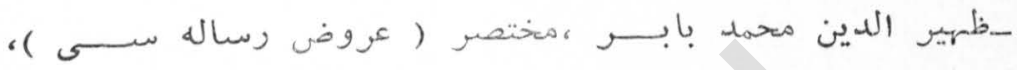

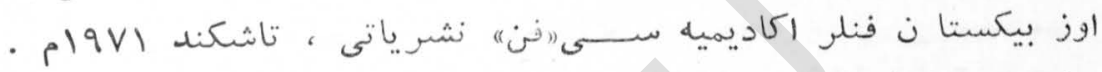

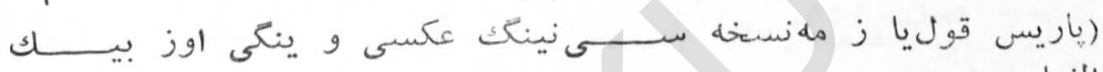

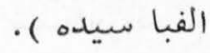

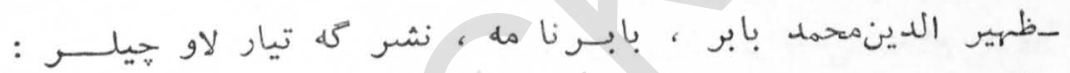

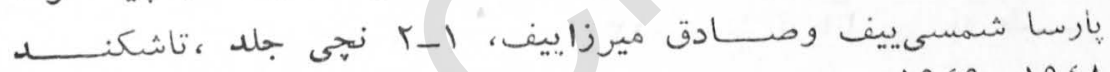

$$
\text { - p } 19 \leqslant 9,19 \leqslant \wedge
$$

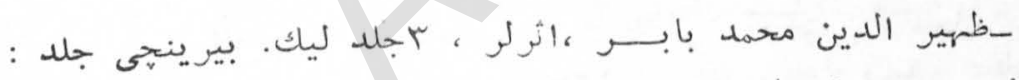

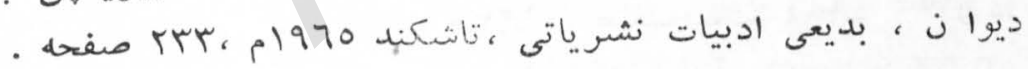

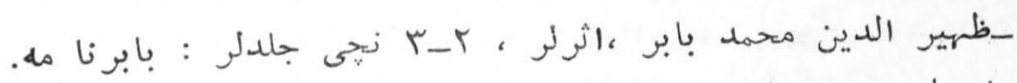

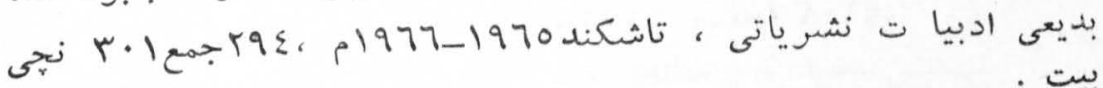
بيت بدى

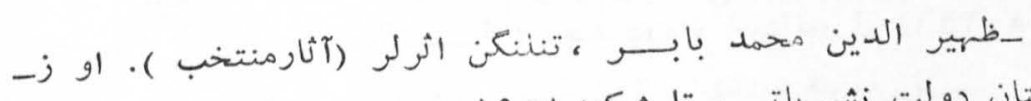

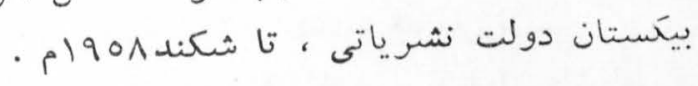

ـظهير الدينمحمد بابر، بابر نامه ، هو شكين ناميده كى تيل و $-r 19-$ 


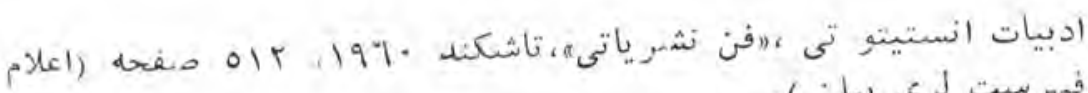

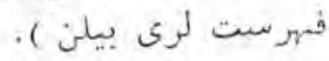

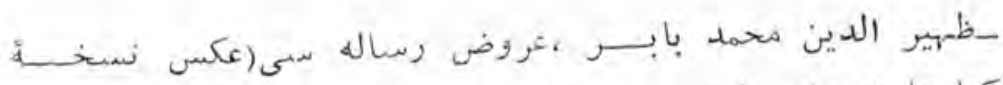

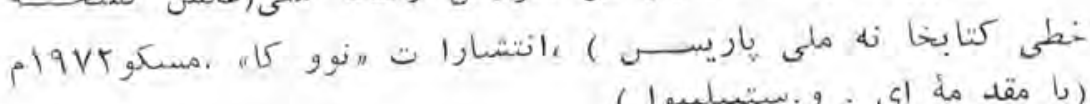

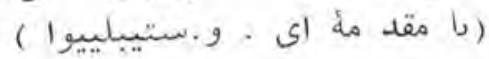

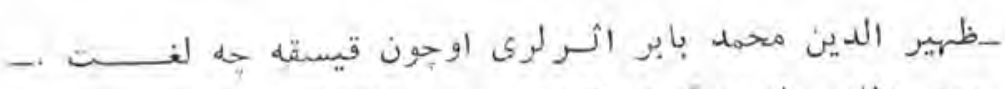

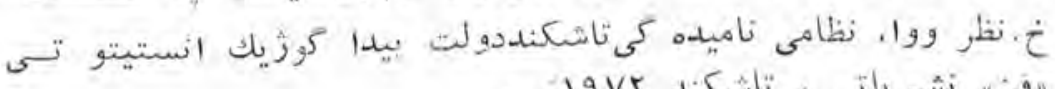

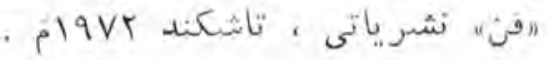

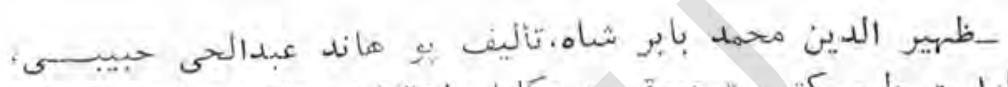

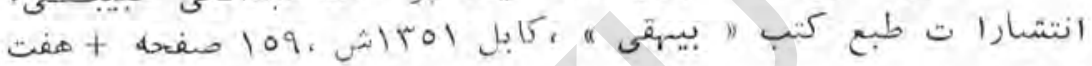

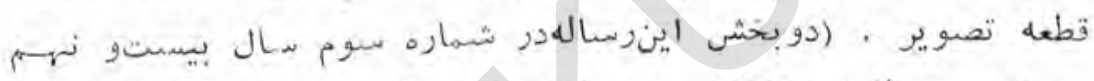

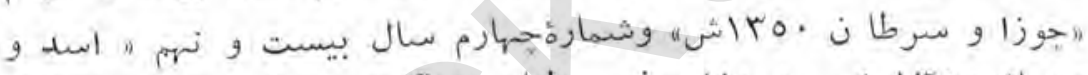

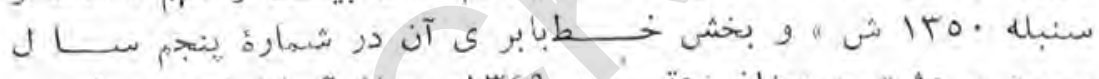

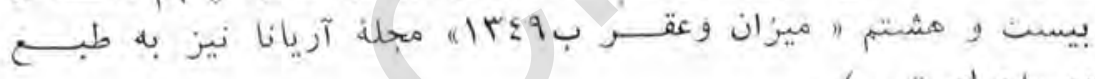

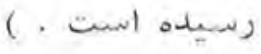

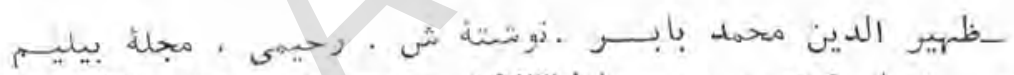

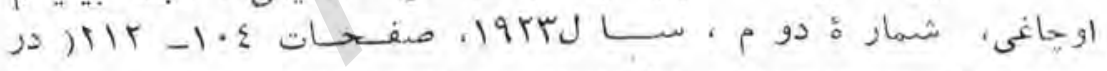

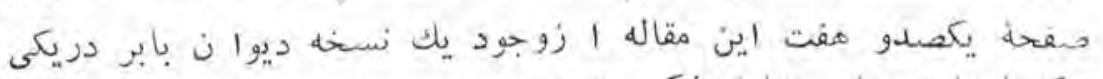

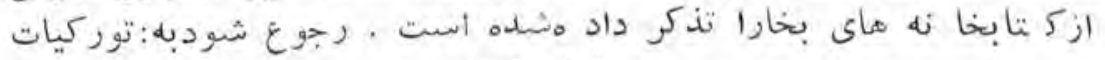

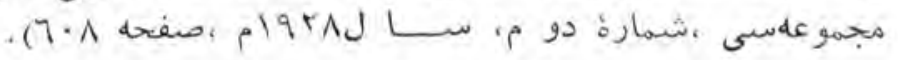

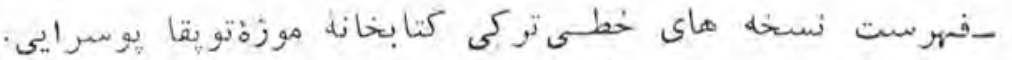

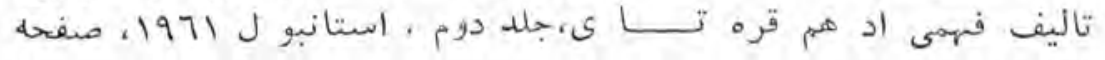
. ملكدو دوازدي

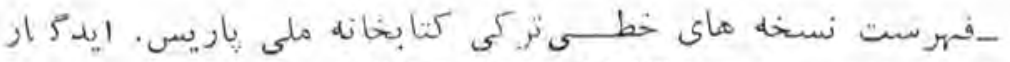

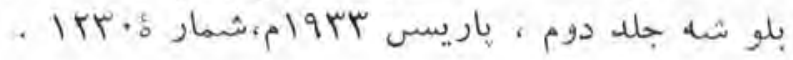


ـمنتخب النتواريخ . تأليـف فعبدالقادر بدايونى ، طبع كلكتــهـ ،

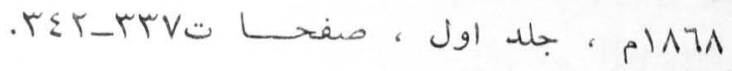

$$
\begin{aligned}
& \text { ـمنتخبا ت توركى ، بلهاهتمامبره زين، قازا ن مOV }
\end{aligned}
$$

ـمنكر احبا ب. تأليفنقيبالا شراف سيد حسنثنارى بخارى،

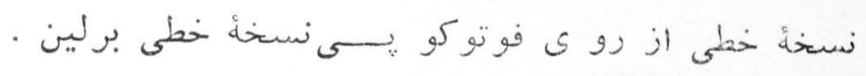

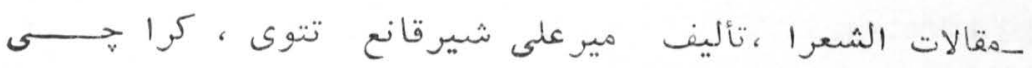

$$
\text { 190V }
$$

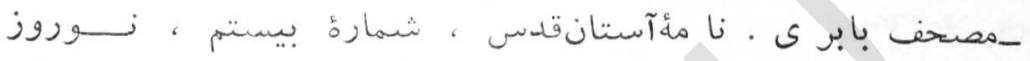

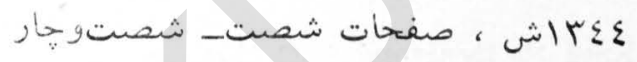

_ نكاهى به تاريخجهان، تأليف جو اهر لعل نهرو ، ترجمال محمهود

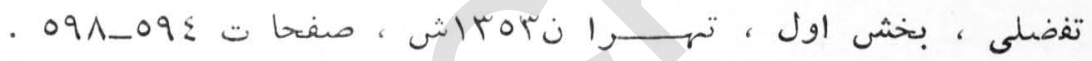

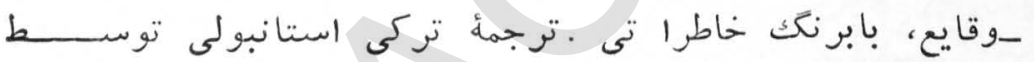

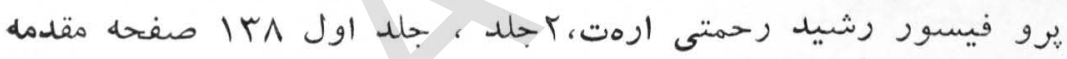

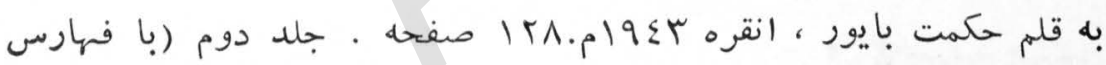

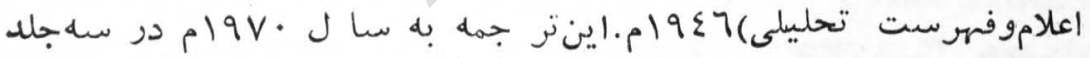

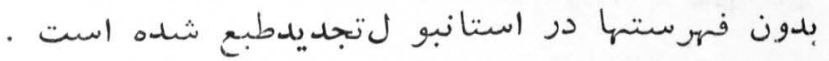

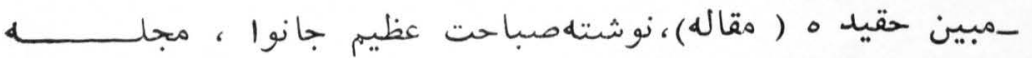

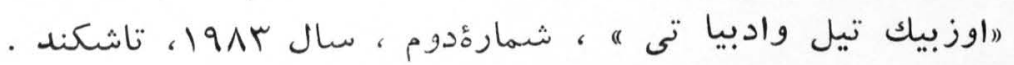

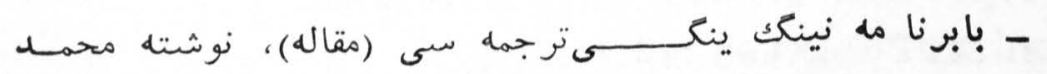

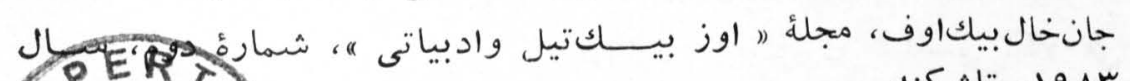

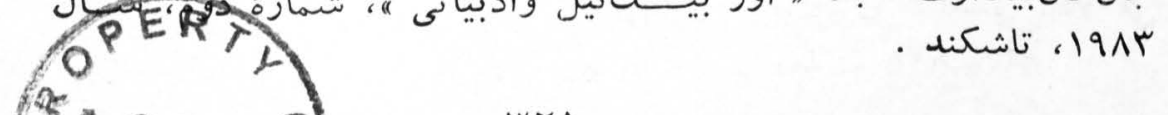
$\left(\begin{array}{c}4 \mathrm{CKU} \\ 45525\end{array}\right.$ 
H. Jagub, Babir, oz Fan Nasrijati, Taskent, 1941

Babur-Nama (Memoirs of Babur) Translated from the original Turki Text of Zahiruddin Muhammad Babur Padshah Ghazi by Annette S. Beveridge. Londen, 1922 (in 2 Vols.)

$$
\text { (در تحبيقا ت كتاب در بارمديواناشعلار بابر صنحبت شده ) }
$$

Schimmel A., Babur Padshah the poet. with an account of the poetical talent in his family. Isl amic Culture, No 34 (1960), pp. 125-138.

Nacimuddin Sayyid. Some unpublished verses of Babur, Islamic Culture, No 30 (1956), pp. 44-50.

Ross E. Denison. A Collection of Poems by the Emperor Babur, Calcutta, 1910 (Jurnal Asiatic Society of Bengal, Vol. VI exta number)

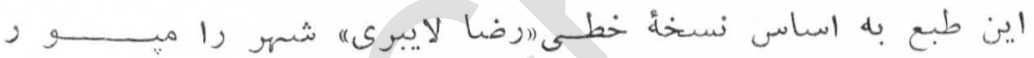

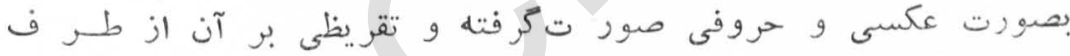

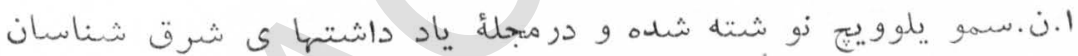

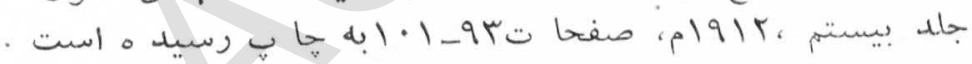

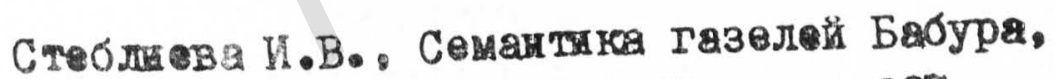

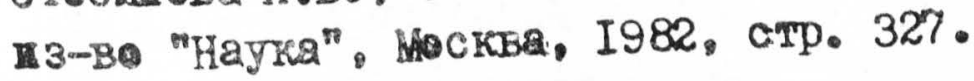
(19 غزل بابو ضميمة اينكتاب بصورت تاييى و آفسيت هاب شهد

\section{Cтора 4.A., Перспдскал митература'/бно- би б}

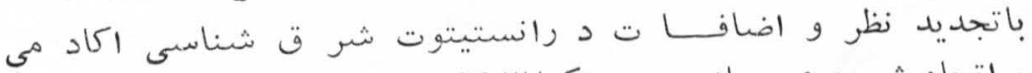

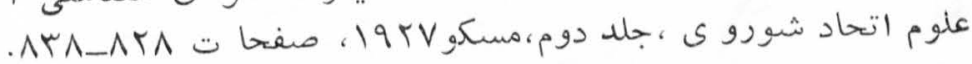

$$
\begin{aligned}
& \text {-ritz }
\end{aligned}
$$


Cen ператор Бабура, часть I.- текст, Пөтреград, I9I\%.

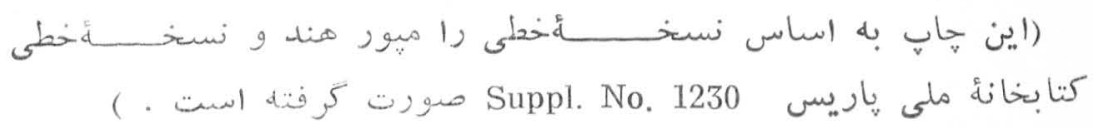

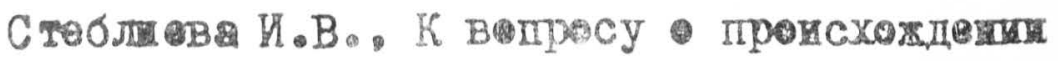

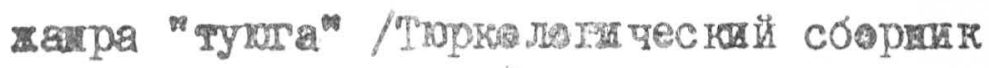

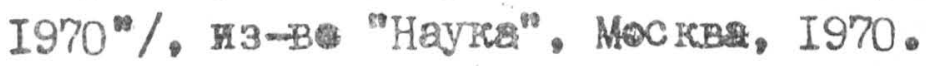

$$
\text { (I) - Iro (r) }
$$

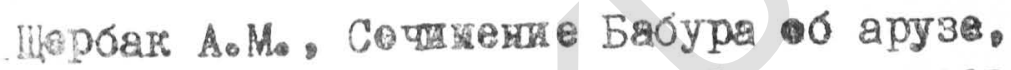

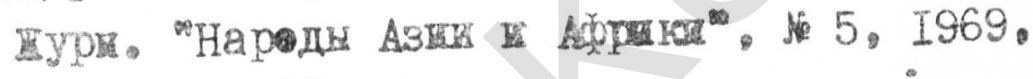
c.7p. I56 168.

Asw

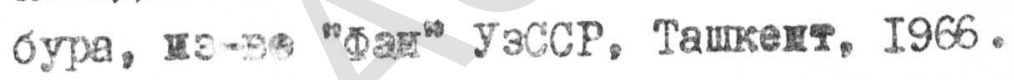

$$
\text { ( } 1 \varepsilon
$$




\section{A \\ COLLECTION OF POEMS OF ZAHIRUDDIN MOHAMMAD B A BUR}

Edited by

\section{Mrs. Shafiqa Yarqin}

Published by

Academy of Sciences of the DRA Center of Languages and Literature

Kabul, 1983 